\title{
FOTOGRAFIA ENTRE FATO E FARSA (URSS - ITÁLIA, 1928-1934)
}


CLARA F. FIGUEIREDO

\section{FOTOGRAFIA ENTRE FATO E FARSA (URSS - ITÁLIA, 1928-1934)}

Tese de doutorado apresentada à Escola de Comunicações e Artes da Universidade de São Paulo, como exigência parcial para obtenção do Título de doutor em Artes Visuais.

Programa de Pós-Graduação em Artes Visuais, área de concentração Teoria, Ensino e Aprendizagem da Arte, linha de pesquisa História, Crítica e Teoria da Arte.

Orientador: prof. dr. Luiz Renato Martins

Trabalho realizado com o apóio da bolsa CAPES/DS (Coordenação de Aperfeiçoamento de Pessoal de Nível Superior - Ministério da Educação), pelo período de 48 meses.

Versão Corrigida (versão original disponível na Biblioteca da ECA/USP)

São Paulo

2018 
Autorizo a reprodução e divulgação total ou parcial deste trabalho, por qualquer meio convencional ou eletrônico, para fins de estudo e pesquisa, desde que citada a fonte.

Email: chiarinh@usp.br

Catalogação na Publicação

Serviço de Biblioteca e Documentação

Escola de Comunicações e Artes da Universidade de São Paulo Dados inseridos pelo(a) autor(a)

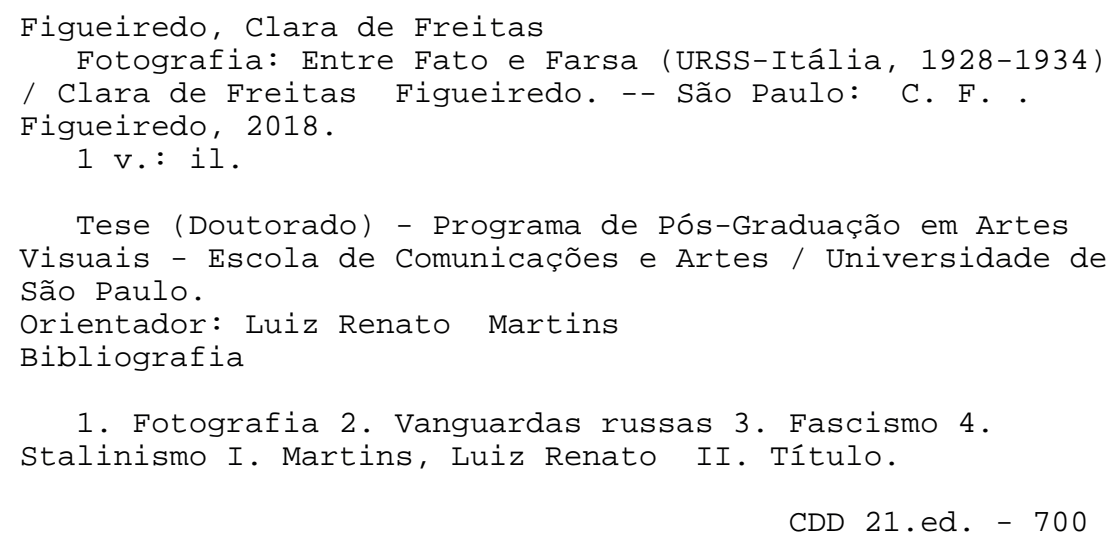

Elaborado por Sarah Lorenzon Ferreira - CRB-8/6888 
NOME Clara de Freitas Figueiredo

TíTULO Fotografia: Entre Fato e Farsa (URSS - Itália, 1928-1934)

TESE APRESENTADA À ESCOLA DE COMUNICAÇÕES E ARTES DA

UNIVERSIDADE DE SÃO PAULO PARA

OBTENÇÃO DO TÍTULO DE DOUTOR EM ARTES VISUAIS

\section{APROVADO EM}

BANCA EXAMINADORA

PROF. DR.

INSTITUIÇÃO

JULGAMENTO

ASSINATURA

PROF. DR.

INSTITUIÇÃO

JULGAMENTO

ASSINATURA

PROF. DR

INSTITUIÇÃO

JULGAMENTO

ASSINATURA

PROF. DR. INSTITUIÇÃO

JULGAMENTO ASSINATURA

PROF. DR. INSTITUIÇÃO

Julgamento Assinatura 



\section{AGRADECIMENTOS}

Ao orientador Luiz Renato Martins e a todas e todos que contribuíram no processo de construção deste trabalho: Alex Calheiros, Alvaro Bianchi, Amanda Batista, Anand F. Figueiredo, Beatriz F. Figueiredo, Camilla R. da Silva, Coletivo Voz Ativa/Pós Ativa!, Coletivo Político Quem, Daniel Nagase, Danilo Oliveria, Davide Di Bella, Elza Ajzenberg, Eric Lemos, Erin Conceição, Fernanda Barrichello, Fábio Franco, Gabriel Kogan, Gustavo Motta, João B. A. Figueiredo, João Tragtenberg, Leonardo A. Corrêa, Luana Rotolo, Lucas S. Paolo Vilalta, Maria G. Gatti, Paulo Simões, Pedro Magalhães, Pedro N. Bonacina, Peterson Pessoa, Polly Rosa, Rafael Padial, Rafael Schincariol, Renata Zancan, Silvia Simões, Thyago M. Villela, Yves Cohen, Yuri Gama; na França, Ada Ackerman e François Albera; na Itália, Antonella Russo, Elisa Smania, Emilia De Gregori, Fabio Frosini, Francesco Lombardi, Giacomo Tarascio, Giuseppe De Gregori, Peter D. Thomas e Renato Bon; na Rússia, Alexey Petukhov, Elena Sharnova, Everson Mayer Simões, Ira Demi, Igor Volkov e Viktoria Shcherbenko.

Agradeço também às instituições e centros de documentação: Centro de Estudos Desmanche e Formação de Sistemas Simbólicos (DESFORMAS), à Coordenação de Aperfeiçoamento de Pessoal de Nível Superior (CAPES), Instituto Cultural Ítalo-brasileiro (ICIB, São Paulo), Instituto Italiano di Cultura di San Paolo (IIC, São Paulo) e Sebo Memória (São Paulo); na Itália, Archivio Centrale dello Stato (ASAC, Roma), Biblioteca dell' Istituto Della Enciclopedia Italiana (Roma), Biblioteca di Storia Moderna e Contemporanea (Roma), Fondazione Istituto Gramsci Onlus (IGS, Itália), Fondazione Istituto Piemontese Antonio Gramsci (Turim/Itália) e Ghilarza Summer School (GSS, Itália); na Rússia, Multimedia Art Museum, Moscow - Rodchenko House of Photography (MAMM, Rússia), Russian State Archive of Literature and Art (RGALI, Moscou), Russian State Library (Moscou), State Archive of the Russian Federation (GARF, Moscou) e The Pushkin State Museum of Fine Arts (Moscou). 


\section{RESUMO}

A presente investigação surgiu da constatação de entrecruzamentos entre os discursos visuais da Mostra da Revolução Fascista (Roma, 1932-34) e do pavilhão soviético na Exposição Internacional de Imprensa de Colônia (Alemanha, 1928). Tais entrecruzamentos - reforçados e consubstanciados por contatos concretos entre hierarcas do fascismo e do stalinismo - levaram, a partir dos materiais visuais selecionados, à investigação de problemáticas comuns aos dois regimes, como a industrialização acelerada tardia, a expansão produtiva e o culto do chefe. Nesse sentido, as reflexões de A. Gramsci e W. Benjamin acerca da "revolução passiva" e da "estetização da política", respectivamente, constituíram constructos crítico-teóricos cruciais no desenvolvimento reflexivo da investigação. O objetivo da pesquisa de doutorado, em síntese, foi examinar e refletir sobre o protagonismo da fotografia como instrumento de reprodução simbólica e dominação, tanto na Itália fascista e quanto na URSS stalinista.

Palavras-chave: fotografia, cultura de massa, fascismo, stalinismo, "estetização da política" e "revolução passiva".

\section{ABSTRACT}

The present research emerged from the perception of intersections in the language field between the Exhibition of Fascist Revolution (Rome, 1932-1934) and the Soviet Pavilion at the International Press Exhibition (Cologne, 1928). These intersections - strengthened and substantiated by concrete interactions between Fascist and Stalinist hierarchs - lead also to a research, based in selected visual material, about common problems for both regimes such as a catch-up industrialization, production expansion and the cult of the leader's personality. In this sense, Antonio Gramsci's reflections on the notion of "passive revolution" and Walter Benjamin's on the "aestheticization of politics" emerged as fundamental critical-theoretical contributions. In short, the aim of this doctoral research was to analyse and reflect about the protagonism of photography as an instrument for symbolic reproduction and domination, both in the Fascist Italy and in the Stalinist URSS.

Keywords: photography, mass culture, fascism, stalinism, "aestheticization of politics" and "passive revolution". 


\section{ÍNDICE}

INTRODUÇÃO

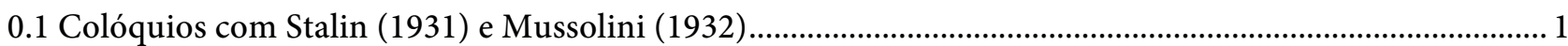

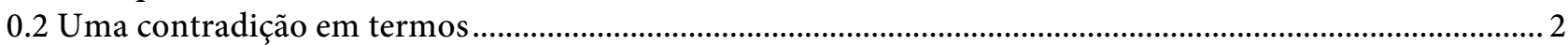

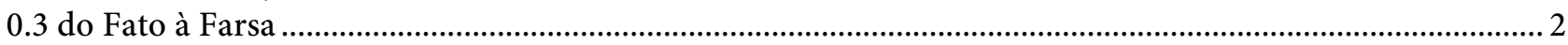

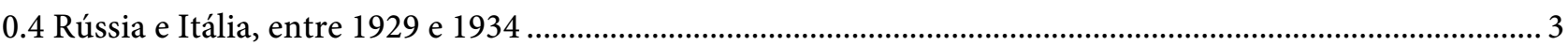

CAPÍTULO 1 | "UMA CENOGRAFIA TEATRAL": 0 pavilhão soviético na Exposição Internacional

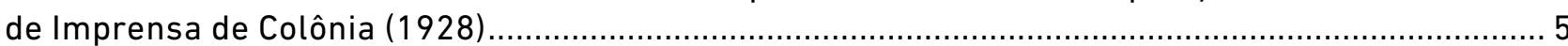

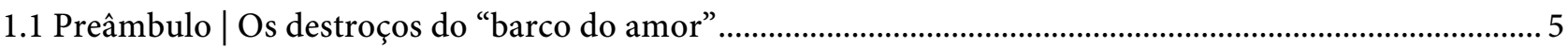

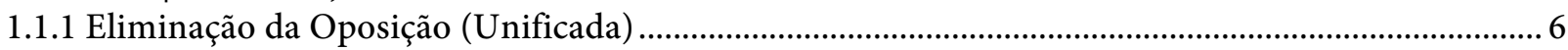

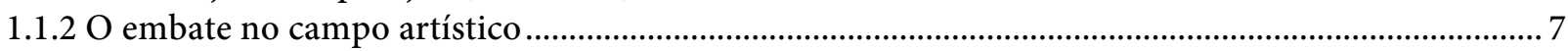

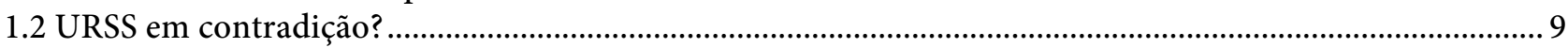

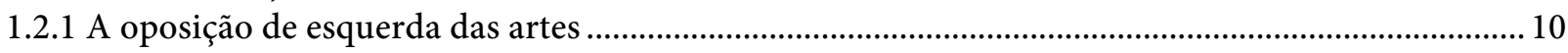

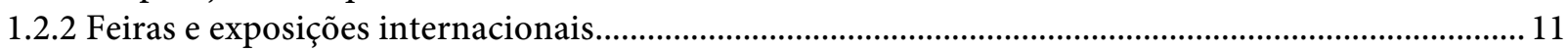

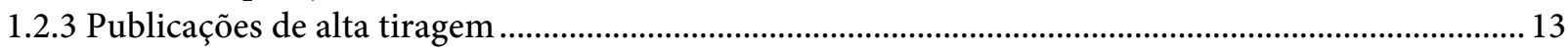

1.3 O pavilhão soviético na Exposição Internacional de Imprensa de Colônia (1928) ......................................... 15

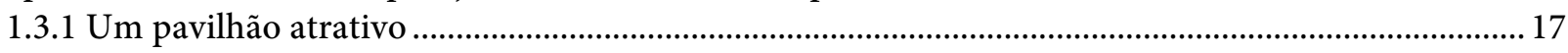

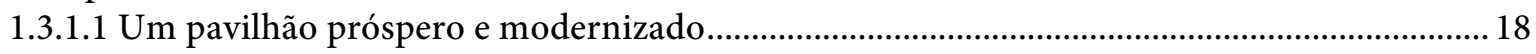

1.3.2 A recepção do pavilhão na imprensa internacional ............................................................................ 19

1.3.3 Uma sintaxe visual vanguardista de agitação e propaganda ...................................................................20

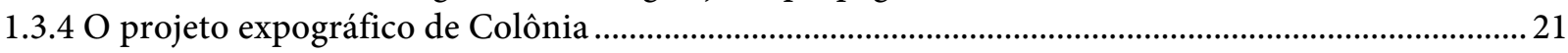

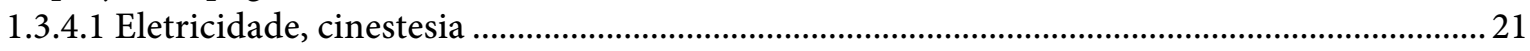

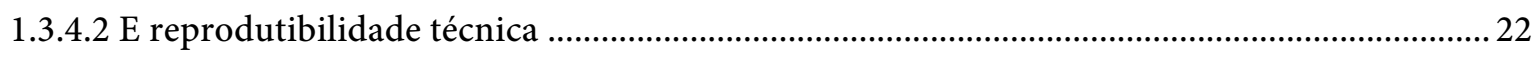

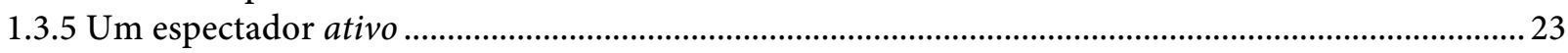

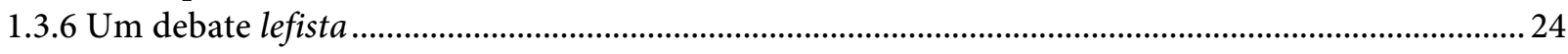

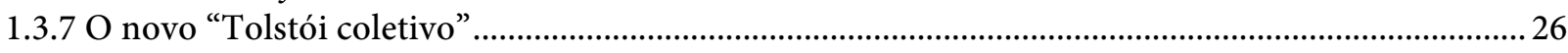

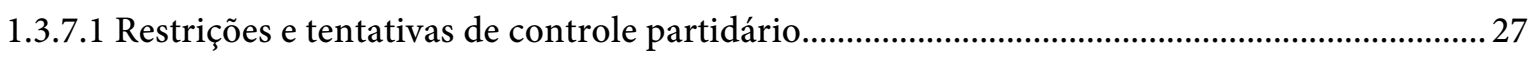

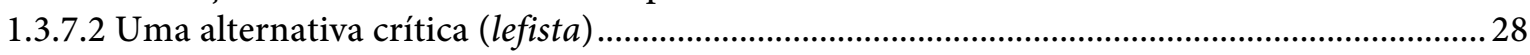

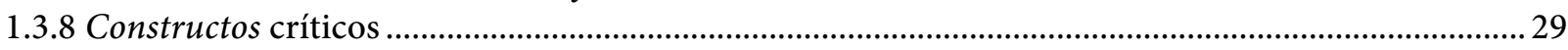

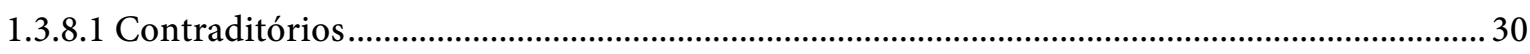

CAPÍTULO 2 | “Algo de hoje, moderníssimo": A construção de um sistema artístico fascista

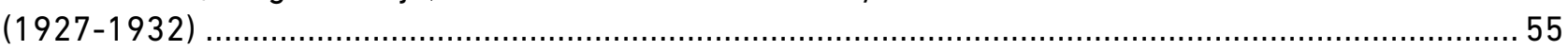

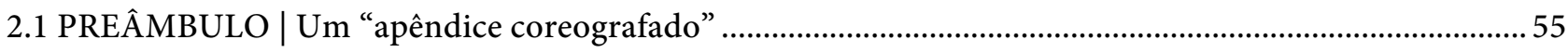

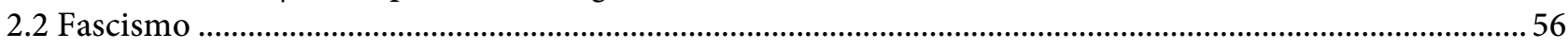

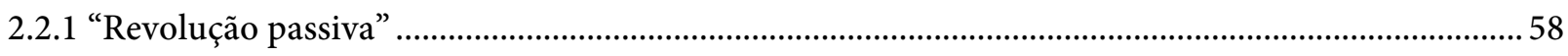

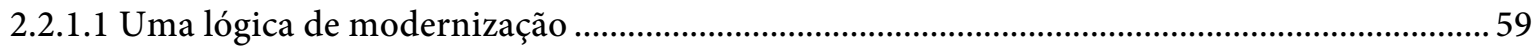

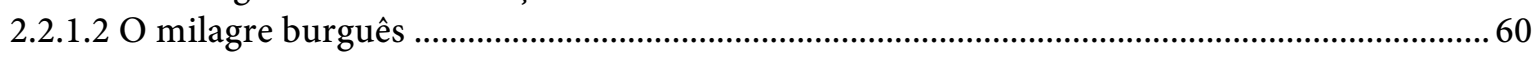

2.3 A constituição de um sistema artístico fascista (1921-1932) ...........................................................................61

2.3.1 Entre controle e coerção.................................................................................................................6

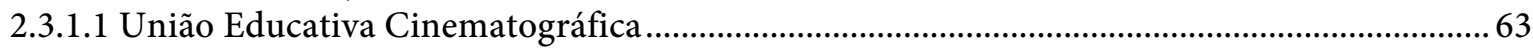

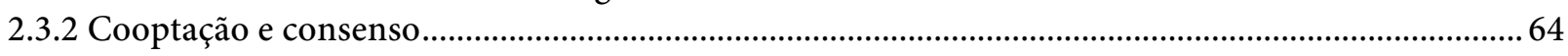

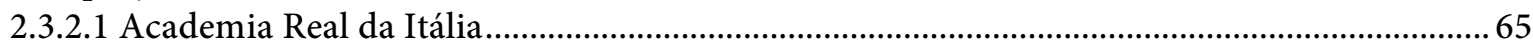

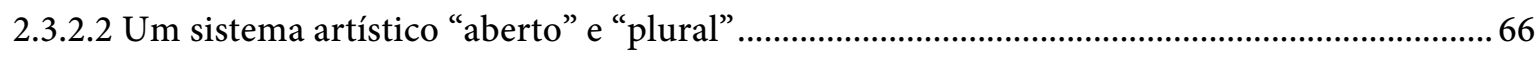

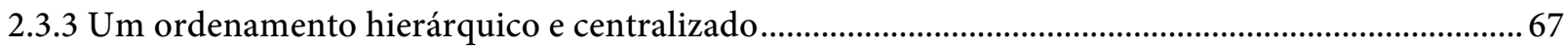

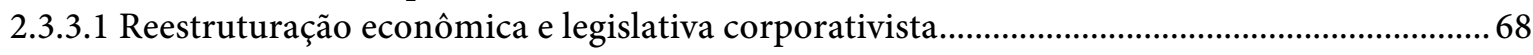

2.3.3.2 Cerceamento do circuito expositivo italiano e enquadramento dos artistas ............................. 71

2.3.3.3 Subsídio financeiro, premiações e popularização das exposições................................................. 73

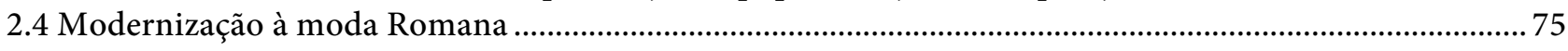

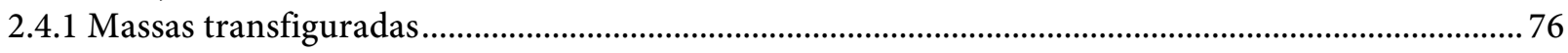




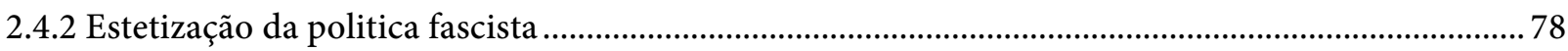

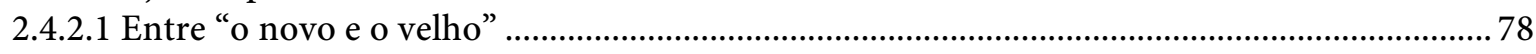

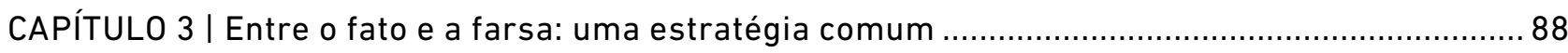

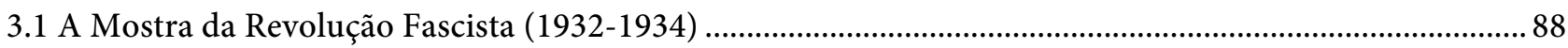

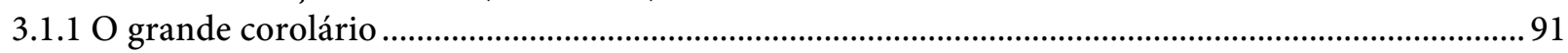

3.1.2 Expografia e recepção da mostra na imprensa local e internacional ..............................................93

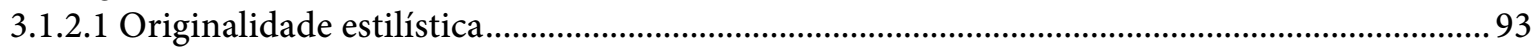

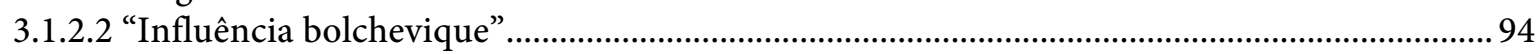

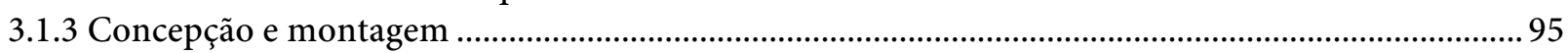

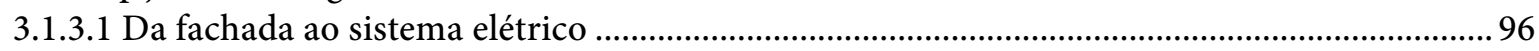

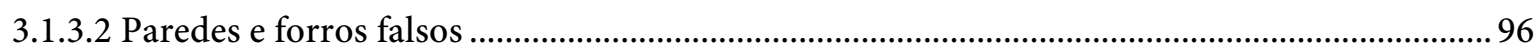

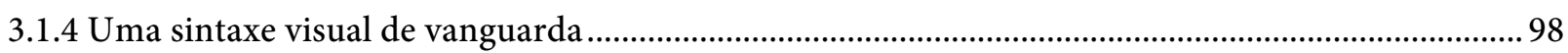

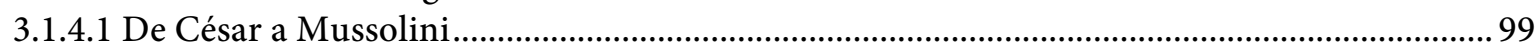

3.1.4.2 Protagonismo e martírio ................................................................................................................. 101

3.1.5 O impacto massivo e litúrgico da mostra: da montagem à recepção ................................................... 103

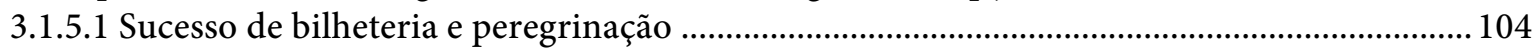

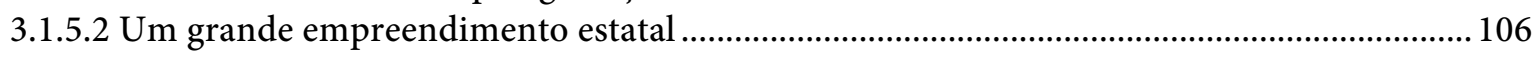

3.2 URSS e Itália: incorporações moleculares e pactos de não agressão ............................................................ 107

3.2.1 Embates, censuras e coerções: a consolidação de uma doutrina artística "soviética" (1928-

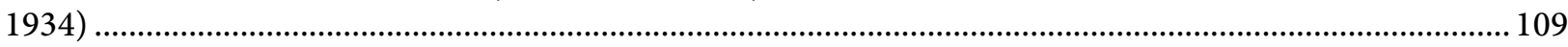

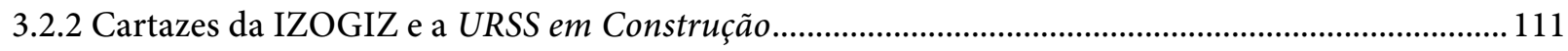

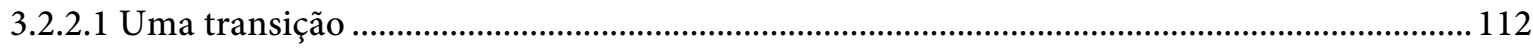

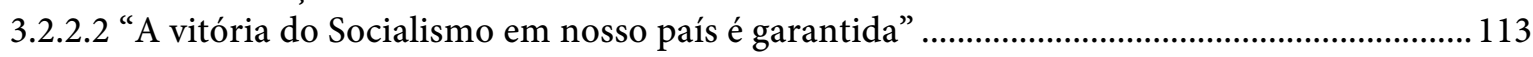

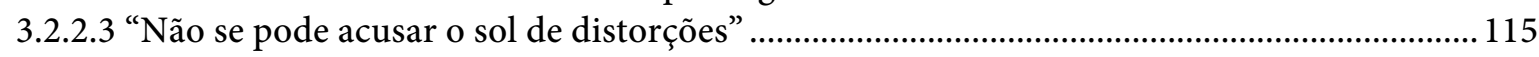

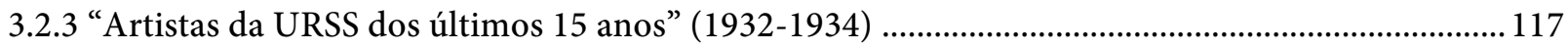

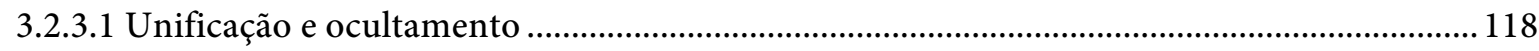

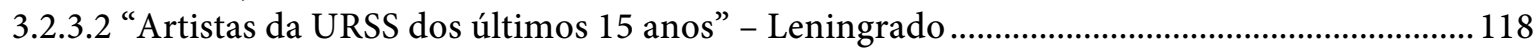

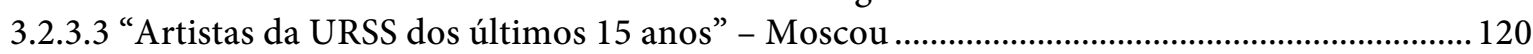

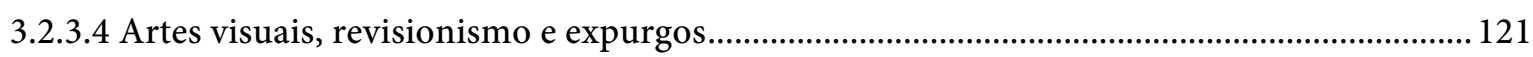

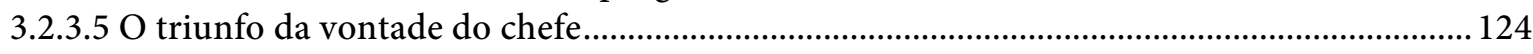

3.2.4 "Uma história em ato": "Artistas da URSS dos últimos 15 anos" e Mostra da Revolução

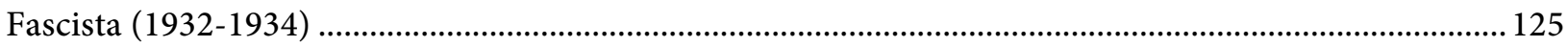

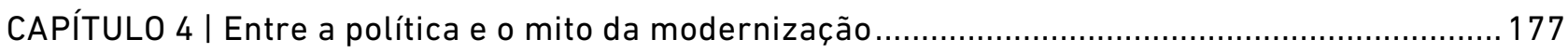

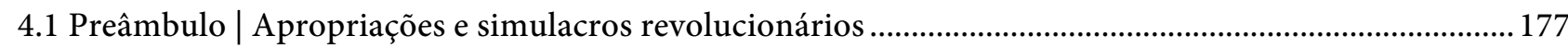

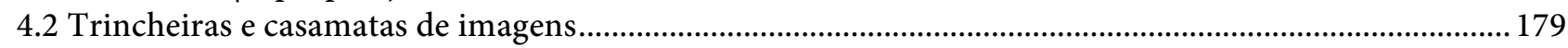

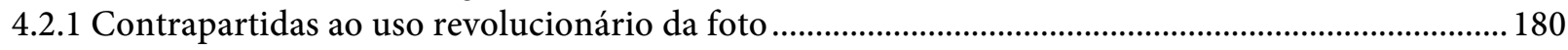

4.2.2 "Estetização da política" e "revolução passiva" ...................................................................................... 181

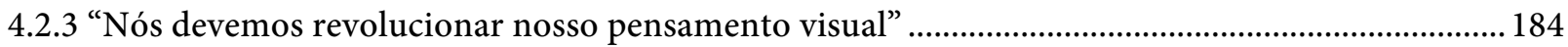

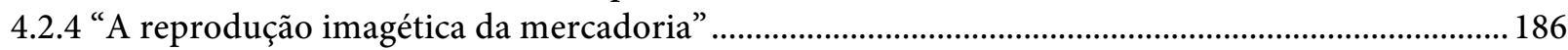

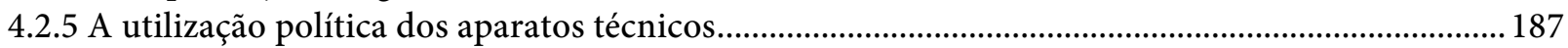

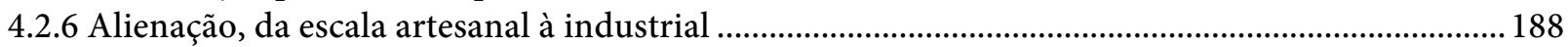

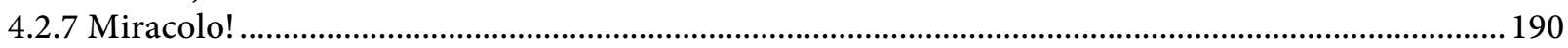

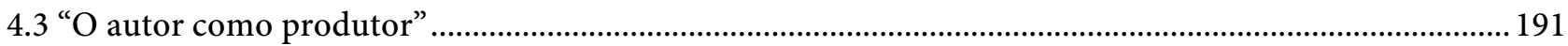

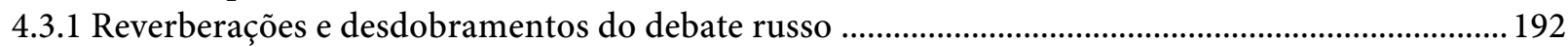

4.3.2 "Função organizativa da arte" e "cultura material" ................................................................................ 193

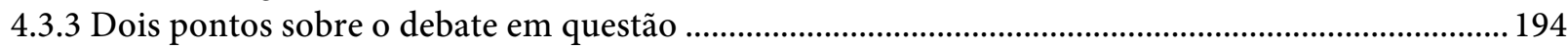

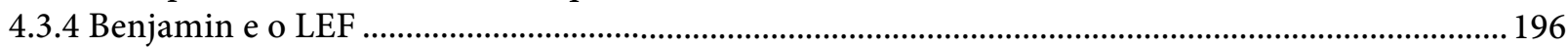

4.3.5 As tentativas de publicação de "A obra de arte...” na Rússia ..........................................................197

4.3.6 Perfilados ao lado da URSS? ............................................................................................................. 198

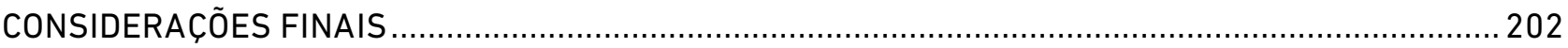


5.1 Itália

5.2 Rússia

5.3 Metamorfoses visuais...

203

5.4 "Estetização da política" e "revolução passiva" 


\section{INTRODUÇÃO}

\subsection{Colóquios com Stalin (1931) e Mussolini (1932)}

Entre 23 de março e 4 de abril de 1932, o escritor alemão Emilio Ludwig (1881-1849) entrevistou Mussolini quase diariamente. As entrevistas foram publicadas, no mesmo ano, com o assentimento do Duce, sob o título "Colóquios com Mussolini". O trecho reproduzido a seguir foi retirado da tradução brasileira dessa obra.

Ludwig: Em 1919 ou 20, declarou o senhor que Lenine [sic] libertará a Rússia do jugo da autocracia e profetizou que esse país será, um dia, a potencia mais produtiva da terra.

Mussolini: Não está, por ventura, nesse caminho? ${ }^{1}$

Em dezembro de 1931, alguns meses antes dos colóquios com Mussolini, Ludwig também entrevistou Stalin. A tradução integral da entrevista de Ludwig a Stalin encontra-se entre os arquivos do chefe do gabinete de imprensa de Mussolini, Gaetano Polverelli (1886-1960), no Arquivo Central do Estado Italiano, em Roma (ACS, MCP, Reports, B.9). Em julho de 1932, três meses após a sua publicação na Rússia (abril de 1932), a tradução da entrevista de Stalin foi enviada pela embaixada italiana em Moscou a Mussolini.

Como se pode aferir pelos trechos da entrevista de Mussolini a Ludwig, e pelos inúmeros documentos encontrados nos arquivos fascistas, conservados no ACS, Mussolini estava bastante atento ao processo russo. Mussolini dedicava especial atenção aos usos das esferas artísticas e culturais - assuntos nos quais, segundo afirmou Mussolini a Ludwig, "os russos eram exemplares". ${ }^{2}$

Com efeito, entre os documentos encontrados destaca-se uma consulta a Mussolini feita pelo presidente do instituto LUCE (União Cinematográfica Educativa, 1924-2009), Alessandro Sardi, a respeito da possível realização de uma exposição de fotografia e cinema russos na Itália, na ocasião da comemoração do $15^{\circ}$ aniversário da Revolução de Outubro (ACS, PCM, 1931-1933, B.1635). ${ }^{3}$

${ }^{1}$ MUSSOLINI (1932), apud LUDWIG, Emilio, Colóquios com Mussolini (1932), trad. Marina Guaspari, Porto Alegre: Livraria do Globo, 1932, p. 159.

2 "Nesse assunto [filmes de propaganda do regime], os russos são exemplares, disse Mussolini. Em breve nós também teremos mais dinheiro para isso. O "film" [sic] é, hoje, uma arma poderosa". MUSSOLINI (1932), apud LUDWIG, E., Colóquios..., op. cit., p. 223.

${ }^{3}$ Sardi, no telegrama enviado a Mussolini, explica que os representantes da VOKS (Sociedade de ralações culturais no exterior de todos os Sovietes da União, 1925-1958) na Itália procuraram-no com tal proposta expositiva, e que, apesar dele apoiar tal exposição, não era do interesse do Instituto LUCE acolher a proposta. Após relatar o fato e enviar uma cópia da proposta expositiva do VOKS, Sardi solicita a opinião de Mussolini a respeito. Não foram encontrados outros documentos referentes a tal negociação. No entanto, sabe-se que, também em 1932, o instituto LUCE mediou uma longa negociação para assegurar a presença de filmes russos na 


\subsection{Uma contradição em termos}

Bastaria mudar os emblemas e essa peça [a fachada da Mostra da Revolução Fascista] seria aplaudida em Moscou. (L. Gillet, 1932)

Em 13 de dezembro de 1932, o historiador da arte francês Louis Gillet (1876-1943) observou, em texto sobre a Mostra da Revolução Fascista (Roma, 1932-1934), a semelhança entre esta e a arte russa do período. Gillet não foi o único a identificar uma proximidade aparente entre a recéminaugurada exposição fascista e a linguagem visual de vanguarda russa. $\mathrm{Na}$ época, críticos, escritores e artistas, próximos ou não ao fascismo, também traçaram `comparações. Mario Sironi (1885-1961), um dos principais pintores da mostra fascista, chegou inclusive a especificar a comparação, com menção ao pavilhão soviético na Exposição Internacional de Colônia (Alemanha, 1928). ${ }^{5}$

\section{3 do Fato à Farsa}

A presente pesquisa surgiu da percepção de similitudes, no campo da linguagem, entre a Mostra da Revolução Fascista (1932) e o pavilhão soviético na Exposição Internacional de Imprensa de Colônia (1928).

Com efeito, no decorrer da minha pesquisa de mestrado sobre o debate fotográfico do grupo Frente de Esquerda das Artes (LEF, 1922-1928), ${ }^{6}$ deparei-me, num primeiro momento, com a apropriação da produção de tal vanguarda russa pela máquina stalinista e, num segundo momento, com sinais de um possível empréstimo da linguagem lefista numa exposição fascista, a mostra de Roma.

$1^{\mathrm{O}}$ Festival Internacional de Cinema de Veneza. Há registro também da participação russa em várias Bienais de Arte. Cf. PISU, Stefano, L'Unione Sovietica alla Mostra internazionale d'arte cinematografica di Venezia (19321953), orientatore Giannarita Mele, tese de dottorato, Cagliari: Università degli Studi di Cagliari, Dipartimento di Studi Storici, Geografici ed Artistici, dottorato di Ricerca in Storia Moderna e Contemporanea, XX ciclo, 2010, pp. 38-43. Sobre o VOKS, ver: FAYET, Jean-François, VOKS. Le laboratoire helvétique. Histoire de la politique culturelle soviétique durant l'entre-deux-guerres, Genéve: Georg, 2014.

${ }^{4}$ GILLET, Louis, "La nuova Roma", Revue des Deux Mondes, Parigi, 15 dicembre 1932, in SCHNAPP, J. T., Anno X: La Mostra della Rivoluzione Fascista del 1932, pref. Claudio Fogu, Pisa, Roma: Istituto Editoriali e Poligrafici Internazionali, 2003 pp. 125-127; p. 125.

${ }^{5}$ Ver: SIRONI, M., "L'architettura della rivoluzione”, Il Popolo d'Italia, 18 nov. 1932, in SCHNAPP, Jeffrey T., Anno X..., op. cit., pp. 77-78.

${ }^{6}$ Ver FIGUEIREDO, C. F., Foto-Grafia/o debate na Frente de Esquerda das Artes, Orientador Prof. Dr. L. R. Martins, Dissertação de Mestrado, São Paulo: Escola de Comunicação e Artes da Universidade de São Paulo, 2012. O grupo LEF - constituído por artistas de vanguarda que durante a guerra-civil russa (1918-1920) atuaram ativamente em defesa da revolução russa - aglutinava pintores, fotógrafos, cineastas etc., que buscaram transformar os paradigmas artísticos, visando à produção de uma arte consoante aos princípios revolucionários de Outubro. 
A constatação de possíveis convergências estéticas entre fascismo e stalinismo levou-me a investigações sobre os referentes históricos e teóricos de tais produções, bem como à reflexão sobre possíveis congruências nos campos político e cultural dos dois regimes em questão. Nesse sentido, os escritos de A. Gramsci (1891-1937) e W. Benjamin (1892-1940), em torno respectivamente das noções de "revolução passiva" (1932) e "estetização da política" (1935), foram articulados, em minha investigação, como aportes teóricos para a construção da problemática central desta tese de doutorado.

Como explicar a convergência de discursos visuais entro o fascismo e o stalinismo a partir de origens histórico-políticas tão dispares?

\subsection{Rússia e Itália, entre 1929 e 1934}

O objetivo inicial posto por minha investigação foi o de compreender o protagonismo da fotografia como instrumento de reprodução simbólica e dominação, na Itália e na URSS. No curso da investigação, a análise do material selecionado de um país, como uma roda dentada, transmitiu movimento à análise do material selecionado do outro país. Com isso, a proposta inicial, de efetuar uma análise comparativa entre algumas obras da mostra fascista de Roma (1932) e certas obras do pavilhão soviético da exposição de Colônia (1928), foi alterada e ampliada.

Para o aprofundamento da investigação sobre os usos e transformações da produção visual fascista e stalinista foi necessário trazer para a discussão outras produções russas do mesmo período. Nesse sentido, incluí, ainda que em alguns casos pontualmente, análises dos cartazes da IZOGIZ (durante $1^{\circ}$ Plano Quinquenal), ${ }^{7}$ da revista URSS em Construção (1930-1931) ${ }^{8}$ e das exposições “Artistas da URSS dos últimos 15 anos" (1932-1934). ${ }^{9}$

A tese estrutura-se em 4 capítulos, que articulam a análise e a investigação das produções artísticas selecionadas, com a apresentação e discussão, simultânea, dos principais acontecimentos e debates históricos, políticos e econômicos do período.

O capítulo 1, intitulado "UMA CENOGRAFIA TEATRAL": os embates artísticos russos e o pavilhão soviético na Exposição Internacional de Imprensa de Colônia (1928), aborda, num primeiro

\footnotetext{
${ }^{7}$ Editora Estatal da URSS. Com o lançamento do $1^{\circ}$ Plano Quinquenal (1929), o departamento de artes da IZOGIZ contratou muitos artistas de vanguarda para a produção de cartazes de celebração e divulgação da agenda de industrialização acelerada.

8 URSS em Construção foi um periódico russo de alta tiragem, publicado pela IZOGIZ. Ilustrada prioritariamente com fotografias e fotomontagens, a revista era dedicada ao registro das "conquistas e avanços" dos planos quinquenais e do "socialismo num só país". Era publicada na Rússia e no exterior.

9 “Artistas da URSS dos últimos 15 anos" foi uma retrospectiva, encomendada pelo governo da URSS, para a comemoração do $15^{\circ}$ aniversário da Revolução. Composta majoritariamente por pinturas, a abertura da primeira versão datou de 13 de novembro de 1932 (Leningrado) e a da segunda de 27 de junho de 1933 (Moscou).
} 
momento, a aparente contradição entre a política artística stalinista dentro da Rússia e a política artística stalinista fora da Rússia (em feiras, exposições e revistas internacionais). Num segundo momento, o capítulo discute tais contradições a partir da análise de algumas peças do pavilhão soviético na Exposição Internacional de Colônia (1928). Nessa segunda parte, discute-se ainda os embates do campo artístico russo e o uso inaugural da prática de fotografia e de fotomontagem lefistas, incorporadas à expografia do pavilhão soviético de Colônia.

Já o capítulo 2, "Algo de hoje, moderníssimo": a construção de um sistema artístico fascista (1927-1932), examina: a instalação de dispositivos de controle governamental e a constituição do sistema artístico fascista, realizadas por meio de novas instituições e estatização das já existentes (como a Bienal, Quadrienal etc.); a constituição de um circuito expositivo hierarquizado; e, por fim, a elaboração de políticas governamentais para gestão e fomento da arte, cultura e propaganda (festivais, bolsas, premiações etc.). Concomitantemente, o capítulo também aborda, à luz da noção de "revolução passiva", o esforço retórico de construção de uma cultura visual de massas fascista - da qual a Mostra da Revolução Fascista foi o grande corolário.

O capítulo 3, "Entre o fato e a farsa: uma estratégia comum", aprofunda a analisa em detalhes da Mostra da Revolução Fascista (1932), para então, em seguida, discutir sua recepção e os entrecruzamentos verificados entre a mostra e o pavilhão soviético de Colônia. Na segunda parte, o capítulo trata dos usos da fotografia durante o $1^{\circ}$ Plano Quinquenal stalinista e da gestação do "realismo socialista", nas duas edições da retrospectiva Artistas da URSS dos últimos 15 anos (19321934). Por fim, o capítulo discute as tangências entre as produções russas e fascistas em questão.

O capítulo 4, "Entre a política e o mito da modernização", discute as intersecções entre a "estetização da política" fascista e a política artística e cultural stalinista, a partir das intersecções entre as noções de "revolução passiva" (Gramsci) e "estetização da política” (Benjamin). 


\title{
CAPÍTULO 1 | "UMA CENOGRAFIA TEATRAL": ${ }^{10}$ 0 pavilhão soviético na Exposição Internacional de Imprensa de Colônia (1928)
}

\subsection{Preâmbulo | Os destroços do "barco do amor"}

\begin{abstract}
Quanto à ideia de que uma contrarrevolução burocrática alcançou o poder, e um novo Estado despótico emergiu de nossas mãos para nos esmagar e reduzir o país a um silêncio absoluto - ninguém em nossas fileiras estava disposto a admitir isso. Das profundezas de seu exílio em Alma-Ata, Trotsky afirmou que esse sistema ainda era nosso, ainda era proletário, ainda era socialista, embora doente; o Partido que estava excomungando, prendendo e começando a nos assassinar permanecia o nosso Partido, e nós ainda devíamos tudo a ele: nós devíamos viver só para ele, pois apenas por meio dele nós poderíamos servir à Revolução (Victor Serge, 1928). ${ }^{11}$
\end{abstract}

No início de 1928, o jornalista belga ligado ao partido bolchevique, Victor Serge (1890-1937), escreveu em suas memórias: “Alexandra Bronstein e eu éramos os únicos Oposicionistas conhecidos ainda em liberdade em Leningrado". ${ }^{12}$ Serge escrevia sobre os destroços do "barco do amor" - ou da Revolução de Outubro, conforme uma das leituras possíveis da alegoria criada pelo poeta Vladimir Maiakovski (1893-1930), dois anos depois, em seu bilhete de suicídio. ${ }^{13}$

Entre 1927 e 1928, com a eliminação do último grande foco oposicionista dentro do partido bolchevique (a Oposição Unificada), a ala liderada por Stalin, sob a bandeira do "socialismo num só país", consolidou o processo Termidoriano em curso. ${ }^{14}$ Apesar de, após 1928, ainda existirem

\footnotetext{
${ }^{10}$ Em uma carta de 26 de dezembro de 1928, Lissitzky se lamentou dos prazos curtos para a montagem do pavilhão soviético de Colônia, que teriam reduzido o, em suas palavras, potencial estético e artístico da mostra a "uma cenografia teatral" ("un decorado teatral”). EL LISSITZKY, apud: ANYSLEY, Jeremy, "Pressa, Colonia, 1928 Diseño de exposiciones y publicaciones en la época de Weimer"(1994), in AA.VV., Espacios Fotográficos Públicos: Exposiciones de Propaganda, de Pressa a the Family of Man, 1928-1955, Barcelona, MACBA, pp. 83107, 2009 (catálogo de exposição), p. 103.

${ }^{11}$ SERGE, Victor, Memoirs of a revolutionary, trad. Peter Sedgwick, New York: Random House, 2012, pp. 283284.

12 SERGE, Victor, Memoirs of..., op.cit., p. 283.

13 "Como dizem: caso encerrado, o barco do amor espatifou-se na rotina. Acertei as contas com a vida, inútil a lista de dores, desgraças e mágoas mútuas. Felicidades para quem fica”. MAIAKOVSKI, 1930, apud MIKHAILOV, Aleksandr, Maiakovski - O Poeta da Revolução, trad. Zoia Prestes, Record: São Paulo, 2008, p. 534.

${ }^{14} \mathrm{O}$ termo "Termidor" era uma referência histórica ao 9 de Termidor do Ano II da Revolução Francesa (27 de Julho de 1794) - data em que os jacobinos foram derrubados. O evento marcou uma inflexão crítica na Revolução, inaugurando um período de acentuado declínio na atividade política de massa e um recuo da parte
} 
oposições, resistências e disputas internas e externas ao partido - como relatou Serge a respeito de Trotsky na citação acima $-{ }^{15}$ o ano de 1928 foi marcado por uma inflexão no campo político e econômico russo.

No campo artístico, a eliminação da oposição e a supressão dos embates entre grupos e correntes artísticas rivais se deram de forma menos direta e foram permeadas por uma série de fluxos, refluxos e contradições (aparentes) - especialmente entre o discurso visual nacional e internacional adotado pelo partido bolchevique. Nesse sentido, o presente capítulo, num primeiro momento, abordará o campo artístico russo e suas contradições à luz das principais inflexões políticoeconômicas do período, para então, num segundo momento, analisar a representação russa no pavilhão Internacional de Imprensa de Colônia (1928) e o uso inaugural da fotografia, da fotomontagem e da expografia de vanguarda enquanto dispositivos de disputas artísticas e políticas.

\subsubsection{Eliminação da Oposição (Unificada)}

A Oposição Unificada foi uma resultante do partido bolchevique, derivada da fusão de "trotskistas" e "zinovievistas" (daí o termo "unificada"). A oposição também contou com antigos

do governo em relação às medidas sociais radicais. Já após o termino da guerra-civil, o prospecto de que a Revolução Russa poderia experimentar um "Termidor" similar ao da Revolução Francesa assustava os operários e parte da liderança bolchevique. Conforme registrado em materiais de época ("memórias" de Victor Serge, por exemplo), no X Congresso do Partido, frente a alguns refluxos estratégicos (como a adoção da Nova Política Econômica/NEP [1922-1928], a deflagração da batalha de Kronstadt e a eliminação da Oposição Operária), Lênin teria comentado junto a membros do Politburo o Termidor como recurso da ditadura do proletariado isto é, como uma guinada à direita dirigida pelo próprio partido bolchevique que visava a assegurar as conquistas da Revolução proletária. Nas palavras de Lênin citadas por Victor Serge: "Não devemos nos deixar ser guilhotinados. Devemos, nós mesmos, fazer um Termidor”. SERGE, Victor, Memoirs..., op.cit., pp. 152-153. Ver: TWISS, Thomas Marshall, Trotsky and the problem of soviet bureaucracy, tese de doutorado, Pittsburgh: University of Pittsburgh, 2009, (disponível em <http://d-scholarship.pitt.edu/7502/1/twisstm_etd2009.pdf $>$ ), pp. 249-252.

${ }^{15}$ É importante ressaltar que o processo de construção de um poder monolítico sob direção de Stalin foi marcado por oposições e disputas internas como, por exemplo, com a Oposição de Direita, liderada por Bukharin e Rikov. No entanto, como escreveu o historiador francês Pierre Broué, no interior do partido a derrota e o expurgo da Oposição de Esquerda e da Oposição Unificada "se converteu de fato na derrota do espírito bolchevique, encarnado naqueles últimos defensores do entusiasmo revolucionário". BROUÉ, Pierre, $O$ Partido Bolchevique, trad. Henrique Canary e João Simões, São Paulo: Sundermann, 2014, p. 265. No plano externo ao partido, conforme argumenta o historiador russo Aleksei Gusev, após a eliminação da Oposição Unificada, ainda ocorreram debates e movimentações da classe trabalhadora, com posicionamentos próximos ou mesmo mais à esquerda que os da Oposição Unificada. Ver: GUSEV, Aleksei, "The 'Bolchevik Leninist' opposition and the Working Class, 1928-1929", in FILTZER, GOLDMAN, KESSLER AND PIRANI (editors), A Dream Deferred New Studies in Russian and Soviet Labour History. International and Comparative Social History, vol.11., New York: Peter Lang AG, Internationaler Verlag der Wissenschaften, 2008. A própria Oposição de Esquerda continuaria a existir e opor-se aos refluxos stalinistas, ainda que na clandestinidade ou no exílio. Ver: TROTSKY, L., The Challenge of the Left Opposition (1923-1925), edited with an introduction by Naomi Allen, New York: Pathfinder Press, 1975, p. 48. 
integrantes da Oposição Operária (1920-1921), retomou as pautas da Oposição de Esquerda (“declaração dos 46”, 1923) - como a crítica ao crescente burocratismo e ao livre mercado - e propôs um programa de planificação econômica (industrialização) articulado ao fomento do poder operário. Um outro ponto fulcral da oposição foi a crítica ao abandono da dimensão internacionalista da Revolução, na concepção do "socialismo num só país”. A Oposição Unificada constituiu um movimento significativamente forte, obtendo grande adesão entre as fileiras operárias e no Politburo (como Trotsky, Znoviev e Kamenev). ${ }^{16}$

Com base na resolução de 1921, "sobre os desvios sindicalistas e anarquistas em nosso partido", que proibia a formação de frações internas, Trotsky e Zinoviev foram expulsos do partido bolchevique, logo após o X aniversário da revolução (24 de outubro de 1927). No mesmo período, outros 75 trabalhadores oposicionistas também foram expulsos e doze membros do Comitê Central, afastados - entre eles, Kamenev. No final de 1927, sob acusação de praticar "atividades contrarrevolucionárias", Trotsky foi deportado de Moscou.

\subsubsection{0 embate no campo artístico}

No âmbito das artes e da cultura, a eliminação (se é que podemos falar em eliminação) dos grupos oposicionistas e a adoção de uma doutrina artística oficial (o "realismo socialista", 1934), foi um pouco mais lenta e tortuosa. Apesar de em 1921 haver uma primeira tentativa de intervenção direta do partido nas esferas da arte e da cultura, até 1934 (data de adoção do "realismo socialista") não havia uma diretriz bolchevique oficial nesse campo.

Após o termino da guerra-civil e adoção da NEP (1921), o partido começou a preocupar-se com as esferas da arte e da cultura, especialmente com o Narkompros (órgão estatal soviético equivalente a um Ministério da Educação e Cultura) e o Proletkult.

O “Movimento Cultura Proletária” (Proletkult, 1917-1923) foi uma organização cultural autônoma russa. Em 1920, o alto número de filiados (superior ao do partido bolchevique) e a influência que a organização exercia entre os grupos de trabalhadores, teria alarmado o partido bolchevique. ${ }^{17}$ Segundo a historiadora da arte norte-americana, Sheila Fitzpatrick, o próprio Lênin teria conduzido o processo de atrelamento do Proletkult ao Narkompros (com uma substantiva

\footnotetext{
${ }^{16}$ Segundo o biografo de Trotsky Isaac Deutscher, o registro do número de militantes da Oposição Unificada entre a classe trabalhadora variava entre 4.000 e 8.000 mil adeptos. DEUTSCHER, Isaac, Trotsky: O profeta desarmado, trad. Waltensir Dutra, Rio de Janeiro: Civilização brasileira, 1966-1968, p. 295.

${ }^{17}$ Além do alto número de filiados do Proletkult, outros fatores que teriam preocupado Lênin seriam: o grande número de integrantes de vanguarda que atuavam dentro do movimento; a proximidade do Proletkult a alguns integrantes da Oposição Operária; e o fato de que um dos dirigentes e fundadores do movimento era Aleksandr Bogdanov (1873-1928), de quem Lênin era um ferrenho opositor. O embate entre Bogdanov e Lênin antecedia a própria Revolução de Outubro. Em 1909, Bogdanov foi inclusive expulso do partido bolchevique russo por divergências teóricas. FITZPATRICK, Sheila, The commissariat of education under Lunacharsky (1917-1921), Ph.D. dissertation, United Kingdom, University of Oxford, 1969, pp. 226-227.
} 
redução orçamentária do primeiro) e a subordinação das produções do Proletkult e do Narkompros ao controle do Glavpolitprosvet (Colegiado Central para a Educação Política), o qual obteve o direito de veto, por razões políticas, de todas as produções do Narkompros e do Proletkult, em 1921. ${ }^{18}$

Segundo Fitzpatrick, os órgãos de controle e reorganização do campo artístico, como o Narkompros e o Glavpolitprosvet, só passaram a de fato dirigir e intervir incisivamente nas produções deste setor na virada dos anos 20 para os $30 .{ }^{19} \mathrm{~A}$ consulta a documentos de época ${ }^{20}$ indica que até abril de 1932 (data do decreto "sobre a restruturação das organizações artístico-literárias", que dissolveu e proibiu organizações e agrupamentos artísticos) os artistas possuíam ainda protagonismo na vida pública russa, promovendo debates, exposições e textos nos quais se posicionavam frente à questão da arte e rivalizavam concepções artístico-políticas. ${ }^{21}$

A ausência de uma diretriz artística nas esferas da arte e da cultura não indicava, entretanto, a ausência de favoritismos nem de certo nível de coação e censura partidária nesse âmbito. Oficialmente, até 1932 o processo de censura e coação era conduzido transversalmente, por meio de boicote das produções de vanguarda e fomento de produções artísticas tradicionais, na constituição de acervo e ornamentação de repartições públicas, nas obras encomendadas para a celebração das datas festivas (aniversário da Revolução, $1^{\circ}$ de maio etc.), ${ }^{22}$ nos processos de reestruturação das

${ }^{18}$ Conforme Fitzpatrick, um dos motivos que teria levado à reestruturação do Narkompros (com o consequente atrelamento do Proletkult ao Narkompros e a subordinação de ambos ao Glavpolitprosvet) seria a suposta grande abertura e permissividade de Lunatcharsky (Comissário para o esclarecimento do povo, ou seja, chefe do Narkompros) para com os artistas de vanguarda. Havia também o temor, por parte de integrantes da direção do partido bolchevique, de que Lunatcharsky não conseguisse controlar o Proletkult por sua proximidade com os artistas de vanguarda, bem como por ele ter sido um dos fundadores do Proletkult. Em relação à repercussão no Politburo do posicionamento (favorável à autonomia do Proletkult) de Lunatcharsky numa conferência do Proletkult (ocorrida três dias antes da resolução da VTSIK que reestruturava o Narkompros), Fitzpatrick escreveu: "A tolerância que o Narkompros mostrou em relação ao Proletkult foi vista como característica de sua política, e alguns líderes do Partido confirmaram as suas suspeitas de que o Narkompros era politicamente duvidoso, administrativamente desorganizado e intimidado pela intelligentsia [artistas de vanguardas, incluídos neste rótulo]". FITZPATRICK, Sheila, The commissariat..., op. cit., pp. 226-227.

${ }^{19}$ FITZPATRICK, S., "The Emergence of Glaviskusstvo: Class War on the Cultural Front, 1928-29", in Soviet Studies, vol. 23, no. 2 (outubro), Glasgow: University of Glasgow, Taylor \& Francis, Ltd., 1971, pp. 236-253, p. 238

${ }^{20}$ Foram consultados, entre outros, periódicos de grupos artísticos: Lef, Novyi Lef, Sovetskoe Foto etc. e relatórios de atividades de instituições de arte e cultura, Narkompros, Glavpolitprosvet etc.

${ }^{21}$ Chlenova menciona inclusive que, para muitos críticos e artistas da época, o decreto de abril de 1932 foi recebido positivamente, enquanto um dispositivo não de censura e favoritismos, mas de apaziguamento e reconciliação artística devido ao grande número de discussões públicas, embates e troca de acusações entre grupos artísticos, em curso no final dos anos 20. "Outra figura chave da administração artística soviética, Alexei Volter, publicou a declaração programática na edição inaugural do jornal Iskusstvo, na qual ele interpretou o decreto de abril como um retorno à 'normalidade' e o fim dos confrontos da 'guerra de classes', afirmando que a União dos Artistas Soviéticos significava 'forçar todos os artistas a trabalhar juntos, pacificamente, sob o mecenato do estado"'. CHLENOVA, Masha, On Display: Transformations of the Avant-Garde in Soviet Public Culture, 1928-1933, Ph.D. dissertation, New York: Columbia University, 2010, pp. 46-47.

${ }^{22}$ Em seus textos e periódicos, o grupo Frente de Esquerda das Artes (LEF, 1922-1928) diagnosticou e questionou tais práticas e preferências partidárias. A esse respeito pode-se citar o editorial da revista $L E F$ de 1923 e o artigo "O atual mercado da arte e a 'pintura de cavalete", do lefista B. Arvatov (1896-1940), de 1928: "Hoje, primeiro de maio, os trabalhadores de todo o mundo manifestam-se em canções e festividades. Cinco anos de grandes conquistas. Cinco anos de palavras de ordem cotidianamente renovadas e cotidianamente 
instituições artísticas e montagem de exposições oficiais e, em momentos chaves de inflexões politicas e econômicas.

Nesta direção, cabe mencionar o reconhecimento extraoficial da AKhRR em 28 de fevereiro de 1928. Na ocasião da exposição "10 anos do Exército Vermelho" a preferência do partido pela AKhRR foi explicitada, após a visita do birô politico do PC à exposição - privilégio que até então não fora concedido a nenhum artista ou grupo de artistas. ${ }^{23}$

A Associação dos Artistas da Rússia Revolucionária (AKhRR, 1922-1932) propunha o retorno ao figurativismo e adotou como estilo artístico o "realismo heroico" - antecessor do "realismo socialista". Uma contradição em termos, o "realismo heroico" consistia na suposta documentação "realista" e heroica da revolução em curso. Devido aos temas (exército vermelho, os heróis do trabalho etc.), ao estilo pictórico elegido (figurativista) e ao forte teor propagandístico (assimilação rápida, fácil e contemplativo-passiva), a AKhRR foi a associação artística mais alinhada às demandas institucionais russas (ornamentação de repartições públicas, constituição de acervo de museus e exaltação litúrgica e acrítica da Revolução).

\subsection{URSS em contradição?}

Se, internamente - principalmente após a consolidação político-policial do suposto “socialismo num só país" -, verificou-se a aproximação da cúpula do partido das escolas artísticas "de cavalete" (pinturas e esculturas figurativistas), externamente, no campo das relações exteriores, verificou-se um movimento inverso. ${ }^{24}$ Justamente nos momentos de maior aproximação do partido

realizadas. Cinco anos de vitórias. E cinco anos de celebrações monótonas. É o balanço quinquenal da impotência quinquenal da arte. [...] Parem de adornar a fácil existência da burguesia da NEP!"; e, "Para o aniversário de Outubro, o governo soviético comissionou, para uma série de pintores de cavalete, quadros sobre os assim ditos temas revolucionários. $\mathrm{Na}$ ocasião da exposição desses quadros foi sustentado e continua-se a sustentar a seguinte ideia: a evolução da arte é determinada pela assim dita ordenação social. Na sociedade capitalista, a ordenação não é regulada, efetua-se por meio do mercado, nas costas dos artistas. Nas condições da economia soviética, o comprador é o Estado e a ordenação é direta. [...] As ordenações estatais, que periodicamente são organizadas, não só definem as evoluções da arte, mas também as sustentam materialmente". LEF, “Declaration: comrades organizers of life!" (1923), in BOWLT, John (edit.) E., The documents of 20th-century art/Russian Art of the Avant-Gard: Theory and Criticism 1902-1934, NY: The Viking Press, pp. 199-201, 1976, p. 199. Tradução para o Italiano in MAGAROTTO, L.; SCALIA, G. (a cura di), L' avanguardia dopo la rivoluzione. Le riviste degli anni Venti nell'URSS: «Il giornale dei futuristi», "L'arte della Comune», "Il Lef», "Il nuovo Lef», Roma: Edizioni Immanenza, 1976, pp. 168-169, p.168; e ARVATOV, B., "L'attuale mercato dell'arte e la pittura di cavalletto", LEF n. 2, 1928; trad. Italiana, in MAGAROTTO, L.; SCALIA, G. (a cura di), L' avanguardia..., op. cit., pp. 253-258, p. 258.

${ }^{23}$ ALBERA, F., Eisenstein e o construtivismo russo, trad. Heloisa Araújo Ribeiro, São Paulo: Cosac \& Naify, 2002, p. 185.

24 "Arte de cavalete" ou "pintura de cavalete" era o modo como os integrantes do grupo LEF chamavam as formas artísticas tradicionais, pré-revolucionárias ou burguesas. A noção de "arte de cavalete" referia-se a produções artísticas baseadas em procedimentos e suportes artesanais, como a pintura em tela. TARABUKIN, Nikolai, El ultimo quadro: del caballete a la maquina, trad. Andrei B. Nakov, Barcelona: G. Gili, 1977. Segundo os lefistas, as formas artísticas de "cavalete" tinham seu modo de produção e circulação condicionados pelo sistema capitalista. Fruto de um modo de produção artesanal, caro e individualista, a "arte de cavalete" reiterava a 
bolchevique das formas artísticas tradicionais, de "cavalete", em grandes pavilhões e feiras internacionais o partido convidou, para representá-lo, artistas oposicionistas (ligados às vanguardas). Assim ocorreu na Bienal de Veneza (1924, 1928 e 1932); na Exposição Internacional de Artes Decorativas e Industriais Modernas, em Paris (1925) (Figuras 1, 2 \& 3); na Exposição Internacional de Imprensa de Colônia (1928) (Figura 4); na Filme e Foto/FIFO, em Stuttgart (1929) (Figura 5); na Exposição Internacional de Higiene, em Dresden (1930) (Figura 6); e, na Exposição Internacional de Couro, em Leipzig (1930) (Figura 7).

\subsubsection{A oposição de esquerda das artes}

Um dos principais grupos de oposição às medidas e diretrizes políticas, econômicas e artísticas do partido e das "artes de cavalete" foi o grupo Frente de Esquerda das Artes (LEF, 19221928).

Grupo interdisciplinar que buscava desenvolver uma arte ligada às premissas da Revolução de Outubro, ${ }^{25}$ o LEF, em seus trabalhos e textos, opôs-se veementemente ao retorno da "arte de cavalete", preconizado pela AKhRR. O grupo opôs-se também ao apoio e fomento, por parte do partido bolchevique, de produções artísticas e culturais de "cavalete". ${ }^{26}$

Os registros textuais de embates e debates entre os lefistas e a direção do partido bolchevique e os membros da AKhRR são muitos. ${ }^{27}$ Entre 1928 e 1929, frente ao reconhecimento extra-oficial da AKhRR e a eliminação da Oposição Unificada, os lefistas, ancoradas na noção de "encomenda social", ${ }^{28}$ produziram textos nos quais propunham uma forma de auto-organização artística pautada

função do especialista (justificado no reconhecimento autoral) apartado do modo de produção de seu tempo (revolução técnica e social em curso). Destinada a ambientes privados (apartamentos, museus e escritórios) e à fruição individual, contemplativa e estratificada, a "pintura de cavalete" estaria em contradição com as formas artística desejadas numa sociedade coletivizada. Ver: ARVATOV, B., "L'attuale mercato dell'arte e la pittura di cavalletto", N. Lef, 2, 1928; trad. Italiana in MAGAROTTO, L.; SCALIA, G. (a cura di), L' avanguardia dopo la rivoluzione..., op. cit., pp. 253-258.

${ }^{25}$ O LEF era composto por pintores, cineastas, fotógrafos, poetas e teóricos de diversas correntes de vanguarda, como futuristas, construtivistas e produtivistas. Entre outros, integraram o LEF: V. Maiakovski (1893-1930), B. Arvatov (1896-1940), S. Tretiakov (1892-1937), A. Rodchenko (1891-1956) e V. Stepanova (1894-1952). Na órbita do LEF encontravam-se V. Tatlin (1885-1953), S. Eisenstein (1898-1948) e D. Vertov (1896-1954). Sobre o grupo LEF, ver: ALBERA, F., Eisenstein..., op. cit.; FIGUEIREDO, C. F., Foto-grafia/o debate na Frente de Esquerda das Artes, Universidade de São Paulo, 2012 (disponível em $<$ http://www.teses.usp.br/teses/disponiveis/27/27160/tde-05032013-110221/en.php >); e, ZALAMBANI, M., L' Arte Nella Produzione: Avanguardia e Rivoluzione nella Russia Sovietica degli anni'20, Ravenna: Longo Editore, 1998.

${ }^{26}$ Ver: FIGUEIREDO, C., “Uma noiva vermelha!”, in SILVA, M., (org.), Revolução russa: passado e presente, São Paulo: Todas as musas, pp. 51-82, 2017.

${ }^{27}$ Ver: VILELLA, Thyago M., O ocaso de outubro: o construtivismo Russo, a Oposição de Esquerda e a Reestruturação do Modo de Vida, dissertação de mestrado, São Paulo: PPGAV-USP, 2014 (disponível em: $<$ http://www.teses.usp.br/teses/disponiveis/27/27160/tde-02032015-104723/pt-br.php $>$ ).

${ }^{28}$ A noção de "encomenda social" partia do pressuposto de que não existiria uma arte universal, mas, assim como em um front de guerra de classes, uma produção artística deveria ser pensada de acordo com os interesses e finalidades de sua classe (no caso do LEF, o campesinato e o proletariado). É importante mencionar que a 
na necessidade da existência de divergências internas a uma mesma classe e da classe com seus representantes formais (o que incluiria, no caso, o partido bolchevique). Conforme escreveu o lefista O. Brik (1888-1945) em 1929:

Se o comitê de Belas Artes de Moscou quer encomendar bustos e monumentos para embelezar a cidade e os lefistas se recusam, e, refutando essa encomenda, sugerem pavimentar as estradas, estes se opõem ao comitê não como a um outro grupo social: a diversidade de opiniões vai colocada no interior dos dois grupos de mesma natureza social que compreendem de maneira diferente as necessidades da mesma classe. ${ }^{29}$

\subsubsection{Feiras e exposições internacionais}

A despeito do claro oposicionismo do grupo (visado por parte da cúpula do partido desde $1921)^{30}$ e da preferência do partido por grupos como AKhRR, foi justamente aos integrantes do grupo LEF ou aos artistas de vanguarda que circulavam em sua órbita que o partido atribuiu a incumbência de sua representação em grandes feiras e pavilhões internacionais.

Entre 1924 e 1925, após a morte de Lênin, o partido bolchevique (particularmente a ala mais próxima a Stalin) adotou uma série de práticas litúrgicas, dentre as quais constavam encomendas

noção de "encomenda social" deveria perpassar todos os elementos constitutivos de uma obra - escolha de materiais, forma, conteúdo, modo de produção e circulação. "Quando os lefistas falam de encomenda [social], não entendem uma encomenda feita por representantes individuais da classe, nem de organizações específicas, nas quais se manifesta a vontade da classe. Se trata, ao invés disso, de uma compreensão autônoma dessa encomenda, que pode entrar em contradição com a encomenda real dos representantes dessa classe". BRIK, O., "Non una teoria, ma solo un slogan", Péchat'i Revolutsia, Moscou, 1929; trad. Italiana, in MAGAROTTO, L.; SCALIA, G. (a cura di), L' avanguardia..., op. cit., pp. 293-299, p. 297.

${ }^{29}$ BRIK, O., "Non una...", op. cit., p. 298. Ver: ALBERA, F., Eisenstein..., op. cit., pp. 180-181; 260 e FIGUEIREDO, C., “Uma noiva...”, op. cit., pp. 56-60.

${ }^{30} \mathrm{~A}$ título de exemplo de uma maior intervenção do partido no campo artístico-cultural (e do boicote do mesmo às produções de vanguarda e do LEF), podemos citar, além da já mencionada vinculação do Proletkult ao Narkompros, a censura de Lênin a Lunatcharsky pela alta tiragem de um livro de Maiakovski em 1921. No período da adoção da NEP (maio de 1921), Lênin escreveu um bilhete dirigido ao bolchevique M. N. Pokrovski (1868-1932), sucessor de Lunatcharsky na direção do Narkompros, pedindo a ajuda deste para barrar a influência e promoção das artes de vanguarda. "Peço-lhe mais uma vez que nos ajude na luta contra o futurismo etc. 1. Lunatcharsky conseguiu do Colégio (ai de mim!) a publicação dos "150 000000 ", de Maiakovski. Será que não é possível colocar um limite nisso tudo? É preciso limites. Acertemos a não-publicação desses futuristas mais de duas vezes por ano, e não mais do que 1500 ex.; 2. Parece que Lunatcharsky ordenou ainda que se eliminasse Kisselis, que é, dizem, um artista "realista", para substituí-lo por um futurista, direta e indiretamente". LENIN, (06.05.1921) in Lenin, Oeuvres completes, apud: ALBERA, F., Eisenstein..., op. cit., p. 184. É importante relembrar que o grupo LEF, assim como muitos grupos de vanguarda, vinha do Proletkult e trabalhava ou trabalhara no mesmo. Conforme a italiana Maria Zalambani revela, os lefistas, tinham uma influência prática e teórica no Proletkult. O que nos faz ver a própria constituição do LEF (entre 1922-1923) como uma espécie de reorganização e reação aos ataques do partido ao movimento. 
massivas de obras de "cavalete" que canonizavam o líder falecido. ${ }^{31} \mathrm{Na}$ mesma época (1924-1925), o partido encomendou ao arquiteto construtivista Konstantin Melnikov (1890-1974) e ao lefista Aleksander Rodchenko o projeto, a montagem e a execução do pavilhão soviético na Exposição Internacional de Artes Decorativas e Industriais Modernas, em Paris (Figuras 1, 2 \& 3).

Cabe mencionar que o grupo LEF opôs-se ferrenhamente à prática de culto de Lênin, fomentada pelo partido bolchevique. ${ }^{32}$ Uma das obras centrais concebidas por Rodchenko para o pavilhão de Paris era, justamente, uma contraposição crítica ao culto de Lênin e às práticas contemplativas nas esferas artísticas, políticas e econômicas russas (fomentadas pelo partido). ${ }^{33}$

Em 1928, dois meses após a visita do Politburo à exposição da AKhRR, foi inaugurado em Colônia um pavilhão soviético idealizado e montado pelo artista de vanguarda ligado ao LEF, El Lissitzky (1890-1941), em parceria com um coletivo de artistas e segundo o esquema de produção coletiva do LEF (Figura 4).

${ }^{31} \mathrm{O}$ culto à figura de Lênin envolveu os mais variados âmbitos da vida russa e proporcionou aos grupos dominantes na direção do partido bolchevique um símbolo unificador - apto a inspirar lealdade e devoção durante o período de potencial instabilidade política que se seguiu à morte de líder. O culto de Lênin, foi um dos eixos centrais da construção de poder stalinista, na medida em que tal prática foi utilizada para o envolvimento litúrgico das massas e como justificativa retórica (na maioria das vezes ancorada em falseamentos e descontextualizações de citações e propostas de Lênin) para ações e medidas stalinistas. Conforme afirmou Trotsky em 1929: "Os epígonos [ala bolchevique liderada por Stalin] recortaram seus [de Lênin] livros em citações e foi com esta arma que começaram a combater o Lênin vivo, ao mesmo tempo que levantavam mausoléus, não só na praça Vermelha, mas até na consciência do Partido. Como prevendo a sorte que caberia, dentro em pouco, às suas ideias, Lenin começou o livro 'O Estado e a Revolução' pelas palavras seguintes, consagradas ao destino dos grandes revolucionários: 'Após a sua morte, tentam convertê-los em inofensivos ídolos, canonizá-los por assim dizer, rodeando seu nome de uma auréola de glória para a 'consolação' das classes oprimidas e para a sua mistificação, ao mesmo tempo que se castra a substância de seus ensinamentos revolucionários, que se lhe embota o gume, que se o avilta [sic]". TROTSKY, L., A Revolução desfigurada, trad. João Leske, São Paulo: Livraria Editora Ciências Humanas, 1979, p. XVI. Acerca do culto de Lênin, ver: TUMARKIN, Nina, Lenin lives! The Lenin cult in Soviet Russia, Cambridge: Harvard University Press, 1997.

${ }^{32}$ É importante mencionar, para que não incorramos em generalizações, que o culto da imagem de Lênin foi recebido com grande reticência por membros do próprio partido bolchevique e entre os núcleos de trabalhadores mais críticos. Nesse sentido, é ilustrativa a denúncia que a viúva de Lênin, Nadezhda Krupskaia (1869-1939), fez no Pravda em 30 de janeiro de 1924. Segundo ela: "não deveríamos venerar o corpo do camarada Lênin, mas a sua causa!". KRUPSKAIA, N. apud DICKERMAN, Leah, Aleksandr Rodchenko's Camera-Eye: Lef Vision and the Production of Revolutionary Consciousness, (tese de doutorado), New York: Departamento de Filosofia/Universidade de Columbia, 1997, pp. 75-76.

${ }^{33}$ Por ocasião da morte de Lênin e da adoção das primeiras medidas de veneração de seu corpo, o LEF publicou no editorial de seu jornal (Lef, n.1, 1924) a seguinte denúncia: "Nós concordamos com os trabalhadores da estrada de ferro de Kazan RR, que pediram a um artista que decorasse o salão Lênin de seu clube sem bustos e retratos, dizendo: 'nós não queremos ícones'. [...] Sigam as lições de Lênin, não o canonizem. [...] Não comercializem Lênin em artigos desse culto. (Lef, n.1, 1924). Apud ALBERA. F., Eisenstein... op. cit., p. 263, nota27. Para consultar a versão no original (russo), ver: <http://www.ruthenia.ru/sovlit/jour.html $>$, acessado em 25 de outubro de 2017. Sobre a crítica do LEF ao culto de Lênin e o projeto que Rodchenko expôs em Paris, ver: FIGUEIREDO, C., "Não comercializem Lênin! A crítica da LEF ao culto de Lênin", in Dazibao - crítica de arte, n.4, 2016, disponível em: <http://dazibao.cc/textos/nao-comercializem-lenin-a-critica-da-lef-ao-culto-de-lenin/ $>$, acessado em 25 de outubro de 2017. 


\subsubsection{Publicações de alta tiragem}

O rápido crescimento da construção socialista da União Soviética está evocando grande interesse nos países estrangeiros. Assim sendo, a Editora Estatal da URSS concebeu a ideia de publicar uma revista ilustrada especial, a URSS em Construção, refletindo a construção colossal que está ocorrendo na União Soviética.

A Editora Estatal escolheu a fotografia como método de ilustração da construção socialista, porque uma foto é, em muitos casos, mais convincente do que o mais brilhante dos artigos.

A URSS em Construção será publicada mensalmente em edições especiais em Inglês, Alemão, Francês e Russo.

O conselho editorial da URSS em Construção espera que a revista alcance a merecida atenção por parte daqueles interessados no progresso da construção socialista na URSS.

(“Dos editores”, URSS em Construção, 1930, no.1) ${ }^{34}$

Em 1930, quando a nascente indústria cultural stalinista investiu num periódico ilustrado para circulação massiva interna e externa, a URSS em Construção (1930-1941), foi justamente à estética, às práticas e aos próprios artistas de vanguarda que eles recorreram. URSS em Construção (1930-1941) foi um periódico quinzenal de alta tiragem, ilustrado prioritariamente com fotografias e fotomontagens (Figuras 8, 9 \&10). A revista era dedicada ao registro das "conquistas e avanços" dos planos quinquenais e do "socialismo num só país" 35 e era publicada em russo, inglês, francês e alemão.

Segundo a historiadora da arte Erika Wolf, "muitos colaboradores editoriais e de criação da revista [URSS em Construção] colaboraram em tal pavilhão [o pavilhão soviético da Exposição Internacional de Imprensa de Colônia]". ${ }^{36}$ Conforme o depoimento de um dos idealizadores da revista URSS em Construção, Máxime Gorki (1868-1936), a ideia de um periódico ilustrado (com fotografias e fotomontagens), de alta tiragem e circulação nacional e internacional, teria surgido após a constatação do sucesso do pavilhão soviético na exposição de Colônia (1928) na imprensa

\footnotetext{
34 "From the Editors", USSR in Construction, 1930, n.1, apud WOLF, E., USSR in Construction: From AvantGarde to Socialist Realist Practice, Ph.D. dissertation, Ann Arbor: The University of Michigan, 1999, p. 12.

${ }^{35}$ WOLF, E., USSR in Construction..., op. cit., p. 5.

${ }^{36} \mathrm{~A}$ revista contava com a participação de uma série de artistas e fotógrafos das mais variadas tendências - como os lefistas A. Rodchenko e V. Stepanova, o já mencionado El Lissitzky e o artista de vanguarda alemão J. Heartfield (1891-1968). WOLF, E., USSR in Construction..., op. cit. (Figuras 8, 9 \& 10).
} 
internacional (como será discutido a seguir) ${ }^{37}$ e seguia os mesmos propósitos do pavilhão: divulgação "do rápido crescimento da construção do socialismo" 38 - conforme o editorial do número 1 da URSS em Construção supracitado. Na mesma direção da contradição apontada nos parágrafos anteriores, cabe lembrar que Gorki também foi um dos idealizadores da doutrina artística stalinista, o "realismo socialista" (1934).

Após a visita ao pavilhão de Colônia, Gorki deu uma série de entrevistas nas quais deixou claro o seu entusiasmo com o pavilhão. Entre elas, cabe destacar a longa reportagem publicada no Pravda (29 de maio de 1928), na qual Gorki aponta um importante desdobramento possível do pavilhão: a produção de uma revista para circulação nacional e internacional que transmitisse otimismo e divulgasse as "conquistas" do "socialismo num só país" - vale mencionar que essa abordagem otimista e apologética, ressaltada por Gorki, era um dos eixos característicos do "realismo heroico" e do futuro "realismo socialista" .

Elas [as notícias da imprensa soviética] alimentam a sarjeta [gutter] do Ocidente. Pouco é dito sobre nossas conquistas. O camarada Khalatov apresentou uma excelente ideia sobre a publicação de uma revista Nashi dostizheniia [Nossas Conquistas]. Sim, nós precisamos de tal revista - e não para o Ocidente. Não, para nós, para consumo interno. Nós não vemos essas conquistas, porque estamos imersos nelas, mas elas precisam ser vistas, é necessário. ${ }^{39}$

No ano seguinte à entrevista de Gorki foi criada a revista "Nossas Conquistas" (1929-1937), dedicada à divulgação das "conquistas" do $1^{\circ}$ Plano Quinquenal. Conforme apontado por Gorki, a revista enfatizava os elementos positivos do "socialismo num só país". Concebida num primeiro momento como um suplemento ilustrado de "Nossas Conquistas" para circulação internacional, a revista URSS em Construção explicitava a herança do pavilhão de Colônia por seu caráter internacionalista, pela forte influência da linguagem de vanguarda e pelo uso quase exclusivo de fotografias e fotomontagens (características do pavilhão soviético de Colônia, como será discutido na sequência). ${ }^{40}$

\footnotetext{
${ }^{37}$ Máxime Gorki era o pseudônimo de Aleksei Maksimovich Peshkov, um importante escritor e dramaturgo russo. Em sua juventude, Gorki foi um ativo militante, tendo inclusive participado da tentativa insurrecionaria de 1905 (o que o levou à clandestinidade e ao exílio). Amigo pessoal de Lênin desde 1902, Gorki sempre manteve uma relação muito próxima ao partido bolchevique. Gorki foi um dos principais escritores do regime stalinista.

38 "From the Editors", USSR in Construction, 1930, n.1, apud WOLF, E., USSR in Construction..., op. cit., p. 12.

${ }^{39}$ GORKI, Pravda (29 de maio de 1928), apud WOLF, E., USSR in..., op. cit., p. 35.

${ }^{40}$ Segundo Wolf, num primeiro momento o suplemento ilustrado visava ao público estrangeiro, sendo somente posteriormente direcionado também à circulação interna. WOLF, E., USSR in..., op. cit., pp. 40-43. A consulta dos arquivos e de vários exemplares da revista nas diversas línguas, mostra pouca diferença entre os exemplares nacionais e os exemplares para o público externo. No entanto, é possível perceber algumas diferenças de
} 


\title{
1.30 pavilhão soviético na Exposição \\ Internacional de Imprensa de Colônia (1928)
}

\author{
No Pavilhão Soviético são expostos, de modo excelente e original, não apenas os \\ resultados do trabalho colossal de nossa imprensa, mas também o próprio \\ processo do trabalho em movimento. \\ As exposições em todos os outros pavilhões são diagramas, livros e afins, \\ apresentados em condições estáticas. Muito disso é executado de forma bonita, \\ elegante, tudo mais ou menos familiar; no todo, é o carimbo pesado do \\ tradicionalismo, da inércia. \\ É como se a massa plural de impressos, executada primorosamente, dissesse: \\ "Isto é sobre onde a imprensa dos governos europeus PAROU". \\ O Pavilhão Soviético diz: "Aqui é como e onde a imprensa da trabalhadora e \\ camponesa União Soviética está INDO”. ${ }^{41}$
}

Em 25 de maio de 1928 foi inaugurado, em Colônia, o pavilhão soviético na Exposição Internacional de Imprensa. O pavilhão foi projetado pelo artista de vanguarda russo El Lissitzky (1890-1941), montado pelo próprio El Lissitzky e por Sergei Senkine (1894-1963) ${ }^{42}$ e fabricado em parceria com um "coletivo de criadores" ${ }^{43}$ de aproximadamente 38 artistas de vanguarda (em sua maioria, ligados às artes gráficas e à produção de cartazes de agitação e propaganda).

Concebido e construído no decorrer de 4 meses, as 227 peças (fotografias, montagens, objetos espaciais etc.) que compuseram o pavilhão foram fabricadas num esquema de produção intensiva e coletiva, nas oficinas das Colinas Lênin, em Moscou, e enviadas pré-fabricadas para Alemanha.

Enquanto uma encomenda estatal, o pavilhão soviético de Colônia (concepção e supervisão) era incumbência de um comitê composto por integrantes do partido bolchevique e presidido por

qualidade de impressão e tamanho (as revistas para circulação fora da Rússia eram um pouco maiores e com uma qualidade de impressão levemente superior).

${ }^{41}$ GORKI, Izvestiia, (1928), apud: WOLF, E., USSR in Construction..., op. cit., p. 34.

${ }^{42}$ Sergei Senkine, assim como Lissitzky, era ligado aos grupos de vanguarda. Ele foi aluno de muitos lefistas durante sua estadia na Vkhutemas e, em 1928, filiou-se ao grupo Outubro (1928-1932). O grupo Outubro foi um grupo de artistas de vanguarda pluridisciplinar (arquitetos, fotógrafos, pintores, cineastas e historiadores da arte) que denunciava o isolamento nacional do "socialismo num só país" e propagava os ideários de uma arte revolucionária proletária. Grande parte dos artistas ligados ao LEF aderiram ao grupo Outubro. Sobre o grupo Outubro, ver: ALBERA, F., Eisenstein..., op. cit.

${ }^{43}$ BUCHLOH, B., "De la faktura a la factografia"(1984), in AA.VV., Espacios Fotográficos Públicos..., op. cit., pp. 29-61, p. 50. 
Anatoly Lunatcharsky (1875-1933). ${ }^{44}$ Foi esse comitê que, em 23 de dezembro de 1927 (6 meses após a URSS ter sido oficialmente convidada a participar da exposição e 5 meses após a constituição do dito comitê para a organização do pavilhão de Colônia), convidou EL Lissitzky para projetar o pavilhão.

O comitê também definiu o tema central do pavilhão: "a imprensa como uma arma e uma participante da construção do socialismo na URSS" ${ }^{45}$ na esteira dos planos quinquenais - em discussão desde dezembro de $1927 .{ }^{46}$ Além disso, esse mesmo comitê supervisionou todas as etapas de desenvolvimento do pavilhão e suas as atas das reuniões sugerem que todo o trabalho artístico deveria ser submetido à aprovação oficial. ${ }^{47}$

Entre 1927 e 1929, devido a uma série de crises de abastecimento das cidades, em função da elevação de impostos, escassez de bens de consumo, problemas com os Kulacs, greves e instabilidade fabril, começou-se a falar sobre a questão da coletivização dos campos e da necessária adoção de um planejamento econômico.

A crise de abastecimento levou à adoção, no primeiro semestre de 1928, das "requisições forçadas" nos campos. Tais práticas agravaram a relação já estremecida entre o campo-cidade (um dos pilares da Nova Política Econômica/NEP). Entre 1928 e 1929, o partido, então, abandonou a NEP e adotou o $1^{\mathrm{O}}$ Plano Quinquenal e a coletivização forçada no campo.

Nas cidades, o $1^{\circ}$ Plano Quinquenal consistiu num planejamento de industrialização acelerada, pautado por metas altíssimas a serem alcançadas no curso de 5 anos. No campo, as coletivizações forçadas previam a estatização das terras e demais propriedades (animais, casas etc.) e a criação de grandes fazendas estatais, os sovkhozes, ou cooperativas de camponeses sob direção do Estado e seus gestores, os Kolkhozes - que deveriam responder às diretrizes econômicas estatais unificadas. O processo de coletivização foi compulsório e muito violento, tendo ocorrido, na maioria das regiões, à revelia dos camponeses e com muitas prisões e mortes. ${ }^{48}$

${ }^{44}$ Como já apontado, o bolchevique Anatoly Lunatcharsky foi o comissário do Narkompros. Além de Lunatcharsky, integravam o comitê: Artemii Khalatov (chefe do Gosizdat - Casa de publicação Estatal de Todos os Sovietes da União); Olga Kameneva (1883-1941), chefe do VOKS; Ivan Gronskii, integrante do Politburo, um dos idealizadores do "realismo socialista" e editor do Izvestiia (Notícias) - um dos periódicos russos de maior circulação, dirigido pelo partido bolchevique; Semen Uritskii (editor do periódico Krestianskaia gazeta, "O Jornal do Camponês”) e Iakov Doletskii (chefe do TASS - Agência Telegráfica da União Soviética, antiga ROSTA).

${ }^{45}$ WOLF, E., USSR in Construction..., op. cit., p. 17.

${ }^{46}$ O primeiro plano quinquenal foi promulgado apenas em abril de 1929, no entanto, conforme o historiador inglês E. H. Carr e o historiador francês Pierre Broué, já no XV Congresso, em dezembro de 1927, após a eliminação da Oposição Unificada, a questão do planejamento econômico (uma das bandeiras da oposição) foi colocada em pauta e começou-se a elaborar, então, os planos quinquenais. "O congresso do partido em dezembro de 1927 marcou a importância do plano quinquenal, dedicando sete reuniões ao seu debate" e definindo “a sua apresentação ao próximo Congresso dos Sovietes da União, na primavera de 1929”. CARR, E. H. A Revolução Russa de Lênin a Stalin, trad. Waltensir Dutra, Rio de Janeiro: Zahar, 1979, p. 133. Ver: BROUÉ, Pierre, O Partido..., op.cit., p. 310.

${ }^{47}$ Ver: WOLF, E., USSR in Construction..., op. cit., p. 20.

${ }^{48}$ Ver: BROUÉ, Pierre, O partido... op. cit.; RODRIGUES, Rogério P., O colapso da URSS: um estudo das causas, orientador: Osvaldo Coggiola, Tese de Doutorado, São Paulo: Departamento de História Econômica, 


\subsubsection{Um pavilhão atrativo}

Segundo a historiadora de arte russa Erika Wolf, relatórios e atas do comitê indicam que El Lissitzky teria sido acionado para solucionar duas questões: 1) a necessidade do desenvolvimento de uma unidade estilística para a ampla gama de matérias já coletadas para compor o pavilhão; 2) a preocupação, do comitê, em tornar o pavilhão inteligível e atrativo para um público ocidental - junto a esse segundo ponto estava também a intensão do comitê de lançar mão, no pavilhão, de displays e tecnologias modernas (rádio, alto-falantes etc.) de modo a mascarar, no pavilhão, a inferioridade técnica da imprensa russa em relação à dos países ocidentais. ${ }^{49}$

Possivelmente um dos fatores que teria influenciaram a escolha de El Lissitzky para o desenho do pavilhão foi o seu trânsito pelo meio artístico alemão e o sucesso de algumas produções recentes do mesmo na Alemanha (Quarto para arte Construtivista, 1926, Dresden; e Cabine de Arte Abstrata, 1927, Hannover). ${ }^{50}$

El Lissitzky era um artista ligado aos grupos de vanguarda russos (como o LEF) que, após a Revolução Russa, aderiram à frente bolchevique e, na guerra-civil, atuaram na produção de cartazes, ilustração de livros, decoração de ruas e praças para eventos comemorativos da Revolução. ${ }^{51}$ Com o término da guerra-civil, transferiu-se para Berlin, com o cargo da representante cultural da Rússia na Alemanha. Subordinado ao INKhUK, ${ }^{52}$ Lissitzky era encarregado de estabelecer contatos, trocas e parcerias com os artistas alemães, bem como de divulgar as produções russas no Ocidente. Apesar de em 1925 já ter se reestabelecido em Moscou, entre 1925-1930 (período no qual ele trabalhou na VKhUTEMAS (Escola Superior de Arte e Técnica, Moscou, 1920-1930), ${ }^{53}$ em colaboração com

Universidade de São Paulo - USP, 2006, p. 78; e, REIS FILHO, Daniel Aarão, URSS: O socialismo real (19211964), São Paulo: Brasiliense, 1983, p. 24.

${ }^{49}$ Nesse sentido, é interessante mencionar que a primeira proposta do Comitê (que seria a de fazer uma história do desenvolvimento da imprensa impressa na Rússia e na União Soviética), foi descartada após a avaliação de que, comparada aos demais países ocidentais (especialmente aos EUA, que tinha a mesma proposta expositiva, conforme documentos do próprio comitê), tal desenvolvimento se mostraria tecnicamente inferior. Assim, o Comitê optou por escolher uma temática que enfatizasse a questão ideológica e de agitação e propaganda do processo de modernização e do papel da imprensa. WOLF, E., USSR in Construction..., op. cit., p. 16.

${ }^{50}$ Ver: AA.VV. Une arme visuelle..., op. cit., p. 140. Cabe mencionar que El Lissitzky não era o único a gozar de prestígio internacional. Grande parte dos artistas de vanguarda russa (ligados ao LEF) gozavam do mesmo prestígio. Os artistas de vanguarda, especialmente os lefistas, após 1924, eram aqueles que mais dominavam os aparatos técnicos de registro e recepção coletiva (cinema e fotografia).

${ }^{51}$ Ver: LODDER, C., Russian..., op. cit.

${ }^{52}$ INKhUK (1920-1924) era um Instituto de Arte e Cultura subordinado ao Narkompros. INKhUK foi uma espécie de centro de discussões e elaborações teóricas que aglutinava os artistas de vanguarda - especialmente ligados ao LEF.

${ }^{53}$ O Ateliêe Superior Estatal Técnico-Artístico (Moscou, 1920-1930) foi um centro estatal de formação artística técnico-industrial. O Vkhutemas contou com uma organização político-administrativa próxima do modelo dos Sovietes e com um quadro de professores constituído por artistas de vanguarda, como A. Rodchenko (18911956), K. Malevich (1878-1935) e V. Tatlin (1885-1953) - os quais levavam para o espaço da formação suas pesquisas e experimentações, transformando o Vkhutemas num importante espaço de discussão e produção 
artistas como o lefista Rodchenko, El Lissitzky continuou a trabalhar no circuito Rússia-Alemanha. Nesse ínterim, projetou 5 exposições na Alemanha.

\subsubsection{Um pavilhão próspero e modernizado}

A participação soviética em feiras e exposições internacionais era uma atividade que envolvia grandes gastos. No pavilhão de Colônia não foi diferente. A análise das atas e relatórios de atividades do comitê demonstra a grande preocupação do mesmo em, por meio do pavilhão, aumentar a visibilidade e credibilidade internacional russa. ${ }^{54}$

A preocupação em mostrar, para o observador estrangeiro, a suposta prosperidade, superioridade e modernização (técnica) soviética, refletiu-se não só na escolha do artista encarregado em projetar o pavilhão, mas também na própria aquisição de matérias para a fabricação das peças que o comporiam.

Dada a escassez e a baixa qualidade dos produtos russos, parte da tecnologia $\operatorname{adotada}^{55} \mathrm{e}$ mesmo dos materiais elementares (como papel e tinta) utilizados na fabricação das peças do pavilhão foram importados da Alemanha e disponibilizados para os artistas russos envolvidos na montagem. ${ }^{56}$ Houve também grande envolvimento do VOKS (Sociedade de ralações culturais no exterior de todos os Sovietes da União; 1925-1958) ${ }^{57}$ no levantamento de materiais (fotografias, periódicos, livros e documentos de época), nacionais e estrangeiros - os quais foram angariados no país e fora para serem disponibilizados aos artistas e ou expostos no pavilhão.

artística. Ver: MIGUEL, Jair Diniz, Arte, ensino, utopia e revolução: os ateliês artísticos Vkhutemas/Vkhutein (Rússia/URSS, 1920-1930), tese de doutorado em história, São Paulo: FFLCH-USP, 2006.

54 “[A URSS] promoveu [o pavilhão] como um meio de aumentar sua credibilidade como um estado político por meio da participação em uma grande exposição internacional”. WOLF, E., USSR in Construction..., op. cit., p. 16.

55 “A transferência [importação] de tecnologia estrangera era perseguida para a criação de um ambiente propagandístico visual”. WOLF, Erika, USSR in Construction..., op. cit., p. 19.

${ }^{56}$ Cartas e diários de artistas registram a surpresa destes, frente à qualidade do material disponibilizado para a fabricação das peças do pavilhão de Colônia. Teria sido o próprio Lissitzky o incumbido de viajar à Alemanha, para estudar as instalações da exposição e adquirir parte do material para a montagem. "Foi graças a Lissitzky que tivemos a chance de ver e trabalhar com materiais reais e importados. Esta foi a primeira vez que pusemos as mãos em celuloide ou que usamos papéis coloridos, de boa qualidade, tintas de boa qualidade que não alteram suas cores e papelões cinza - tingidos industrialmente - aptos a receber pintura a óleo ou tempera ou o que fosse" E. Semenova, "From My Reminiscences of Lissitzky". LISSITZKY, apud WOLF, E., USSR in Construction..., op. cit., p. 19.

${ }^{57}$ Ver: FAYET, Jean-François, VOKS. Le laboratoire helvétique. Histoire de la politique culturelle soviétique durant l'entre-deux-guerres, Genéve: Georg, 2014. 


\subsubsection{A recepção do pavilhão na imprensa internacional}

Historicamente, as feiras universais, como grandes vitrines internacionais, eram palco de autopromoção, amostragem de tecnologias e transações comerciais e diplomáticas, bem como centros "de peregrinação ao fetiche da mercadoria" (Figura 12). ${ }^{58}$

Realizado sob encomenda e supervisão direta de um comitê ligado ao partido bolchevique (stalinista) com o objetivo de propagandear as conquistas do "socialismo num só país" a nível internacional, ${ }^{59}$ a recepção do pavilhão na imprensa internacional foi cuidadosamente registrada e relatada, em atas e relatórios, pelo membro do comitê e chefe do Gosizdat (Editora pública russa), Artemií Khalatov (1894-1938) - que acompanhou a montagem da exposição e sua vigência in loco.

O próprio catálogo do pavilhão soviético incluía algumas das primeiras avaliações positivas de jornais internacionais (em alemão, inglês, espanhol, holandês e polonês) sobre o mesmo. As criticas coletadas e analisadas pelos organizadores do pavilhão vinham fundamentalmente de órgãos da grande imprensa. Conforme Khalatov, tal escolha era proposital: "Nós intencionalmente não citamos o trabalho da imprensa próxima a nós, porque, se considerarmos as críticas burguesas citadas a cima, o sentimento de boa-vontade com o qual a imprensa dos trabalhadores comunistas olhou para nós ficará bastante claro". 60

Segundo a historiadora Erika Wolf, o comitê coletou mais de 400 críticas publicadas na imprensa estrangeira sobre o pavilhão soviético. Todas elas destacavam a originalidade e a superioridade do pavilhão soviético em relação aos demais. Como foi o caso do jornal Die Breslauer Neueste Nachrichten:

Em relação à tecnologia de exibição, aqui o Pavilhão Soviético está sem dúvida em primeiro lugar. [...] Tudo está em movimento. Rodas e esferas se movem, aspirais perfuram o forro, tabelas estatísticas piscam de cima a baixo, na esquerda e na direita, aqui, ali e em todos os lugares. De qualquer forma, os russos, melhor do que ninguém, dominaram o espírito do tempo. Todos os outros pavilhões parecem antiquados depois dele. ${ }^{61}$

\footnotetext{
${ }^{58}$ BENJAMIN, W., "Paris, capital do século XIX", in idem, Textos de Walter Benjamin, org. e trad. Flávio R. Kothe, São Paulo: Ática, 1985, p. 35.

${ }^{59}$ Cabe mencionar que, segundo os registros de arquivos levantados por Wolf, a montagem do pavilhão soviético de Colônia contou com o apoio da delegação comercial soviética de Berlim (com vasta experiência em feiras e negócios no Oeste Europeu). Conforme as trocas de correspondências do Comitê, teria sido inclusive o chefe dessa delegação, I. M. Shneerson, a sugerir que o Comitê do pavilhão formulasse o mesmo "tendo em vistas visitantes ocidentais e incluísse displays e técnicas mecânicas, filmes, rádio e autofalantes". WOLF, E., USSR in Construction..., op. cit., pp. 16-17.

${ }^{60}$ WOLF, E., USSR in Construction..., op. cit., p. 32.

${ }^{61}$ Apud: WOLF, E., USSR in Construction..., op. cit., p. 32.
} 
Com base nos relatos de Khalatov e na troca de correspondência do comitê, ${ }^{62}$ pode-se perceber que, além do objetivo primário de fabricação da própria imagem para um observador estrangeiro (de modo a garantir futuros pactos de não agressão e acordos comerciais) ${ }^{63}$, a preocupação com o impacto positivo do pavilhão soviético de Colônia também visava à reversão imediata da repercussão negativa da detenção (março de 1928), sob acusação de sabotagem industrial, de cinco técnicos alemães no distrito de Shakty (Ucrânia). O ocorrido havia prejudicado significativamente as relações diplomáticas entre Rússia e Alemanha e a imagem da Rússia na imprensa internacional. ${ }^{64}$

Conforme relatos do próprio Khalatov, a repercussão do pavilhão na imprensa internacional correspondeu às expectativas e objetivos oficiais do pavilhão. ${ }^{65}$ Segundo o historiador da arte Benjamin Buchloh, devido ao sucesso da exposição, Lissitzky teria sido inclusive condecorado com uma medalha e nomeado membro honorífico do soviete da cidade de Moscou. ${ }^{66}$

\subsubsection{Uma sintaxe visual vanguardista de agitação e propaganda}

A linguagem dinâmica, modernizante e sofisticada (tecnicamente falando) adotada, destacouse da expografia solene e tradicional dos demais pavilhões, como podemos perceber na crítica de Die Breslauer Neueste Nachrichten e na crítica de Berliner Tageblatt: “"Que contraste entre o pavilhão da Inglaterra e da União Soviética". "A Inglaterra é a mais pomposa, piedosa e autoconfiante representação da ordem social. A Rússia Soviética age sobre nós com aparatos mecânicos, correias em movimento, ziguezagues cubistas fantásticos, que fazem com que se mova adiante com choques nervosos, que são representados corajosamente, vangloriosamente e em cores vibrantes"”. ${ }^{67}$

Como podemos constatar por meio da análise das críticas sobre o pavilhão soviético publicadas na imprensa estrangeira e mesmo dos relatórios do comitê responsável pelo pavilhão, o caráter inovador e moderno (técnico) do pavilhão foi objeto de grande enfoque e repercussão. Tais

${ }^{62}$ GARF, f. 5383, op. 6., d.50, 1.42, apud WOLF, E., USSR in Construction..., op. cit.

${ }^{63}$ A título de exemplo dos pactos de não agressão e transações comerciais pretendidas pelas URSS, podemos citar acordos e pactos entre a Rússia e Itália. Fabbri, no livro Fascismo e Bolscevismo: Le relazioni nei documenti diplomatici ítalo-russi, reconstitui, com base em pesquisas nos arquivos russos e italianos, acordos comerciais, transações diplomáticas e pactos de não agressão e amizade entre a Rússia e a Itália. Até 1927, por exemplo, a Itália tinha grande parte de seu abastecimento de petróleo suprido pela Rússia. Entre 1927 e 1928, as relações tornaram-se relativamente hostis, o que levou a uma necessária renegociação de vários acordos comerciais e diplomáticos, consolidados apenas em 1933, quando foi firmado um "pacto de amizade, não agressão e neutralidade" (02.09.1933). Ver: FABRI, T., Fascismo e Bolscevismo: Le relazioni nei documenti diplomatici ítalorussi, Padova: libreriauniversitaria.it, 2013, pp. 66-67; 155.

${ }^{64}$ Ver: WOLF, E., USSR in Construction..., op. cit., pp. 32-33.

${ }^{65}$ Em relação à repercussão negativa da prisão dos técnicos alemães na imprensa internacional e da função de reversão do quadro atribuída ao pavilhão de Colônia, Khalatov afirmou em um de seus relatórios sobre o pavilhão: "Deve ser dito que nossa presença em Colônia foi um fator decisivo para manter essa agitação hostil sob controle, até certo ponto". Khalatov, GARF, f. 5283, apud WOLF, E., USSR in Construction... op. cit., p. 34.

${ }^{66}$ BUCHLOH, B., "De la faktura..., op. cit., p. 54.

${ }^{67}$ WOLF, E., USSR in Construction..., op. cit., p. 29. 
aspectos teriam sido proporcionados pela adoção de uma sintaxe visual vanguardista de agitação e propaganda associada a meios de massa (fotos, jornais, frisos, murais e montagens) e a apologia da industrialização e do progresso mediante luzes, maquinaria e imagéticas seriais, frases e formas geometrizadas que suscitavam a ideia de movimento e modernidade.

\subsubsection{0 projeto expográfico de Colônia}

Dividido em 20 áreas de concentração (Figura 11), o projeto expográfico do pavilhão soviético narrava "o papel da imprensa na construção do socialismo" (num só país), por meio de temas econômicos e políticos como a industrialização e a construção da rede elétrica do país, os sindicatos e os correspondentes operários, os jornais e o programa de alfabetização promovido pelo partido bolchevique.

O percurso expositivo era composto por: 1. Entrada principal; 2. Seção Histórica [Historische Abteilung]; 3. Transmissões; 4. Sindicatos; 5. Reforma social da aldeia; 6. Grande estrela; 7. Mapa da URSS; 8. Academia de Ciências; 9. Repúblicas Federais; 10. Lenin como jornalista; 11. Escritório e informações; 12. Cinema: (Podium: Repúblicas Federais); 13. Empresas; 14. Mapa mundial “TASS”; 15. Correio; 16. Estande de vendas; 17. Sala de leitura; 18. Movimento de correspondentes; 19. Exército Vermelho; 20. Editora Estatal (Figura 11).

Com um forte teor internacionalista (como, por exemplo, na área de concentração 9, 14 ou na grande estrela, área 6), o percurso expositivo montado por Lissitzky alternava momentos dedicados à questão da imprensa e seus desdobramentos educativos e políticos (como o incentivo à leitura e os programas de alfabetização, nas áreas de concentração 2, 10, 17 e 18), com momentos dedicados ao protagonismo das massas e ao aspecto ideológico dos processos em curso na URSS (por exemplo, nas áreas de concentração 4, 5, 6, 12, 18 e 19).

Contemporâneo à coletivização forçada nos campos (1928) e aos debates que levariam à adoção dos planos quinquenais (1927-1929), ${ }^{68}$ o pavilhão de Colônia ecoava (na escolha de materiais, forma e conteúdo) as discussões do campo econômico russo - como no caso da eletricidade.

\subsubsection{Eletricidade, cinestesia}

Um dos principais programas de planejamento econômico sob a direção de Lênin foi o plano GOELRO $^{69}$ (1920-1921) - programa de reestruturação econômica ancorado na criação e

68 Conforme já mencionado, segundo historiadores como Carr, os debates e medidas que levaram à implementação dos planos quinquenais teriam tido início em dezembro de 1927. CARR, Edward Hallett, Revolução russa..., op. cit., p. 133.

${ }^{69}$ GOELRO é a transliteração da abreviatura russa de "Comissão do Estado para Eletrificação da Rússia". 
implementação de um sistema de eletrificação nacional. Pinturas e cartazes da época (Figuras 13, 14, $15 \& 16)^{70}$ largamente exploraram a questão da eletrificação, na medida em que a associação do plano GOELRO (1920-1921) ao $1^{\circ}$ Plano Quinquenal (1929-1933) respaldava simbolicamente o segundo e reforçava a retórica stalinista vigente, segundo a qual Stalin apresentar-se-ia como o fiel continuador de Lênin (Figuras 13, 14, 15 \& 16) (11 $^{71}$ na toada das práticas de legitimação litúrgicas calcadas na canonização de Lênin, a partir de 1924.

No pavilhão de Colônia, a questão da eletrificação foi incorporada como temática em alguns cartazes da área 3 (Figuras 19), no painel central (Figura 29, 30 \& 31), bem como enquanto dispositivo constitutivo da própria expografia (Figuras $20,22,24$, \& 26). A iluminação elétrica e a eletricidade foram incorporadas por El Lissitzky: em letreiros neon (como o da fachada, Figura 17); em painéis, como no painel da TASS (Agência Telegráfica da União Soviética), no qual botões que se iluminavam foram inseridos num grande mapa da URSS, gerando ritmo aos fluxos de informações e eventos ao redor da União Soviética (Figura 23); em maquinarias (Figura 20); em cilindros e objetos giratórios, como os cilindros recobertos por imagens do exercito vermelho (Figura 26), os tambores giratórios que alternavam reportagens de correspondentes operários e camponeses (Figuras 24 e 25), e os espirais que aludiam a transmissores da área 9, na qual o movimento contínuo em espiral fazia alegoria ao movimento incessante e ascendente em direção ao comunismo (Figura 22); e, nas próprias projeções cinematográficas - segundo registros da montagem da exposição, a sala de projeções cinematográficas teria sido uma das primeiras propostas de Lissitzky para a exposição. ${ }^{72}$

\subsubsection{E reprodutibilidade técnica}

Lissitzky também se valeu dos novos meios de reprodutibilidade técnica e recepção coletiva e simultânea (fotografia, montagem, periódicos e cinema) como elementos constitutivos da sintaxe visual do pavilhão de Colônia. O pavilhão privilegiou então materiais de fotografias, fotomontagens, palavras de ordem, recortes de jornais e cartazes de agitação e propaganda.

${ }^{70}$ A relação entre o plano GOELRO e os planos quinquenais, assim como entre o culto de Lênin e, consequentemente, o de Stalin (como seu fiel seguidor), serão retomadas exaustivamente nos cartazes produzidos para a divulgação do $1^{\circ}$ Plano Quinquenal (1929-1933) e na revista URSS em Construção (19301941). (Figuras 8, 9 \& 10).

${ }^{71}$ Cabe mencionar que a relação entre os planejamentos de eletrificação nacional encampados por Lênin e os planos quinquenais stalinistas será retomada na exposição Artistas da URSS dos últimos 15 anos (Leningrado, novembro de 1932), a ser discutida nos próximos capítulos. À diferença do pavilhão de Colônia, nessa exposição de 1932 tem-se uma maior ênfase na figura dos chefes e no fortalecimento da imagem de Stalin como o grande continuador de Lênin. Ao que tudo indica, no pavilhão de Colônia, não foram utilizadas muitas imagens de Stalin. Nas várias fotografias e materiais encontrados sobre o pavilhão de Colônia e mesmo nas fotos do catálogo deste, encontramos apenas uma figura que possivelmente é Stalin (Figura 27).

${ }^{72}$ No ano seguinte à exposição em Colônia, em 1929, na montagem do pavilhão russo para a FIFO (Filme e Foto Internacional Ausstellung, Stuttgart, Alemanha) El Lissitzky e A. Rodchenko (responsáveis pelo pavilhão russo) lançaram mão de filmes e fotografias de artistas de vanguarda, como Eisenstein e Vertov, muito similares à seleção adotada em Colônia por El Lissitzky. 
O ritmo e os processos de montagem do cinema e da fotografia foram transpostos para a expografia do pavilhão, reconfigurando o espaço expositivo por meio dos seguintes elementos: abandono da disposição simétrica dos objetos expostos; ruptura com a visão centralizada e linear do circuito expositivo em favor de uma reconfiguração assimétrica das obras e da disposição destas no espaço; deslocamentos de perspectivas; simultaneidade dos pontos de vista; alternância entre planos (primeiros planos, planos médios e planos abertos) e ambientes; volume e caráter cinético de algumas peças. Tal reformulação, na direção das proposições lefistas, estimulavam e ampliavam a percepção sensorial do observador a partir de diferentes ângulos e materiais, retirando-o da posição contemplativa tradicional (Figuras, 21, 22, 28, 29, 30 e 31 ). ${ }^{73}$

\subsubsection{Um espectador ativo}

Se, em ocasiões anteriores, em seu deslocamento nas paredes em que se expunham as imagens, o espectador se deixava envolver pelos quadros até cair numa espécie de passividade, nosso desenho quis fazer do homem um elemento ativo. $^{74}$

A peça central do pavilhão, o painel "A tarefa da imprensa é a educação das massas na transição do capitalismo para o comunismo" (citação de Lênin), condensava em termos de forma, material e conteúdo a linha geral da exposição. O próprio nome do painel sintetizava a tese central do pavilhão (Figuras 4, 22, 28, $30 \& 31$ ).

O painel em questão media aproximadamente 23,5 metros de largura X 3,8 metros de altura $^{75}$ e ocupava quase toda a parte superior da parede (instalado a 3 metros do chão) traseira da exposição,

\footnotetext{
${ }^{73}$ A oposição à "pintura de cavalete", por parte do grupo LEF, passa, entre outros motivos, pela discussão acerca do tipo de recepção e circulação da pintura tradicional, a qual fundamentava-se na separação entre produção e circulação, e, via de regra, impunha ao expectador uma postura contemplativa, passiva e alienada. As contraposições críticas do grupo LEF a tais processos, foram muitas, entre elas, podemos destacar o recuso da fotografia enquanto um modo de expansão das capacidades perceptivas, críticas e psíquicas do expectador. Segundo o lefista Brik, as imagens de Rodchenko corresponderiam, na fotografia, à noção vertoviana de que "a tarefa do cinema e da câmera não é aquela de imitar o olho humano, mas de ver e registrar aquilo que o olho humano não vê normalmente". Ao registrá-la a partir de ângulos inusitados, Rodchenko utiliza a máquina fotográfica como um instrumento de expansão da visão humana. "Aquele objeto familiar (a sua casa) é transformada em uma construção nunca vista antes, a escada de incêndio torna-se uma construção maravilhosa e as varandas são transformadas em torres de uma arquitetura exótica". BRIK, O., "What the eye does not see", (Sovetskoe kino, n. 2, 1926), in PHILLIPS, Christopher, Photograph in Modern Era, New York, Metropolitan Museum/ Art-Arperture, pp. 219-220, 1989, pp. 219-220. Ver: FIGUEIREDO, C., Foto-Grafia... op. cit.; idem, "Uma nova...", op.cit.; idem, "Não falsifiquem...", op. cit.

${ }^{74}$ EL LISSITZKY, "Espacios de exposición” (1926), in AA.VV., Espacios Fotográficos Públicos..., op. cit., pp. 7579, p.75.

${ }^{75}$ POHLMANN, Ulrich, "Los diseños de exposiciones de El Lissitzky" (1999), in AA.VV., Espacios Fotográficos Públicos..., op. cit., pp. 167-191, p. 170.
} 
funcionando como uma espécie de pano de fundo de todo o pavilhão (o painel está indicado com o número 3 na figura 32, uma ilustração que recria a perspectiva de entrada do pavilhão).

Conforme descrito no catálogo do pavilhão- permeado ele mesmo por fotomontagens (Figura $18,25,33$ \& 35) -, o painel consistia numa gigantesca fotomontagem composta por duas grandes camadas sobrepostas. A primeira grande camada era constituída pela montagem (recortes e colagens) de fotografias tomadas a partir de diferentes ângulos, perspectivas e planos (primeiros planos, planos médios e tomadas panorâmicas) sobre uma rede transparente, pendurada rente à parede. A segunda grande camada era constituída pela própria parede localizada atrás da rede transparente com as fotografias; na parede Lissitzky e Serkin escreveram palavras de ordem em alemão e inglês (Figura 29, 30 e 31$)^{76}$

Em “A tarefa da imprensa...", recortes fotográficos irregulares (de retratos individuais, cenas de grupos e tomadas de massa de trabalhadores, camponeses e lideranças, em atividades agrícolas, militares, industriais e literárias), afixados numa espécie de rede, deixavam transparecer, mediante a movimentação do espectador e a consequente alteração do seu ponto de observação, palavras de ordem (Figura 29, $30 \& 31$ ).

O painel ainda era recortado por telas triangulares vermelhas que o subdividiam em pequenos frames interconectados (Figuras 29 \& 30), reforçando o vínculo do mesmo com a linguagem cinematográfica e acentuando o ritmo da montagem e o caráter cinético do painel.

Os fragmentos de fotografias "autênticas" (conforme a contraditória adjetivação atribuída, no texto de abertura do catálogo da exposição assinado pelo comitê organizativo do pavilhão) eram, então, animados pela sobreposição de telas triangulares vermelhas e pela obstrução dos textos. Para serem vistas e lidas, fotografias e palavras de ordem requeriam do espectador deslocamentos espaciais e alterações de ângulos de observação.

O destaque dado à imagem fotográfica em toda a exposição - que, como no exemplo do painel "A tarefa da imprensa...", sobrepunha-se ao próprio texto; o uso extensivo de recortes de jornais, cartas e montagens; a adoção de ângulos oblíquos, linhas diagonais e composições geométricas; a referencia aos correspondentes operários; e a ruptura com a postura contemplativa do espectador, remetiam diretamente às produções e discussões do grupo LEF, especialmente após a guinada que o grupo fez em direção à fotografia e à factografia. ${ }^{77}$

\subsubsection{Um debate lefista}

\footnotetext{
${ }^{76}$ Catálogo do pavilhão Soviético (1928), apud WOLF, E., USSR in Construction..., op. cit., pp. 21-22.

${ }^{77}$ Ver: FIGUEIREDO, C., Foto-Grafia..., op. cit.; GARCÍA, Víctor del Rio, Conceptos factográficos entre el origen soviético y su recepción por la neovanguardia, Tese de Doutorado, Departamento de Filosofía y Filosofía Moral y Política, São Paulo: Faculdade de Filosofia, Universidad Nacional de Educación a Distancia, 2007; ZALAMBANI, M., La morte del romanzo: dall'avanguardia al “realismo socialista”, Roma, Carocci, 2003.
} 
Que tipo de propaganda nós realmente precisamos na Rússia Soviética?

Precisamos de propaganda que não estupidifique o público, mas que, ao contrário, esclarece a [sua] consciência (O. Brik, 1924)..$^{78}$

Entre 1926 e 1928, o grupo LEF realizou uma inflexão em direção à fotografia e à factografia (grafia dos fatos, caracterizada pela adoção de gêneros literários menores como a reportagem, cartas e diários e a ruptura entre obra e público). Movidos por sua conjuntura político-econômica, pela contraposição entre as noções de construção e composição, ${ }^{79}$ e por noções como a de "cultura material" ${ }^{\prime 0}$ os lefistas viram na fotografia, no cinema e na factografia alternativas críticas ao retorno da "pintura de cavalete" liderado pela AKhRR e respaldado pela ala stalinista do partido bolchevique (como já apontado anteriormente).

Por suas características técnicas (baixo custo de produção, reprodutibilidade, precisão e velocidade), por seu potencial disruptivo (ruptura com o "valor de culto", com a noção de aura, autoria e originalidade, bem como com certas relações simbólicas de poder ${ }^{81}$ e por sua dimensão

${ }^{78}$ BRIK, O., (1924), apud COX, Randi, "NEP Whitout Nepmen!: Soviet Advertising and the Transition to Socialism”, in KIAR, C.; NAIMAN, E. (edit.), Every day life in early Soviet Russia: taking the revolution inside, Bloomington: Indiana University Press, 2006, pp. 119-152, p. 134.

${ }^{79} \mathrm{O}$ antagonismo entre construção e composição foi um dos eixos orientadores do construtivismo russo. A composição indicava as operações ilusionistas da pintura de tipo naturalista representativa (efeitos volumétricos, de profundidade, de caráter rítmico, luminosidade etc.), enquanto com a construção reivindicavase a ênfase no tratamento do material, dos elementos reais e concretos da pintura (a textura, a massa, a pincelada e a sua faktura - isto é, as técnicas de tratamento do material, o trabalho do artista). Os construtivistas, dai a origem do nome, visavam à superação da composição enquanto princípio estético puro, vinculado à bidimensionalidade e historicamente associado à noção de representação e contemplação passiva da vida, para afirmar a verdade materialista da construção, articulada à organização de elementos materiais e reais, e, portanto, capaz de desvelar as estruturas ilusórias e fetichistas da representação pictórica e do próprio modo de vida e produção capitalista. Ver: TARABUKIN, Nikolai, El último cuadro: Del caballete a la máquina/Por una teoría de la pintura, [1923], Barcelona, Gustavo Gili, 1977; FIGUEIREDO, C., "Construtivismo russo: história, estética e política", in JINKINGS, I.; DORIA, K. (org.), 1917: o ano que abalou o mundo, São Paulo: Boitempo, Ed. SESC/SP, pp. 91-102, 2017; MARTINS, Luiz Renato, “O debate entre o construtivismo e o produtivismo, segundo Nikolay Tarabukin”, in Ars, São Paulo: departamento de artes plásticas, ECA-USP, ano 1, n. 2, 2003; e ZALAMBANI, M., L’Arte Nella Produzione..., op. cit.

${ }^{80}$ A "cultura material" de sociedade seria "o sistema universal de objetos, as formas materiais socialmente úteis criadas pela humanidade através da transformação das assim chamadas formas naturais. A cultura material é tanto a produção quanto o consumo de valores materiais". Conforme o lefista Boris Arvatov, byt (modo de vida cotidiano) assim como o psiquismo de uma pessoa seria formado pela totalidade do ambiente material ("cultura material") que a cerca. Deste modo, a questão da "cultura material" (assim como a do byt e do psiquismo) seria imprescindível para superação do modo de vida capitalista - modo de vida este pautado na cisão entre trabalho intelectual e manual; circulação e produção. ARVATOV, Boris, "Everyday Life and the Culture of the Thing", trad. Christina Kiar, October 81, Cambridge: MIT Press, pp. 119-128, Summer 1997, p. 120.

${ }^{81}$ Para os lefistas, na produção de um retrato, por exemplo, a fotografia, diferentemente da pintura, estaria apta a registrar um objeto em seu contexto, reconectando assim a produção e a circulação da obra, bem como evidenciando a dimensão material da vida em oposição a produções litúrgicas centradas nas características físicas e subjetivas da figura do herói - tradicionalmente retratado descolado da dimensão material e social do entorno que o constitui. Tal possibilidade, segundo o LEF, não só romperia com os aspectos individualizantes e elitistas do retrato pictórico, como também possibilitaria a construção de representações visuais de situações de caráter coletivo, fomentando práticas coletivistas e a autonomia do proletariado em detrimento das figuras dos chefes. BRIK, O., "What the...", op. cit., in PHILLIPS, C., Photograph... op. cit., p. 230. 
formativa (ampliação da capacidade perceptiva e crítica do observador por meio de decalagens entre a percepção e o reconhecimento do objeto ${ }^{82}$ e desvelamento de relações e estruturas sociais por meio de reportagens e ensaios), ${ }^{83}$ a fotografia suplantaria a pintura.

Para o grupo LEF, a fotografia, por suas qualidades materiais, seria capaz de romper os automatismos e as estruturas ilusionistas e apassivadoras da arte e do modo de produção capitalista, constituindo-se em uma arma a serviço da constituição de um novo byt (modo de vida cotidiano) e psiquismo revolucionário. ${ }^{84}$

Cinema, fotografia e fotomontagem não só responderiam às demandas de um modo de produção coletivizado, como também responderiam às demandas de uma produção industrializada e de uma circulação e recepção massivas, coletivas e simultâneas. Na linha da noção de "encomenda social", ${ }^{85}$ para o LEF, a fotografia não se restringiria ao domínio dos especialistas, dos artistas geniais, sobretudo em sua prática amadora. Nesse sentido, uma vez mais é interessante perceber a incorporação do movimento dos "correspondentes operários e camponeses" na temática e na seleção de materiais constitutivos do pavilhão soviético (área de concentração 18, Figuras 24 \& 25).

\subsubsection{0 novo "Tolstói coletivo"}

Formado em 1921 e fomentado pelo partido bolchevique, o movimento dos "correspondentes operários" e dos "correspondentes camponeses" visava a estimular a produção de relatos (visuais e textuais) pelos operários e camponeses sobre os principais acontecimentos cotidianos da esfera pública e do trabalho. As reportagens e fotorreportagens dos fotógrafos e escritores operários e camponeses tiverem um papel contraditório na União Soviética - oscilavam entre ser um meio de

\footnotetext{
${ }^{82}$ Ver: RODCHENKO, A., "Downright ignorance or mean trick?", in PHILLIPS, C. (Org.), Photography in the modern era: European documents and critical writings, 1913-1940, New York: The Metropolitan Museum of Art/Aperture, 1989, pp. 245-248, p. 247. "A tarefa do cinema e da câmera não é aquela de imitar o olho humano, mas de ver e registrar aquilo que o olho humano não vê normalmente". BRIK, O., "What the...", op. cit., in PHILLIPS, C., Photograph... op. cit., p. 219.

83 "Nós devemos prestar atenção não nas características individuais como tais, mas nos movimentos sociais e conexões que definem suas posições particulares". "Diferenciar individualmente os objetos para fazer um registro pictórico deles não é só uma técnica, mas também um fenômeno ideológico. No período prérevolucinário (feudalismo e burguesia), a pintura e a literatura fixaram o objetivo de diferenciar pessoas singulares e eventos de seus contextos gerais e concentrar a atenção sobre eles". BRIK, O., "From the painting to the photograph", Novyi Lef, n. 3, 1928, in PHILLIPS, Christopher, Photograph..., op. cit., pp. 227-233, p. 230231.

${ }^{84}$ Conforme explica a pesquisadora italiana Maria Zalambani, segundo o esquema do lefista Boris Arvatov (1896-1940) o produtivismo teria como tarefa repensar a produção e a construção não apenas de objetos, mas também de comportamentos e relações. Nesse sentido, destacam-se as discussões sobre byt e psiquismo e o papel da fotografia enquanto um elemento material apto a atuar na edificação do novo psiquismo revolucionário. Maria Zalambani, L'arte nella produzione..., op., cit., p. 88.

${ }^{85}$ Sobre a noção de "encomenda social" ver: BRIK, O., "Non una teoria, ma solo un slogan", Péchat'i Revolutsia, Moscou, 1929; trad. Italiana in MAGAROTTO, L.; SCALIA, G. (a cura di), L' avanguardia dopo la rivoluzione. Le riviste degli anni Venti nell'URSS: "Il giornale dei futuristi», "L'arte della Comune», "Il Lef», "Il nuovo Lef», Edizioni Immanenza, pp.293-299, 1976 e FIGUEIREDO, C., “Uma noiva...”, op.cit.
} 
estimular a alfabetização, os debates e uma postura crítico-reflexiva dos trabalhadores e ser um instrumento de delação e vigilância (especialmente, nos ambientes de trabalho fabril, após 1926). ${ }^{86}$

Conforme a pesquisadora de arte russa Aya Kawamura, principalmente após a Primeira Conferência dos Correspondentes Operários e Camponeses (na qual o movimento foi formalmente fundado), em 1923, muitos artistas e intelectuais se inspiraram no movimento dos "Correspondentes Operários e Camponeses". A prática de produção textual dos trabalhadores e camponeses e sua sucessiva publicação em periódicos do próprio partido e de outras instituições e mesmo grupos de artistas (como no caso do LEF, após 1923) iniciou-se ainda no período da guerra-civil - período no qual eram publicados relatos das frentes de batalha.

\subsubsection{Restrições e tentativas de controle partidário}

Após a formalização das atividadas, o partido bolchevique requisitou o movimento a relatar problemas nos locais de trabalho e vilas. No entanto, por se tratar de uma produção textual com certa autonomia, o controle do conteúdo e mesmo do teor de tais produções escapava à direção do partido, que já em 1926, por meio de justificativas conspiratórias, apontou a necessidade de um maior controle de tal produção, consolidando seu caráter vigilante e subordinado às diretrizes do partido.

Em maio de 1926, na Terceira Conferência dos Correspondentes Operários e Camponeses, Bukharin aventou a necessidade de maior controle da produção dos correspondentes, tendo em vista o risco de que forças hostis (como os kulaks e sacerdotes atrasados, ou mesmo camponeses recém ingressados na indústria soviética mas ainda com ideias pequeno-burgesas) poderiam se infiltrar no movimento e contaminar, com seus relatos, os demais trabalhadores e camponeses ${ }^{87}$ Entre $1927 \mathrm{e}$ 1928, os editores chefes do Pravda passaram a priorizar relatos assinados coletivamente, desse modo seria mais fácil garantir um maior controle, e, conforme afirmou o bolchevique Aleksei Kapustin,

\footnotetext{
${ }^{86} \mathrm{Tal}$ movimento influenciou particularmente o movimento de cinema documental russo. Kawamura menciona que muitas revistas e jornais do período publicavam e fomentavam a produção dos correspondentes. De modo que, de fato, na primeira metade dos anos 1920, até 1927-28, tal movimento contribuía na alfabetização e politização do operariado e campesinato russo. O próprio grupo LEF muitas vezes publicou em suas revistas produções dos correspondentes. Os trabalhos de Vertov e seus cine-olhos também dialogam diretamente com tais produções. Ver: KAWAMURA, Aya, "La création collective dans le documentaire soviétique: photographie, cinéma et "correspondants-ouvrier»", 1895: Revue d'histoire du cinéma, n. 63, 2011, pp. 48-144, p. 48. Disponível online em: <www.cairn.info/revue-1895-2011-1-page-48.htm>, acessado em 4 de maio de 2015; FERRETTI, Maria, Le Mouvement des correspondants ouvriers, 1917-1931 : révolution culturelle et organisation du consensus dans l'Union soviétique des années vingt, tese de doutorado, Paris: EHESS, 1998.

${ }^{87}$ Segundo Bukharin (1926): “[As cartas dos rabcors] são marcadas por uma rispidez inadequada com relação aos gestores [especialistas] e aos dirigentes sindicais, por denúncias excessivamente enfáticas dos superiores, pela incapacidade de reconhecer as realizações reais da indústria soviética e pelo ocultamento dos aspectos negativos do trabalho dos próprios operários". BUKHARIN, apud LENOE, Matthew, Closer to the masses: stalinist culture, social revolution and soviet newspapers, Massachusetts: Harvard Press, 2004, pp. 121-122; 133.
} 
diretor da sessão "vida do trabalhador" do Pravda (abril de 1929), uma mensagem política "adequada" e de "qualidade". 88

\subsubsection{Uma alternativa crítica (lefista)}

O grupo LEF viu nos correspondentes operários e camponeses elementos para uma alternativa crítica à literatura épica e ao subjetivismo do gênero romanesco (fundamentados no drama, na narrativa ficcional e no subjetivismo). ${ }^{89} \mathrm{O}$ grupo não só apoiava a produção dos correspondentes (inclusive veiculando tal produção em suas revistas), como também redirecionou sua própria produção artística a partir do contato com a experiência dos primeiros..$^{90}$

Num movimento análogo ao da "morte da pintura", ${ }^{11}$ a proposta lefista de uma literatura factográfica estava apoiada no potencial revolucionário das classes trabalhadoras (neste caso, representada pela prática dos correspondentes). Os novos "Tolstói vermelhos" ou "Tolstoy coletivos", conforme reivindicou Tretiakov em 1927, seriam as massas (de correspondentes) anônimas, criativas e autodeterminadas. ${ }^{92}$

\footnotetext{
${ }^{88}$ KAPUSTIN, apud LENOE, Matthew, Closer to the..., op. cit., p. 159.

${ }^{89}$ Sobre a relação entre a factografia e a fotografia, ver: FIGUEIREDO, C. F., Foto-Grafia..., op. cit.
}

90 À luz da noção de "encomenda social”, o LEF propunha a superação das formas literárias clássicas (como o romance), em prol da atividade crítica, criadora e reflexiva da própria classe trabalhadora (reportagens, diários etc.). Atividade esta que, rompendo com os dispositivos alienantes e com as cisões entre esfera de produção e circulação, emergiria como uma forma dos trabalhadores e camponeses pensarem, lerem e escreverem sobre as contradições da sociedade soviética, de modo a poderem atuar ativamente na construção da Revolução. Sobre o debate entre o LEF e integrantes do partido bolchevique a respeito do movimento dos correspondentes operários e camponeses, ver: VILELLA, T. M., O Ocaso..., op. cit., pp. 172-179.

${ }^{91}$ A “morte da pintura" ou a "morte da arte" marcou o apogeu do construtivismo analítico, a superação da pintura enquanto forma de representação e da postulação da obra como um objeto com valor em si. Dalí em diante, para os construtivistas (para os lefistas, como um todo), a pintura não teria mais razão de ser. Havia-se dado o último passo na decomposição da superfície pictórica em direção ao real. Segundo Segundo o lefista N. Tarabukin, depois do tríptico monocromático de Rodchenko (Cor vermelha pura, Cor amarela pura e Cor azul puro, 1921) a arte, tal como era entendida pela burguesia, enquanto forma que se justificava mediante o reconhecimento autoral burguês, estava morta. Dessa morte, surgiria uma nova arte, uma arte justificada socialmente - o produtivismo. Ver: TARABUKIN, N., El último cuadro: Del caballete a la máquinal por una teoría de la pintura, trad. Rosa Feliu e Patrícia Vélez, Barcelona: Gustavo Gili, 1977.

92 "Alguns estão desconsolados. Eles reclamam: onde está a arte monumental da revolução? Onde estão as obrasprimas do 'épico vermelho'? Onde estão nossos Homeros e Tolstoys vermelhos? [...] Toda a massa anônima que escreve para os jornais, dos correspondentes-operários até o redator do artigo principal: eis o Tolstoy coletivo de nosso tempo. [...] Nossa primeira tarefa é parar de esperar por 'literatos vermelhos', mas, ao contrário, educar o público soviético a ler os jornais, essas bíblias de nosso tempo atual”. TRETIAKOV, Sergei, “The new Leo Tolstoy", in October 118, Cambridge: MIT Press, pp. 47-50, Fall 2006, pp. 47-50. Cabe ainda mencionar que a ênfase no papel crítico e reflexivo do jornal era um ponto comum a vários trabalhos dos lefistas, como, por exemplo, o já mencionado projeto para Clube de Trabalhadores de Rodchenko (1924-1925). Ver: FIGUEIREDO, C., "Não comercializem...”, op. cit. 


\subsubsection{Constructos críticos}

Para o grupo LEF, a estética contemplativa estava associada a um modo de produção capitalista que reiterava um psiquismo alienado e passivo. Nesse sentido, estes buscaram em seus debates e produções artísticas desenvolver soluções práticas que antagonizassem com tais processos ilusionistas e fetichistas. ${ }^{93}$ Entre 1926 e 1928, inspirados nos movimentos dos correspondentes, a factografia e a fotografia foram discutidas e apropriadas pelo grupo.

Movidos pela noção de "encomenda social", que incluía também um debate acerca da função política da forma, o redirecionamento dos lefistas para a fotografia articulava forma e conteúdo a partir de sua inserção na produção e na luta de classes. Nesse sentido, cabe relembrarmos os debates acerca da atualidade produtiva (industrial) ${ }^{94}$ e do potencial de estranhamento e ampliação do olhar humano inerentes à câmera fotográfica. ${ }^{95}$ Vertigem e deslocamentos na fotografia, foram acionados, por alguns lefistas, na tentativa de intervir materialmente e na edificação do novo psiquismo revolucionário - por meio, também, da politização da forma. ${ }^{96}$

93 Segundo os lefistas, as formas artísticas de "cavalete" tinham seu modo de produção e circulação condicionados pelo sistema capitalista. Fruto de um modo de produção artesanal, caro e individualista, a "arte de cavalete" reiterava a função do especialista (justificado no reconhecimento autoral) apartado do modo de produção de seu tempo (revolução técnica e social em curso). Destinada a ambientes privados (apartamentos, museus e escritórios) e à fruição individual, contemplativa e estratificada, a "pintura de cavalete" estaria em contradição com as formas artística desejadas numa sociedade coletivizada. Ver: ARVATOV, B., "L'attuale mercato dell'arte e la pittura di cavalletto", N. Lef, 2, 1928; trad. Italiana in MAGAROTTO, L.; SCALIA, G. (a cura di), $L^{\prime}$ avanguardia dopo la rivoluzione..., op. cit., pp. 253-258. Por seu caráter aurático e sua dimensão ilusionista, a arte funcionava, na sociedade burguesa, não apenas como um "narcótico que criava na mente humana uma vida distinta, paralela à vida real", mas, também, como um dispositivo de distinção de classes e de reprodução de poder (os retratos e as pinturas históricas, por exemplo, eram destinados às figuras ilustres, nobres e burgueses de destaque). TRETIAKOV, S., "Art in the revolution and the revolution in art (aesthetic consumption and production)", in October 118, Cambridge: MIT Press, pp. 11-18, Fall 2006, p. 15. Ver: LEF, "Aos companheiros que dão forma à vida!", Lef, 2, 1923; trad. Italiana in MAGAROTTO, L.; SCALIA, G. (a cura di), L' avanguardia dopo la rivoluzione..., op. cit., pp. 168-169; FIGUEIREDO, C., "Construtivismo russo...", op. cit.; MARTINS, Luiz Renato, “O debate...”, op. cit.; e ZALAMBANI, M., La morte... op. cit.

${ }^{94}$ Ver: RODCHENKO, A., "The paths of contemporary photography", Novyi Lef, n. 9, 1928, in Aleksandr Rodchenko experiments for the future: diaries, essays, letters, and other writings, org. Alexander Lavrentiev, trad. Jamey Gambrell, int. John Bowlt, New York: Museum of Modern Art, 2005, pp. 207-212, p. 210.

${ }^{95}$ Conforme a teoria do estranhamento (ostranenie), de Chklóvskii, quando o artista cria - recorta, cola, monta - imagens que surpreendem o expectador, ele não simplesmente desloca as imagens da vida cotidiana para uma estrutura formal artística; mas cria uma nova experiência da realidade, apta a combater os automatismos que o mundo do trabalho e as necessidades práticas cotidianas inserem na vida mental subjetiva. O procedimento de "estranhamento" é o que, conforme Chklóvskii, faz a arte ser artística e, ao mesmo tempo, vivifica as experiências vividas. Desse modo, o objetivo do recurso ao "estranhamento" é, justamente, criar uma perceção nova e crítica dos objetos, mediante decalagens. Trata-se de estabelecer uma nova visão de mundo e não o reconhecimento do mundo dado. CHKLÓVSKII, V., "A arte como procedimento" (1917), in Teoria da literatura: formalistas russos, trad. Ana M. R. Filipouski; Antônio C. Hohlfeld; Maria A. Pereira; e Regina L. Zilberman, Porto Alegre: Ed. Globo, 1970.

${ }^{96}$ Cabe mencionar que, até 1928 o grupo LEF não possuía uma proposta fotográfica consensual, mas pesquisas e debates sobre. Entretanto, pode-se supor que a proposta fotográfica do grupo Outubro seja um desdobramento dos debates do grupo LEF. Como já mencionado, o grupo Outubro (1928-1932) foi um grupo de artistas de vanguarda internacionalista, do qual muitos lefistas forem integrantes e ou fundadores. 
No pavilhão soviético de Colônia, Lissitzky retoma e atualiza, em seu projeto expositivo, as discussões e reflexões lefistas, como o antagonismo entre construção e composição e a oposição entre contemplação e ativação do espectador. ${ }^{97}$

Tal aproximação pode ser constatada, em maior ou menor escala, em uma série de elementos do pavilhão, como no canto "Lênin como jornalista" (Figura 33), que dialoga com o protótipo de clube de trabalhadores de Rodchenko (1924-1925) (Figuras $3 \& 35),{ }^{98}$ ou no painel central do pavilhão supracitado (Figuras 33, $34 \& 36) .{ }^{99} \mathrm{Em}$ tal painel é possível verificar uma conjugação entre: 1) escolha de materiais (recortes de fotos e jornais possivelmente produzidos em sua maioria por correspondentes operários e camponeses); 2) conteúdo (fotografias de trabalhadores e trabalhadoras protagonistas, revolucionários, fotógrafos, escritores e leitores); 3) forma (fotomontagens de recortes fotográficos a partir de diversos ângulos e pontos de vista, etc); 4) modo de produção (produzido coletivamente por um grupo de artistas e por uma massa de correspondentes anônimos através de instrumentos técnicos); 5) circulação (circulação em larga escala, coletiva, simultânea e não contemplativa).

\subsubsection{Contraditórios}

Se, por um lado, a aproximação entre o pavilhão de Colônia e as proposições práticas e teóricas do LEF destaca uma série de constructos críticos, por outro lado, evidência também uma série de contradições (questões), especialmente quando inscrevemos o pavilhão nos processos políticos, artísticos e produtivos de seu tempo. Para que melhor visualizemos ditas contradições, ou supostas contradições, basta lembrarmos que o pavilhão foi realizado sob encomenda e supervisão direta estatal para fabricar uma imagem atrativa (comercial e diplomaticamente falando) para um público ocidental a respeito do "socialismo num só país" - a ser ressaltada a ênfase conferida por Khalatov à repercussão do pavilhão nos órgãos de imprensa burguesa.

${ }^{97}$ Segundo o historiador Benjamin Buchloh, já em exposições anteriores Lissitzky dialogara com alguns elementos e proposições do LEF. Ver: BUCHLOH, B., “De la faktura...”, op. cit.

${ }^{98}$ O protótipo de Clube dos trabalhadores (1924-1925), desenvolvido por Rodchenko para representar a Rússia no pavilhão soviético de Paris (1925), como já apontado anteriormente, consistia numa alternativa crítca ao culto de Lênin. O protótipo de Rodchenko conjugava, por exemplo, as demandas do operariado (melhoria das condições de moradia, trabalho e lazer, novas formas de organização material da vida), com princípios construtivos e teóricos do LEF (rigorosa racionalização do espaço, dos materiais e da função social-ideológica do clube etc.) e elementos que remetiam a propostas, ações e práticas de Lênin (como a mesa de xadrez, os cartazes das campanhas de eletrificação e alfabetização e o fomento à escrita e leitura de jornais - como no caso dos correspondentes operários). Para uma análise e discussão detalhada do protótipo de Rodchenko, ver: FIGUEIREDO, C., "Não comercializem...”, op. cit.

${ }^{99} \mathrm{Na}$ linha da proposta de Rodchenko em seu clube de trabalhadores (1924-1925) (Figura 35), Lênin, como o próprio título da área de concentração já indica, era enfatizado como um jornalista, próximo aos correspondentes e não como um líder distante das massas. Tal relação torna-se mais evidente na fotomontagem realizada para o catálogo da mostra (Figuras 34 \& 36), na qual, apesar de destacar a imagem de Lênin, associa tal imagem à de um operário e um camponês escrevendo. 
Podemos ainda apontar o deslocamento entre a representação ativa e protagonista das massas no pavilhão (as quais, conforme aludido na cabeça da silhueta da cozinheira, seriam estimuladas, pelo partido bolchevique, a participar da direção estatal - Figura 37) e o crescente distanciamento entre o partido e as bases, bem como a passividade do campesinato e proletariado em curso na URSS - sem comentar a brutalidade do processo de coletivização forçada, que levou à morte de muitos camponeses. ${ }^{100}$

Nesse sentido, podemos inclusive mencionar as inflexões referentes ao próprio movimento dos correspondentes operários e camponeses, as quais oscilavam entre delação e atuação autodeterminada; bem como podemos questionar os propósitos e a própria circulação da obra de Lissitzky, dado que se tratava de um pavilhão internacional voltado a propagandear o "socialismo num só país" aos representantes internacionais e órgãos de imprensa da grande burguesia ocidental ${ }^{101}$ - como podemos perceber pelos relatórios de Khalatov, nos quais a análise do impacto e da recepção era realizada via coleta de artigos e críticas veiculadas na grande imprensa burguesa, ${ }^{102}$ evidenciado o distanciamento entre os objetivos propagandísticos do pavilhão e as discussões sobre formação e atuação crítica do proletariado e campesinato do LEF.

Partindo do pressuposto lefista de que para melhor compreendermos uma produção artística devemos pensá-la dentro dos processos produtivos e artísticos de seu tempo, ${ }^{103}$ cabe perguntar: a que demandas sociais e de que lado da trincheira da luta de classes o pavilhão de Colônia se inseria? Como ele respondia a elas? Seria possível, dentro desse contexto termidoriano, uma produção artística encomendada pelo regime stalinista para sua autorrepresentação que não trouxesse em si também as contradições de dito regime e contexto produtivo? Por que tais vanguardas foram paulatinamente

${ }^{100}$ Conforme já mencionado, segundo Trotsky, a crescente burocratização do Estado e a crescente passividade do proletariado teriam sido dois elementos centrais para uma espécie de restauracionismo (termidoriano) em curso a partir de 1924, na Rússia. Benjamin, em seus diários de Moscou, também questiona uma espécie de pacificação das massas, as quais, segundo escreveu, vivenciavam, cada vez mais, a Revolução como discurso e não como experiência. Ver: BENJAMIN, W., Diário de Moscou, (1926-1927), trad. Hildegard Herbold, São Paulo: Cia das Letras, 1989; TROTSKY, L., El nuevo curso (1923), in <http://ceipleontrotsky.org/El-nuevocurso-1923>, acessado em 17 de abril de 2016, idem, Revolução e Contra-revolução (1926), trad. Mário Pedrosa, Rio de Janeiro: Laemmert, 1968 e idem, Teses sobre revolução e contra-revolução (1926), in $<$ https://revistaiskra.wordpress.com/especiais-iskra-trotsky-e-engels/teses-sobre-revolucao-e-contra-revolucao/>, acessado em 05 de maio de 2016.

${ }^{101}$ A análise da correspondência e dos relatórios do Comitê responsável pela montagem do pavilhão de Colônia e dos releases que saíram na imprensa soviética sobre a concepção e montagem do pavilhão deixa evidente a preocupação do mesmo em fabricar uma imagem atrativa e próspera da URSS e seu desenvolvimento políticoeconômico por meio do pavilhão. "É necessário encontrar meios para a comunicação visual do conteúdo da nossa imprensa para um público estrangeiro", afirmou Mikhail Gus (membro do Comitê e editor do Imprensa Vermelha), numa nota sobre a montagem do pavilhão, publicada em janeiro de 1928 no Imprensa Vermelha. GUS, “Pechat'SSR na vystavke v kel'ne”: 12-15, apud WOLF, E., USSR in Construction..., op. cit., p. 18.

${ }^{102}$ Em mais de uma passagem, a preocupação do Comitê com a reprecursão do pavilhão na grande imprensa internacional evidencia-se: "Acima de tudo, deve ser dito que nenhum único periódico [paper] burguês que escreveu sobre a exposição pode silenciar-se a nosso respeito [a respeito do pavilhão soviético]"." "Nós intencionalmente não citamos o trabalho da imprensa próxima a nós, porque, se considerarmos as críticas burguesas citadas acima, o sentimento de boa-vontade com o qual a imprensa dos trabalhadores comunistas olhou para nós ficará bastante claro". WOLF, E., USSR in Construction..., op. cit., pp. 31-32.

${ }^{103}$ Ver: FIGUEIREDO, C., "Uma noiva...”, op. cit. 
marginalizadas (ou melhor, realocadas) no plano interno (nacional) e adotadas no plano externo (internacional)? Do ponto de vista estatal, tratar-se-ia, de fato, de uma contradição ou de um processo de embate ainda em curso? Ou tratar-se-ia, ainda, de duas politicas de produção e circulação artísticas distintas e combinadas? 


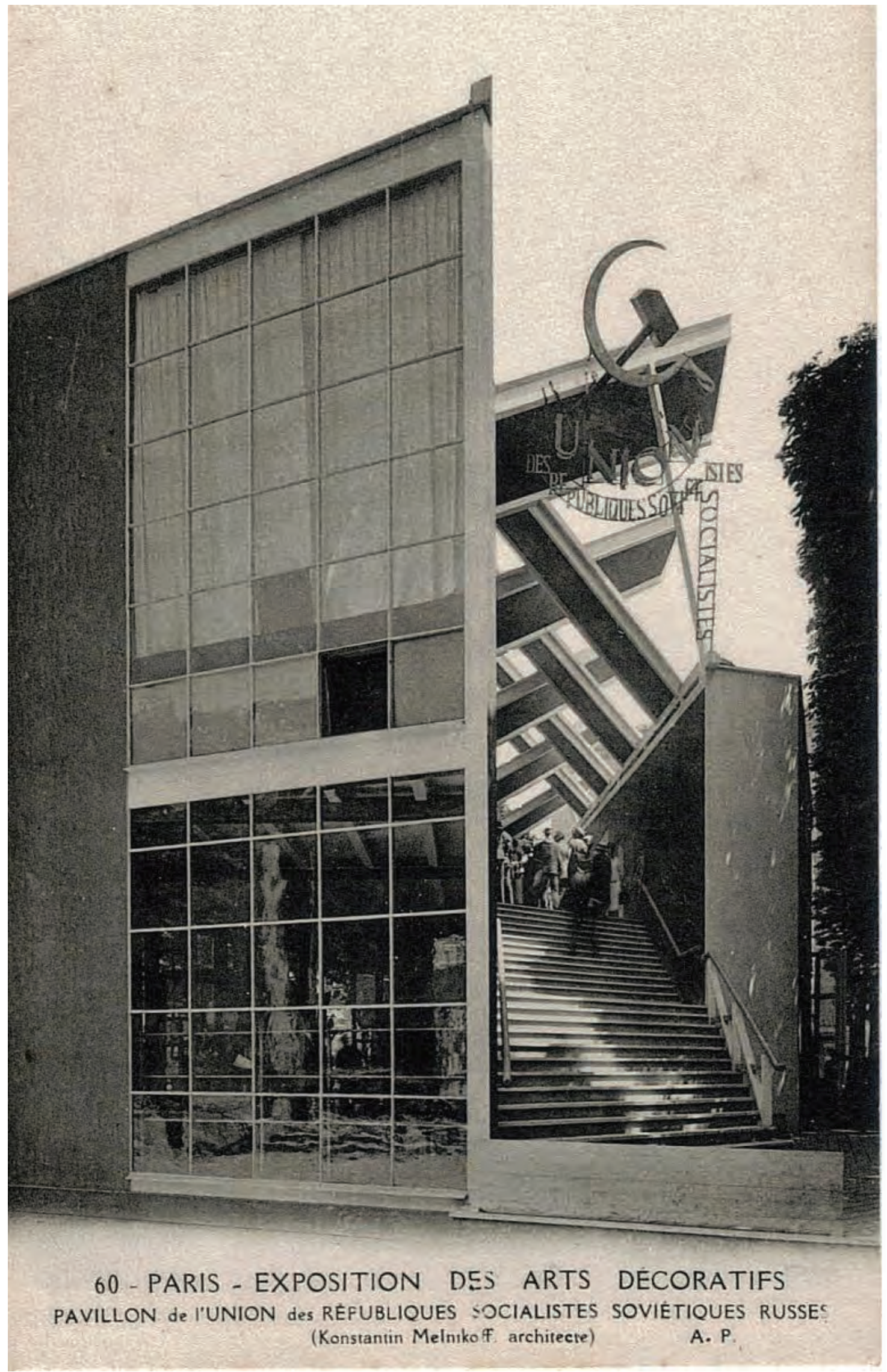

Fig.1 Pavilhão soviético na Exposição Internacional de Artes Decorativas e Industriais Modernas, em Paris, 1925 


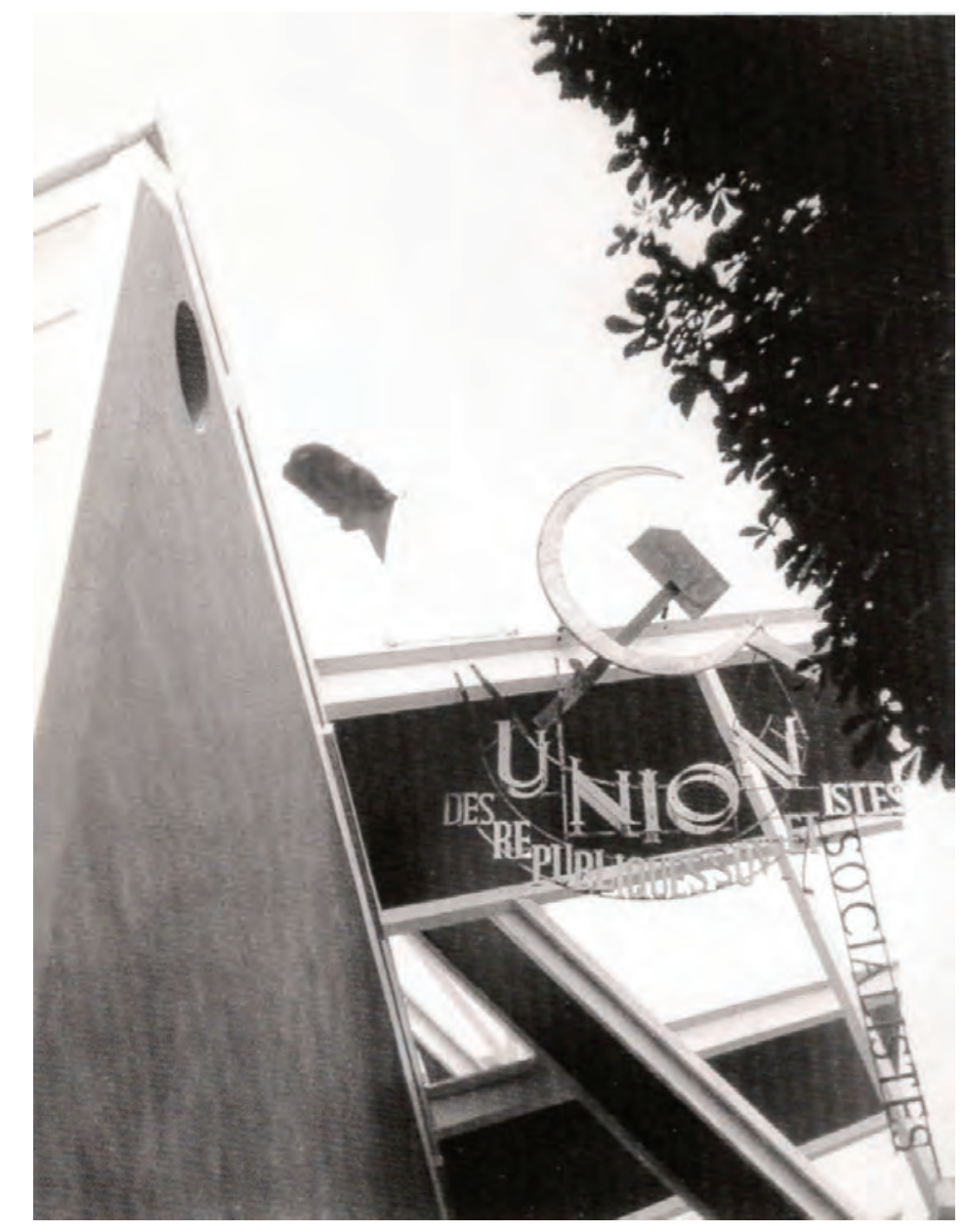

Fig.2 Pavilhão soviético na Exposição

Internacional de Artes Decorativas e Industriais Modernas, em Paris, 1925

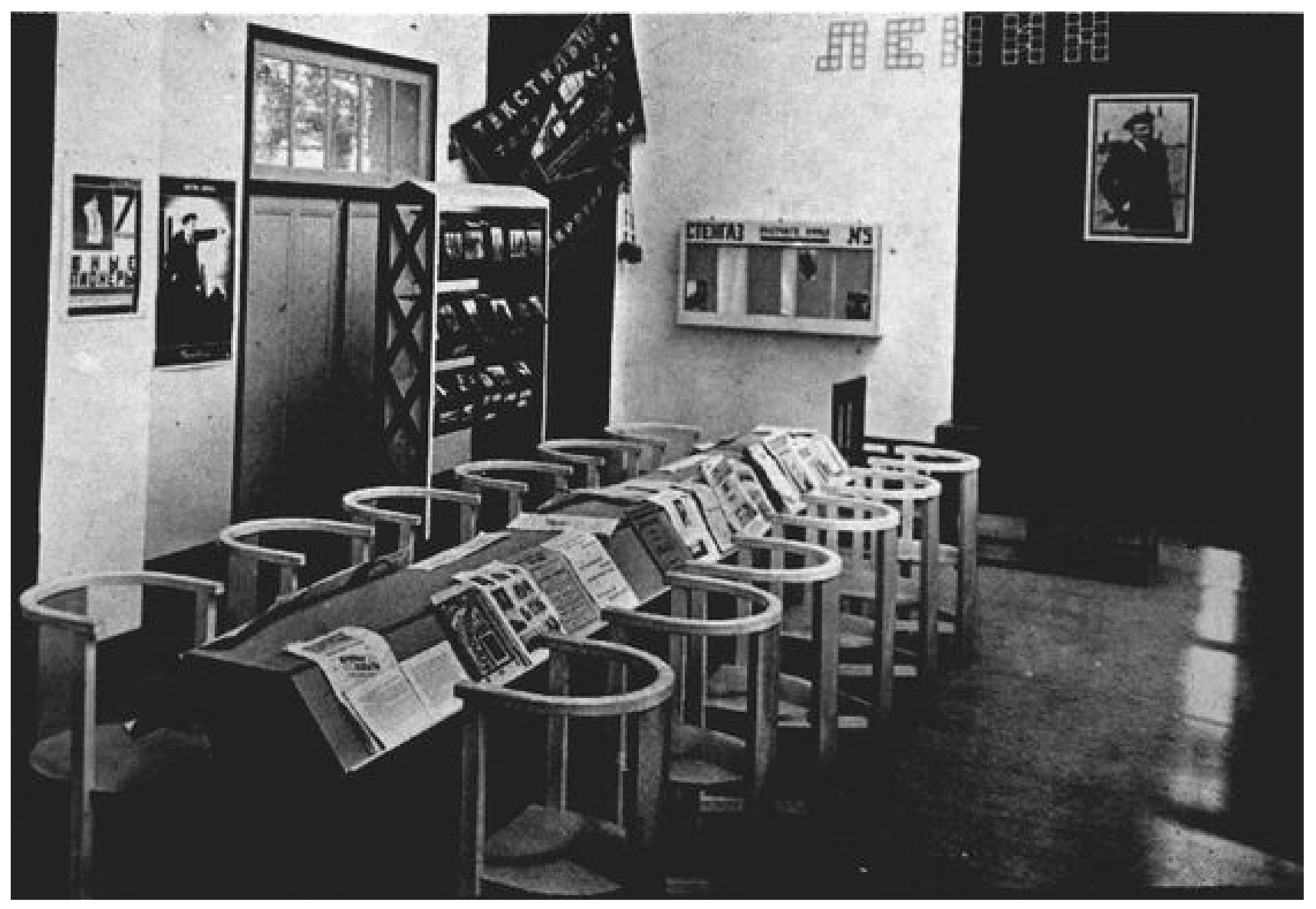

Fig.3 Projeto de clube dos trabalhadores de A. Rodchenko.

Pavilhão soviético na Exposição Internacional de Artes Decorativas e Industriais Modernas, em Paris, 1925 
Fig.4 Pavilhão soviético na Exposição Internacional de Imprensa de
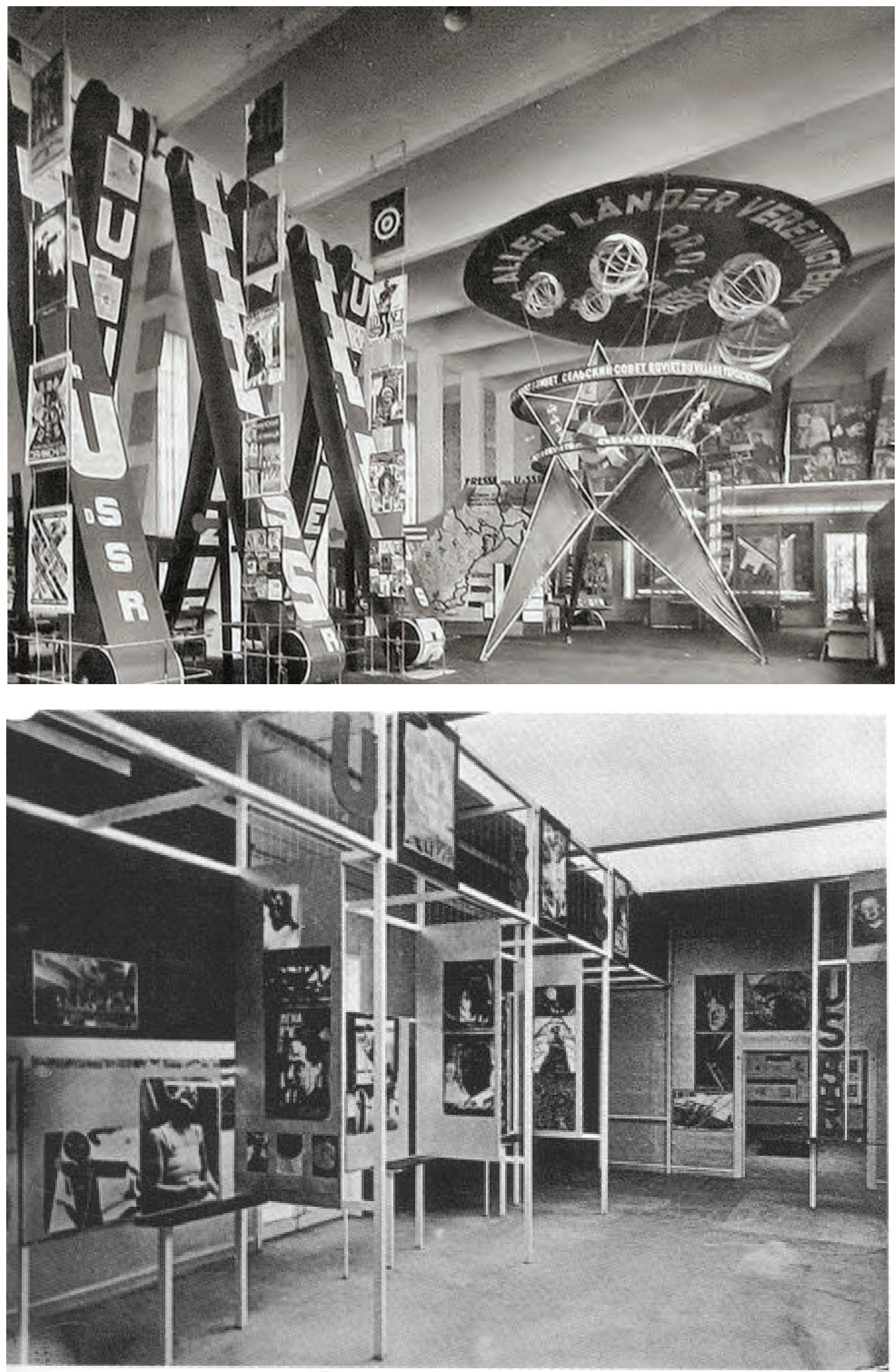

Fig.5 Pavilhão soviético na Exposição Filme e Foto/FIFO, em Stuttgart, 1929 

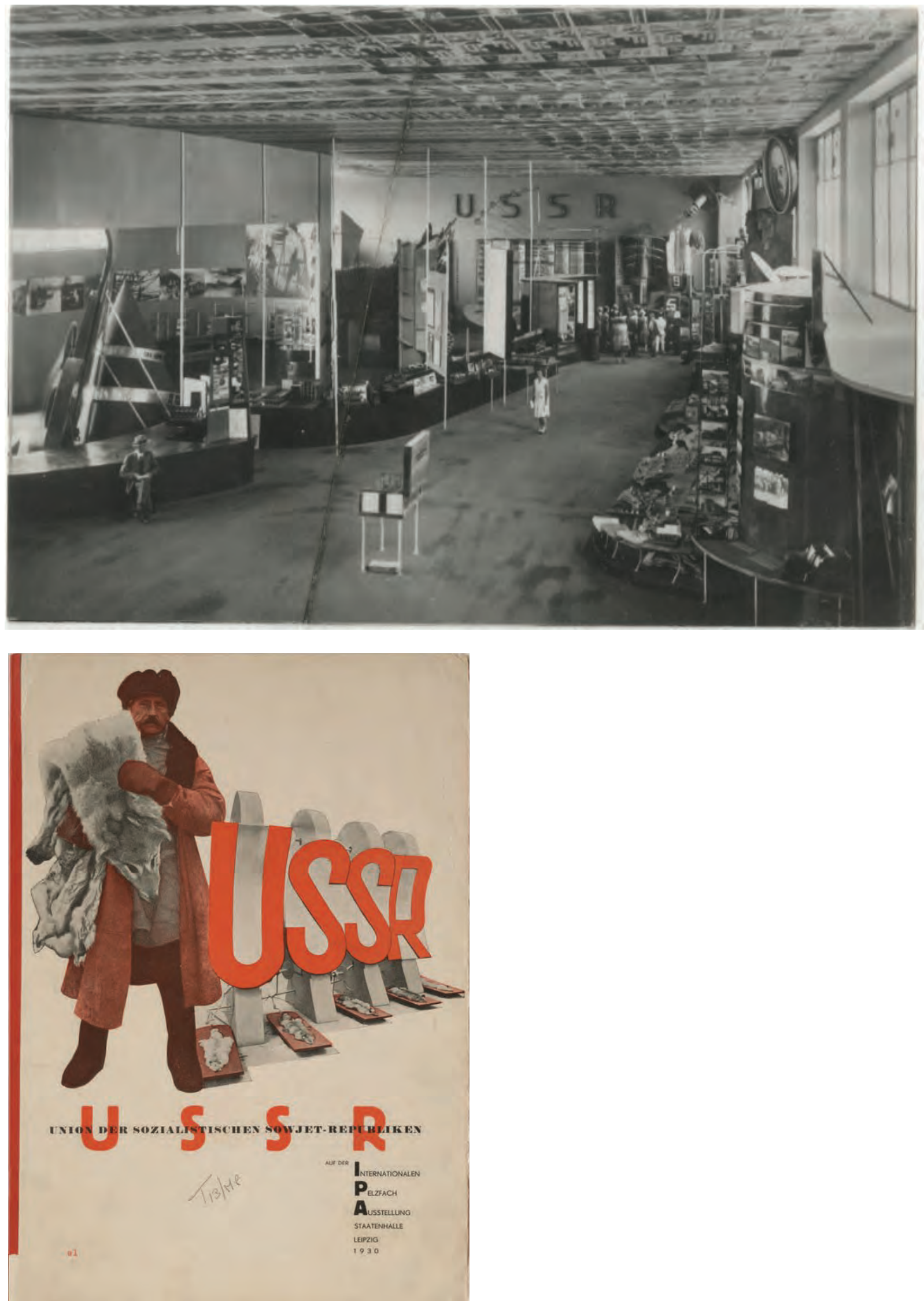

Fig. 7 Cartaz da Exposição

Internacional de Couro, em Leipzig,

1930 
Fig. 8 Revista "URSS em Construção" (editada por Lissitzky), Moscou, 1933
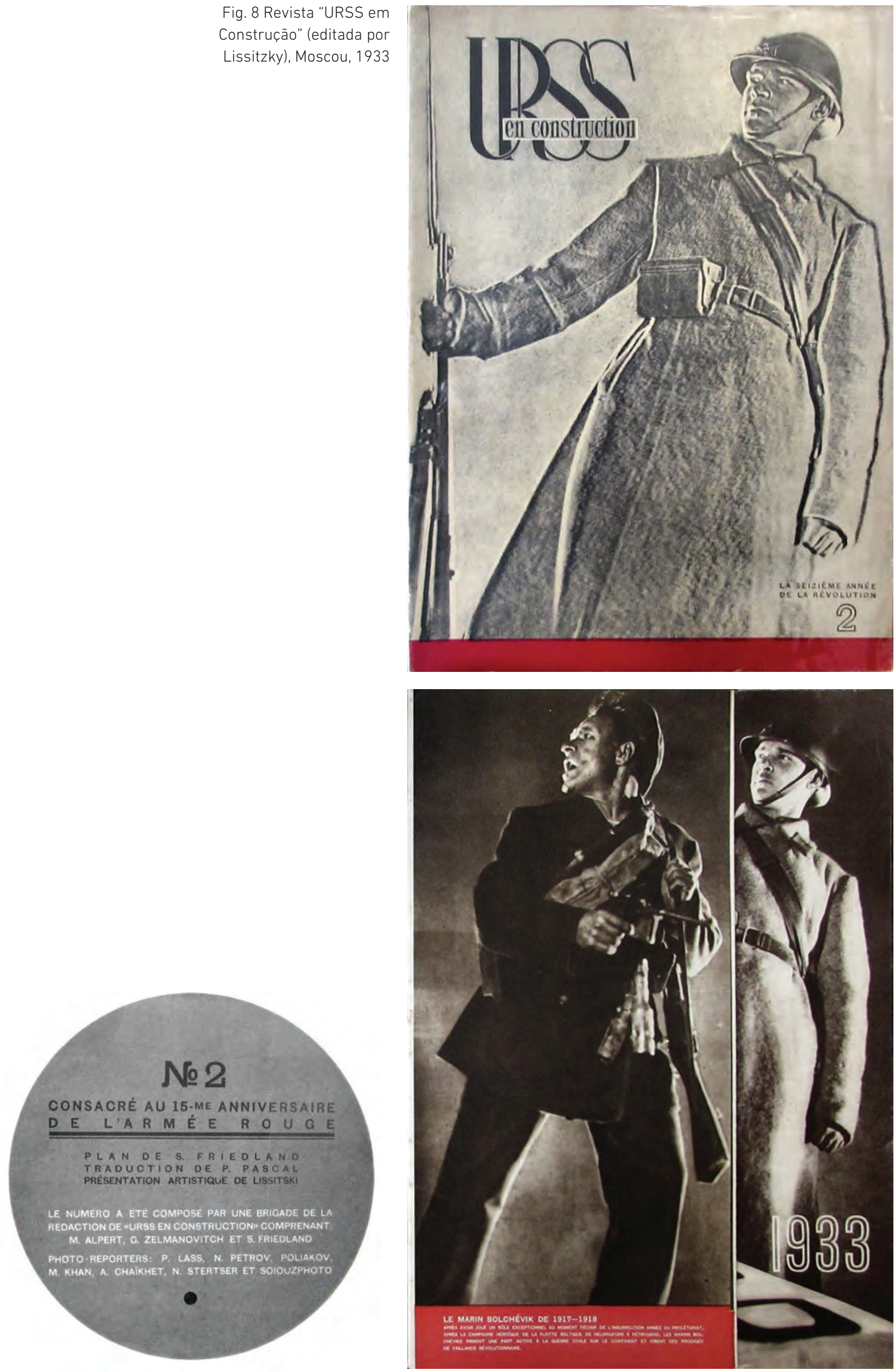

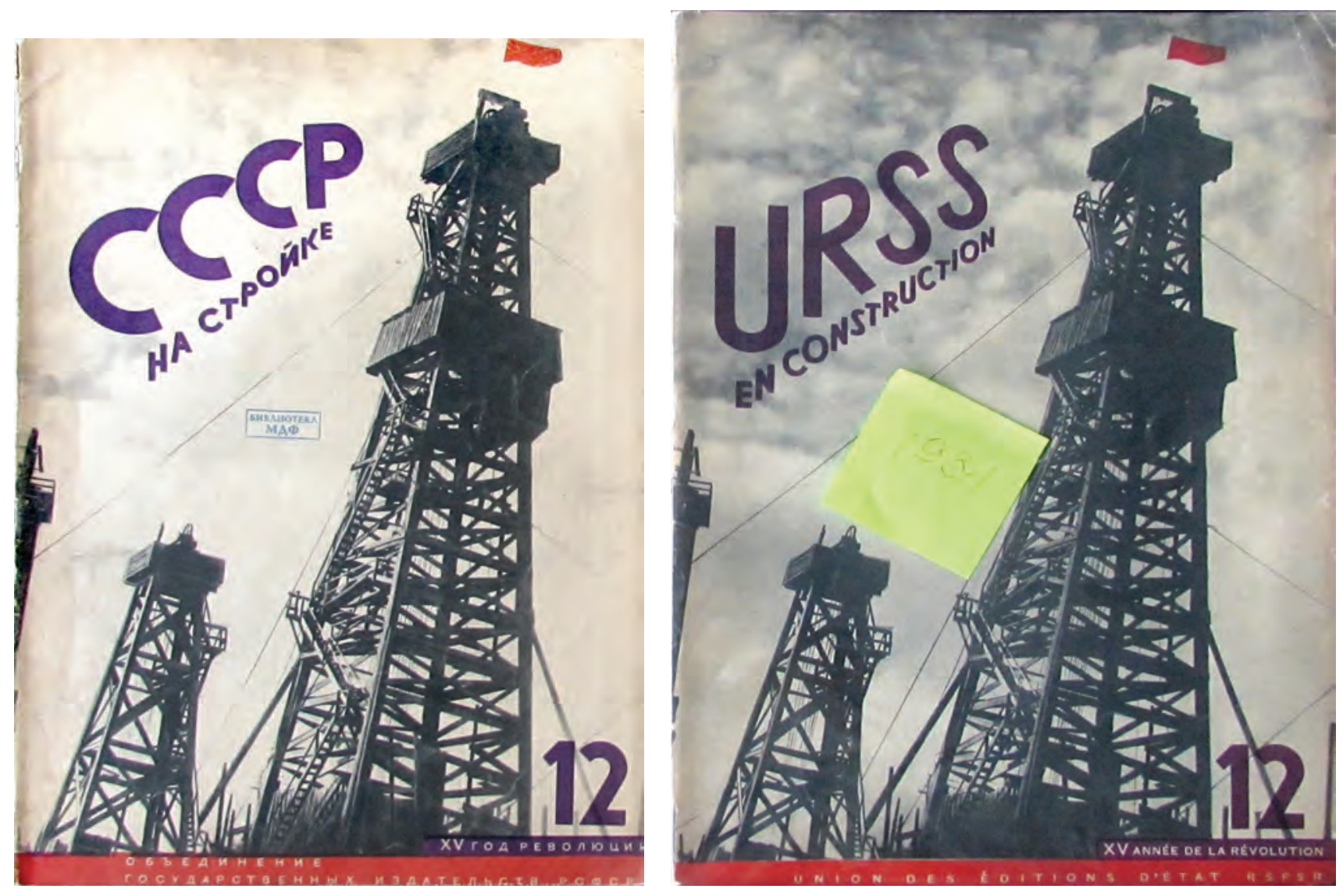

URSS EN CONSTRUCTION REVUE MENSUELLE ILLUSTREE

No 12 CONSACRÉ A L'INDUSTRIE DU NAPHTE DE LUURSS

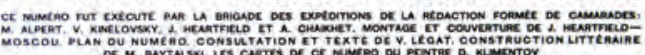
COLLEGE DE REDACTION: $M$, OORKI, $A$ HOLZMANN, Q. ORINKO, T, ENOUKIDZE,

ABONNEMENTS POUR 1932: UN AN-B DOLLARS; MOIS-2,5 DOLLARS;

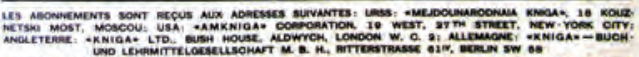

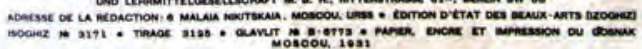

Fig.9 Revistas "URSS em

Construção (editadas por Heartfield), Moscou, 1931. Canto suoerior esquerdo, versão russa; superior direito, versão francêsa (edição impressa em formato maior - imagens na mesma escala). Canto inferior, à esqueda, créditos da edição.

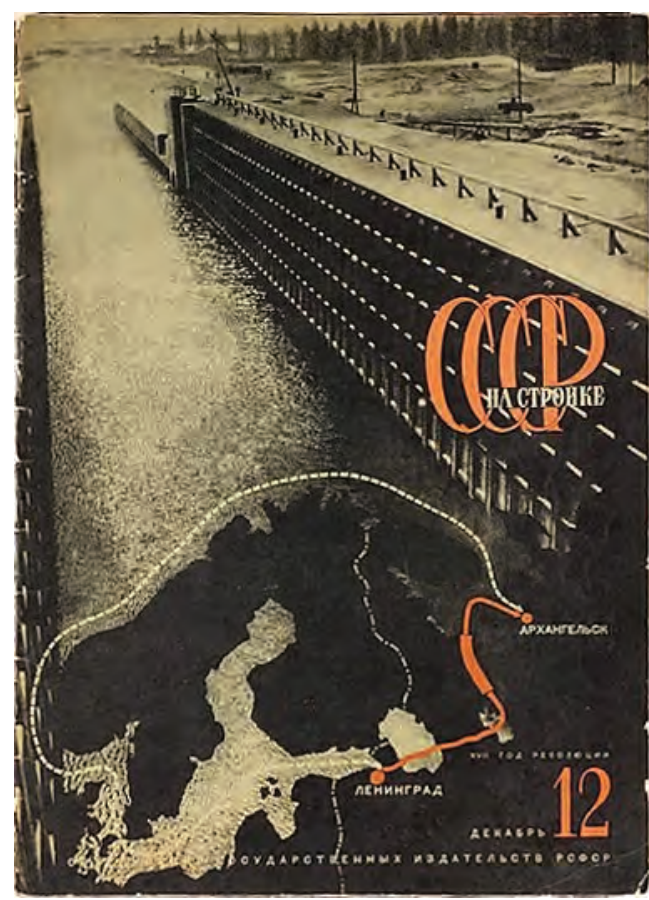

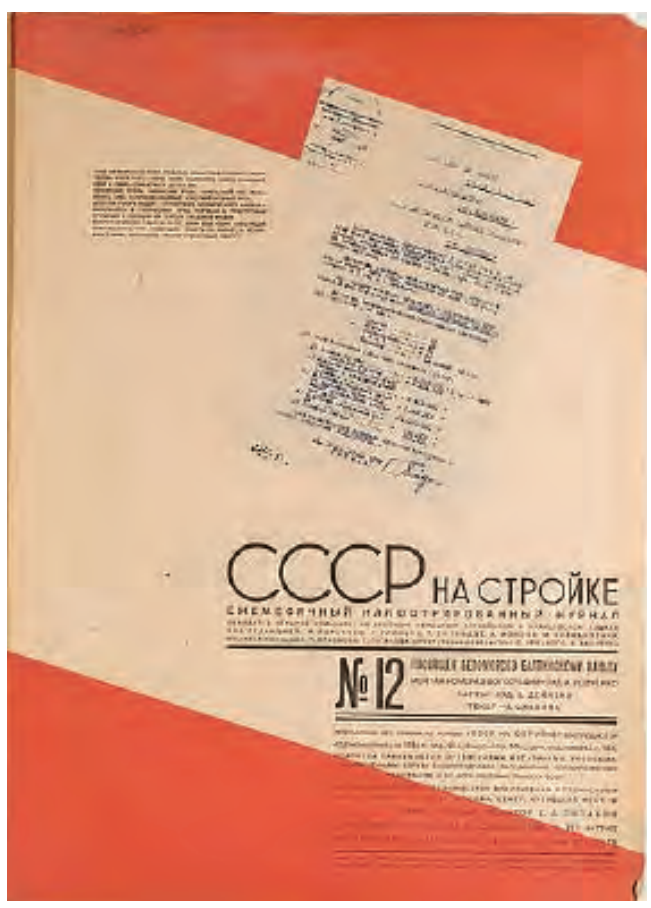

Fig.10 À direita, Revista "URSS em Construção" (editada por Rodchenko), Moscou, 1933 
Fig. 11 Planta do pavilhão soviético na Ex-

posição Internacional de Imprensa de Colônia,

imagem retirada do catálogo da mostra, 1928

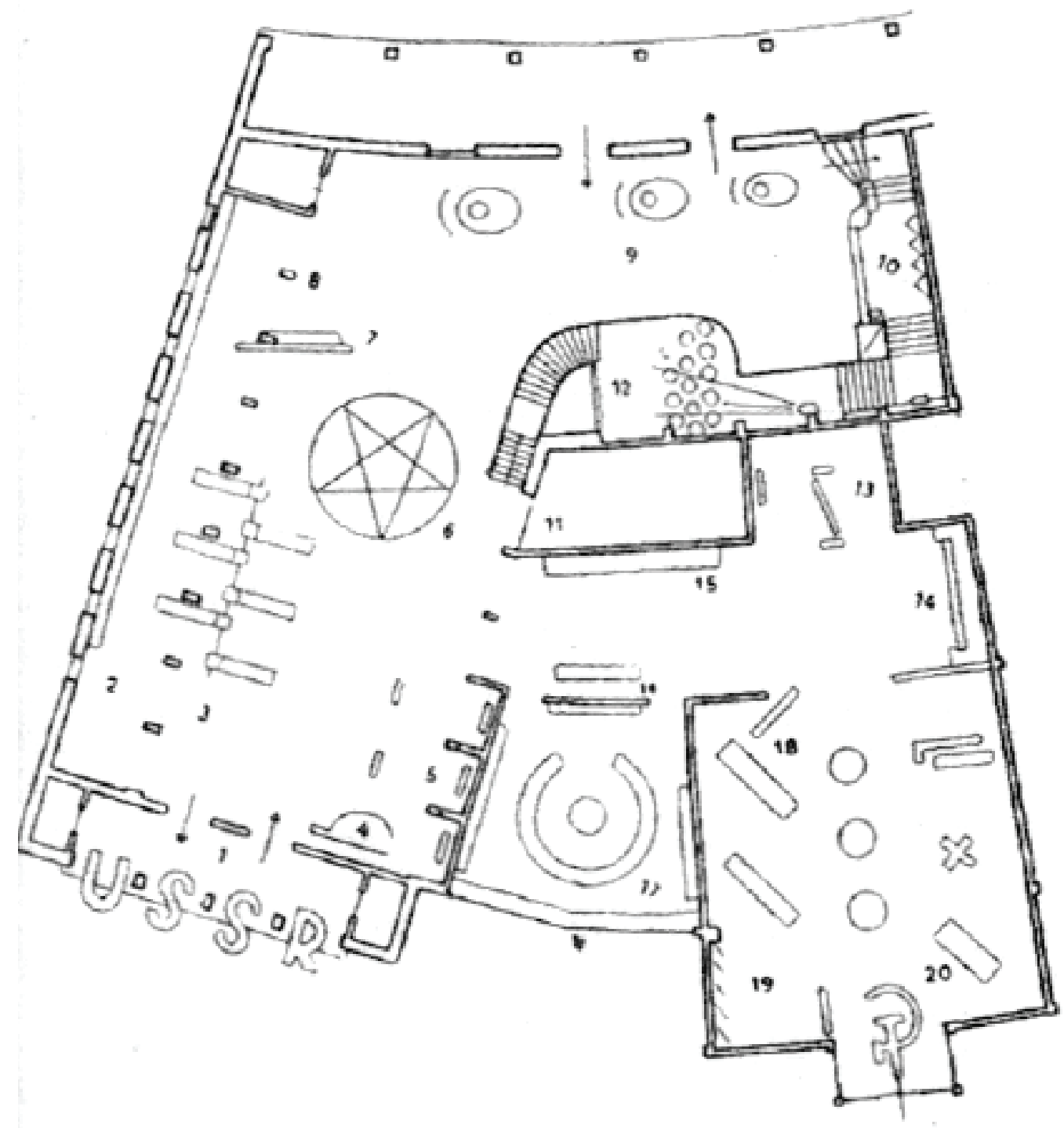

LAYOUT DA EXPOSIÇÃO

1. Entrada principal

2. Departamento Histórico

3. Transmissões

4. Sindicatos

5. Reconstrução social da aldeia

6. Grande estrela

7. Mapa da URSS

8. Academia de Ciências

9. URSS

10. Lenin como jornalista
11. Escritório e informações

12. Cinema: (Podium: Repúblicas Federais)

13. Empresas

14. Mapa mundial "TASS"

15. Correio

16. Estande de vendas

17. Sala de leitura

18. Movimento dos correspondentes

19. Exército Vermelho

20. Editora Estatal 


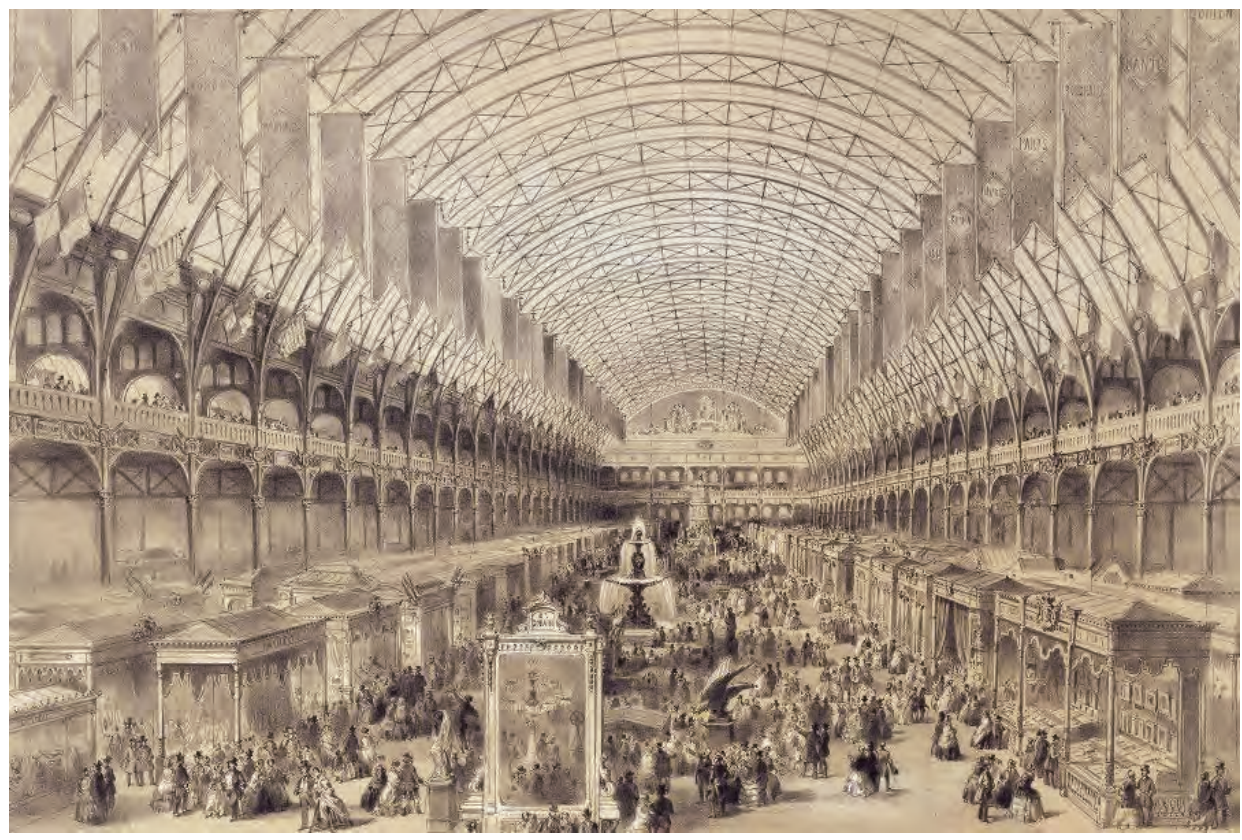

Fig. 12 A. Provst. Feira Universal. Vista interior geral, 1855
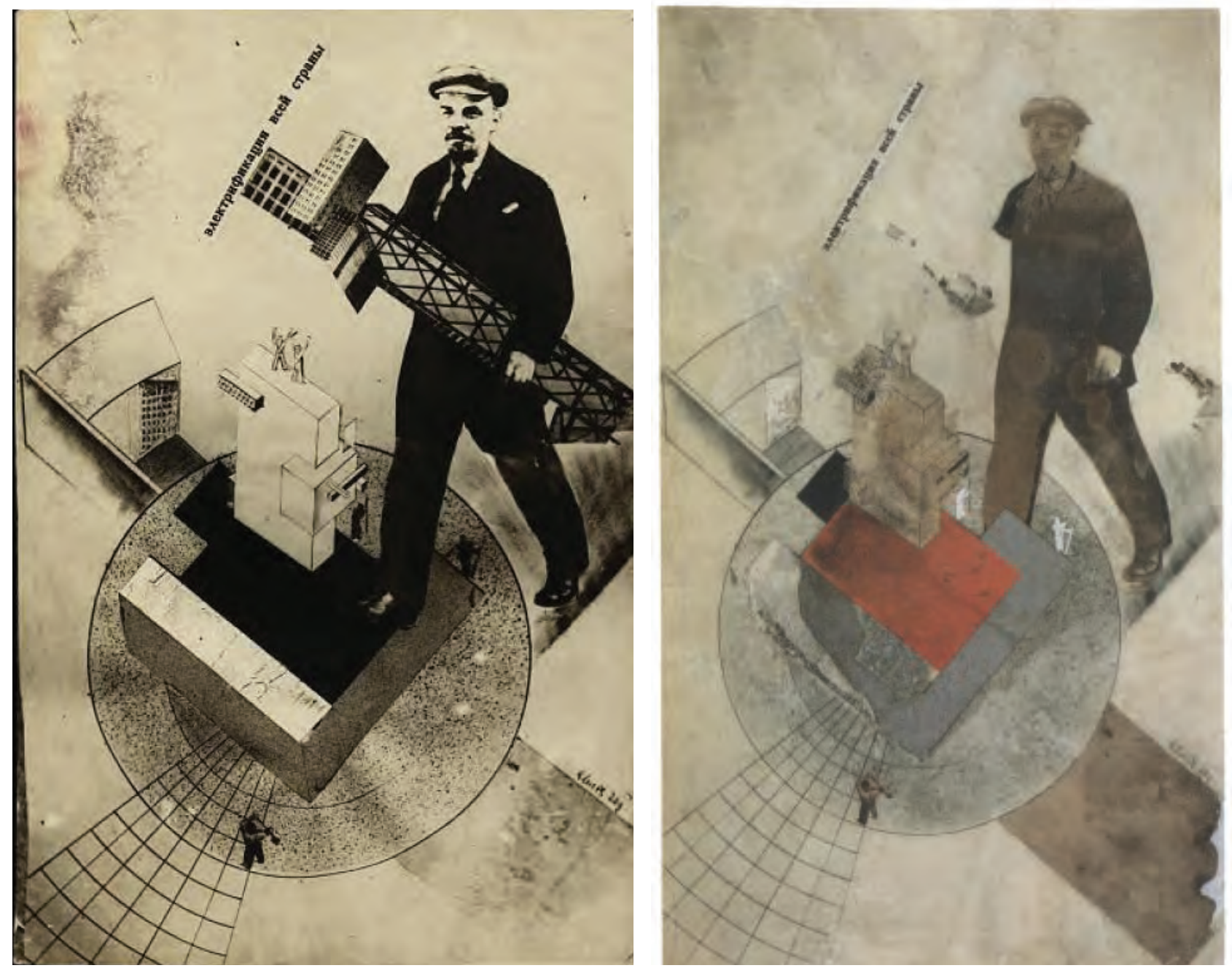

Fig. 13. Cartazes e colagem de G.

Klutsis. "Eletrificação do País Inteiro",

1920 
Fig.14 Fotomontagem de G. Klutsis. "Construindo o Socialismo sob a Bandeira de Lenin", 1932

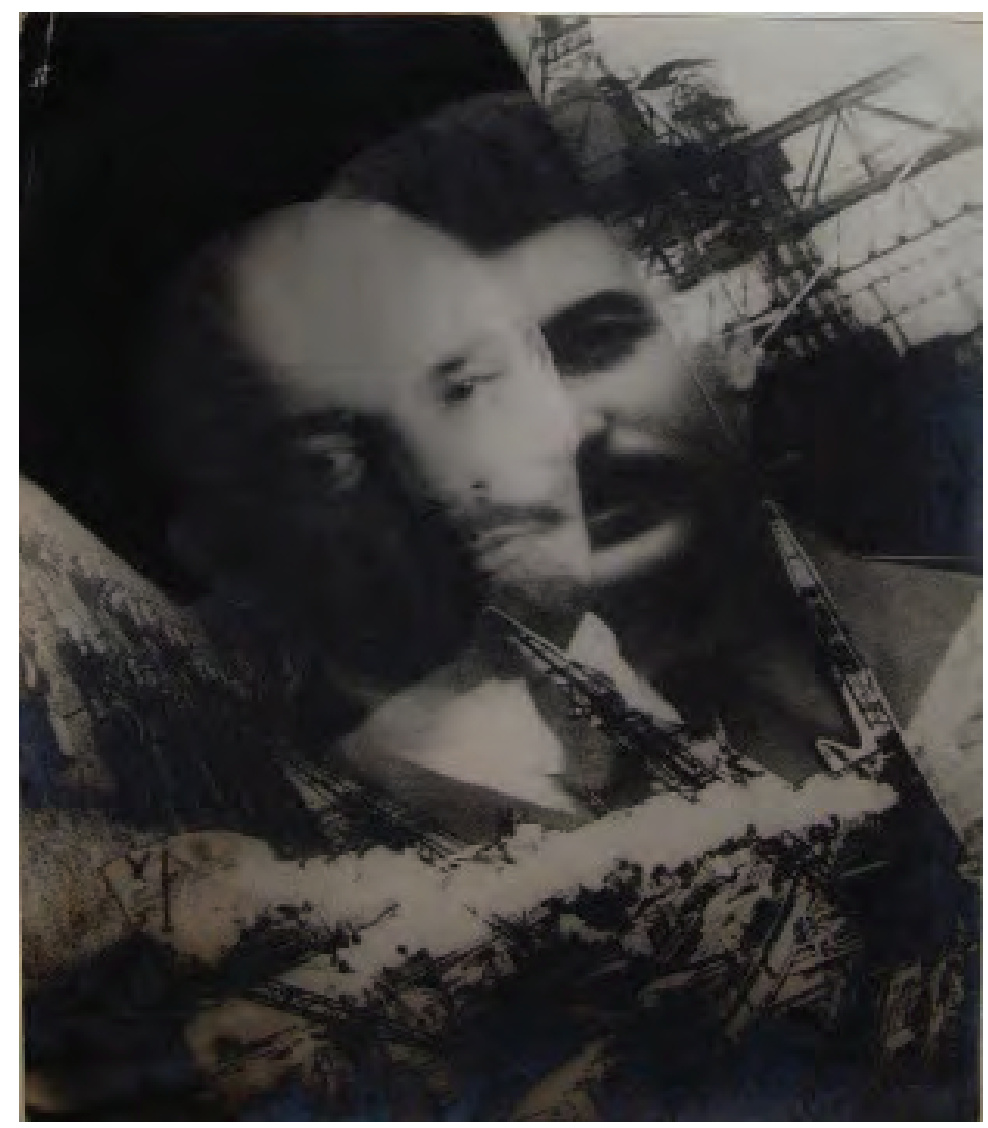

Fig.15 Cartaz de G. Klutsis. Construindo o Socialismo sob a Bandeira de Lenin, 1932

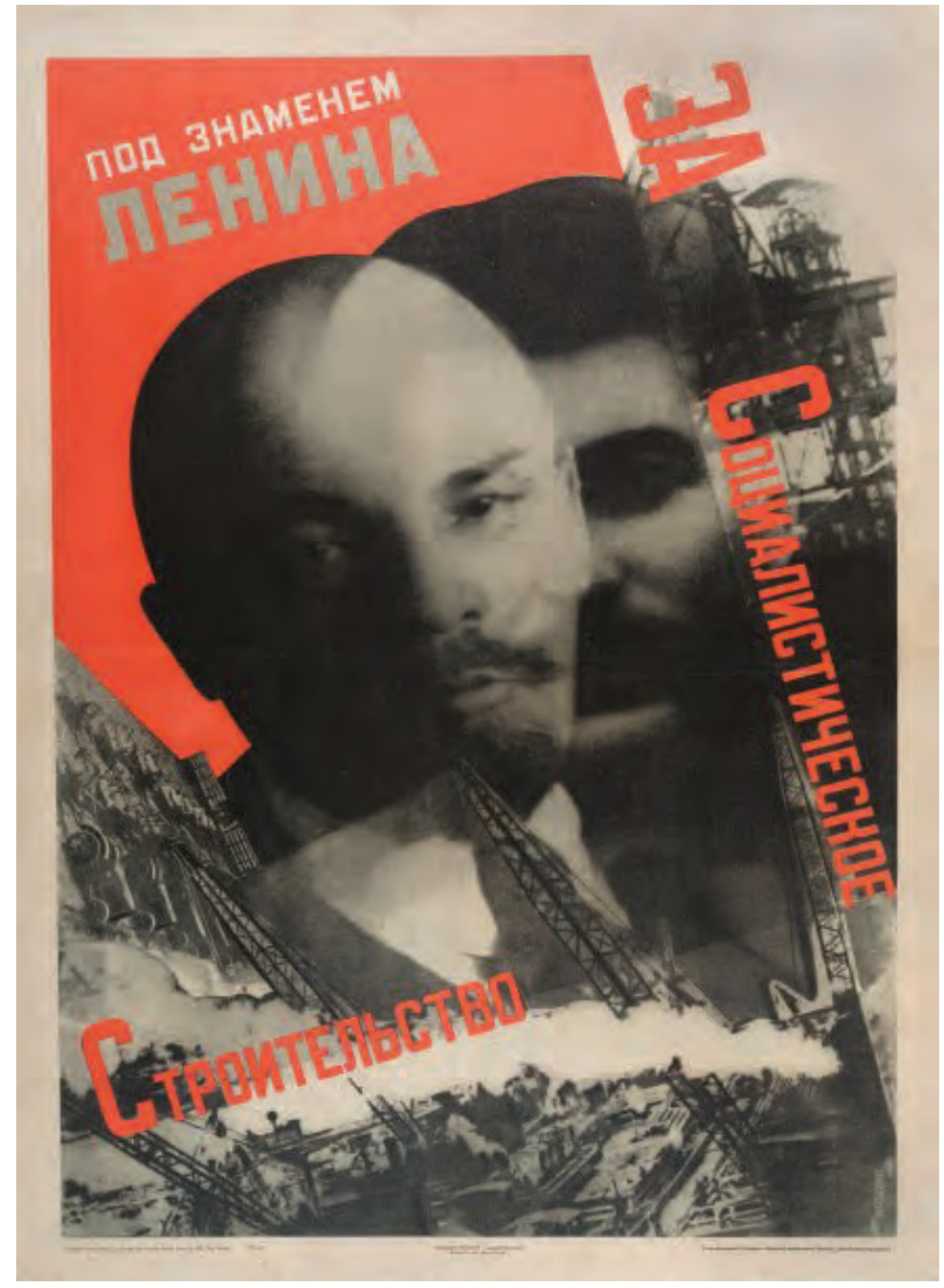




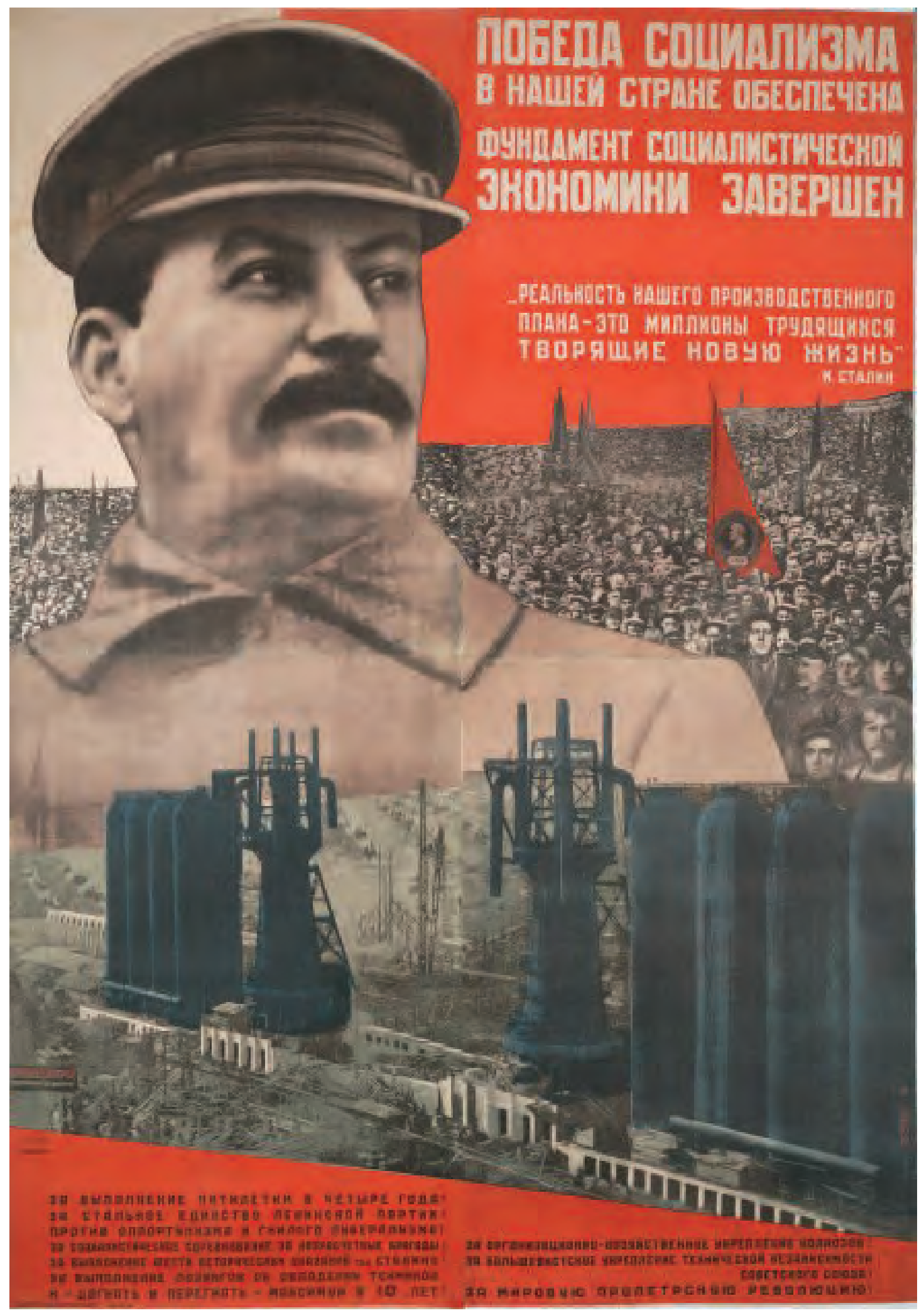

Fig. 16 Cartaz de G. Klutsis. "A Vitória do Socialismo no Nosso País é

Garantida", 1932 


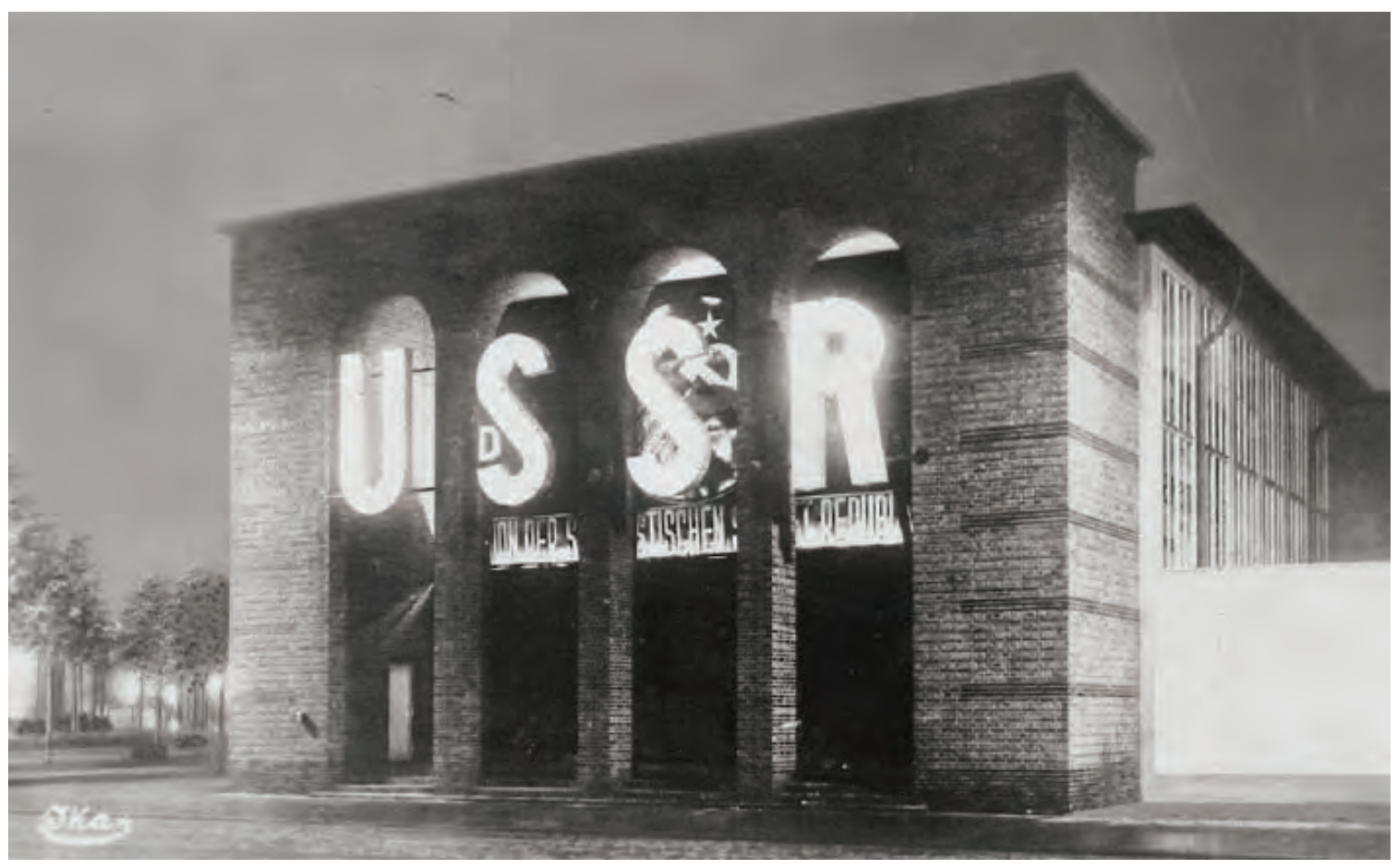

Fig. 17 Fotos da fachada do pavilhão soviético na Exposição Internacional de Imprensa de Colônia, 1928

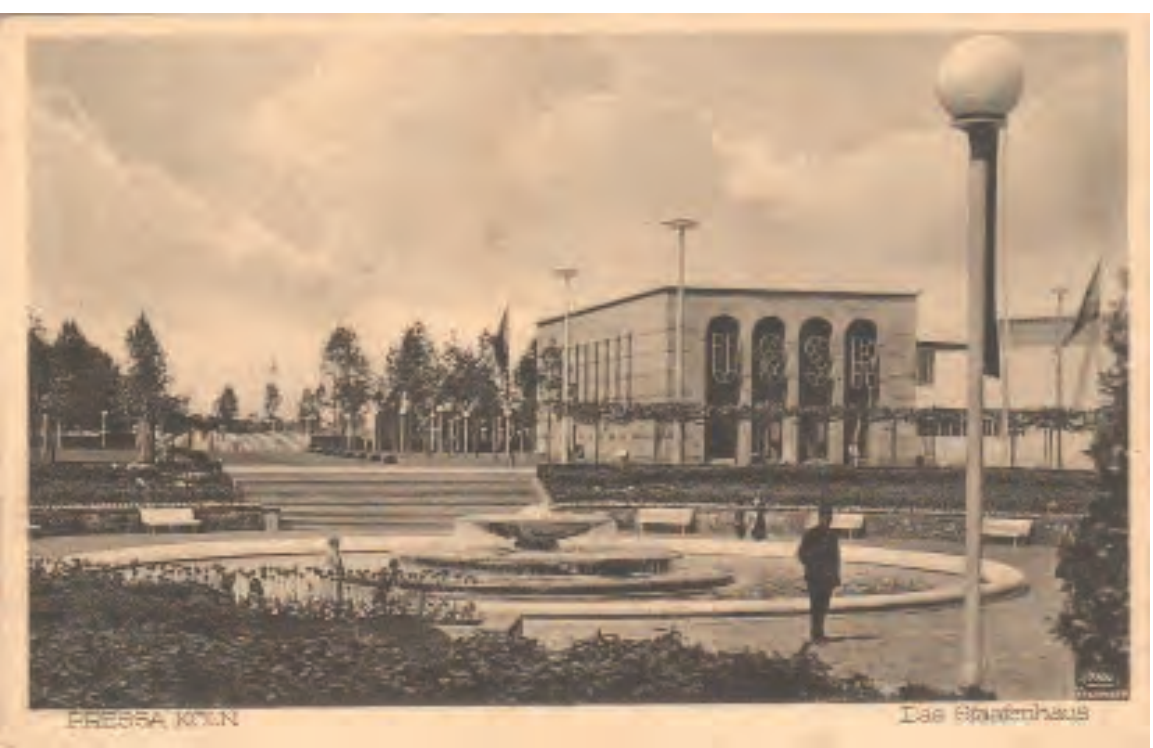



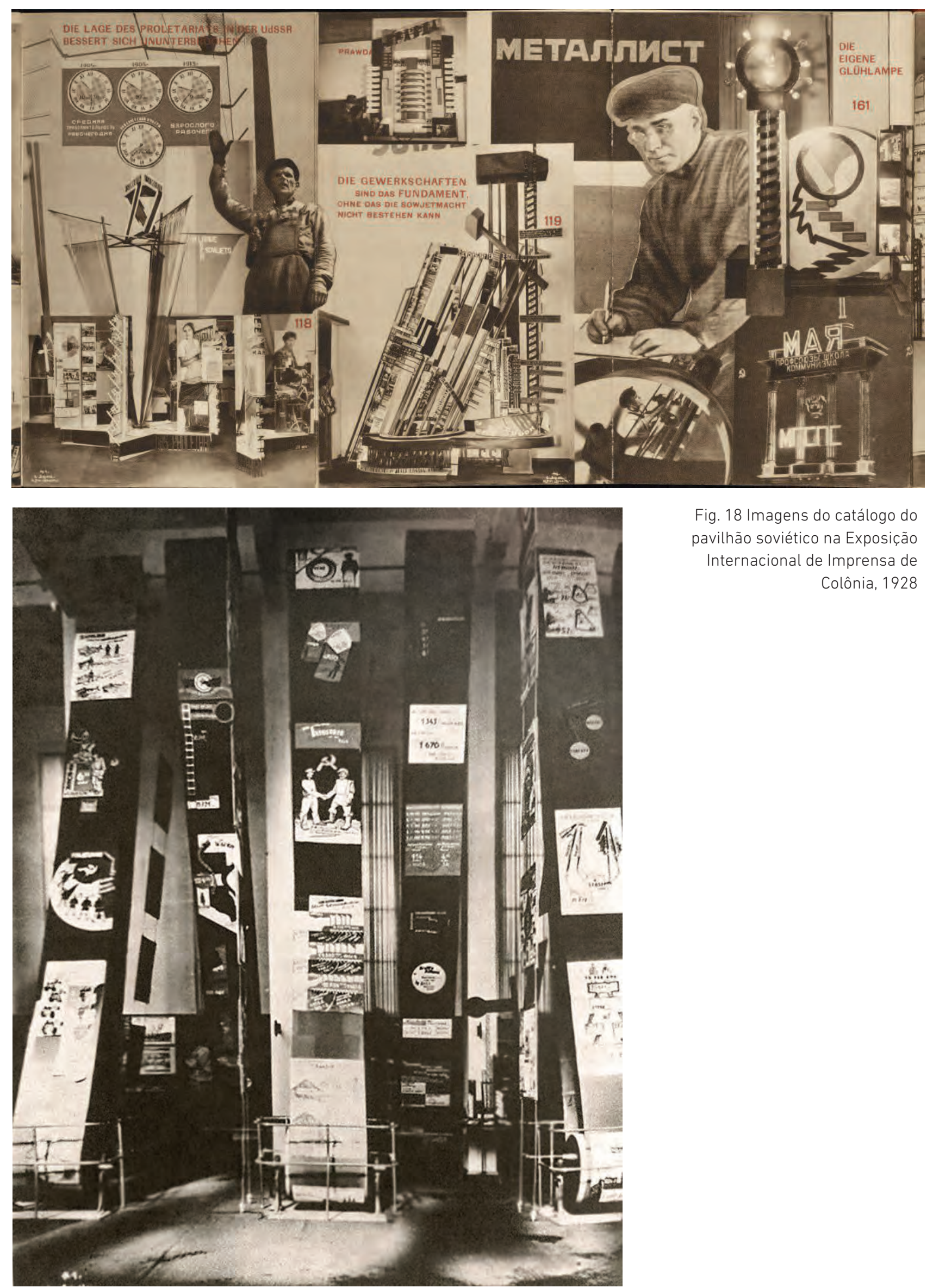

Fig. 18 Imagens do catálogo do pavilhão soviético na Exposição Internacional de Imprensa de Colônia, 1928

Fig. 19 Área 3, "Transmissões", pavilhão soviético na Exposição Internacional de Imprensa de Colônia, 1928 
Fig. 20 Obras do pavilhão soviético na Exposição Internacional de Imprensa de Colônia, 1928. Máquinas acionadas com eletricidade
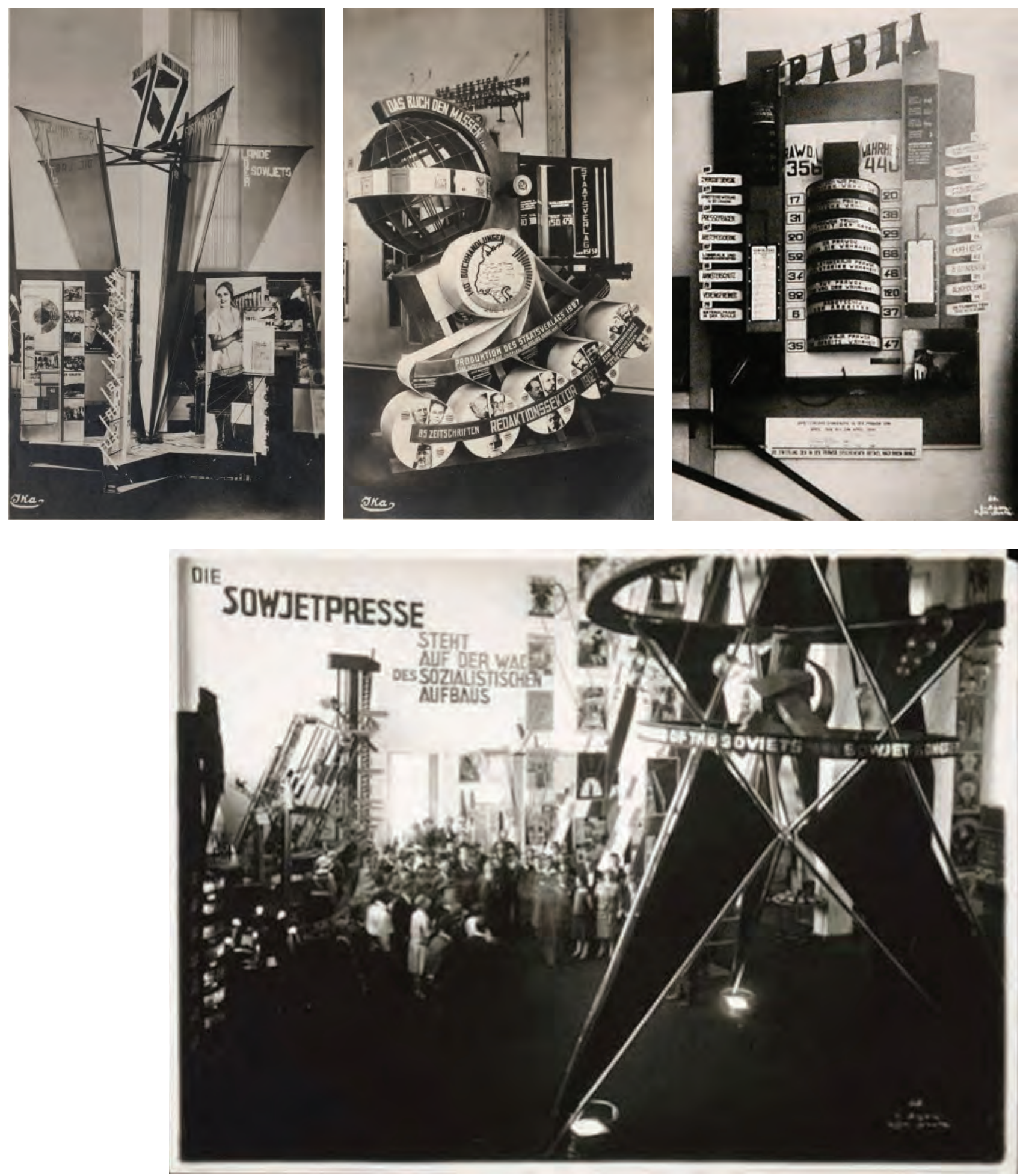

Fig. 21 Área 6, "Grande Estrela", pavilhão soviético na Exposição Internacional de Imprensa de Colônia, 1928 


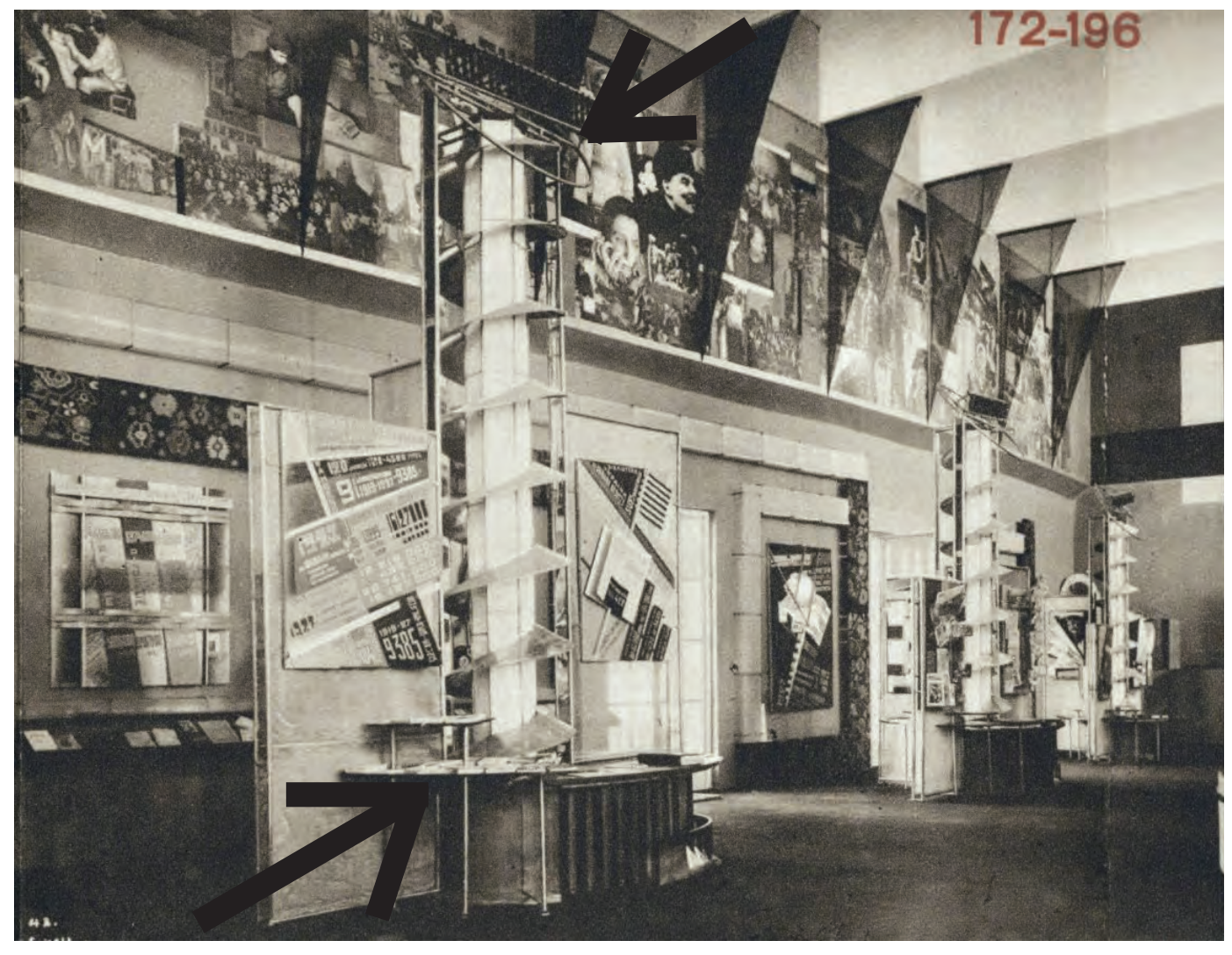

Fig. 22 Área 9,

"Repúblicas Federais", pavilhão soviético na Exposição Internacional de Imprensa de Colônia, 1928. Em destaque: os aspirais cinéticos

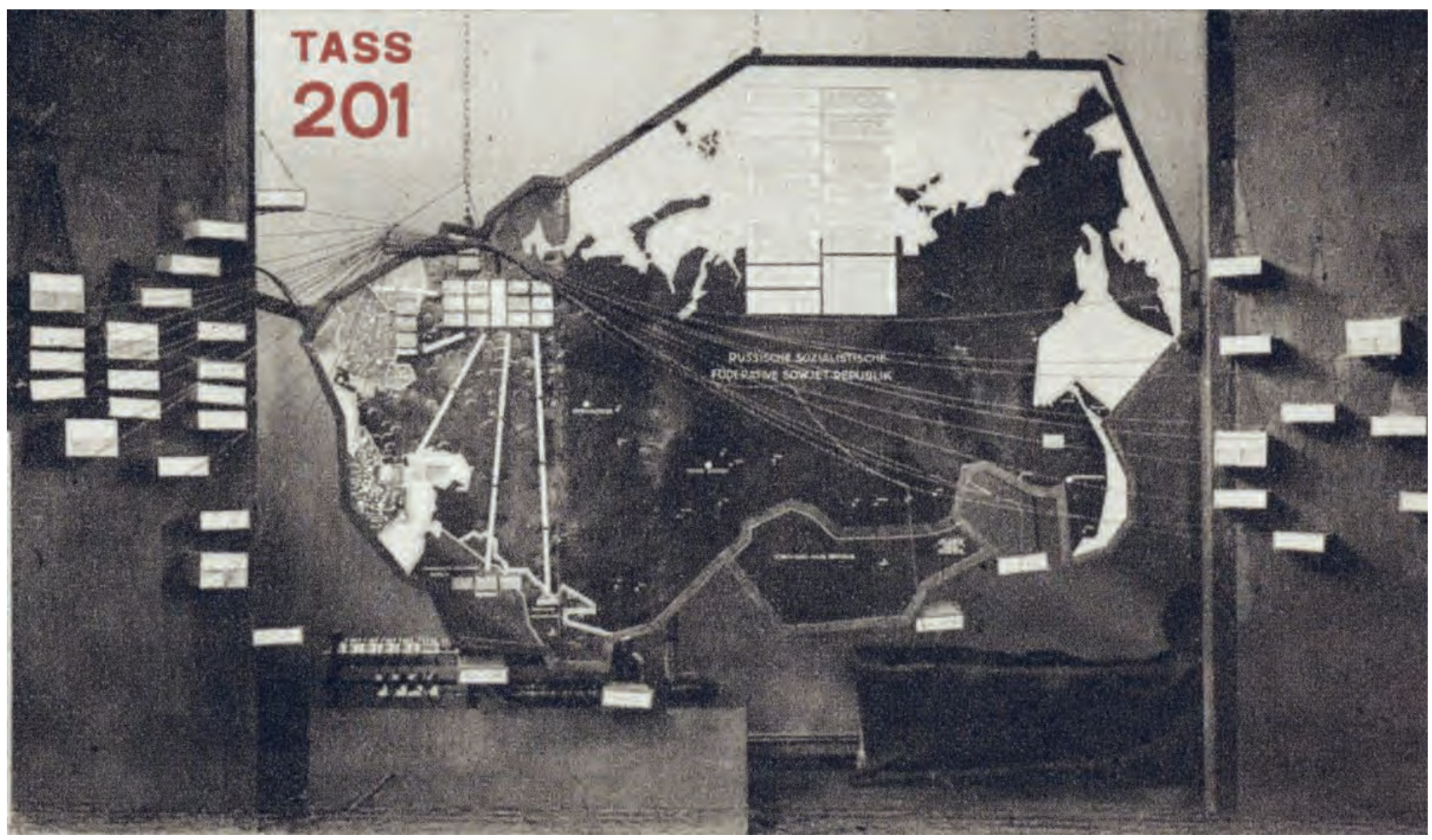

Fig. 23 Área 14, "Mapa Mundial 'TASS', pavilhão soviético na Exposição Internacional de Imprensa de Colônia, 1928 
Fig. 24 Área 18, "Correspondentes Operários'", pavilhão soviético na Exposição Internacional de Imprensa de Colônia, 1928
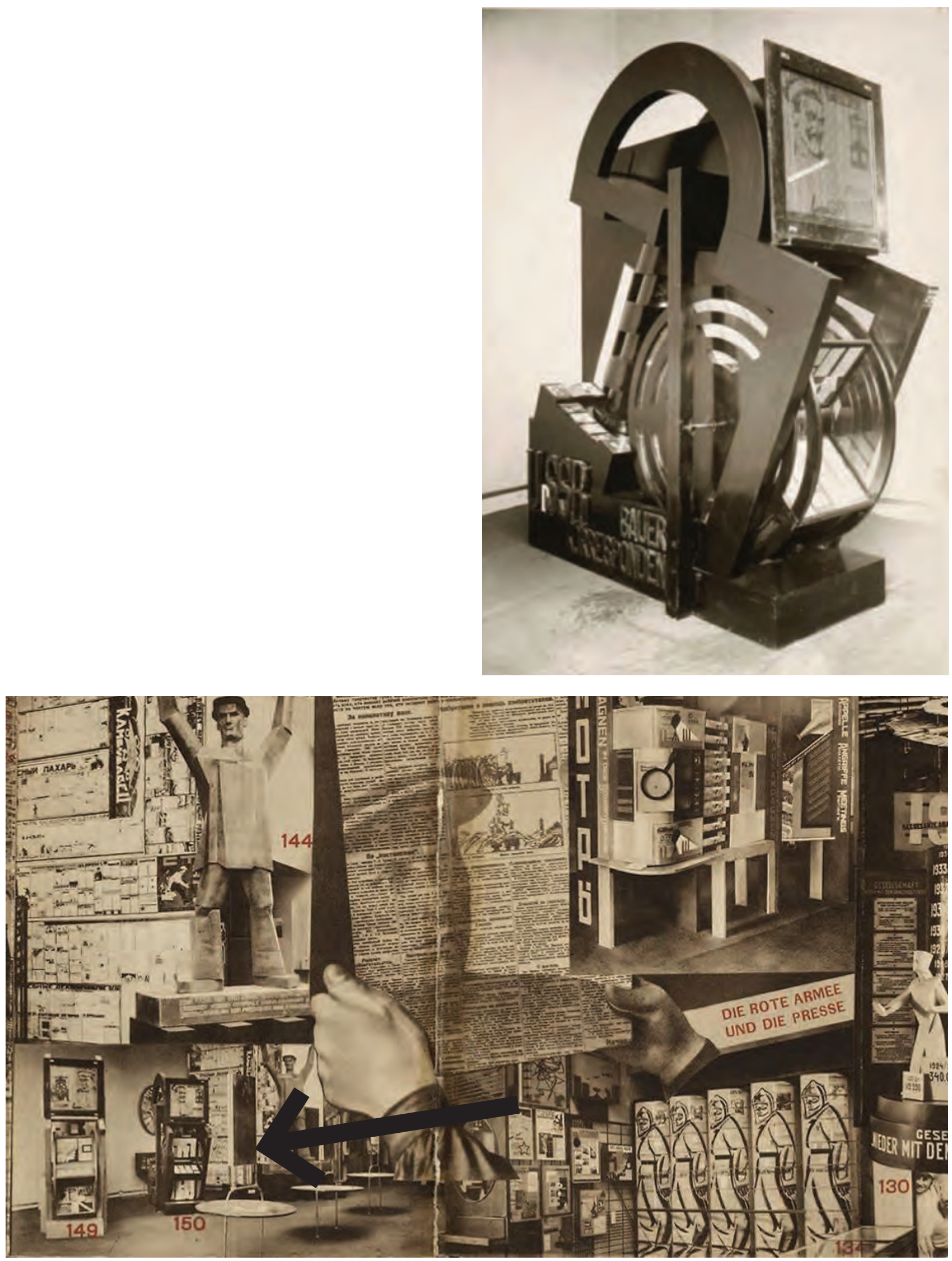

Fig. 25 Área 18, "Correspondentes Operários'”, pavilhão soviético na Exposição Internacional de Imprensa de Colônia, 1928 
Fig. 26 Área 19, "Exército Vermelho'", pavilhão soviético

na Exposição Internacional de Imprensa de Colônia, 1928.

Cilindros giratórios.
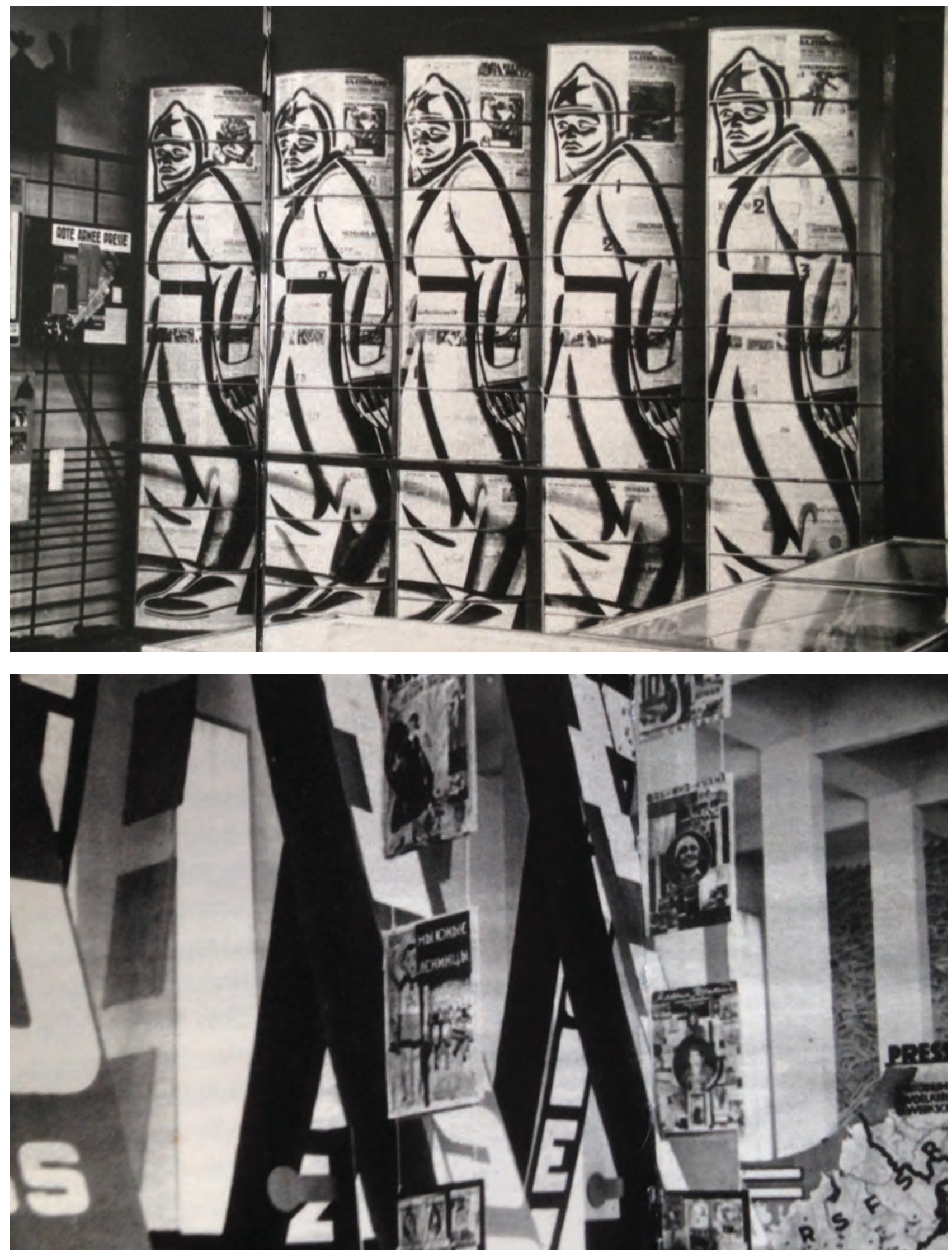

Fig. 27 Detalhe da área 3, "Transmissões", pavilhão soviético na Exposição Internacional de Imprensa de Colônia, 1928. Única suposta imagem de Stalin encontrada nas fotos do pavilhão (cartaz na direita, inferior; imagem central do cartaz) 


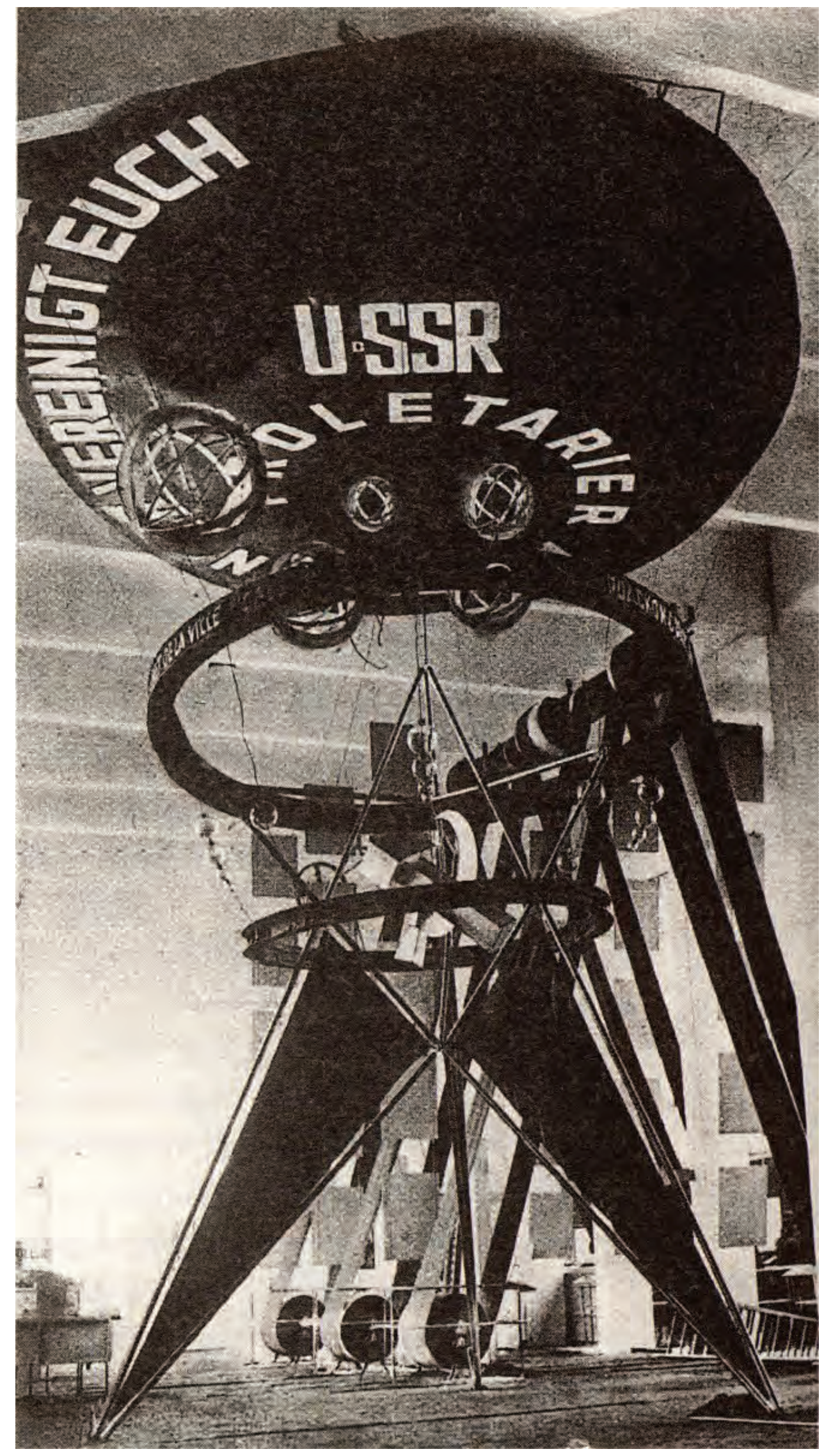

Fig. 28 Área 6, "Grande Estrela", pavilhão soviético na Exposição Internacional de Imprensa de Colônia, 1928 
Fig. 29 Detalhe da área 9, painel "A Tarefa da Imprensa é a Educação das Massas na Transição do Capitalismo para o Comunismo", pavilhão soviético na Exposição Internacional de Imprensa de Colônia, 1928
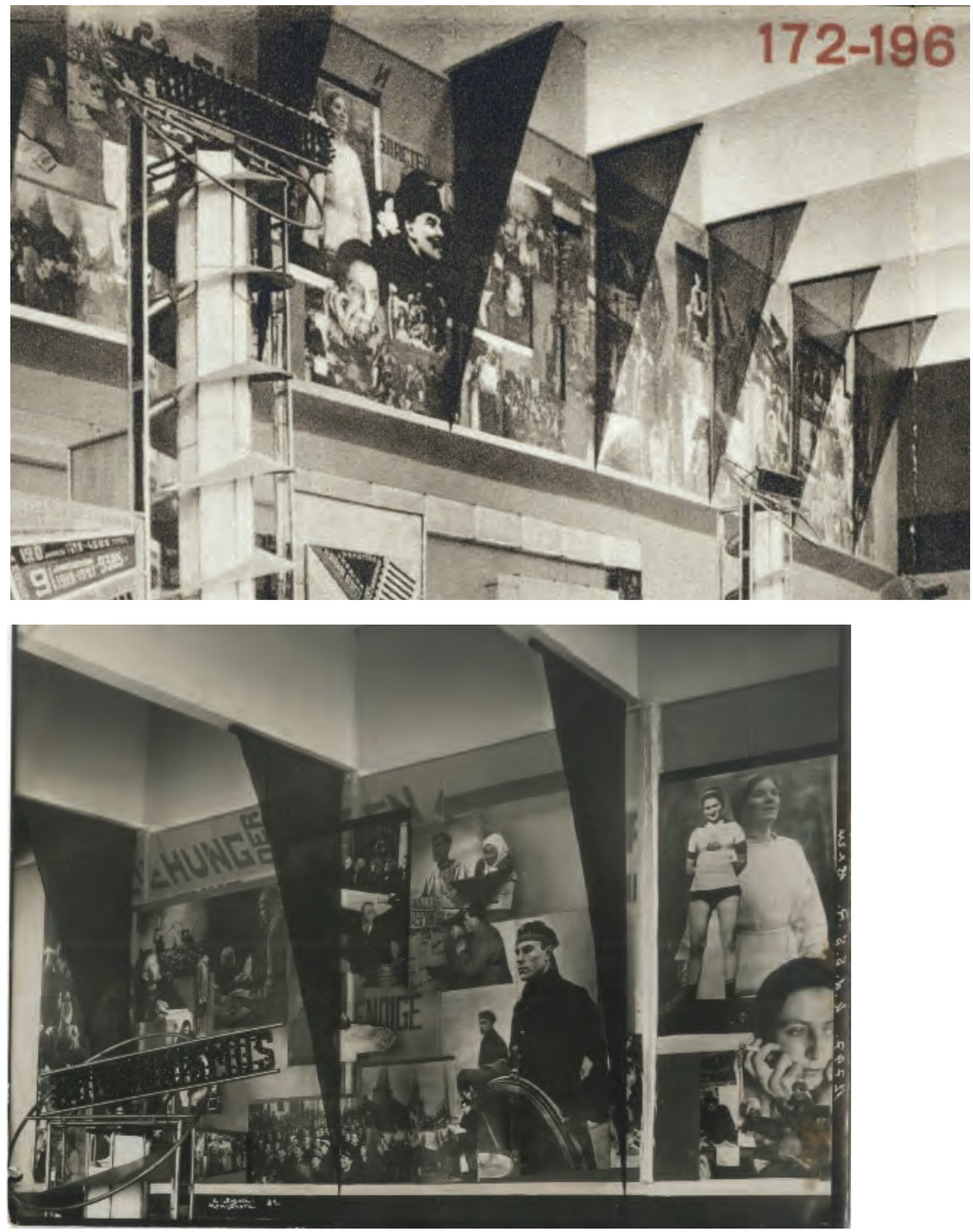

Fig. 30 área 9, painel "A Tarefa da Imprensa é a Educação das Massas na Transição do Capitalismo para o Comunismo", pavilhão soviético na Exposição Internacional de Imprensa de Colônia, 1928 
Fig. 31 Área 9, painel "A Tarefa da Imprensa é a Educação das Massas na Transição do Capitalismo para o Comunismo", pavilhão soviético na Exposição Internacional de Imprensa de Colônia, 1928,
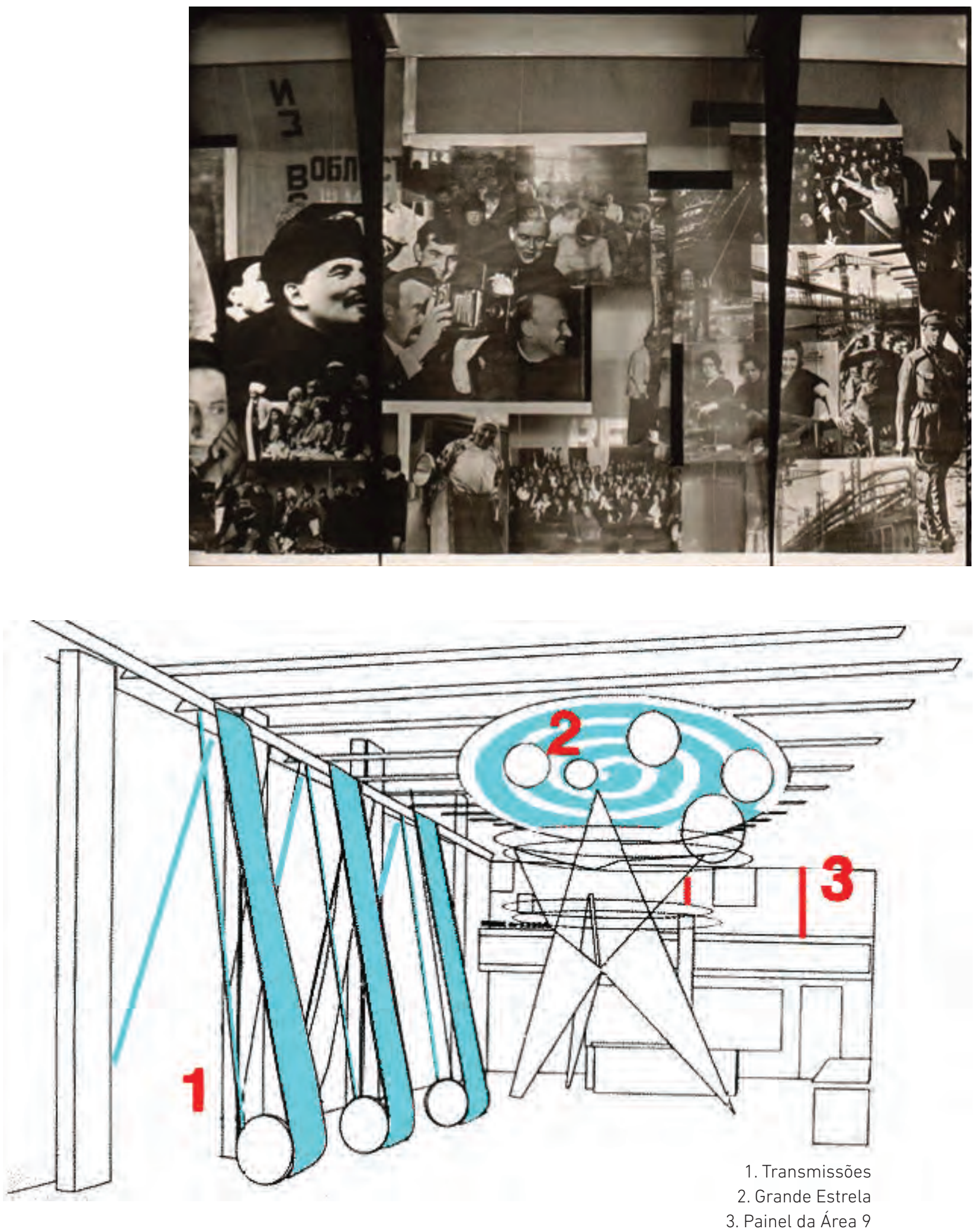

Fig. 32 Desenho simulando parte da configuração espacial do pavilhão soviético na Exposição Internacional de Imprensa de Colônia, 1928 
Fig. 33 Área 10, "Lênin como um jornalista",

pavilhão soviético na Exposição Internacional de

Imprensa de Colônia, 1928
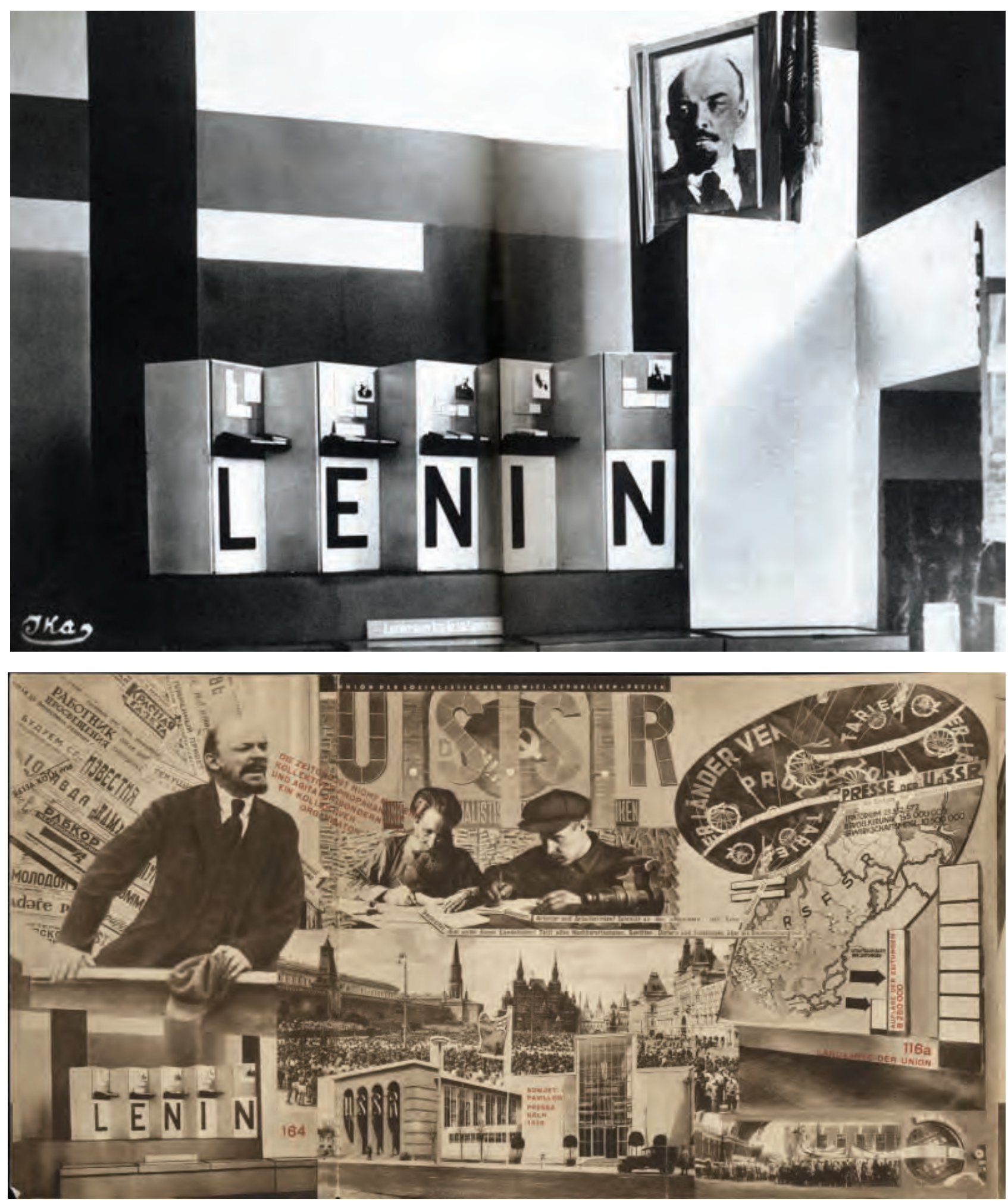

Fig. 34 Fotomontagem do catálogo, pavilhão

soviético na Exposição Internacional de Imprensa

de Colônia, 1928 
Fig. 35 Desenhos para o Clube dos Trabalhadores de A. Rodchenko, Pavilhão Soviético na Exposição Internacional de Artes Decorativas e Modernas Industriais, em Paris, 1925
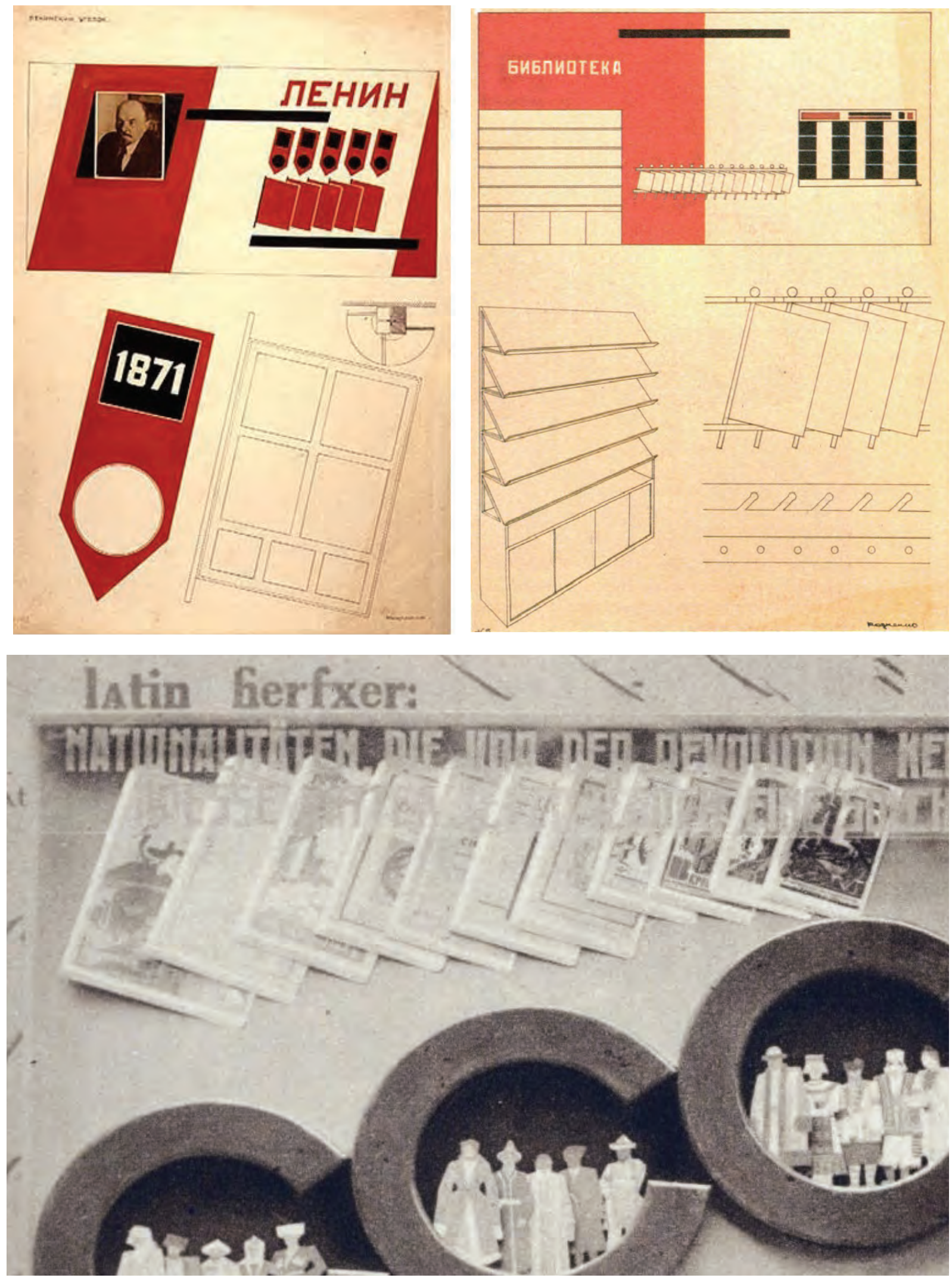

Fig. 36 Área 9, "União das Repúblicas Socialistas", pavilhão soviético na Exposição Internacional de Imprensa de Colônia, 1928 

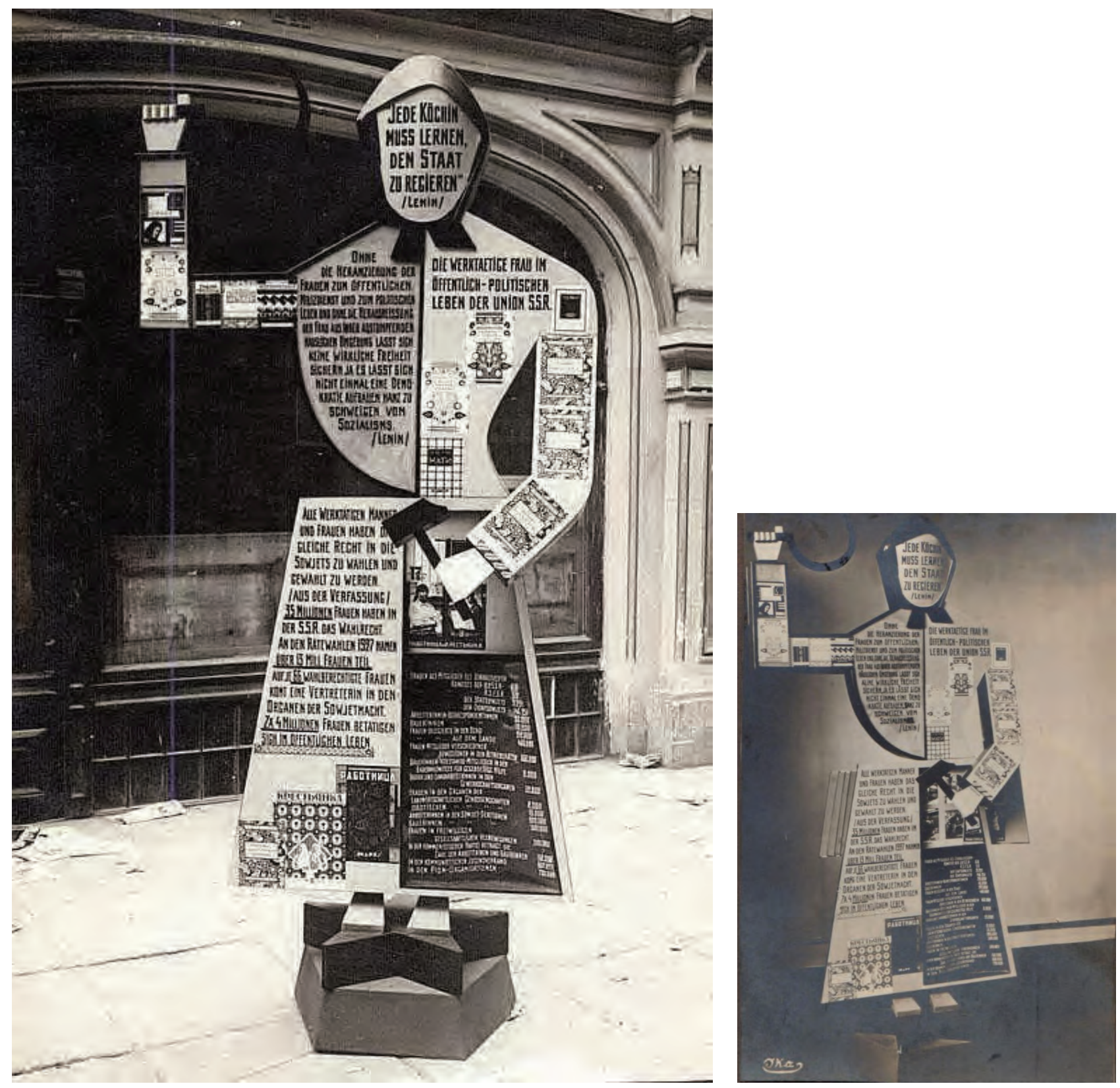

Fig. 37 Silhueta de camponesa realizada para o pavilhão soviético na Exposição Internacional de Imprensa de Colônia, 1928 


\title{
CAPÍTULO 2 | "Algo de hoje, moderníssimo": A construção de um sistema artístico fascista (1927-1932)
}

\subsection{PREÂMBULO I Um "apêndice coreografado"}

\begin{abstract}
Se o governo deixa impunemente violar a Constituição, se o governo permite a formação, no país, de bandos armados, [...] o que significa isso senão que se está preparando, por parte dos organismos estatais que se agrupam no poder executivo, um golpe de Estado? O que significa isso senão que na Itália vivemos já no ambiente de que automaticamente deve desabrochar o golpe de Estado? (Gramsci, 1921). ${ }^{104}$
\end{abstract}

Segundo o dirigente do Partido Comunista da Itália Antônio Gramsci (1891-1937), nos dois anos posteriores à grande guerra (1914-1918), a crise capitalista (italiana) adquirira um estágio agudo. Isto favorecera - "depois que em 1920 a classe operária tinha falhado na sua tarefa de criar [sic], com seus meios, um Estado capaz de satisfazer também as exigências nacionais unitárias da sociedade italiana” 105 - o surgimento e a ascensão “de uma ideologia confusamente patriótica” e antiproletária, o fascismo. ${ }^{106}$

Em 28 de outubro de 1922, onze meses após a denúncia que A. Gramsci fez sobre a postura complacente do Estado italiano para com os squadristas, Benito Mussolini (1883-1945), então líder do Partido Nacional Fascista (PNF, 1921-1943), ascendeu ao poder com a ameaça de insurreição armada e uma "marcha sobre Roma”.

Em 28 de outubro de 1922, dia marcado para o “assalto” fascista, o Rei Vitorio Emanuelle III (1869-1947) convidou Mussolini para compor o Governo - no cargo de Primeiro Ministro. O blefe foi bem-sucedido e a "ofensiva"107 transformada num apêndice coreografado da nomeação legal de

${ }^{104}$ GRAMSCI, A., “O apoio do Estado”, L’Ordine Nuovo, 13.11.1921, in GRAMSCI, A., Escritos politicos, trad. Manuel Simões, v. III, Lisboa: Seara Nova, Instituto Gramsci, 1977, pp. 29-33, p. 29.

${ }^{105}$ GRAMSCI, A., "La crisi italiana”, L’Ordine Nuovo, 01.09.1924, in GRAMSCI, Antonio, Scritti politici III, org. Paolo Spriano, Roma: Editori Riuniti, 1973, p. 63.

${ }^{106}$ GRAMSCI, A., “A crise italiana”, L'Ordine Nuovo, 01.09.1924, in GRAMSCI, A., Escritos..., op. cit., pp. 123136, p. 124.

${ }^{107}$ Em 27 de outubro de 1922, alguns lideres fascistas estabeleceram um quartel general nas proximidades de Roma e esperavam ordens de Mussolini para a invasão de Roma e a tomada do poder por via armada. Mussolini, até a manhã do dia 30 de outubro, aguardou o desenrolar das negociações em Milão. “Tratava-se evidentemente de um bluff, ao qual só poderia ter dado crédito quem estivesse interessado nos resultados positivos da ameaça”. FIORANI, Mario, Breve historia do fascismo, Rio de Janeiro: Editora Civilização brasileira, 1963 , p. 68. 
Mussolini. No dia 31 de outubro, os camisas negras celebraram sua revolução sem revolução por meio de uma grande parada militar, que entraria para a história oficial fascista como "a marcha sobre Roma”. ${ }^{108}$

O caráter espetaculoso e ambivalente do encadeamento de fatos que instauraram a solução italiana para a crise de representatividade e hegemonia burguesa vigente parece constituir em si um prelúdio da articulação entre política e estética na "revolução passiva" ${ }^{109}$ fascista.

O presente capitulo discute a articulação entre arte, cultura e propaganda durante o fascismo italiano à luz da noção de "revolução passiva" e das principais inflexões históricas do período. Para tanto, o capitulo, num primeiro momento, abordará a noção de "revolução passiva" de Gramsci, para então, na sequencia, analisar a instalação de dispositivos de controle estatal (mecenato estatal, constituição de um circuito expositivo fascista etc.) e o esforço retórico de construção de uma cultura visual fascista que respondesse às demandas da "revolução-restauração" italiana.

\subsection{Fascismo}

Se a classe dominante perdeu o consenso, ou seja, não é mais "dirigente", mas unicamente "dominante", detentora da força coercitiva pura, isso de fato significa que as grandes massas se destacaram da ideologia tradicional, não acreditando mais naquilo que antes acreditavam etc. A crise consiste exatamente no fato de que o velho morre e o novo não pode nascer: nesse interregno se verificam os fenômenos mórbidos mais variados (Gramsci, 1930). ${ }^{110}$

Gramsci identificou, num primeiro momento, o fascismo a uma reação à crise capitalista, à crise de governabilidade italiana e ao fracasso do movimento operário italiano. ${ }^{111}$ Segundo Gramsci, "o fascismo surgiu e se desenvolveu no terreno desta crise", da crise radical do regime capitalista

\footnotetext{
${ }^{108}$ Conforme a historiadora italiana Falasca-Zamponi, se os camisas negras estavam prontos para invadir Roma, o primeiro ministro Luigi Facta (1861-1930) também estaria pronto para evocar o estado de sítio e defender Roma com um exército superior em número de homens, armamento e treinamento aos squadristas. FALASCAZAMPONI, Simonetta, Fascist spectacle the aesthetics of power in Mussolini's Italy, 1st pbk, Berkeley: University of California Press, 2000, p. 1.

${ }^{109}$ O conceito de "revolução passiva" e a leitura gramsciana do fascismo enquanto "revolução passiva" serão discutidos na sequência.

${ }^{110}$ GRAMSCI, Antonio, Quaderni del carcere, edizione critica dell' Istituto Gramsci, org. Valentino Gerratana, Torino: Einaudi, 2007, Q. 3, \$34, 1930, p. 311.

${ }^{111}$ GRAMSCI, A., “A crise italiana”, L'Ordine Nuovo, 01.09.1924, in GRAMSCI, A., Escritos..., op. cit., pp. 123136.
} 
iniciada com o pós-guerra. Conforme os escritos de Gramsci do período pré-cárcere, enquanto uma reação armada à crise capitalista e ao movimento operário, o fascismo teria chegado ao poder opondo-se ao proletariado e "explorando e organizando a inconsciência e o carneirismo [pecoraggine] da pequena burguesia bêbeda de ódio contra a classe operária" ${ }^{112}$

Em dois textos de 1924, publicados em L'Ordine Nuovo, Gramsci apontou a incapacidade de o fascismo apresentar uma alternativa real à crise econômica e política italiana. Gramsci também aventou a possibilidade de que o fascismo viesse a ser derrubado por uma insurgência proletária - a qual seria a única alternativa possível para que a Itália saísse da crise instaurada no pós-guerra.

A crise radical do regime capitalista, iniciada na Itália, assim como em todo o mundo, com a guerra, não foi resolvida pelo fascismo. [...] A crise geral do sistema capitalista, não foi, portanto, parada[sic] pelo regime fascista. [...] A crise italiana só pode ser resolvida pelo proletariado. Só inserindo-se numa revolução europeia e mundial, o povo italiano pode reconquistar a capacidade de fazer valer as suas forças produtivas humanas e voltar a desenvolver o aparelho nacional de produção. O fascismo só retardou a revolução proletária, não a tornou impossível. ${ }^{113}$

Dois anos depois, nas “Teses de Lyon” (1926), Gramsci e Togliatti ainda afirmavam que a revolução socialista seria a única forma de superar a crise econômica na Itália. Nas palavras dos dirigentes do PCd'I (Partido Comunista da Itália): "só a classe operária é capaz de traduzir em ato as transformações de caráter econômico e político que são necessárias para que as energias do nosso país tenham liberdade e possibilidade de desenvolvimento completas". ${ }^{114}$

Diferentemente das afirmações de 1924 e 1926, o fascismo passou a ser visto por Gramsci, nos Cadernos do Cárcere (1929-1937), como uma via burguesa de enfrentamento da crise capitalista. Isto é, segundo Gramsci, enquanto uma "revolução passiva", o fascismo "poderia ser a única solução para desenvolver as forças produtivas da indústria sob a direção das classes dirigentes tradicionais [...] e então manter o sistema hegemónico e as forças de coerção militar e civil à disposição das classes dirigentes tradicionais". ${ }^{115}$

\footnotetext{
${ }^{112}$ GRAMSCI, A., “A crise italiana”, L'Ordine Nuovo, 01.09.1924, in GRAMSCI, A., Escritos..., op. cit., pp. 123124 e GRAMSCI, A., Scritti..., op. cit., p. 63.

${ }^{113}$ GRAMSCI, A., “A crise italiana”, L'Ordine Nuovo, 01.09.1924, in GRAMSCI, A., Escritos..., op. cit., pp. 124126.

${ }^{114}$ GRAMSCI, Antônio; TOGLIATTI, Palmiro, “A situação italiana e as tarefas do PCI”, teses aprovadas pelo III Congresso do Partido Comunista Italiano, Lyon, janeiro de 1921, in GRAMSCI, A., Escritos políticos, Volume IV, trad. Manuel Simões, Lisboa, Instituto Gramsci e Seara Nova, pp.201-241, 1978, p. 204.

${ }^{115}$ GRAMSCI, A., Cadernos..., op. cit., Q. 10, §1, 9, 1932-1935, p. 299.
} 
Em síntese, entre A crise italiana (1924) e os Cadernos do Cárcere (1932), Gramsci mudou sua análise do fascismo ${ }^{116}$ e passou a vê-lo, conforme o grasmciano A. Bianchi apontou, como "solução capitalista para a crise" e "agente de modernização do aparelho produtivo". ${ }^{117}$

\subsection{1 "Revolução passiva"}

O termo "revolução passiva" foi apropriado por Gramsci da obra "Saggio storico sulla rivoluzione di Napoli" (1801), de Vincenzo Cuoco (1770-1823) e associado à noção de "revoluçãorestauração" - derivação gramsciana da obra "Les révolutions d'Italie" de Edgar Quinet (18031875)..$^{118}$

Em contraposição crítica às práticas de modernização conservadora, Gramsci desenvolveu o conceito de "revolução passiva" entre 1929 e 1930 (Q. 1, \$44), ao estudar a ausência de participação popular no Risorgimento. ${ }^{119}$ Para Gramsci, o modo de ruptura presente na Revolução Francesa não se aplicaria ao caso italiano. O Risorgimento teria inaugurado uma fórmula de revolução burguesa, sem ruptura de poder, participação popular e concomitante à restauração.

Segundo Gramsci, no caso francês, o partido jacobino, enquanto partido dirigente, teria conduzido a burguesia francesa a uma posição muito mais avançada do que a mesma teria desejado e do que as próprias premissas históricas permitiriam, "daí os contragolpes e a função de Napoleão I". ${ }^{120}$

Já no caso italiano, teria ocorrido uma transição pacífica, na qual a revolução e a restauração aconteceram concomitantemente, sem grandes rupturas de tipo radical-jacobino. ${ }^{121}$ No Risorgimento,

116 Ver: DE FELICE, Franco, "Revolução passiva, fascismo, americanismo em Gramsci”, in Inst. Gramsci, Política e História em Gramsci, Rio de Janeiro: Civilização Brasileira, 1978.

${ }^{117}$ BIANCHI, A., "Revolução passiva: pretérito do futuro", Crítica Marxista, n 23. São Paulo: Revan, 2006, pp. 34-58, p. 51.

${ }^{118}$ Segundo o estudioso de Gramsci Antonio di Meo, Gramsci desenvolvera o termo "revolução-restauração" a partir do escrito de E. Quinet "Les révolutions d'Italie" (1848). Em As revoluções da Itália, Quinet identifica na históriografia italiana a vigência de uma lógica restaurativa. Conforme Quinet, "na história da Itália, a partir da Idade Média até a sua época, cada mudança, inovação ou revolução ocorrida fora descrita pelos historiadores e sobretudo pelos cronistas, como uma tentativa de restauração". DI MEO A., "La 'rivoluzione passiva' da Cuoco a Gramsci", <www.filosofia-italiana.it>, acessado em 13 de setembro de 2016, Outubro de 1914, p. 16. Ainda segundo Di Meo, a apropriação gramsciana da discussão de Quinet fora motivada, sobretudo, pela intensão de ressaltar a "capacidade das classes dominantes de gerir de maneira dúctil e eficaz os conflitos com aqueles subalternos, dada a ausência de paixão ativa destes últimos”. idem, ibidem.

${ }^{119}$ Risorgimento é o nome do movimento político-militar que levou à unificação da Itália em meados do século XIX. "O pano de fundo da unificação, para Gramsci, é a transformação econômica que permite à Itália se modernizar industrialmente, espraiar a relação assalariada de trabalho e tornar o país efetivamente capitalista". SECCO, L., Gramsci e a Revolução, São Paulo: Alameda, 2006, p. 51.

${ }^{120}$ GRAMSCI, A., Cadernos..., op. cit., Q. 10, \$61, 1932-1935, p. 79. “A propósito do jacobinismo e do Partido de Ação, um elemento a ser posto em primeiro plano é este: os jacobinos conquistaram, com uma luta sem tréguas, sua função de partido dirigente; na realidade, eles se 'impuseram' à burguesia francesa, conduzindo-a para uma posição muito mais avançada do os núcleos burgueses originalmente mais fortes gostariam de ocupar 'espontaneamente' e até muito mais avançada do que as premissas históricas poderiam permitir; daí os contragolpes e a função de Napoleão I”. GRAMSCI, A., Cadernos do cárcere, ed. Carlos Nelson Coutinho, trad. Luiz Sérgio Henriques, Rio de Janeiro: Civilização brasileira, 2002, Q. 19, §24, 1934-1935, p. 79. 
o temor de rupturas revolucionárias de tipo radical-jacobina "induziu a burguesia a não lutar até o fim contra o velho regime, mas a deixar subsistir uma parte de sua fachada sob a qual ocultar o próprio domínio efetivo". ${ }^{122}$

\subsubsection{Uma lógica de modernização}

Os Cadernos mostram que o uso por Gramsci da noção de "revolução passiva" sofreu inflexões. Em 1930 (Q. 4, §57), o conceito passou a ser utilizado como categoria de análise para países em que se haviam constituído Estados capitalistas modernos, sem rupturas e verticalmente, como na unificação alemã, sob Bismark. ${ }^{123} \mathrm{Em} 1932$ (Q. 8, §236), noutra inflexão, "revolução passiva" deixou de se referir a eventos históricos específicos e passou a designar uma lógica de modernização burguesa: processos de expansão produtiva, sem rupturas de classe e de regime de poder. ${ }^{124}$

Assim como em sua primeira acepção gramsciana (Q. 1), o conceito de "revolução passiva" continuou a ressaltar a ausência de participação ativa das classes subalternas em processos de modernização (progressistas) burgueses. No entanto, nesse terceiro momento, ela deixou de ser uma categoria de análise histórica de eventos específicos e passou a discutir um processo social complexo, liderado pela burguesia para manter-se hegemônica. ${ }^{125}$ Isso é, a partir de 1932 (Q. 8), "revolução

${ }^{121}$ Diferentemente do partido jacobino, o Partido de Ação italiano não teria conseguido elevar-se a uma posição de dirigente, $\mathrm{e}$, ao invés de conduzir à revolução, teria sido guiado pelos moderados e pela nobreza piemontesa. "Historicamente o Partido de Ação foi guiado pelos moderados: a afirmação atribuída a Vítor Emanuel II de 'ter no bolso' o Partido de Ação, ou algo semelhante, é praticamente exata, e não só pelos contatos pessoais do Rei com Garibaldi, mas porque, de fato, o Partido de Ação foi dirigido 'indiretamente' por Cavour e o Rei". GRAMSCI, A., Cadernos..., op. cit., Q. 19, \$24, 1934-1935, p. 62.

${ }^{122}$ GRAMSCI, A., Cadernos..., op. cit., Q. 19, \$24, 1934-1935, p. 85. Em outras palavras, no Risorgimento, dada a impossibilidade "das classes subalternas assumirem o papel dirigente" e a "impossibilidade das classes dominantes obterem o consenso ativo das classes subalternas através da incorporação dos interesses e aspirações dessas classes, principalmente a reforma agrária", a burguesia se aliou às antigas classes feudais, numa "revolução passiva". BIANCHI, Álvaro, "Revolução passiva...", op. cit., p. 46.

${ }^{123}$ GRAMSCI, A., Cadernos..., op. cit., pp. 209-210 e GRAMSCI, A., Quaderni..., op. cit., pp. 1088-1089.

${ }^{124}$ Ver: BIANCHI, A., "Revolução passiva...”, op. cit., pp. 34-58. Sobre as inflexões do conceito, ver THOMAS, P., "Hegemony, passive revolution and the modern Prince", Thesis Eleven, Londres: SagePub, Brunel University, 2013, pp. 20-39, disponível em < http://journals.sagepub.com/doi/10.1177/0725513613493991>, acessado em 30 de janeiro de 2017 e idem, "Modernity as 'passive revolution': Gramsci and the fundamental concepts of historical materialism", in Journal of the Canadian Historical Association / Revue de la Société historique du Canada, $\mathrm{n}^{\circ}$ 2, Quebec, Montereal: Érudit, 2006, pp. 61-78, disponível em <http://id.erudit.org/iderudit/016590ar; DOI: 10.7202/016590ar>, acessado em 29 de abril de 2016.

125 "Revolução aqui se refere à capacidade da classe dominante de ainda entregar ganhos históricos reais e substantivos, produzindo transformações sociais reais que poderiam ser compreendidas, ao menos formalmente, como progressivas; passiva continua a denotar a tentativa de produzir estas transformações sem o envolvimento extensivo das classes subalternas como classes, mas por meio da absorção molecular dos seus principais elementos em um projeto hegemônico já estabelecido". THOMAS, P., "Modernity as 'passive revolution'...", op. cit., p. 37. Sobre o conceito de hegemonia, o historiador Lincoln Secco explica que a hegemonia é "a direção e depois direção + domínio. [...] A hegemonia, como se disse, é a capacidade de dirigir uma aliança de classes, sendo baseada tão somente no consentimento dos dirigidos; num outro estágio, ela pode, se necessário, incluir a coerção, mas sem que desapareça o consenso". SECCO, Lincoln, Gramsci e a revolução, São Paulo: Alameda, 2006, pp. 55-56. 
passiva" dizia respeito à capacidade da burguesia de manter-se protagonista de transformações sociais quando não era mais uma classe propriamente revolucionária. ${ }^{126}$

Em 1932, na nota $\$ 236$ (Q. 8) e, em sua reelaboração, na nota $\$ 1$ (Q. 10, 1932-1935), Gramsci atualiza o conceito de "revolução passiva", ao identificar no fascismo sua nova expressão. "Não seria o fascismo precisamente a forma de 'revolução passiva' própria do século XX como o liberalismo foi do século XIX?". ${ }^{127}$

\subsubsection{0 milagre burguês}

Um verdadeiro milagre burguês, o fascismo corresponderia então a uma "solução capitalista para a crise do capitalismo" ${ }^{128}$ e a necessidade do desenvolvimento de novas formas de contenção das classes subalternas e suas demandas. ${ }^{129}$ Não por acaso, Gramsci se refere ao fascismo como "um laboratório no qual não apenas definia-se a nova estratégia da burguesia para sair da crise orgânica do pós-guerra, mas em que (para responder ao desafio lançado pelo proletariado) modificavam-se de forma decisiva as próprias categorias de cunho 'liberal'”. ${ }^{130}$

Ao associar o fascismo à noção de "revolução passiva", Gramsci aponta a possibilidade do fascismo, além de ser uma forma de reação anti-operária, ser também um agente da modernização do aparelho produtivo. Bem como, passa a reconhecer, no fascismo, elementos que ultrapassariam o

${ }^{126}$ LOSURDO, Domenico, Gramsci: dal liberalismo al "comunismo critico", Rome, Gamberetti, 1997, p. 155 apud THOMAS, P., “Modernity...”, op. cit., p. 73.

${ }^{127}$ GRAMSCI, Antonio, Quaderni..., op. cit., Q. 8, \$236, 1932, pp. 1088-1089. Conforme o pesquisador italiano Fábio Frosini, Gramsci teria designado o fascismo como "revolução passiva”, em maio de 1932, em sua crítica ao recém publicado livro de Benedetto Croce (1866-1952) Storia dell'Europa. "Como se pode ver, a hipótese de que o fascismo seja a forma da revolução passiva do século XX, nasce como um incidente da reflexão sobre a atividade historiográfica de Croce". FROSINI, Fabio, "Croce, fascismo, comunismo", Il Cannocchiale. Rivista di studi filosofici, vol. 48, pp. 141-162, 2012, p. 159.

${ }^{128}$ BIANCHI, A., “Revolução...”, op. cit., p. 51.

${ }^{129}$ A crise de hegemonia burguesa, agudizada pela $1^{\text {a }}$ Guerra Mundial e a insurgência revolucionária do proletariado e campesinato italianos, gerou, segundo a interpretação gramsciana nos Cadernos, a necessidade do desenvolvimento de novas formas de contenção das classes subalternas e suas demandas por parte das classes dirigentes tradicionais (burguesia e nobreza), mas também a necessidade do desenvolvimento de novas formas de transformações sociais efetivas por uma classe que já não era mais propriamente revolucionária; daí o recurso à "revolução passiva" fascista. Daí também a ampliação e complexificação da interpretação gramsciana do fascismo, que deixa de ser apenas uma reação armada às insurgências revolucionárias e à crise e passa a ser também uma solução burguesa para as mesmas questões. Ver: THOMAS, P., "Modernity as 'passive revolution'...", op. cit., p. 37. A título de exemplo das insurgências revolucionárias italianas, podemos mencionar os movimentos de ocupações de fábricas e greves operárias ocorridas no chamado o Biênio Vermelho, (1919-1920). Ver: FROSINI, F., “'Pueblo’ y 'Guerra de posición’ como clave del populismo. Una lectura de los Cuadernos de la cárcel de Antonio Gramsci”, Cuadernos de Ética y Filosofía Política, ASPEFIP, pp. 63-82, 2014.

${ }^{130}$ FROSINI, F., "Fascismo, parlamentarismo e lotta per il comunismo in Gramsci”, Laboratorio Culturale, 2011, pp. 29-35, p. 30. 
aspecto meramente coercitivo de uma reação à crise capitalista e à crise de representatividade burguesa.

Para manter o "sistema hegemônico e das forças de coerção militar e civil à disposição das classes dirigentes tradicionais" (Q. 10, \$1, 9) o fascismo assimilaria, de forma "molecular", os impulsos dos subalternos para a mudança, ${ }^{131}$ enquanto desenvolveria métodos (transformismos) de contenção, cooptação e assimilação das classes subalternas - contemplando, assim, parcialmente as demandas destas classes dentro de um projeto hegemônico burguês. ${ }^{132}$

Nesse sentido, será que, analogamente, a cooptação de artistas modernos, a constituição de um sistema artístico nacional e a adoção de um discurso estético modernista com traços conservadores não consistiriam em operadores da "revolução passiva" fascista?

\subsection{A constituição de um sistema artístico fascista (1921-1932)}

Está longe de mim encorajar qualquer coisa que possa se parecer com uma arte de Estado (Mussolini, 1923). ${ }^{133}$

É necessário fazer renascer uma arte grande, que possa ser tradicional e ao mesmo tempo moderna [...]. É necessário criar uma arte nova, do nosso tempo, uma arte fascista (Mussolini, 1926). ${ }^{134}$

Em 3 de janeiro de 1925, como meio de frear a reação da oposição e a crescente onda de violência e instabilidade governamental desencadeadas pelo assassinato do deputado socialista Giacomo Matteotti (1885-1924), ${ }^{135}$ Mussolini, então Primeiro Ministro, proferiu um inflamado

${ }^{131}$ FROSINI, F., “Fascismo, parlamentarismo...”, op.cit., pp. 30-31.

${ }^{132}$ GRAMSCI, A., Cadernos..., op. cit., pp. 299-300.

${ }^{133}$ MUSSOLINI, B., Opera omnia, pp. 187-188, apud GENTILE, Emilio, Il culto del littorio: La sacralizzazione della politica nell'Italia fascista, Bari: Editori Laterza, 1993, p. 177.

${ }^{134}$ MUSSOLINI, B., Opera omnia, p. 230, apud GENTILE, Emilio, Il culto..., op. cit., p. 176.

${ }^{135}$ Em 6 de abril de 1924, o Partido Nacional Fascista (PNF, 1921-1943) conseguiu a maioria no parlamento, totalizando 374 representantes. Numa das primeiras seções do Congresso, em maio de 1924, o deputado socialista Matteotti, fez um longo discurso denunciando a fraude e a violência fascista durante as eleições e exigindo a sua anulação. Poucos dias depois Matteotti foi sequestrado e em agosto do mesmo ano, seu corpo foi encontrado num bosque no entorno de Roma. O episódio desencadeou manifestações e denúncias de grupos antifascistas e, em resposta, aumentou consideravelmente o uso da violência por parte das milícias fascistas. Uma das principais manifestações antifascista foi o chamado “Aventino parlamentare”. Em 27 de junho de 1924, "os grupos da oposição [antifascista], reunidos em Montecitorio, após uma homenagem a Matteotti [...], aprovaram uma moção que os impelia a não participar dos trabalhos na Câmera até que fosse formado um novo governo, dissolvida todas as milícias [fascista] e restabelecida a completa legalidade no país". COLARIZZI, S., Storia del novecento italiano: cent'anni di entusiasmo, di paure, di speranza, Milão: Bur Rizzoli, 2000, p.163. Mussolini ignorou a oposição parlamentar e, como forma de frear a reação negativa do Aventino, especialmente a repercussão deste na grande mídia, lançou mão da lei que restringia a liberdade de imprensa, aprovada em 15 de junho de 1923 mas até então em desuso. Como discutiremos adiante, Mussolini também lançou mão de uma 
discurso na Câmera de Deputados, no qual "assumiu" a responsabilidade histórica do ocorrido ${ }^{136}$ e, nos bastidores, radicalizou o processo de fascistização do Estado italiano. ${ }^{137}$

Entre 1925 e 1926, as chamadas "leis fascistíssimas" deram forma jurídica a um regime ditatorial de controle pessoal, com um aparato repressivo legalmente respaldado. ${ }^{138}$ As principais áreas afetadas pelas chamadas "leis fascistíssimas" foram as liberdades de organização política e de imprensa: partidos e sindicatos foram colocados na ilegalidade; órgãos de imprensa autônomos (não ligados ao governo e ao partido) foram fechados; o direito de greve foi abolido; a pena de morte foi introduzida; foram criadas as comissões provinciais para a l'ammonizione e il confino politico; ${ }^{139} \mathrm{e}$ também foi criado um tribunal especial para os delitos contra a segurança nacional. ${ }^{140}$

Um novo passo em direção à consolidação da "revolução passiva" fascista, o processo de "fascistização" do Estado italiano deu-se com a conivência da monarquia e o apoio interessado da burguesia industrial italiana, seguindo a lógica bonapartista (ou, para usarmos um termo gramsciano, cesarista) em curso. Em outras palavras, burguesia e nobreza, assustadas com as manifestações proletárias (greves, insubordinações e protestos) e escaldada com a experiência do biennio rosso, viram na constituição de um regime ditatorial a saída necessária para a manutenção de seus

série de medidas repressivas e decretos autoritários para manter-se no poder e abafar a oposição. Ver: Idem, ibidem.

136 "Se as frases mais ou menos deturpadas são suficientes para enforcar um homem, foram a estaca e a corda! Se o fascismo não foi mais do que óleo de rícino e cassetete, ao invés de ser uma paixão soberba da melhor juventude italiana, a mim a culpa! Se o fascismo foi uma associação de delinquência, eu sou o chefe dessa associação de delinquências!". MUSSOLINI, B., Il discorso alla camera (3 gennaio 1925), apud: DE FELICE, R., Mussolini: Il fascista: 1. La conquista del potere, 1921-1925. 2. L'organizzazione dello Stato fascista, 1925-1929, Torino: Enaudi, 1964, p. 331.

${ }^{137}$ Ver: DE FELICE, Renzo, Explicar o fascismo, (1976) trad. Carlos Veiga Ferreira, Lisboa: Edições 70, 1978, pp. 213-250. O discurso de Mussolini na Câmara foi seguido por dois telegramas dirigidos a todos os prefeitos italianos, emitidos pelo ministro fascista Luigi Federzoni (1878-1967). O primeiro telegrama, os convocava a fazer valer seu trabalho com vigilância, prontidão e firmeza e a noticiar ao partido manifestações, comissões e demais manifestações públicas. No segundo telegrama (enviado 25 minutos depois), os prefeitos eram orientados a "tomar todos os cuidados necessários para a adoção de medidas aptas a garantir a manutenção da ordem pública em qualquer circunstância". FEDERZONI, L., (1925), apud DE FELICE, R., Mussolini: Il fascista..., op. cit., p. 330.

${ }^{138}$ Conforme o historiador italiano Emilio Gentile, entre 1925 e 1926 teria ocorrido o movimento "mais significativo de 'transformação do Estado", quando foram adotadas as leis fascistíssimas. Concebidas por Alfredo Rocco, tais leis marcariam a ruptura com o ordenamento liberal vigente e sancionavam o predomínio do Poder Executivo em relação aos demais. DE FELICE, R.; GENTILE, E., A Itália de Mussolini e a origem do fascismo, São Paulo: Ícone Editora, 1988, p. 36. Além do caso Matteotti, uma suposta tentativa de assassinato de Mussolini deu respaldo moral para o acirramento dos processos repressivos. Em 31 de outubro de 1926, na ocasião de uma comemoração da Marcha sobre Roma, um garoto de 15 anos, Anteo Zamboni (1911-1926), teria tentado assassinar Mussolini, atirando nele. $\mathrm{O}$ caso é bastante controverso. $\mathrm{O}$ garoto não chegou a atingir Mussolini e foi linchado e assassinado em praça pública, no local do suposto atentado.

${ }^{139}$ CANALI, M., "Repressione e consenso nell'esperimento fascista", in GENTILE, E. (a cura di), Modernità totalitária: Il fascismo italiano, Bari: Laterza, p. 74.

${ }^{140}$ Em 6 de janeiro de 1925, uma circular do Ministério do Interior registrou os efeitos imediatos do cerceamento político em curso. Segundo tal circular, "95 círculos e reuniões suspeitas tinham sido encerrados, juntamente a 150 demonstrações públicas, 25 organizações subversivas e 120 grupos da Itália livre foram dissolvidos, 111 'perigosos' subversivos foram presos, foram efetuadas 655 buscas domiciliares". DE FELICE, R., La conquista..., op. cit., p. 289. 
privilégios de classe. Nesse sentido, é exemplar o pacto do Palazzo Vidone (2 de outubro de 1925), firmado entre industriais (Confindústria - Confederação Geral da Indústria Italiana) e o governo fascista na constituição das bases do sistema corporativo (1925-1926) e da Carta del Lavoro (1927). ${ }^{141}$

\subsubsection{Entre controle e coerção}

Paralelamente à constituição do aparato jurídico repressivo Estatal, os processos de controle de informação, coerção, cooptação e construção de consenso foram acelerados. Entre 1925 e 1926, os instrumentos de propaganda e imprensa - como o gabinete de imprensa governamental, a União Radiográfica Italiana ${ }^{142}$ e o instituto LUCE (L'Unione Cinematografica Educativa - União Cinematográfica Educativa) ${ }^{143}$ - ainda em estágio germinal (entre 1923 e 1924) foram implementados, replicados e estatizados. Datada de 15 de julho de 1923, a lei (R.D.L. n.3288) que restringia a liberdade de imprensa e a filiação sindical (fascista) para o exercício da profissão de jornalista, por exemplo, foi publicada e colocada em vigor imediatamente após o delito Matteotti, em julho de $1924 .{ }^{144}$

Nesse ínterim (1925-1926), entes estatais para a gestão e controle das novas tecnologias de comunicação de massas e recepção coletiva (rádio, cinema e fotografia), como o Instituto LUCE (L'Unione Cinematografica Educativa - União Educativa Cinematográfica) passaram a exercer uma função primordial na política cultural de fabricação de consenso fascista.

\subsubsection{União Educativa Cinematográfica}

Fundada em 1924, por B. Mussolini, seu chefe de gabinete Paolucci De Calboli (1887-1961) e o jornalista Luciano De Feo, a sociedade anônima LUCE foi reconhecida como órgão público tornando-se Instituto Nacional LUCE - em 5 de novembro de $1925 .{ }^{145}$ Vinculado ao chefe de governo

${ }^{141}$ Ver: COLARIZZI, S., Storia..., op. cit., pp. 174-176. Ainda a respeito da aproximação entre os industriais italianos e o fascismo, cabe mencionar que em novembro de 1925 a Confindústria (composta por representantes de mais de 6 mil indústrias italianas) aceita definir-se fascista em troca de uma cadeira no Grande Conselho Fascista (órgão máximo do partido fascista, estatizado constitucionalmente em 1928, por meio do R.D.L. (Real Decreto de Lei) n. 2693.

${ }^{142}$ A Unione Radiografia Italiana foi uma companhia de rádio do Estado fascista, criada entre 1923 e 1924 . Ver: BEN-GHIAT, Ruth, Fascist modernities: Italy, 1922-1945, Berkeley: University of California Press, 2004, p. 21.

${ }^{143}$ Ver: ARGENTIERE, Mino, L'occhio del regime, Roma: Bulzooni Editore, 2003, pp. 30-31.

${ }^{144}$ FERRARI, Francesco Luigi, Il regime fascista italiano, editado por Giuseppe Ignesti, Collana Opere di Francesco Luigi Ferrari, Roma: Edizioni di storia e letteratura, 1983, p. 172.

${ }^{145}$ A sociedade anônima LUCE, foi transformada em Ente Autônomo (Ente Autonomo era uma instituição jurídica fascista ligada ao governo, similar a uma Autarquia), por intermédio do Decreto Real de Lei n. 1985. Cf. R.D.L., ano 1925, volume IX, pp. 8982-8988, Biblioteca Nazionale Centrale di Roma, sala Emeroteca, apud idem, ibidem. O Decreto reconhecia o Instituto LUCE como órgão técnico cinematográfico de Estado. ARGENTIERE, Mino, L'occhio..., op. cit., p. 30. 
(Mussolini) e ao seu gabinete de imprensa, o LUCE detinha o monopólio sobre a produção cinematográfica educativa e de propaganda do governo fascista, previsto por decreto. ${ }^{146}$

O instituto LUCE era vinculado diretamente a Mussolini. ${ }^{147}$ Era, inclusive, prevista no estatuto do instituto a supervisão do próprio Mussolini em todo material produzido. Ele também tinha a liberdade de anular qualquer deliberação do conselho administrativo e ratificar a entrada de qualquer novo membro.

Em 1927, o instituto LUCE deu inicio à produção de cinejornais, os quais eram transmitidos obrigatoriamente em todos os cinemas italianos, antes de qualquer sessão. ${ }^{148}$ No mesmo ano, o instituto criou a sua seção de fotografia, a qual era responsável por completar e conservar o arquivo fotográfico nacional e de gerenciar e difundir as imagens de Mussolini. ${ }^{149}$ Por intermédio do Instituto LUCE, o regime fascista tinha pleno domínio de todas as fotografias que circulavam em território italiano. Bem como, por meio dos cinejornais produzidos pelo mesmo instituto, o regime fascista ampliava em escala massiva o alcance de uma de suas máquinas de fabricação de consenso.

Se no campo das novas tecnologias, liberdade de imprensa e organização política o governo fascista lançou mão de uma política de controle direto e repressivo, no campo artístico Mussolini adotou uma política de controle indireto e inclusão molecular. Nesse âmbito, o regime fascista italiano foi marcado por uma relativa autonomia da arte e a cooptação programática de artistas e intelectuais.

\subsubsection{Cooptação e consenso}

Neste mesmo período que se seguiu ao delito Matteotti, Mussolini lançou as bases de uma política artístico-cultural "tolerante" e dissimuladora da onda repressiva em curso. A retórica de autonomia criativa no campo da "alta cultura"150 e da produção intelectual foi estrategicamente

${ }^{146}$ O Decreto que reconhecia o Instituto LUCE como órgão estatal também garantia ao LUCE o monopólio sobre a produção cinematográfica educativa e de propaganda do governo fascista. ARGENTIERE, Mino, L'occhio..., op. cit., p. 30. Segundo a retórica oficial, o objetivo do Instituto era a "difusão da cultura popular e da instrução geral, por meio da visão cinematográfica [e fotográfica], comercializadas com as condições mínimas de venda possíveis e distribuídas com o objetivo de beneficiar a propaganda nacional e patriótica (art. 1)". ARGENTIERE, Mino, L'occhio..., op. cit., p. 30 e $<$ http://www.archivioluce.com/archivio/>, acessado pela última vez em 25 de setembro de 2012.

${ }^{147} \mathrm{O}$ artigo 17 do Real Decreto de Lei sancionava que o instituto era "submetido ao controle da autoridade do Ministro dos Assuntos do Exteriores" (cargo ocupado por Mussolini). Cf. R.D.L., anno 1925, volume IX, pp. 8982-8988, Biblioteca Nazionale Centrale di Roma, sala Emeroteca, apud idem, ibidem.

${ }^{148}$ De acordo com o pesquisador italiano Stefano Mannucci, "com o Real Decreto de Lei n. 1000, de 3 de abril de 1926, tornou-se obrigatória, em todos os cinemas, a projeção de um ou mais documentários do LUCE, antes de cada espetáculo. Quem não obedecesse à norma, arriscava o fechamento temporário da sala [de cinema] ou mesmo a revogação permanente da licença". MANNUCCI, Stefano, Luce sulla guerra. La fotografia di guerra tra propaganda e realtà. Italia 1940-45, Roma: Nuova Arnica Editrice, 2007, p. 18.

${ }^{149}$ Ver: Idem, p. 24.

${ }^{150}$ MALVANO, Laura, Fascismo e politica dell'immagine, Torino: Bollati Boringhieri editore, 1988, p. 49. 
combinada com a estruturação de um circuito expositivo, mecenato estatal e fomento de uma produção e debate artísticos ecléticos.

Em março de 1925, foi criado o "Istituto fascista di cultura" e em janeiro de 1926 a "Academia Real da Itália”. Nesse período, como será discutido na sequencia, Mussolini também adotou a retórica de abertura e apoio à produção de jovens artistas, como na ocasião da abertura da $1^{\text {a }}$ Mostra do Novecento Italiano, em 1926.

\subsubsection{Academia Real da Itália}

Criada em 1926, mas inaugurada somente em 1929, a “Academia Real da Itália” (“Accademia d'Italia") ${ }^{151}$ foi uma das principais instituições fascistas de mecenato e cooptação artística e intelectual. Respondendo à lógica de cooptação e criação de consenso, a “Academia Real da Itália” não só subsidiava os artistas e intelectuais convidados a serem membros da mesma (os associados da academia recebiam 36.000 liras por ano), como também funcionava enquanto uma instância de legitimação e reconhecimento artísticos. ${ }^{152}$

Se, por um lado, somente artistas e intelectuais convidados por Mussolini poderiam integrar o seleto grupo dos associados à academia, por outro lado, conforme a retórica eclética do regime, encontravam-se entre os associados e premiados pela academia artistas sem filiação partidária fascista - como seria o caso de escritores como Ada Negri (1870-1945), Elio Vittorini (1908-1966) e Emilio Cecchi (1884-1966) - este último signatário do "Manifesto dos intelectuais antifascistas" (1 de maio de 1925). ${ }^{153}$

Conforme afirmado por Mussolini em uma entrevista coletiva em 1928, no campo artístico e intelectual o fascismo fomentaria "a diversidade de artistas e temperamentos", bem como a "liberdade" de crítica e de debates. Nas palavras de Mussolini: "No campo da arte, ciência e filosofia, a carteirinha do partido não pode criar uma situação de privilégio ou imunidade. (...) Aqui a disciplina

${ }^{151}$ BEN-GHIAT, Ruth, Fascist modernities..., op., cit., p. 25. Conforme o Estatuto da Academia, esta teria sido criada com o objetivo de "promover e coordenar o movimento intelectual italiano no campo das ciências, letras e das artes, de conservar puro o caráter nacional, segundo o gênio e a tradição da raça para favorecer a expansão e a influência (desse espírito nacional) para além dos confins do Estado". BEN-GHIAT, Ruth, Fascist..., op. cit., p. 25.

152 Por meio de prêmios e doações, a instituição promovia na Itália e no exterior, os grandes artistas e intelectuais do período.

${ }^{153} \mathrm{O}$ "Manifesto dos intelectuais antifascistas" foi uma reação ao "Manifesto dos intelectuais fascistas" (21 de abril de 1925). Redigido por Giovanni Gentile e assinado por intelectuais e personalidades do campo da arte e cultura, o "Manifesto dos intelectuais fascistas" foi o primeiro documento público desse campo em apoio ao fascismo. O documento foi desenvolvido no congresso pela cultura fascista, organizado em Bolonha entre 29 e 30 de março de 1925 e publicado em todos os jornais fascistas da época. 
do partido não tem lugar. (...) A carteirinha do partido não pode dar talento para aqueles que já não o possuem". ${ }^{154}$

\subsubsection{Um sistema artístico "aberto" e "plural"}

O discurso de autonomia criativa e subsídio do Estatal era parte de uma política cultural que visava a domesticar e incluir molecularmente intelectuais e artistas a serviço de projeto hegemônico fascista, enquanto ludibriava-os com a retorica de um sistema artístico aberto e plural.

No campo específico das artes visuais, até 1925, Mussolini fazia questão de registrar seu apreço pelos grupos de jovens artistas ${ }^{155}$ e sua intenção de respeitar a "autonomia criativa" da arte. ${ }^{156}$ Em 1925, com a progressiva instauração do régime ditatorial fascista, a posição oficial de Mussolini nas esferas da arte e a cultura nacional foi levemente modificada, não com a adoção de cânones estéticos para a arte de Estado, mas com o apelo aos artistas para a criação de uma arte fascista e um grande subsídio estatal nesse campo. ${ }^{157}$

O apelo de Mussolini e as medidas adotadas para incentivar a produção de uma arte fascista ${ }^{158}$ provocaram disputas entre grupos e correntes artísticas que se auto reivindicavam expoentes da arte

${ }^{154}$ MUSSOLINI, B., "Il giornalismo come missione", discurso de 10 de outubro de 1928, in Scritti e discorsi, 6: 251, apud BEN-GHIAT, Ruth, Fascist..., op. cit., p. 23. Apesar da relativa liberdade no campo das artes a inserção no mercado de trabalho e no circuito artístico do período era condicionada à adesão ao regime fascista, para os artistas e intelectuais não consagrados. Dificilmente um artista não consagrado que se posicionasse abertamente contrário ao fascismo seria aceito no sindicato dos profissionais das artes fascista (criado em 1926, o sindicato era uma espécie de pré-requisito para entrar no mercado de trabalho) ou premiado em algum festival ou mostra de arte fascista. Ver: BEN-GHIAT, Ruth, Fascist..., op. cit., pp. 20-22.

${ }^{155}$ Desde o surgimento dos fasci de combate (“fasci di combattimento”), em 1919, Mussolini apoiou os futuristas italianos (os quais aderiram prontamente ao fascismo). Por volta de 1923, o líder fascista também passou a apoiar o recém-criado grupo de pintores do Novecento. Em 1926, “pela primeira vez na história, um chefe do governo [Mussolini] inaugurou pessoalmente, com um discurso memorável, uma mostra de artistas jovens [a mostra do Novecento]". BAROCCHI, Paola (org), Storia moderna dell'arte in Italia manifesti polemiche documenti, Torino: Giulio Einaudi, 1990, p. 11, nota de rodapé n. 1.

${ }^{156}$ Num discurso proferido em 1923, na Mostra del Novecento, Mussolini declarou estar longe de seus planos “encorajar qualquer coisa que pudesse se parecer com uma arte de Estado". MUSSOLINI, B., Opera Omnia, pp. 187-188, apud GENTILE, Emilio, Il culto del..., op.cit, p. 177.

${ }^{157}$ GENTILE, Emilio, Il culto..., op. cit., p. 176. Como registro dessa alteração no posicionamento de Mussolini em relação à "autonomia” da arte, Gentile menciona um discurso de Mussolini, realizado em Perugia, em 1926. Nesse discurso, Mussolini teria lançado um apelo aos artistas, no qual afirmaria a necessidade de "fazer renascer uma arte grande, que possa ser tradicional e ao mesmo tempo moderna", de "criar uma arte nova, do nosso tempo, uma arte fascista”. MUSSOLINI, B., Opera omnia, p. 230, apud GENTILE, Emilio, Il culto..., op. cit., p. 176.

${ }^{158}$ Mussolini, principalmente após 1925, buscou fomentar por meio de festivais, competições e premiações a produção artística italiana. Em 1926 Mussolini criou a “Academia Real da Itália” (inaugurada só em 1929), instituição criada com o intuito de reconhecer, financiar (os associados da academia recebiam 36.000 liras por ano) e promover os grandes artistas e intelectuais do fascismo. 
fascista. ${ }^{159}$ Em 1926, o então diretor da revista quinzenal Critica Fascista, G. Bottai (1895-1959), lançou uma enquete, na mesma revista, sobre a questão da arte fascista. Entre 1926 e 1928, uma série de críticos, artistas e intelectuais disputaram, em discursos públicos e artigos de periódicos, sobre o que seria ou deveria ser arte fascista. ${ }^{160}$

\title{
2.3.3 Um ordenamento hierárquico e centralizado
}

\begin{abstract}
Praticando um mecenatismo cauteloso e sedutor, e, no fundo, também corruptor, o fascismo envolveu no experimento totalitário artistas e arquitetos clássicos e modernos, afirmados e desconhecidos, jovens e idosos, convidados pela primeira vez, como categoria privilegiada com comissões e prebendas [ocupações rendosas e de pouco trabalho], a participar da grandiosa empreitada de construir uma nova civilização, italiana e moderna, com aspirações de época e universais. Os artistas e arquitetos [...] não aderiram ao fascismo apenas por sedução ou corrupção, atraídos pela prodigalidade do Duce, mas foram fascistas por convicção de ideias. ${ }^{161}$
\end{abstract}

Muito próxima à lógica da "revolução passiva" descrita por Gramsci, a "estetização da política" fascista e a constituição de um sistema artístico fascista foram pautadas por um esquema de inclusão, concessão e cooptação artística a serviço de um determinado projeto hegemônico.

Como já mencionado anteriormente, apesar do controverso e eficiente discurso de autonomia criativa que o Estado fascista propagandeava para o campo das artes e da cultura, é possível identificar, de forma cada vez mais evidente a partir de 1927, a construção de um ordenamento artístico hierárquico e centralizado nas mãos do Estado e seus representantes.

Analogamente aos processos de reestruturação econômica e legislativa corporativista ${ }^{162}$ (marcados pela intervenção estatal no planejamento produtivo, a constituição de um mercado

159 Conforme o historiador italiano Emilio Gentile, durante o regime fascista teria ocorrido uma série de "polêmicas entre as diversas correntes de pintores, escultores e arquitetos que reivindicavam ser reconhecidos como autênticos intérpretes do 'estilo fascista”". GENTILE, Emilio, Il culto..., op. cit., p. 176.

${ }^{160}$ Num artigo de 1927, o poeta futurista Filippo Marinetti (1876-1944) respondeu à sondagem de Bottai e ressaltou o pioneirismo dos futuristas. "Quem tem o direito de falar sobre a questão da Arte fascista? Antes de todos, os futuristas. Os quais foram os primeiros colaboradores de Mussolini na praça, nos comícios, na prisão pela fundação dos Fasci di Combattimento". MARINETTI, "L’Arte fascista futurista", Critica Fascista, 1927, in DEL BUONO, Oreste (a cura di), Eia, eia, eia, alala': la stampa italiana sotto il fascismo 1919-1943, pref. Nicola Tranfaglia, Milano: Feltrinelli, 1971, p. 96.

${ }^{161}$ GENTILE, E., "Introduzione”, in BRAUN E., Modernità totalitaria, editado por Emilio Gentile, Bari: Laterza, 2008, p. XV.

${ }^{162} \mathrm{O}$ corporativismo foi um sistema de regulamentação da vida político-econômica do Estado italiano, proposto pelo fascismo. O processo de restruturação corporativa do Estado foi lento e impreciso. Em julho de 1926, foi criado o Ministero delle Corporazioni. Em abril de 1927, os princípios do Estado corporativo foram anunciados, por meio da chamada "A Carta del Lavoro". Entre 1927 e 1934, algumas corporações foram criadas. Somente em 
nacional e adoção de um novo sistema trabalhista), entre 1927 e 1931, por meio de uma série de decretos e medidas de financiamento, promoção e premiações, o Estado fascista realizou um processo de cerceamento do circuito expositivo italiano e enquadramento dos artistas em um campo artístico hierarquizado e condicionado à filiação sindical sob a mascara tolerante de apoio e liberdade de criação. ${ }^{163}$

Grandes e renomadas exposições, como a Bienal Internacional de Artes de Veneza e a Trienal Internacional de Artes Decorativas e Industriais Modernas de Milão, foram fundadas ou atreladas ao Estado fascista e seu circuito expositivo. As demais exposições locais, regionais e inter-regionais, foram atribuídas aos sindicatos fascistas. ${ }^{164}$

\subsubsection{Reestruturação econômica e legislativa corporativista}

Um dos possíveis e principais dispositivos da "revolução passiva" fascista, segundo a hipótese de Gramsci, o corporativismo e a intervenção legislativa do governo, "no quadro concreto das relações sociais italianas", constituiria, em termo práticos, parte da solução italiana para a crise capitalista. ${ }^{165}$

1934 um projeto de lei determina a criação das 22 corporações. Segundo o historiador do fascismo e biógrafo de Mussolini, Renzo De Felice, a proposta de reestruturação corporativa do fascismo italiano não era muito bem definida, nem tampouco consensual entre os integrantes do PNF. De Felice afirma que, entre 1927 e 1933, havia no mínimo 4 diferentes concepções, dentro do fascismo, sobre a natureza do corporativismo. Entretanto, o biógrafo de Mussolini afirma ainda que "todas essas formulações tinham porém em comum a intenção de dar ao corporativismo uma função dinâmica e aceleradora, de renovação em relação ao desenvolvimento econômico e social do país”. DE FELICE, Renzo, Mussolini il Duce: Gli anni del consenso 1929-1936, Torino: Giulio Einaudi editore, 1974, p. 12.

${ }^{163}$ É importante mencionar que, tendo em vista a retórica de autonomia artística adotada pelo regime fascista, diferentemente dos jovens artistas - que para se inserir no circuito artístico deveriam participar das mostras sindicais -, os artistas já consagrados eram estimulados a aderir ao sistema artístico fascista por meio de convites para a participação nas grandes exposições e com a venda de suas obras para os órgãos do Estado e do partido fascista. Ainda nesse sentido, em 1932, a Bienal de Artes de Veneza passou a funcionar apenas por convite.

${ }^{164}$ Em 1929, na coluna "Cronache milanesi", da revista Emporium (publicação da cidade de Bergamo), o colunista Giolli Raffaello, ao discutir a exposição do sindicato lombardo, registrou o processo de ordenamento e enquadramento das exposições e feiras de artes nacionais no novo sistema artístico italiano. "A sistematização geral das mostras de arte na Itália trouxe, sem dúvida, ordem e disciplina; as mostras não se abrem mais como se fossem bazares beneficentes [pescha di beneficenza], e cada cidadezinha turística não pode mais alçar [inalberare], no programa das festividades de verão, o estandarte de uma grotesca exposição "internacional". Mas a sistematização levou também a Bienal de Brera a ser - no lugar de uma mostra nacional - somente uma mostra regional, e, naturalmente, empobreceu seu programa”. RAFFAELLO, Giolli, "Cronache milanesi: La mostra del sindacato", Bergamo: Emporium, 1929, vol. LXX, n. 420, pp. 369-373, p. 370. Disponível online em: $<$ http://www.artivisive.sns.it/galleria/libro.php?volume=LXX\&pagina=LXX_420_368.jpg >, acessado em 21 de abril de 2015.

${ }^{165}$ Gramsci não chega a desenvolver muito suas discussões sobre o corporativismo fascista. Segundo Frosini, ele oscila entre a redução do corporativismo a elemento de propaganda e a apreciação das novidades reais que o corporativismo introduziria. "A tal propósito vamos fazer referência apenas a dois textos, que são respectivamente - a primeira redação, de fevereiro-março de 1930, e a segunda redação, do segundo semestre de 1934, de uma nota inicialmente intitulada Americanismo e depois Autarchia finanziaria dell'industria. Aqui Gramsci se pergunta se as corporações, que "tiveram origem de polícia econômica [polizia economica], e não de revolução econômica" poderão, ao invés, se tornar "a forma” daquela revolução. Na primeira versão Gramsci responde logo: “Somos levados necessariamente a negá-lo.” (Q. 1, \$135). Na segunda, o juízo é nuançado e 
Forma econômica da "revolução passiva" fascista, o corporativismo italiano, como já mencionado, foi um sistema de regulamentação político-econômico pautado por uma maior intervenção governamental, que atuaria como um investidor a médio e longo prazo da indústria nacional e de empresas privadas. Uma “economia média" (“mista”), conforme a designação gramsciana (Q. 8, \$236, 1931-1932) ${ }^{166}$ que ressaltava o caráter híbrido do novo sistema - marcado por políticas como os resgates industriais, via a criação do IRI (Instituto para a Reconstrução Industrial), em 24 de janeiro de $1933 .{ }^{167}$

O corporativismo era apresentado pelo regime fascista como a terceira via entre o liberalismo e o socialismo. ${ }^{168}$ Fundado não no conflito (luta de classes), mas na colaboração entre as classes (organizadas em corporações de ofício), reguladas pelo Estado. Era a solução italiana à crise capitalista e a movimentação operária (greves, insatisfações, desempregos etc.); conforme a retórica fascista da época, o corporativismo respondia à queda do mito do mercado autorregulado e à fragilidade, por exemplo, do sistema parlamentar na sociedade de massas. ${ }^{169}$

Apesar de já no período as críticas ao sistema corporativistas (principalmente vindas de grupos oposicionistas, antifascistas e ligados ao PCd'I) apontarem o descolamento entre propaganda e

duvidoso: 'Por enquanto, temos razão para duvidar. O elemento negativo da 'polícia econômica' predominou até agora sobre o elemento positivo da exigência de uma nova política econômica que renove, modernizando-a, a estrutura econômico-social da nação mesmo nos quadros do velho industrialismo’ (Q. 22, \$258, itálico nosso) [sic]". FROSINI, F., "Entre...", op. cit., pp. 7; 32-33. Gramsci utiliza o termo "polícia" não só para designar o serviço estatal de controle da criminalidade e repressão, mas para designar "o conjunto das forças organizadas pelo Estado e pelos particulares [sic] para defender o domínio político e econômico das classes dirigentes" (Q. 13, \$27) (CC, v.3, p. 78). Nesse sentido, conforme explica o gramsciano Alessio Gagliardi, o uso do termo "polícia econômica" designa um tipo de domínio que passaria pela coerção, mas também por um sistema mais complexo de dominação econômica, o qual, no caso do fascismo italiano, estaria pautado no atrelamento sindical, no sistema coorporativo etc. Ver: GAGLIARDI, A., "O Problema do corporativismo no debate europeu e nos Cadernos", in AGGIO, Alberto; HENRIQUEZ, Luiz Sergio; VACCA, Giuseppe (Orgs.), Gramsci no seu tempo, Rio de Janeiro/Brasilia: Fundação Astrojildo Pereira-Contraponto, 2010, pp. 233-62, pp. 234-235.

${ }^{166}$ GAGLIARDI, A., “O Problema...”, op. cit., pp. 240-241.

167 Ver: GAGLIARDI, A., "Per rifondare lo Stato...", op. cit., pp. 241-242. Sobre o IRI ver: $<$ http://www.archiviostoricoiri.it/index/pagina-80.html $>, 21$ de dezembro de 2017.

${ }^{168}$ Conforme discutido anteriormente, a definição e mesmo as propostas sobre o corporativismo não eram consensuais, o corporativismo era um campo de disputas mesmo no interior do Partido Nacional Fascista. Segundo Gagliardi, entre o final dos anos 1920 e o início de 1930, o corporativismo era um tema recorrente no debate público fascista (e mesmo antifascista), havendo, como também aponta De Felice, muitas vertentes e concepções sobre o corporativismo. Ver: GAGLIARDI, A., "Per rifondare lo Stato: progetti corporativi tra fascismo e antifascismo", in SERNERI, S. N. (a cura di), 1914-1945: L'Italia nella guerra europea dei trent'anni, Toscana, Viella, 2016, pp. 237-257. Ver: DE FELICE, Renzo, Mussolini il Duce..., op. cit., p. 12.

${ }^{169}$ Gagliardi aponta que, além da dimensão propriamente econômica, havia, no corporativismo (enquanto argumento retórico e ideológico, mas também, prático - em algumas medidas e reestruturações conduzidas pelo fascismo, como a criação do 'Conselho Nacional das Corporações', 1930) uma dimensão política institucional que visava a responder à crise de representatividade e hegemonia burguesa e a crise do próprio sistema liberal, do parlamentarismo e dos aparatos tradicionais de representação, domínio e coerção. Segundo Gagliardi, a necessidade de reformulação do sistema parlamentar, por exemplo, apareceria em diversos textos e documentos do período, como no próprio Manifesto do partido futurista italiano (1918). Ver: GAGLIARDI, A., "Per rifondare lo Stato...", op. cit., pp. 241-244. 
prática (teoria e fato), ${ }^{170}$ o próprio Gramsci identificou no corporativismo uma resposta apta se não a reverter economicamente a crise burguesa e inserir a Itália num novo modo de produção capitalista internacional, ao menos a criar um "período de expectativa e de esperanças" entre as classes dirigentes tradicionais. ${ }^{171}$

Segundo Gramsci aventa, o corporativismo e a intervenção legislativa fascista, podem ter sido "a única solução para desenvolver as forças produtivas da indústria sob a direção das classes dirigentes tradicionais". ${ }^{172}$ Pois, por intermédio da intervenção legislativa e da organização corporativa, "teriam sido introduzidas na estrutura econômica do país modificações mais ou menos profundas para acentuar o elemento "plano de produção»". ${ }^{173}$ Teriam sido acentuadas “a socialização e cooperação da produção, sem com isso tocar (ou limitando-se apenas a regular e controlar) a apropriação individual e grupal do lucro". ${ }^{174}$

Em outros termos, o fascismo, por meio do corporativismo e da economia programada, renovaria e modernizaria a estrutura econômico-social da nação, introduzindo na Itália elementos do modelo de produção industrial americano (tayloristas e fordistas). Conforme Gagliardi, para Gramsci, o debate sobre "americanismo e fordismo" 175 (articulado à noção de "revolução passiva") não se restringiria apenas à "racionalização técnica do processo de trabalho", mas também a um processo de reorganização social nacional, baseado "por um lado, na extensão a toda a sociedade do modelo da fábrica, e, por outro, na ativação de mecanismos de integração [regulamentação] e ampliação das bases sociais do capitalismo (produção e consumo de massa, altos salários)". ${ }^{176}$

\footnotetext{
${ }^{170}$ Gagliardi afirma que, apesar de tal descolamento durante o fascismo italiano, havia de fato uma série de medidas e intervenções econômicas governamentais, no entanto, muitas delas ocorreriam independentemente do sistema corporativo italiano. Como, por exemplo, as medidas tomadas entre 1933 e 1934: criação do IMI (Instituto Imobiliario Italiano), o IRI e a "batalha pela autarquia", lançada em março de 1936, num plano de regulamentação, centralização e planificação econômica italiana. GAGLIARDI, A., “O Problema do corporativismo...”, op. cit., p. 245.

${ }^{171}$ O juízo de Gramsci sobre o sucesso da reestruturação corporativa e da intervenção legislativa fascista, enquanto uma alternativa burguesa à crise capitalista, não é conclusivo. "Que um tal esquema possa traduzir-se em prática, e em que medida e em que formas, isto tem um valor relativo". O que importaria, segundo o autor dos Cadernos é que, tal esquema tinha, no plano político e econômico, "a virtude de servir para criar um período de expectativa e de esperanças, notadamente em certos grupos sociais italianos, como a grande massa dos pequenos burgueses urbanos e rurais e, consequentemente, para manter o sistema hegemônico e as forcas de coerção militar e civil à disposição das classes dirigentes tradicionais”. GRAMSCI, A., Cadernos..., op. cit., Q. 10, §I, 9, 1932-1935, pp. 299-300.

${ }^{172}$ GRAMSCI, A., Cadernos..., op. cit., Q. 10, §I, 9, 1932-1935, p. 229 e FROSINI, F., “Entre...”, op. cit., pp. 7-8.

${ }^{173}$ GRAMSCI, A., Cadernos..., op. cit., Q. 10, §I, 9, 1932-1935, p. 229.

${ }^{174}$ GRAMSCI, A., Cadernos..., op. cit., p. 229.

${ }^{175}$ Ver: LIGUORI, Guido e VOZA, Pasquale (org.), Dicionário gramsciano: (1926-1937), pref. Alvaro Bianchi, trad. Ana Maria Chiarini, Diego Silveira Coelho Ferreira, Leandro de Oliveira Galastri e Silvia de Bernardinis, São Paulo, Boitempo, 2017, pp. 41-43.
}

${ }^{176}$ GAGLIARDI, A., “O Problema do corporativismo...”, op. cit., p. 237. 


\subsubsection{Cerceamento do circuito expositivo italiano e enquadramento dos artistas}

Antecedendo em 14 dias o lançamento da "A Carta del Lavoro" (21 de abril de 1927), em de 7 de abril de 1927, com o R.D.L. n.515, ${ }^{177}$ determinou-se que, a partir daquela data, qualquer exposição, feira ou mostra, fosse ela de arte ou agrícola, só poderia ser realizada com uma autorização prévia do chefe do governo. ${ }^{178}$ A chamada "Carta do Trabalho" ("A Carta del Lavoro") foi um dos principais documentos fascistas de reestruturação das relações econômicas e trabalhistas italianas sob a base do sistema coorporativo. Conforme a retórica da terceira via e da "colaboração" entre classes, a "Carta do Trabalho" deu sequência ao atrelamento sindical (ao Estado) e à supressão dos direitos de mobilização e luta das classes trabalhadoras em curso desde a lei de 3 de abril de 1926, que abolia o direito de greve. ${ }^{179}$

Na mesma toada da centralização trabalhista sob o sistema de corporações com a criação do Ministério das Corporações (criado em 1926, mas estruturado a passos lentos, entre 1927 e 1934), ${ }^{180}$ em 1929, um decreto (R.D.L. n.1162, de 7 de abril de 1929) transferiu a responsabilidade da fiscalização e montagem das exposições de arte em todo o território nacional para o Sindicato Nacional de Artistas. ${ }^{181}$

Entre 1928 e 1931, também por meio de decretos, a Bienal de Veneza, a Quadrienal de Roma e a Trienal de Milão receberam uma autorização de funcionamento permanente (R.D.L. n.3229, de 24 de dezembro de 1928, e R.D.L. n.170, de 12 de fevereiro de 1929) ${ }^{182}$ e se tornaram "Enti Autonomi"183

\footnotetext{
177 R.D.L. é a abreviação do italiano para Regio Decreto Legge - Real Decreto de Lei.

178 “As exposições ou mostras de arte, as feiras de amostras de índole agrícola, industrial ou comercial, ocasionais, periódicas ou permanentes, de caráter regional, nacional ou internacional, devem ser autorizadas com um decreto do Chefe do Governo, consultados os ministros interessados”. D.R.L., 7 aprile 1927, n. 515, apud: SALVAGNINI, Sileno, Il sistema delle arti in Italia: 1919-1943, Bologna, Minerva Edizione, 2000, p. 359. A pesquisa realizada nos arquivos Presidenza del Consiglio dei Ministri (PCM) do ACS (Arquivo Central Estatal Italiano) mostra que o processo de cessão de uma autorização para a realização de uma exposição (agrícola, industrial, artística etc.) em todo o território italiano era consideravelmente lento e burocrático, bem como pautado numa articulação entre ministérios do campo económico e cultural. O processo de requerimento de autorização passava, via de regra, por vários ministérios (Ministério da Comunicação, Ministério das Finanças, Ministério da Educação e Ministério das Corporações) antes da emissão da autorização final pelo chefe do governo (Conselho dos Ministros). ACS; PCM; 1931-1933; F. 14-1-4699.
}

${ }^{179}$ GAGLIARDI, A., “O Problema do corporativismo...”, op. cit., p. 235.

${ }^{180}$ Conforme mencionado anteriormente, a criação do Ministero delle Corporazioni data de Julho de 1926. No entanto, a constituição do sistema corporativo ocorreu de forma lenta e gradual entre 1927 e 1934 . Em abril de 1927, com "A Carta del Lavoro", os princípios das legislações trabalhistas foram definidos, no entanto, o projeto de lei que determinou a criação das 22 corporações data apenas de 1934 . Sabe-se que nesse ínterim algumas corporações já teriam sido criadas e as relações trabalhistas já eram fortemente marcadas pela direção sindical fascista. Ver: DE FELICE, Renzo, Mussolini il Duce..., op. cit., p. 12.

${ }^{181}$ SALVAGNINI, Sileno, Il sistema..., op. cit., p. 17, nota de rodapé n. 13.

$182 \mathrm{O}$ decreto R.D.L. n. 3229, 24 de dezembro de 1928 dizia respeito à Bienal e à Quadrienal, enquanto o decreto e R.D.L. n. 170, 12 de fevereiro de 1929 legislava sobre a Trienal. SALVAGNINI, Sileno, Il sistema..., op. cit., p. 39. 
ligados ao Estado italiano - não devendo mais se reportar a seus respectivos municípios, mas ao Chefe do governo (R.D.L. n.33, de 13 de janeiro de 1930, e R.D.L. n.949, de 25 de junho de 1931). ${ }^{184}$

$\mathrm{Na}$ hierarquia expositiva que se construía, as "exposições promovidas e geridas pelos sindicatos [...] deveriam constituir a primeira triagem". ${ }^{185}$ Os sindicatos, de acordo com a região, ${ }^{186}$ seriam os responsáveis por organizar exposições regionais e inter-regionais, compostas principalmente por trabalhos de jovens artistas. ${ }^{187}$

Conforme o esquema da época, os melhores artistas das exposições regionais sindicais eram convidados para as exposições inter-regionais, e assim por diante, até serem convidados para expor na Quadrienal e na Bienal internacional de Artes. ${ }^{188}$ Assim, apesar do discurso de "liberdade artística", a inserção no circuito artístico do período era condicionada à filiação sindical, conforme a lógica corporativista de enquadramento trabalhista.

Entretanto, cabe mencionar que os sindicatos fascistas supostamente não possuíam o dever de padronizar ou estabelecer um estilo artístico específico. Pelo contrário, conforme declarações de dirigentes sindicais da época, o papel dos sindicatos era o de encorajar e dar suporte econômico, por meio de exibições, prêmios e competições, a jovens artistas fascistas de diversas tendências e estilos (organizando e fomentando a carreira dos ingressantes no mercado de trabalho nacional). O que corroborava com a lógica de captação e assimilação dos novos artistas para o regime.

A Quadrienal de Roma teve sua primeira exposição em 1931. A exposição sediada em Roma foi criada para suprir a demanda de uma grande exposição de cunho nacional e ocupar o degrau intermediário entre as exposições sindicais e a Bienal Internacional de artes. ${ }^{189}$ No topo do circuito

${ }^{183}$ Os Enti Autonomi (Entidades Autônomas) eram instituições jurídicas fascistas que se aproximariam das atuais Autarquias. Isto é, instituições fiscalizadas e tuteladas pelo Estado, mas com personalidade jurídica e recursos próprios.

${ }^{184}$ SALVAGNINI, Sileno, Il sistema..., op. cit., p. 39, nota de rodapé n. 79. Diferentemente das exposições de Veneza e de Milão, a Quadrienal de Roma, inaugurada em 1931, já foi criada como um "Ente autônomo", ligada diretamente ao chefe do Estado, de modo que ela não passou pela transição descrita acima.

${ }^{185}$ BOTTAI, G., lettera dattiloscritta al sottosegretario della Presidenza del Consiglio Giunta, gennaio 1928 , apud SALVAGNINI, Sileno, Il sistema..., op. cit., p. 17.

${ }^{186}$ Segundo Sileno Salvagnini, o desenvolvimento das exposições sindicais teria ocorrido de forma desigual nas diversas cidades italianas. SALVAGNINI, Sileno, Il sistema..., op. cit., p. 14.

${ }^{187}$ Dentro da lógica corporativista do fascismo italiano, os sindicatos regionais eram subordinados ao sindicato nacional que, por sua vez, integrava a Corporação dos profissionais e dos artistas. No entanto, conforme a historiadora da arte Laura Malvano, tratava-se de um sistema desenvolvido de maneira desigual e a passos lentos. Malvano afirma ainda que o órgão maior das instituições artísticas, a Corporação dos profissionais e dos artistas (Corporazione dei professionisti e degli artisti), criada em 1926, só teria sido realmente estruturada a partir de 1931, sob direção de Dino Alfieri. MALVANO, Laura, Fascismo..., op. cit., p. 45, nota de rodapé n. 33.

${ }^{188}$ STONE, Marla, The politics of cultural production: the exhibition in fascist Italy, 1928-1942, Ph.D. Theses, New Jersey: Department of History, Princeton University (USA), 1990, p. 39.

${ }^{189}$ A Quadrienal foi criada com o intuito de exaltar a arte nacional, destinada a expor as obras dos grandes nomes das artes italianos. Críticos como Salvagnini e Malvano apontam que, dado o caráter nacionalista do fascismo, já no primeiro ano a Quadrienal passou a competir em grau de importância e prestigio com a própria Bienal de Artes. MALVANO, Laura, Fascismo..., op. cit. e SALVAGNINI, Sileno, Il sistema..., op. cit. 
expositivo italiano estaria a Bienal de Artes sediada em Veneza. ${ }^{190}$ Por fim, um pouco abaixo da Quadrienal e da Bienal, estava a Trienal internacional de artes decorativas da indústria moderna e arquitetura, sediada em Milão. ${ }^{191}$

\subsubsection{Subsídio financeiro, premiações e popularização das exposições}

Contemporaneamente à constituição de uma hierarquia expositiva, como já apontado, medidas (como o subsídio de exposições, a criação de um acervo de arte moderna do Estado e a instituição de premiações) foram tomadas pelo Estado fascista para estimular a adesão de artistas ao fascismo e mascarar o cerceamento artístico em curso. ${ }^{192}$ No decorrer dos anos 30, a dinamização do novo mercado nacional (artístico) levou ao aumento do número de exposições, de trabalhos expostos, de público frequentador e de subsídios do Estado nas mostras e exposições organizadas pelo sindicato. ${ }^{193}$

Nesse mesmo período, a promoção de premiações e subsídios financeiros por parte do Estado tornou-se uma prática recorrente adotada em todos os níveis do circuito expositivo. Em 1930, pela primeira vez na Bienal Internacional de Artes, o Partido Nacional Fascista, o Ministério de Educação

\footnotetext{
${ }^{190}$ Em 1930, o então secretário-geral da Bienal de Veneza, Antonio Maraini (1886-1963), em uma nota de avaliação da instrução artística (intitulada "A nova ordenação da Bienal veneziana") sublinhou a importância da nacionalização da Bienal e a posição a ela destinada, no topo da hierarquia expositiva: "a Bienal não pode mais ser considerada nem funcionar como um simples escritório da cidade de Veneza... A Itália herdou uma grande instituição artística que vai representar para as artes figurativas o que La Scala representa para a ópera". MARAINI, A., "Il nuovo assetto della Biennale Veneziana", Rassegna dell'istruzione artistica, febbraio 1930, p. 35, apud STONE, Marla, The politics..., op. cit., p. 59. La Scala, sediada em Milão, era uma das mais prestigiadas e famosas casas de ópera da Itália e do mundo.

${ }^{191}$ Cabe apontar que apesar da relativa independência entre as três grandes instituições de Artes do período (Bienal, Quadrienal e Sindicato nacional) que pairavam acima do sindicato, os gestores de tais entidades eram os mesmos dirigentes dos sindicatos. O secretário-geral da Bienal, de 1928 a 1942, Maraini, era também, até 1932, membro da direção do sindicato nacional de belas artes e, a partir de 1932, secretário-geral do sindicato nacional de belas artes. Já Cipriano Efisio Oppo (1891-1962) foi, até 1931, secretário-geral do sindicato nacional de belas artes e, de 1931 a 1943, secretário-geral da Quadrienal de Roma. Em 1932, Cipriano Oppo também foi encarregado da direção artística da Mostra da Revolução Fascista.

192 Conforme Stone, as promessas de "autonomia criativa" e o discurso agregador do fascismo em relação às diferentes escolas artísticas eram adotados inclusive nos concursos e premiações promovidos pelo Estado. A própria composição do júri, muitas vezes, contemplava integrantes de várias vertentes artísticas. “Após 1930, o partido do governo inundou a Biennale com fundos para competições e aquisições. Altos níveis de patrocínio, sem uma diretiva estética específica, vinculavam os artistas ao regime e encorajava-os a ver a ditadura como uma benfeitora". STONE, Marla, The politics..., op. cit., p. 75.

${ }^{193}$ Conforme a historiadora Marla Stone, entre 1930 e 1938, o valor dispendido pelo governo fascista em premiações de obras passou de 7.500 liras a 153.350 liras. Já o número de exposições locais, regionais e interregionais, realizadas pelos sindicatos, aumentou de duas, em 1927, para treze exposições provinciais, em 1939; bem como de quatro para onze exposições inter-regionais no mesmo período. STONE, Marla, The Politics..., op. cit., p. 66. Além do montante despendido em prêmios e aquisição de obras para a galeria de arte moderna, o Estado fascista contribuía com 200.000 liras anuais para a Bienal de Veneza. Ver: STONE, Marla, The Politics..., op. cit., p. 66.
} 
e outros órgãos governamentais (como a Opera Nazionale Balilla, ${ }^{194}$ a Confindústria e o Sindicado

fascista dos profissionais e artistas) instituíram uma série de dezenove prêmios que totalizaram 331.000 liras. $^{195}$

Em 1930 foi criada em Roma a Galleria d'Arte Moderna, com a incumbência de constituir um patrimônio nacional de arte moderna. Grande parte das obras adquiridas pelo governo em exposições sindicais, Bienais e Quadrienais eram destinadas ao acervo da recém-criada galeria. Só em 1932, a galeria recebeu uma doação do Ministério de Educação de 35 obras (avaliadas na época em 130.000 liras), pinturas e esculturas, adquiridas na Bienal do mesmo ano. ${ }^{196}$

Além do subsídio financeiro e da promoção de prêmios e concursos, o governo fascista também desenvolveu políticas de popularização das exposições de artes. A criação de um amplo mercado consumidor de artes se deu por meio de abonamentos de bilhetes de trens para quem

${ }^{194}$ Opera Nazionale Balilla foi uma instituição fascista criada em 1925 com o intuito de dar assistência e educação física e moral a jovens entre 8 e 18 anos. A instituição funcionava no contra-turno escolar. Já a Opera Nazionale del Dopolavoro foi criada em 1926, com o objetivo de ocupar o tempo dos trabalhadores por meio de esporte, excursões turísticas e visitas a exposições, por exemplo. Conforme notado por Togliatti, em seu livro Lições sobre o fascismo (redigido entre janeiro e abril de 1935), as instituições dopolavoristicas se assemelhavam bastante (se não foram inspiradas em) às associações populares de confraternização camponesas e aos clubes de trabalhadores de fábricas. Ver: TOGLIATTI, Palmiro, Lições sobre o fascismo, trad. Maria Tereza Teixeira, São Paulo, Ciências Humanas, 1978.

${ }^{195}$ STONE, Marla, The politics..., op. cit., p. 99 . O maior prêmio, de 50.000 liras, era destinado a uma pintura histórica, inspirada em um personagem ou evento real da formação dos fasci di combattimento. Havia também prêmios menores para, por exemplo, uma estátua que exaltasse o "vigor físico da raça" italiana e uma medalha de bronze com a efígie do Duce. A proposta de prêmios temáticos não foi muito bem aceita nos ciclos artísticos do período. Stone e Salvagnini mencionam que os artistas mais promissores ou já conhecidos não se inscreviam para tais prêmios temáticos. STONE, Marla, The politics..., op. cit., pp. 100-105 e SALVAGNINI, Sileno, Il sistema..., op. cit., pp. 37-42. Em 1929, quando os prêmios temáticos da VIII Bienal foram anunciados, um referendum artístico sobre o "quadro histórico" foi lançado, na revista Le Arti Plastiche, assinado por 6 pintores de Turim (Levi, Menzio, Chessa, Paulucci, Galante e Boswell). O referendum buscava questionar a proposta de um prêmio temático e, principalmente, a noção de "quadro histórico". O referendum foi publicado, com suas devidas respostas, em quatro números do periódico turinense, entre 1 de dezembro de 1929 e 16 de janeiro de 1930. 6 pittori di Torino, "Referendum del 'quadro storico"', I, Le Arti Plastiche, 1 dicembre 1929, in BARROCHI, Paola (org), Storia moderna dell'arte in Italia manifesti polemiche documenti, Torino, Giulio Einaudi, 1990 , pp. 89-95. O concurso era aberto a qualquer artista que possuísse a carteira do sindicato nacional de belas artes.

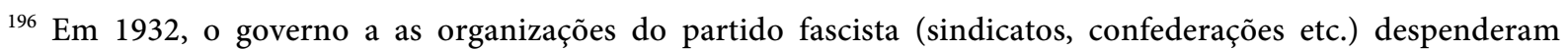
268.000 liras na aquisição de 137 obras da Bienal de Artes. Além das 130.000 liras, destinadas a obras para a Galeria de arte moderna, o Estado italiano destinou 70.000 liras a aquisições de obras a serem usadas como decoração nos prédios ministeriais. Cabe ressaltar que as Quadrienais e Trienais também contavam com um suporte financeiro anual do governo e um montante destinado a prêmios e aquisições de obras. Na primeira edição da Quadrienal (1931), por exemplo, entidades governamentais e do PNF destinaram 600.000 liras para premiar as melhores obras. Os prêmios iam de 100.000 liras para a melhor pintura e escultura e 10.000 liras para os últimos colocados. SALVAGNINI, Sileno, Il sistema..., op. cit., p. 87. 
visitasse as mostras (Figuras 1, 2, 3 \& 4), ${ }^{197}$ e por meio de ampla divulgação nacional e internacional das mesmas. ${ }^{198}$

Outra medida de ampliação e popularização do circuito artístico fascista residia na incorporação de outras expressões artísticas, como a música, o cinema e o teatro, à Bienal de Artes (Figuras 3 \& 4). Entre 1930 e 1934 pode-se identificar uma expansão dos gêneros artísticos

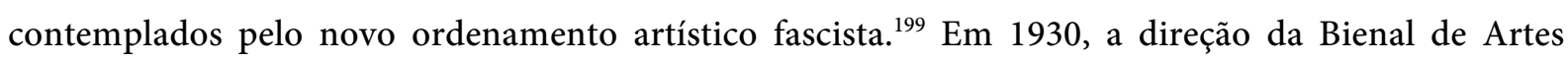
organizou o primeiro Festival Internacional de Música Contemporânea. ${ }^{200}$ Em 1932, Maraini (secretário-geral da Bienal de Artes) organizou a Mostra Internacional de Cinema (Figura 4). ${ }^{201} \mathrm{Em}$ 1934 também foi criado o Festival Internacional de Teatro de Prosa (Figura 3).

\title{
2.4 Modernização à moda Romana
}

\begin{abstract}
A saudação romana, os hinos e as fórmulas, as datas e as comemorações solenes são indispensáveis para conservar o entusiasmo [da multidão]. Assim era já na antiga Roma (Mussolini, 1932). ${ }^{202}$
\end{abstract}

${ }^{197}$ Os descontos nos bilhetes ferroviários eram anunciados nos próprios cartazes das Bienais. Por exemplo, na figura 1 é possível ler, à direita, na parte inferior do cartaz, a seguinte frase: "Agevolezze Ferroviarie" (Facilitações Ferroviárias). Já na figura 2, também centralizada na parte inferior do cartaz, podemos ler: "Riduzione di viaggio del 30 e 50\%" (Reduções de viagem de 30 e 50\%).

${ }^{198}$ Stone afirma que, a partir de 1930, a agência governamental de turismo e a imprensa da Bienal tomaram uma série de medidas para divulgação das Bienais. Cartazes enormes divulgando a Bienal e ressaltando os descontos nos bilhetes ferroviários foram afixados em trens e estações ferroviárias. Folhetins informativos foram traduzidos em seis línguas e disponibilizados em agências de turismo, pousadas e hotéis. STONE, Marla, The politics..., op. cit., pp. 36-140. Conforme Stone, entre 1930 e 1934, o número de visitantes aumentou exponencialmente. A Bienal de 1934 teve o triplo de visitação da Bienal de 1928. STONE, Marla, The politics..., op. cit., p. 133.

199 BOTTAI, Giuseppe, "Il nuovo ordine artistico", Critica Fascista, $1^{\circ}$ agosto 1927, in BOTTAI, Giuseppe, La politica delle arti: scritti 1918-1943, Roma, Libreria dello stato, Istituto poligrafico e zecca dello stato, pp. 74-77, 2009.

${ }^{200}$ Em 1931, o Festival Internacional de Música Contemporânea foi oficialmente instituído enquanto um dos eixos da Bienal. Ver: <http://www.labiennale.org/it/musica/storia/>, acessado em 28 de maio de 2015 . Ver também STONE, Marla, The politics..., op. cit., pp. 123-125.

${ }^{201}$ A Mostra Internacional de Cinema foi um sucesso de público. A primeira edição da mostra recebeu 25.000 espectadores e projetou 40 filmes. A Mostra Internacional de Cinema foi composta por filmes nacionais e internacionais (Figuras 5 \& 6). STONE, Marla, The politics..., op. cit., p. 125. Cabe ainda notar, sobre a primeira edição da Mostra Internacional de Cinema, a influência do cinema russo e o esforço, por parte da direção da mostra, para que houvesse representantes soviéticos no evento. Segundo o pesquisador italiano Stefano Pisu, durante os anos de 1932 e 1934, houve uma longa negociação entre a diplomacia russa e a italiana, com o intuito de assegurar a presença dos filmes soviéticos nas respectivas mostras. PISU afirma ainda que, no verão de 1932, Luciano de Feo (um dos fundadores do Instituto LUCE - L'Unione Cinematografica Educativa e presidente do ICE - Instituto Internazionale del Cinema Educativo) esteve em Moscou para entrar em contato com a produção cinematográfica e de vanguarda local. O LUCE e o ICE foram entidades parceiras da Bienal de Artes na criação e organização da $1^{\circ}$ Mostra Internacional de Cinema de Veneza. Ver: PISU, Stefano, L'Unione Sovietica alla Mostra internazionale d'arte cinematografica di Venezia (1932-1953), orientatore Giannarita Mele, tese de dottorato, Cagliari: Dipartimento di Studi Storici, Geografici ed Artistici (dottorato di Ricerca in Storia Moderna e Contemporanea), Università degli Studi di Cagliari, XX ciclo, 2010, pp. 38-43.

${ }^{202}$ LUDWIG, E., Colóquios com Mussolini, (1932), trad. Marina Guaspari, Porto Alegre, Livraria do Globo, 1932, p. 131. 
A historiadora da arte italiana Laura Malvano aponta para a existência de duas políticas da imagem no sistema artístico italiano durante o fascismo:

[...] de um lado, a imagem de massa, destinada a um vasto público, investida de uma função social precisa e elaborada em função direta da figura social do seu receptor; no seu lado oposto, a produção artística, pintura ou escultura, reservada, pela unicidade que caracteriza o seu estatuto estético, a um público mais restrito e selecionado. ${ }^{203}$

Se, de fato, como descrito por Malvano, pode-se perceber dois regimes de liberdades e políticas de imagens distintos, pode-se perceber também uma articulação e momentos de fusão entre as ditas "alta cultura" e "cultura massas". Políticas de facilitação do acesso e medidas de popularização das exposições de arte (como descontos em bilhetes ferroviários), expansão das linguagens artísticas contempladas (como a incorporação do festival de cinema à Bienal Internacional de Artes em Veneza) e cooptação de artistas para o regime apontam um esforço, por parte do Estado fascista italiano, de transposições de procedimentos econômicos, bem como de implementação de técnicas e práticas de comunicação de massa e recepção coletiva nas esferas da "alta cultura" (produção em escala industrial, planejamento para amplos mercados e processos de massificação). Em menor instância o contrário também ocorria, principalmente por meio da participação de artistas renomados nas instâncias de comunicação de massa do regime, como, por exemplo, a participação regular de M. Sironi (1885-1961) no suplemento ilustrado do periódico fascista Il Popolo d'Italia (1914-1943) (Figura 5).

Os próprios meios e suportes de comunicação de massa (slogans, montagens, jornais, fotografias e mesmo projeções cinematográficas) foram adotados em exposições oficiais. Tal processo ficou particularmente evidente na Mostra da Revolução Fascista (1932), que será discutida nos dois capítulos seguintes (Figuras 6 \& 7).

\subsubsection{Massas transfiguradas}

Transformadas em trincheiras da "revolução passiva" fascista, exposições, galerias e museus tornaram-se dispositivos de construção hegemônica e inclusão molecular das classes subalternas via representações visuais de massa (especialmente fotografia e cinema). De tal modo, como descrito por Benjamin, o fascismo procurava "organizar as massas proletarizadas recém-surgidas sem tocar nas

${ }^{203}$ MALVANO, Laura, Fascismo... op. cit., p. 48. 
relações de propriedade, por cuja eliminação elas pressionam". ${ }^{204}$ Isto é, o fascismo permitiria que as massas alcançassem "a sua expressão (de modo algum o seu direito)". ${ }^{205}$

Segundo o historiador Emilio Gentile, o fascismo italiano desenvolveu soluções para lidar com a crescente desagregação e insurgência das massas, pautadas em dois elementos: práticas litúrgicas e míticas de integração e mobilização das massas (especialmente o mito da nação italiana); e na constituição de ordenamentos sociais hierárquicos (Opera Nazionale Balilla, oppo Lavoro, Corporações etc.) aptos a ocupar as mais diversas instâncias cotidianas. ${ }^{206}$

A massa era, para o fascismo, um material humano que podia ser plasmado através da sugestão do mito e da força coesiva da organização. [...] Por isso a política de massas fascista teve uma intrínseca atitude pedagógica voltada à socialização das ideias e dos comportamentos da massa segundo os próprios "valores". Os ritos, os mitos e os símbolos agiriam sobre a mentalidade do indivíduo e da massa imprimindo-lhe o caráter fascista e transformando-os em uma força coesa para a grandeza e a potência da nação. ${ }^{207}$

Como representado visualmente no painel "O pensamento-ação de Mussolini atrai como uma turbina o povo italiano e o torna fascista", da sala "O", da Mostra da Revolução Fascista (1932), na política artística fascista a massa e os artistas italianos seriam transfigurados, ao ritmo das batidas do tamburino (figura folclórica do Risorgimento), pelas turbinas da "revolução passiva", segundo a vontade do chefe, em membro integrante do corpo do Estado (Figuras 8).

${ }^{204}$ BENJAMIN, W., A Obra de arte na época de sua reprodutibilidade técnica, trad. Francisco De Ambrosis Pinheiro Machado, Porto Alegre: Zouk, 2012, p. 83.

${ }^{205}$ Idem, ibidem, p. 83.

${ }^{206}$ Segundo Gentile, "Em uma sociedade caracterizada por uma profunda fragmentação cultural e na qual a única tradição cultural de caráter popular era a religião católica, a condição preliminar para a realização do Estado totalitário era a nacionalização das massas, em sentido fascista. Isso implicava, na ótica fascista, a mobilização e a participação das massas nos mitos do 'regime'. Não se tratava, obviamente, de uma participação obtida através de uma adesão livre e revogável, amadurecida por uma opção autônoma da consciência individual, mas de uma participação que deveria ser produto de uma socialização fascista das consciências. De fato, através da educação escolástica e das organizações do 'regime', esta socialização iniciava-se na infância e continuava por toda a vida do cidadão, que o Estado acompanhava em cada fase de seu crescimento e em cada aspecto da sua existência, tentando penetrar, através da política da família e da ideologia demográfica, na esfera mais íntima da vida privada. Este propósito explica também, para além das razões de controle, a 'mania de organização' do fascismo". DE FELICE, R.; GENTILE, E., A Itália..., op. cit., p. 47.

${ }^{207}$ Idem, ibidem, p. 31. 


\subsubsection{Estetização da politica fascista}

Além do dispositivo de "estetização da política" fascista - pautada na articulação de dois regimes e práticas distintos de circulação e produção imagética -, o fascismo italiano também adotou como operador simbólico da "revolução passiva" a combinação entre o "novo e o velho", modernização e conservação.

O recurso ao uso de espaços expositivos (a chamada "alta cultura") para a redefinição de valores nacionais, construção de identidade e disputas de hegemonia, remeteria à própria criação da Bienal de Veneza e ao processo de unificação italiana, o Risorgimento.

Inaugurada em 1895, na presença da realeza de Savóia, a Bienal de Veneza, teria surgido da demanda do V Congresso Artístico Italiano (Roma, 1883) de constituição de uma exposição de caráter nacional, capaz de auxiliar o controverso processo de unificação italiano (Risorgimento) e a formação de uma identidade cultural que superasse os regionalismos. ${ }^{208}$

Ainda sobre as duas políticas de imagens e a combinação de uma retórica modernista com chaves nacionalistas litorianas, cabe mencionar as funções e impactos nacionais e internacionais de tais práticas. Historiadores da arte italiana, como Braun e Gentile, apontam os distintos objetivos e recepções internos e externos das produções modernas e do discurso nacionalista italiano. ${ }^{209}$

O esforço de constituição de um sistema expositivo nacional e a adoção de práticas e símbolos litúrgicos romanos nacionalistas ("o culto do litório", como definiu Gentile) corroborava na construção do mito nacional, respondendo às demandas de unificação e constituição identitária nacional. Enquanto isso, o fomento e a adoção de uma linguagem moderna conformavam uma nova imagem da Itália, especialmente no cenário internacional, como um país dinâmico e moderno, na vanguarda do progresso mundial.

\subsubsection{Entre "o novo e o velho"}

"Revolucionária" e tradicional, a arte moderna fascista não só constituía-se como um espaço de aceitação e prestígio político da Itália no exterior - na medida em que maquiava o caráter coercitivo e autoritário do regime -, como também apresentava-se enquanto um instrumento econômico-político que ultrapassava as esferas propagandísticas, na medida em que artistas eram empregados em programas pela retomada econômica nacional, reduzindo o desemprego e mobilizando a economia. O campo da "alta cultura" também apresentou-se como uma esfera de

${ }^{208}$ BEILES, La., "The futurist exhibitions at the venice biennale under fascism, 1928-42", palestra proferida em 13 de março de 2008, Nova York: MoMA, disponível em < http://www.moma.org/explore/multimedia/audios/11/246>, acessado em 8 de agosto de 2017.

${ }^{209}$ Ver: BRAUN E., Modernità..., op. cit.; GENTILE, Emilio, Il culto del littorio: La sacralizzazione della politica nell'Italia fascista, Bari: Editori Laterza, 1993. 
transações diplomáticas: sob a fachada da participação italiana em feiras e exposições eram realizados acordos e firmados laços diplomáticos internacionais. ${ }^{210}$

Assim, conforme a dinâmica de modernização e conservação, a política artística fascista articulava escopos nacionalistas com a apologia da modernização. De um lado, Mussolini convocava os jovens artistas modernos a produzirem uma arte fascista, de outro lado, Mussolini lançava mão do aparato simbólico romano na constituição estético-litúrgica do regime. De um lado, o regime fascista mascarava sob o slogan da autonomia criativa um complexo sistema de cooptação e assimilação artística, de outro lado, este controlava e coagia órgãos de propaganda e comunicação. Em outras palavras, a coexistência do novo e do velho, característicos da "revolução passiva", caracterizou os dispositivos artísticos e culturais do regime fascista, atualizando o projeto risorgimental de modernização e unificação da Itália.

${ }^{210}$ Idem, ibidem. 


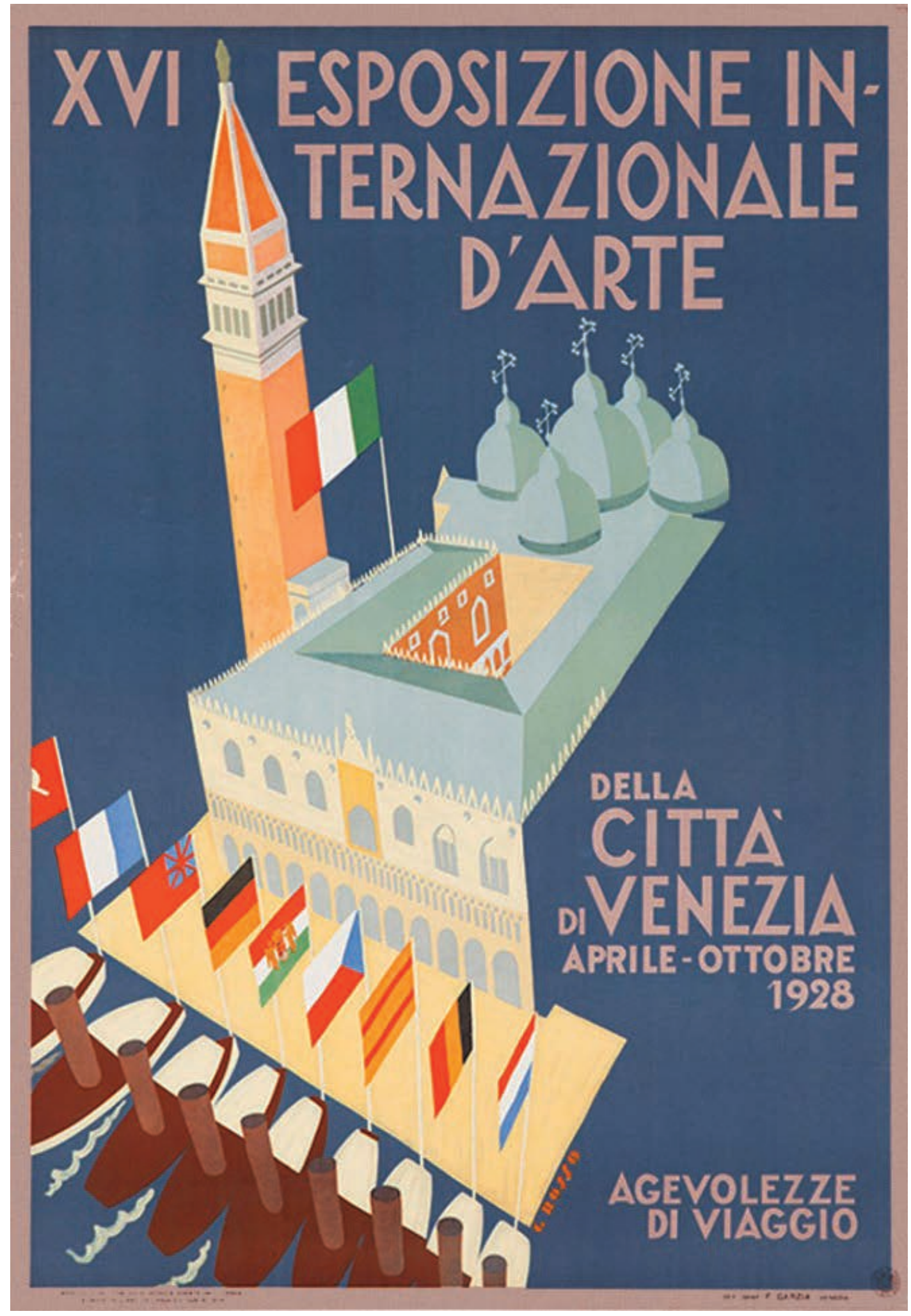

Fig. 1 Cartaz do $1^{\circ}$ Festival Internacional de Teatro, Veneza, 1932 


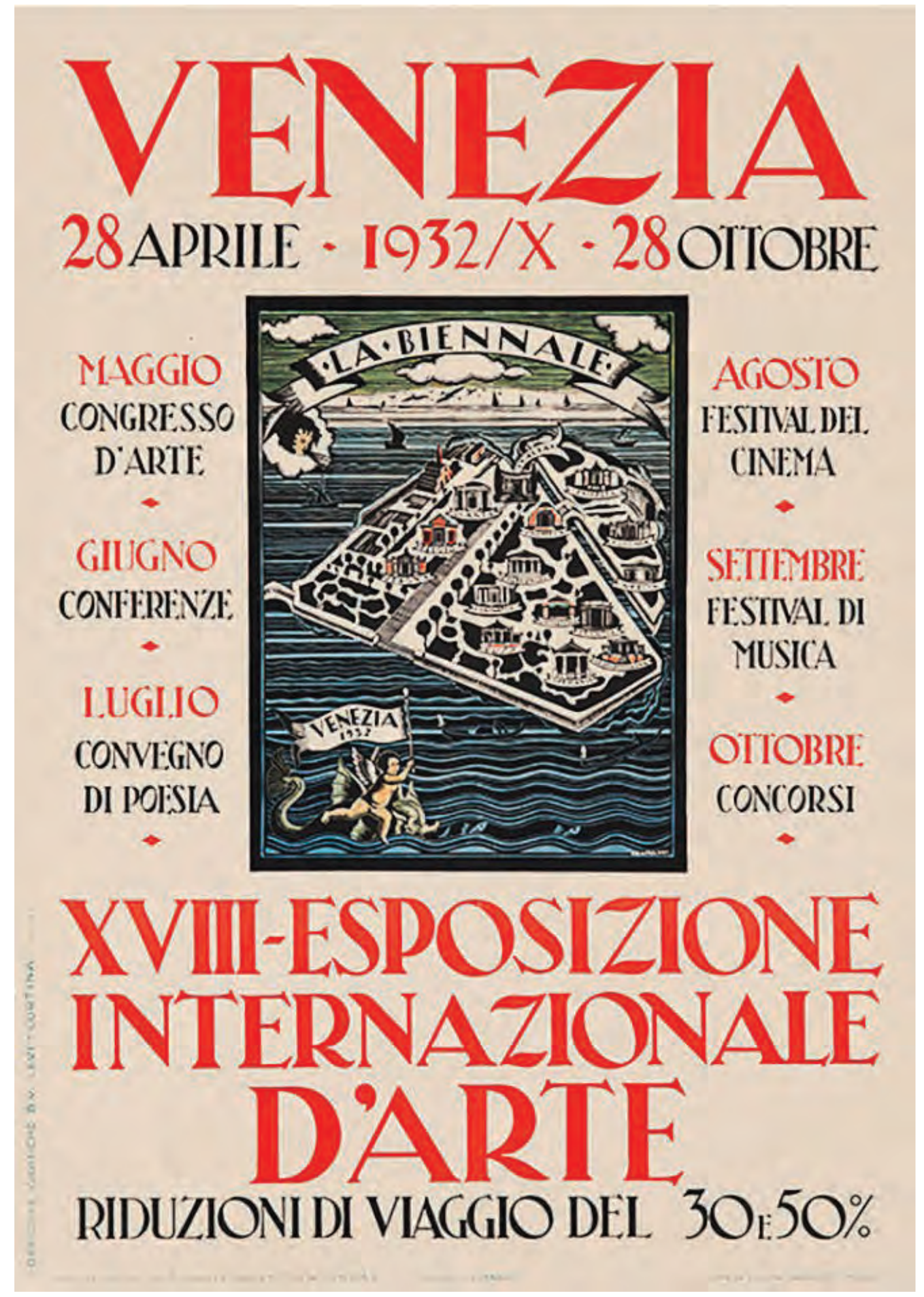

Fig. 2 Cartaz da XVIII Bienal de Veneza, 


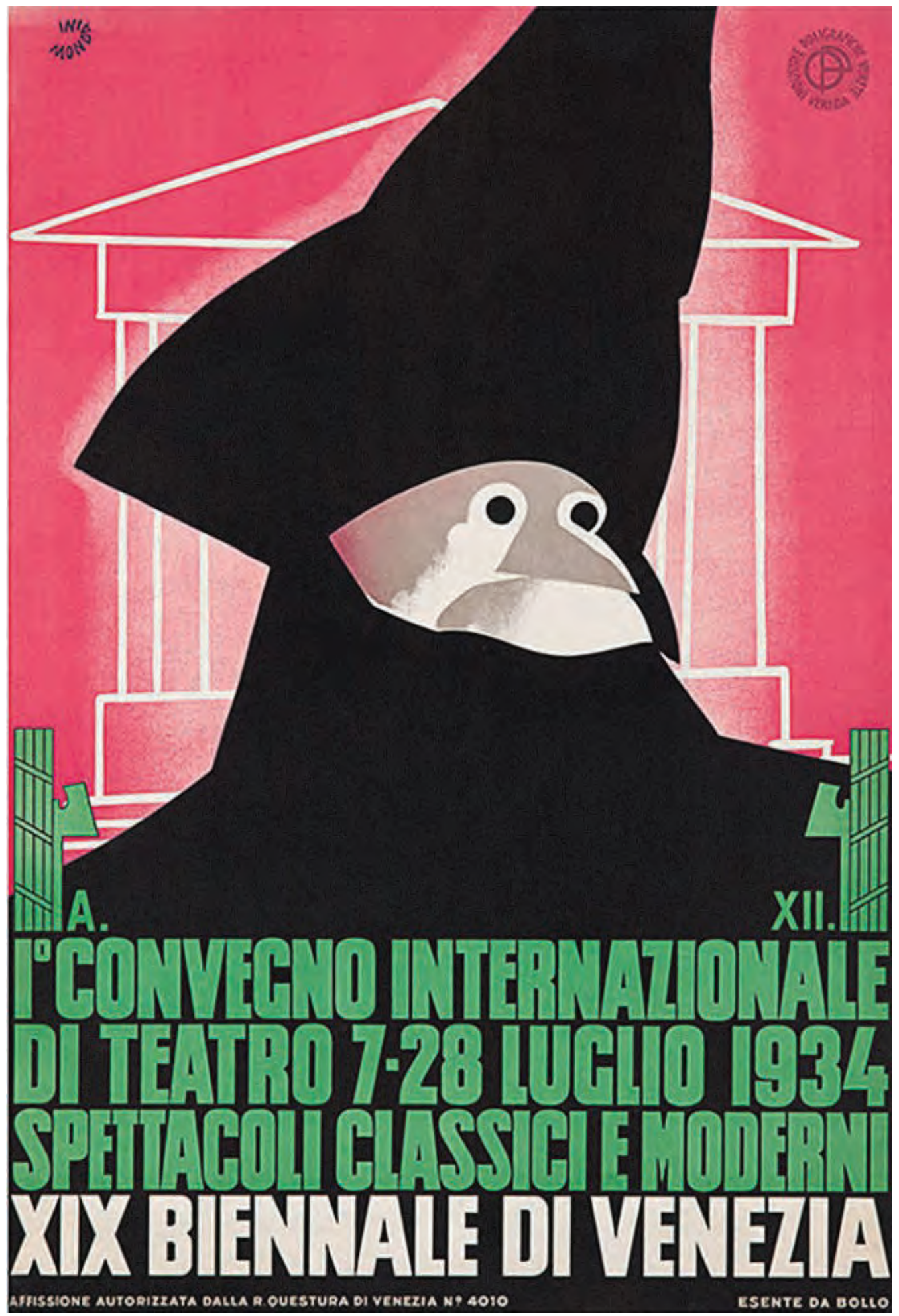

Fig. 3 Cartaz do $1^{\circ}$ Festival

Internacional de Teatro,

Veneza, 1932 


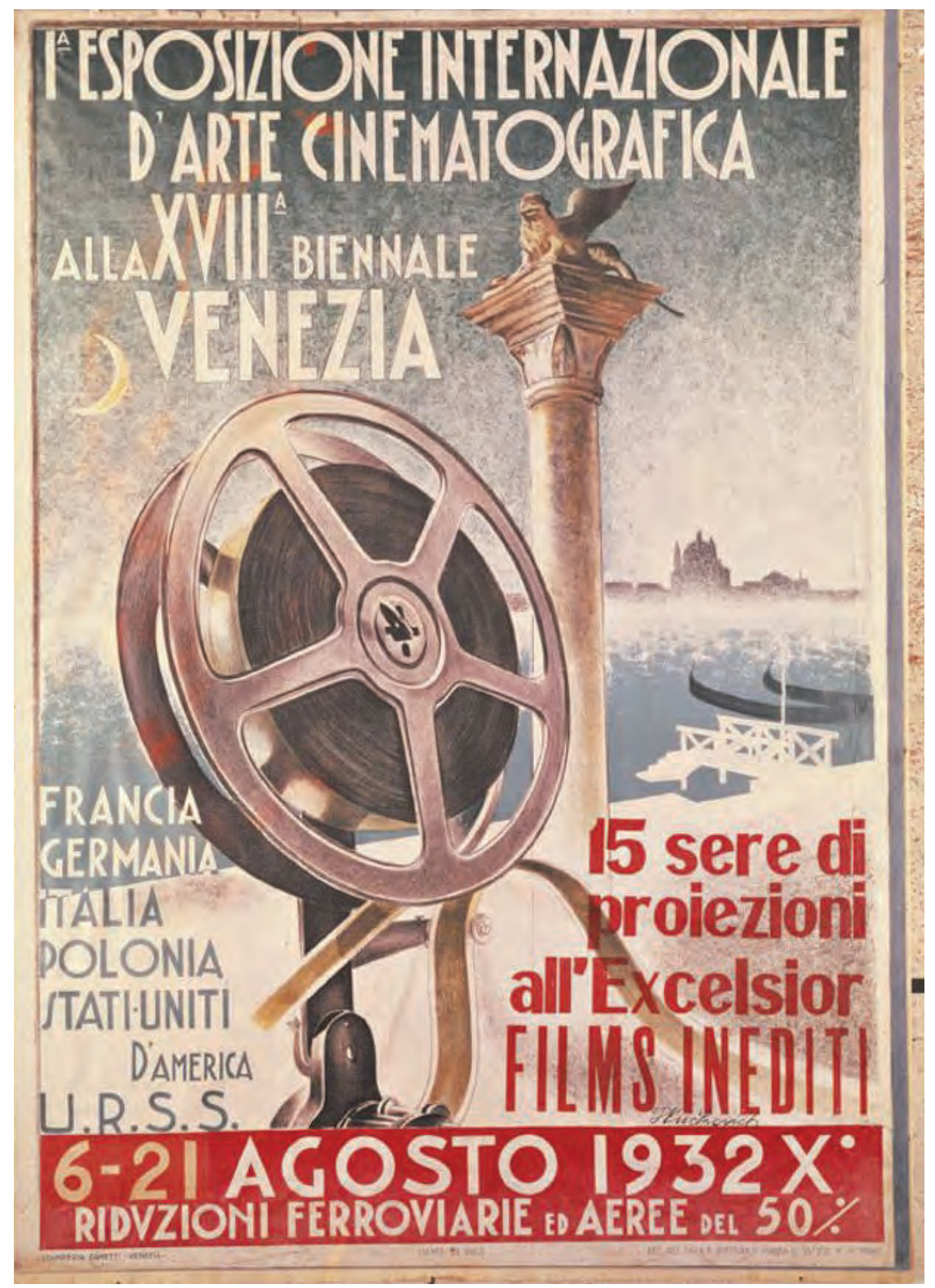

Fig. 4 Cartaz da $1^{\text {a Mostra }}$

Internacional de Arte Cinematográfica,

Veneza, 1932 


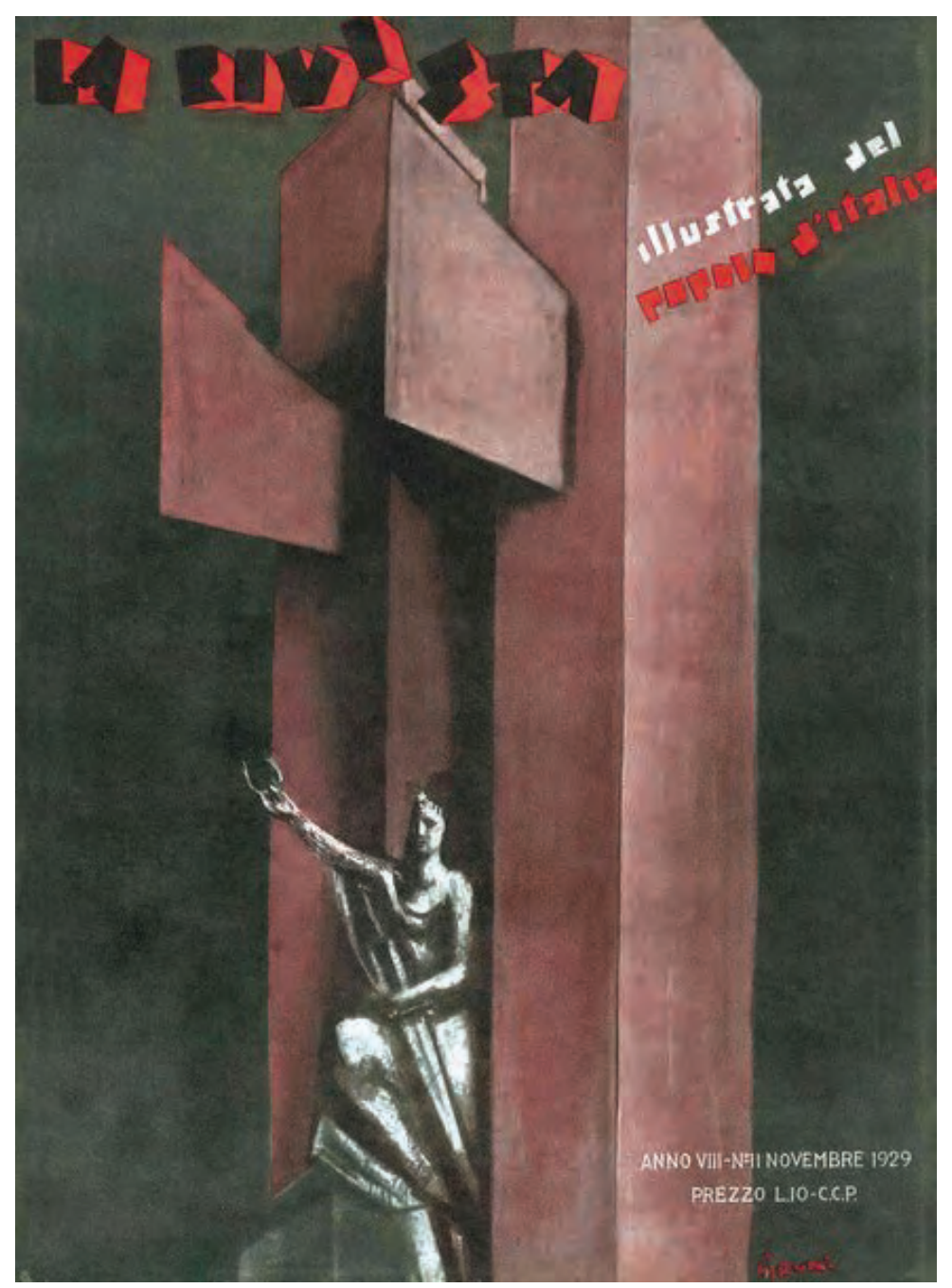

Fig. 5 Capa da revista llustrada, do jornal "Il Popolo d'Italia", 1929 (Ilustrada por M. Sironi) 


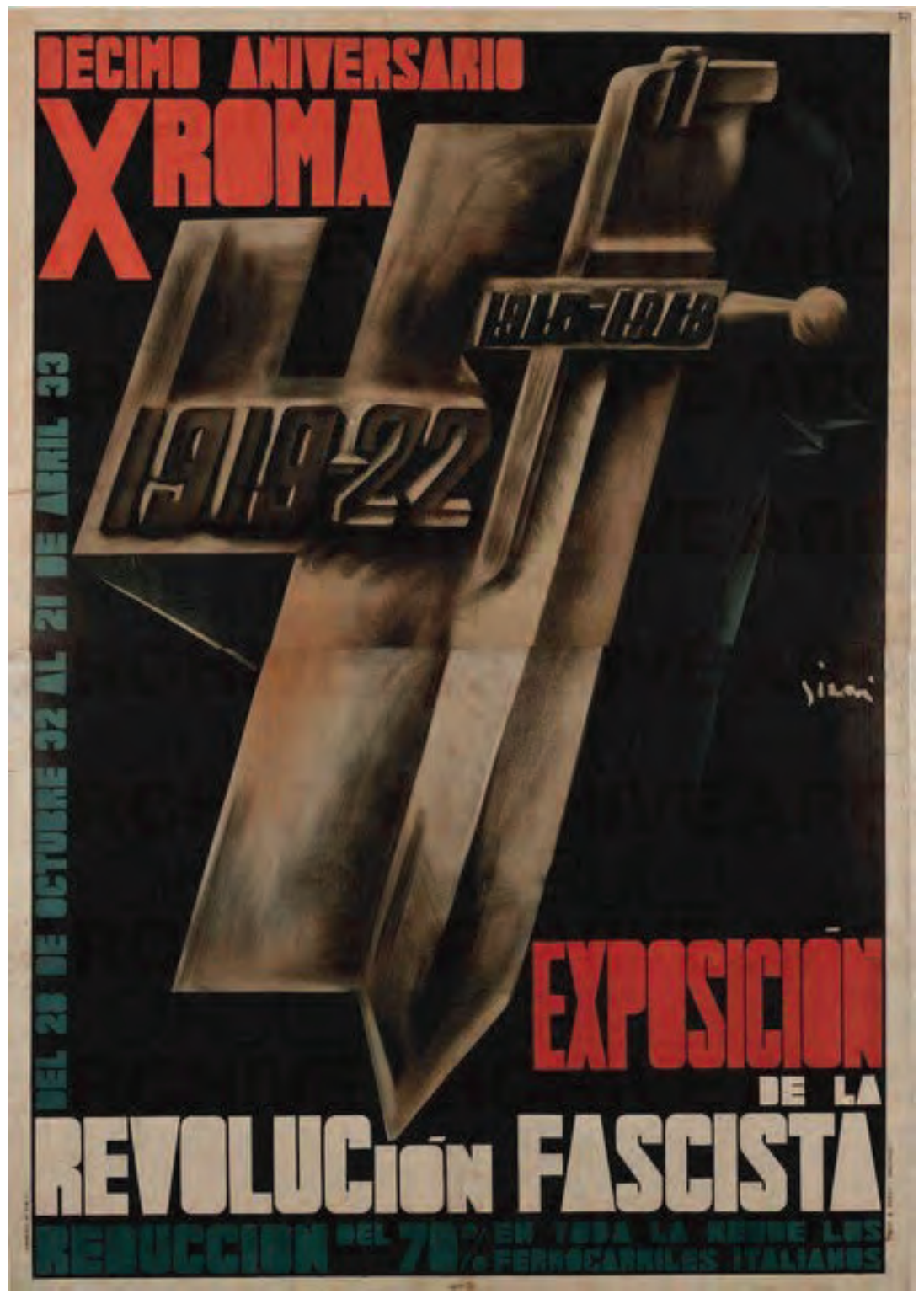

Fig. 6 Cartaz da Mostra da Revolução Fascista, 1932 (em espanhol) 


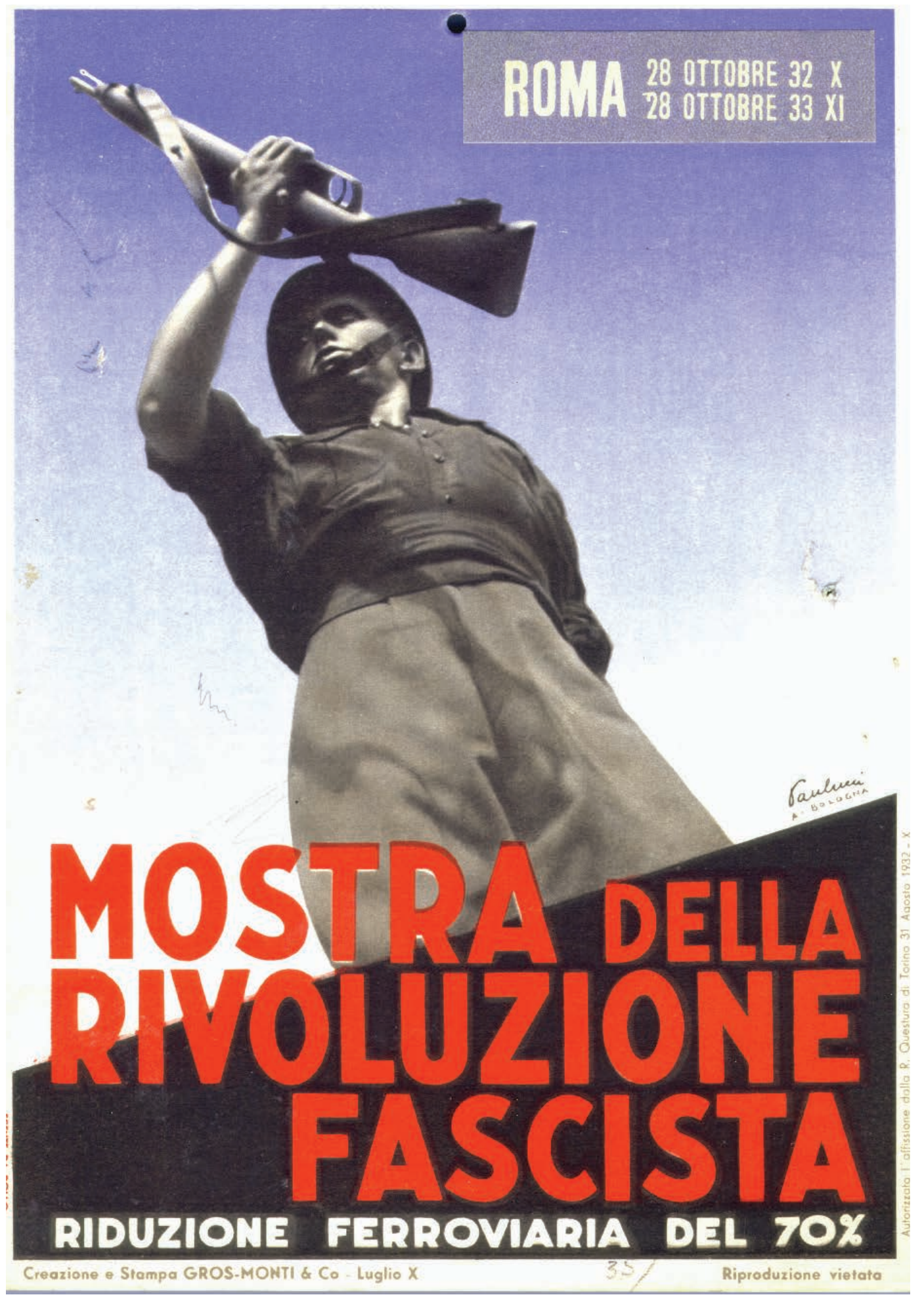

Fig. 7 Cartaz da Mostra

da Revolução Fascista,

1932 


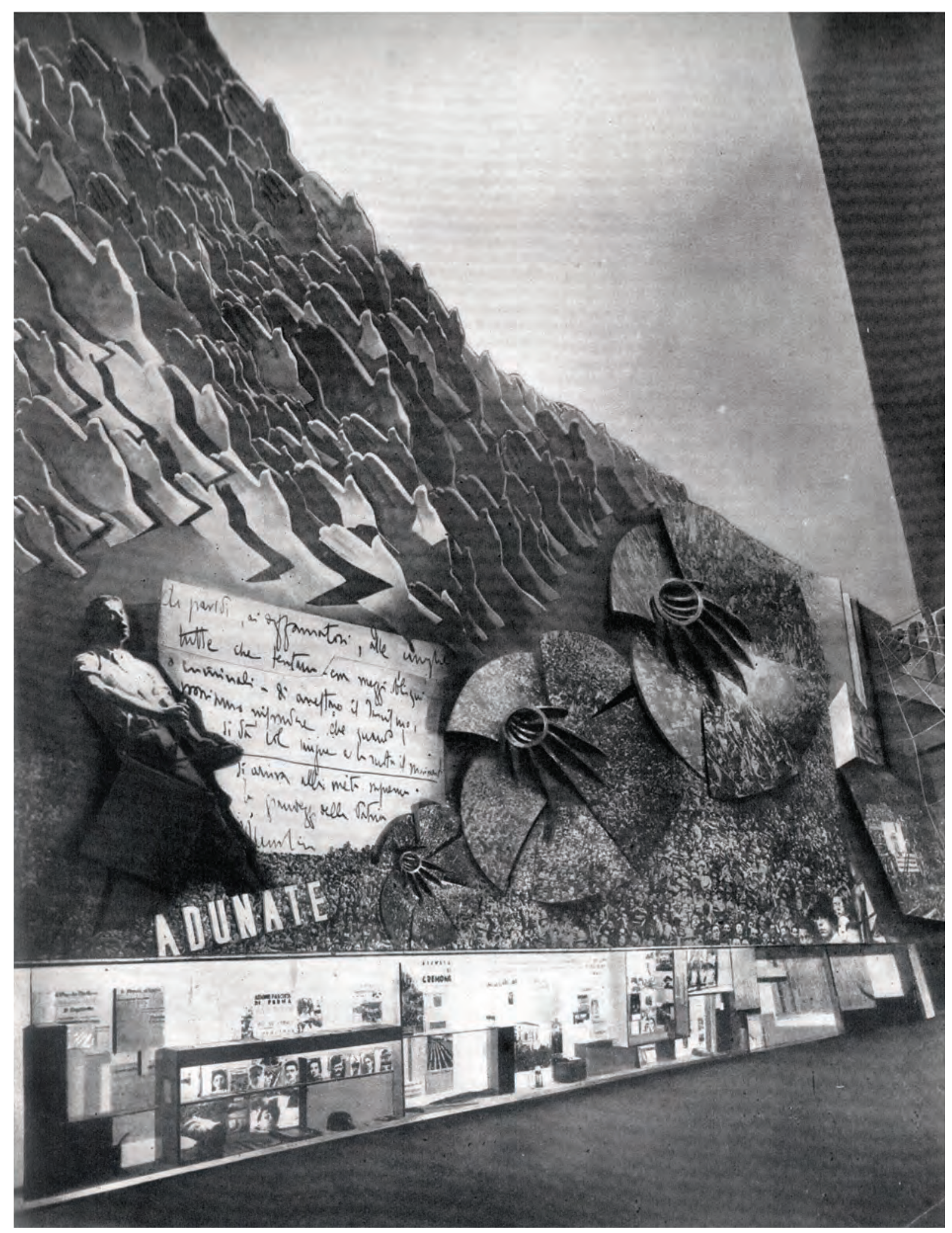

Fig. 8 sala 0, da Mostra da Revolução Fascista, 


\title{
CAPÍTULO 3 | Entre o fato e a farsa: uma estratégia comum
}

\subsection{A Mostra da Revolução Fascista (1932-1934)}

\begin{abstract}
Eu não tinha ainda estado tão próximo para poder ver o quanto naquela construção de linhas potentes e severas tem de postiço, isto é, de lenha, de estuque, folhas metálicas. E posso te dizer que o todo me impressionou muito, não tanto pela coisa em si quanto imaginando como um edifício similar ficaria bem assim no meio da via Nazionale, se fosse uma construção plena e definitiva, e não uma efêmera máscara destinada a esconder por algum tempo a maçante fachada que Piacentini senior desenhou para aquela barraca que era o velho Palácio das Exposições. ${ }^{211}$
\end{abstract}

No dia 28 de outubro de 1932, no palácio das Exposições, em Roma, Mussolini inaugurou a Mostra da Revolução Fascista (Figura 1 \& 2) - grande exposição realizada para comemorar os 10 anos da Marcha sobre Roma. A exposição teve uma duração de dois anos (outubro de 1932 a outubro de 1934) e recebeu aproximadamente 3.8 milhões de visitantes.

Inspirada, conforme documentos de época sugerem, ${ }^{212}$ no pavilhão soviético de Colônia (1928) (Figuras $36 \& 37,41 \& 42,43 \& 44)$ ), a mostra de Roma (1932) constituiu a primeira iniciativa

${ }^{211}$ FRATELI, Arnaldo, “Proposta per il palazzo delle esposizione (lettera aperta)”, La Tribuna, 21 ottobre 1932, in SCHNAPP, Jeffrey T., Anno X: la mostra della rivoluzione fascista del 1932, pref. Claudio Fogu, Pisa, Roma: Istituto Editoriali e Poligrafici Internazionali, MMIII, 2003, p. 89.

${ }^{212}$ Ver: SIRONI, M., "L'architettura della rivoluzione”, Il Popolo d'Italia, 18 nov. 1932, in SCHNAPP, J. T., Anno X..., op. cit., pp. 77-78 e BARDI, Pietro Maria, “Come è la mostra della rivoluzione”, L'Ambrosiano, 31 ottobre 1932, in SCHNAPP, J. T., Anno X..., op. cit., pp. 73-75. Além das críticas e textos de época supramencionados, nos quais a aproximação entre a mostra e a exposição de colônia foi estabelecida, cabe mencionar que o principal artista da mostra, Mario Sironi (1885-1961), era o responsável pelo pavilhão italiano na Exposição Internacional de Imprensa de Colônia (1928), tendo tido, provavelmente, contato direto com o pavilhão soviético da dita exposição. A pesquisadora da arte americana Marla Stone afirma ainda que o próprio Sirone admitiria que o pavilhão soviético de Colônia o havia inspirado. "Sironi reconheceu sua dívida com o construtivismo soviético, citando o pavilhão soviético na exposição de Colônia, em 1928, como uma fonte primária da organização formal da Mostra della Rivoluzione Fascista". Ver: STONE, M., Staging fascism: the exhibition of the fascist revolution, Journal of Contemporary History, Vol. 28, No. 2. (Apr., 1993), Londres: SAGE Publications, pp. 215-243, p. 224. Cabe ainda mencionar que Giuseppe Terragni (1904-1943), um dos arquitetos da mostra, teria sido diretamente influenciado pelas produções construtivistas-produtivistas russas, em particular o pavilhão russo em Paris (1925). Ver: STONE, M., Staging..., op. cit., p. 224. Ainda a respeito da influência da produção bolchevique e de vanguarda russa na mostra fascista, conforme pode-se constatar pelas fotografias da mostra fascista e pela consulta aos arquivos utilizados para a montagem da mostra (hoje conservados no Arquivo Central Estatal, em Roma), foram utilizados muitos jornais e livros do Partido Comunista Italiano, especialmente da sede de Turim (onde havia bastante material sobre o Proletkult italiano). Na pesquisa realizada nos arquivos da mostra fascista, conservados no Arquivo Central Estatal (ACS - Archivio Centrale Statale), encontramos, além do material documental e jornalístico do Partido Socialista Italiano, um vasto material sobre a Rússia e sobre o partido bolchevique: cartas, notícias de jornais, fotografias de Lênin, 
planejada em escala industrial para a integração das massas no corpo do Estado fascista italiano e a celebração da modernização industrial - conforme a reorganização artístico-cultural em curso e a lógica corporativista da época, que visava a inserir a Itália num novo modo de produção capitalista internacional e ativar mecanismos de integração, regulamentação e ampliação das bases sociais do capitalismo nacional (produção e consumo de massa). ${ }^{213}$

A Mostra da Revolução Fascista deveria representar a "revolução" “com formas e aspectos novos e originais, que deliberadamente se diferenciassem das tendências e dos estilos precedentes", ${ }^{214}$ pois, segundo a concepção artístico-politica vigente, “uma Revolução que havia assinalado o início de uma nova era, e, de todo modo, o destaque inexorável de todo um passado agora irremediavelmente sepultado, deveria logicamente ser representada com formas e aspectos novos". ${ }^{215}$

Para tanto, a fachada do palácio, que dois meses e três semanas antes da abertura da mostra fascista abrigava uma exposição em homenagem ao herói do Risorgimento, Giuseppe Garibaldi (18071882), ${ }^{216}$ foi completamente encoberta (Figuras 2, 4, 5, 6, $7 \& 8$ ). Devido a questões econômicas e à importância arquitetônica do prédio histórico, os arquitetos Mario De Renzi (1897-1967) e Adalberto Libera (1903-1963) "tiveram que remediar, providenciando um revestimento [temporário] da fachada”217 (Figura 6). Isto é, os arquitetos mascararam a fachada neoclássica do prédio - solução material esta que, ironicamente, evidenciava, no revestimento da fachada da mostra, o caráter farsesco da revolução fascista italiana.

Assim como no restante da exposição, a nova fachada do Palácio das Exposições combinava linguagem e técnicas de vanguarda com elementos simbólicos tradicionais e nacionalistas para ocultar o caráter conservador do prédio que sediava a mostra.

Trotsky, Zinoviev (ACS; MRF; Collezione Pennati. Carte Giacinto Menotti Serrati; e Documentazione Fotografica). Ainda a respeito da influência da produção russa na concepção da mostra, cabe mencionar as informações levantadas pelo historiador americano Jaffrey Schnapp. Schnapp afirma que no memorando de Alfieri, enviado aos vários departamentos governamentais e instituições de cultura italianos, havia uma clara solicitação de recolhimento de objetos bolcheviques e ou russos - os quais teriam a função de "não apenas documentar os eventos histórico do pós-guerra, mas também de evidenciar o triunfo da revolução de outubro de Mussolini sobre a sua concorrente soviética". SCHNAPP, Jeffrey T., Anno X..., op. cit., p. 23. Por fim, cabe ainda mencionar o alto número de produções russas trazidos para as bienais de 1924 e 1928 (especialmente de produções ligadas às vanguardas e ao LEF, como já mencionado).

${ }^{213}$ GAGLIARDI, A., “O Problema do corporativismo...”, op. cit., p. 237.

${ }^{214}$ ALFIERI, Dino; FREDDI, Luigi (org), Mostra dela rivoluzione fascista: guida storica, $1^{\circ}$ Decennale della Marcia su Roma, Roma: Partito Nazionale Fascista, Instituto Italiano d'Arti Grafiche di Bergamo, 1933 , p. 65.

${ }^{215}$ ALFIERI, Dino; FREDDI, Luigi (org), Mostra dela..., op. cit., p. 65. Conforme o catálogo da mostra fascista, "arquitetos, pintores e escultores tiveram do Duce ordens claras e precisas: fazer algo de hoje, moderníssimo, portanto, audaz, sem melancólicas recordações dos estilos decorativos do passado”. ALFIERI, Dino; FREDDI, Luigi (org.), Mostra della rivoluzione fascista: guida storica, Roma: Partito Nazionale Fascista, Istituto Italiano d'Arti Grafiche di Bergamo, 1933 - XI, p. 8.

${ }^{216}$ Até o dia 5 de agosto de 1932, o Palácio das Exposições abrigava uma exposição em homenagem a Garibaldi e os seus feitos no Risorgimento italiano. SCHNAPP, Jeffrey T., Anno X..., op. cit., p. 33.

${ }^{217}$ ALFIERI, D.; FREDI, L., Mostra..., op. cit., p. 66. 
A antiga fachada do edifício neoclássico (Figura 5) foi escondida por um cubo de trinta metros de largura ${ }^{218}$ (Figura 6), de gesso batido vermelho escuro, ou melhor, vermelho pompeiano "cor típica, tradicional das construções romanas". Segundo a organização da mostra, a fachada retomaria a cor "o tom, peculiar da Urbe". ${ }^{219} \mathrm{Na}$ frente do cubo de gesso batido, quatro grandes fasci metalizados (de vinte e cinco metros de altura, de ferro revestido com folhas de cobre polido e oxidado ovais, dispostos sobre eixos ortogonais de $2,5 \times 1,28$ metros), facilmente associados a chaminés de fábricas ou de navios (Figuras 9,10 \& 11), ${ }^{220}$ atualizavam o antigo fascio littorio romano (Figuras $7,8 \& 12){ }^{221}$

Os quatro fasci eram ligados por um volume retangular (de 38 metros de largura, 4,22 metros de profundidade e 40 centímetros de espessura) que também servia de suporte para caracteres metálicos pretos (de 1,60 metros de altura), que formavam o nome da exposição "Mostra della Rivoluzione Fascista" (Figuras 2, 4, 7 \& 8). Para completar o travestimento da fachada, as duas alas laterais do edifício também foram revestidas com blocos de gesso e pintadas. Nas extremidades destas alas laterais, dois algarismos romanos estilizados, revestidos com folhas de cobre polido e oxidado, simbolizavam os 10 anos da marcha sobre Roma e os 10 anos que estariam por $\operatorname{vir}^{222}$ (Figura 4 \& 7).

"Soberba e tipicamente fascista", 223 a fachada da Mostra da Revolução Fascista e a própria mostra sintetizavam o processo de modernização conservadora - ou, conforme a terminologia gramsciana, "revolução passiva" - realizada pelo fascismo. ${ }^{224}$

\footnotetext{
${ }^{218}$ Segundo os idealizadores da mostra, "o gigante volume cúbico pode representar com sua pureza geométrica a síntese da concepção totalitária e integral do Regime Fascista”. ALFIERI, D.; FREDDI, L., Mostra..., op. cit., p. 67. Já o vermelho pompeiano poderia representar "o espírito da Revolução em ação". Idem, ibidem.

${ }^{219}$ ALFIERI, D.; FREDDI, L., Mostra..., op. cit., pp. 67-68. Urbe é uma palavra do Latim que significa cidade.

220 "Sim, nós podemos aceitar a observação pseudo-irônica de um crítico tradicionalista e mesquinho que lhes [os fasci estilizados da fachada] comparava a chaminés de navios". ALFIERI, D.; FREDDI, L., Mostra..., op. cit., pp. 69-70 (Figuras 4, 7, $8 \& 12$ ). Tal aproximação entre os fasci e a imagem de chaminés de fábricas ou navios fica bastante evidente no primeiro projeto de reformulação da fachada (Figura 11).

${ }^{221} \mathrm{O}$ fascio littorio romano era símbolo de unidade, força, justiça e disciplina. Conforme o historiador italiano, Emilio Gentile, os fasci romanos também tinham uma conotação sagrada. GENTILE, Emilio, Il culto del littorio: La sacralizzazione della politica nell'Italia fascista, Bari: Editori Laterza, 1993, p. 78. Gentile afirma que a popularização do fasci como símbolo do regime fascista se deu a partir de 1923, quando Mussolini ordenou a emissão de 1000 milhões de liras, em moedas de uma e duas liras, com a imagem do fascio (no estilo romano) de um lado e a efígie do rei do outro lado da moeda (Figura 13). Idem, pp. 75-78.
}

${ }^{222}$ ALFIERI, D.; FREDDI, L., Mostra..., op. cit., pp. 65-68

223 "Soberba e tipicamente fascista" foi um elogio que, segundo os organizadores do catálogo da Mostra, Mussolini teria feito à nova fachada da exposição. Idem, p. 66.

${ }^{224}$ Gramsci identifica no fascismo "a forma de 'revolução passiva' própria do século XX". GRAMSCI, Antonio, Quaderni del carcere, edizione critica dell' Istituto Gramsci, org. Valentino Gerratana, Torino, Einaudi, 2007, Q. $8 \$ 236,1932$, p.1089. 


\subsubsection{O grande corolário}

A proposta de uma Mostra Fascista foi concebida pelo presidente do Instituto Fascista de Cultura de Milão - IFCM, Dino Alfieri (1886-1966). ${ }^{225}$ Num movimento similar ao ocorrido com as grandes exposições artísticas italianas (Bienal e Trienal), entre 23 de março de 1928 (data da aprovação da proposta de Alfieri) e 28 de outubro de 1932 (data da abertura da exposição), o projeto original da mostra foi progressivamente modificado e subordinado às diretrizes do chefe do Estado. ${ }^{226}$

A proposta expositiva de Alfieri foi, então, inserida nas atividades comemorativas da marcha sobre Roma, o que implicou em alterações substanciais no projeto original de 1928. Em sua reformulação, o quarto tópico do programa original 227 "a Marcha sobre Roma (1922)" adquiriu maior ênfase, enquanto o último eixo do programa inicial, a "regeneração da Itália levada a cabo pelo fascismo (1922-1929)", foi praticamente suprimido. No novo projeto expositivo, "a regeneração da Itália realizada pelo fascismo" seria o tema central de uma futura exposição. ${ }^{228}$

$\mathrm{Na}$ reformulação da proposta expositiva de Alfieri, o enredo foi concentrado entre "julho de 1914 (eclosão da Conflagração europeia, neutralidade da Itália, primeiras lutas pela intervenção)”, e

${ }^{225}$ Segundo Schnapp, a proposta inicial teria sido desenvolvida por Alfieri, em parceria com o diretor da IFCM, Leo Pollini (1891-1953), o historiador Antonio Monti (na época diretor do museu do Risorgimento) e o comandante Bertarello. SCHNAPP, Jeffrey T., Anno X: la mostra della rivoluzione fascista del 1932, pref. Claudio Fogu, Pisa, Roma, Istituto Editoriali e Poligrafici Internazionali, MMIII, 2003, p. 21.

${ }^{226}$ No início de 1928, Alfieri submeteu a Mussolini a proposta de uma exposição para comemorar os dez anos da fundação dos fasci di combattimento (fundados em 1919). No dia 23 de março de 1928, Mussolini aprovou a proposta de Alfieri, doou 500.000 liras para financiar a produção e aparelhou a mostra com a nomeação de membros do PNF para a comissão organizadora. A comissão encarregada por supervisionar e organizar a mostra era composta, além de Alfieri, pelo próprio Mussolini, por quatro integrantes do grande conselho fascista (De Bono, De Vechi, Balbo e Bianchi), por dois secretários administrativos do PNF (Turati e Marinelli), pelo diretor administrativo do jornal oficial do regime (Il Popolo d'Italia), Arnaldo Mussolini, pelo prefeito de Milão e pelo secretario da Federação fascista de Milão. SCHNAPP, Jeffrey T., Anno X..., op. cit., p. 21. Em novembro de 1928, um dos secretários do partido solicitou a alteração da sede da mostra de Milão para Roma. Em 20 de novembro de 1928, um comunicado publicado no periódico oficial Il Popolo d'Italia afirmou que o secretário do Partido Nacional Fascista - PNF (ou seja, Turati ou Marinelli) havia solicitado a mudança da sede da mostra de Milão para Roma. SCHNAPP, Jeffrey T., Anno X..., op. cit., p. 24. No início de 1929, a abertura da mostra foi adiada um mês e, na sequência, por tempo indeterminado. Em 6 de março de 1929, um artigo do jornal Corriere della Sera informou que a mostra tinha sido adiada por tempo indeterminado, devido à ausência de um local adequado à quantidade e à qualidade de materiais recolhidos para a mesma. SCHNAPP, Jeffrey T., Anno X..., op. cit., p. 25. Por fim, em 1931, a direção do PNF solicitou que Alfieri reformulasse o plano original da mostra para que ela ocorresse no Palácio das Exposições, em Roma, entre 28 de outubro de 1932 e 21 de abril de 1933, como parte dos eventos comemorativos do aniversário de dez anos da Marcha sobre Roma.

${ }^{227}$ A proposta de Alfieri compreendia o período de 1919 a 1929 e era subdividida em 5 partes: 1) "o período do intervencionismo e da neutralidade" (1914-1915); 2) "a guerra (pela terra, pelo mar e pelo ar; o papel dos italianos na vitória dos Aliados; e, a batalha de Vittorio Veneto)" [1915-1918]; 3) "o crepúsculo do fascismo e a sua luta para salvar a nação" (1919-1922); 4) "a Marcha sobre Roma" (1922); e, 5) "a regeneração da Itália levada a cabo pelo fascismo" (1922-1929). SCHNAPP, Jeffrey T., Anno X..., op. cit., p. 21.

${ }^{228}$ Segundo Schnapp, o projeto inicial de Alfieri teria sido dividido em duas mostras complementares, a Mostra Política do Fascismo e a Mostra das Realizações (Mostra Politica del Fascismo e a Mostra delle Realizzazioni). Apesar da mudança de nome da primeira, que se tornaria Mostra da Revolução Fascista (Mostra della Rivoluzione Fascista), a proposta de duas Mostras combinadas se manteria. SCHNAPP, Jeffrey T., Anno X: La mostra della rivoluzione fascista del 1932, pref. Claudio Fogu, Pisa, Roma: Istituto Editoriali e Poligrafici Internazionali, MMIII, 2003, p. 52. 
"outubro de 1922, o mês da [suposta] insurreição armada e da conquista "revolucionária" do poder. ${ }^{229}$ Fruto da suposta insatisfação com a neutralidade italiana na guerra, do crescente fervor nacionalista, da crise italiana e da oposição aos movimentos revolucionários de esquerda do biênio vermelho (1919-1921), o fascismo era apresentado, no novo esquema expositivo, como uma alternativa redentora que teria "levado a Nação italiana do cinza inglorioso do pré-guerra [...] à radiosa aurora resplandecente do 22 ". 230

A mostra foi montada, então, em 19 salas (nomeadas em ordem alfabética de A a U) no piso inferior e 5 salas (1-5) no piso superior (Figura 1). No térreo, as salas estavam dispostas cronologicamente de acordo com o período histórico abordado - de julho de 1914, início da $1^{\circ}$ Guerra Mundial, a outubro de 1922, data da marcha sobre Roma. No primeiro andar, as salas abordavam, de forma sintética, "as realizações do fascismo no campo estatal, no mundo do trabalho, das forças armadas e do espírito". ${ }^{231}$

A mostra reiterava o discurso, corrente nos anos trinta (especialmente em relação à reestruturação corporativista e à intervenção legislativa e econômica estatal), segundo o qual o fascismo representava uma terceira via triunfal à modernidade. Como já apontado no capítulo 2, com maior ênfase a partir de 1929 o fascismo passou a ser apresentado, pelos fascistas italianos, como uma espécie de síntese entre o capitalismo e o comunismo. Conforme o próprio Mussolini, o fascismo seria um autêntico produto da história italiana que, frente à crise do liberalismo e à Revolução Bolchevique, "apresentava-se ao mundo europeu como o anunciador de uma nova forma de coligação orgânica entre produção e política, entre Estado e sociedade", ${ }^{232}$ que levaria à "salvação da Itália e, em essência, da Europa". ${ }^{233}$

${ }^{229}$ ALFIERI, Dino; FREDDI, Luigi (org.), Mostra..., op. cit., p. 7.

${ }^{230}$ ALFIERI, D.; FREDDI, L. (org), Mostra..., op. cit., p. 49.

${ }^{231}$ SCHNAPP, Jeffrey T., Anno X..., op. cit., p. 52. Segundo o historiador americano Jeffrey Schnapp, "o primeiro andar propunha um apêndice independente e temático, dedicado aos projetos do regime e a suas realizações. [...] Estas áreas [do $1^{\circ}$ andar] deveriam ser completamente reelaboradas em uma futura Exposição das Realizações, a mostra de 1932 se limitava a oferecer uma degustação". SCHNAPP, Jeffrey T., Anno X..., op. cit., p. 52. Jeffrey Schnapp é professor de literatura comparada na Universidade de Harvard, estudioso da cultura italiana medieval e moderna. Entre outros, Schnapp foi autor dos livros Mussolini e l'opera d'arte di massa (1996) e A primer of italian fascism (2000). Os trabalhos de Schnapp, assim como os da historiadora americana Marla Stone e do historiador italiano Claudio Fogu, podem ser inseridos num grupo de estudos recentes que investigam a paradoxal proposta, em curso nos dois primeiros decênios do fascismo italiano, de uma arte moderna fascista. O livro Anno X..., de Schnapp, é particularmente interessante por trazer uma série de dados e discussões sobre a Mostra da Revolução Fascista e por se tratar, também, de uma compilação de apreciações sobre a mostra fascista. A segunda parte do livro Anno X... é uma antologia composta por 22 textos de época sobre a Mostra da Revolução Fascista.

${ }^{232}$ MUSSOLINI, B., Messagio per l'anno IX, 27 de outubro de 1930, apud: FROSINI, F., “Entre...”, op. cit., p. 6.

${ }^{233}$ LUDWIG, E., “Colloqui con Mussolini” (1929), Milano, 1932, p. 149, apud: DE FELICE, Renzo, Mussolini il Duce..., op. cit., p. 48. Ver: LUDWIG, E., Colóquios..., op. cit., 


\subsubsection{Expografia e recepção da mostra na imprensa local e internacional}

Inserida num complexo de experimentações de novas formas de cultura coletiva para uma integração totalitária das massas, ${ }^{234}$ a mostra fascista inaugurou, na Itália, uma nova relação entre grande público, propaganda e artes - consolidando a articulação, em curso, entre as ditas "alta cultura" e "cultura de massas" na transposição de procedimentos econômicos e técnicas e práticas de comunicação de massa e recepção coletiva para as esferas da dita "alta cultura".

Tendo em vista a inexistência de uma doutrina artística ou mesmo um estilo artístico fascista, a mostra destacou-se por ser uma das primeiras produções artísticas demandadas pelo Estado fascista com o intuito de autorrepresentação e mobilização psíquica em escala industrial e coletiva das massas.

\subsubsection{Originalidade estilística}

A mostra se tornou rapidamente o grande paradigma da representação visual fascista. ${ }^{235}$ Menções ao caráter inovador e revolucionário (estilisticamente falando) da mostra eram recorrentes em resenhas e críticas do período. O poeta futurista italiano F. Marinetti (1876-1944), num artigo intitulado "Estilo Revolucionário", registrou a originalidade estilística da "Mostra da Revolução Fascista", bem como a radical distinção entre a produção anterior e a realizada para a mostra de pintores como E. Pratelli (1892-1983), A. Carpanetti (1898-1969) e M. Sironi (1885-1961). Sobre o pintor Esodo Pratelli, Marinetti afirmou: "se vocês compararem essa sala [sala B] aos seus quadros expostos na Bienal e na Quadrienal, vocês terão que constatar mais do que uma superação". ${ }^{236}$

O elemento de maior impacto da mostra foi a já discutida reformulação da fachada do Palácio das Exposições (sede da exposição) (Figuras 2, 4, 5, 6, 7 \& 8). ${ }^{237}$ Finalizada no dia 25 de outubro de

${ }^{234}$ GENTILE, Emilio, Il culto..., op. cit., p. 148.

${ }^{235}$ A Mostra da Revolução Fascista serviu de inspiração para outras grandes exposições e obras fascistas, como a Mostra dell'aeronautica de Milão, em 1934 e o Sacrário de Redipuglia, em 1938. Em 1933, durante o terceiro Congresso dos institutos fascistas de cultura, o então diretor do museu do Risorgimento de Milão, Antonio Monti, destacou o caráter exemplar e moderno da mostra: "Que todos os museus históricos, e em particular todos os museus do Risorgimento, tenham a necessidade de ser atualizados e modernizados, e, sobretudo, que ainda se deva trabalhar muito para infundir vida em tantas memórias do passado, não é mais uma novidade para ninguém. A possibilidade e a necessidade de fazer tudo isso é exatamente aquilo que a Mostra da revolução fascista demostrou". MONTI, Antonio, "La mostra della rivoluzione e i musei storici, 'Atti del terzo congresso degli istituti fascisti di cultura”, Roma: PNF, 1933, p. 19, apud SCHNAPP, J. T., Anno X..., op. cit., p. 137.

${ }^{236}$ MARINETTI, F. T., "Stile rivoluzionario", Gazzetta del Popolo, 30 ottobre 1932, in SCHNAPP, Jeffrey T., Anno X..., op. cit., pp. 85-87.

${ }^{237}$ As estátuas que adornavam a entrada do palácio foram removidas, substituídas por quatro fasci de ferro, revestidos com folhas de cobre polido e oxidado. A antiga fachada foi coberta por uma estrutura cúbica vermelha escura, de gesso batido, com trinta metros de largura. Sobre essa base se sobrepunham os números romanos polidos e estilizados. Os fasci eram ligados, a quatro metros de altura do chão, por uma espécie de cobertura do vão de entrada, localizada no topo das escadarias que dão acesso ao edifício, uma laje metálica retangular de 38 metros de largura, 4,22 metros de profundidade e 40 centímetros de espessura. A cobertura do 
1932, a nova fachada teve muita repercussão local e internacional e gerou grande polêmica entre críticos de arte e membros mais tradicionalistas do partido. ${ }^{238}$

\subsubsection{2 "Influência bolchevique"}

Outro elemento comum às resenhas e críticas produzidas sobre a mostra fascista na época era a sua suposta proximidade visual com as produções de vanguarda russa e o pavilhão soviético na Exposição Internacional de Imprensa de Colônia. Tal proximidade, que já poderia ser constatada pela simples observação de imagens da fachada das duas exposições (Figuras 3 e 4), gerou grandes discussões entre os críticos e artistas ligados ao regime fascista italiano. ${ }^{239}$

Num texto de 1932, intitulado "A arquitetura da revolução", um dos grandes expoentes da mostra fascista, Mario Sironi (1885-1961), ${ }^{240}$ destacou o caráter político, a originalidade da mostra e sua nova posição, ao lado da URSS, na vanguarda da arte moderna internacional. Segundo Sironi, "houve, acreditamos, somente duas outras vezes exemplos [de exposições] comparáveis àquela de Roma [a Mostra da Revolução Fascista]: em Colônia na mostra da 'Imprensa' e em Moscou na mostra da revolução bolchevique". ${ }^{241}$

vão de entrada também servia de suporte para caracteres metálicos pretos, de 1,60 metros de altura, que formavam o nome da exposição "Mostra della Rivoluzione Fascista". A máscara criada para cobrir a fachada do prédio neoclássico, por sua escolha de cores, formas e materiais, combinava elementos que remetiam à tradição romana (os fasci e os numerais romanos) com elementos que remetiam à industrialização (o ferro, a geometrização das formas e a ausência de ornamentos). Conforme apontado pelo historiador da arte francês Louis Gillet (1876-1943) a nova fachada do Palácio das Exposições se aproximava de produções russas. Em sua crítica à mostra, Gillet a descreveu como uma composição tão bolchevique que "bastaria mudar os emblemas e essa peça seria aplaudida em Moscou" (Figuras 3 \& 4). GILLET, Louis, "La nuova roma", Revue des Deux Mondes, (Parigi, 15 dicembre 1932), in SCHNAPP, Jeffrey T., Anno X..., op. cit., pp. 125-127, p. 125.

${ }^{238}$ As discussões sobre a nova fachada (provisória) da mostra foram registradas inclusive no catálogo da exposição. "Para a confusão de todos os misoneístas, podemos dizer que os seus [da fachada] desenhos e as suas fotografias invadiram as revistas de arquitetura de todo o mundo, suscitando em toda parte discussões infinitas e bajulações". ALFIERI, D.; FREDDI, Luigi (org), Mostra..., op. cit., p. 65.

${ }^{239}$ Nesse contexto é exemplar a afirmação de Giovanni Papini (escritor e crítico de arte do regime fascista), segundo o qual o "temor da influência bolchevique é ridículo, bobo. Em toda a mostra a única ligação possível é com a majestade, o vigor expressivo dos períodos mais felizes da arte italiana. O resto não conta". Giovanni Papini, apud CAPANNA, Alessandra, Roma 1932: Mostra della rivoluzione fascista, Universale di Architettura, Torino: Testo\&imagine, 2004, pp. 30-36.

${ }^{240}$ Mario Sironi (1885-1961) foi um dos principais artistas fascistas italianos. Entre 1921 e 1942, ele foi responsável pelas ilustrações do jornal oficial do regime fascista, Il popolo d'Italia. Sironi foi integrante do grupo Novecento e expôs nas mais prestigiadas exposições do regime (Bienais e Quadrienais). Ele também realizou algumas pinturas murais, encomendadas pelo regime fascista, nos anos 30 (1935, o afresco A Itália, entre as artes e a ciência, na aula magna da universidade La Sapienza di Roma; 1936, o mosaico A justiça, entre a lei e a força, no Palácio da Justiça de Milão, etc.). Conforme discutido em nota de rodapé 210, provavelmente Sironi teve contato direto com o pavilhão soviético de Colônia e teria declarado a influência do pavilhão de Colônia na concepção da mostra fascista.

${ }^{241}$ SIRONI, M., "L'architettura della rivoluzione", Il Popolo d'Italia, 18 novembre 1932, in SCHNAPP, J. T., Anno X: La Mostra..., op. cit., pp. 77-78. Cabe mencionar que Sironi participou da Exposição Internacional de Imprensa de Colônia, enquanto responsável pelo projeto artístico do pavilhão italiano. Sironi não especifica qual seria esta segunda mostra por ele mencionada, a "Mostra da Revolução bolchevique". É possível inferir que Sironi estaria se referindo ao conjunto de museus, obras e manifestações comemorativas da Revolução de 


\subsubsection{Concepção e montagem}

Conforme é afirmado no próprio catálogo da mostra fascista, a exposição teria sido planejada e executada com o intuito de responder à demanda do chefe do Estado de criação de uma arte nova, que fosse moderna e fascista. ${ }^{242}$ Segundo os idealizadores da exposição, a mostra fascista representaria o início de uma revolução no campo dos museus e das exposições e teria levado a Itália à dianteira das artes modernas internacionais. ${ }^{243}$

A parte artística da mostra fascista foi delegada a 22 pintores, escultores e arquitetos de diferentes tendências artísticas, conforme a retórica de ecletismo e "liberdade" criativa da época. A seleção compreendia em sua maioria jovens artistas já consagrados, integrantes de correntes modernistas italianas distantes entre si, como o Novecento (Mario Sironi, Achilli Funi, Esodo Pratelli, Arnaldo Carpanetti e Domenico Rambelli), o Razionalismo (Giuseppe Terragni, Marcello Nizzoli, Adalberto Libera e Antonio Valente), o futurismo (Enrico Prampolini, Gerardo Dottori e Antonio Sagata) e o Strapaese ${ }^{244}$ (Amerigo Bartoli, Mino Maccari e Leo Longanesi). ${ }^{245}$

Apesar da relativa heterogeneidade do grupo de artistas selecionados, o complexo expositivo apresentava uma unidade estilística ancorada em uma sintaxe visual vanguardista associada a meios de massa e em elementos recorrentes de culto ao chefe e à pátria - fazendo coro com a retórica

Outubro e não a um evento específico denominado "Mostra da revolução bolchevique". Entre outros, o então jornalista e colecionador de arte Pietro Maria Bardi (1900-1999) também traçou uma comparação entre a Mostra da Revolução Fascista e a arte de vanguarda soviética, em seu artigo sobre a mostra italiana. "Nós conhecemos, por tê-los visitado minuciosamente, os museus da revolução soviética, aquele de Moscou especialmente, que é o mais importante, e pudemos estabelecer uma comparação entre a Mostra do Fascismo e as exposições [russas] de que falamos, que são como se diz, as exposições politicas mais famosas do mundo: pois bem, a nossa iniciativa, em comparação [às russas], é de uma superioridade que não admite discussões do ponto de vista artístico". BARDI, Pietro Maria, “Come è la Mostra della Rivoluzione”, L'Ambrosiano, 31 ottobre 1932, in SCHNAPP, Jeffrey T., Anno X..., op. cit., pp. 74-75.

${ }^{242}$ Conforme mencionado no capítulo anterior, em mais de um discurso Mussolini mencionou a sua intenção em fomentar uma produção artística "nova”, "moderna" fascista. Em Perugia, em 1926, por exemplo, Mussolini teria lançado um apelo aos artistas, no qual afirmaria a necessidade de "criar uma arte nova, do nosso tempo, uma arte fascista”. MUSSOLINI, B., Opera omnia, p.230, apud GENTILE, Emilio, Il culto..., op. cit., p. 176.

243 “A Mostra do Fascismo representará talvez o início de uma revolução no campo dos Museus e das Exposições e leva ao primeiro plano a Itália também neste setor, no qual outras nações haviam muito caminhado e muito realizado". ALFIERI, D., FREDDI, L. (org), Mostra..., op. cit., p. 7.

${ }^{244}$ Strapaese foi um movimento artístico literário italiano cujos autores circulavam em torno do periódico humorístico Il Selvaggio (1924-1942). Entre outras coisas, o movimento celebrava o nacionalismo e a revalorização da cultura popular e folclórica italiana.

245 Além de artistas vinculados a correntes especificas, a seleção também compreendia artistas que eram considerados de "vanguarda" mas não estavam associados diretamente a um grupo ou estilo determinado, como, por exemplo, Giannino Marching (1897-1983), Guido Mauri, Publio Morbiducci (1889-1963), Angelo Della Torre (1903-2000), Italo Mancini, Antonio Barrera (1889-1970) e Enrico Paolucci (1901-1999). Alguns, como Arnaldo Carpanetti (1898-1969) e Gerardo Dottori (1884-1977), foram artistas que emergiram no cenário artístico via competições e premiações promovidas pelo fascismo em Bienais, Quadrienais e mostras sindicais. Carpanetti foi premiado em 1929, na exposição do sindicato lombardo, e, em 1930, venceu um prêmio (financiado pelo PNF) na Bienal de Artes. Já Dottori foi premiado na Bienal de 1932. STONE, Marla, The politics..., op. cit., p. 262. 
corporativista de solidariedade e colaboração entre diferentes (superação da luta de classe). Como os próprios intelectuais e artistas do período assinalaram, a exposição tinha sido realizada por "nomes e gostos diversos, que, todavia, se harmonizavam". "Stracittadini e Strapaesani, Novecentistas e Oitocentistas, Futuristas e rebeldes isolados mesmo a estas definições [...]. Talentos diversíssimos, e frequentemente opostos, convergem numa expressão de solidariedade, compacta". ${ }^{246}$

\subsubsection{Da fachada ao sistema elétrico}

A mostra "entrou na sua fase de realização no início do ano de 1932 ". ${ }^{247}$ Paredes, pavimentos, teto, salas e vias de acesso foram transformados para adaptar a construção oitocentista ${ }^{248}$ à retórica modernista da mostra. Da fachada ao sistema elétrico, o projeto expositivo da Mostra da Revolução Fascista reformou cada detalhe do Palácio das Exposições.

No catálogo da mostra, os artífices Freddi e Alfieri descrevem com certo detalhamento o novo sistema elétrico do Palácio das Exposições. O sistema elétrico e toda a fiação do edifício foram modificados especialmente para a exposição. Segundo os autores do catálogo, o novo sistema elétrico contava inclusive com um esquema de reserva elétrica, permitindo que numa eventual queda de energia ainda houvesse iluminação suficiente para o público circular tranquilamente na mostra até alcançar as portas de saída. A ênfase dada pelos organizadores da mostra à modernização do sistema elétrico do Palácio das Exposições parece dialogar diretamente com a apologia da industrialização presente na exposição fascista. ${ }^{249} \mathrm{~A}$ eletricidade como alegoria da modernização também foi explorada no pavilhão soviético de Colônia (conforme discutido no capítulo 1). ${ }^{250}$

\subsubsection{Paredes e forros falsos}

Para conferir um ar "moderno" à mostra e transformar o espaço expositivo e o material coletado num todo homogêneo, os artistas lançaram mão de paredes e forros falsos, objetos em relevo

${ }^{246}$ PELLIZZI, Camillo, Molti artisti e una rivoluzione, “Corriere della Sera”, 25 aprile 1933, in SCHNAPP, Jeffrey T., Anno X..., op. cit., pp. 79-81, p. 81.

${ }^{247}$ ALFIERI, D.; FREDDI, Luigi (org), Mostra..., op. cit., p. 52.

${ }^{248}$ O Palácio das Exposições (Palazzo delle Esposizione) foi projeto pelo arquiteto italiano Pio Piacentinni e inaugurado em 1883. Ver: <http://www.palazzoesposizioni.it/categorie/la-storia>, acessado em 20 de outubro de 2017.

${ }^{249}$ ALFIERI, D.; FREDDI, Luigi (org), Mostra..., op. cit., pp. 57-58.

${ }^{250}$ Como já discutido, a questão da eletricidade estava presente também nos cartazes e revistas dos planos quinquenais soviéticos (a questão da eletrificação russa era um dos pontos do primeiro plano quinquenal). Ver: WOLF, Erika, USSR in Construction: from avant-garde to socialist realist practice, Ph. D. Dissertation, Ann Arbor: University of Michigan, 1999, p. 28. 
(baionetas, soldados estilizados e palavras de ordem), pinturas murais e, conforme a terminologia da época, foto-mosaicos - termo italiano para fotomontagens (Figuras 14, 15, 16, 35, 38, 39, 41 \& 45). ${ }^{251}$

A exposição era dividida em 21 unidades temáticas dispostas em 24 salas. ${ }^{252}$ A estrutura narrativa propriamente dita ocupava apenas 15 (A-Q) das 24 salas. Para cada umas dessas unidades temáticas havia um ou mais responsáveis pela parte artística (artistas ou arquitetos) e um responsável pela parte histórica (historiadores ou antigos membros do PNF). ${ }^{253}$ As quinze salas narrativas (A-Q), dispostas de forma circular, em sentido anti-horário, nas extremidades do edifício (Figura 1), conduziam o público às quatro salas centrais da mostra (R-U).

As quatro salas centrais (R-U) (Figuras 17, 18, 20, 27, 28, 29, $30 \& 31$ ), que sucediam a sala $\mathrm{Q}$ (“A Marcha sobre Roma”) (Figura 19), representariam um ponto de ruptura com a história precedente, reforçando então o imbróglio da "Revolução" fascista. Conforme o próprio guia da mostra: "Saindo da Sala [sala Q], com os olhos ainda com a visão do drama vivido pelo nosso país nos anos do pré-guerra e do pós-guerra, sobre o qual se ergue gigantesca e mágica a figura do Duce, o visitante intui que daquele ponto em diante se inicia uma nova história da Itália”. ${ }^{254}$ Para tanto, as quatro salas centrais, localizadas no coração da exposição, interrompiam a abordagem cronológica e reforçavam os pontos principais da liturgia fascista: apologia da pátria e dos mártires da "revolução" e culto do líder, bem como adotava um estilo mais tradicional e imponente (abandonando fotomontagens e fotografias). ${ }^{255}$

\footnotetext{
${ }^{251} \mathrm{O}$ termo fotomontagem, nos escritos da época e no catálogo da exposição foi muitas vezes substituído pelo termo "foto-mosaicos", que, segundo os críticos de arte do regime, seria mais coerente com a tradição artística italiana. Ver: CAPANNA, Alessandra, Roma 1932..., op. cit., pp. 36-37 (Figuras 14, 15, 16, 32, 33, 34 \& 39). Possivelmente o termo "foto-mosaico", tenha sido utilizado para forjar um caráter nacional em uma técnica e um estilo artístico com clara influência estrangeira (russa e alemã).

${ }^{252}$ As unidades temáticas da exposição eram: sala $\mathrm{A}$ - Da conflagração europeia à fundação do Il Popolo d'Italia (1914); sala B - Da adunata dos Fasci d'azione rivoluzionaria à intervenção da Itália na guerra europeia (1915); sala C - A guerra italiana (1915-1918); sala D - A vitória italiana (1918); sala E - Da vitória à fundação dos Fasci italiani di combattimento (1918-1919); salas F e G - Da fundação dos Fasci di Combattimento a todo o ano de 1919; salas H e I - O primeiro e o segundo semestre de 1920; salas L e M - Fiume e Dalmácia; sala N - O ano de 1921; sala O - O ano de 1922 até o início de outubro; Sala P - A adunata de Nápoles e as preliminares da Marcha sobre Roma; sala Q - A Marcha sobre Roma; sala R - Salão de honra; sala S - Galeria dos fasci; sala T Sala Mussolini; sala U - Memorial dos mártires; sala 1 - Os fasci no exterior; sala 2 - O espírito fascista - A bibliografia fascista; sala 3 - As conquistas do regime fascista; sala 4 - As realizações do regime no setor de agricultura e transporte; sala 5 - $\mathrm{O}$ trabalho no regime fascista (Figura 1).

${ }^{253}$ As 15 primeiras salas, de A a Q, possuíam um responsável pela parte histórica e um ou mais artistas responsáveis pela parte artística. As demais salas (R, S, T e U) do andar térreo não possuíam um historiador responsável, mas apenas responsáveis pela parte artística. Já no primeiro andar, somente a sala 1 tinha um responsável pela parte histórica e artística, as demais salas $(2,3,4$ e 5) ficaram a cargo apenas de um ou mais artistas.

${ }^{254}$ ALFIERI, D.; FREDDI, Luigi (org), Mostra..., op. cit., p. 210.

${ }^{255}$ Duas das quatro salas (R e T) eram dedicadas à exaltação de Mussolini e ao seu papel como propagador dos ideais fascistas, visionário e condutor da Itália (Figuras 28, 29, 30 \& 31). As demais salas, $\mathrm{S}$ e U, respectivamente, ressaltavam o papel dos fasci di combattimento e dos italianos arditi [fascista convictos] que morreram pela pátria (Figuras 17, 18, 21, 22, 23, $24 \& 25$ ).
} 


\subsubsection{Uma sintaxe visual de vanguarda}

Conforme os relatos da época, os elementos visuais que conferiam unidade ao todo expositivo eram: o dinamismo das composições; ${ }^{256}$ a adoção sistemática de formas geométricas que suscitavam a ideia de movimento e modernidade; uma sintaxe visual vanguardista de agitação e propaganda associada a meios de massa (fotos, jornais, murais e montagens); ${ }^{257}$ e a repetição da imagem e dizeres de Mussolini. ${ }^{258}$

De acordo com a narrativa do historiador e crítico de arte francês Louis Gillet (1876-1943), a exposição fascista era composta por:

Uma série de episódios, de reconstruções e de cenas individuais [...] nos quais se misturam e se multiplicam entre si abstrações e concretudes, estatísticas, fotografias, baixos relevos [...] alegorias e símbolos, o todo como naquelas colagens cubistas nas quais os fragmentos reais, uma caixinha de fósforo, um pedaço de cachimbo, um recorte de jornal são colocados a serviço de uma construção cerebral. ${ }^{259}$

Em sua apreciação da mostra, Gillet (que já havia na primeira parte de seu texto traçado uma aproximação entre a fachada da mostra fascista e a produção artística soviética ${ }^{260}$ apontou uma relação entre a sintaxe expositiva da mostra italiana e as colagens cubistas. ${ }^{261}$

${ }^{256}$ Segundo Schnapp, "a sequência organizada no interior do palácio de uma planta arquitetônica retangular vem substituída por uma progressão imprevisível de salas assimétricas com relações e proporções espaciais irregulares. Muros falsos ortogonais rompiam com os ângulos retos, muros parciais sobressaíam agressivamente e em estranhos ângulos; volumes escultóricos e relevos se elevavam sobre um dos dois lados dos planos salientes; tetos se abaixavam, se inclinavam e se levantavam; os pisos se tornavam ilusórios". SCHNAPP, Jeffrey T., Anno X..., op. cit., pp. 54-55. O dinamismo óptico, identificado por Schnapp, na composição do espaço expositivo da mostra fascista se aproxima muito da concepção expositiva desenvolvida por Lissitzky no pavilhão soviético em Colônia e reproduzida no pavilhão soviético em Dresden (Figura 44).

${ }^{257}$ Conforme alguns críticos da época, colagem, montagem e fotomontagem eram os elementos de maior destaque da Mostra da Revolução Fascista. "A fotomontagem deu à coleção inteira [da Mostra da Revolução Fascista] sua mais peculiar e incontestável característica visual”. NEPPI, Alberto, L'Opera degli artisti all mostra della rivoluzione fascista, "Rassegna istruzione artistica", november-december 1932, p. 338, apud: STONE, Marla, The politics..., op. cit., p. 263 (Figuras 14, 15, 16, 32, 35, 36, 39, 45 \& 47).

${ }^{258}$ Cabe mencionar que o grande destaque dado à figura de Mussolini emergiu apenas na reformulação do plano expográfico da mostra para as comemorações do aniversário da Marcha sobre Roma. No projeto de 1928, dada a ênfase na formação e desenvolvimento dos fasci de combattimento, a celebração da figura de Mussolini era quase ausente ${ }^{258}$. Já no projeto final, de 1932, a figura de Mussolini como protagonista e condutor dos eventos representados pela mostra e do próprio circuito expositivo, adquiriu grande destaque. FOGU, Claudio (posf.), L'immaginario storico fascista e la Mostra della Rivoluzione, in SCHNAPP, Jeffrey T., Anno X..., op. cit., p. 133.

${ }^{259}$ GILLET, Louis, "La nuova...", op. cit., in SCHNAPP, Jeffrey T., Anno X..., op. cit., p. 125.

${ }^{260}$ Como já mencionado, em sua crítica à mostra fascista, Gillet escreveu a respeito da nova fachada do Palácio das Exposições que "bastaria mudar os emblemas e essa peça seria aplaudida em Moscou" (Figuras 3 \& 4). GILLET, Louis, "La nuova...", op. cit, in SCHNAPP, Jeffrey T., Anno X..., op. cit., pp. 125-127, p. 125. 
Da mesma forma que a criação de um ambiente interno fechado em si mesmo, a adoção das técnicas de colagem e fotomontagem, a escolha de materiais ("estatísticas", "fotografias", "um recorte de jornal") "a serviço de uma construção mental" também dialoga com o pavilhão soviético na Exposição Internacional de Imprensa de Colônia e com os debates sobre fotografia e factografia do grupo LEF russo. ${ }^{262}$

Em 1928, por meio de um longo debate realizado nas páginas da Novyi Lef, os lefistas O. Brik, A. Rodchenko, B. Kushner (1888-1937) e S. Tretiakov (1892-1937) tentaram estabelecer o elemento responsável pelo caráter revolucionário da fotografia. ${ }^{263}$ Entre outras questões, foram levantadas: a necessidade de romper com a realidade fictícia do romance e da pintura e com a individualização burguesa da figura do herói em direção a práticas artísticas criativas e autodeterminadas (“Tolstoys coletivos"); ${ }^{264}$ o papel da fotografia e do cinema de expandir a percepção do observador fomentando uma postura ativa e desautomatizada; ${ }^{265}$ e a necessidade de "revolucionar nosso pensamento visual" e psiquismo. $^{266}$

Visto que dificilmente uma exposição a serviço da ideologia fascista objetivaria revolucionar o olhar e desenvolver uma percepção crítico-reflexiva no observador, como seria o caso da proposta das vanguardas russas, cabe aqui a seguinte questão: a disposição e seleção de materiais da Mostra da Revolução Fascista estariam mesmo a serviço de uma construção mental? Se sim, de qual tipo?

\subsubsection{De César a Mussolini}

Um terceiro e quarto trechos da crítica de Gillet sobre a mostra fascista podem apontar algumas respostas para essa questão:

${ }^{261}$ Em El último cuadro, o lefista Tarabukin supõe o construtivismo e o produtivismo enquanto fases do desenvolvimento das artes plásticas. Para tanto, ele reconstrói o percurso da arte moderna até a proposta dos construtivistas, de morte da "arte de cavalete" - passando pelas colagens cubistas (as quais estariam na base do próprio surgimento da fotomontagem). A morte da arte, proclamada pelos construtivistas, é vista por Tarabukin não como destruição da arte, mas como um desenvolvimento histórico e reflexivo, um desenvolvimento em decorrência do próprio esgotamento das formas artísticas precedentes, assim como pautado pelas demandas sociais da sociedade revolucionária em construção. Segundo ele, com Manet (18321883), a pintura perdera a primeira pedra de seu pedestal, dando início a uma decomposição irreversível do organismo pictórico e de seus elementos constituintes, o que conduziu à proposta produtivista de dissolução da arte no processo de produção da vida. TARABUKIN, N., El último cuadro..., op. cit., p. 37. Ver também: FIGUEIREDO, C., "Construtivismo russo...”, op. cit.; MARTINS, L. R., “O debate entre...”, op. cit.

${ }^{262}$ Ver capitulo 1. Ver também: VILELLA, T. M., O Ocaso..., op. cit.

${ }^{263}$ FIGUEIREDO, C. F., Foto-Grafia..., op. cit.

${ }^{264}$ FIGUEIREDO, C. F., Foto-Grafia..., op. cit., pp. 141-144.

${ }^{265}$ Segundo Brik, "a tarefa do cinema e da câmera não é aquela de imitar o olho humano, mas de ver e registrar aquilo que o olho humano não vê normalmente". BRIK, O., "What the...", op. cit., p. 219.

${ }^{266}$ Como já discutido no capítulo 2, para Brik e Rodchenko, a fotografia - por intermédio da vertigem e da desorientação, que se transformariam em forças produtivas, capazes de obrigar o observador a realizar realocações conscientes - expandiria o pensamento visual e cognitivo do observador. 
E no mesmo contexto vemos crescer a estatura do Maestro, aquele que se começou a chamar de Duce. Aqui o seu ofício de chefe-redator do "Popolo d'Italia" [...] de onde ele redige os artigos, lança proclamações que agitam, pronuncia discursos, recebe a ovação da multidão e o plebiscito da nação. Depois chega a manobra decisiva: o golpe da Marcha sobre Roma, o gesto clássico de todas as revoluções italianas de César a Garibaldi. ${ }^{267}$

No fim se penetra em uma espécie de capela [...]. Em cima, ao redor da capela inteira, repetido sobre diversas fileiras como apelo a uma tropa infinita, uma resposta monótona e uniforme: “Presente!”. A palavra recorre mil vezes e parece a aclamação unanime dos seus mortos e a expressão do consenso dos próprios túmulos [...]. Assim, o fascismo imprime nas almas o culto do sacrifício e a lenda de seus mártires. ${ }^{268}$

A constante presença da figura de Mussolini - seja por meio de sua imagem, seja por meio de seus artigos no jornal Il Popolo d'Italia - realizava o papel de condução dos eventos narrados e do próprio circuito expositivo (Figuras 28, 29, 30, 31, 33, 34 \& 38). Orquestrada para construir o consenso e reforçar a ideologia fascista, a mostra reiterava o protagonismo do chefe e a passividade das massas, para as quais eram destinados o sacrifício e a obediência, conforme sugerem outros relatos da exposição:

Só Mussolini: Mussolini entre a multidão dominada e arrastada: Mussolini em toda parte. Com o artigo que dispara certeiro. Com o discurso na praça. Com as feridas de guerra. Com o risco perene. Com a certeza perene. Com a autoridade que vem de Deus e da pátria, e à qual não resta senão obedecer. (Ada Negri, $1933)^{269}$

Quando entrares no ingresso, na frente,

Lerás esculpido em granito o Juramento

que te lembra [que] não se sabe quantos

morreram para obedecer ao mandamento!

Dentro de cada sala encontram-se reportadas:

fotografias, retalhos de jornais,

${ }^{267}$ GILLET, Louis, “La nuova...”, op. cit., in SCHNAPP, Jeffrey T., Anno X..., op. cit., p. 126.

${ }^{268}$ Idem, ibidem, p. 125 (Figuras 17 \& 18).

${ }^{269}$ NEGRI, Ada, “Madri di martiri”, Corriere della Sera, 11 marzo 1933, in SCHNAPP, Jeffrey T., Anno X..., op. cit., pp. 99-100, p. 99. Ada Negri (1870-1945) foi uma poetisa italiana que já nos primeiros anos aderiu ao fascismo, mas só teve seu trabalho oficialmente reconhecido pelo regime em 1940, com o convite para integrar a Reale Accademia d'Italia. 
relíquias de valor, nome e datas.

Mas aquilo que acima de tudo ilumina,

em todo essa obra colossal,

é a palavra do Duce!

$[\ldots]$

Todos depois saíram com uma luz

de orgulho no olho, dentro do coração

e na boca, uma palavra: DUCE!

(Pino Morgana, 1934) ${ }^{270}$

\subsubsection{Protagonismo e martírio}

Para que melhor compreendamos o tipo de oposição visual criado pela mostra, entre o protagonismo do chefe e a obediência incondicional das massas, podemos mencionar dois exemplos paradigmáticos: o painel da sala $N$ (Figura 21) e a reconstituição do escritório de Mussolini, na segunda sede do Il Popolo d'Italia (sala T) (Figura 29).

No painel da sala $N$ (Figuras 14, 21 \& 23), que homenageava os mortos e feridos nos embates do biênio vermelho, a fotografia de Mussolini, registrada a partir de baixo (localizada à direita, no alto do painel), era combinada a frases, recortes de jornais e fotografias de Mártires fascistas. Já na sala T, na reconstituição do escritório de Mussolini, tem-se na decoração do ambiente a contraposição entre um retrato 3x4 de Mussolini (também registrado a partir de baixo e devidamente emoldurado) e uma fotografia (um recorte de jornal afixado diretamente na parede) de uma multidão, clicada a partir de cima, em uma espécie de comício (Figuras 29, 30 \& 31). ${ }^{271}$

Nestes e em outros momentos da mostra, as estruturas simbólicas de poder, liturgia e subserviência das massas ficavam evidenciadas pelas próprias escolhas expográficas: materiais adotados; disposição das obras no espaço; uso de sobreposições, montagem e oposição de ângulos; e

270 MORGANA, Pino, A la mostra della rivoluzione. Sonetti popolari, Roma, Lucci, s. p., s.d., 1934, in SCHNAPP, Jeffrey T., Anno X..., op. cit., pp. 119-120. O juramento esculpido em mármore, a que Pino Morgana se refere, é uma placa posicionada na parede do hall de entrada da mostra, na qual está inscrito o juramento fascista (Figura 26). "Em nome de deus e da Itália juro executar sem discutir as ordens do Duce e servir com todas as minhas forças e se necessário com o meu sangue à causa da revolução fascista". Segundo Schnapp, não existem muitas informações sobre a autora do poema, Pino Morgana, além da própria compilação de sonetos populares sobre a Mostra da Revolução Fascista, escritos em dialeto romano e publicado em 1934.

${ }^{271}$ Ainda a respeito do culto ao martírio e à morte presente na liturgia fascista e representado sistematicamente na mostra em questão, vale mencionar que a pesquisa aos arquivos da mostra revela um número altíssimo de fotografias e recortes de jornais de funerais, enterros e obituários. Entre os arquivos da mostra, encontravam-se também tantas fotografias de cadáveres em seus caixões semi-abertos e de cenas de explosões e mortes em guerras (Figuras 23, $24 \& 25$ ). 
mesmo na articulação entre imagens e textos. Enquanto Mussolini era observado a partir de baixo, as massas eram observadas a partir de cima. Enquanto destacava-se a trajetória pessoal e biográfica de Mussolini, as massas eram apresentadas como uma massa disforme. Enquanto o retrato de Mussolini era emoldurado e afixado acima da altura do olhar, a imagem das massas era serial (jornal) e figurava em segundo plano (Figura 30).

Tal oposição fica ainda mais evidente quando em relação com as produções do pavilhão soviético de Colônia. O confronto entre o modo de representação das classes populares e do líder nas produções artísticas do pavilhão soviético de Colônia e da mostra fascista aponta para dois processos de construção de hegemonia estatal distintos. Como já mencionado, enquanto na mostra fascista a massa é condenada ao martírio e representada como um corpo mutilado cuja cabeça exibe frases como "a quem a honra? a nós" e "a quem o sacrifício? a nós”, no pavilhão soviético as representações visuais das massas e do chefe evidenciam o conflito entre o ideário revolucionário dos artistas e a direção stalinista (Figura 36).

No pavilhão soviético de Colônia, poucos são os elementos de culto ao chefe e submissão das massas ao industrialismo e ao líder. Apesar de haver uma área temática dedicada a Lênin, "Lênin como jornalista” (área temática 10), é possível verificar uma maior ênfase no protagonismo dos trabalhadores e camponeses. As imagens de Stalin são quase nulas (no catálogo da mostra, por exemplo, não é possível identificar nenhuma imagem de Stalin). Ao contrário da retórica cultual do chefe (adotada na mostra fascista), na mostra de Colônia, mulheres, correspondentes operários e camponesas são alfabetizadas, repórteres, parte ativa da revolução, protagonista da vida política estatal, conforme a frase "toda cozinheira deve aprender a governar o Estado", exibida na cabeça da silhueta da camponesa (Figura 37).

Ainda a respeito da oposição entre a massa e o chefe, cabe mencionar a inexistência do protagonismo feminino na mostra fascista. O papel relegado às mulheres na mostra fascista é o de mães e esposas que escrevem cartas destinadas a seus entes queridos (nos fronts de guerra), colecionam relíquias e choram seus mortos. Nesse sentido cabe mencionarmos um trecho da fala de Mussolini em entrevista concedida ao jornalista Emilio Ludwig (1881-1948), em 1932, na qual ele, ao responder à pergunta se um ditador poderia ser amado pelas massas, responde afirmativamente e associando as massas à figura feminina: "Sim [um ditador pode ser amado pelas massas], replicou firmemente o Duce, desde que, ao mesmo tempo o povo o tema. Este adora homens fortes. A multidão é mulher". ${ }^{272}$

Como podemos constatar pelo confronto das imagens e dos relatos dos visitantes e críticos das exposições, o tipo de envolvimento e de impacto psíquico da mostra fascista, longe das

\footnotetext{
${ }^{272}$ LUDWIG, Emilio, Colóquios..., op.cit., p. 68.
} 
proposições do grupo LEF, aproximariam-se muito mais das produções litúrgicas e cultuais denunciadas pelo grupo (como no culto de Lênin, 1925) ${ }^{273}$.

O recorrente uso da figura do chefe, a ruptura com a narrativa linear e historiográfica das salas (R-U) e a conclusão apoteótica do circuito expositivo no "memorial dos mártires" (descrito por Gilles como uma espécie de capela dedicada aos mortos pelo fascismo) reforçavam, por meio do próprio circuito expositivo e da relação estabelecida com o expectador, o papel relegado às massas pelo fascismo italiano.

Claramente influenciada pelo culto à guerra e à máquina do futurismo italiano, na mostra fascista as massas eram convidadas, por um complexo expositivo litúrgico, em escala industrial, a apreciar o espetáculo de sua própria destruição.

Vertigem e desorientação, reconstruções históricas com uma roupagem factual, espetacularização da morte e culto à imagem do chefe, tal qual as turbinas do painel de Giuseppe Terragni (1904-1943) na sala "O” (“O pensamento-ação de Mussolini atrai como uma turbina o povo italiano e o torna fascista"), transformavam as massas de espectadores em membros da "revolução passiva fascista" (Figuras 38 e 39 ).

\subsubsection{0 impacto massivo e litúrgico da mostra: da montagem à recepção}

Fui até mesmo atingido. Claro que não será isso a me fazer comprar uma croix de feu esmaltada, nem me fará mesmo minimamente mudar, mas faz efeito. ${ }^{274}$

O caráter de massa da Mostra da Revolução Fascista permeou todo o processo expositivo, de sua montagem ao seu encerramento. Além da forte divulgação que antecedeu sua inauguração, ${ }^{275} \mathrm{o}$ próprio projeto expositivo já apresentava elementos de espetacularização e culto. Conforme notado por Gentile, "a preparação da mostra assumiu o aspecto de uma empreitada coletiva comparável à construção de uma 'catedral'”. 276

Já no ano de 1928, a comissão organizadora enviara um memorando a todas as sedes do PNF, solicitando a coleta de materiais para a exposição. O projeto expositivo deveria narrar o surgimento e o desenvolvimento do fascismo, mediante a combinação de objetos e documentos de época com

\footnotetext{
${ }^{273}$ Sobre a crítica do LEF ao culto de Lênin ver: FIGUEIREDO, C., “Não comercializem Lênin!...”, op. cit.

274 BATAILlE, G., Choix de lettres 1917-1962, Paris: Gallimard, 1997, pp. 80-83, apud FOGU, C. (post.) "L'immaginario...", op. cit., p. 131. O trecho citado foi retirado de uma carta redigida por Georges Bataille (18971962) durante sua visita à Mostra da Revolução Fascista. Na carta, Bataille narra ao seu amigo e destinatário da carta, o escritor francês Raymond Queneau (1903-1976), suas impressões sobre a exposição fascista. Georges Bataille foi um sociólogo de esquerda francês que, alguns meses antes de sua visita à mostra, escrevera um livro (Estrutura psicológica do fascismo) no qual discutia de modo crítico o fenômeno fascista.

${ }^{275}$ Segundo Stone, a partir da primavera de 1932 o jornal do PNF, Il Popolo d'Italia, passou a publicar, quase diariamente, notícias (artigos, fotografias e ilustrações) sobre a Mostra da Revolução Fascista.

${ }^{276}$ GENTILE, E., Il Culto..., op. cit., p. 192.
} 
produções artísticas e descrições históricas. Replicando numa chave litúrgica a ênfase aos elementos factuais e a construção coletiva do pavilhão de Colônia, na mostra fascista correspondentes operários e trabalhadores engajados na "construção do socialismo" foram substituídos por fieis que sacrificavam seus corpos em nome da "revolução" fascista italiana.

Assim como a restruturação corporativista do Estado legitimou - esvaziando e atrelando à engrenagem estatal - os órgãos de resistência econômica (sindicados e cooperativas) e os aparelhos de produção e socialização artístico-cultural-midiáticos (exposições, museus, LUCE, cinecittà etc.), a Mostra da Revolução Fascista mobilizou e redirecionou de modo paradigmático (e contrarrevolucionário) os anseios revolucionários das massas.

Numa lógica marcadamente corporativista, a exposição é apresentada como fruto da cooperação de distintos grupos sociais movidos pela vontade do Duce e pelo ideal "revolucionário" fascista. ${ }^{277}$ No próprio catálogo da mostra é possível verificar inúmeras menções ao grande trabalho e sacrifício realizado pelo coletivo para a montagem da mostra. ${ }^{278}$

Todo dia eram caixas, pacotes, embrulhos, que vinham entregues por todos os meios, por vezes eram velhos squadristi que se desprendiam dolorosamente de preciosas relíquias ciumentamente conservadas, por vezes eram as mães mesmas dos fascistas mortos em guerra que traziam os seus pequenos tesouros, aquilo que tinha restado do filho perdido. ${ }^{279}$

\subsubsection{Sucesso de bilheteria e peregrinação}

A Mostra da Revolução Fascista teve um número recorde de público. Durante os dois anos de exibição (outubro de 1932 a outubro de 1934), a exposição recebeu aproximadamente 3.701 .818 milhões de visitantes. ${ }^{280}$ Devido ao sucesso de público, a data de encerramento da exposição foi adiada

277 “A Mostra da Revolução Fascista, montada - segundo a vontade do Duce e por obra do Partido - para celebração do Decenal, [...] quer e entende ser, uma manifestação, a mais compacta e eficaz, de vontade e força”. ALFIERI, D.; FREDDI, Luigi (org), Mostra..., op. cit., p. 7. Em seu artigo sobre a mostra, o artista Mario Sironi também enfatizou o caráter cooperativista e subordinado dos artistas às demandas da mostra. "A Mostra da Revolução foi assim confiada legitimamente aos artistas novos, síntese de todas as possibilidades artísticas expressas pelos nossos tempos, os quais souberam colocar na dianteira de seus esforços um imperativo: a obra a serviço da Mostra, não o contrário. E aqui estão os sinais desta coordenação disciplinada, desta subordinação de vontades inteligentes e refinadas a uma missão, a uma tarefa". SIRONI, Mario, "L'architettura della rivoluzione”, Il Popoli d'Italia, 18 novembre 1932, in SCHNAPP, Jeffrey T., Anno..., op. cit., pp. 77-78, p. 77.

278 "É bem difícil para o público perceber agora o enorme trabalho realizado durante dez meses, primeiramente nas instalações da Rua Nacional 66 e da Rua Cernaia 4, onde estavam as sedes da Secretaria Geral, o Escritório técnico e o Escritório e depósitos de recolhimento do material histórico-político, e, por fim, no Palácio das Exposições”. dell'Esposizione. ALFIERI, D.; FREDDI, Luigi (org), Mostra..., op. cit., p. 53.

${ }^{279}$ ALFIERI, D.; FREDDI, Luigi (org), Mostra..., op. cit., p. 60.

${ }^{280}$ SCHNAPP, Jeffrey T., Anno X..., op. cit., p. 43. Segundo Schnapp, o número de visitantes superou as expectativas dos organizadores. A estimativa da equipe organizadora era de 500,000 espectadores (um número 
duas vezes - primeiro para novembro de 1933 e, por fim, para novembro de 1934. Em outubro de 1933, um ano e um mês antes de seu suposto encerramento, Mussolini declarou a mostra permanente. ${ }^{281}$

Menções ao alto número e à diversidade dos visitantes da mostra eram um ponto comum dos artigos e relatos da época. ${ }^{282}$ Conforme o artista italiano Mino Maccari (1898-1989), a exposição teria sido bem recebida pela maior parte da população italiana, o que, tendo em vista o caráter moderno e a "audácia das formas" decorativas adotadas, poderia ser surpreendente para os mais tradicionalistas. ${ }^{283}$

A exposição tornou-se rapidamente um ponto de peregrinação patriótica. ${ }^{284}$ Segundo o colaborador do Il Popolo d'Italia, Ottavio Dinale, a mostra teria recebido uma "multidão incontável, que vence as proporções das tradições de Roma, de Meca, dos grandes centros de atração espiritual". ${ }^{285}$

alto se considerado que, com 6 meses de duração, a XVII Bienal de Veneza [1930] recebeu 193.000 visitantes e a Bienal posterior [1932], com a mesma duração, recebeu 250.000 visitantes) para os seis meses de duração da mostra. No final de março de 1932, o número de visitantes já tinha ultrapassado em 200.000 visitantes as estimativas iniciais. Conforme a documentação do período, no decorrer dos dois anos de exposição, entre 3.701.818 e 3.854.927 pessoas visitaram a mostra. As informações sobre o número total de visitantes da Mostra da Revolução Fascista não são consensuais. Segundo Schnapp, documentos conservados no arquivo central do Estado, mencionam os números 3.701 .818 ou 3.708.214. Enquanto alguns textos e livros da época, como Italiani e stranieri alla mostra della rivoluzione fascista, mencionam um total de 3.854 .927 visitantes. SCHANPP, J. T., Anno X..., op. cit., p. 17.

${ }^{281}$ A mostra foi encerrada em 28 de novembro de 1934, mas com previsão de ser reaberta permanentemente, num curto espaço de tempo, na nova sede do PNF, o Palazzo del Littorio. Diferentemente do programado, a mostra foi reaberta (numa reedição bem menor e menos impactante) em setembro de 1937, na Galeria Nacional de Arte Moderna. SCHNAPP, Jeffrey T., Anno X..., op. cit., p. 62 e CAPANNA, Alessandra, Roma 1932..., op. cit., p. 86.

${ }^{282}$ Ver: DINALE, Ottavio, "Pelegrinaggio di fedeli”, La rivoluzione che vince (1914-1934), Roma: F. Campitelli, 1934, pp. 213-19, in SCHNAPP, Jeffrey T., Anno..., op. cit., pp. 103-104; MACCARI, Mino, "Il carattere popolare della mostra della rivoluzione", Illustrazione Italiana, 2 aprile 1933, pp. 498-99, in SCHNAPP, Jeffrey T., Anno X..., op. cit., pp. 93-94; e, BARDI, Pietro Maria, "Come è la Mostra della Rivoluzione", L'Ambrosiano, 31 ottobre 1932, in SCHNAPP, Jeffrey T., Anno X..., op. cit., pp. 73-75.

283 "A popularidade da Mostra: aqui temos um fato que talvez alguém, atendo-se excessivamente à novidade e à audácia das formas decorativas adotadas, poderia ter duvidado". MACCARI, Mino, "Il carattere popolare della mostra della rivoluzione", Illustrazione Italiana, 2 aprile 1933, pp. 498-99, in SCHNAPP, Jeffrey T., Anno X..., op. cit., pp. 93-94, p. 93.

${ }^{284}$ Apesar dos convidativos descontos ferroviários, como uma demonstração de fervor e sacrifício patriótico, pequenos grupos, famílias ou pessoas sozinhas fizeram longos percursos até a mostra, a pé ou de bicicleta. Segundo os registros da exposição e os jornais do período, entre 19 de novembro de 1933 e 27 de novembro de 1934, 49 pessoas percorreram trajetos, como Paris-Roma, Madrid-Roma, Veneza-Roma e Palermo-Roma, para visitar a mostra, de bicicleta e 129 o fizeram caminhando. SCHNAPP, Jeffrey T., Anno X..., op. cit., p. 45.

${ }^{285}$ DINALE, Ottavio, "Pelegrinaggio...", op. cit., p. 103. O vocabulário religioso não era exclusivo de Dinale, periódicos, artigos e até poemas dedicados à mostra utilizavam tal terminologia. Sobre a questão da liturgia fascista ver: GENTILE, Emilio, Il culto del littorio: La sacralizzazione della politica nell'Italia fascista, Bari: Editori Laterza, 1993. 


\subsubsection{Um grande empreendimento estatal}

Além da sintaxe visual impactante e envolvente, conforme atesta o já referido depoimento do escritor francês Georges Bataille, ${ }^{286}$ o grande sucesso da mostra deve ser atribuído também aos esforços de propaganda e promoção da exposição por parte da organização da mostra.

Assim como nas Bienais, Trienais e Quadrienais, foi tomada, por parte do Estado e da organização da mostra, uma série de medidas para popularização da exposição - descontos de $70 \%$ em bilhetes ferroviários; descontos para visitação em grupos; venda de cartões postais, fotografias, adesivos e guia da exposição a um valor acessível; distribuição de cartazes e manifestos; ${ }^{287}$ estímulo à produção de resenhas e críticas da mostra por parte da população. ${ }^{288}$

A politica de descontos ferroviários teria, de fato, mobilizado a economia italiana por meio do consumo e turismo em Roma (Figura 40). Segundo a pesquisadora americana Marla Stone, os convidativos descontos ferroviários teriam levado inclusive intelectuais oposicionistas ao fascismo à Roma e, consequentemente, à mostra fascista. Stone cita uma carta de Simone de Beauvoir (19081986), na qual a escritora francesa afirmou que ela e Jean-Paul Sartre (1905-1980) teriam "tirado proveito disso [dos descontos ferroviários] sem escrúpulos" e, a fim de validar o desconto em seus tíquetes, tiveram de visitar a exposição. ${ }^{289}$

Mobilizando intensamente a recém-criada indústria cultural fascista, a mostra contou com uma exaustiva divulgação na imprensa oficial do partido (jornais, revistas, cinejornais e programas de rádio) durante todo o período em que esteve aberta. O instituto LUCE, entre outubro de 1932 e outubro de 1934, produziu 27 curtas sobre a mostra, os quais eram transmitidos, por meio dos cinejornais LUCE, em todos os cinemas italianos do período. ${ }^{290}$

286 BATAILlE, G., Choix de lettres 1917-1962, Paris: Gallimard, 1997, pp. 80-83, apud FOGU, C. (post.) "L’immaginario...", op. cit., p. 131.

${ }^{287}$ A organização da mostra imprimiu 1.330 .000 cartazes publicitários da exposição, os quais foram afixados em estações de trens, trens, aviões, ônibus, repartições públicas e escolas. Foram reproduzidos também 100.000 pôsteres e 1.330 .000 cartões postais para distribuição e propaganda da mostra na Itália e no exterior. SCHNAPP, Jeffrey T., Anno X..., op. cit., pp. 37-39.

${ }^{288}$ Conforme Schnapp, na época teria sido organizado um concurso de melhor texto ensaístico sobre a mostra. SCHNAPP, Jeffrey T., Anno X..., op. cit., p. 39.

${ }^{289}$ BEAUVOIR, S., La force de l'Age, Paris: Gallimard, 1960, p. 179, apud STONE, Marla, The politics..., op. cit., p. 304. O espaço destinado à validação dos descontos ferroviários estava situado no primeiro andar da exposição, para chegar à cabine onde se carimbavam os bilhetes era necessário percorrer todo o percurso expositivo, o que obrigava a visitação de todo o circuito expositivo por parte dos que pretendiam usufruir dos descontos ferroviários (Figura 40).

${ }^{290}$ Os curtas do instituto LUCE registravam alguns momentos da exposição (o processo de montagem da mostra, a inauguração e a visita de pessoas ilustres como Mussolini e o Rei) e eram transmitidos nos cinejornais produzidos pelo Instituto. Ver: "I lavori per l'allestimento della mostra della rivoluzione fascista", Giornale Luce B0150, Roma, 14/10/1932, disponível em:

$<$ http://www.archivioluce.com/archivio/jsp/schede/videoPlayer.jsp?tipologia=\&id=\&physDoc=6074\&db=cinem atograficoCINEGIORNALI\&findIt=false\&section=/>, acessado em 4 de abril de 2015; "La visita di Mussolini alla mostra della rivoluzione fascista", Giornale Luce A1016, Roma,10/1932, disponível em: 
$\mathrm{Na}$ mostra (na reorganização artística italiana como um todo), pode-se perceber a combinação de um esforço colossal de construção de hegemonia, com uma efetiva mobilização da economia nacional (geração de renda, trabalho e turismo, por exemplo). Na toada da criação da própria Bienal de Veneza - que responderia à necessidade do Risorgimento de modernização da Itália e unificação para a criação de um amplo mercado consumidor e industrialização nacional - a mostra fascista inseria-se nas medidas e esforços da nova política econômica interventista e nacionalista italiana (corporativismo fascista) frente à crise capitalista e ao agravamento desta com a onda de desemprego e instabilidade internacional de 1929.

\subsection{URSS e Itália: incorporações moleculares e pactos de não agressão}

Um diplomata soviético, referindo-se às relações "até mesmo confidenciais" entre Stalin e Mussolini nos anos trinta, revelou que Mussolini pedira e recebera de Stalin o roteiro das manifestações na praça Vermelha para o Primeiro de Maio e para o aniversário da revolução de outubro; e que as havia copiado, conforme constatara o mesmo diplomata, que assistiu a uma manifestação fascista na presença de Mussolini. ${ }^{291}$

O interesse italiano pela URSS salientou-se no pavilhão soviético em Colônia (1928), nos planos quinquenais russos (1929-1933) e na participação soviética na I Bienal de Cinema (Veneza, 1932). ${ }^{292 \_293}$ Antecipando em um ano a assinatura do "pacto de amizade, não agressão e neutralidade"

$<$ http://www.archivioluce.com/archivio/jsp/schede/videoPlayer.jsp?tipologia=\&id=\&physDoc=4961\&db=cinem atograficoCINEGIORNALI\&findIt=false\&section=/>, acessado em 4 de abril de 2015; "L'inaugurazione della mostra della Rivoluzione Fascista", Giornale Luce B0160, Roma,04/11/1932, disponível em: $<\mathrm{http}: / / \mathrm{www}$. archivioluce.com/archivio/jsp/schede/videoPlayer.jsp?tipologia $=\& \mathrm{id}=\&$ physDoc $=6137 \& \mathrm{db}=\mathrm{cinem}$ atograficoCINEGIORNALI\&findIt=false\&section=/>, acessado em 4 de abril de 2015. A partir de 1927, o instituto LUCE passou a produzir cinejornais, os quais eram transmitidos obrigatoriamente em todos os cinemas italianos, antes de qualquer sessão. Segundo Schnapp existem registros de que o cineasta italiano Alessandro Blasetti (1900-1987) teria realizado, pelo instituto LUCE, um filme de propaganda sobre a mostra intitulado Il Decennale. O filme teria sido finalizado no verão de 1933 e projetado em todas as escolas elementares e médias, por ordens do Ministério da Instrução Pública. SCHNAPP, J. T., Anno X..., op. cit., p. 39. Segundo Schnapp, diferentemente dos curtas produzidos para os cinejornais LUCE, o filme Il Decennale não se encontra nos arquivos do LUCE ou da mostra.

291 "Veterans speak of the diplomatic service", in International Affairs, 1989, n. 9, p. 123, apud DE FELICE, R., Mussolini l'alleato, vol. I, tomo II, Torino: Enaudi, 1990, p.1281, apud: GENTILE, Emilio, Il culto del littorio: La sacralizzazione della politica nell'Italia fascista, Bari : Editori Laterza, 1993, p. 149.

${ }^{292}$ Sobre as negociações diplomáticas para assegurar a participação soviética na Bienal, ver PISU, S., L'Unione Sovietica alla mostra internazionale d’arte cinematografica di Venezia (1932-1953), Cagliari: Università degli Studi di Cagliari, 2010, pp. 38-43.

${ }^{293}$ Conforme a pesquisa em arquivos diplomáticos italianos e soviéticos sistematizadas no livro As relações nos documentos diplomáticos ítalo-russos, de Tonino Fabri, no início de 1930 os italianos teriam visitado a URSS e, no retorno, publicado, com o consentimento do regime fascista, diários e relatos sobre a Rússia. FABRI, T., Le relazioni nei documenti diplomatici italo-russi, Padova: libreriauniversitaria.it, 2013, p. 155. 
(02 de setembro de 1933) ${ }^{294}$, a Mostra da Revolução Fascista (1932) acentuou a convergência, apropriando-se de elementos do discurso visual do pavilhão soviético na exposição de Colônia.

Muitas são as intersecções entre a mostra fascista de Roma e o pavilhão soviético de Colônia, ${ }^{295}$ bem como muitos são os antagonismos entre as obras das exposições russa e italiana, especialmente quando se ultrapassa a esfera da aparência. Enquanto no pavilhão soviético de Colônia ressaltava-se visual e textualmente o protagonismo das massas (basta ver a frase escrita na silhueta da camponesa do pavilhão soviético: “Toda cozinheira deve aprender a governar o estado”) (Figura 36), na mostra fascista exaltava-se a obediência e o martírio das massas (basta ver as frases escritas na cabeça da silhueta do soldado da mostra fascista: “A quem o sacrifício? A nós”) (Figura 37). Apesar de convergências no campo da técnica, das formas e mesmo dos materiais adotados, havia divergências significativas: na mostra fascista, exaltava-se visualmente a subordinação das massas a um projeto de dominação que as subalternizava; no pavilhão de Colônia, ressaltava-se, visualmente, o protagonismo das massas segundo um ideal revolucionário que as realizaria.

Tal antagonismo, entretanto, não é tão evidente na análise comparada entre a mostra fascista e outras produções russas contemporâneas a ela, como os cartazes e revistas produzidos para a divulgação do $1^{\circ}$ plano quinquenal stalinista (especialmente após 1932) ou a exposição "Artistas da URSS dos últimos 15 anos" (1932-1934) (Figuras 65, 66, 67, 68, 69, 70 \& 71).

Neste segundo conjunto de imagens verifica-se, por exemplo, a representação da massa submetida à figura do chefe - em alguns casos, até como parte constituinte do corpo do chefe. Por exemplo, nas fotomontagens em questão (Figuras 49 \& 50) são utilizadas sobreposições de fotografias tomadas a partir de ângulos e enquadramentos opostos (os líderes são registrados em plano fechado, de baixo pra cima, enquanto as massas são registradas num plano aberto, de cima para baixo). Nelas, as imagens das massas, em grandes desfiles e comícios monstruosos, aparecem subordinadas e mobilizadas de acordo com o interesse do Líder - tal qual na mostra fascista ( Figuras 39, 47, 53 \& 54).

Em outras palavras (e como se esmiuçará adiante), o confronto entre o modo de representação das classes populares e do líder, nas produções em questão (a saber, o pavilhão soviético de Colônia, a mostra fascista, os cartazes e revista da IZOGIZ e a exposição “Artistas da URSS...”), aponta dois processos de construção de hegemonia e de coerção civil-militar distintos e ambíguos. Se na Itália fascista verificou-se um processo de inclusão "molecular" e progressiva das instâncias e demandas artísticas, na Rússia stalinista verificou-se um processo de manobras e embates acirrados,

\footnotetext{
${ }^{294}$ FABRI, T., Le relazioni..., op. cit., p. 147.

${ }^{295}$ Em "O espírito fascista: bibliografia" (Figura 41), no painel da sala "Q" (Figura 45), nas silhuetas dos soldados fascistas (Figura 36) ou no painel da sala "O" (Figura 47) - facilmente associáveis, respectivamente, à "sala de leitura” (Figura 42), ao painel da TASS (Figura 46), à silhueta da camponesa do pavilhão soviético (Figura 37) e aos cartazes do $1^{\circ}$ Plano Quinquenal (Figuras 48) -, percebe-se que os italianos apropriaram-se, na mostra fascista, de elementos da sintaxe visual dos artistas de vanguarda russos, como já discutido no presente capítulo.
} 
no campo das artes, e uma tentativa de repressão e cooptação do impulso revolucionário das vanguardas oposicionistas.

\subsubsection{Embates, censuras e coerções: a consolidação de uma doutrina artística "soviética" (1928-1934)}

Até 1928, na URSS, os processos de coação e censura davam-se transversalmente e indiretamente (como discutido no capítulo 1). Em 1928, com a visita do politburo a uma exposição da AKhRR, a preferência do partido por tal corrente foi explicitada.

Entre 1921 e 1928, os embates foram muitas vezes protagonizados pelos próprios grupos e escolas artísticas que se digladiavam publicamente na disputa por tornarem-se os representantes, por excelência, da arte após Outubro. ${ }^{296}$ Não eram raras as acusações policialescas de desvio formalista e capitulação burguesa. Em abril de 1928, por exemplo, o lefista A. Rodchenko foi acusado pelo periódico Sovietskoe foto de plagio e influência formalista ocidental (influência burguesa) (Figura 92). ${ }^{297}$ Entre 1928 e 1932, tanto os processos de crítica e censura entre grupos e correntes artísticas tornaram-se mais agressivos, como também houve uma maior intervenção do partido stalinista nesse campo - isto é, na reorganização de antigas instituições artísticas e culturais e na criação de novos órgãos para a centralização, distribuição e controle das artes.

Em abril de 1928 foi criado o Glaviskusstvo, órgão responsável pela regulação e direção político-ideológica das produções artísticas e literárias russas. ${ }^{298}$ Em 1929, foi criada a Vsekokhudozhnik (Cooperativa Central de Artistas da Rússia), espécie de agência estatal responsável

\footnotetext{
${ }^{296}$ Dois grupos artísticos que protagonizavam muitos dos embates sobre a produção artística da Rússia após a Revolução de Outubro foram os grupo rivais LEF e AKhRR. Ver: ARVATOV, Boris, "Respuesta al camarada Katsman", (1926), pp. 217-221, in ARVATOV, Boris, Arte y produccion: el programa del productivismo, trad. José Fernandez Sanchez, Madrid: Alberto Corazon, 1973; e KATSMAN, C., “Que respondan” (1926), pp. 214216, in ARVATOV, Boris, Arte y produccion..., op. cit. Ver também: FIGUEIREDO, C., Foto-Grafia..., op. cit. e VILELLA, T. M., O ocaso de outubro..., op. cit.

${ }^{297}$ Ver: FABRIS, Annateresa, “Um olhar sob suspeita”, Anais do Museu Paulista, São Paulo, v. 14, n. 2, pp. $107-$ 140, jul./dez., 2006 e FIGUEIREDO, C., Foto-Grafia..., op. cit., p. 145. A partir de 1928, também no campo da fotografia, as diretrizes oficiais registradas em discursos curatoriais e catálogos de exposições destacava uma abordagem pretensamente "naturalista" e com um forte teor apologético propagandístico. No catálogo da exposição 10 Anos de Fotografia Soviética (Moscou, 1928), por exemplo, exaltava-se o fotojornalismo prógovernamental e as fotografias propagandísticas que enfatizassem os avanços e conquistas do "socialismo num só país”. TUPITSYN, Marguerite, The soviet photography, 1924-1937, New Haven and London: Yale University Press, 1996, pp. 34-38.

${ }^{298}$ CHLENOVA, Masha, On Display: Transformations of the Avant-Garde in Soviet Public Culture, 1928-1933, Ph.D. dissertation, New York: Columbia University, 2010, p. 45. Conforme explica Fitzpatrick, no período da reformulação do Narkompros, em 1921, a repartição responsável pela produção artística fora extinguida, e, até 1928, não fora criado nenhum novo órgão oficial encarregado exclusivamente por esse campo. Fitzpatrick acrescenta que, ainda em 1921, discutiu-se que a regulamentação do campo artístico deveria ser incumbência do Glavpolitprosvet, mas, por questões politicas e divergências internas, especialmente em relação às produções de vanguardas, tal processo tardou a se consolidar. Ver: FITZPATRICK, S., "The emergence of glaviskusstvo...”, op. cit.; e idem, The commissariat of education under Lunacharsky (1917-1921), Ph.D. dissertation, Oxford: University of Oxford, 1969, p. 226.
} 
por montar exposições e comissionar pinturas por meio de um sistema de contratos (kontraktatsiia) com artistas ou grupos artísticos. Tais contratos visavam à produção e aquisição de obras, bem como, posteriormente, ao repasse das mesmas a instituições, galerias e museus estatais. ${ }^{299} \mathrm{Em} 1929$, Anatoly Lunacharsky foi removido da direção do Narkompros e substituído pelo ex-administrador do Exército Vermelho Andrei Bubonov (1884-1938). ${ }^{300}$

Entre 1930 e 1931, a Vkhutemas foi remodelada (transformada em Vkhutein), sendo anuladas todas as propostas vanguardistas do projeto inicial. Nessa reestruturação, Rodchenko e outros artistas de vanguarda foram demitidos de seus cargos. ${ }^{301} \mathrm{Em} \mathrm{1932,} \mathrm{um} \mathrm{decreto} \mathrm{"sobre} \mathrm{a} \mathrm{restruturação} \mathrm{das}$ organizações artístico-literárias" (1932) determinou a dissolução de todos os grupos e escolas artísticas. Em 1933, foi decretada uma lei segundo a qual, daquele momento em diante, seria necessária uma autorização para realizar fotografias em Moscou. ${ }^{302} \mathrm{Em} \mathrm{1934,} \mathrm{instaurou-se} \mathrm{o} \mathrm{"realismo}$ socialista". ${ }^{303}$

Como uma espécie de laboratório, exposições e cartazes foram utilizados - por artistas e dirigentes de entidades artístico-culturais russas (diretores de museus, historiadores da arte ligados ao partido etc.) - enquanto mecanismos históricos, ideológicos e linguísticos para a análise e formulação de um discurso visual apto a inscrever o espectador no novo sistema artístico-cultural. ${ }^{304} \mathrm{Com}$ efeito, os cartazes de G. Klutsis (1859-1938) para a IZOGIZ (Departamento de Artes da Editora Estado) e as duas montagens da exposição “Artistas da URSS dos últimos 15 anos” (1932-1934) são emblemáticos, como corolários da reestruturação da esfera política, artística e propagandística em curso.

${ }^{299}$ Os contratos muitas vezes eram estabelecidos mediante a determinação de temas, números de obras e mesmo viagens de artistas para algumas regiões agrícolas ou industriais. Ver: KIAER, Christina, "Was socialist realism forced labour? the case of Aleksandr Deineka in the 1930s", Oxford art journal, 28, Oxford: University Press, 2005, pp. 321-345, p. 332.

${ }^{300}$ Já em 1921, parte da direção bolchevique (como o próprio Lênin) questionava a proximidade do partido com as vanguardas. Ver: FITZPATRICK, S., The commissariat..., op. cit., p. 227. Sobre os questionamentos de Lênin frente à postura de Lunatcharsky com os artistas de vanguarda, ver: ALBERA, F., Eisenstein..., op. cit., p. 184

${ }^{301}$ Para o detalhamento do processo de reestruturação da Vkhutemas, ver: MIGUEL, Jair Diniz, Arte, Ensino, Utopia e Revolução: Os ateliês artísticos vkhutemas/vkhutein (Rússia/URSS, 1920-1930), Orientador Dr. Marcos Silva, Tese de Doutorado, São Paulo: Universidade de São Paulo, 2006, pp. 130-133.

302 AA.VV., Rodchenko: La construcción del futuro, Catalunya: Fundacion Caixa Catalunya, 2008 (catálogo da exposição), p. 284.

${ }^{303}$ Entre 17 de agosto e $1^{\circ}$ de setembro de 1934 foi realizado o I ${ }^{\circ}$ Congresso da União dos Escritores Soviéticos. Nesse congresso, determinou-se os rumos da arte e da cultura na Rússia stalinista, o "realismo socialista".

${ }^{304}$ Conforme Chlenova, entre 1930-1932, debates eram realizados nos principais museus dedicados à arte contemporânea russa (como Tretyakov Gallery e Museu Russo). As maiores exposições geralmente eram acompanhadas de discussões e de detalhados registros de análises da recepção e repercussão da mesma. Ver: CHLENOVA, M., On Display..., op. cit., p. 50. Sobre a reestruturação de museus e exposições russas, ver: CHLENOVA, M., On Display..., op. cit., p. 57. 


\subsubsection{Cartazes da IZOGIZ e a URSS em Construção}

Concomitantemente ao lançamento do $1^{\circ}$ Plano Quinquenal (1929), o departamento de artes da Editora do Estado (IZOGIZ) contratou artistas para a produção da propaganda de celebração e divulgação do programa de industrialização acelerada. Rapidamente, cartazes produzidos por Gustav Klutsis e seu colaborador Serguei Senkin passaram a ser o estilo predominante da IZOGIZ.

Klutsis foi um artista de vanguarda integrante do grupo Outubro e próximo ao grupo LEF, tendo inclusive sido aluno de Rodchenko e outros lefistas na Vkhutemas. Já Sergei Senkin, também estudante da Vkhutemas e membro do grupo Outubro, foi o assistente de Lissitzky na direção do pavilhão soviético de Colônia (1928).

Como parte do imbróglio do processo de reestruturação do campo artístico russo, Klutsis, Senkin e outros artistas (como o próprio Lissitzky e Rodchenko) participaram ativamente, durante o $1^{\circ}$ Plano Quinquenal, da produção da propaganda stalinista (Figuras 52 e 53). Veja-se, por exemplo, a participação de Klutsis e Senkin nos cartazes da IZOGIZ, bem como a de Lissitzky e de Rodchenko na revista URSS em Construção (Figura 64).

No entanto, tendo em vista a situação concreta em que tais artistas se encontravam (sob cooptação, censura e repressão crescentes), a participação de tais artistas na máquina propagandista stalinista foi permeada por muitas contradições e oscilações, as quais devem ser discutidas a partir da análise especifica de cada caso (de cada artista e de cada obra produzida), evitando-se assim generalizações. Nesse sentido, cabe mencionar a vinculação de tais artistas (Senkin, Klutsis, Lissitzky e Rodchenko) ao grupo Outubro (1928-1932). Num momento de consolidação do "socialismo num só país” e eliminação dos focos de resistência (Oposição Unificada, por exemplo), muitos lefistas internacionalizam as propostas e debates do grupo LEF na constituição do grupo Outubro. O grupo Outubro poderia ser visto como uma derradeira tentativa de radicalização internacionalista frente à consolidação do "realismo heroico" (futuro "realismo socialista", em 1934) e do "socialismo num só país" ${ }^{305} \mathrm{O}$ grupo denunciava o isolamento nacional do "socialismo num só país" em manifestos, textos e por meio de sua própria composição internacionalista (sendo formado por artistas de diferentes nacionalidades e locais de atuação). ${ }^{306}$

\footnotetext{
305 "Somos contra o tipo de arte da AKhRR e a doçura interminavelmente doentia de seus sorrisos graciosos, chauvinismo sob a forma de chaminés, tediosos trabalhadores com foices, martelos e capacetes do Exército Vermelho (viva - vamos jogar nossos chapéus no ar)". ANONYMOUS, "Program of the october photo section" (1930), Izofront, Moscou, 1931, in PHILLIPS, C. (Org.), Photography in the modern era: European documents and critical writings, 1913-1940, New York: The Metropolitan Museum of Art/Aperture, pp. 283-285, 1989, p. 284.

${ }^{306}$ Entre outros, integraram o Outubro o comunista alemão Alfred Kurella (1895-1975) e o muralista mexicano Diego Rivera (1886-1957). Sobre o grupo Outubro, ver: ALBERA, F., Eisenstein..., op. cit.
} 


\subsubsection{Uma transição}

Entre 1930 e 1932, as fotomontagens de Klutsis e Senkin tornaram-se uma espécie de paradigma visual da IZOGIZ. ${ }^{307}$ Nesse período, verifica-se, nos cartazes de propaganda da IZOGIZ para o $1^{\circ}$ Plano Quinquenal, o aumento (em termos de escala e frequência, por exemplo) da figura de Stalin e a realocação da massa no papel de coadjuvante (Figuras 56 \& 61).

Alguns dos primeiros cartazes nesse sentido seriam os "Construindo o Socialismo sob a bandeira de Lênin", de 1930 (Figura 51) e "A viabilidade de nosso programa são as pessoas reais, somos você e eu”, de 1931 (Figura 52). No primeiro cartaz, a figura de Lênin sobrepõe-se à de Stalin (por meio da sobreimpressão ou da sobreposição de negativos), e, no segundo, Stalin é representado marchando lado a lado dos trabalhadores. A análise da representação visual das massas e do chefe nos cartazes de Klutsis desse período (1930-1934) aponta uma transição entre 1) a representação visual do protagonismo do campesinato e do operariado na construção da URSS (na toada do pavilhão de Colônia) e 2) a retórica celebrativa das forças produtivas com culto da imagem do chefe (na direção do "realismo socialista").

Stalin, nos cartazes da IZOGIZ, passaria a ser representado (principalmente após 1934) como o "Líder", o "Pai dos povos", o "Tribuno dos povos", o "Construtor do comunismo", o "Timoneiro" e o "General", de acordo com a temática e o objetivo do cartaz (Figuras 53, 60 \& 63). Conforme Jan Plamper, cada uma dessas designações verbais corresponderia a uma série de associações visuais. Stalin como "o tribuno do povo", invariavelmente, foi mostrado com representantes de diferentes nacionalidades soviéticas; Stalin como o "construtor do comunismo" foi representado entre fábricas e tratores do plano quinquenal; enquanto Stalin, no papel de 'General', "era impensável sem o seu uniforme branco". ${ }^{308}$

Tal processo assemelhava-se muito aos padrões de representação de Mussolini por meio do instituto LUCE. A fotografia do LUCE tinha o papel de moldar a imagem de Mussolini e difundir o culto do líder. Nos registros visuais do LUCE, Mussolini normalmente era fotografado com enquadramentos de baixo para cima, dando-lhe uma estatura heroica e elevando-o acima dos homens comuns. Nos retratos em primeiro plano, por outro lado, favoreciam-se os enquadramentos que ressaltassem, no rosto de Mussolini, um olhar pensativo, procurando conferir-lhe uma sensação de agudeza e profundidade. Assim como, ainda nos primeiros planos, privilegiava-se um enquadramento

${ }^{307}$ GOUGH, Maria, "Back in the USSR: John Heartfield, Gustavs Klucis, and the medium of soviet propaganda", in New German Critique, 36, No. 2, Ithaca: Duke University Press, pp. 133-183, 2009, p. 139.

308 PLAMPER, Jan, The Stalin cult in the visual arts, 1929-1953 (Russia), Ph.D, Berkeley: University of California, 2001, p. 138. Esse processo não dizia respeito apenas à construção de cartazes, mas também de pinturas, esculturas, fotografias e demais meios de propagação da imagem de Stalin durante o "realismo socialista". 
de baixo para cima, levemente inclinado da esquerda para a direita, como se seu olhar apontasse para o futuro, proporcionando, assim, a sensação de longevidade, progresso e vitória (Figura 62). ${ }^{309}$

Ou seja, entre 1930-1934, nos cartazes produzidos por Klutsis para a IZOGIZ, tem-se uma reelaboração do embate entre o ideário revolucionário dos artistas ligados ao LEF (presente no pavilhão soviético de Colônia) e o ideário do "realismo socialista". Assim, ao mesmo tempo em que se tornariam um dos principais meios de propaganda e comunicação oficial, os cartazes russos seriam progressivamente transformados num instrumento de construção do culto de Stalin e da mobilização das massas para a produção - aproximando, assim, tais cartazes das fotomontagens e fotografias da Mostra da Revolução Fascista.

\subsubsection{2 "A vitória do Socialismo em nosso país é garantida"}

Um caso exemplar foi o cartaz "A vitória do Socialismo em nosso país é garantida" (Figura 53), de Gustav Klutsis (IZOGIZ, 1932) 310 $^{310}$ composto por uma grande fotomontagem (Figuras 53 \& 54), que ocupa quase todo o espaço do cartaz, e por slogans acrescentados posteriormente pela IZOGIZ.

A fotomontagem em questão (Figura 53) era estruturada por três camadas que se sobrepunham. Na primeira, encontrava-se uma paisagem industrial - usinas elétricas, indústrias, pontes e antenas. Na segunda, a figura de Stalin; na última, um plano geral de uma multidão fragmentos de fotografias de passeatas.

Em “A vitória do Socialismo...”, as técnicas de estranhamento e desestabilização do espectador foram substituídas pelas de empatia e exaltação do líder e da industrialização. A figura do trabalhador, que antes ocupara uma posição de destaque (Figuras $58 \& 59$ ), passou a ser coadjuvante (Figuras $54 \&$ 55). O fragmento fotográfico utilizado para a representação dos trabalhadores derivava de uma ou mais fotografias panorâmicas de uma manifestação, tomadas de um ângulo levemente inclinado de cima para baixo (Figura 53). A fotografia selecionada para representar Stalin, por outro lado, era tomada a partir de um ângulo inverso, levemente inclinado de baixo para cima e bastante retocada. $\mathrm{Na}$ fotomontagem em questão (Figura 53), Stalin aparecia estático, com o olhar voltado para o horizonte, como um visionário (como nos retratos de Mussolini, do mesmo período) (Figuras 33 \& $62)^{311}$

\footnotetext{
${ }^{309}$ Sobre as fotografias de Mussolini produzidas pelo LUCE, ver: MANNUCCI S., Luce sulla guerra. La fotografia di guerra tra propaganda e realtà. Italia 1940-45, Roma: Nuova Arnica Editrice, 2007.

${ }^{310}$ Cópias enormes do cartaz "A vitória do Socialismo em nosso país é garantida" foram afixadas em muros e painéis pelas ruas de Moscou, propagadas em periódicos e utilizadas como modelo para a produção de outros cartazes da IZOGIZ (Figuras 56 e 61). Ver: TUPITSYN, Margarita, The soviet photograph 1924-1937, New Haven: Yale University Press, 1996, pp. 156-158.

311 Como mencionado em passagem anterior, nos registros visuais do LUCE, Mussolini normalmente era fotografado com enquadramentos de baixo para cima e o olhar voltado para o horizonte. Ver: MANNUCCI S., Luce sulla..., op. cit.
} 
A terceira e a primeira camadas da fotomontagem formavam duas sutis diagonais convergentes (Figura 53), da direita para a esquerda, dirigindo o olhar do observador para a figura central de Stalin. Localizada na camada intermediária, a figura de Stalin destacava-se como o ponto central da construção do "socialismo num só país", o responsável pela "vitória do socialismo".

A escolha dos ângulos e dos fragmentos selecionadas para compor a fotomontagem estabelecia uma clara relação hierárquica, na medida em que o líder era observado de baixo para cima e a multidão de cima para baixo. O vulto dos trabalhadores, posicionado atrás da figura de Stalin, sugeria a liderança e a legitimidade do líder - reforçando a leitura de Stalin como aquele à frente da massa, seguido e adorado pelos trabalhadores (Figura 53). Em termos de escala e localização, a fotomontagem de Klutsis evidenciava uma nova relação de forças e a subordinação das massas à vontade do chefe e ao desenvolvimento econômico e industrial do país (posto que, na fotomontagem em questão, até mesmo as usinas tinham um destaque maior do que os trabalhadores) (Figura 53). Em “A vitória do Socialismo...", tal qual o futuro painel da sala "O” (Figura 38, 39 \& 47), realizado por Terragni para a Mostra da Revolução Fascista, trabalhadores e trabalhadoras eram retratados a serviço do chefe e de um plano de modernização.

Em “A vitória do socialismo...” (e em muitos outros cartazes do $1^{\circ}$ Plano Quinquenal) (Figuras 53, $54 \& 55$ ), ${ }^{312}$ recorre-se a fotomontagens e sobreposições de imagens que, paulatinamente, distanciavam-se da silhueta da cozinheira protagonista de Colônia (Figura 37) e avizinhavam-se das mãos do painel da "sala O" da mostra fascista (Figura 38, 39 \& 47), no qual as massas apareciam subordinadas ao chefe ou ao projeto de modernização acelerada em curso - mártires do desenvolvimento econômico industrial, mobilizados segundo a vontade do chefe (Figuras 53 \& 55). ${ }^{313}$

312 A estrutura da fotomontagem “A vitória do socialismo..." foi utilizada como parâmetro de outras fotomontagens do próprio Klutsis e outros artistas contratados pela IZOGIZ no período. No mesmo ano (1932), por exemplo, Klutsis realizou outro cartaz ("No final do plano quinquenal, coletivização da URSS deve estar fundamentalmente terminada"- Figura 55) muito similar a "A vitória do Socialismo...". A fotomontagem de "No final do plano..." possuía a mesma estrutura em camadas: no primeiro plano, fragmentos fotográficos de tratores e campos sendo arados; no plano intermediário, a figura de Stalin (provavelmente a mesma fotografia utilizada em “A vitória do socialismo...”); e no terceiro plano, fragmentos fotográficos de uma massa de camponeses.

${ }^{313}$ Trata-se de processo violento que acompanhou medidas de coletivização dos campos e industrialização acelerada nas cidades durante o $1^{\circ}$ Plano Quinquenal. O "grande giro" (conforme terminologia de Pierre Broué), foi marcado pela coletivização forçada nos campos (estatização compulsória das terras e demais propriedades, a criação de grandes fazendas estatais, os sovkhozes, ou cooperativas de camponeses sob direção do Estado e seus gestores, os Kolkhozes) e industrialização acelerada nas cidades. Devido ao caráter policialesco das coletivizações forçadas houve no campo muitas revoltas camponesas. Assim como no período do "comunismo de guerra", os camponeses opuseram-se a tais processos boicotando as plantações e mesmo matando seus próprios animais. Conforme Broué, as perdas foram incalculáveis, “as estatísticas oficiais confessam que, entre 1929 e 1934, desapareceram 55\% dos cavalos (19 milhões de cabeças), 40\% do gado bovino (11 milhões), 55\% dos porcos e 66\% das ovelhas. As perdas humanas não foram contadas”. BROUÉ, Pierre, $O$ partido..., op. cit., pp. 307-309. Nas cidades, a industrialização acelerada foi acompanhada de um regime de controle e exploração do trabalho. idem, ibidem, p. 314. 


\subsubsection{3 "Não se pode acusar o sol de distorções"}

Há um vínculo indissociável entre política, economia e controle da imagem nos planos quinquenais russos. A gestão stalinista da economia, no decorrer dos anos 30, lançou mão de uma "politica da imagem" (via cartazes e revistas da IZOGIZ), visando à mobilização das classes trabalhadoras para o trabalho e a dinamização da economia russa.

Com o advento da reprodutibilidade técnica, a autenticidade do objeto original seria abalada, com isso, a "objetividade" do registro mecânico e o valor de exposição tornar-se-iam elementos de primeira ordem, conforme apontado por Walter Benjamin entre 1935 e 1936, em "A obra de arte na era de reprodutibilidade técnica". ${ }^{314} \mathrm{Com}$ isso, mais do que a qualidade do objeto, importaria, para a propaganda e a dinamização da economia, sua representação visual (via fotografias, fotomontagens e cartazes). São ilustrativos de tal lógica a adoção massiva da fotografia e fotomontagem nos cartazes da IZOGIZ para o $1^{\circ}$ Plano Quinquenal (Figuras 53, 54, 55, 56 \& 61), bem como a constituição da revista URSS em Construção (1930-1941) (Figuras 63 \& 64). ${ }^{315}$

Ao apresentar a revista ilustrada URSS em Construção, Maxime Gorki (um dos idealizadores da revista) escreveu: "nós decidimos nos voltar para o desenho com luzes, para o trabalho do sol para a fotografia. Não se pode acusar o sol de distorções, o sol ilumina o que existe tal como existe". ${ }^{316}$

$\mathrm{Na}$ industrialização acelerada stalinista, além do aspecto coercitivo, que condicionava a subsistência do trabalhador à sua obediência e produtividade, ${ }^{317}$ o estímulo ao aumento da

314 "As marcas de automóveis, de cigarro, de têxteis foram habituando o público a reconhecer na imagem determinadas qualidades dos seus produtos. Colocaram a fotografia no lugar da amostra do produto". BENJAMIN, W., "Pintura e arquitetura, fotografia e cinema" (paralipômenos, 1936-1940), in idem, Estética e sociologia da arte, trad. João Barrento, São Paulo: Autêntica, 2017, pp. 249-258; p. 255. O debate benjaminiano sobre $\mathbf{o}$ abalo da autenticidade do objeto (aura) frente ao advento da reprodutibilidade técnica e o valor de exposição serão melhor discutidas em seguida, no capítulo 4.

${ }^{315}$ Conforme discutido no capítulo 1, URSS em Construção foi um periódico quinzenal de alta tiragem, ilustrado prioritariamente com fotografias e fotomontagens e dedicada à propagação nacional e internacional das "conquistas e avanços" dos planos quinquenais. (Figuras $63 \& 64$ )

${ }^{316}$ GORKI, M., URSS em Construção, n. 1, Moscou: IZOGIZ, 1930, apud WOLF, E., USSR in Construction..., op. cit., p. 47. A citação de Gorki foi retirada do editorial do $1^{\circ}$ número da edição nacional da revista URSS em Construção. Segundo a pesquisa de doutorado de Erika Wolf, havia duas versões da revista (uma para circulação nacional e outra para circulação internacional). A análise comparativa entre as duas versões não apresentava muitas distinções no campo gráfico e visual, no entanto, segundo Wolf, existiriam algumas pequenas diferenças entre os textos de ambas versões. Segundo Wolf, a versão para circulação fora da Rússia possuía uma retórica "revolucionária" mais moderada. Ver: WOLF, E., USSR in Construction... op. cit., p. 46.

${ }^{317}$ Qualquer infração disciplinar poderia gerar demissão, o que, sob o regime stalinista, tinha consequências gravíssimas, visto que, no decorrer de 1930, o partido retirou qualquer tipo de auxílio-desemprego a demitidos por infrações disciplinares. Posteriormente, o partido passou a incentivar a não contratação dos operários "perturbadores" e infratores. Um decreto de 15 de novembro de 1932, por exemplo, "obriga o diretor [de fábrica] a despedir um operário por um só dia de ausência não justificada, com a complementar retenção da caderneta de racionamento [alimentação] e expulsão da moradia, se esta pertence [sic] à empresa". BROUÉ, P., O partido..., op. cit., p. 314 . 
produtividade no trabalho passava pelo falseamento de dados, resultados e imagens. ${ }^{318}$ Em outras palavras, a mobilização para o trabalho, durante os planos quinquenais, passava pela consolidação de uma narrativa visual das "conquistas" econômicas, do heroísmo e voluntarismo dos trabalhadores. O heroísmo e voluntarismo trabalhista tornam-se emblemáticos após a criação do stakhanovismo. ${ }^{319}$

Filmes, fotografias e fotomontagens, no início de 1930, passaram a ser usados largamente em exposições internacionais, revistas e cartazes. As "conquistas" do "socialismo num só país" e o "heroísmo" dos trabalhadores russos eram veiculados (em exposições, revistas e cartazes) na Rússia e no exterior. Fruto de alto investimento financeiro, a revista ilustrada URSS em Construção, por exemplo, foi um dos elementos centrais da política de promoção das conquistas dos planos quinquenais na Rússia e no ocidente capitalista. Em 1930, por exemplo, as tiragens giravam em torno de 60.000 exemplares por edição (Figura 64). ${ }^{320}$

Havia, especialmente entre 1930 e 1934, uma política de divulgação e circulação das revistas gratuitamente aos principais interlocutores da União Soviética no Ocidente. Os editores enviavam cópias gratuitas a comerciantes, representantes de governo, intelectuais e simpatizantes da URSS ${ }^{321}$

${ }^{318}$ Ver: COHEN, Yves, "Política e arte na verdade e na ficção do trabalho: elementos para uma comparação histórica entre o Oriente socialista e o Ocidente capitalista", in OLIVEIRA, Francisco; BRAGA, Ruy; RIZEK, Cibele, Hegemonia às avessas, São Paulo: Boitempo, pp. 93-108, 2010.

319 Stakhanovismo foi um movimento de estimulo ao máximo esforço pessoal (produtividade) no trabalho. O movimento teve origem no "caso exemplar" e farsesco do mineiro Alexei Stakhanov (1906-1977), o qual teria, por "força de sua vontade pessoal”, extraído, num único dia, 102 toneladas de carvão (14 vezes a cota diária de um trabalhador). Conforme Broué, posteriormente soube-se que a elevada cota de Stakhanov apenas fora atingida graças ao auxílio de uma grande equipe de mineiros. BROUÉ, P., O Partido..., op. cit., p. 313 . O stakhanovismo foi largamente explorado em propagandas do período, as quais lançavam mão das conquistas de Stakhanov para fomentar a espoliação e o auto-martírio das classes trabalhadoras russas.

${ }^{320}$ Ver: WOLF, Erika. "When photographs speak, to whom do they talk? The origins and audience of SSSR na stroike (USSR in construction)", Left History, vol. 6, n.2, pp. 53-82, 2000, pp. 50-54.

${ }^{321}$ Em pesquisa nos arquivos da URSS em Construção, Wolf encontrou a seguinte listagem acerca do público alvo da revista em 1930: "1. Bancos; 2. Organizações e empresas industriais de capital aberto [Industrial joint stock organizations and companies]; 3. Membros do parlamento britânico; 4. Revistas e jornais; 5 . Políticos, figuras literárias e figuras públicas". WOLF, E., "When photographs...”, op. cit., p. 64. Devido ao caráter da revista, com poucos textos e muitas imagens (Figuras 63 \& 64), suas matérias eram flexíveis o bastante para interessar por diferentes motivos um público amplo. "Por exemplo, uma questão sobre eletrificação pode ser lida por um empresário norte-americano como uma oportunidade para vender conhecimento [expertise] e equipamentos técnicos; por um intelectual, como uma evidência de transformação da atrasada Rússia em um sociedade moderna progressista; ou por um trabalhador comunista como uma prova da realização em curso dos planos revolucionários de Lenin na União Soviética". WOLF, E., "When photographs...”, op. cit., p. 62. Em sua extensa pesquisa nos arquivos da URSS em Construção, Wolf identificou a associação entre alguns acordos comerciais (de importação de tecnologia estrangeira ou exportação de produtos russos, por exemplo) e representantes comerciais destinatários de exemplares da URSS em Construção. Wolf aponta, por exemplo, entre os destinatários da edição de luxo da revista, os nomes de "J.P. Morgan e Edsel Ford, diretores da Ford Motor Company, com quem a União Soviética assinou um contrato de US\$30 milhões para comprar automóveis e assistência técnica para construção de uma fábrica de carros em Nizhni-Novgorod em maio de 1929”. idem, ibidem, p. 64. Nesse sentido, Wolf aponta ainda o papel central do banco estatal Gosbank e do VOKS na seleção dos destinatários e circulação das edições de Luxo da URSS em Construção no exterior. idem, USSR in Construction..., op. cit., p. 51. Segundo Wolf, além de promover a revista fora da Rússia, Gosbank possuía também a incumbência de recolher os comentários dos leitores estrangeiros. idem, ibidem, p. 54. 
aos dois primeiros grupos eram destinadas versões de luxo, enquanto aos dois últimos, geralmente, versões econômicas. ${ }^{322}$

Assim como no caso do pavilhão soviético de Colônia (referido no capítulo 1), os editores e colaboradores da URSS em Construção tinham grande preocupação em registrar a recepção da revista fora da Rússia. Eles muitas vezes pediam expressamente retornos e comentários aos destinatários das edições de luxo das revistas. ${ }^{323}$ Esses comentários eram então divulgados na imprensa russa, como uma segunda propaganda - consolidando a combinação entre os dois planos de circulação (russa e estrangeira) por meio da republicação, na imprensa russa, da recepção positiva dos pavilhões internacionais, cartazes e revistas soviéticos. Isto é, por meio da divulgação da aprovação e admiração internacional (vindas do Ocidente capitalista), reafirmavam-se, na Rússia, as "conquistas" do plano modernizador stalinista - concretizando-se, assim, a substituição da experiência e do objeto pelo seu valor de exposição. ${ }^{324}$

\subsection{3 "Artistas da URSS dos últimos 15 anos" (1932-1934)}

Em 13 de novembro de 1932 foi inaugurada, no Museu Estatal de Leningrado, a exposição “Artistas da URSS dos últimos 15 anos". A exposição, que ficou aberta até janeiro de 1933, contou com aproximadamente 2.640 obras (majoritariamente pinturas), de 423 artistas russos. Em 27 de junho de 1933, cinco meses após o fechamento da exposição de Leningrado, foi aberta na Galeria Estatal Tretiakov, de Moscou, a segunda montagem da exposição "Artistas da URSS dos últimos 15 anos" (Figura 65). A versão moscovita da exposição foi ainda maior (contou com aproximadamente 3.500 obras, de 500 artistas) e ficou aberta até fevereiro de 1934 (Figura 66). ${ }^{325}$

“Artistas da URSS dos últimos 15 anos" foi uma grande retrospectiva, encomendada pelo governo, para a comemoração do $15^{\circ}$ aniversário da Revolução. Inicialmente concebida com o propósito de expor as conquistas artísticas soviéticas em oposição às ocidentais, a exposição deveria lançar mão de vários suportes (pintura, escultura etc.) e estilos, apresentando um grande balanço da produção artística "soviética".

Orquestrada numa escala industrial sem precedentes, a exposição (tal qual a mostra fascista, na Itália) foi um ponto de inflexão na trajetória artística russa e pavimentou a estrada para o "realismo

${ }^{322}$ WOLF., E., "When photographs...”, op. cit., p. 62.

${ }^{323}$ Idem, ibidem, p. 65 e idem, USSR in Construction..., op. cit., pp. 55-57.

${ }^{324}$ COHEN. Y., "Política e arte...”, op. cit., p. 14. Um dos elementos que teria corroborado para o "sucesso" de tal procedimento seria a grande atenção dada aos planos quinquenais russos após a crise de 1929. Ver: RODRIGUES, Rogério P., O colapso da URSS: um estudo das causas, orientador Osvaldo Coggiola, Tese de Doutorado, São Paulo: Departamento de História Econômica, Universidade de São Paulo - USP, 2006, p. 86.

${ }^{325}$ CHLENOVA, M., On display..., op. cit., p. 347. A primeira versão da exposição foi inaugurada em novembro de 1932, no Museu da Rússia de Leningrado. A segunda versão, substancialmente modificada, foi inaugurada em junho de 1933, no Museu Histórico, de Moscou. Ver: CHLENOVA, M., "Staging soviet art: 15 years of artists of the Russian Soviet Republic, 1932-33”, October 147, Cambridge: MIT Press, pp. 38-55, 2014, p. 41. 
socialista”, que seria implantado no ano seguinte (1934). A retrospectiva acentuava persecutórios e inaugurava um novo cânone interpretativo da história da arte russa (calcado no revisionismo do passado próximo).

\subsubsection{Unificação e ocultamento}

Se, num primeiro momento, a exposição fora encarregada de narrar a trajetória artística da URSS, oferecendo um amplo panorama retrospectivo, ${ }^{326}$ num segundo momento, após o decreto de abril de 1932 (“Sobre a restruturação das organizações artístico-literárias”), ela foi também incumbida de um outra tarefa: construir uma narrativa unificadora (que apaziguasse as disputas, dissidências e embates entre correntes e grupos artísticos russos), de modo a reforçar a retórica de continuidade e avanço (na qual, os artistas eram apresentados deslocados de suas filiações e agrupamentos, constituindo uma frente coesa a serviço do "socialismo num só país"). Agia-se assim, no campo artístico, em forma análoga à retórica economicista do período.

\subsubsection{2 "Artistas da URSS dos últimos 15 anos" - Leningrado}

Nas duas retrospectivas, a montagem foi encarregada a dois comitês de gestores e artistas, que trabalharam com obras e ambientes já existentes. No caso de Leningrado, a concepção e a montagem da exposição foram realizadas por dois comitês inter-relacionados, tal qual o sistema de direção unipessoal fabril russa. ${ }^{327} \mathrm{Um}$ comitê responsável por supervisionar a direção ideológica da retrospectiva e ligado ao partido stalinista e um comitê de "especialistas", responsável pela parte curatorial (seleção dos artistas, obras e montagem). A direção ideológica foi delegada ao Comissário para o Esclarecimento Andrei Bubnov (1883-1938), enquanto a artística foi incumbida ao pintor e diretor da Galeria Tretiakov, Igor Grabar (1871-1960). Além de Grabar, o corpo curatorial foi composto por Ivan Matsa (1893-1974), historiador da arte búlgaro e por alguns artistas de diferentes tendências "realistas" (AKhRR e OST etc.).

\footnotetext{
${ }^{326}$ Para um maior detalhamento sobre o comitê montado para a elaboração da exposição e o processo de elaboração e montagem da mesma, ver: CHLENOVA, M., On display..., op. cit. O jornal Sovetskoe Iskusstvo anunciou que, durante os primeiros dois meses, a exposição foi visitada por cerca de 163.000 pessoas, e que, conforme registros da exposição, após cinco meses esta teria recebido por volta de 300.000 pessoas. CHLENOVA, M., On display..., op. cit., p. 362.

327 Com a implementação da NEP (1921-1928), introduziu-se, nas fábricas estatais russas, a figura do "especialista" (técnicos, administradores e engenheiros provenientes da antiga burguesia russa. Os especialistas ocupavam cargos de destaque e comando e ganhavam salários maiores que a média do proletariado russo). Ver: KOLLONTAI, Alexandra, Oposição operária 1920-1921, trad. Grupo Aurora, São Paulo: Global Editora, 1980, p. 45. O sistema de direção unipessoal das empresas dava grandes poderes à direção centralizada de um técnico ou gestor "especialista", o qual era acompanhado de um comissário "operário" (responsável pelo controle ideológico). Ambos eram indicados pelo partido bolchevique. Ver: RODRIGUES, Rogério P., O colapso da URSS..., op. cit., p. 52.
} 
Os artistas selecionados tiveram liberdade na hora da montagem - sendo atribuída a eles a escolha do posicionamento e disposição de suas obras no espaço expositivo. A narrativa curatorial foi realizada mediante o ordenamento das salas (constituição do percurso expositivo) e a escolha dos artistas que comporiam a retrospectiva - em sua maioria, pintores e escultores figurativistas (1.050, pinturas, 1.500 desenhos gráficos e 90 esculturas). ${ }^{328}$

Com poucas marcas de intervenção curatorial e transformações do espaço expositivo, a retrospectiva de Leningrado respaldava o decreto de abril de 1932, apresentando-o como uma espécie de desaguadouro de uma história da arte "soviética", linear e cronológica. A exposição reescrevia o passado mediante um percurso circular que consolidava simbolicamente a perspectiva economicista $\mathrm{e}$ a retórica stalinista vigente, por meio da associação entre os planos quinquenais e o plano de eletrificação nacional (GOELRO), as imagens de Stalin e Lênin.

O circuito expositivo de "Artistas da URSS dos últimos 15 anos" começava e terminava na mesma sala, onde encontravam-se, lado a lado, os retratos pintados de Lênin e Stalin. Após subir uma escadaria imponente, recoberta por um tapete vermelho e adornada com bandeiras, emblemas e flores (Figura 65), o público deparava-se com uma pintura de Lênin falando às massas (Figura 77). ${ }^{329}$ Uma vez percorridas as 35 galerias do complexo, o público concluía o percurso expositivo circular na mesma sala do início, de frente a uma - também monumental - pintura de Stalin, discursando (no caso, no gabinete)(Figura 82). ${ }^{330}$

Assim como as proibições de dissidências e agrupamentos políticos, marcadas pela eliminação da Oposição Unificada em 1928, os embates artísticos e as correntes artísticas oposicionistas (como o grupo LEF) foram suprimidos da exposição ou apartados do circuito expositivo central. Artistas de peso no cenário artístico local e internacional, como Lissitzky e Rodchenko, foram excluídos da retrospectiva. Enquanto outros, como Malevich, foram contemplados, porém isolados do circuito expositivo central.

Malevich teve uma galeria individual, na qual pôde expor livremente suas obras. Porém, o suposto prestígio e destaque, atribuídos às galerias individuais, na exposição de Leningrado, denotava exclusão e difamação (Figura 83). Apartada do circuito expositivo, a galeria de Malevich, assim como a do outro artista de vanguarda "contemplado" na retrospectiva, Pavel Filonov (1883-1941), era apresentada ao público mediante sua disposição espacial e simbólica enquanto um "desvio" em relação ao percurso linear e "natural" da arte "soviética".

\footnotetext{
${ }^{328}$ CHLENOVA, M., On display..., op. cit.

${ }^{329}$ Aleksandr Gerasimov (1881-1963), Lênin num pódio, 1930, óleo sobre tela, 218 x 210cm (Figura 77).

${ }^{330}$ Isaak Brodsky (1883-1939), Stalin, 1928, óleo sobre tela (Figura 82).
} 


\subsubsection{3 "Artistas da URSS dos últimos 15 anos" - Moscou}

A segunda versão da exposição (Moscou, 1933-1934) ficou a cargo de um único comitê, chefiado por Andrei Bubnov. Na retrospectiva moscovita, a intervenção curatorial foi mais incisiva e evidente do que na versão de Leningrado. Os artistas selecionados não puderam escolher a disposição de suas obras e, apesar do aumento do número de obras e artistas, havia uma maior homogeneidade e prevalência das produções de "cavalete", ao estilo da AKhRR.

A exposição foi dividida em quatro partes. As duas principais, unificadas sob o slogan "o estilo de nossa época é o realismo socialista", seguiam um critério geracional e enfatizavam a retórica economicista e celebrativa de um "futuro ofuscante", conforme o irônico diagnóstico de Maiakovski. ${ }^{331}$ Destoando dessa homogeneização, encontravam-se apartadas do circuito expositivo central duas galerias unificadas pela nomenclatura "formalistas não objetivos" (ecoando a retórica difamatória do período). A inter-relação entre as imagens de Lênin e Stalin - o plano de eletrificação GOELRO e os Planos Quinquenais - foi mantida e enfatizada também nessa segunda edição (Figuras $69,70 \& 71)$.

O discurso curatorial e o projeto expositivo de "Artistas da URSS dos últimos 15 anos", especialmente em sua segunda montagem (que acentuou os métodos em germe na expografia russa do período), ${ }^{332}$ foram marcados por falsificações historiográficas, simulacros revolucionários, ocultamentos, difamações e perseguições internas - tal qual a mostra fascista de 1932. Nesta, narravase a "revolução" armada fascista, em oposição à insatisfação das massas com a demora italiana em entrar na guerra, bem como em oposição à crise capitalista e ao que chamavam de "besta reincidente" ou "sabotadores da vitória" - termos pejorativos utilizados na mostra fascista para caracterizar os movimentos revolucionários de esquerda (a saber, greves operárias, partidos de esquerda [PS, PCd’I] e a Revolução de Outubro [Figuras 86, 87, 88 \& 89]). ${ }^{333}$

Na primeira montagem da exposição (Leningrado, 1932), construtivistas-produtivistas foram excluídos, e outros, como Malevich, foram apartados do circuito expositivo central (Figura 83) ${ }^{334} \mathrm{Na}$

331 “Ao Comitê Central do futuro ofuscante, sobre a malta dos vates velhacos e falsários, apresento em lugar do registro partidário todos os cem tomos dos meus livros militantes". MAIAKOVSKI, V., "A plenos pulmões" (1929-1930), in SCHNAIDERMAN, Boris (trad.); CAMPOS, Haroldo (trad.); CAMPOS, Augusto (trad.), Maiakovski, poemas, São Paulo: Perspectiva, pp. 131-136, 2006.

${ }^{332}$ Conforme Chlenova, a tática de difamação da arte de vanguarda e de exaltação de pinturas próximas ao estilo "realismo heroico" já fora utilizada em menor escala em outras exposições a partir de 1930. A título de exemplo, pode-se citar as exposições “Trabalhos artísticos sobre temas soviéticos e revolucionários” (Galeria Tretiakov, 1930), "Guerra e Arte” (Museu Russo, 1930), “A arte da era do capitalismo" (Galeria Tretiakov, 1930) e “Arte russa da era imperialista” (Museu Russo, 1931-32). CHLENOVA, M., “Staging...”, op. cit., p. 51. (Figuras 84 \& 85)

${ }^{333}$ ALFIERI, D.; FREDDI, Luigi (org), Mostra..., op. cit. (catálogo da exposição).

${ }^{334}$ Ver: CHLENOVA, M., “Staging...”, op. cit., p. 47. 
segunda montagem (1933), lançou-se mão de outro recurso curatorial: expor para difamar e incriminar. ${ }^{335}$

Entre as obras difamadas e incriminadas de "esquerdismo", "formalismo" e "desvio burguês", na segunda versão, enquadravam-se as produções de artistas ligados às correntes construtivistasprodutivistas, como os artistas vinculados ao LEF: Rodchenko, Tatlin (1885-1953) e Popova (18891924).

Na montagem moscovita da exposição, os procedimentos de difamação e de exaltação foram constituídos, entre outros, mediante: 1) discriminação na disposição espacial das obras - assim, enquanto as pinturas "de cavalete" eram expostas em duas salas amplas e claras (Figuras 69, 70 \& 71), as "esquerdistas" eram expostas amontoadas em corredores escuros; 2) uso capcioso das legendas nas salas - por exemplo, lia-se: "o estilo de nossa época é o realismo socialista" versus "formalistas não objetivos"; 3) manipulação de frases atribuídas a Lênin, para condicionar a apreciação das obras pelas massas de espectadores.

Nas galerias que comportavam as pinturas de vanguardas, as galerias dos "formalistas não objetivos", havia, pintada na parede, uma frase difamatória, atribuída a Lênin: "Eu não sou capaz de considerar trabalhos do expressionismo, futurismo, cubismo e outros 'ismos' como a mais alta manifestação do gênio artístico. Eu não os entendo. Eles não me dão alegria alguma”.

\subsubsection{Artes visuais, revisionismo e expurgos}

Com efeito, a execução é um sacrifício humano, e a cena que a descreve recebe deliberadamente a cor das sinistras civilizações escravocratas do mundo antigo. É esta apropriação intuitiva do lado irracional do totalitarismo - sacrifício humano, crueldade como um fim em si, idolatria de um líder a quem se atribuiu características divinas - que faz do livro de Zamiátin [Nós] superior ao de Huxey [Admirável mundo novo].

No entanto, é bem possível que Zamiátin não visasse ao regime soviético como alvo particular de sua sátira. Escrevendo na mesma época da morte de Lênin, ele talvez não tivesse em mente a ditadura de Stalin.

\footnotetext{
${ }^{335}$ Segundo Chlenova, a tática de difamação dos supostos "formalistas", adotada pela curadoria da exposição, foi bastante consciente. Segundo ela, Katsman reportou em seu diário que o "Comissário Bubnov [responsável pela montagem da exposição] disse, durante os preparativos da retrospectiva de Moscou: 'Eles [os artistas lefistas] estão fazendo escândalo? Ótimo, então nós vamos mostrar o trabalho deles, e vamos desmascará-los em nossa exibição."' CHLENOVA, M., On display..., op. cit., p. 358.
} 
Preso pelo governo czarista, em 1906, e posteriormente pelos bolcheviques, em 1922, no mesmo corredor da mesma prisão, Zamiátin tinha razão em desprezar os regimes políticos sob os quais viveu. (George Orwell, 1946). ${ }^{336}$

Em "Artistas da URSS dos últimos 15 anos", as contradições ideológicas e formais - ainda abertas como luta entre contrários, no pavilhão de Colônia - deram lugar a um discurso curatorial que emulava e reproduzia as práticas de coerção, repressão e falsificação histórica que caracterizaram o regime stalinista. Desse modo, em “Artistas da URSS dos últimos 15 anos" - especialmente na versão moscovita -, as montagens fotográficas que antes, na mostra de Colônia, enfatizavam o protagonismo da cozinheira (do proletariado e do campesinato) (Figura 37), foram substituídas por "pinturas de cavalete" realizadas a partir de fotografias forjadas, ${ }^{337}$ conquistas econômicas falseadas e um líder vitorioso (Figuras 77, 78, 79, 80 \& 81).

Em “Artistas da URSS dos últimos 15 anos”, a experiência revolucionária foi substituída por uma retórica pseudo-revolucionária; a tribuna, pelo gabinete; Lênin por Stalin; e os debates por decretos, ocultações e isolamento. Elaborava-se assim uma experiência de transformação da linguagem e reconstrução fictícia da realidade, posteriormente acentuada nos processos de Moscou. ${ }^{338}$ A tal dispositivo, George Orwell (1903-1950) denominaria, em sua obra 1984 (1949), "novilingua”. 339

Assim como ocorreu no plano político (entre 1924, data da morte de Lênin, e 1928, data da deportação de Trotsky) e no plano econômico (entre 1927 e 1929, com a adoção dos planos quinquenais e dos processos de coletivização forçada), as disputas do campo artístico russo foram progressivamente substituídas por uma série de difamações, falsificações, decretos e medidas, entre 1928 e 1934. Preparou-se assim o terreno para a imposição do "realismo socialista" (1934). Pode-se supor que, não por acaso, o ano do título da novela de "ficção científica", de Orwell, 1984, ecoava, no seu título, o ano de 1934 - ano da adoção do "realismo socialista". Com efeito, um mero corte vertical no número 8 revela o número 3, nele embutido e espelhado. Para além de haver no título de 1984 uma

${ }^{336}$ ORWELL, G., "Resenha de Nós, de Ievguêni Ivánovitch Zamiátin”, 4 de janeiro de 1946, in ZAMIÁTIN, I.I., Nós (1924), trad. Gabriela Soares, São Paulo: Editora Aleph, 2017, pp. 317-323.

${ }^{337}$ Conforme o artista gráfico e historiador inglês David King (1943-2016), na URSS o retoque fotográfico para a publicação de livros e periódicos data de 1917, mas somente em 1936, após o período dos expurgos, teria se tornado uma prática recorrente. Comissários banidos e outros condenados nos Processos de Moscou eram sistematicamente retirados das fotografias. Ver: KING, David, "Photographic images should not be relied upon, but even falsified photographs can be illuminating for students of history", New perspective - for modern history students, V. 6, n. 2, 2000, pp. 24-25; p. 24. (Figura 78 \& 79).

338 "Processos de Moscou" é como ficaram conhecidos os julgamentos e expurgos realizados a partir de junho de 1936 na URSS. Sob acusações infundadas de traição e conspiração contra a revolução, no curso de poucos anos Stalin liquidou um terço do Comitê Central do Partido, grande parte da chamada velha guarda: revolucionários que entraram no partido em 1905 ou em 1917, outrora figuras centrais que atuaram ao lado de Lênin; por exemplo: Bukharin, Zinoviev [1883-1936] e Kamenev [1883-1936], filhos, familiares e simpatizantes de Trotsky, milhares de oficiais do exército, entre outros. Ver: BROUÉ, Pierre, O partido bolchevique, op. cit., p. 349.

${ }^{339}$ Ver: ORWELL, George, 1984, trad. Alexandre Hubner e Heloisa Jahn, São Paulo: Companhia das Letras, 2015. 
referência (ou não) ao ano de 1934, nesse livro Orwell denuncia os simulacros da revolução e sua reprodução falsificada em termos históricos e visuais diariamente. ${ }^{340} \mathrm{~A}$ tal hipótese, acrescenta-se a influência da obra Nós (1924), do russo Ievguêni Zamiátin, sobre a novela de Orwell. Soma-se também o elogio que Orwell fez, em 1946, às descrições, contidas em Nós, do sacrifício humano e da idolatria ao líder em governos totalitários (o que, no caso, incluiria também o regime stalinista, conforme pode-se aferir pela leitura do restante da crítica de Orwell e de outras obras como " $A$ revolução dos bichos").

“Artistas da URSS dos últimos 15 anos” intervém decisivamente nesse contexto repressivo. Enquanto reescreviam a historia, as duas retrospectivas, de Leningrado e Moscou, denegavam o papel ocupado por artistas de vanguarda na trajetória artística e política russa, ou incriminavam-nos estimulando as práticas de coação e delação entre pares. ${ }^{341}$ A revisão historiográfica praticada pela expografia, que pavimentou o caminho para o "realismo socialista", ecoava as práticas de difamação, espetacularização e expurgo (material, imagético e discursivo) em desenvolvimento nos julgamentos públicos do período ("processo de Chakhty", 1928 e "processo do Partido Industrial", 1930) ) $^{342}$ e que caracterizariam os "Processos de Moscou" (1936), ${ }^{343}$ caracterizados pela exaltação do regime stalinista mediante a difamação, autocrítica e a exposição pública de seus opositores.

As práticas de delação e difamação entre pares também foram um importante mecanismo de controle político e econômico stalinista. No âmbito do trabalho, como apontado no capítulo 1, as práticas de delação entre pares já eram estimuladas por meio da cooptação e controle de relatos dos próprios correspondentes operários e camponeses. No período dos “expurgos", tais práticas se acentuaram e se disseminaram para as mais variadas esferas da vida russa, por meio do conceito de “responsabilidade pessoal”.

${ }^{340}$ ZAMIÁTIN, I., Nós, op. cit.

${ }^{341} \mathrm{Na}$ época o secretário da AKhRR, Katsman (já mencionado anteriormente no debate com Arvatov, em 1926), escreveu em seu diário acerca do sucesso da exposição e do papel relegado aos "esquerdistas" por ela:

"Os formalistas foram completamente derrotados. Eles nunca mais vão levantar. Os esquerdistas acham que nós, realistas, os derrubamos. Não, foram os expectadores que o fizeram... Vitória, droga, vitória! Vitória em ambas as exposições! Por 15 anos, os formalistas, esses bastardos, estavam nos enganando. Derrotados, derrotas em todas as partes. Tal foi o impacto que a exposição teve". KATSMAN, apud CHLENOVA, M., "Staging...", op. cit., p. 52.

${ }^{342}$ Os "processos de Chakhty", 1928, e o "processo do Partido Industrial", 1930, foram processos que antecederam os "Processos de Moscou" mas que já anunciavam a lógica do mesmo: exposição para a difamação. Em 1928, por exemplo, mais de cinquenta engenheiros da cidade de Chakthty foram acusados, presos e condenados, devido a uma suposta aliança com o inimigo (antigos proprietários das minas da região), que os teria levado à sabotagem industrial. Ver: REIS FILHO, Daniel Aarão e COSTA, Emília Viotti da, As revoluções russas e o socialismo soviético, São Paulo: EDUNESP, 2008, pp. 100-101. Ver também: LUCAS, Marcílio Rodrigues, De Taylor a Stakhanov: utopias e dilemas marxistas em torno da racionalização do trabalho, IFCH, Ciências Sociais, Tese de doutorado, Orient: Liliana Segnini, Campinas: Unicamp, 2015, p. 157.

${ }^{343}$ Muitos artistas e intelectuais também foram exterminados ou enviados ao campo de trabalho forçado. Ver: KING, David, "Photographic images should not...", op. cit., p. 24. 
Com o conceito de "responsabilidade pessoal", não só as práticas de vigilância se aceleraram, como também o próprio processo de reconstrução da historia recente intensificou-se. ${ }^{344}$ Os nomes e as imagens daqueles que "caíram em desgraça" não mais poderiam ser mencionados e/ou veiculados em território soviético. A imprensa, professores, fotógrafos e outros deveriam adotar a autocensura removendo, por conta própria, tais personagens da história (Figuras 90 \& 91). ${ }^{345}$

\subsubsection{0 triunfo da vontade do chefe}

Em "Artistas da URSS dos últimos 15 anos", aquele Lênin que defendia o protagonismo do proletariado e campesinato - do protótipo de clube de trabalhadores de Rodchenko e da cabeça da silhueta do pavilhão soviético de Colônia (Figuras 37 e 93) - deu lugar ao Lênin dos sorrisos amarelados das pinturas a óleo, nos termos do "socialismo num só país" (Figuras 66, 67, 68, 69, 70 \& $71)$.

Um novo fenômeno mórbido, em "Artistas da URSS dos últimos 15 anos" (e no "realismo socialista" como um todo): pinturas a óleo em escalas industrial ecoavam falsas fotografias ${ }^{346}$ na representação das "conquistas" do "socialismo num só país". Representações estas marcadas por cenas farsescas de trabalhadoras e trabalhadores heroicos, fortes e otimistas, em momentos de lazer e trabalho ao sol; camponeses munidos de tratores nos campos; trabalhadores entusiasmados nas fábricas; mulheres e homens, adultos e crianças, todos unidos sob a égide do socialismo (num só país) e a direção de um líder.

As retrospectivas "Artistas da URSS dos últimos 15 anos" consolidaram o triunfo das velhas práticas artísticas "de cavalete", a serviço de um "futuro ofuscante". Futuro este, calcado no descolamento do fato, substituído pelo embuste, na propaganda nacional e internacional farsesca e na intersecção entre "alta cultura" (pinturas e esculturas museológicas) e "cultura de massa" (cartazes e revistas de agitação e propaganda).

\footnotetext{
${ }^{344}$ De acordo com King, o conceito de "responsabilidade pessoal" foi adotado pelos stalinistas durante uma vasta campanha de vigilância contra os inimigos do regime. Os nomes daqueles que tinham sido presos ou "desaparecido" já não podiam ser mencionados, nem suas fotos poderiam ser mantidas, sob o risco de prisão. KING, David, "Photographic images should not...”, op. cit., p. 24.

${ }^{345}$ King, na introdução de The Commissar Vanishes, narra que em sua visita ao acervo pessoal de A. Rodchenko e V. Stepanova, teria encontrado no livro, de uso pessoal, Dez Anos de Uzbequistão (1937), a intervenção feita pelo próprio artista nas fotografias do livro. Rodchenko teria escurecido com nanquim a face de uma série de comissários banidos. KING, David, The commissar vanishes: the falsification of photographs and art in Stalin's Russia, New York, N.Y., H. Holt, c1997 (Figuras 90 e 91).

${ }^{346}$ Durante o período de gestação do "realismo socialista" e no da vigência do mesmo, tornou-se uma prática recorrente o uso de fotografias e fotomontagens como base de pinturas e esculturas. Após os Processos de Moscou, com a disseminação da prática de falsificação fotográfica (na supressão de comissários banidos, por exemplo), muitas fotografias retocadas ou montadas tornaram-se base para pinturas e esculturas, nas quais a observação da realidade era substituída pela observação de representações fotográficas falseadas. Ver: DICKERMAN, Leah Anne, "camera obscura: socialist realism in the shadow of photography", October 93, Cambridge: MIT Press, pp. 138-153, 2000.
} 


\subsection{4 "Uma história em ato": "Artistas da URSS dos últimos 15 anos" e Mostra da Revolução Fascista (1932-1934)}

Se, numa primeira comparação, ressaltam diferenças quanto às técnicas, materiais e estilos adotados, devido ao carater tradicionalista da retrospetiva russa - caracterizada por pinturas "de cavalete", penduradas em paredes num estilo que remontava aos próprios salões parisienses dos séculos anteriores; já, num segundo momento, ao confrontar a dimensão econômica, cultual e o impacto ideológico das retrospetivas russas e da mostra fascista, podemos notar algumas tangências, especialmente com as salas de "Q" a "U", da mostra fascista (Figuras 17, 18, 19 \& 20).

A partir da sala "Q" ficam para trás as fotomontagens e os recortes de jornais; adota-se o mármore e as esculturas heroicizantes (Figura 20). Os espaços tornam-se mais amplos e grandiosos e suspende-se a narrativa histórica que interligava o circuito expositivo. A partir dessa sala, a figura do Duce é reforçada, seja por seu busto onipresente (Figura 27), seja por uma espécie de resgate biográfico heroicizante do líder (como, por exemplo, na reconstituição dos escritórios de Mussolini nas sedes de "Il Popolo d'Italia", nas salas "R" e "T", da mostra fascista. Figuras 21, 27, 28, 28, 30, 31, $32,33 \& 34)$. Assim como é reforçada também a posição de obediência e auto-martírio delegada às massas, especialmente na apoteótica capela dos mártires da sala "U” da mostra (Figuras 17, 18 \& 19).

$\mathrm{Na}$ mostra fascista, a sintaxe de vanguarda aparecia combinada a elementos simbólicos tradicionais e nacionalistas (como o "culto do litório", evocando a tradição romana). Tal combinação, a partir da sala "Q", sofria uma importante inflexão, na qual a linguagem de vanguarda dava lugar a uma estética monumental, calcada na suspensão da narrativa histórica, no retorno das esculturas ("de cavalete") em mármore (tal qual o tapete de veludo vermelho, da retrospectiva russa) e no triunfo do martírio coletivo (Figuras $27 \& 65$ ).

$\mathrm{Na}$ mostra fascista, conforme a lógica da "revolução-restauração", a combinação entre o "novo e o velho" foi sintetizada num único discurso expositivo que combinava habilmente as várias sintaxes numa assimilação molecular do "novo", depurado de efeitos disruptivos e apassivado. Novo esse que, entre o final dos anos 30 e início dos 40, será, tal qual a expografia da mostra fascista, sistematicamente substituído, no campo da forma, por um estilo mais clássico - como a análise das várias fachadas das reedições da Mostra da Revolução Fascista atesta (Figuras 94, 95 \& 96).

Já no caso russo, a conjugação entre o "novo e o velho" se deu mediante a alternância de estilos e políticas de produção e circulação de imagens, diluídos num arco temporal mais amplo. Tal processo foi marcado, num primeiro momento, por uma forte resistência artística e a adoção de uma sintaxe de vanguarda, confinadas às exposições internacionais (como em 1924 e 1928) e ao âmbito da cultura de massas (revistas e cartazes da IZOGIZ, 1929-1934), para a mobilização da economia na Rússia e no exterior. Ulteriormente, dá-se o aumento da repressão e a adoção de práticas próprias à "arte de cavalete" (1932-1934). Nestas, as temáticas dão enfase ao economicismo e aparecem 
combinadas a práticas políticas persecutórias, numa chave litúrgica-termidoriana, reproduzida em escala industrial (após 1934).

Nos dois casos (mostra fascista e retrospectivas), as exposições respondiam a uma demanda de propaganda do regime e reconstrução de uma narrativa histórico-mitológica farsesca (no caso russo, a construção de um percurso artístico e político "homogêneo" e vitorioso; no caso italiano, a "salvação" da Itália, levada a cabo pelo fascismo).

Nos dois casos, as exposições estruturaram-se em oposição a um inimigo interno e externo: no caso russo, os artistas de vanguarda - representantes da burguesia ocidental e aqueles que se “opunham” à Revolução (na verdade, a contrarrevolução levada a cabo pelo stalinismo); no caso italiano, os partidos de esquerda italianos (como PS e PCd'I), o bolchevismo russo e a crise capitalista internacional.

Nos dois casos, as exposições eram mais do que a mera representação, eram a própria "história em ato" - como constatou a crítica de arte fascista, e amante de Mussolini, Margherita Sarfatti (1880-1961). ${ }^{347}$ As exposições em questão eram apresentadas ao público como o corolário de um processo histórico. Era o triunfo de uma narrativa farsesca; da transposição de técnicas econômicas e política para a esfera das artes; de um projeto de dominação e modernização que demandava o sacrifício das massas; de um líder forte - que pairava acima de tudo e todos, inclusive dos espectadores, realocados no papel de contempladoras passivos de sua própria destruição. Conforme comentou Benjamin, entre 1935 e 1936, acerca da "estetização da política" fascista:

\footnotetext{
"Faça-se arte, pereça o mundo", diz o fascismo, e espera a satisfação artística da percepção sensorial transformada pela técnica, tal como Marinetti confessa, da guerra. Isso é evidentemente a consumação da arte pela arte. A humanidade, que outrora, em Homero, foi um objeto de espetáculo para os deuses do olímpicos, tornou-se agora objeto de espetáculo para si mesma. Sua autoalienação atingiu um grau que lhe permite vivenciar sua própria destruição como um gozo estético de primeira ordem. Essa é a situação da estetização da política que o fascismo pratica. ${ }^{348}$
}

${ }^{347}$ SARFATTI, Margherita, "Architettura, arte e simbolo ala Mostra del Fascismo", (1932), in SCHNAPP, Jeffrey T., Anno X..., op. cit., pp. 69-72, p. 70.

${ }^{348}$ BENJAMIN, W., “A obra de arte na época ...", op. cit., p. 123. Cabe mencionar que Benjamin conheceu pessoalmente o poeta futurista F. Marinetti em 1924, em Capri. 

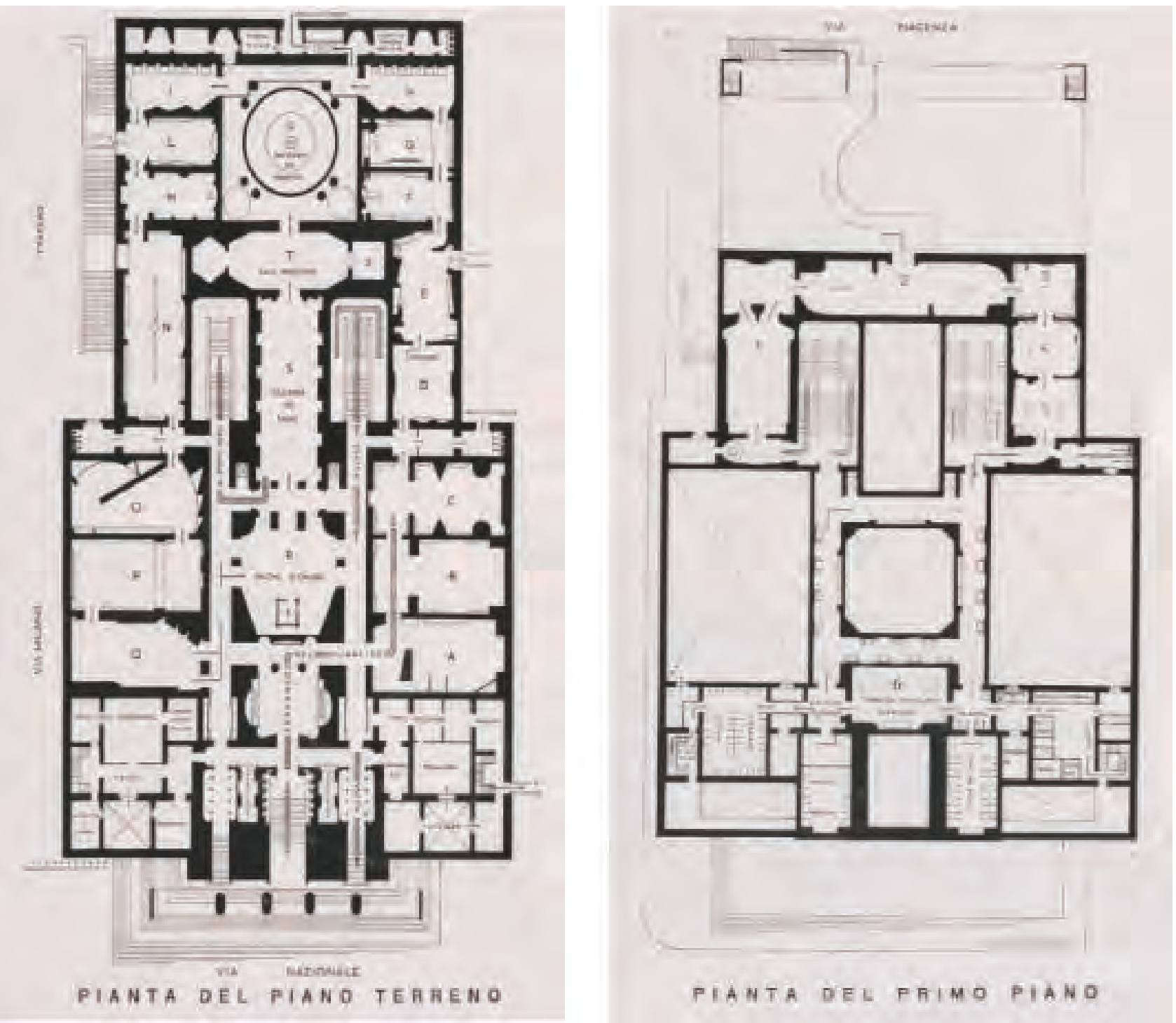

LAYOUT DA EXPOSIÇÃO

Sala A - Da conflagração europeia à fundação do "Il Popolo d'Italia" (1914);

Sala B - Da adunata dos Fasci d'azione rivoluzionaria à intervenção da Itália na guerra europeia (1915);

Sala C - A guerra italiana (1915-1918);

Sala D - A vitória italiana (1918);

Sala E - Da vitória à fundação dos Fasci italiani di combattimento (1918-1919):

Salas F e G - Da fundação dos Fasci di Combattimento à todo o ano de 1919;

Salas H e I- 0 primeiro e o segundo semestre de 1920;

Salas L e M - Fiume e Dalmácia;

Sala N - O ano de 1921;

Sala 0 - 0 ano de 1922 até o início de outubro;

Sala P - A adunata de Nápoles e as preliminares da Marcha sobre Roma;

Sala Q - A Marcha sobre Roma;

Sala R - Salão de honra;

Sala S - Galeria dos fasci;

Sala T - Sala Mussolini:

Sala U - Memorial dos mártires:

Sala 1 - Os fasci no exterior;

Sala 2 - 0 espírito fascista - A bibliografia fascista:

Sala 3 - As conquistas do regime fascista;

Sala 4 - As realizações do regime no setor de agricultura e transporte;

Sala 5 - 0 trabalho no regime fascista

Sala 6 - Local para carimbar os descontos ferroviários

Fig. 1 Planta da Mostra da Revolução Fascista, imagem retirada do catálogo da exposição, 1932 


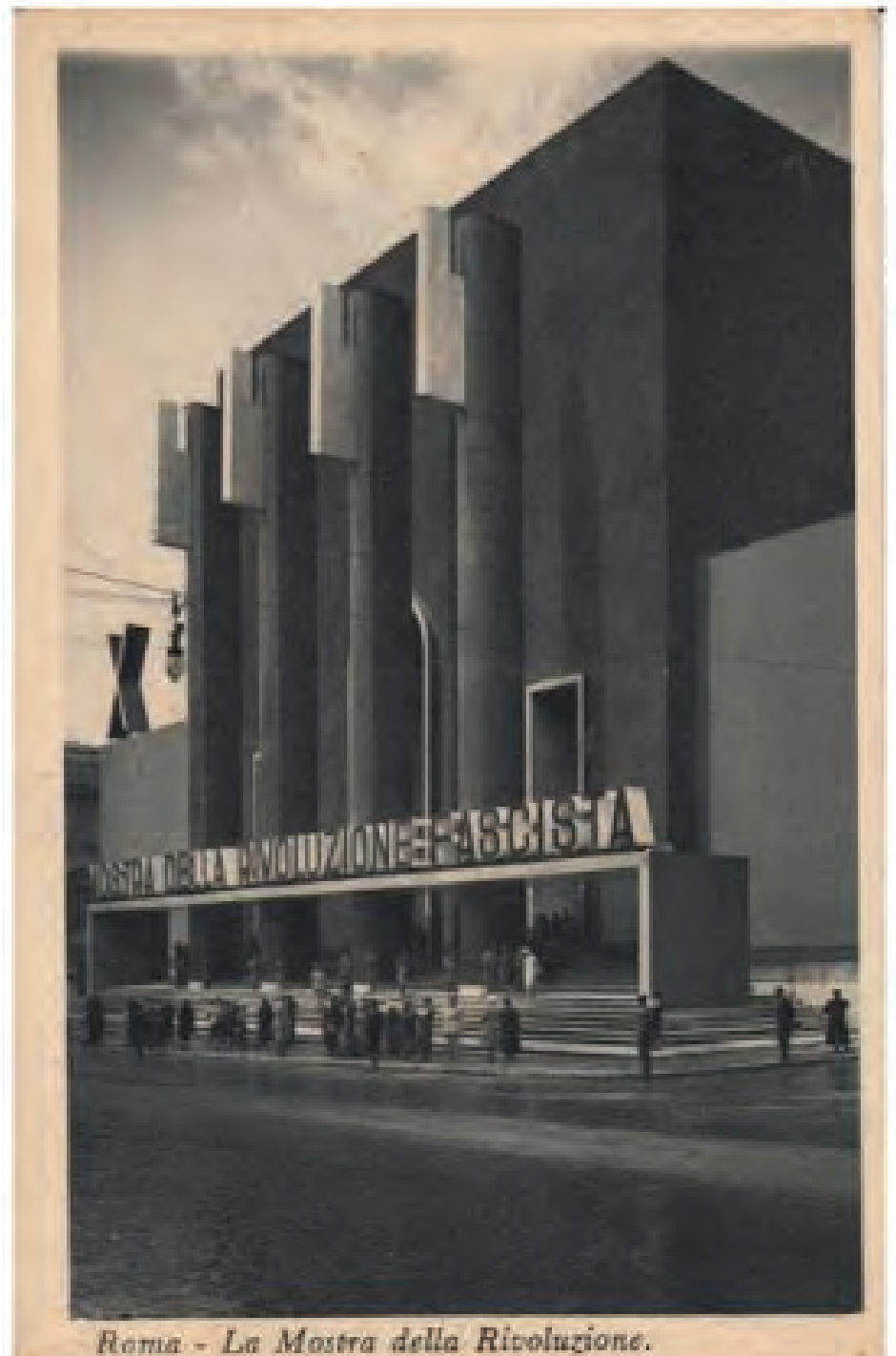

Fig. 2 Fachada do Palácio das Exposições, Mostra da Revolução Fascista, Roma, 1932 


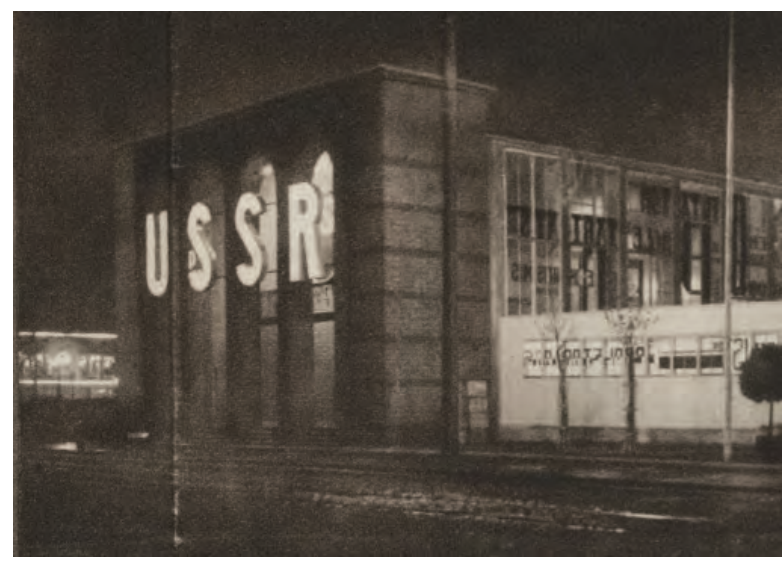

Fig. 3 Fachada do pavilhão soviético na Exposição Internacional de Imprensa de Colônia, 1928

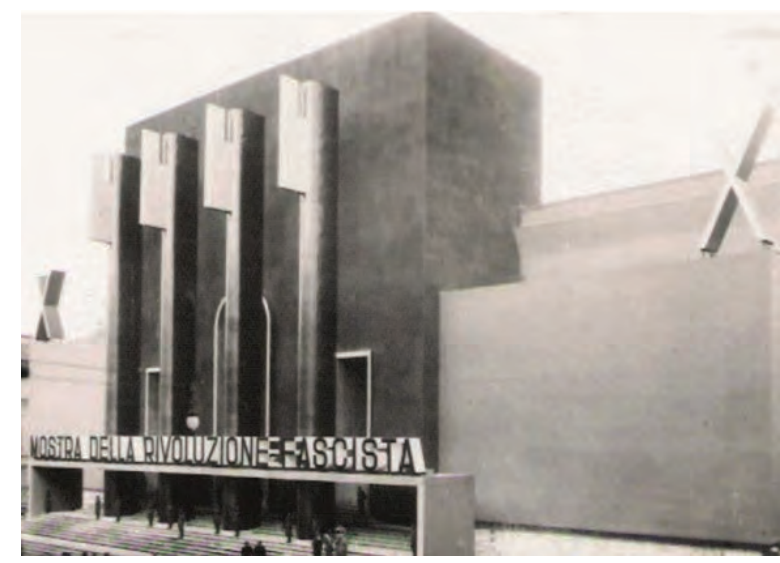

Fig. 4 Fotos da fachada do Palácio das Exposições, Mostra da Revolução Fascista, Roma, 1932
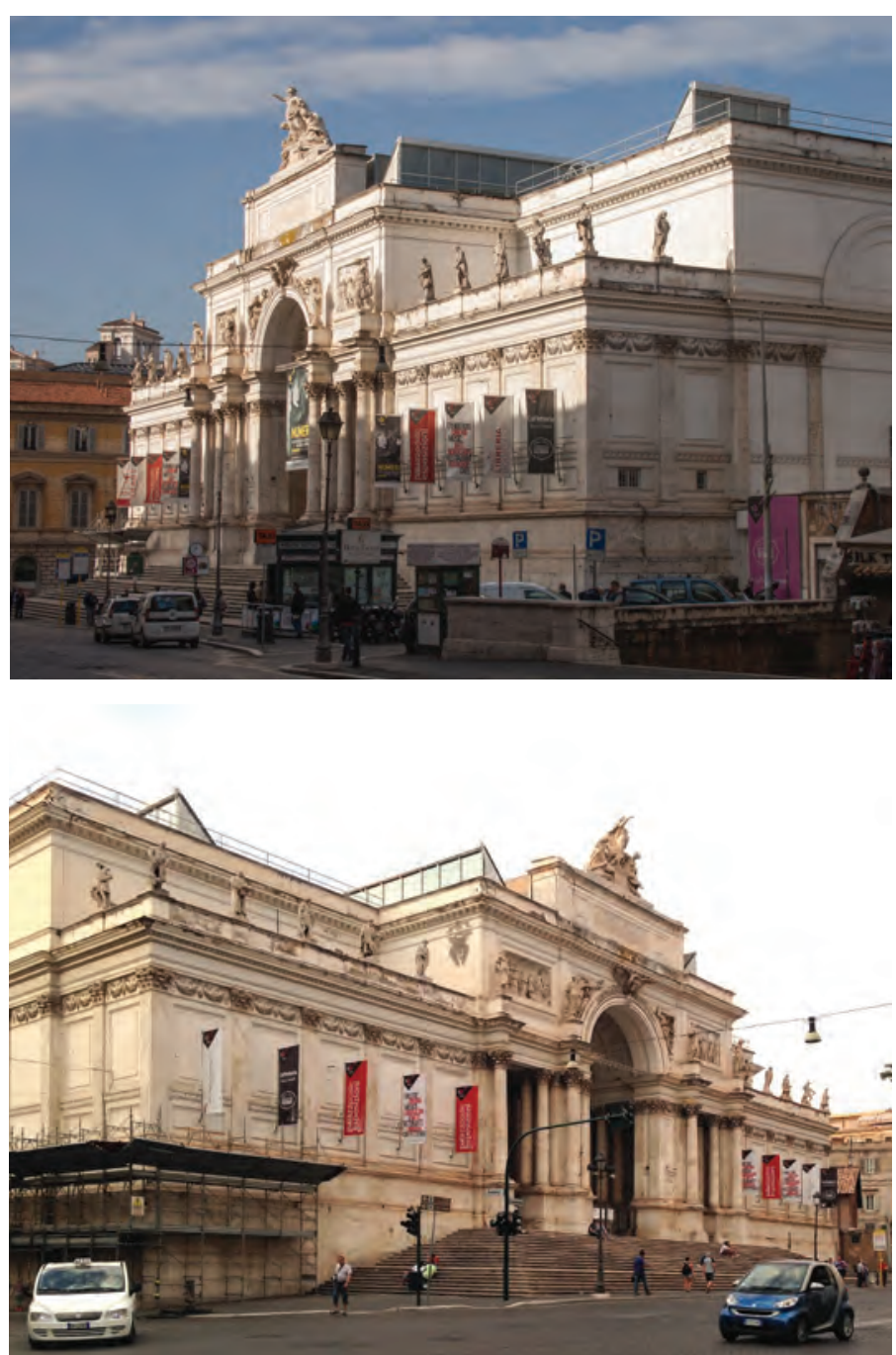
Fig. 6 Revestimento da fachada da Mostra da Revolução Fascista, 1932
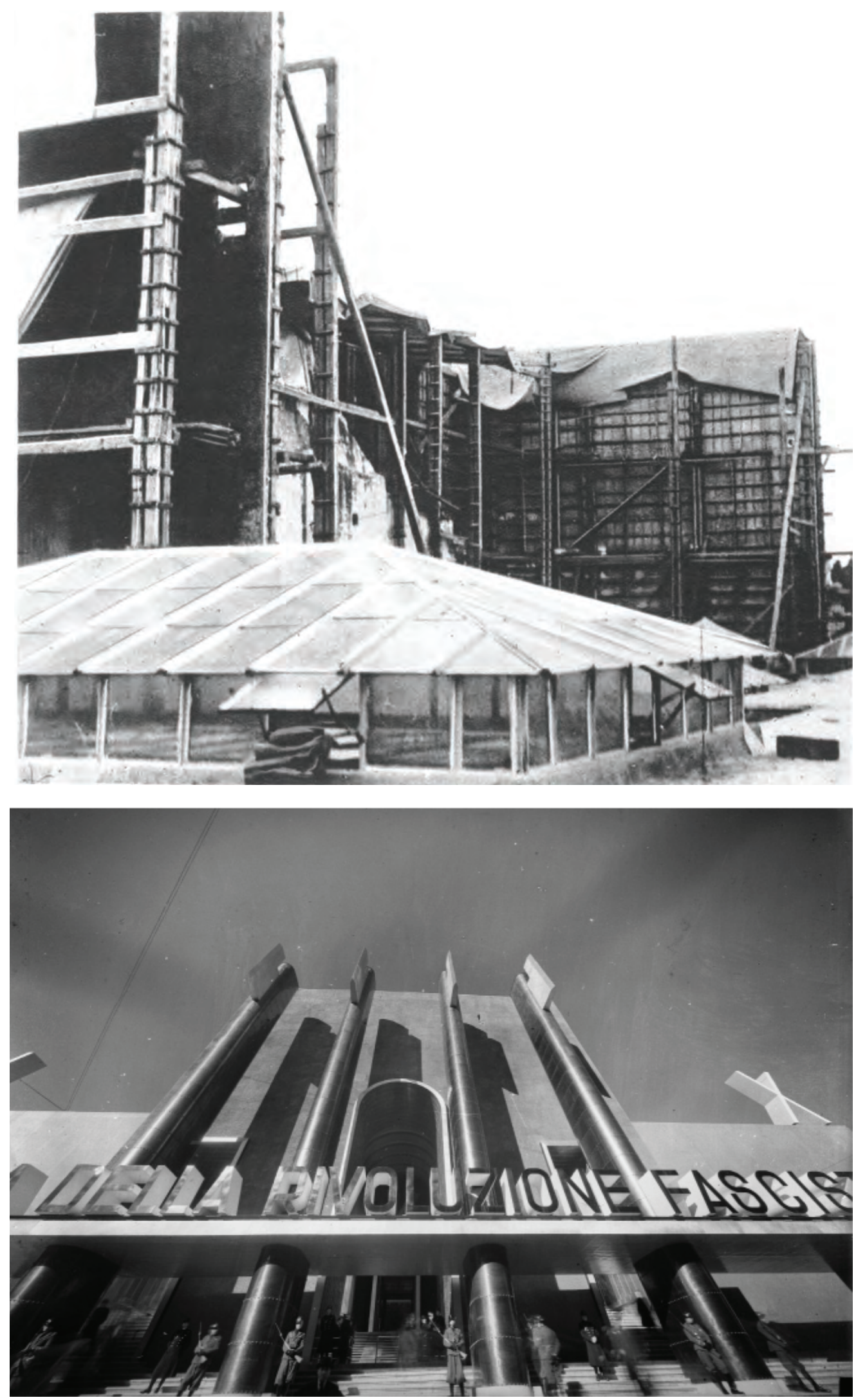

Fig. 7 Fachada do Palácio das Exposições, Mostra da Revolução Fascista, Roma, 1932 

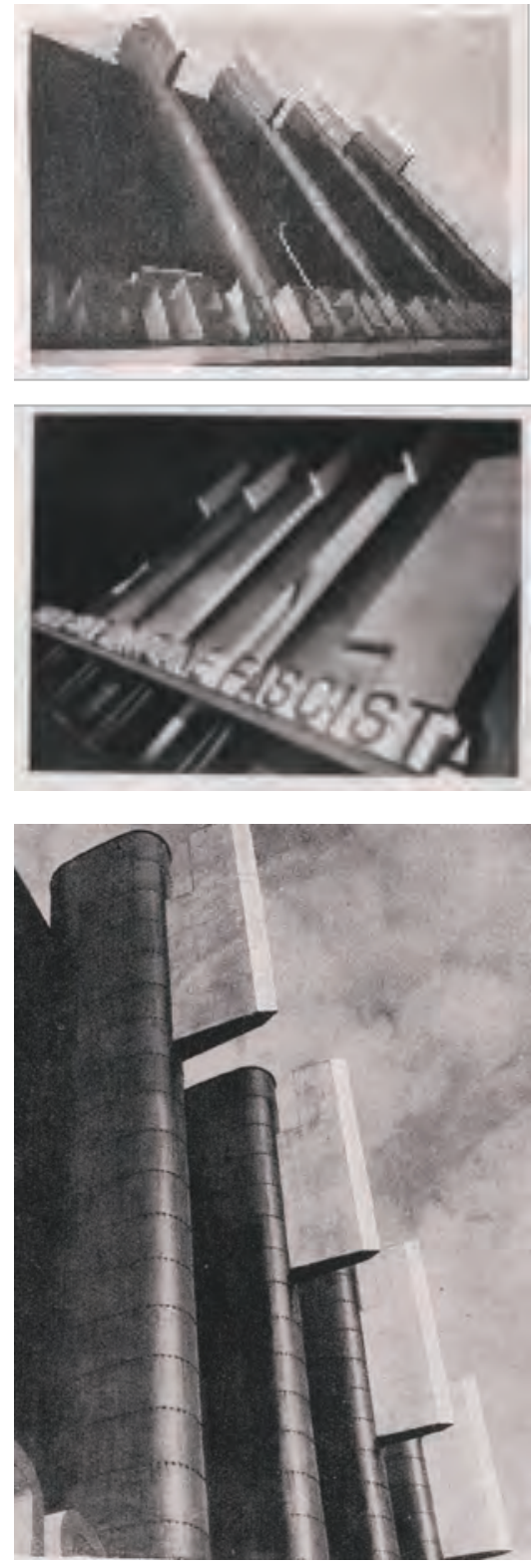

Fig. 8 Detalhes da fachada da Mostra da Revolução Fascista, Roma, Itália 1932
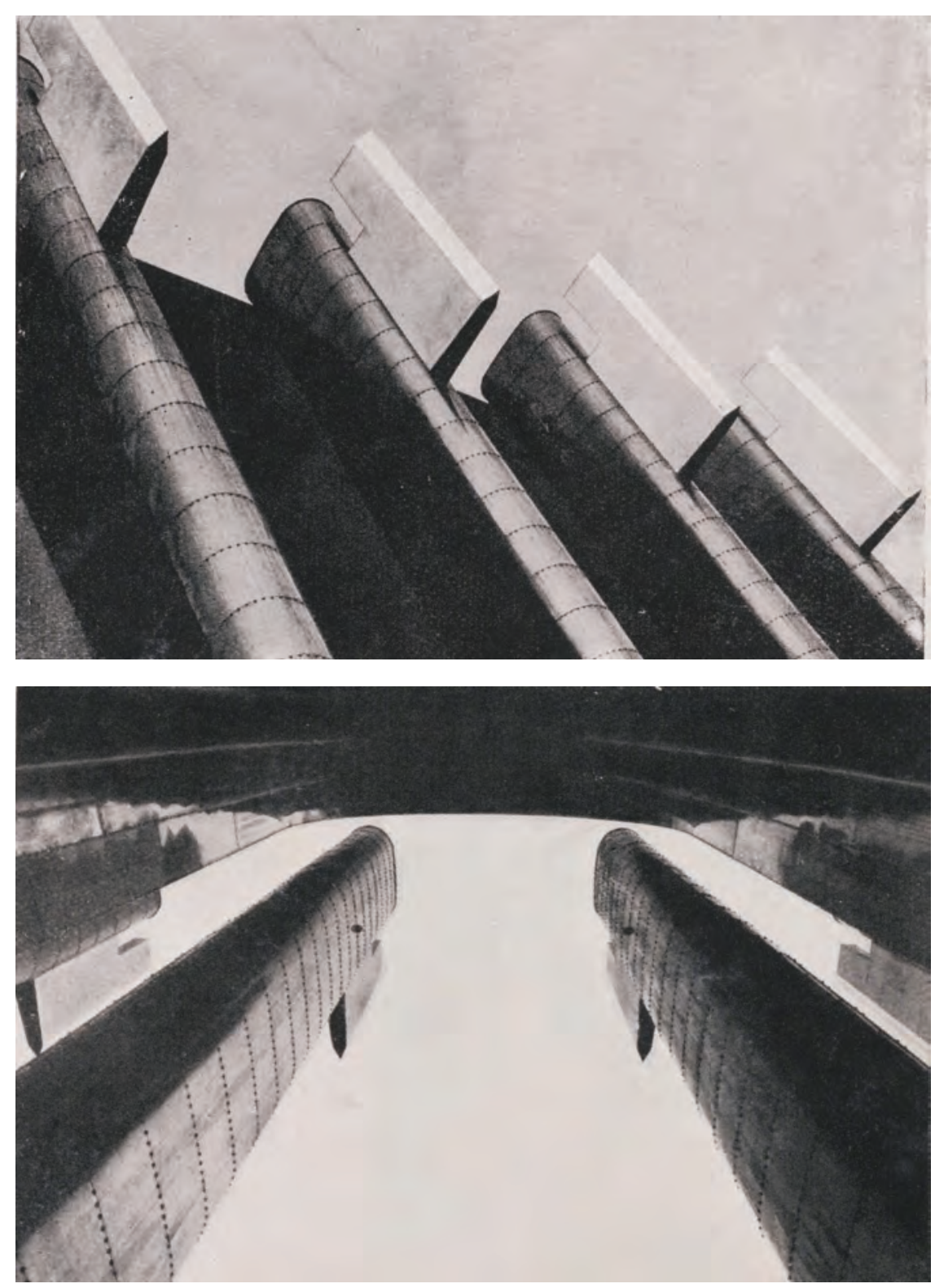

Fig. 9 Gustav Klutsis, detalhe do cartaz "Pela Luta por Carvão e Metal", Moscou, 1932

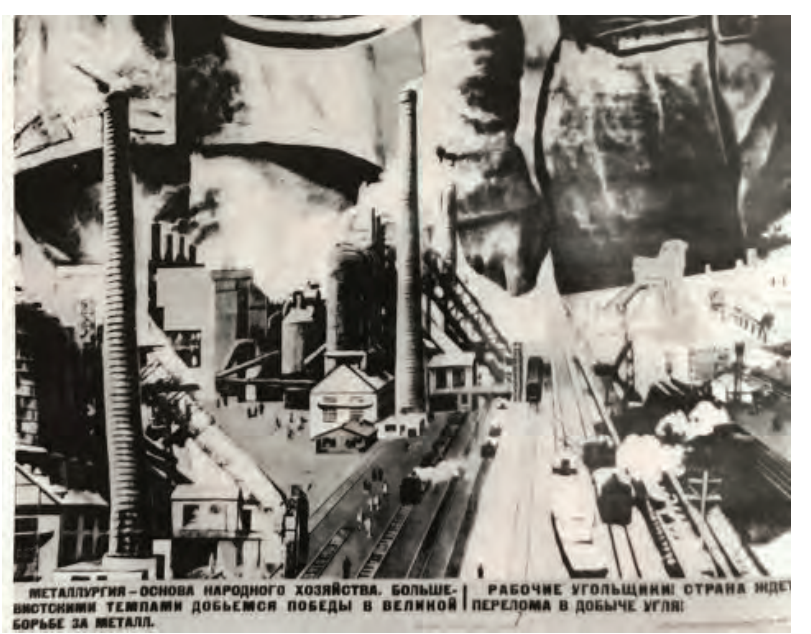

Fig. 10 Valentina Kulagina, detalhe do cartaz "Primeiro de Maio: Transmitir as Novas Vitórias!", Moscou, 1930

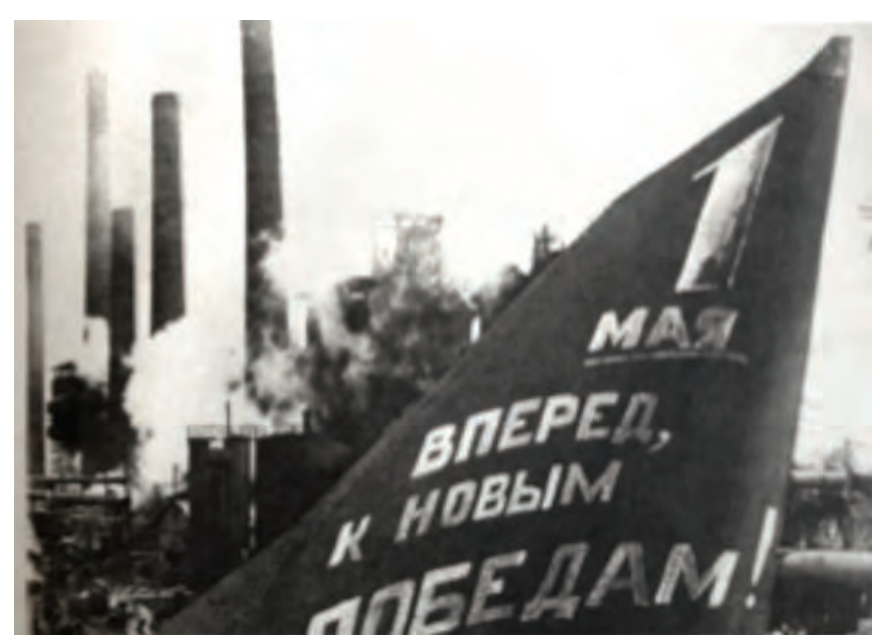


Fig. 11 À direita, primeiro rascunho da fachada da Mostra da Revolução Fascista, Roma, 1932

Fig. 12 Canto inferior, à direita, Fachada da Mostra da Revolução Fascista, Roma, 1932

Fig. 13 Canto inferior, à esquerda, moeda de uma lira com o símbolo do fascio romano, Itália, 1923

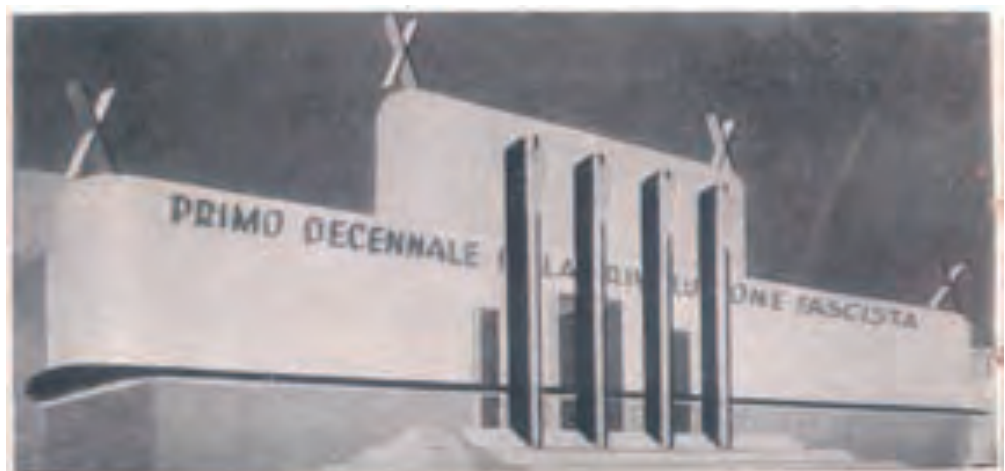

primisvo borzetto della thecian
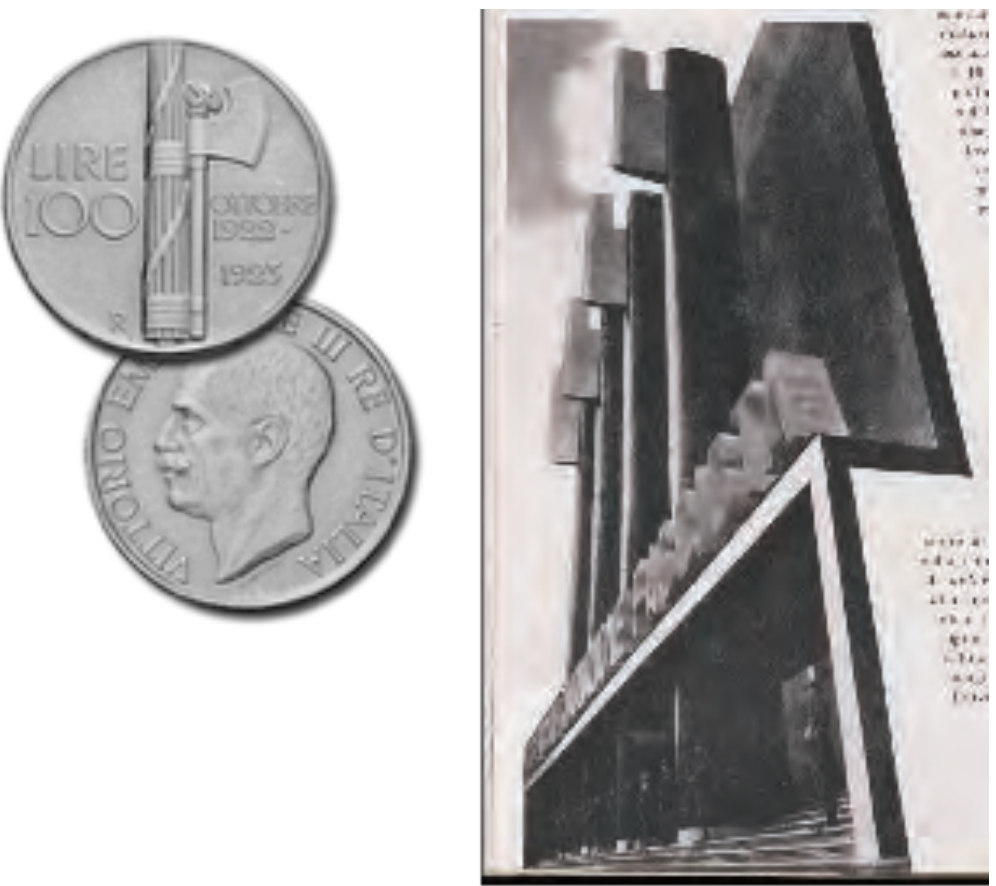

Fig. 14 Sala N, Mostra da Revolução Fascista, 1932

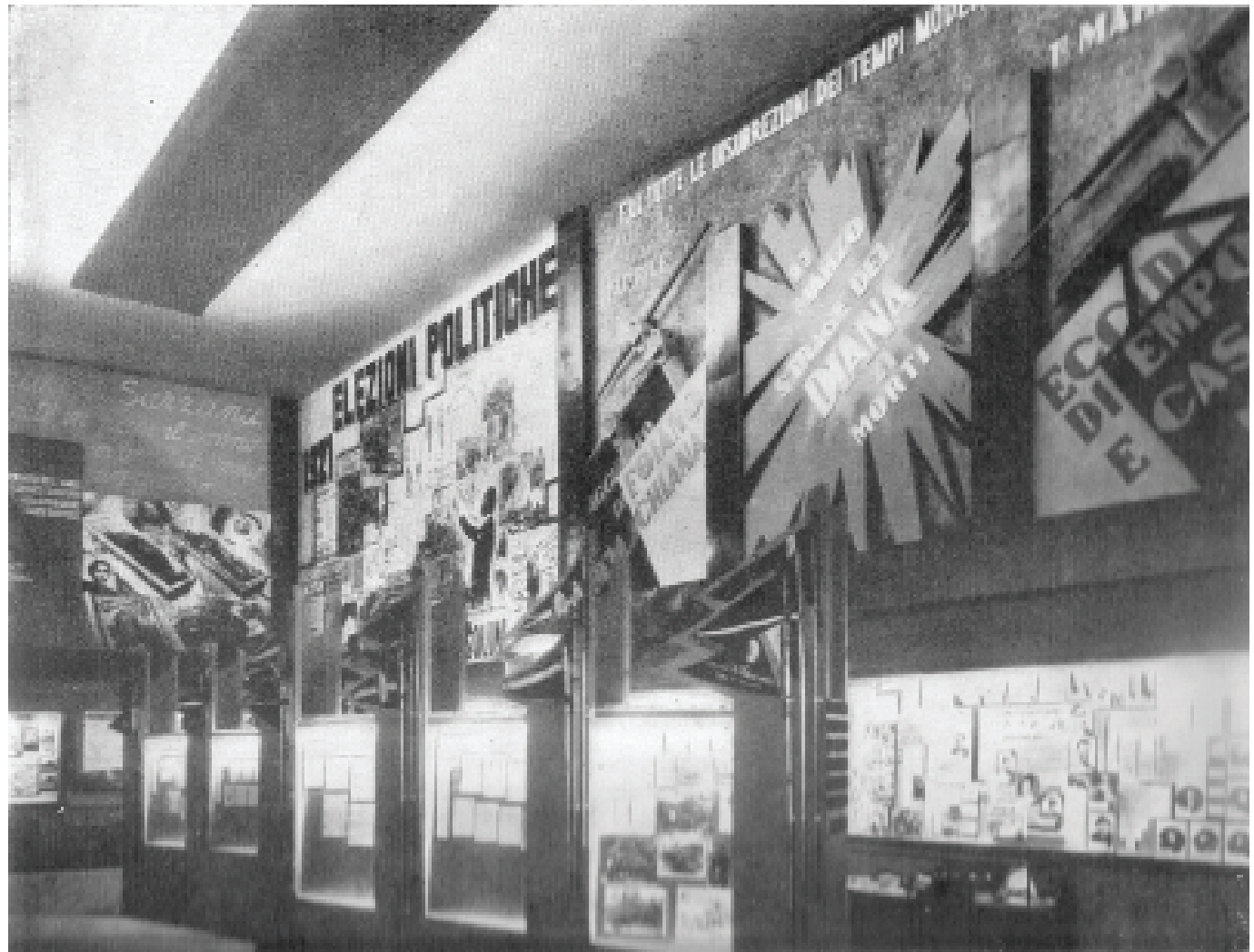




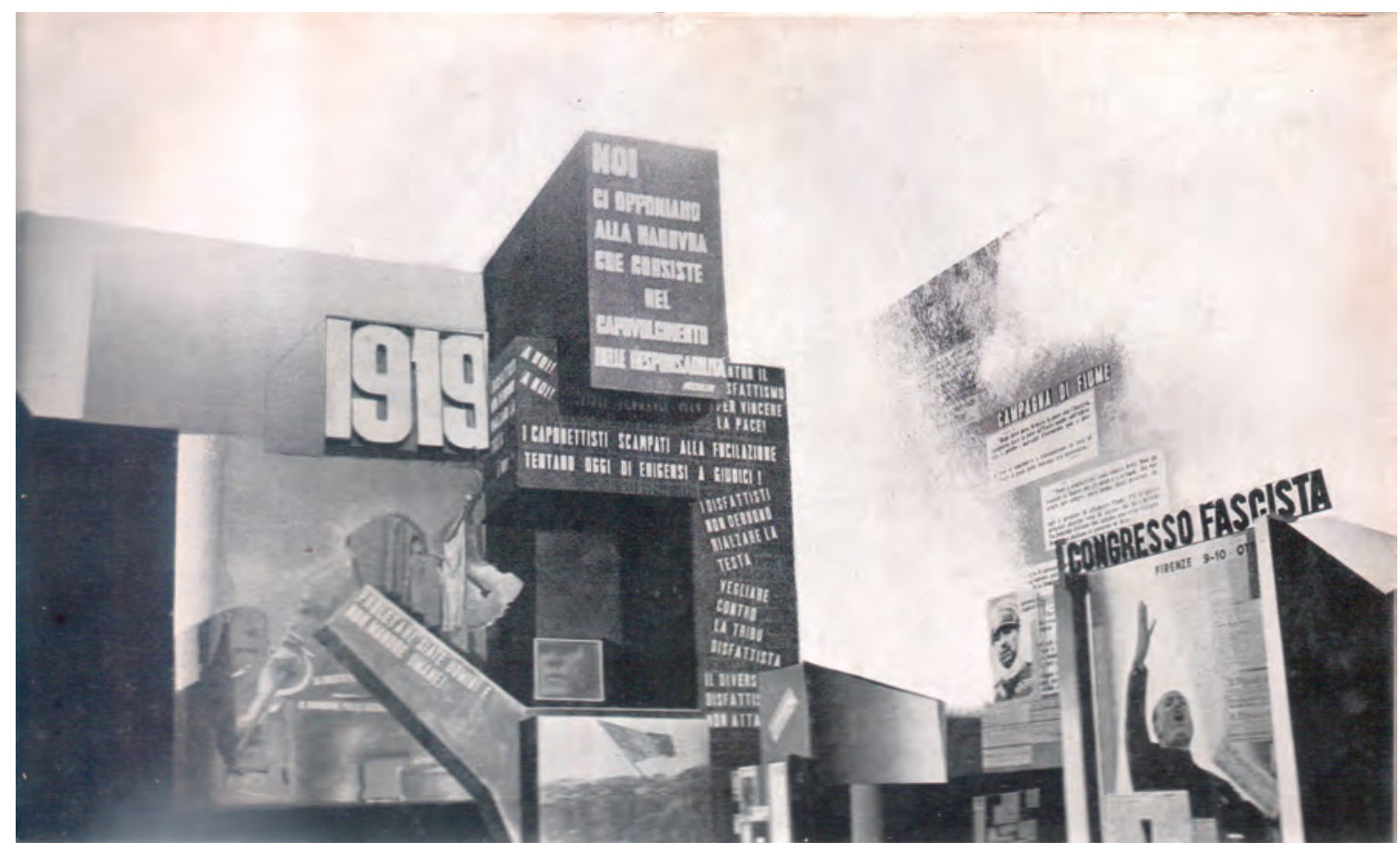

Fig. 15 Sala G, Mostra

da Revolução Fascista,

1932
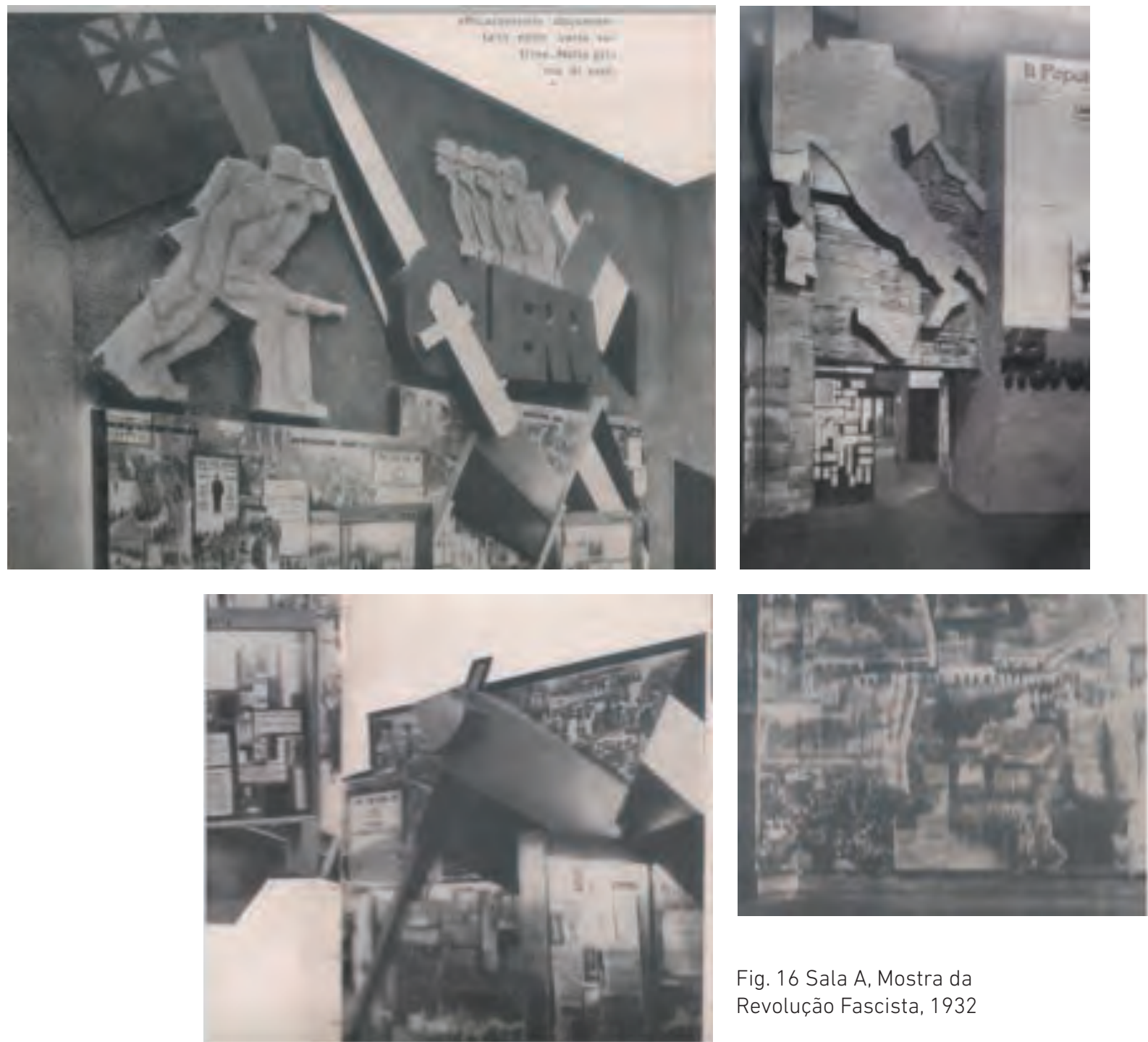

Fig. 16 Sala A, Mostra da

Revolução Fascista, 1932 
Fig. 17 Sala U, Mostra

da Revolução Fascista,

1932

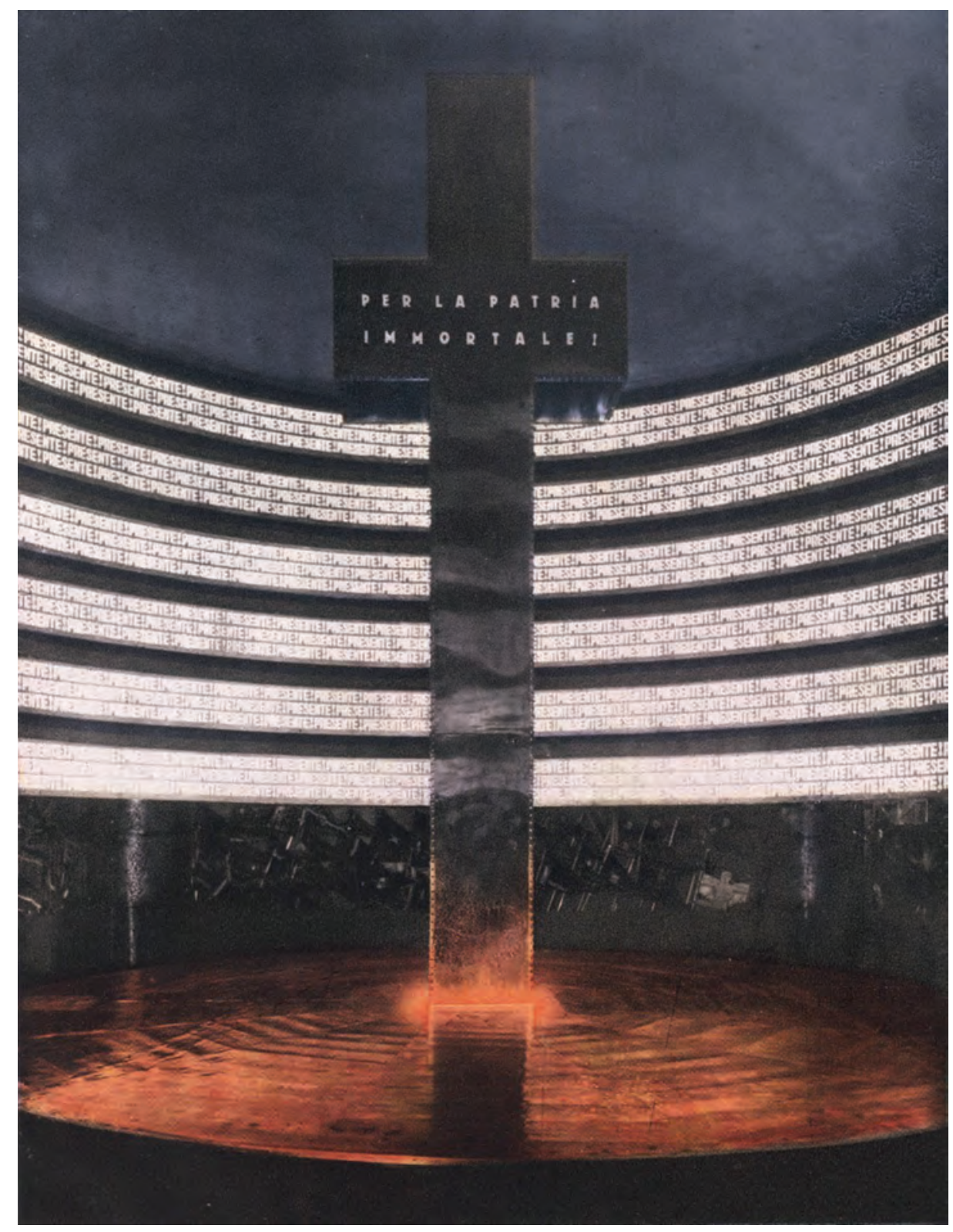



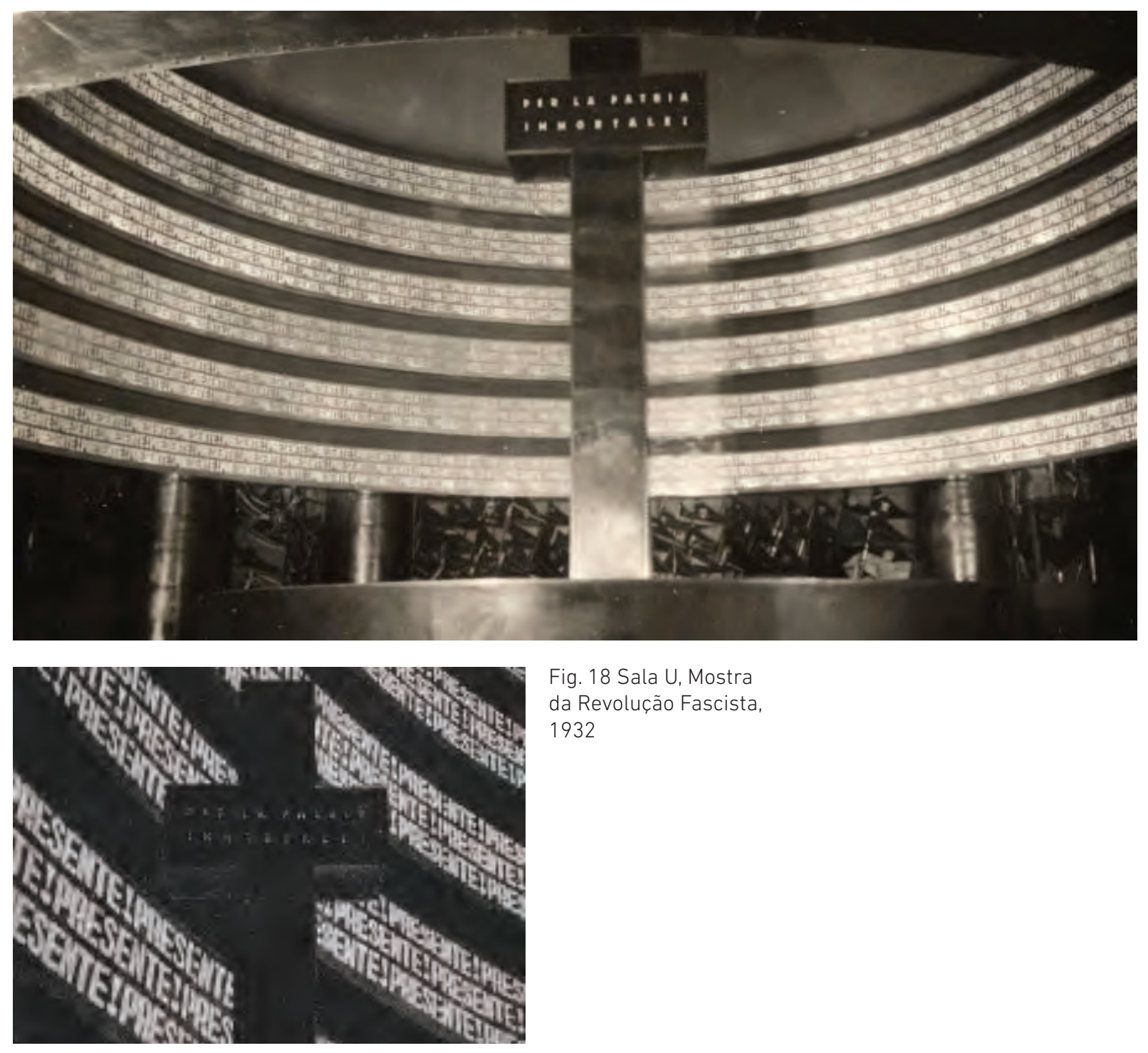

Fig. 18 Sala U, Mostra

da Revolução Fascista,

1932

Fig. 19 Sala Q, Mostra

da Revolução Fascista,

1932

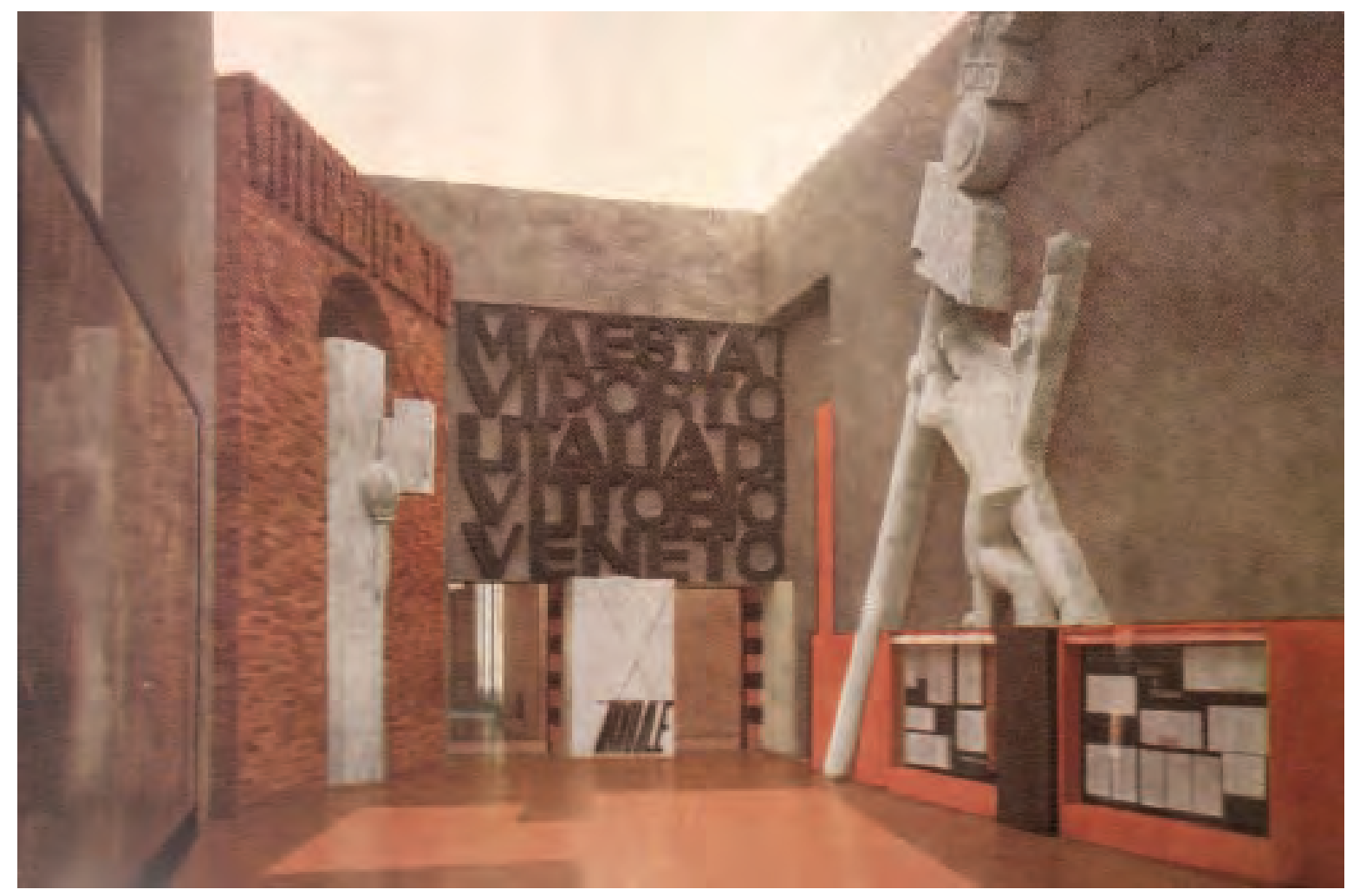


Fig. 20 Sala S, Mostra

da Revolução Fascista,

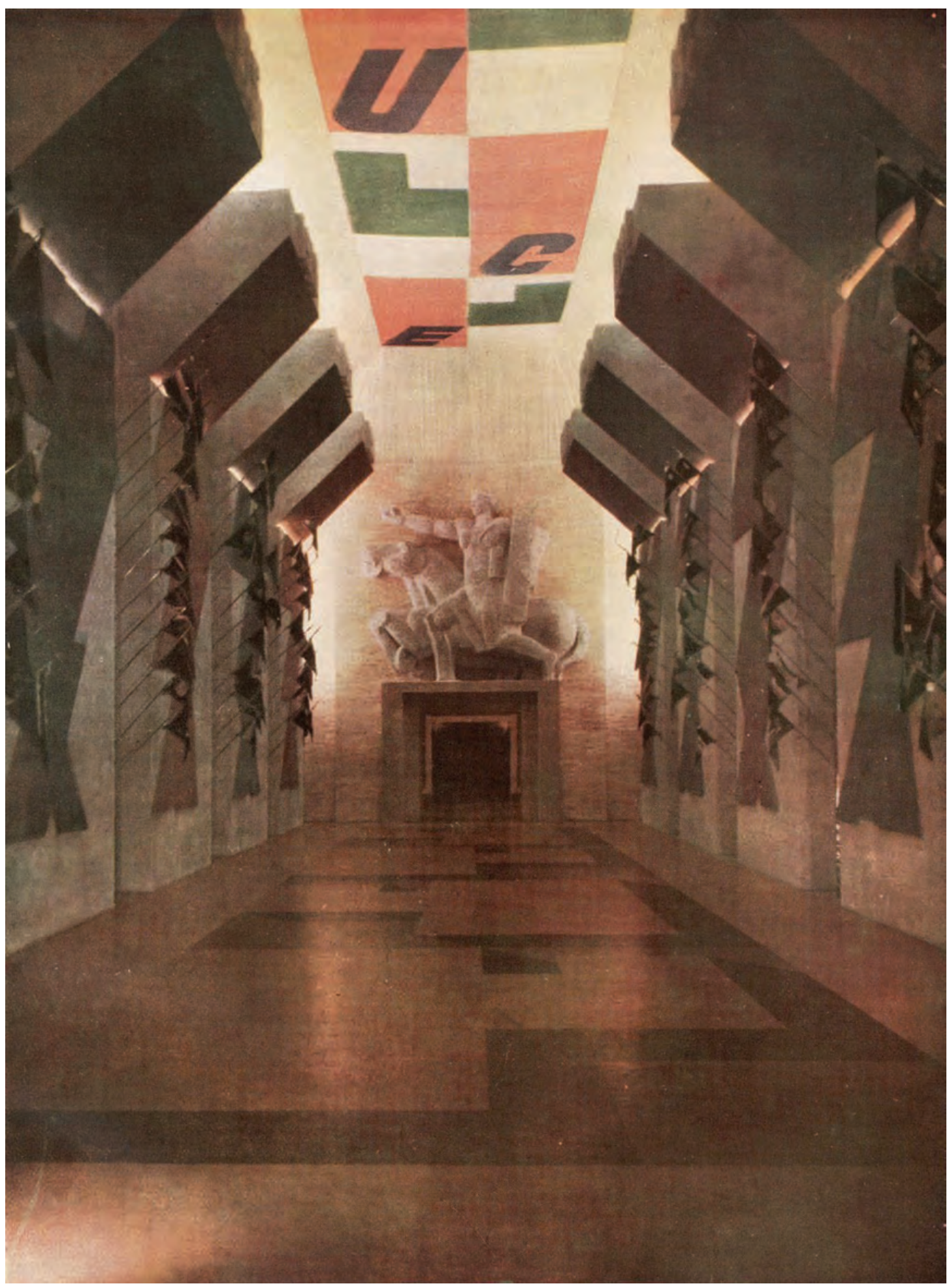



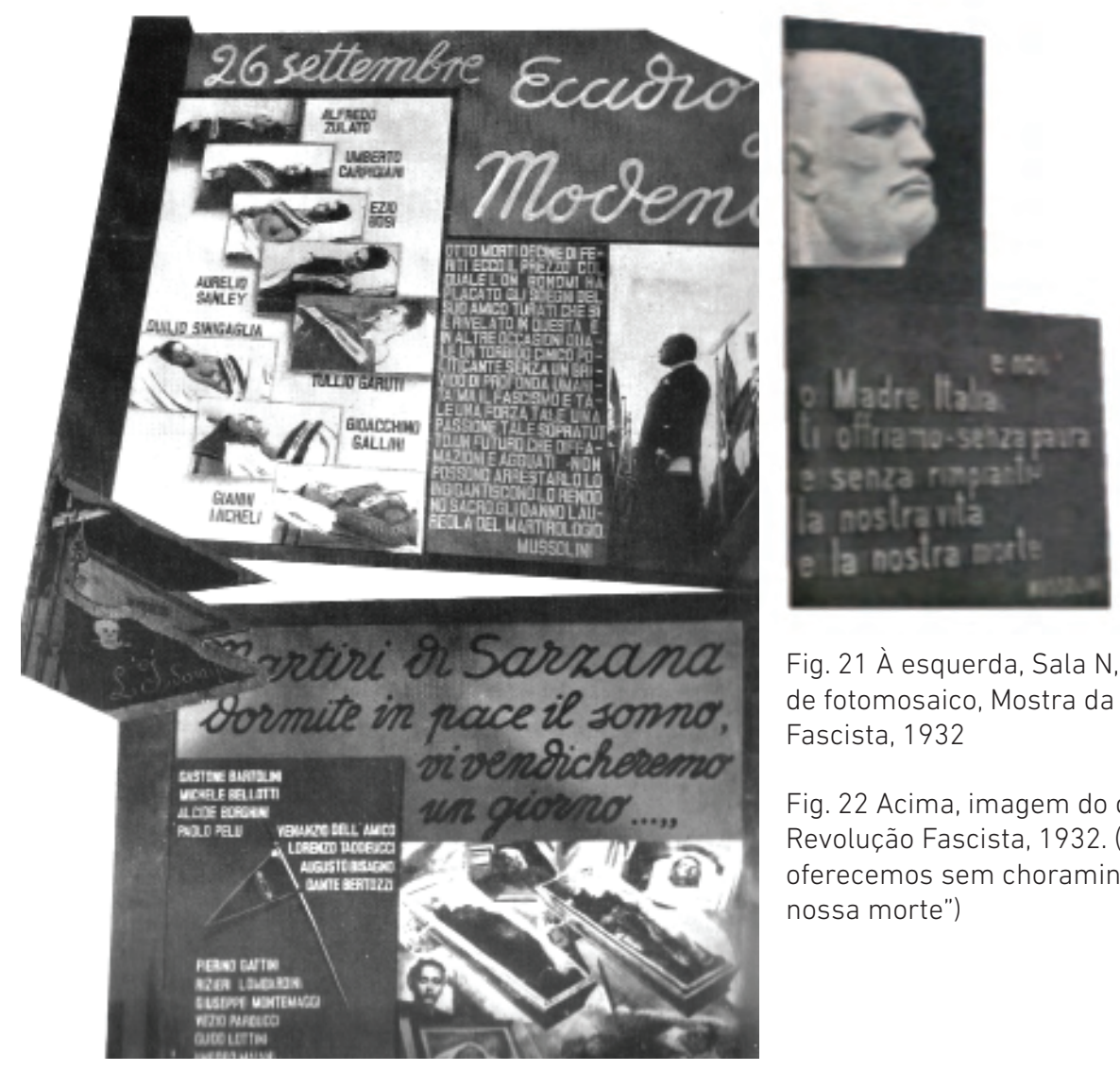

Fig. 21 À esquerda, Sala N, fragmento de fotomosaico, Mostra da Revolução Fascista, 1932

Fig. 22 Acima, imagem do catálogo da Mostra da Revolução Fascista, 1932. (Texto: "Ó Mãe Itália, te oferecemos sem choramingar a nossa vida e a nossa morte")

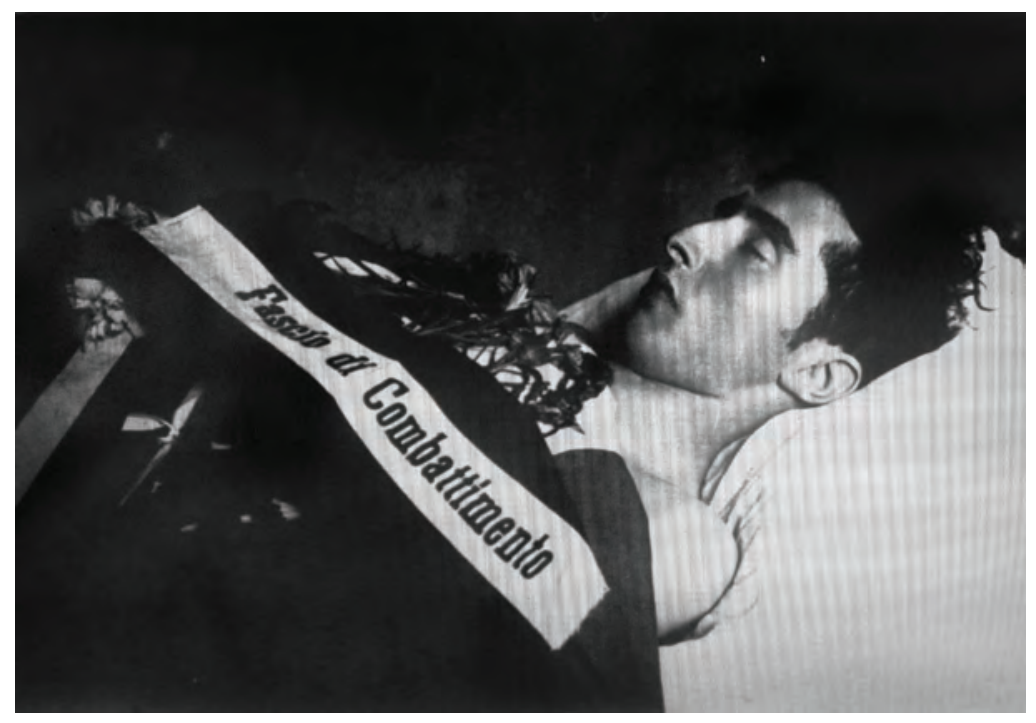

Fig. 23 À esquerda e abaixo, fotografias do arquivo da Mostra da Revolução Fascista, 1932, ACS
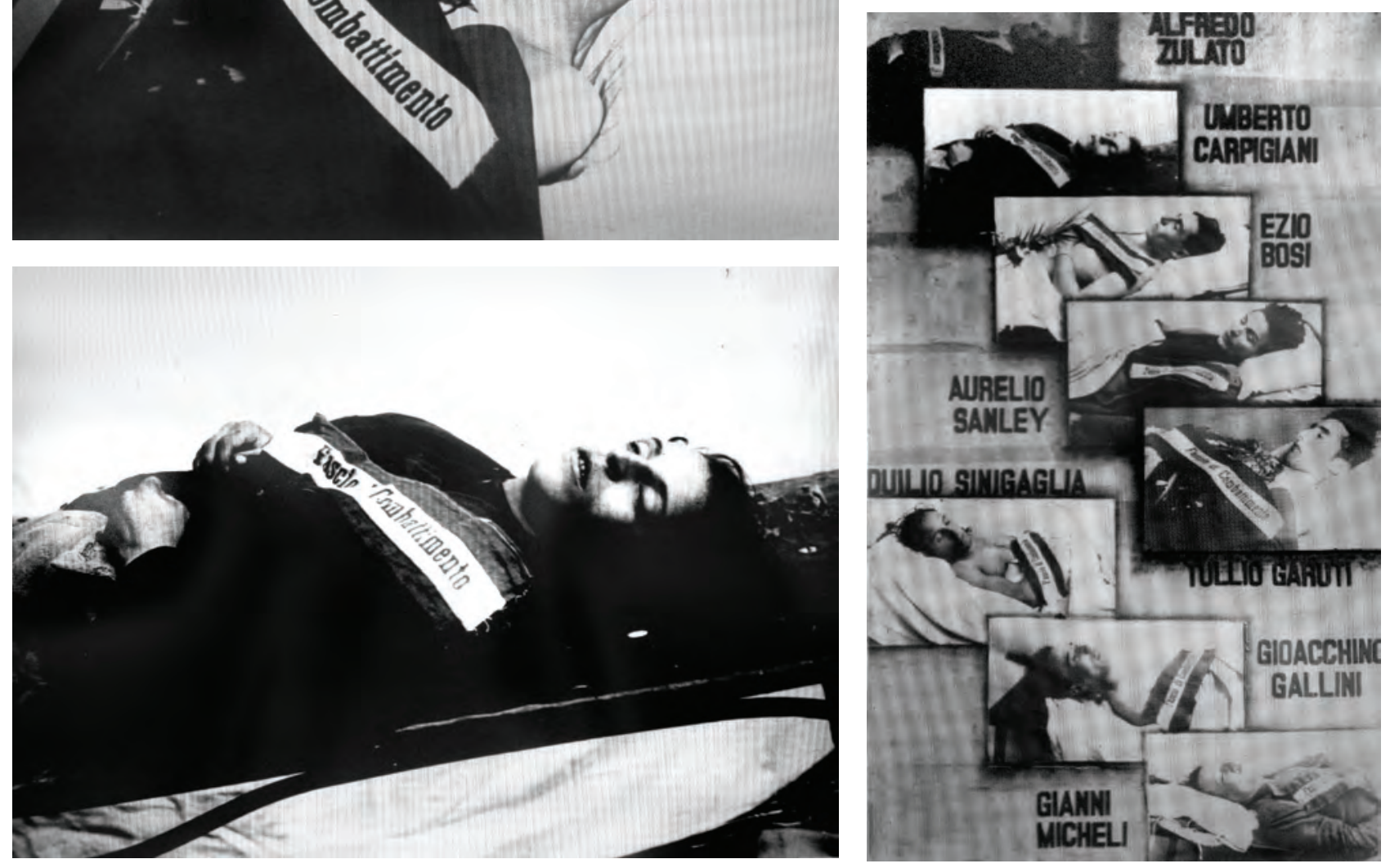
Fig. 24 Fotografias do arquivo da

Mostra da Revolução Fascista

1932, ACS
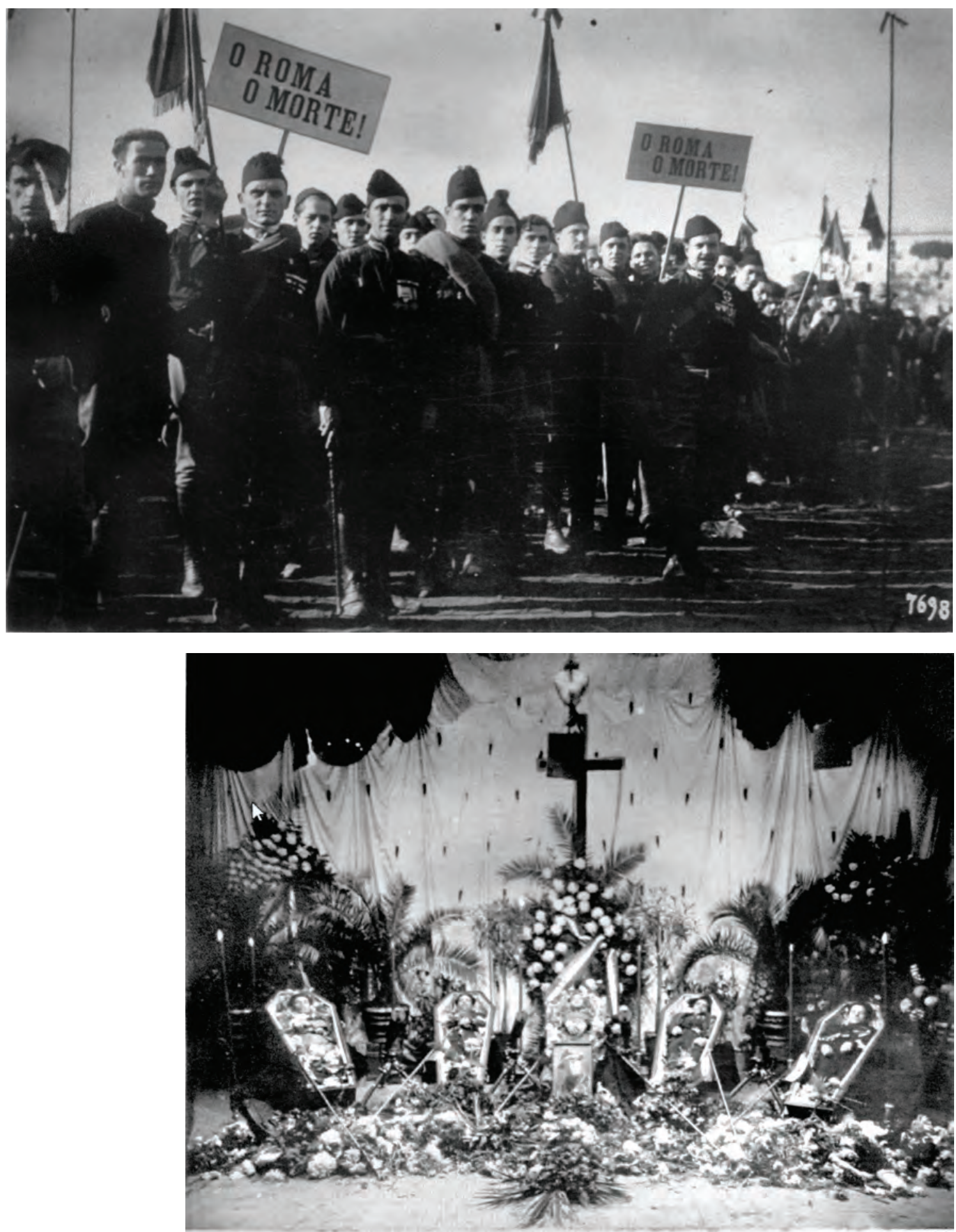

\footnotetext{
Favest bolognea

(Namim, Paflech, Diszan ex.

caduti a S. Tuffllo (Bologna) nell'Oth bre 192 ?
} 

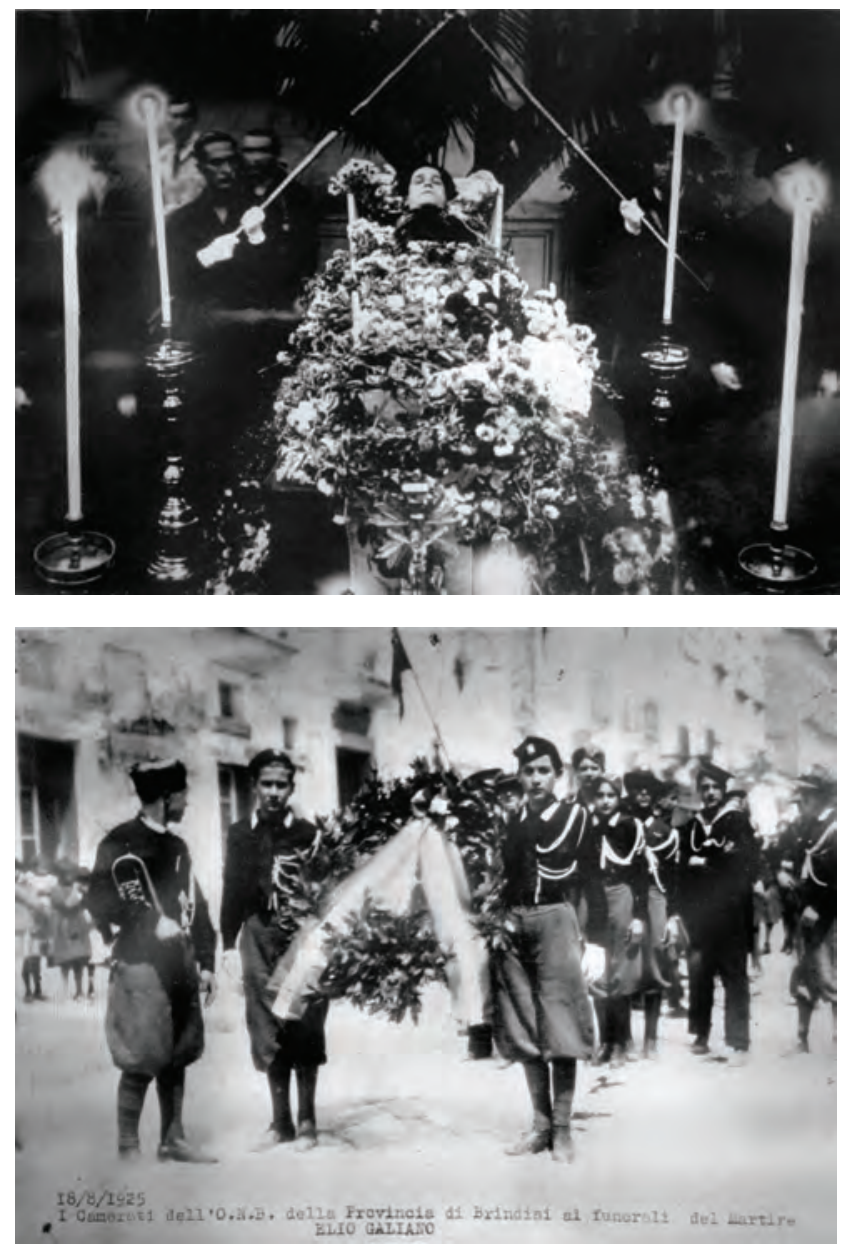

Fig. 25 À esquerda e abaixo, fotografias do arquivo da Mostra da Revolução Fascista, 1932, ACS

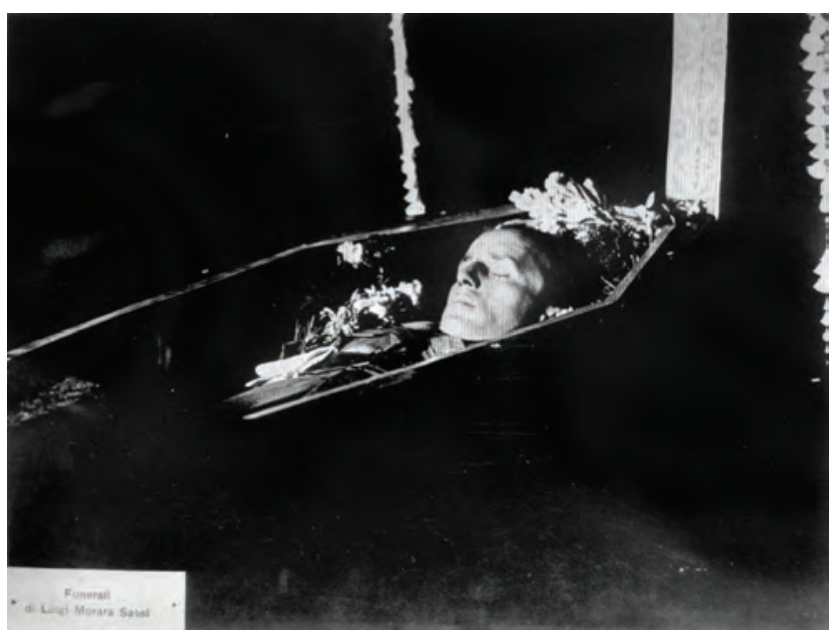

Fig. 26 Hall de entrada da Mostra da Revolução Fascista, 1932 (Texto: "Em nome de Deus e da Itália = juro seguir as ordens do Duce e de servir com todas as minhas forças e se necessário com o meu sangue a causa da revolução fascista")
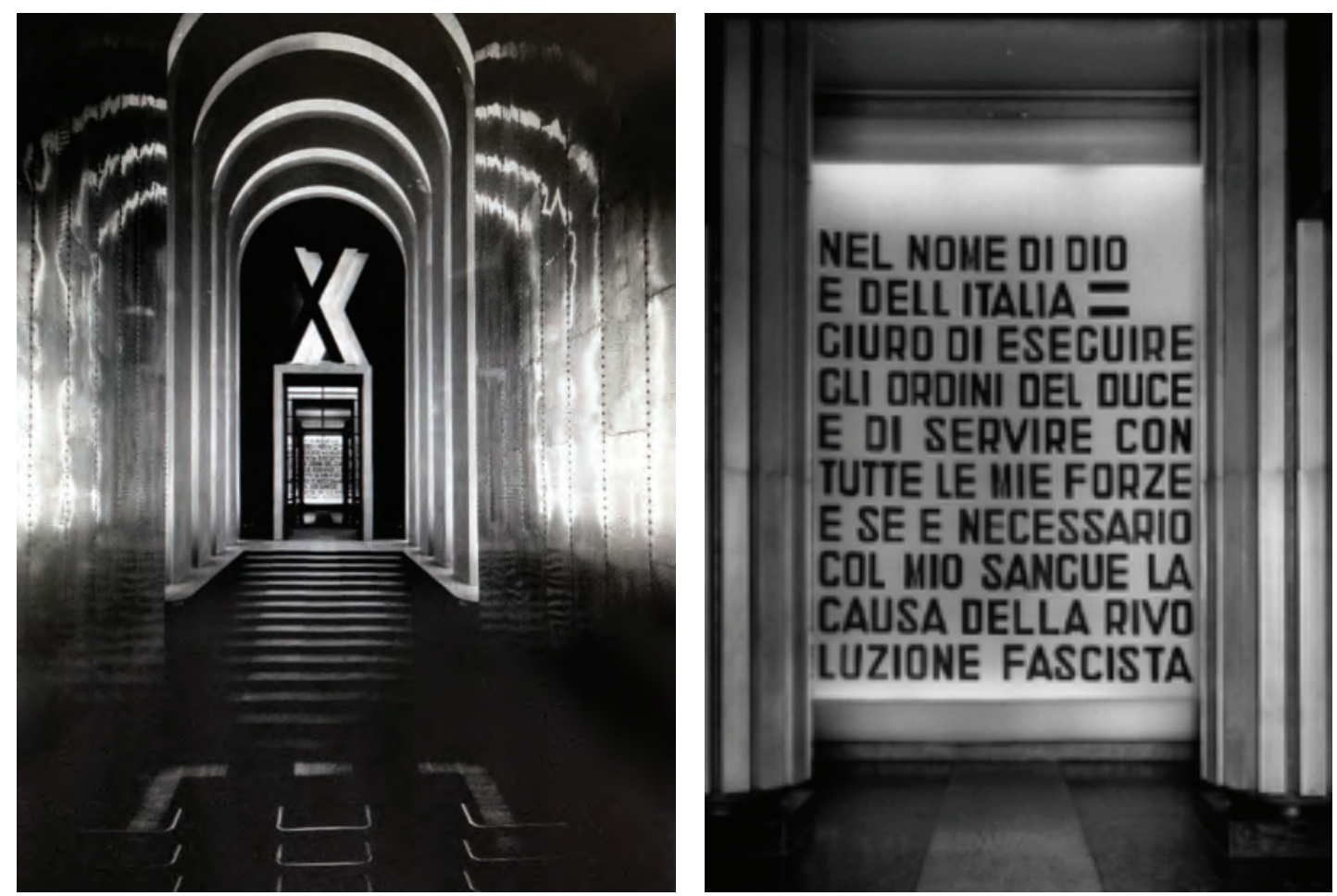
Fig. 27 Sala S, Mostra

da Revolução Fascista,
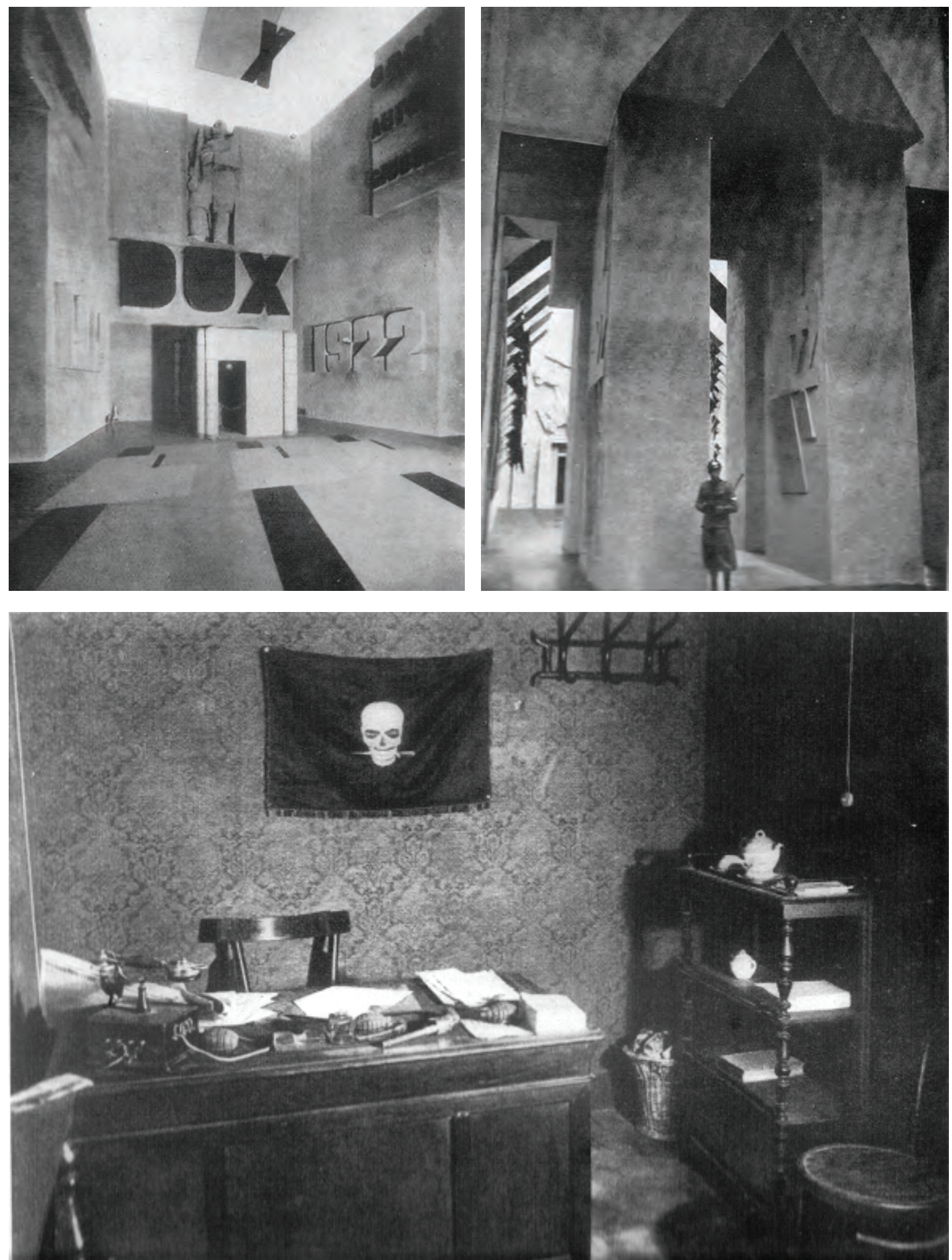

Fig. 28 Sala R, escritório de Mussolini na primeira sede do "Il Popolo d'Italia". Mostra da Revolução Fascista, 1932 
Fig. 29 Sala T, remontagem do escritório de Mussolini

na segunda sede do "Il Popolo d'Italia" para a Mostra da

Revolução Fascista, 1932
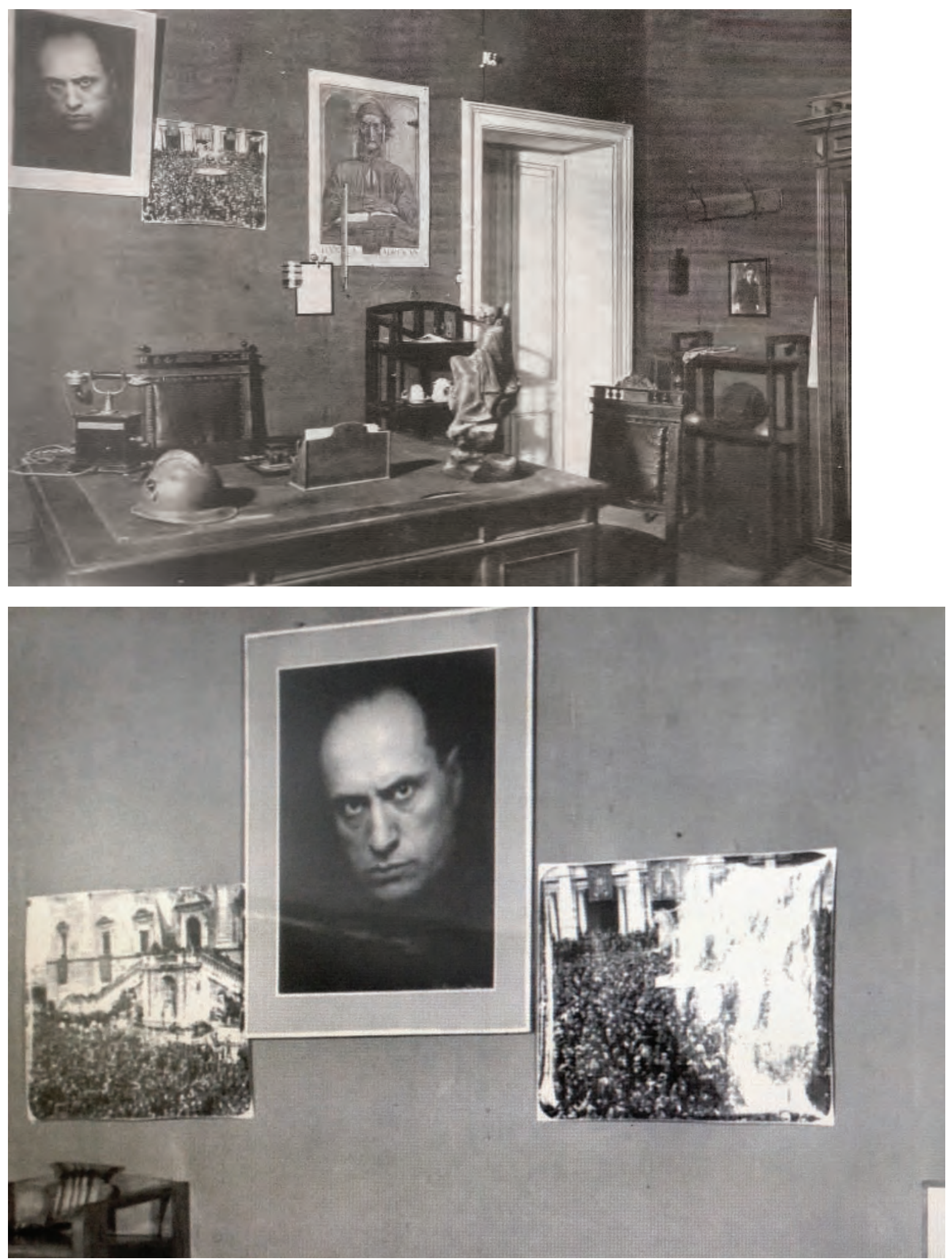

Fig. 30 Sala T, detalhe do escritório de Mussolini, Mostra da Revolução Fascista, 1932 
Fig. 31 Sala T, detalhe do escritório

de Mussolini, Mostra da Revolução

Fascista, 1932
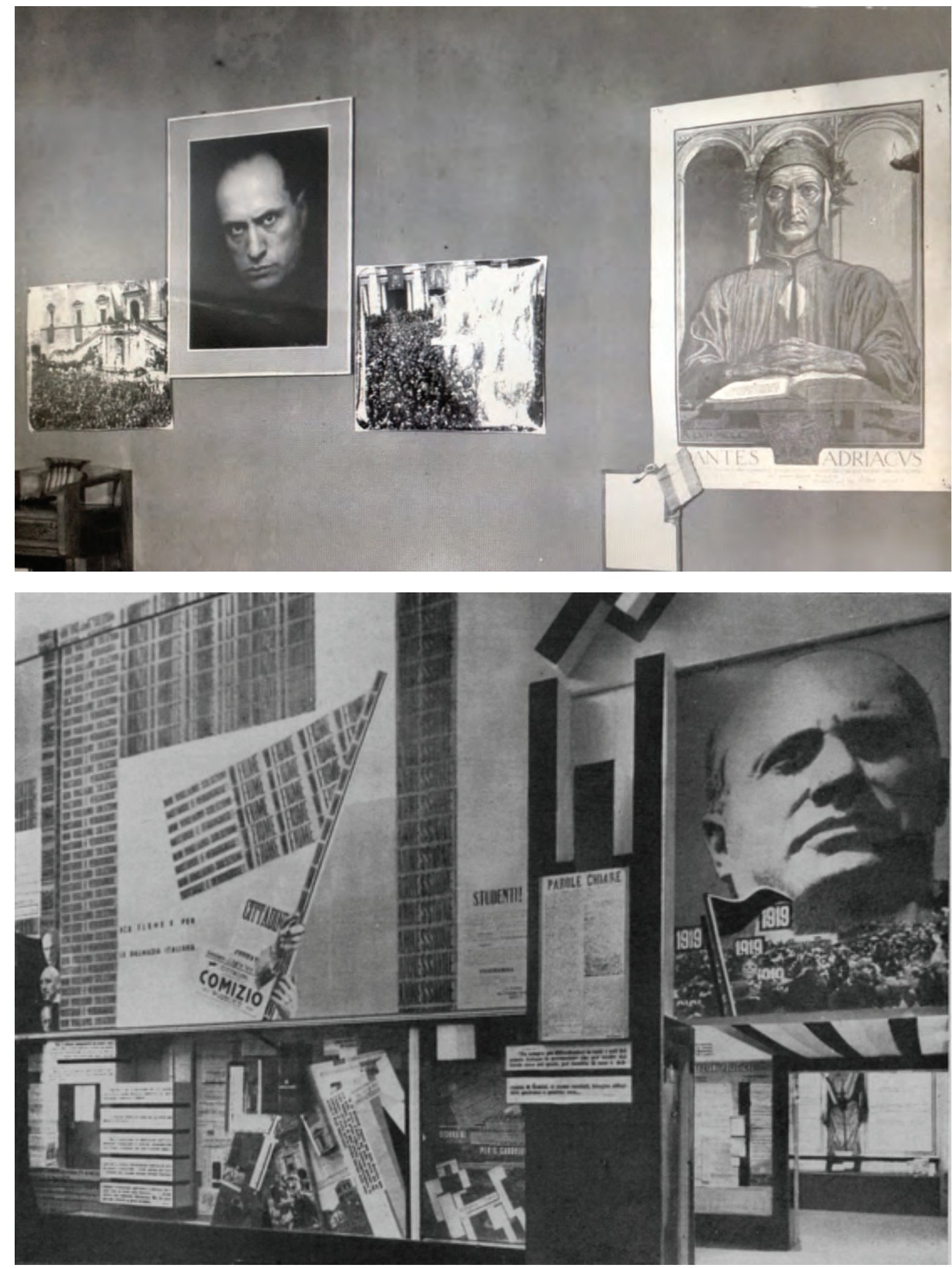

Fig. 32 Fotomontagem da Sala G. Mostra da Revolução Fascista, 
Fig. 33 Detalhe da fotomontagem da

Sala G, Mostra da Revolução Fascista,

1932
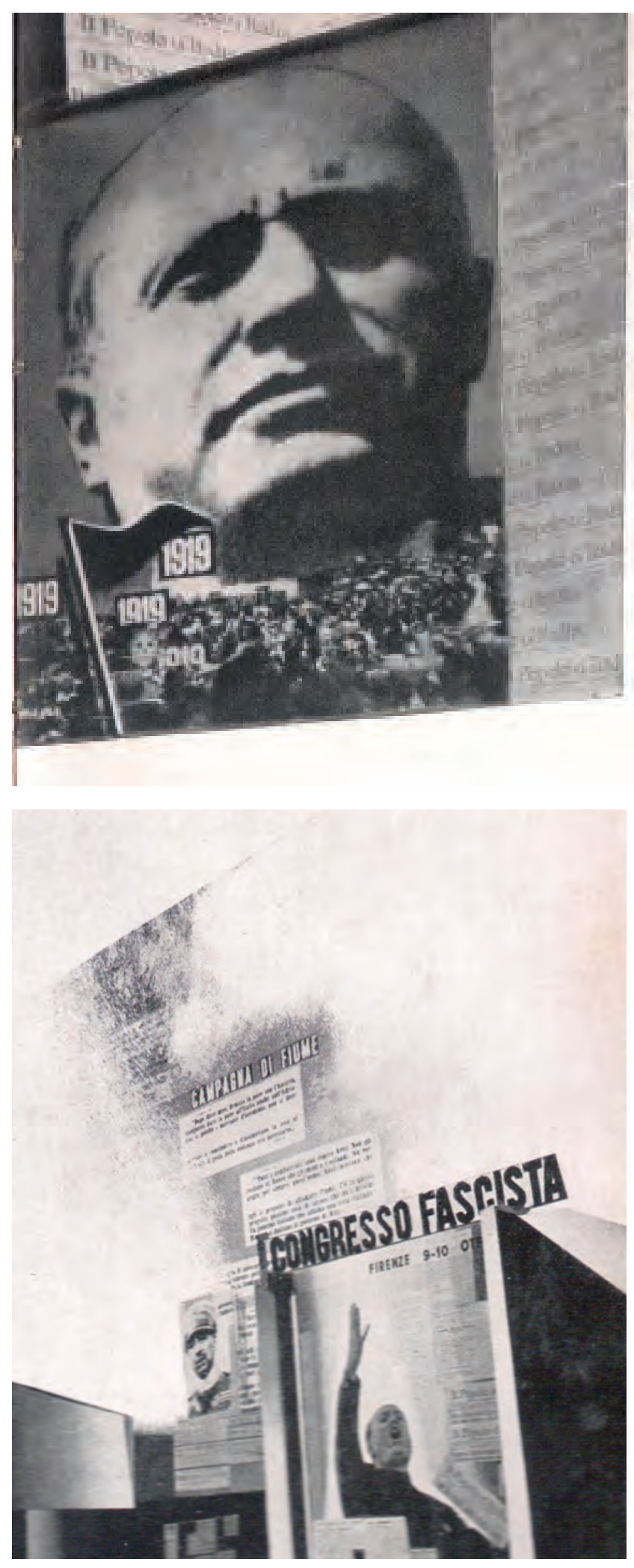

Fig. 34 Detalhe da Sala

G, Mostra da Revolução

Fascista, 1932 


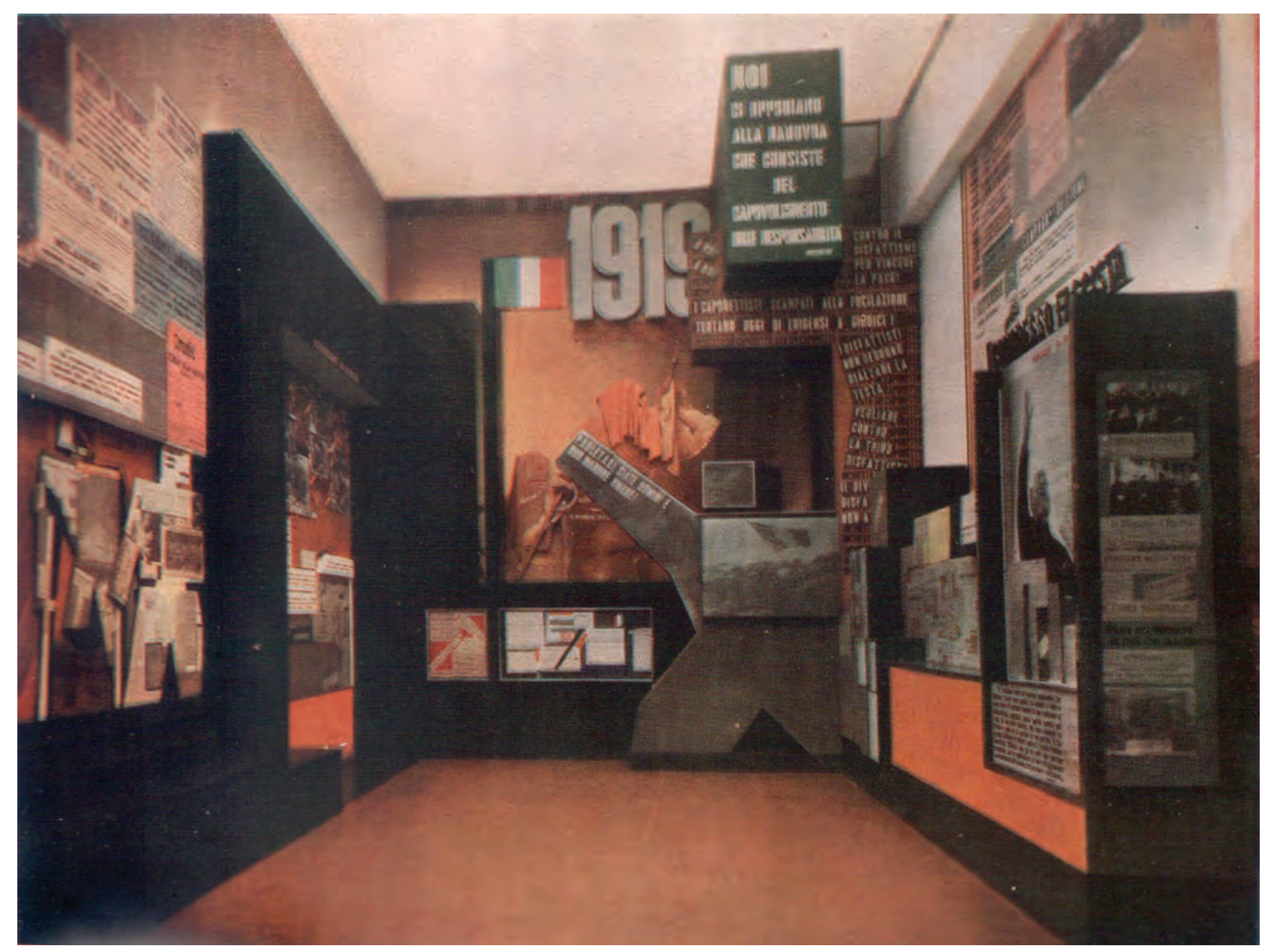

Fig. 35 Sala G, Mostra da Revolução Fascista, 


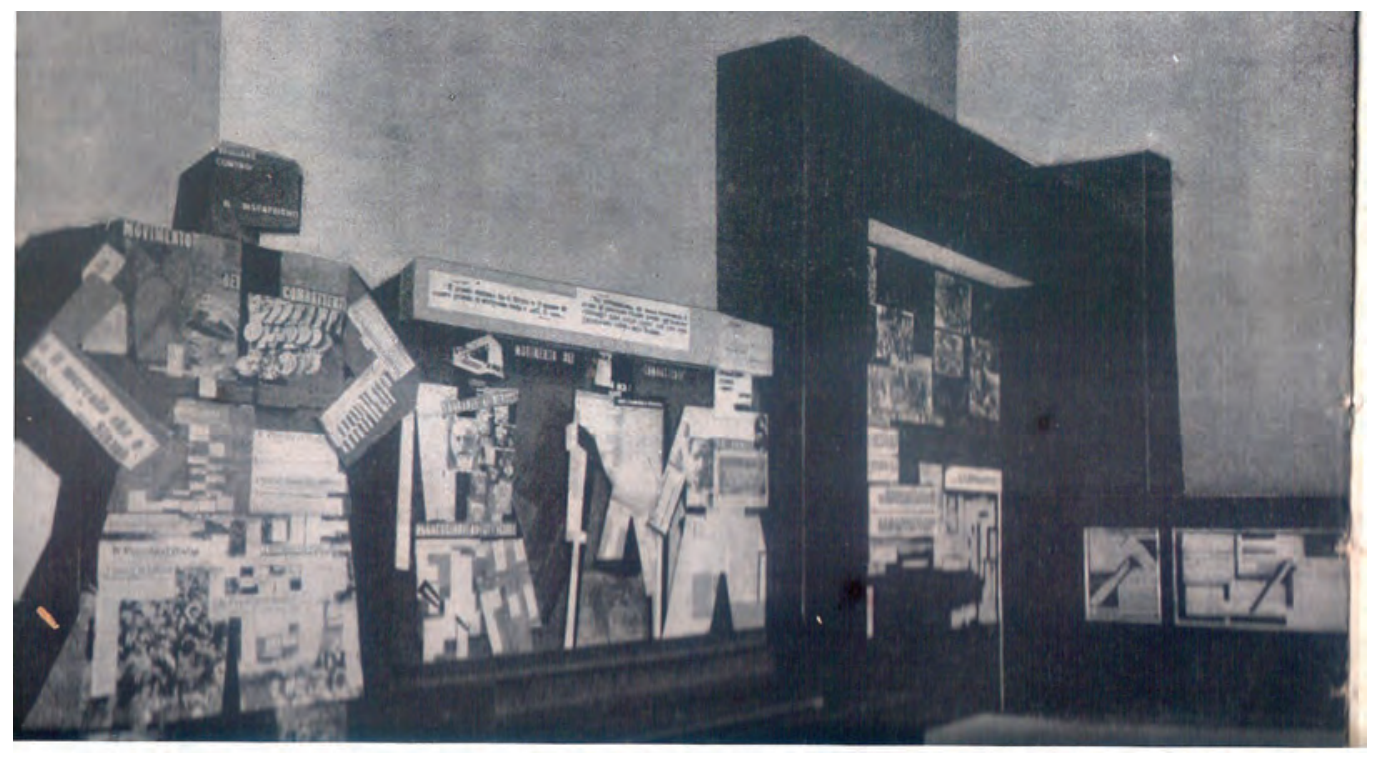

Fig. 36 Detalhes da Sala G, Mostra da Revolução Fascista, 1932 (Texto escrito na cabeça de cada uma das três

silheutas: "a quem a honra? a nós", "a quem o sacrifício? a nós" e "os combatentes, contra o inimigo interno").
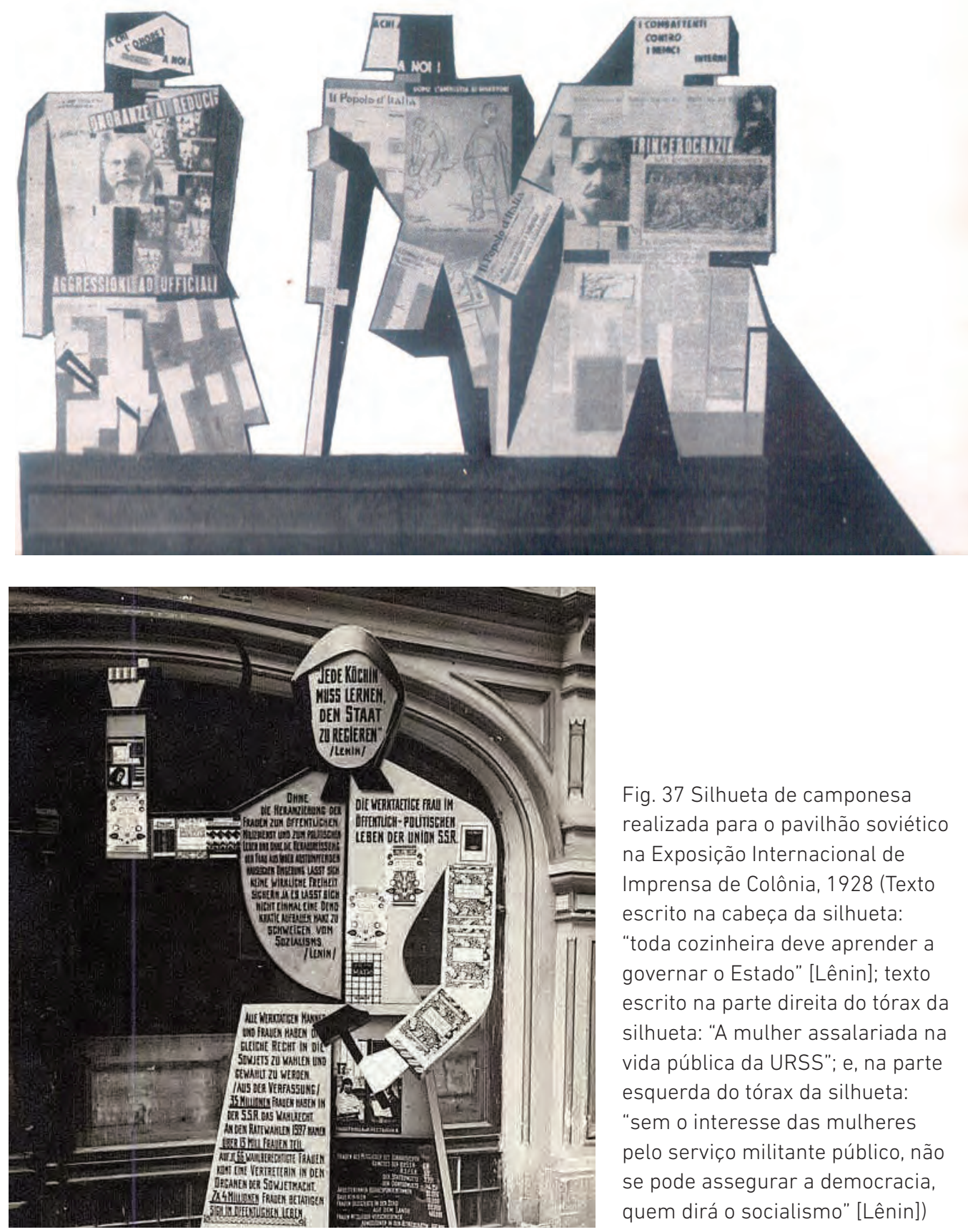

Fig. 37 Silhueta de camponesa realizada para o pavilhão soviético na Exposição Internacional de Imprensa de Colônia, 1928 (Texto escrito na cabeça da silhueta: "toda cozinheira deve aprender a governar o Estado" [Lênin]; texto escrito na parte direita do tórax da silhueta: "A mulher assalariada na vida pública da URSS"; e, na parte esquerda do tórax da silhueta: "sem o interesse das mulheres pelo serviço militante público, não se pode assegurar a democracia, quem dirá o socialismo" [Lênin]) 


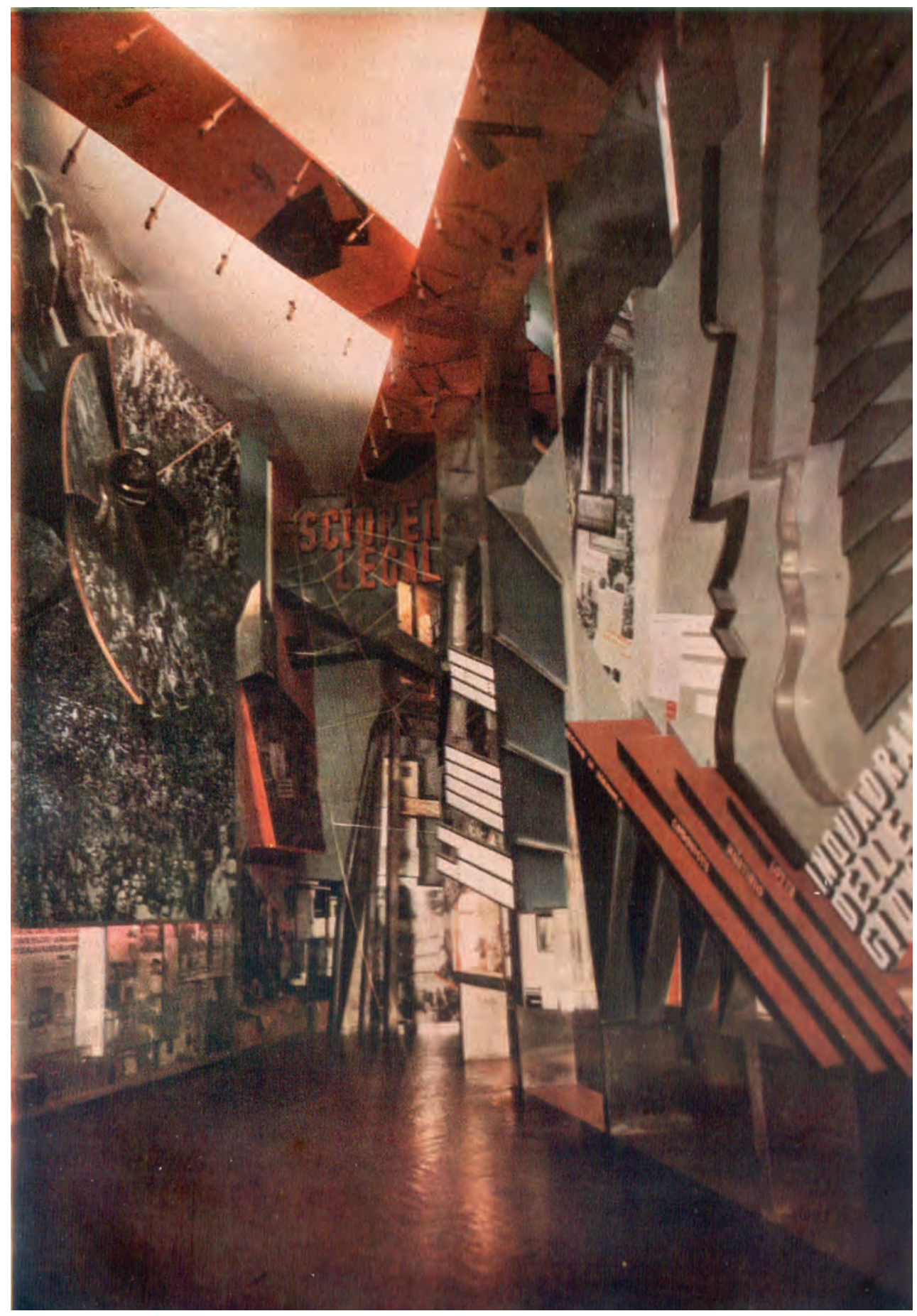

Fig. 38 Sala 0, Mostra da Revolução Fascista, 1932 


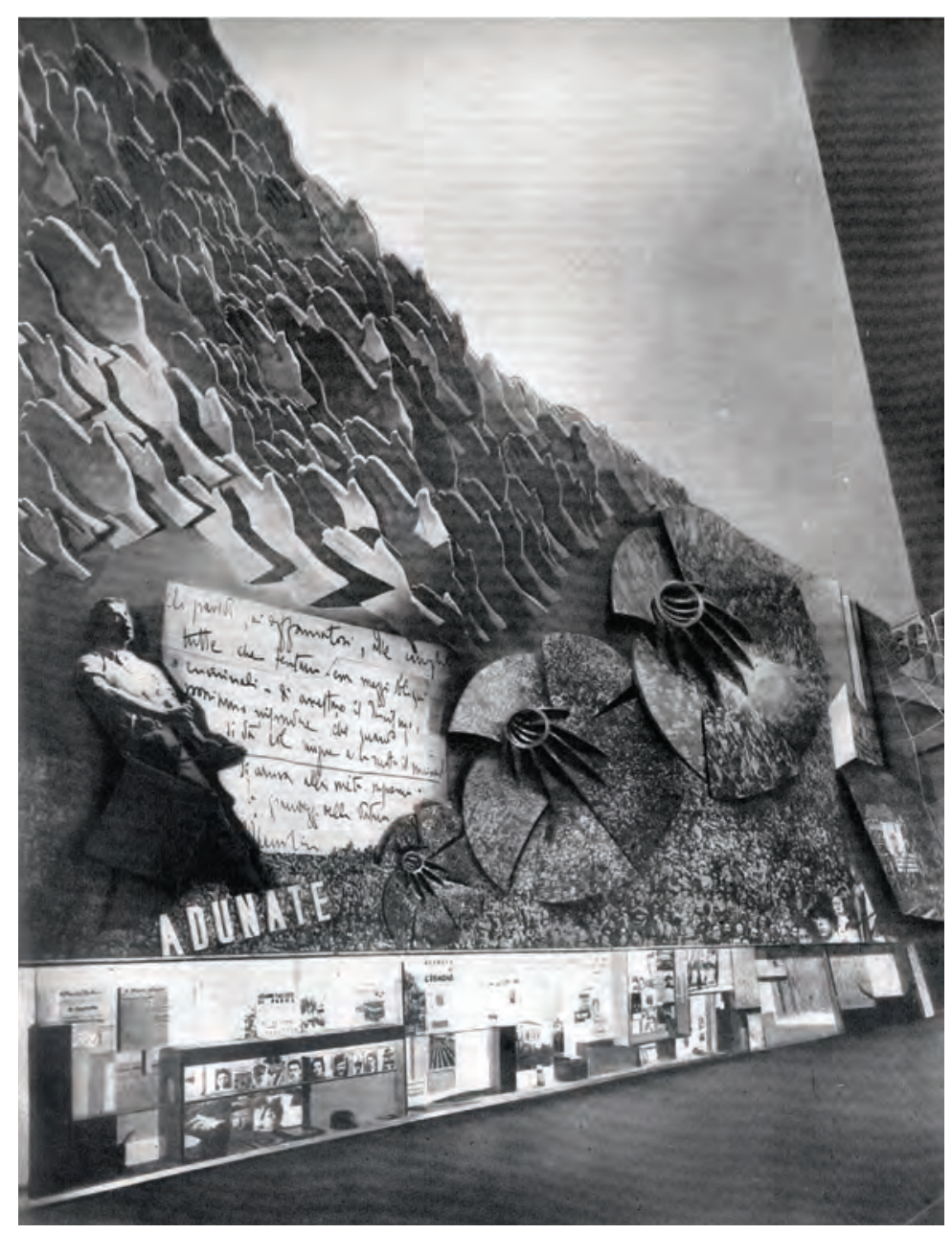

Fig. 39 Painel da Sala

0, Mostra da Revolução

Fascista, 1932

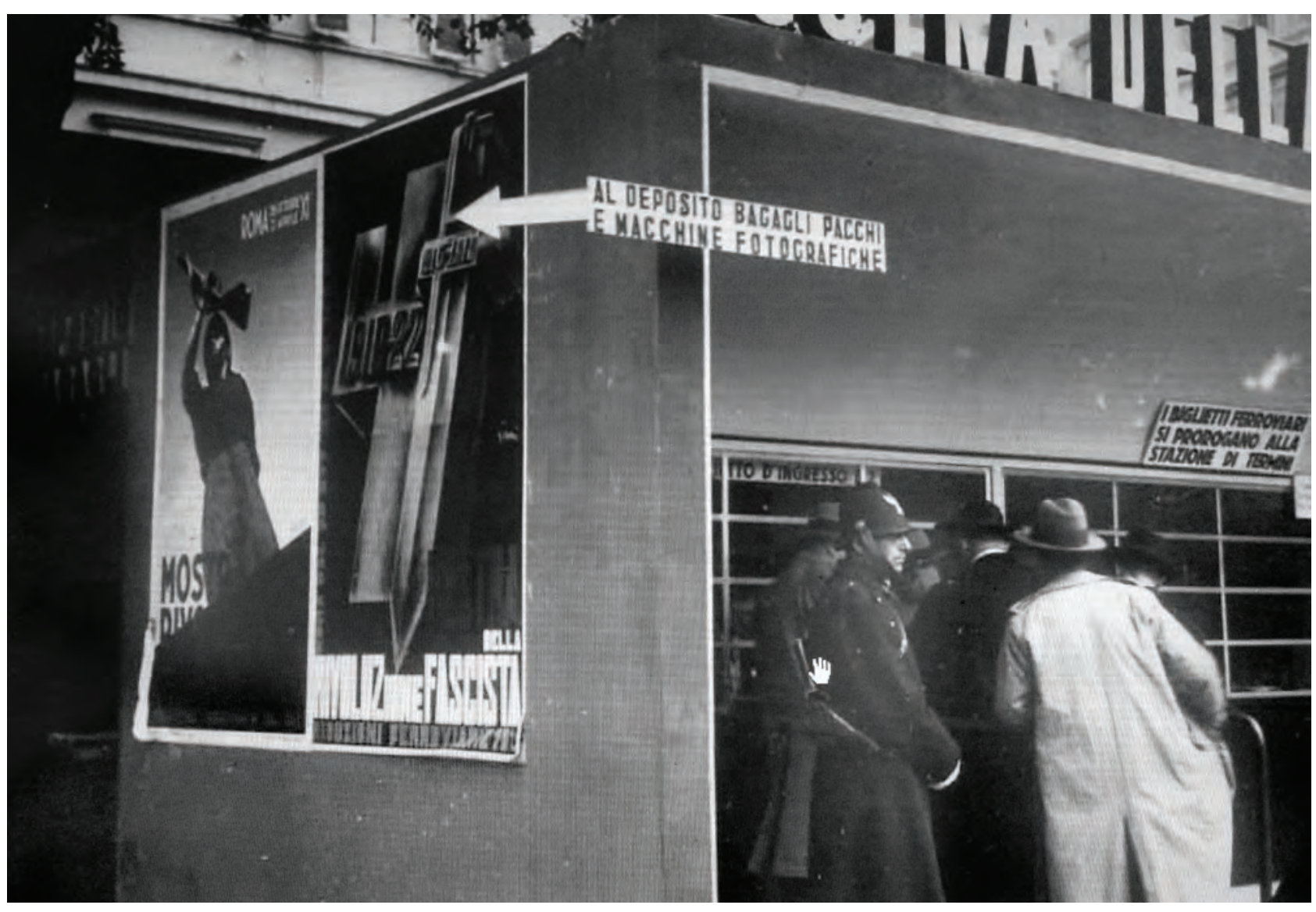

Fig. 40 Bilheteria da Mostra da Revolução

Fascista, 1932 (menção aos bilhetes

ferroviários) 
Fig. 41 Biblioteca montada na Mostra da Revolução Fascista, Sala 2, 1932
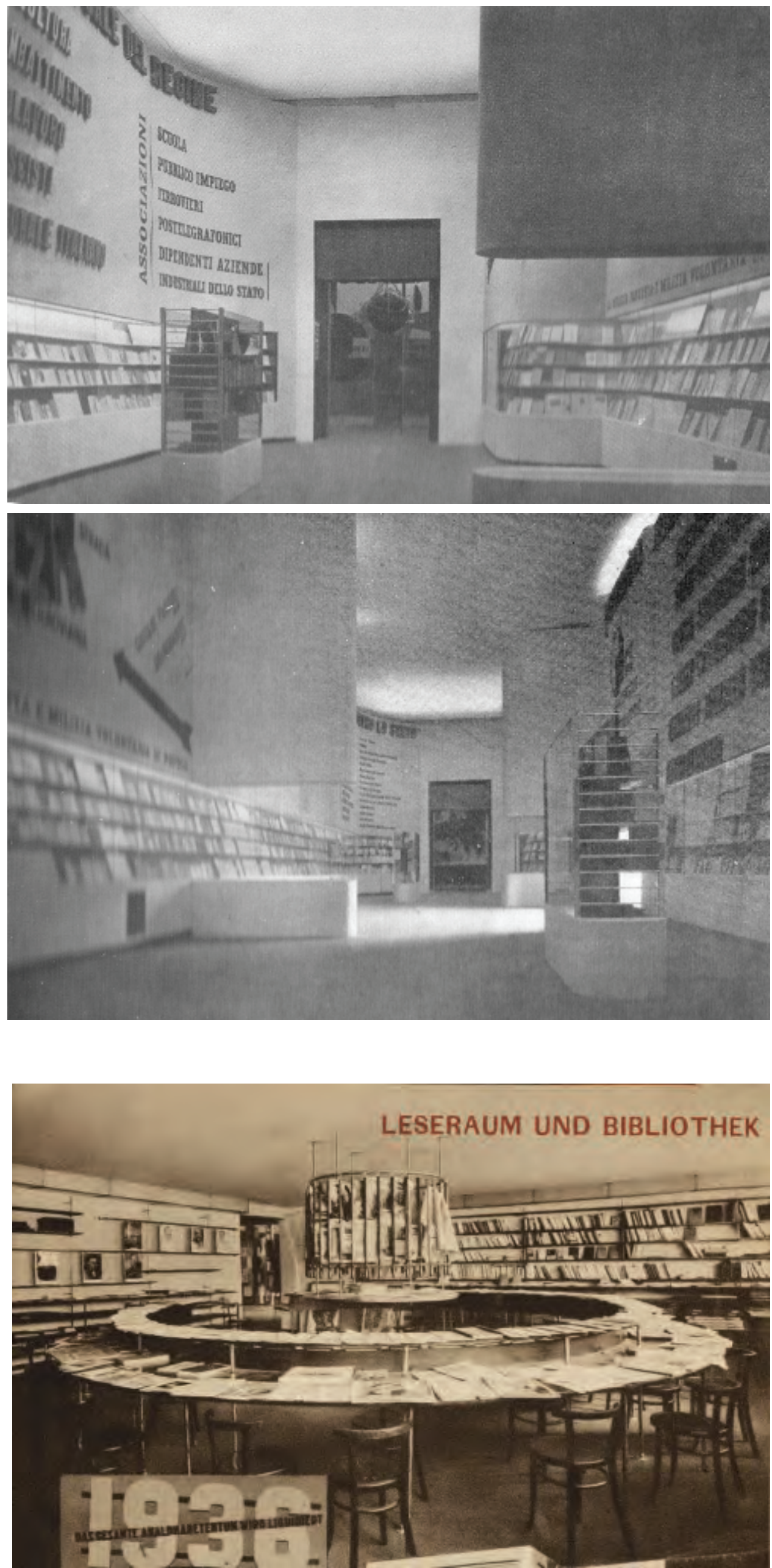

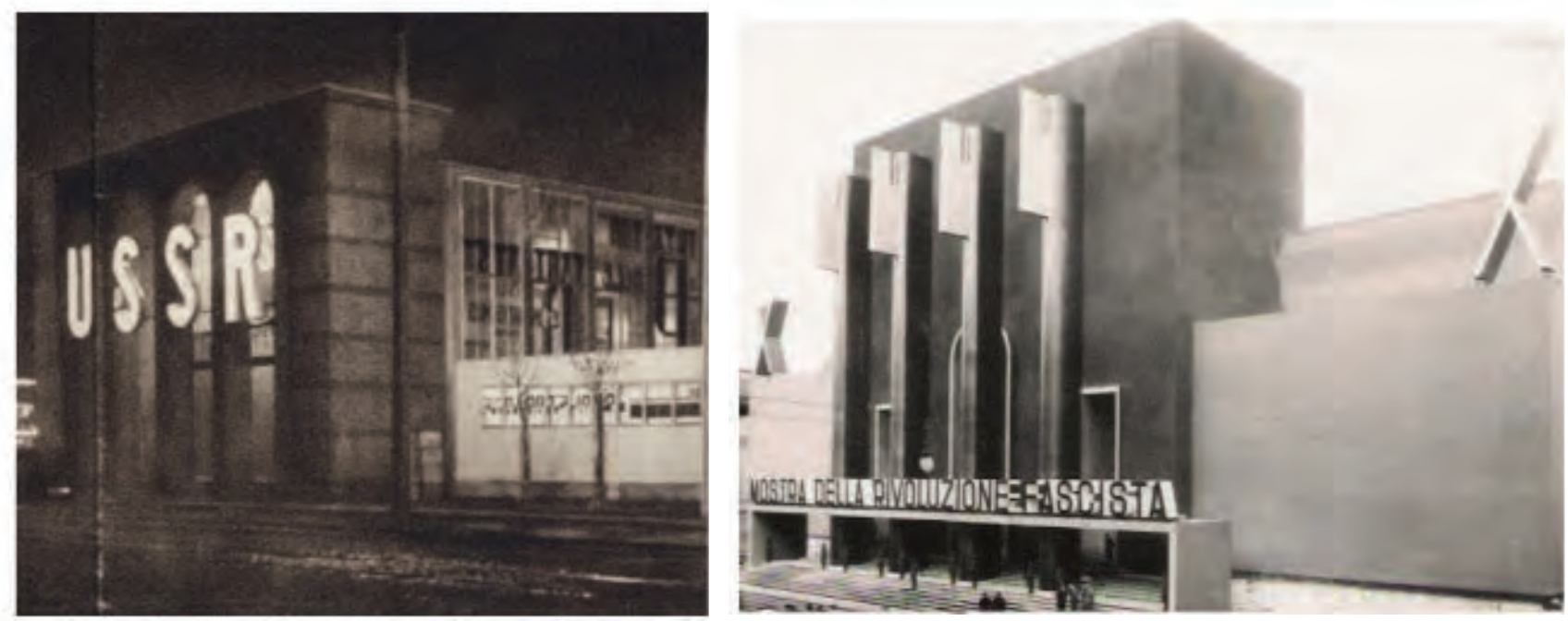

Fig. 43 Comparação das fachadas do Pavilhão Soviético na

Exposição Internacional de Imprensa de Colônia, 1928, e do

Palácio das Exposiç̃es, Mostra da Revolução Fascista, Roma, 1932

Fig. 44 Comparação entre a expografia do Hall de entrada do pavilhão soviético na exposição Internacional de Higiene, Dresden, 1930 e da Sala 0 da Mostra da Revolução Fascista, Roma, 1932
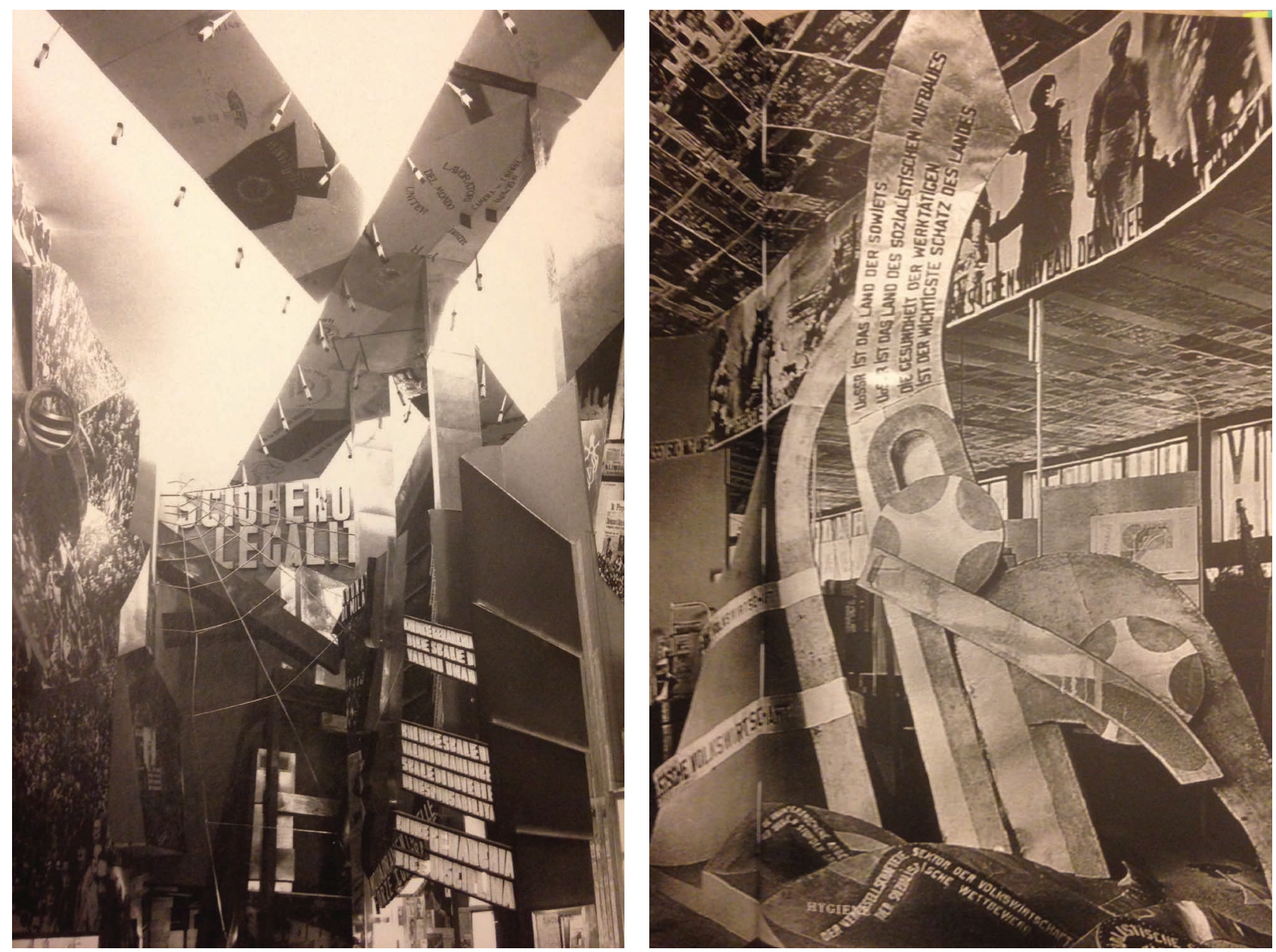
Fig. 45 Sala

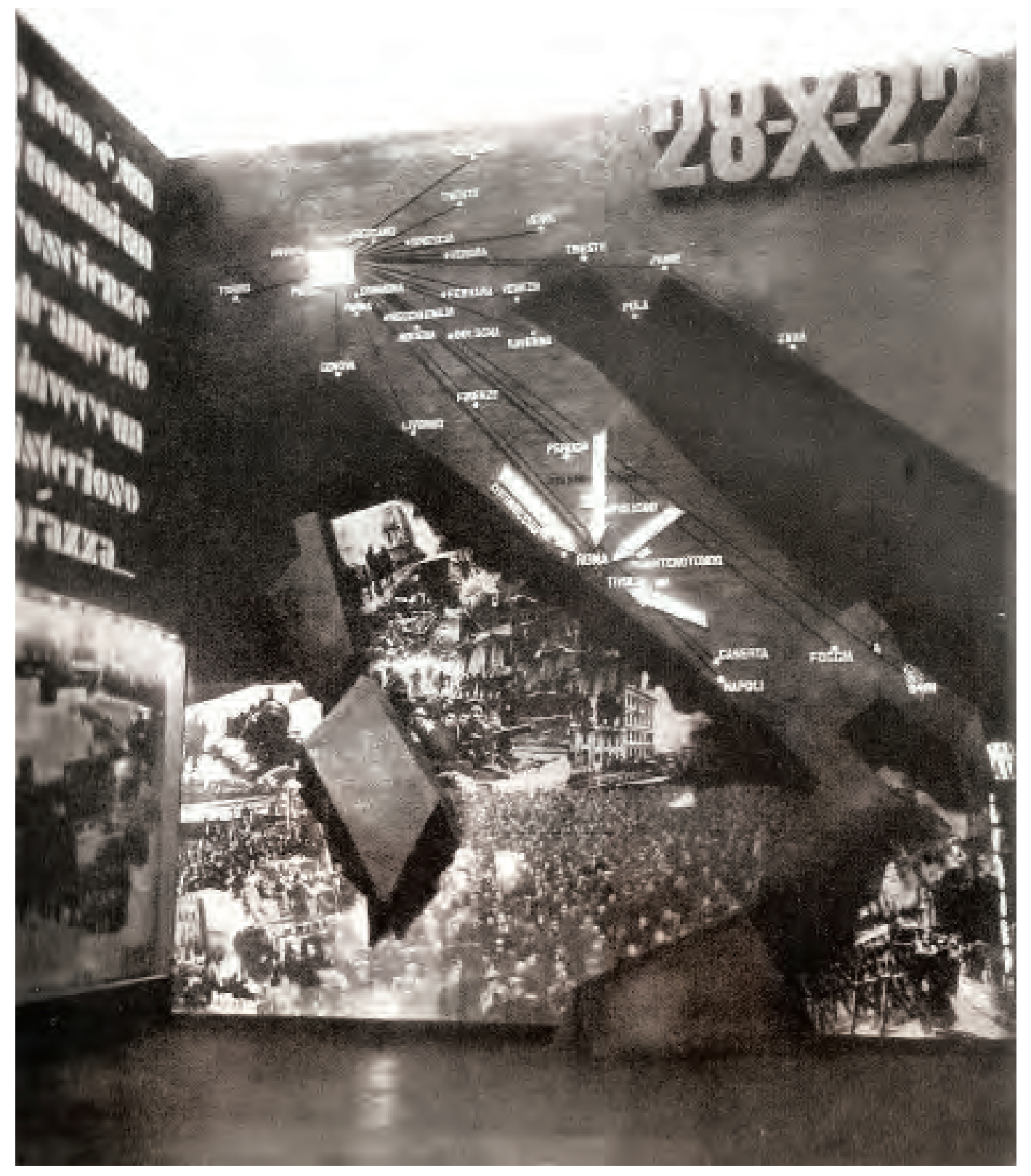

Revolução Fascista,

1932. Mapa da

Itália.

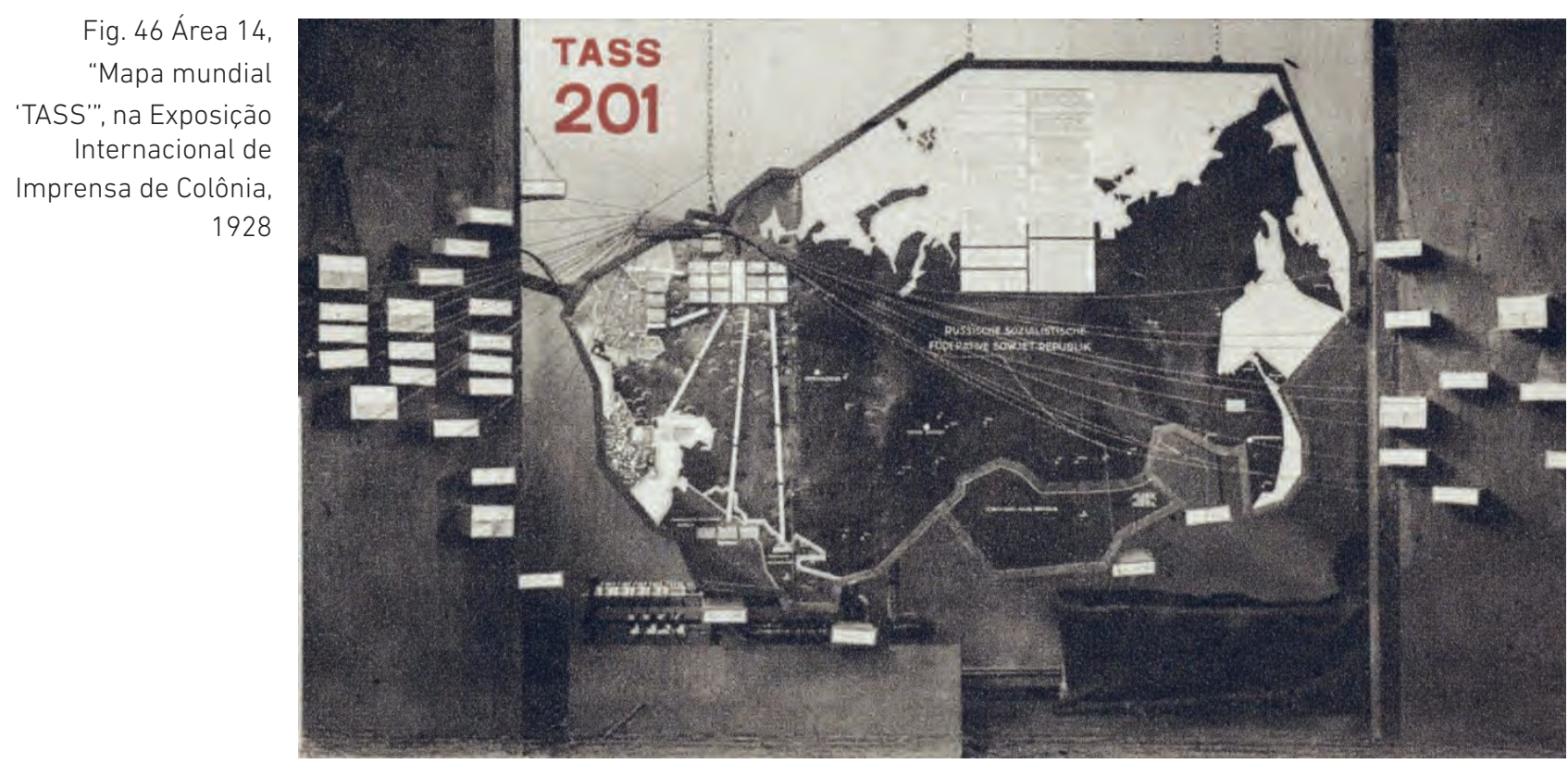




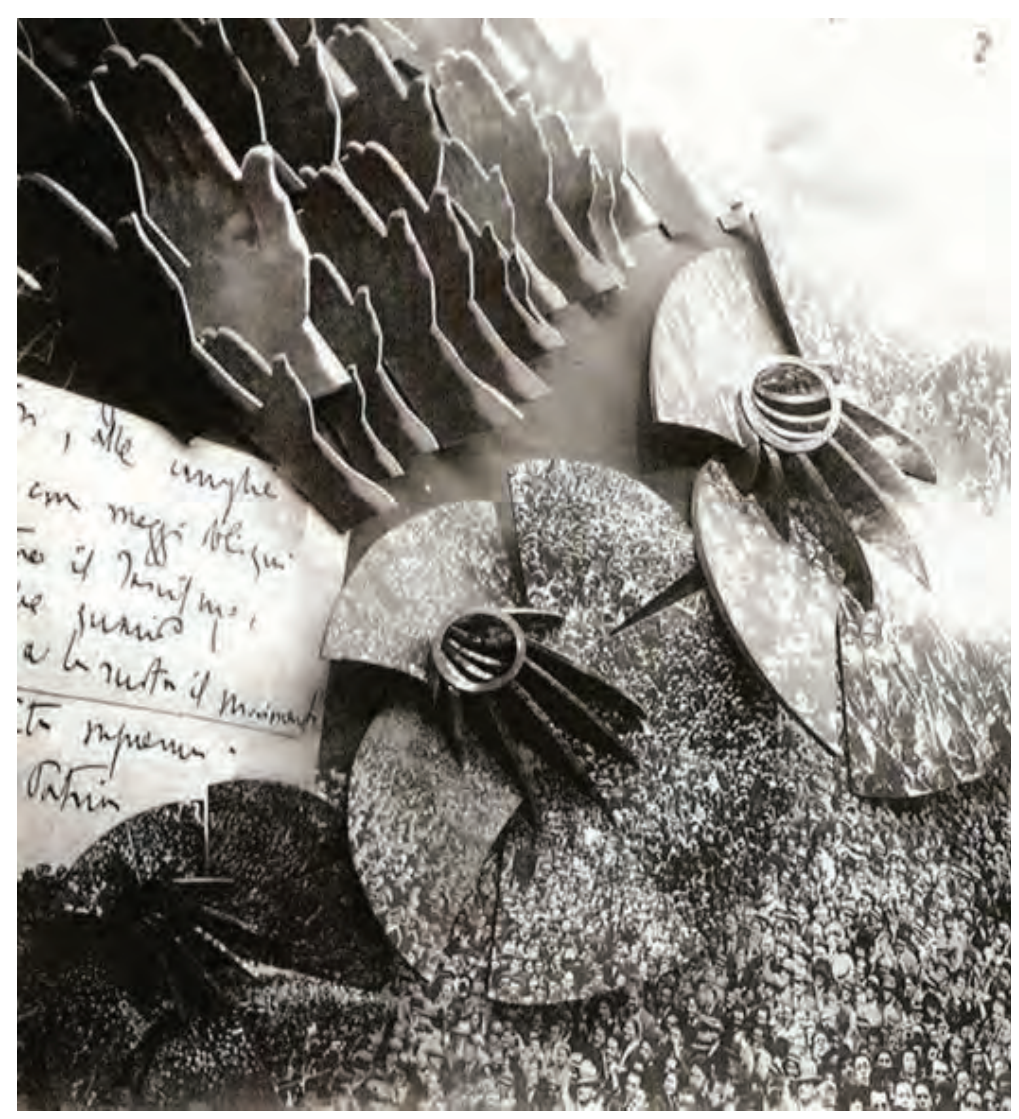

Fig 47 Ampliação do painel da

sala O, Mostra da Revolução

Fascista, 1932

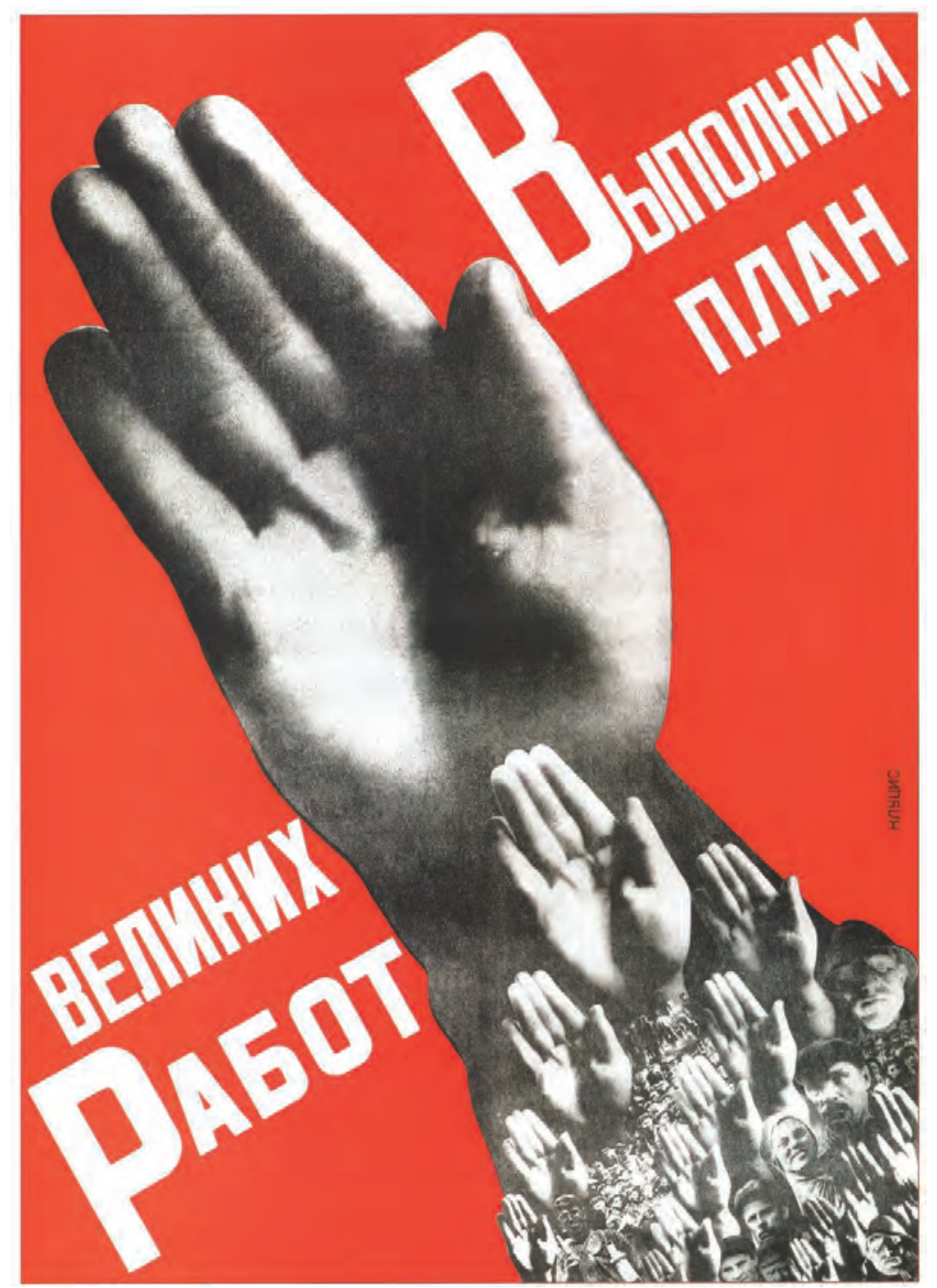

Fig 48 Cartaz de G. Klutsis

"Vamos Completar o Plano de

Grandes Obras", 1930 
Fig. 49 Fotomontagens de G. Klutsis, para

produções de cartazes e revistas, Moscou, 1930

(esquerda) e 1929 (direita)
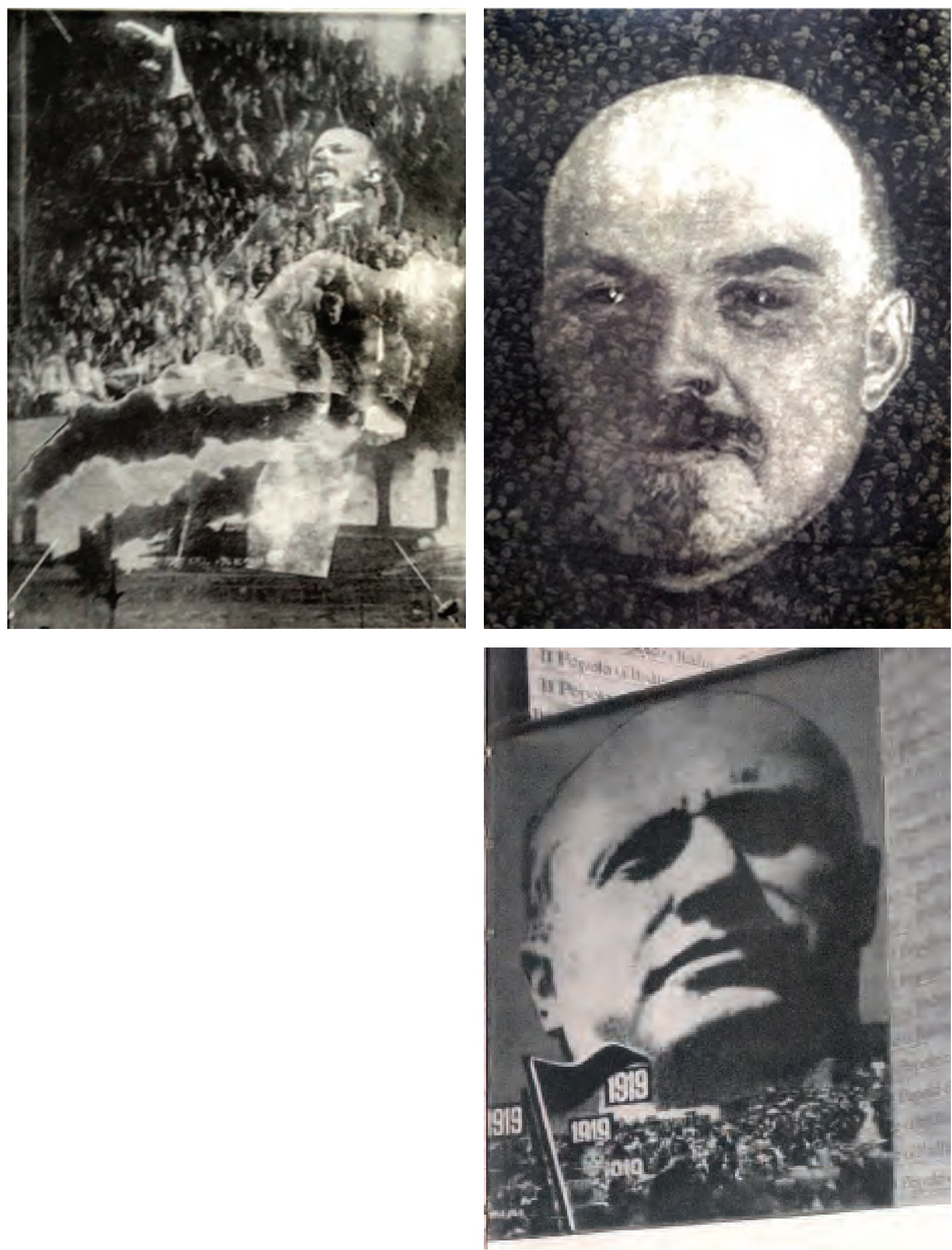

Fig 50 Fotomontagem com a imagem de Mussolini e massas populares apresentada em um dos painéis da Mostra da Revolução Fascista, 1932 

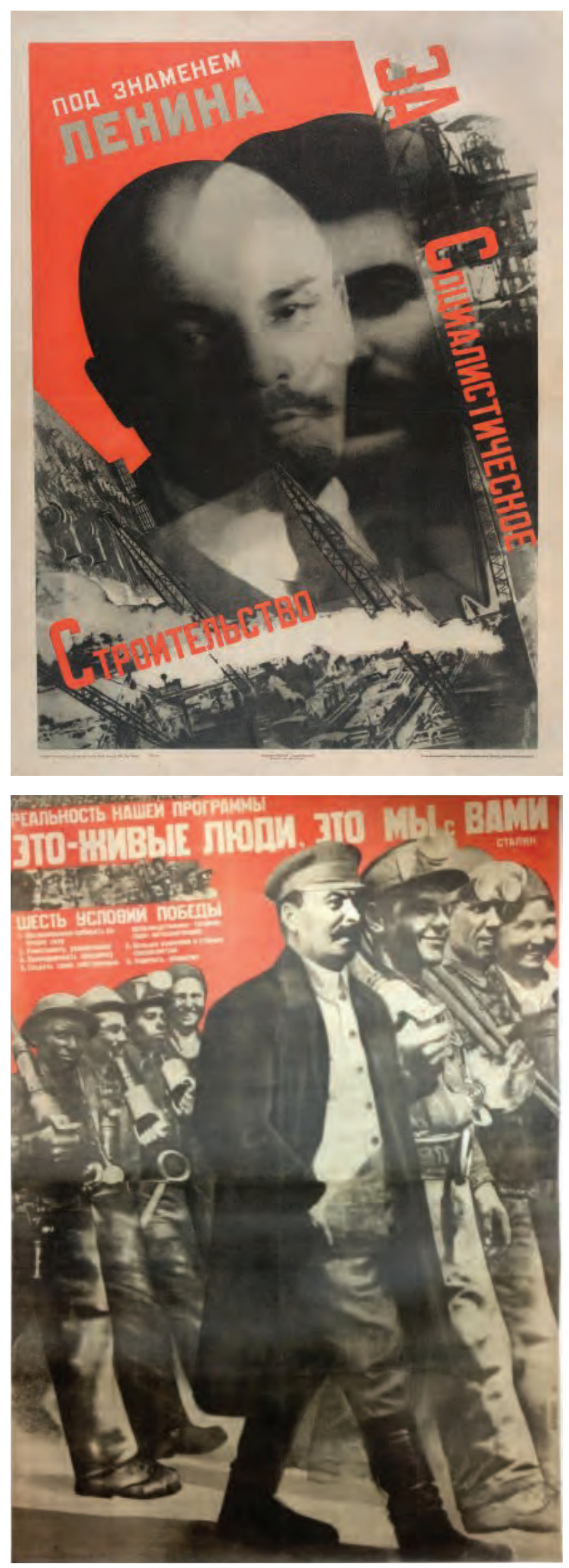

Fig. 51 Cartaz "Construindo o

Socialismo sob a Bandeira de Lênin" de G. Klutsis, 1930

Fig. 52 Cartaz "A Viabilidade de Nosso Programa são as Pessoas Reais, Somos Você e Eu", de G. Klutsis, 1931 
Fig 53 Cartaz "A Vitória do Socialismo em Nosso País é Garantida", de G. Klutsis, 1932

Fig 54 Fotomontagem que deu origem ao cartaz "A Vitória do Socialismo em Nosso País é Garantida", de G. Klutsis, 1932

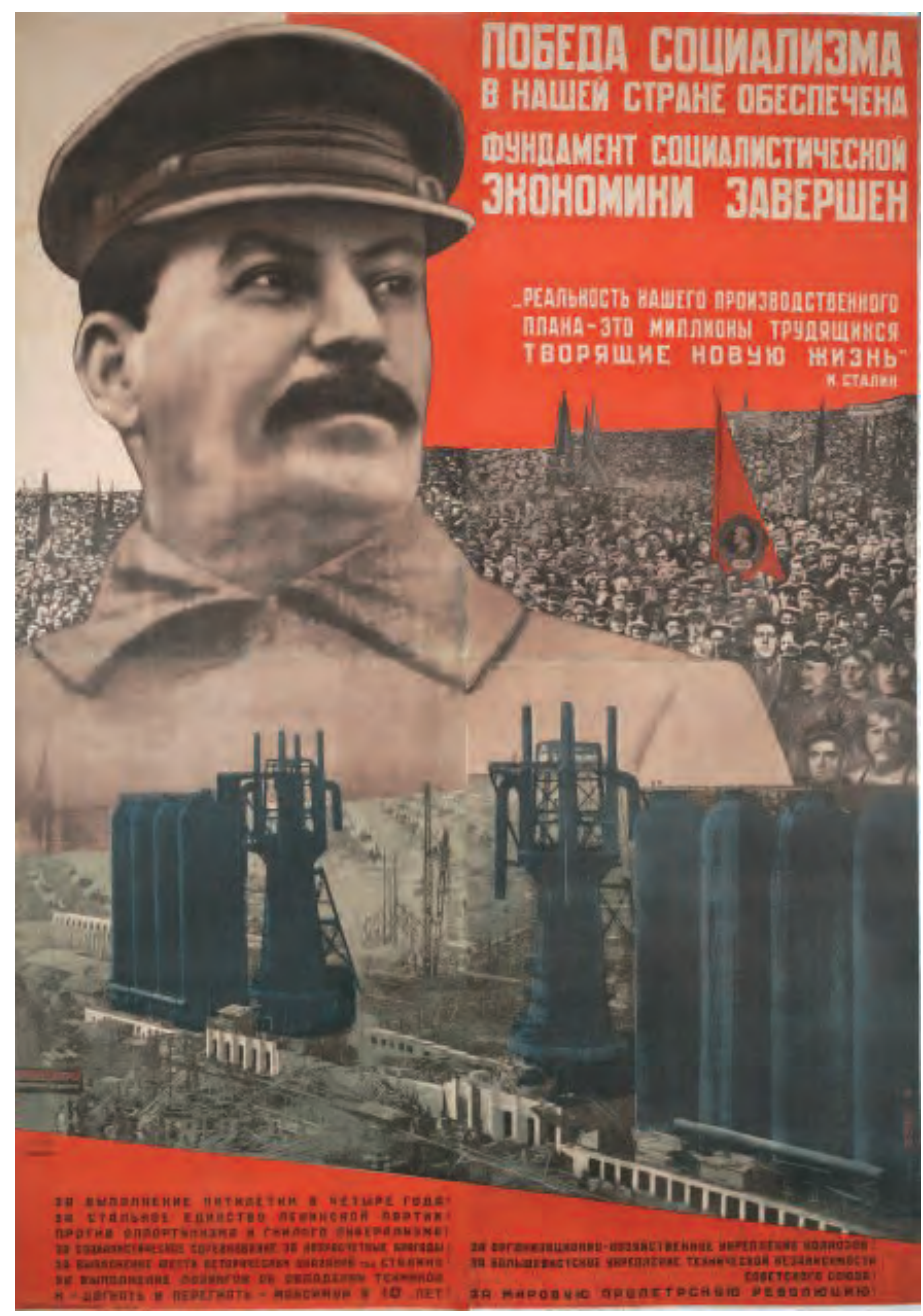

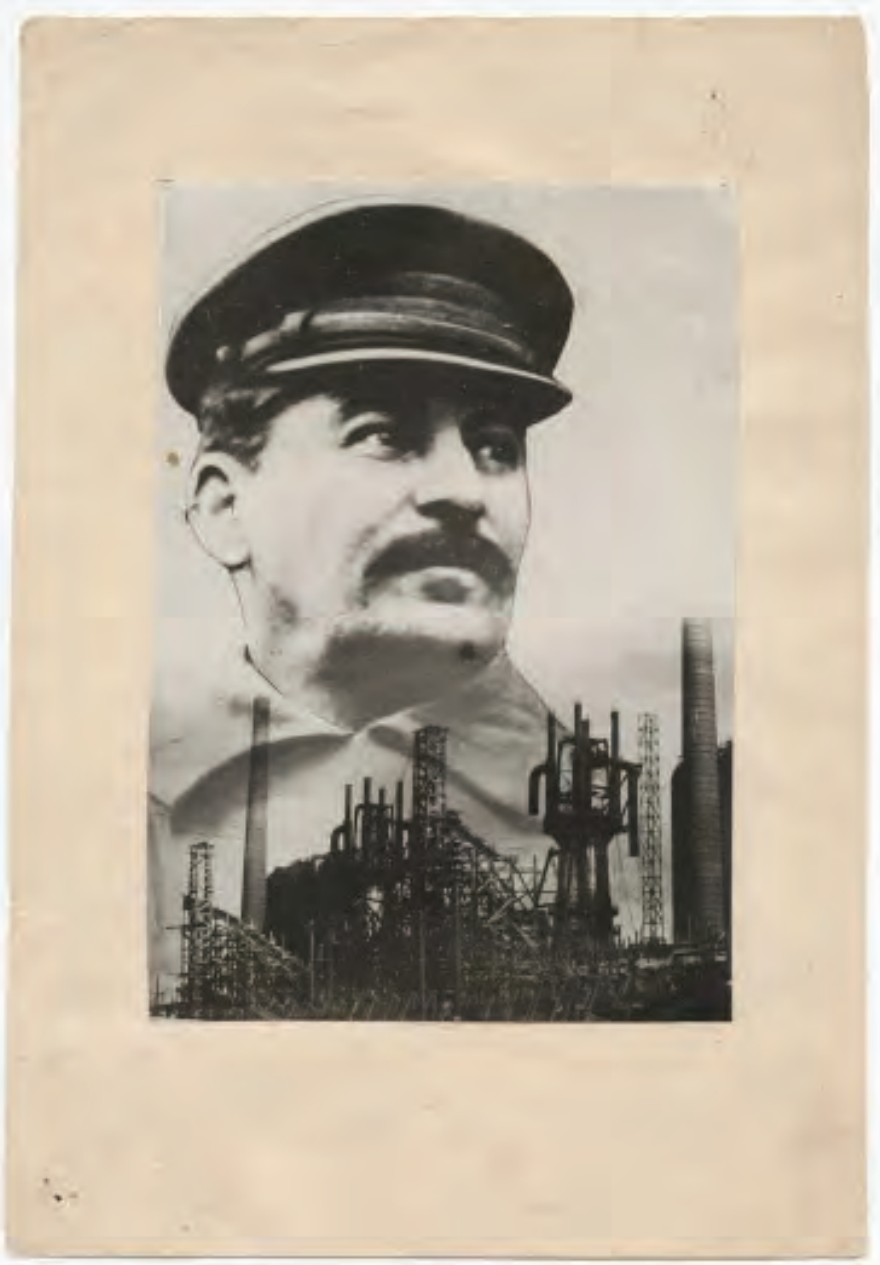

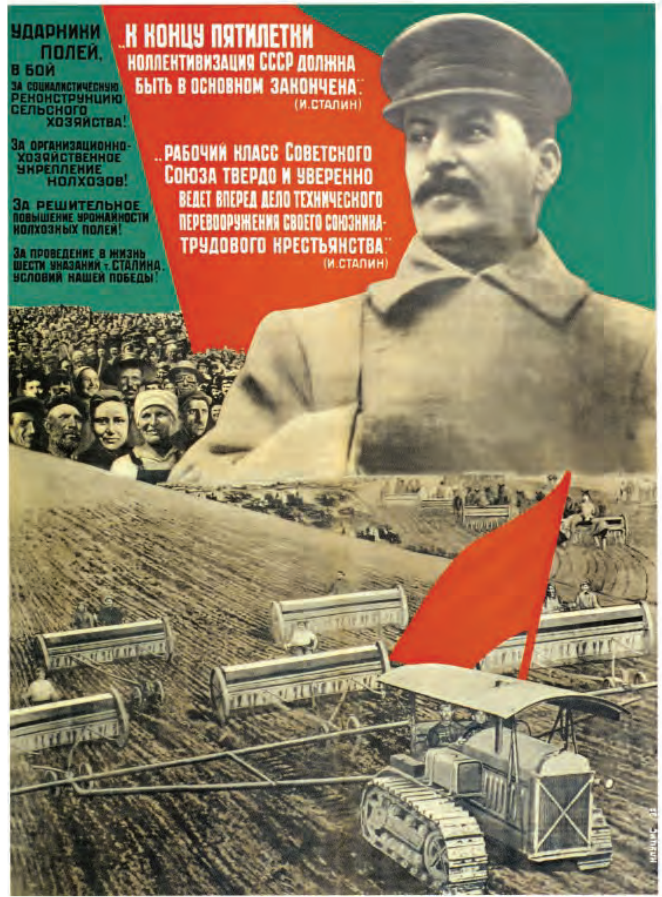

Fig 55 Cartaz "No Final do Plano Quinquenal, Coletivização da URSS Deve Estar Fundamentalmente Terminada", de G. Klutsis, 1932 

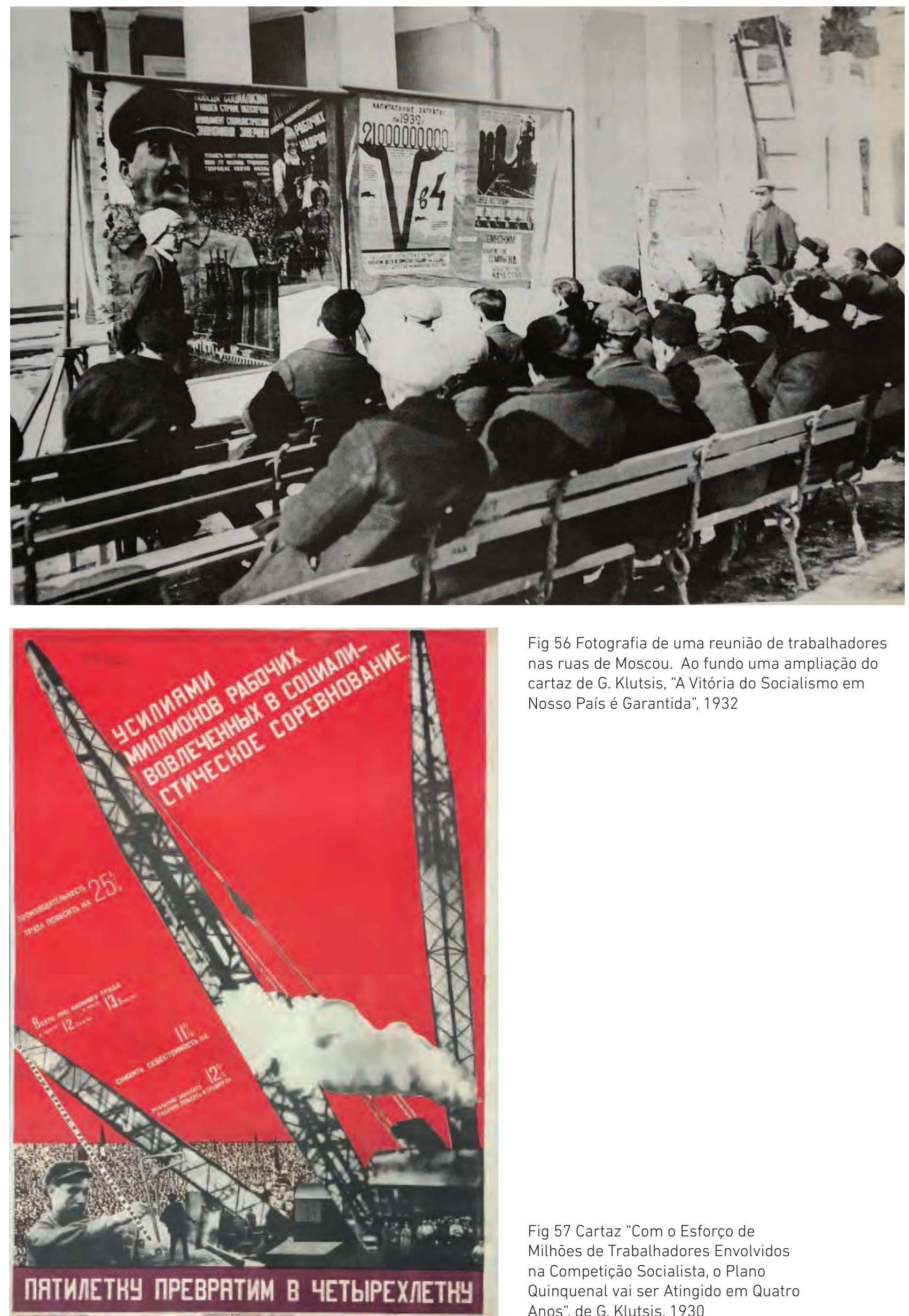

Fig 56 Fotografia de uma reunião de trabalhadores nas ruas de Moscou. Ao fundo uma ampliação do cartaz de G. Klutsis, "A Vitória do Socialismo em Nosso País é Garantida", 1932

Fig 57 Cartaz "Com o Esforço de Milhões de Trabalhadores Envolvidos na Competição Socialista, o Plano Quinquenal vai ser Atingido em Quatro Anos", de G. Klutsis, 1930 
Fig 58 Cartaz "A União Soviética é a Brigada de Choque para os Proletários do Mundo Todo", de G. Klutsis, 1931

Fig 59 Cartaz "Vamos Quitar a Dívida de Carvão do Nosso País", de G. Klutsis, 1930
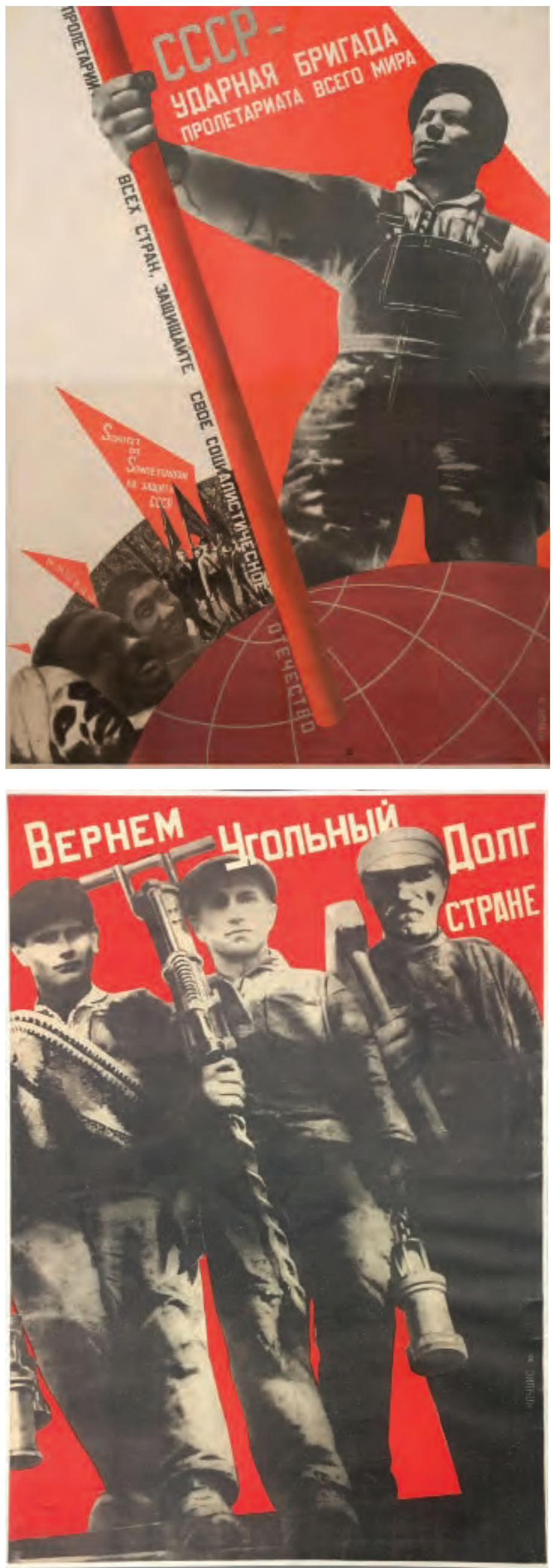
Fig 60 Cartaz "Vida Longa à União Soviética - o

Protótipo de Unidade para Trabalhadores de Todas as

Nacionalidades do Mundo!",1935
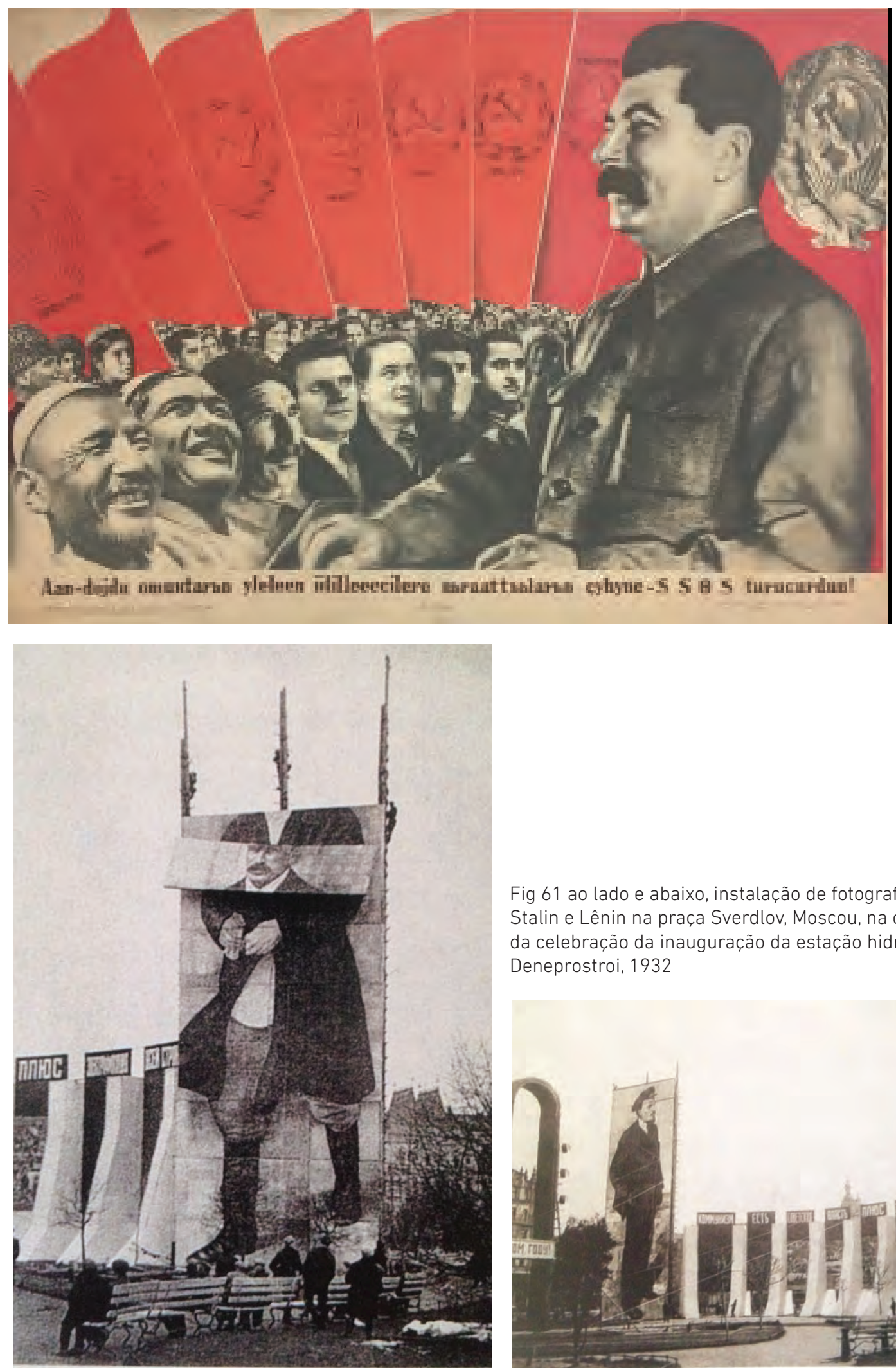

Fig 61 ao lado e abaixo, instalação de fotografias de Stalin e Lênin na praça Sverdlov, Moscou, na ocasião da celebração da inauguração da estação hidrelétrica Deneprostroi, 1932

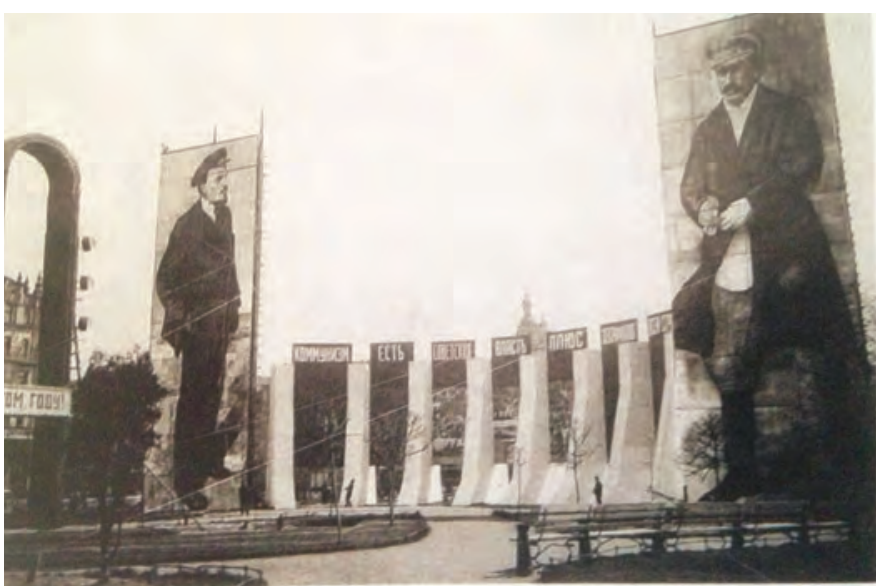


Fig 62 Benito Mussolini em

fotos do Instituto Luce, anos

1930
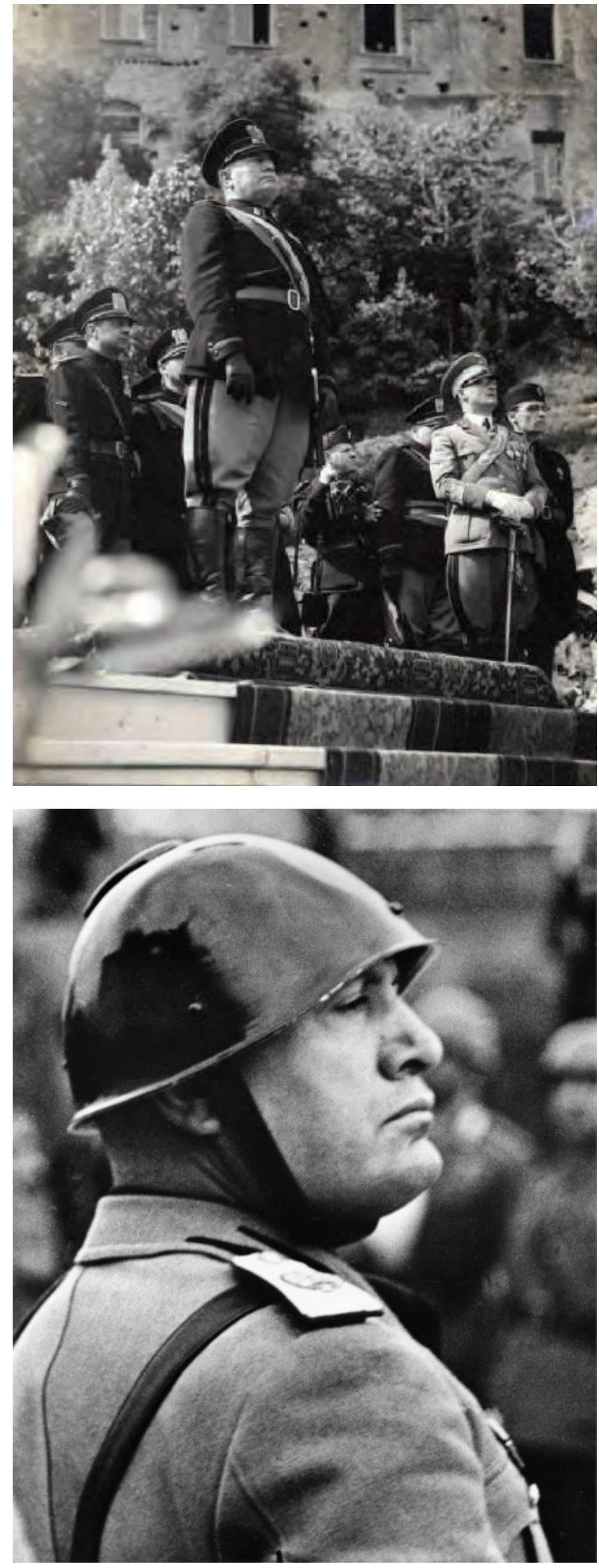


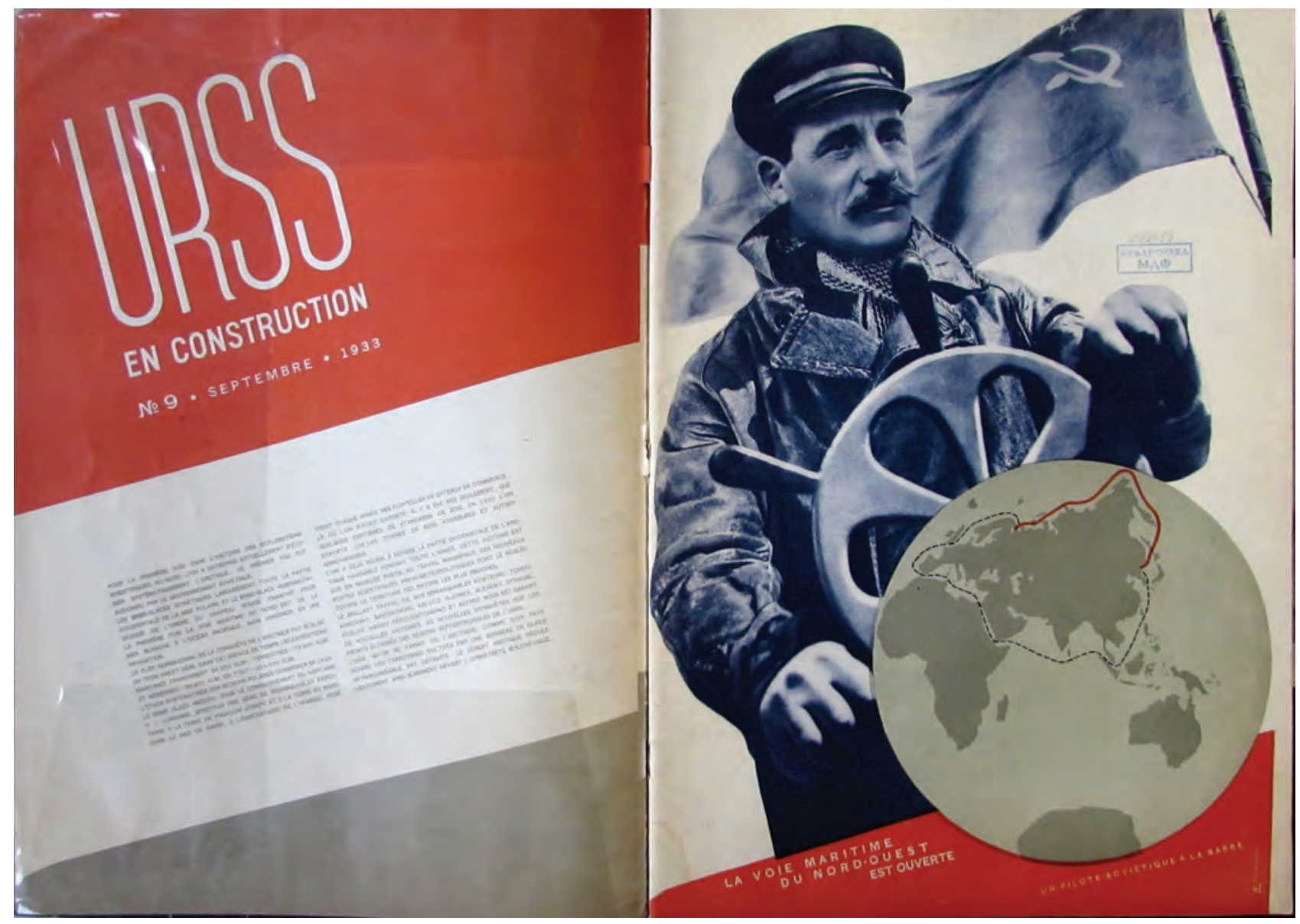

Fig.63 Revista "URSS em Construção",

(editada por El Lissitzky), n. 9, Moscou,

setembro de 1933 


\section{Subject of № 11 - LENINGRAD IN CONSTRUCTION}

The pletures for this number were taken by a brigade of photo-correspondents for . USSR in construction* consisting of: B. Ignatovitch, E. Ignatovitch, N. Shtertzer (the .October* group), and S. Magaziner, A. Shaikhe and $\mathrm{P}$. Shtertzer

Birds-eye vlew of Leningrad were taken from an airplane specially for, USSR in construction* by B. Igatovitch COMPOSITION BY N. ILLYIN

Editorial Board: M. Gorky, A. Goltsman, G. Grinko, T. Enukidze, I. Ionoff, M. Kalmanovich, M. Koltsoff, F. Konar, P. Krasnoff, G. Piatakoff (editor in-chief), S. Uritsky, A. Halatoff

SUBSCRIPTION RATES FOR 1931: ONE YEAR $-\$ 5.00$; SIX MONTHS $-\$ 2.5$; THREE MONTHS $-\$ 1.25$ Subscriptions accepted by: USSR: .Mezhdunarodnaya Kniga*, 18 Kuznetsky Most, Moscow; USA: Amkniga* Corporation, 19 West, 27 th street, New-York City: England: Kniga* Lid Bush House, Aldwych, London, W. C. 2; Germany: ,Kniga*-Buch- und Lehrmittelgesellschaft m. b. H., Ritterstrasse 61 iv, Berlin SW 68 Editorial Offices: Malaya Nikltskaya, 6, Moscow, USSR. The State Publishing Union of RSFSR IZOGIS 2919. Issue -77 000. Glavilt Ne B-10040

Paper, colours and printing by GOZNAK. Printed in USSR (Russla). Moscow, 1931

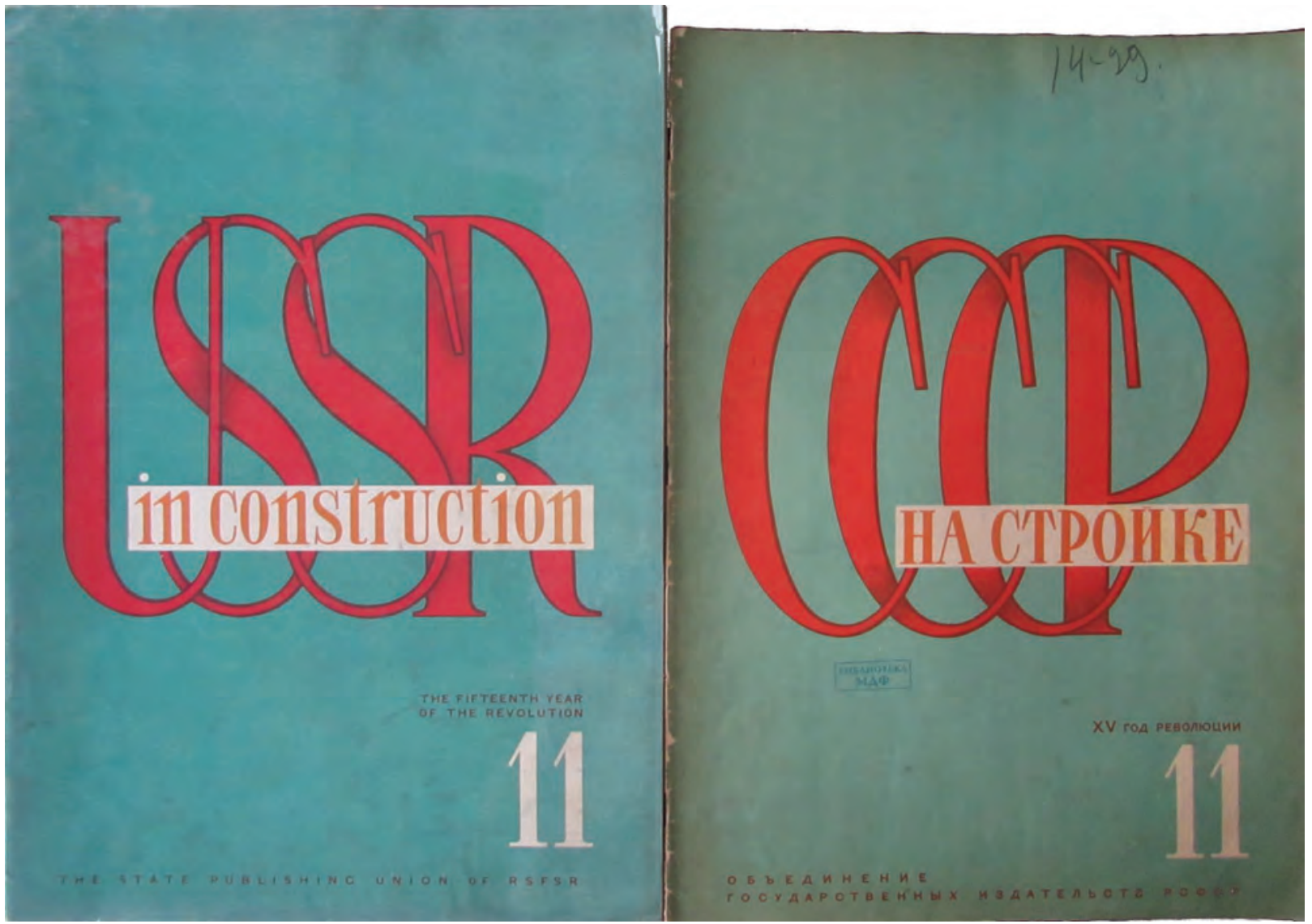

Fig.64 Revista URSS em Construção, n. 11, Moscou, setembro de 1931. Como pode-se ver na ficha técnica, esta edição contou com fotografias realizadas por uma brigada de correspondentes fotógrafos vinculados ao

Grupo Outubro 

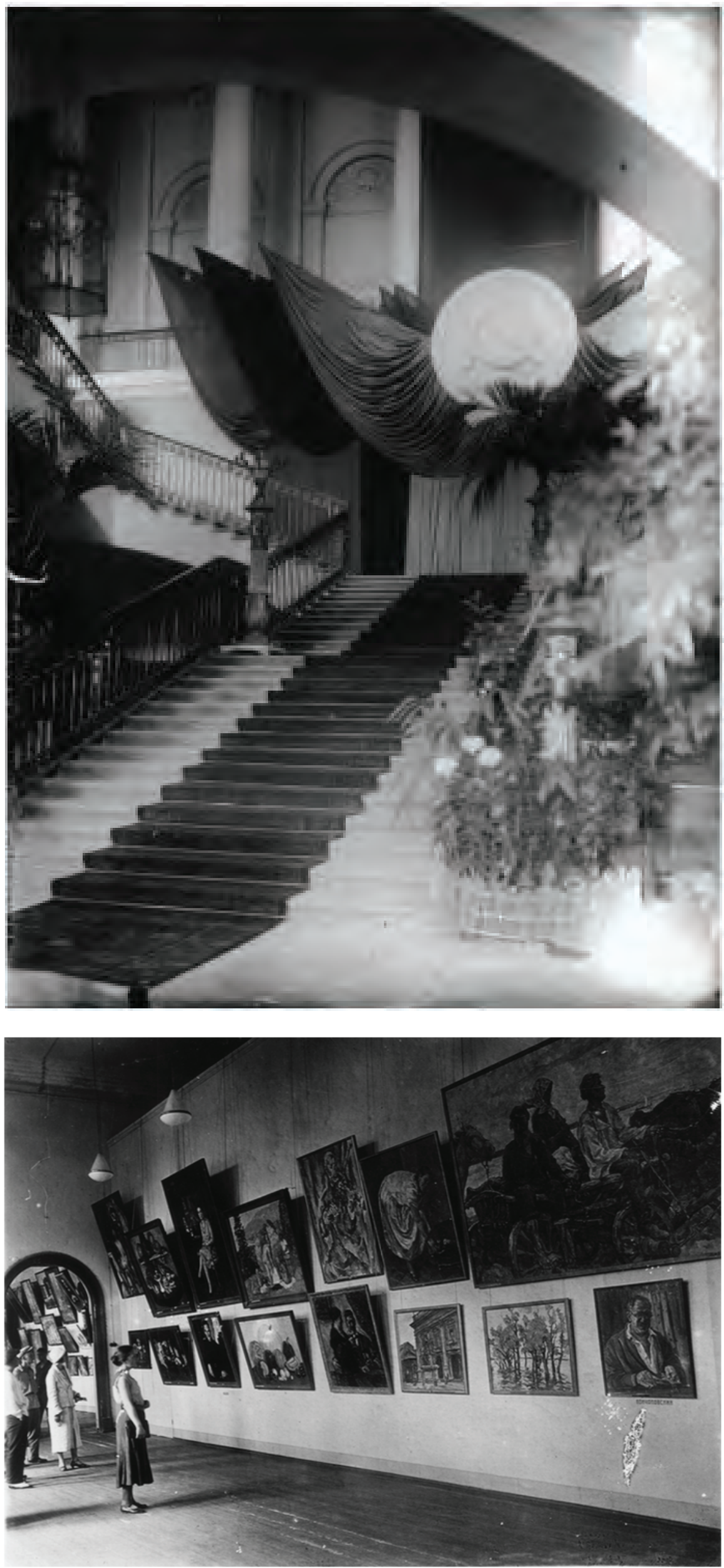

Fig 65 Entrada da mostra "Artistas da URSS dos últimos 15 anos",

Leningrado, 13 de novembro de 1932

Fig 66 Galerias da mostra "Artistas da URSS dos Últimos 15 Anos", Moscou, 1933-34 
Fig 67 Visita guiada na exposição "Artistas

da URSS dos Últimos 15 Anos", Moscou,

1933-34
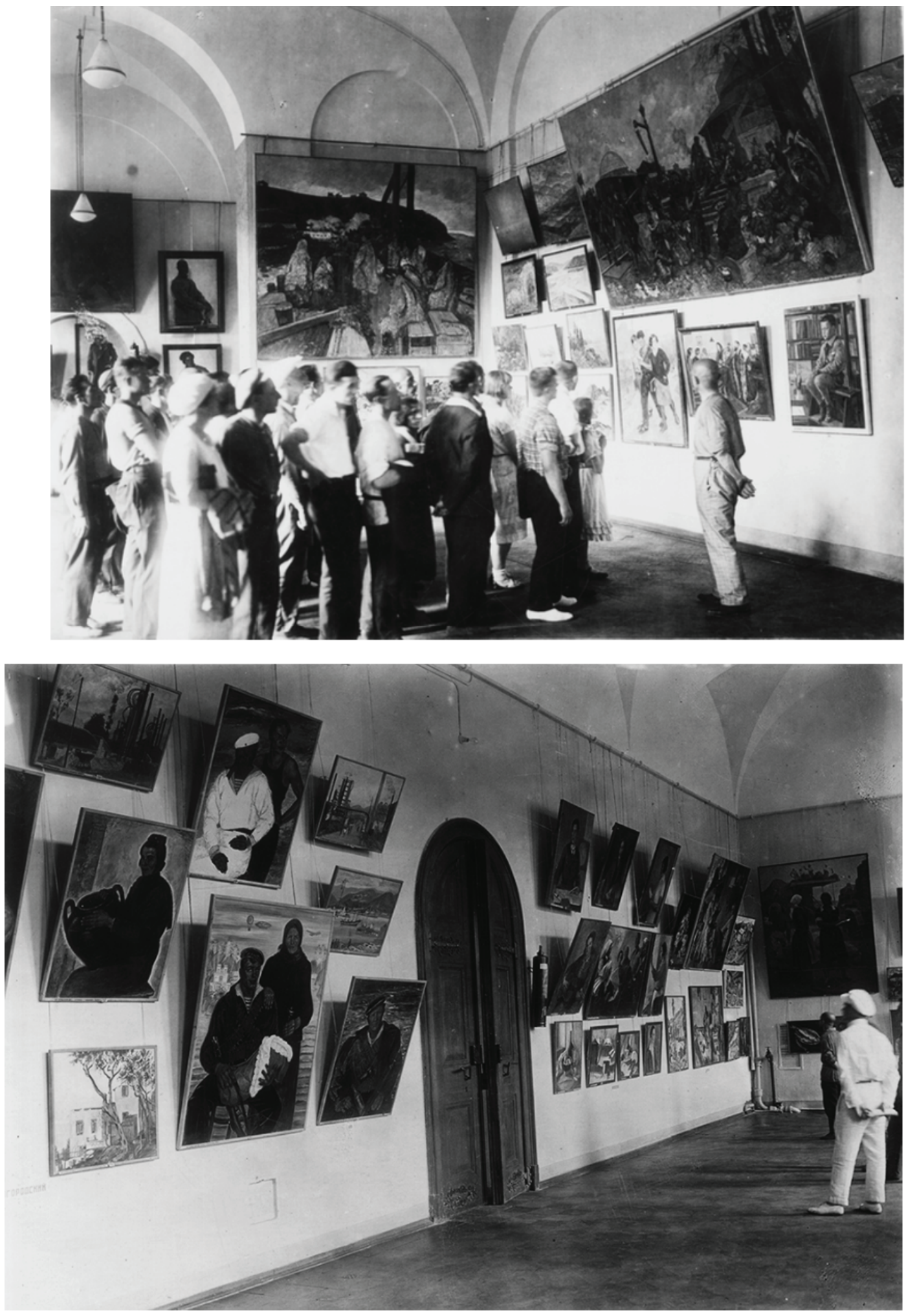

Fig 68 Visita guiada na exposição "Artistas da URSS dos Últimos 15 Anos", Moscou, 1933-34 

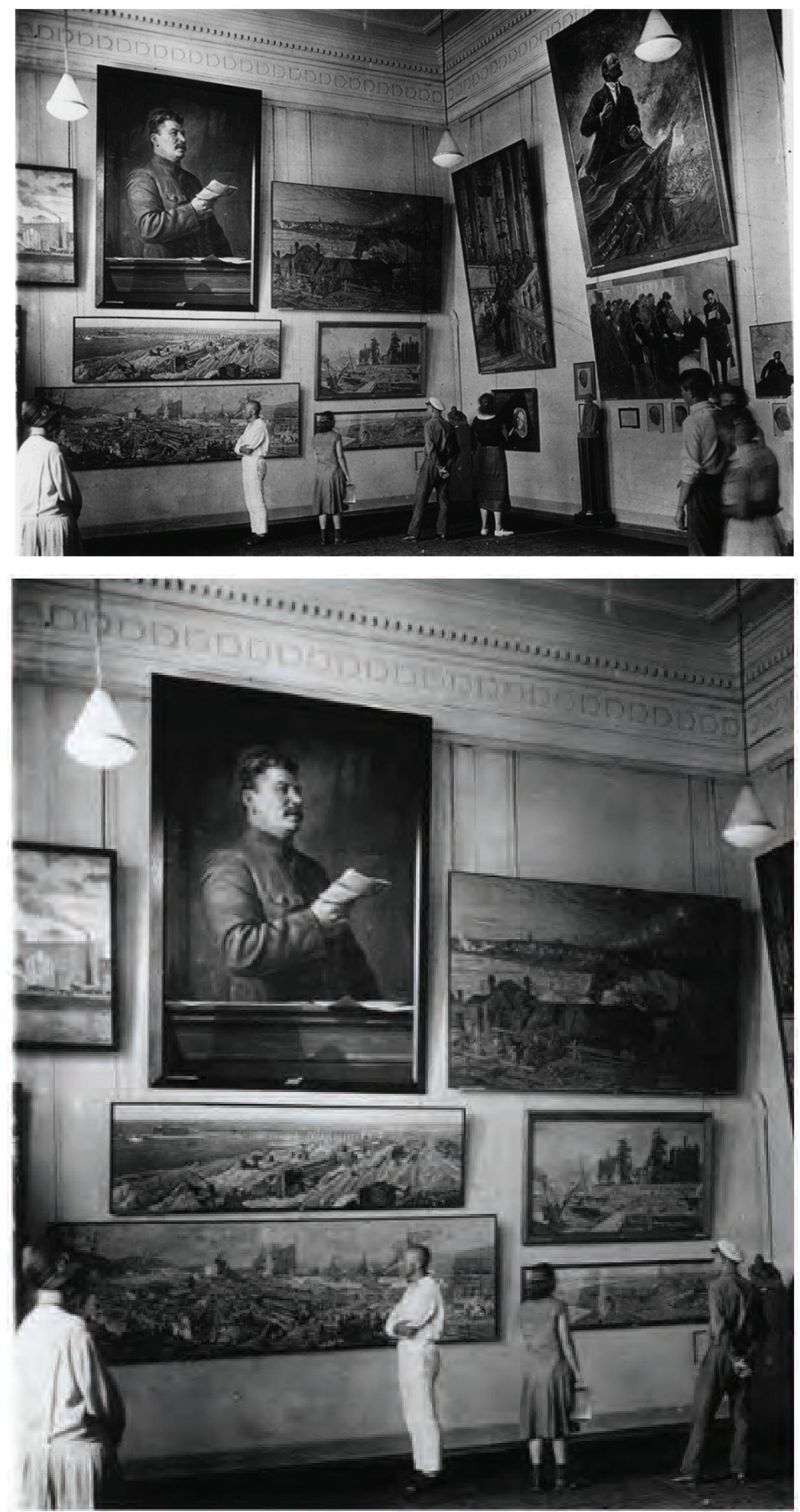

Fig 69 Galeria central da mostra "Artistas da URSS dos Últimos 15 Anos", Moscou, 1933-34

Fig 70 Detalhe da mesma foto. Galeria central da exposição, à esquerda, acima, Stalin pintado por Brodsky, e pinturas com cenas de industrialização 
Fig 71 Detalhe da foto da galeria central da exposição

"Artistas da URSS dos

Últimos 15 anos", Moscou, 1933-1934 (no centro, acima, Lênin pintado por Gerasimov,

e pinturas com cenas de atividades revolucionárias)

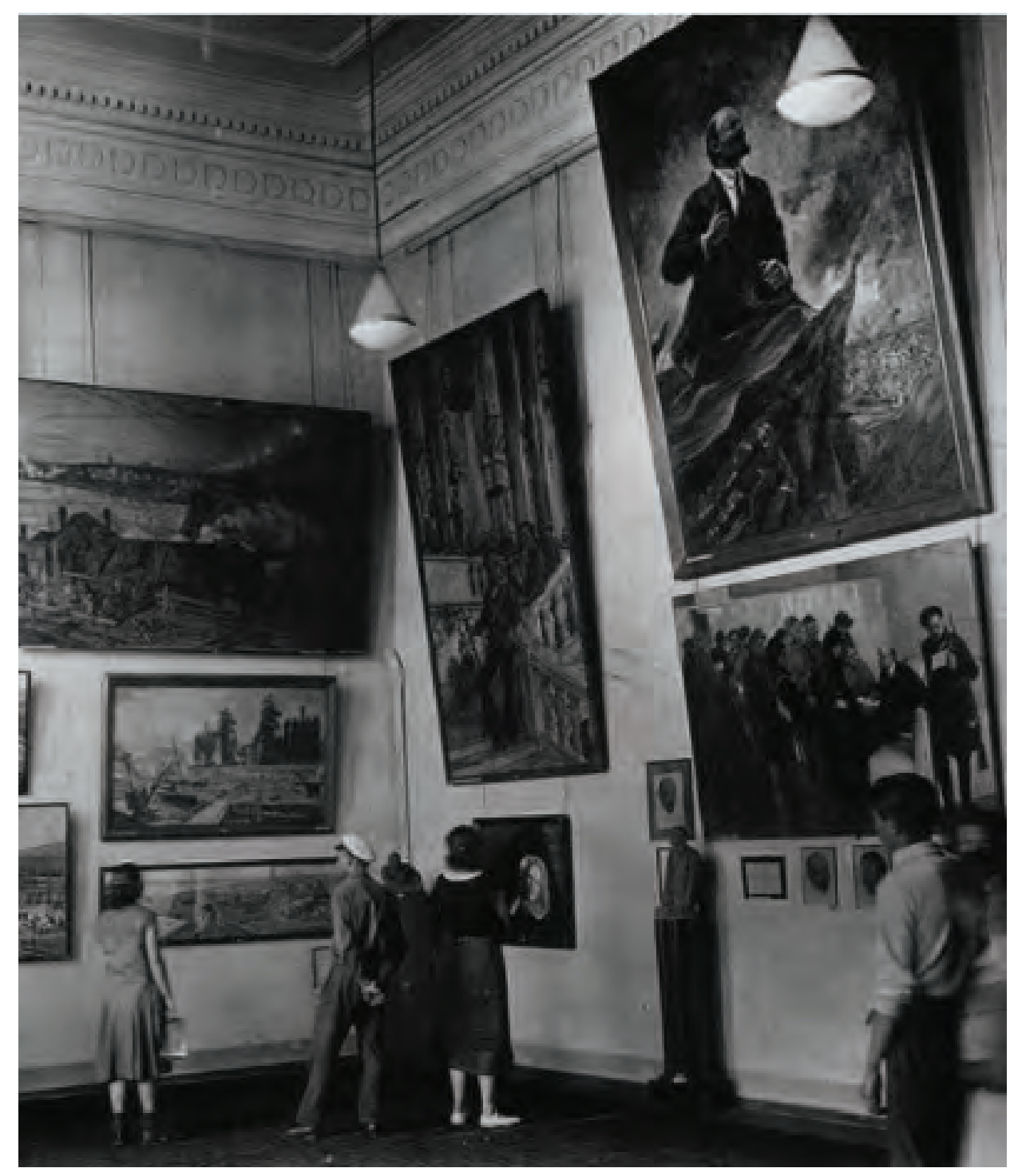



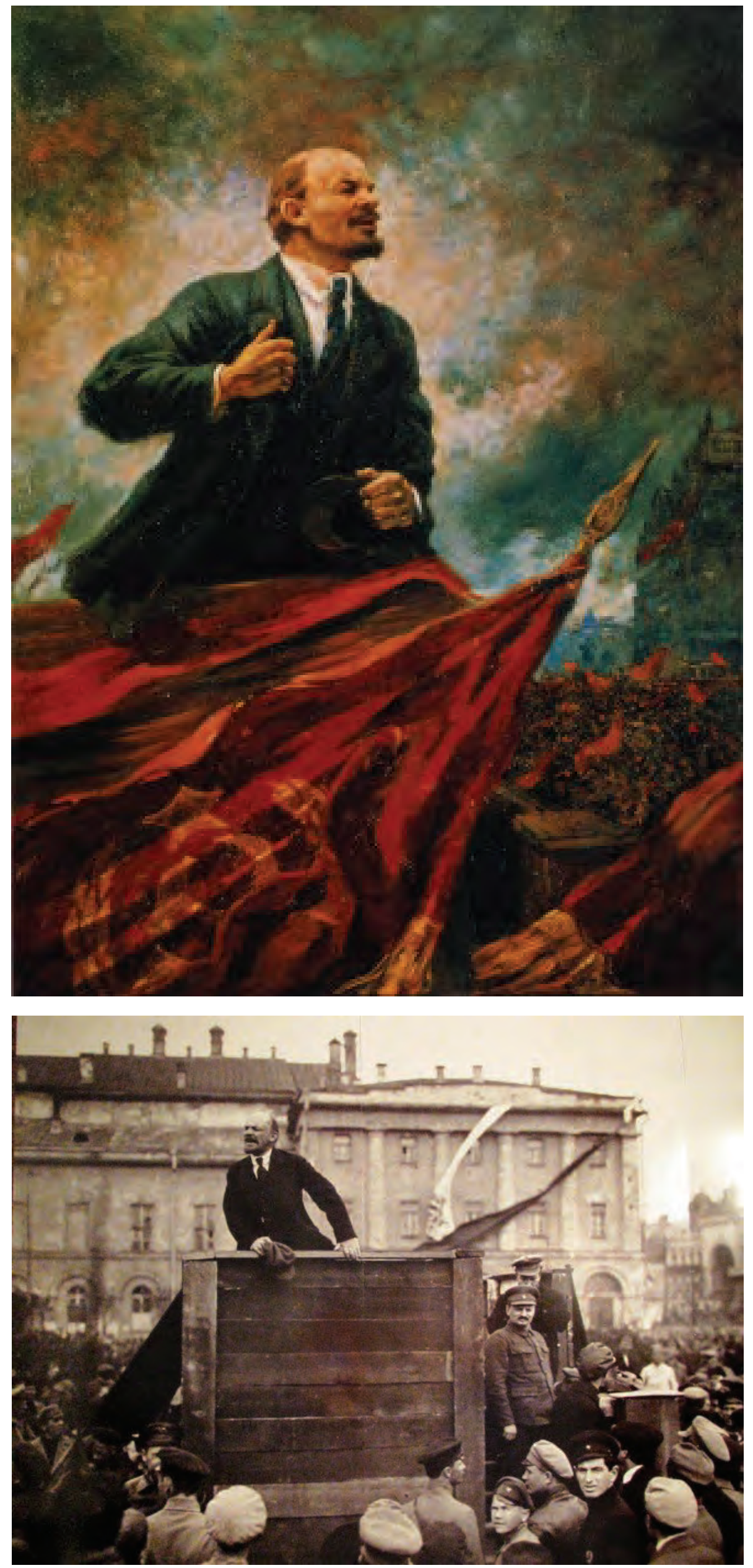

Fig 77 Lênin num Pódio, óleo sobre tela, $218 \times 210 \mathrm{~cm}, 1929$ 1930, de Aleksandr Gerasimov (1881-1963)

Fig 78 Fotografia anônima, "Lênin Dirge-se a uma Multidão em Petrogrado", 1917. Por volta de 1930, Trotsky e Kamenev são retirados da foto. Esta fotografia foi base de muitas pinturas do "realismo heroico" e do "realismo socialista" 

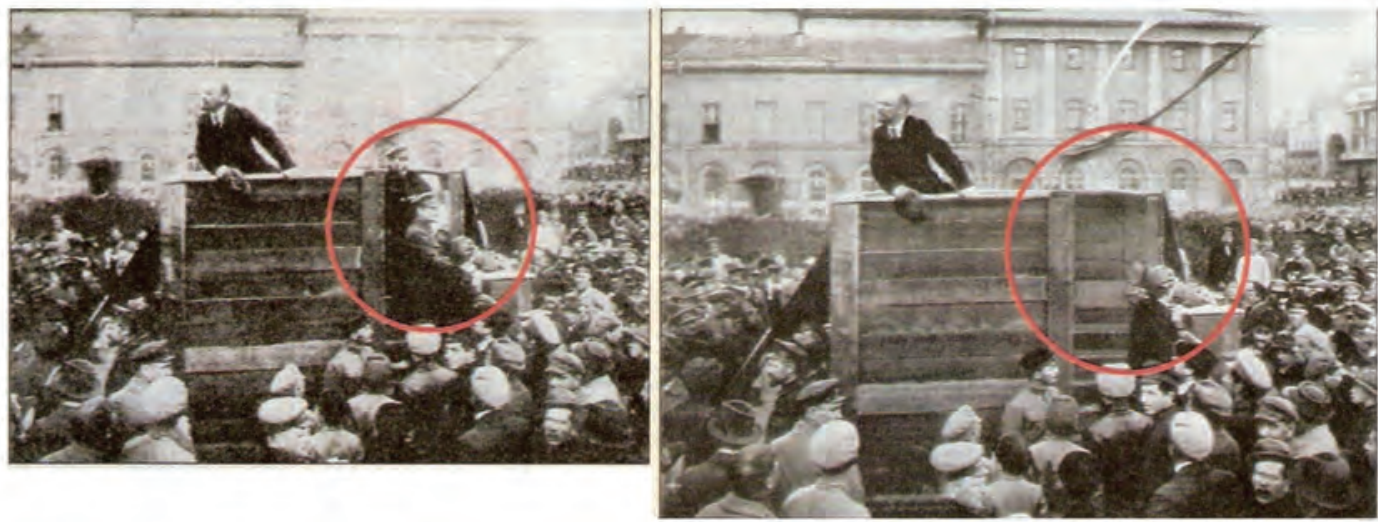

Fig 79 Fotografias anônimaS "Lênin dirige-se a uma multidão em Petrogrado", 1917. Na segunda fotografia, Trotsky e Kamenev são retirados

Fig 80 Isaak Brodsky, pintura a óleo, "Lênin na Fábrica Putilov, em maio de 1917", 1929

Fig 81 Isaak Brodsky, pintura a óleo,

"Discurso de Lenin para o Exército Vermelho Antes do Envio para o Fronte

Polonês em 5 de Maio de 1920", 1933
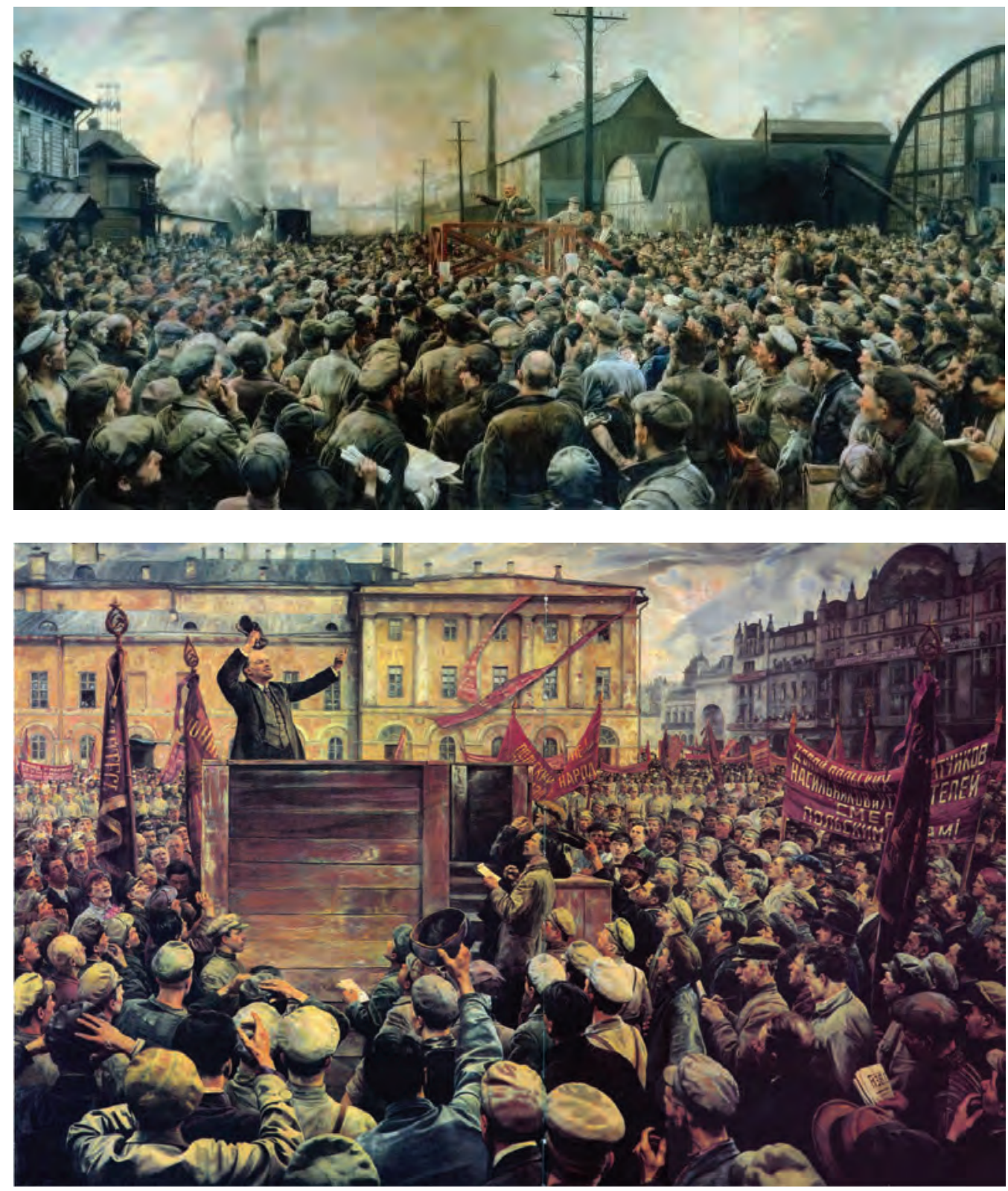


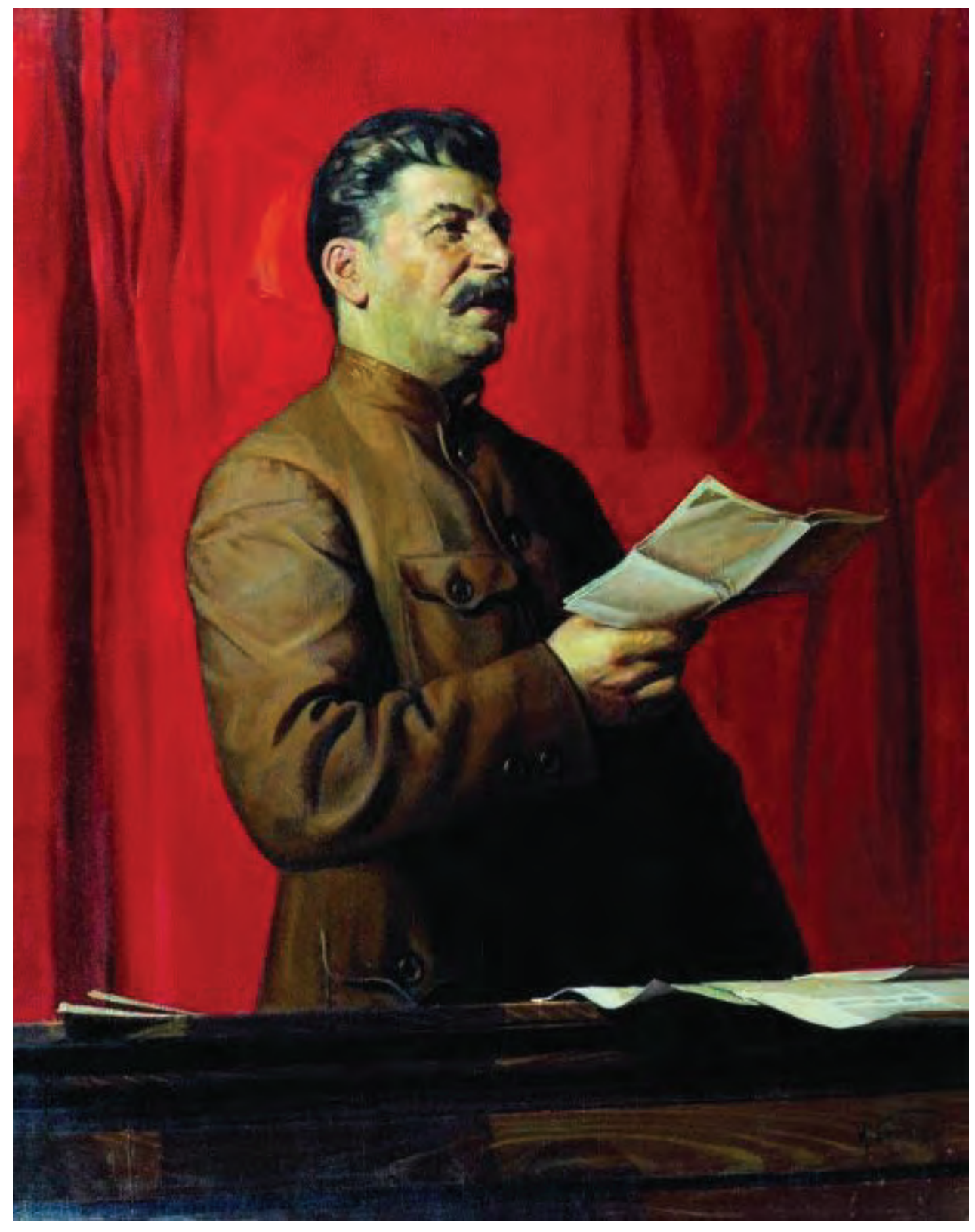

Fig 82 Isaak Brodsky (18831939), Stalin, 1928, óleo sobre tela

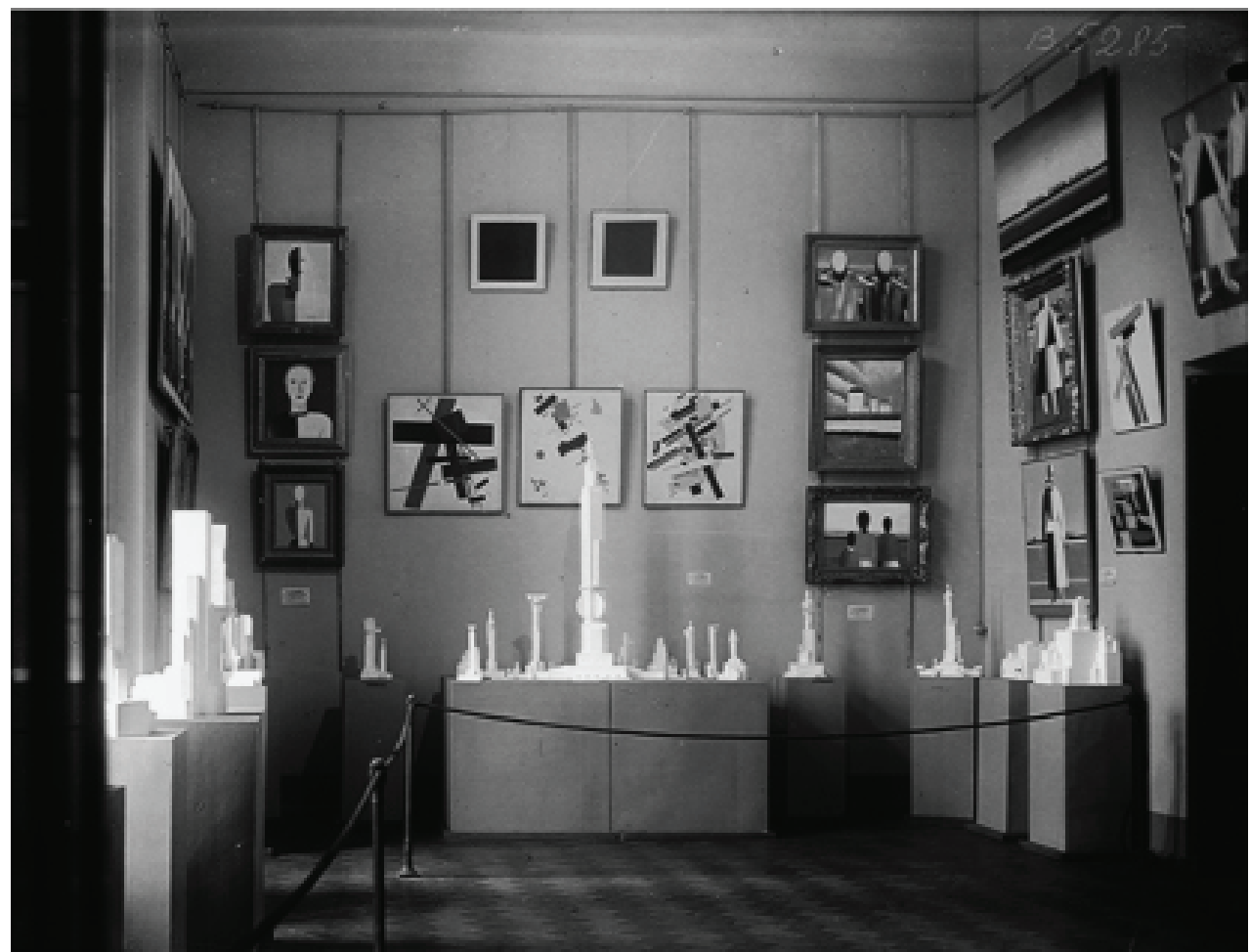

Fig 83 Galeria de Malevich, na exposição "Artistas da URSS dos Últimos 15 Anos", Leningrado, 1932 

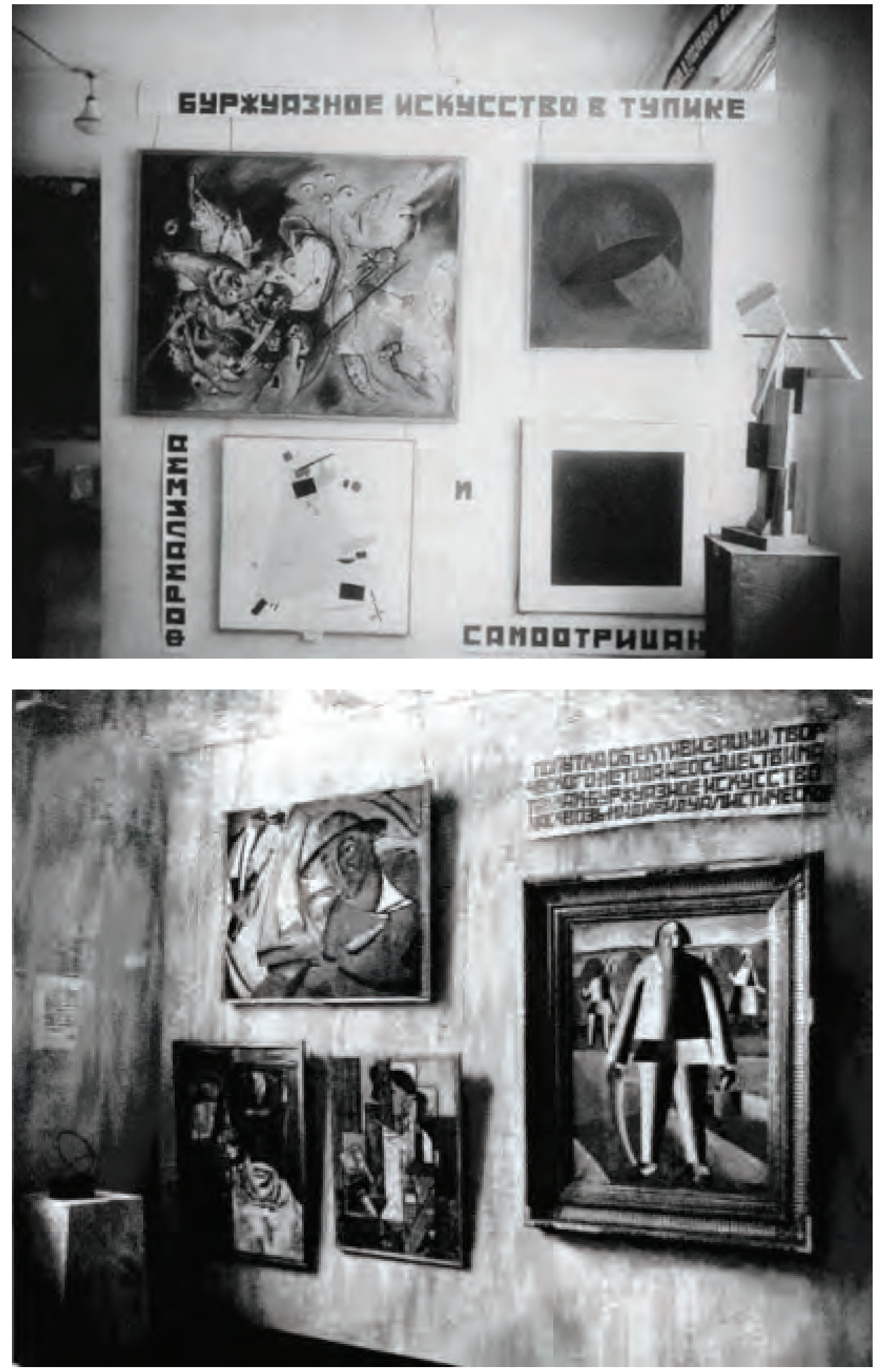

Fig 84 Exposição "Arte Russa da Era Imperialista", Galeria Estatal Tretiakov, Moscou, 1931-32 (Texto escrito na parede: "Arte burguesa no beco sem saída do formalismo e a auto-negação")

Fig 85 Exposição experimental "A Arte na Era do Capitalismo", Galeria Estatal Tretiakov, 1931-1932 (Texto escrito na parede: "Qualquer tentativa de tornar o método artístico [criativo] mais objetivo está condenado ao fracasso, porque a arte burguesa é individualista completamente") 


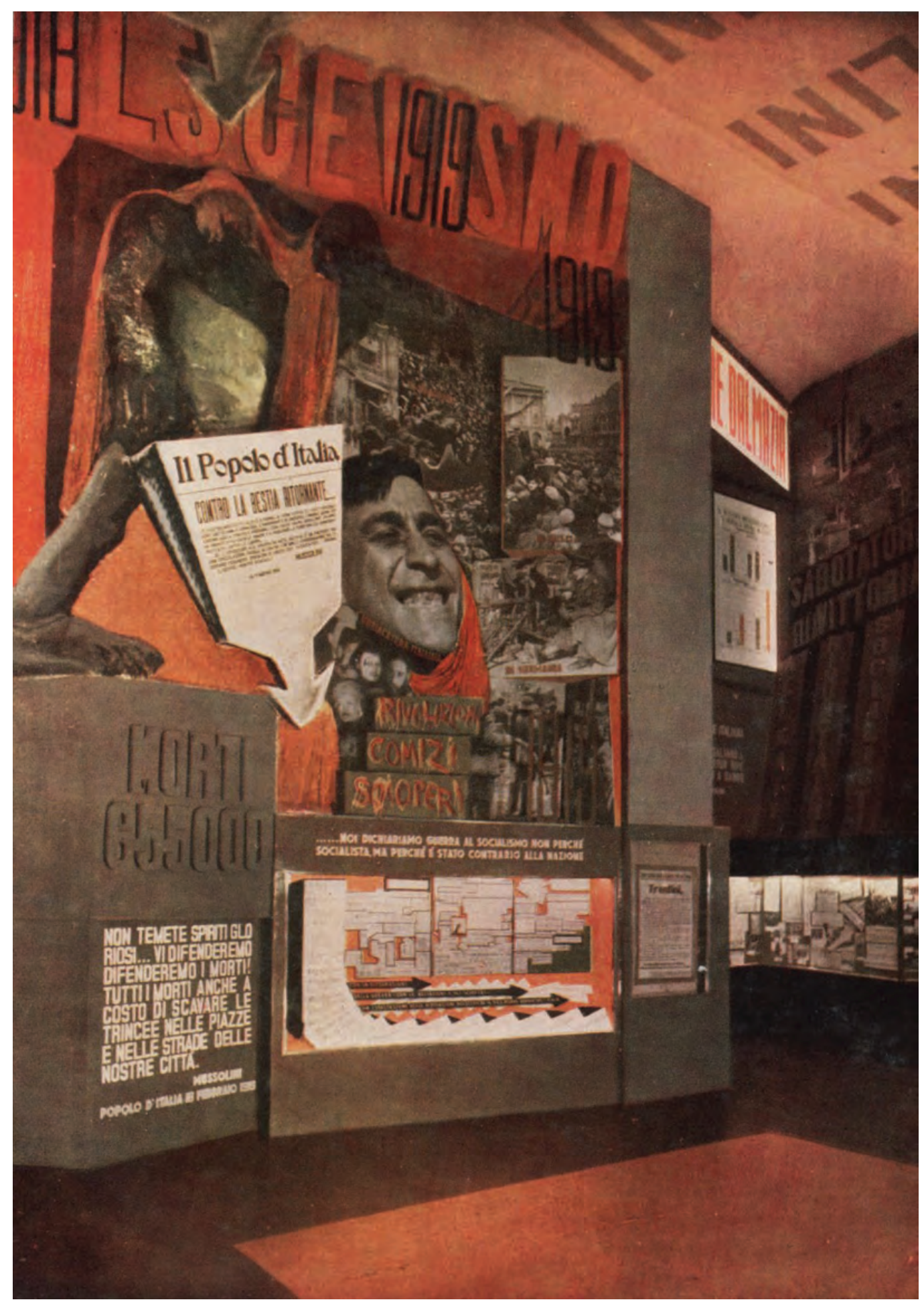

Fig. 86 Sala E, Mostra da Revolução Fascista, 1932 (Na manchete do jornal "Il Popolo d'Italia", está escrito acima, à direita: "Contra a Besta reincidente"). Atrás do jornal encontra-se a pintura de uma espécie de besta desforme. Na fotomontagem, àcima, à direita, pode-se também perceber a mesma foto de Lênin em Petrogrado, de 1917 (Figuras 78 e 79 ) 

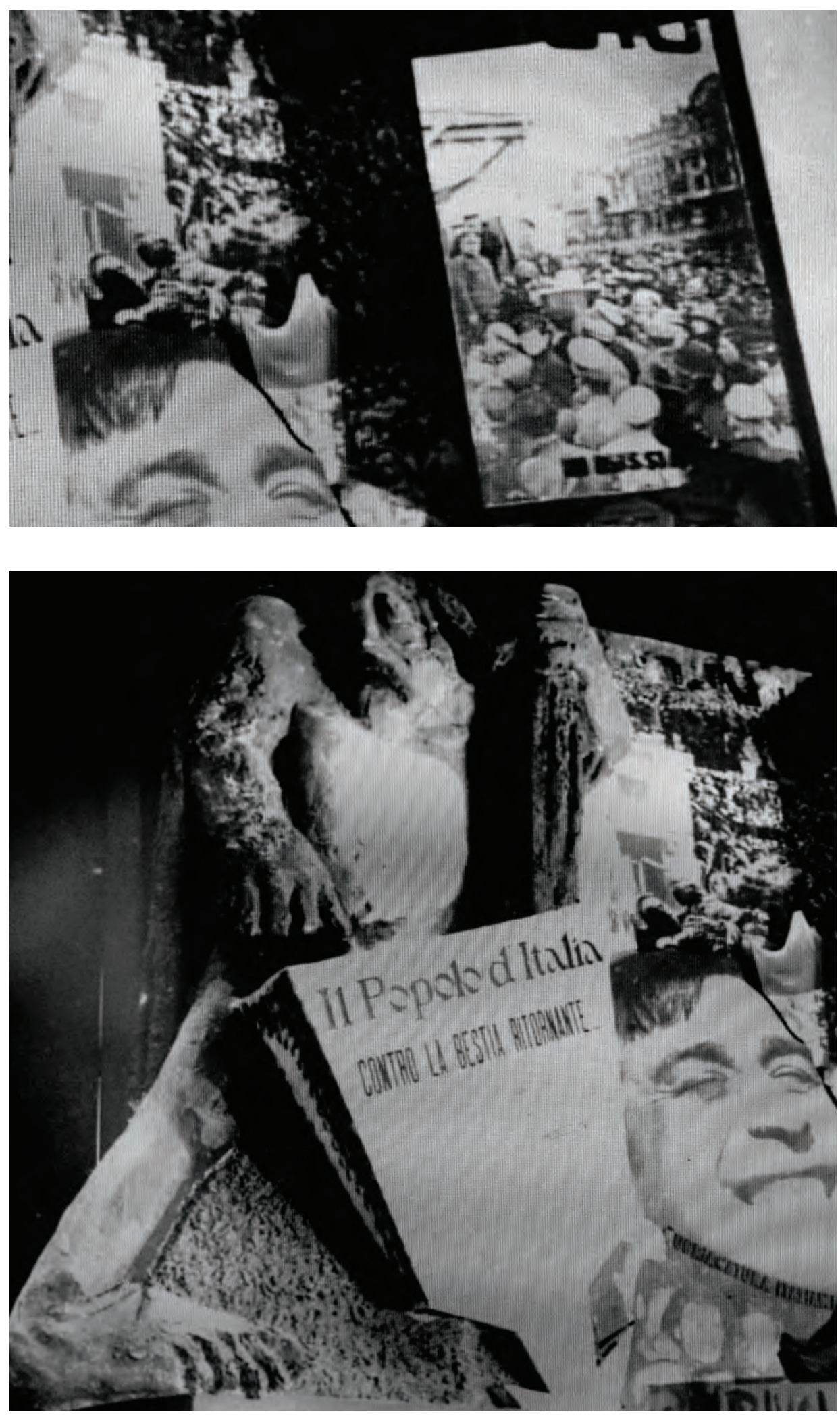

Fig. 87 Sala E, Mostra da Revolução Fascista, 1932 (Fragmentos da fotomontagem da Sala

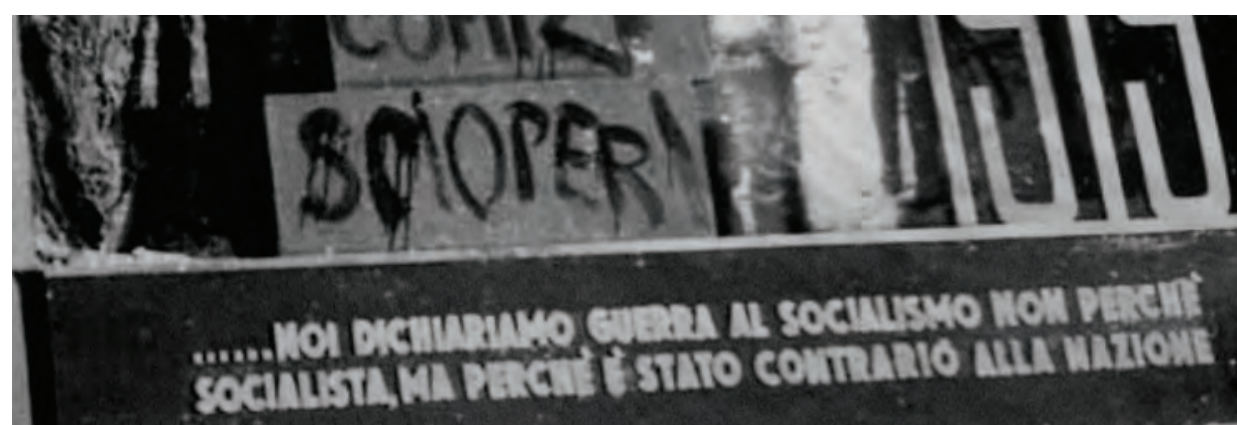



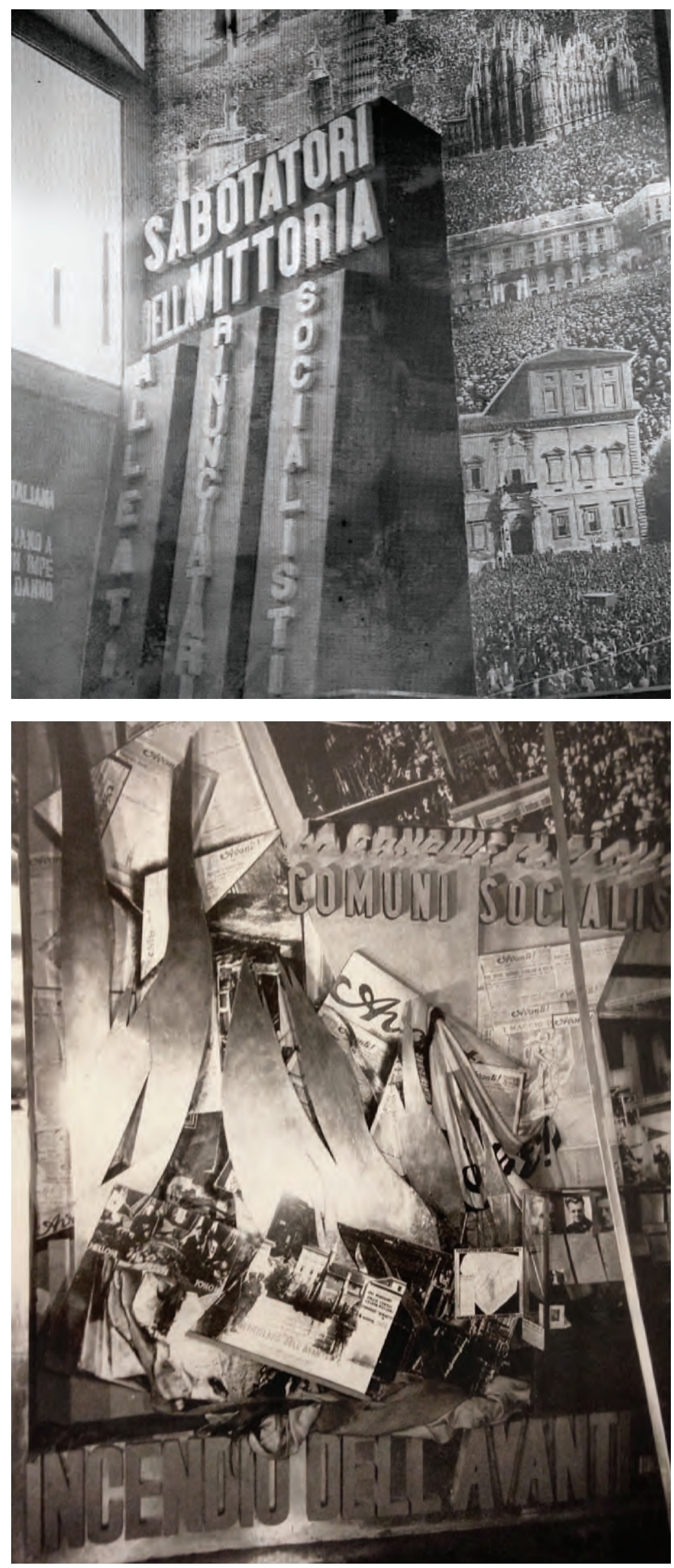

Fig. 88 Sala E, Mostra

da Revolução Fascista 1932

Fig. 89 Sala 0, Mostra da Revolução Fascista, 1932 (ampliação de um dos paineis da sala). 

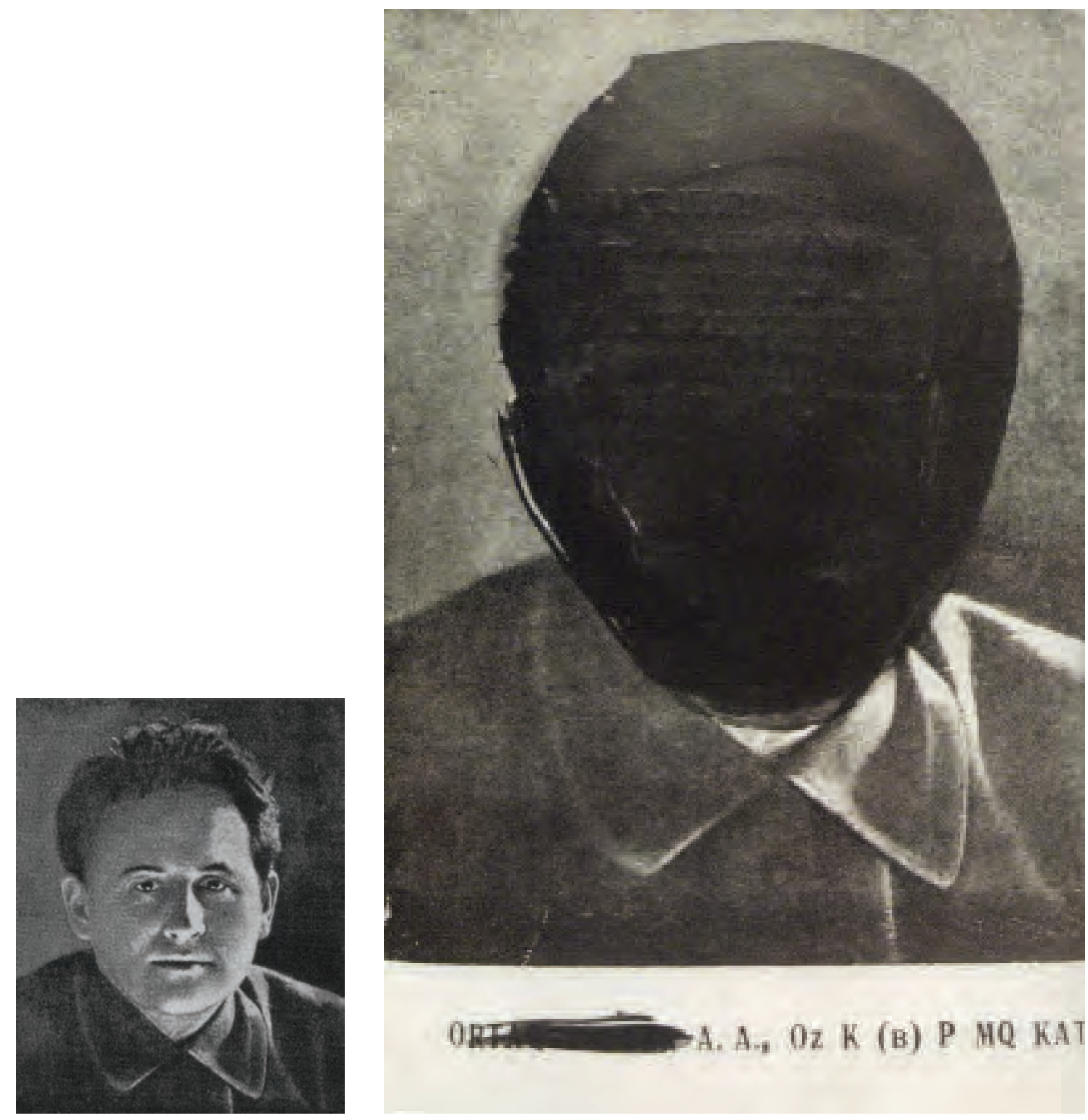

Fig 90 Fac-símile de página do livro "Dez anos de Uzbequistão" feito por Rodchenko em 1934. Em

1935, as versões foram alteradas por questões políticas. Em 1937, Stalin ordenou o expurgo das lideranças uzbeques e o livro foi posto na ilegalidade.

O próprio Rodchenko tratou de esconder os rostos dos comissários banidos em seu cópia da publicação. Nesta página, A. Tsexer, secretário do Comitê Central do Partido Comunista do Uzbequistão 

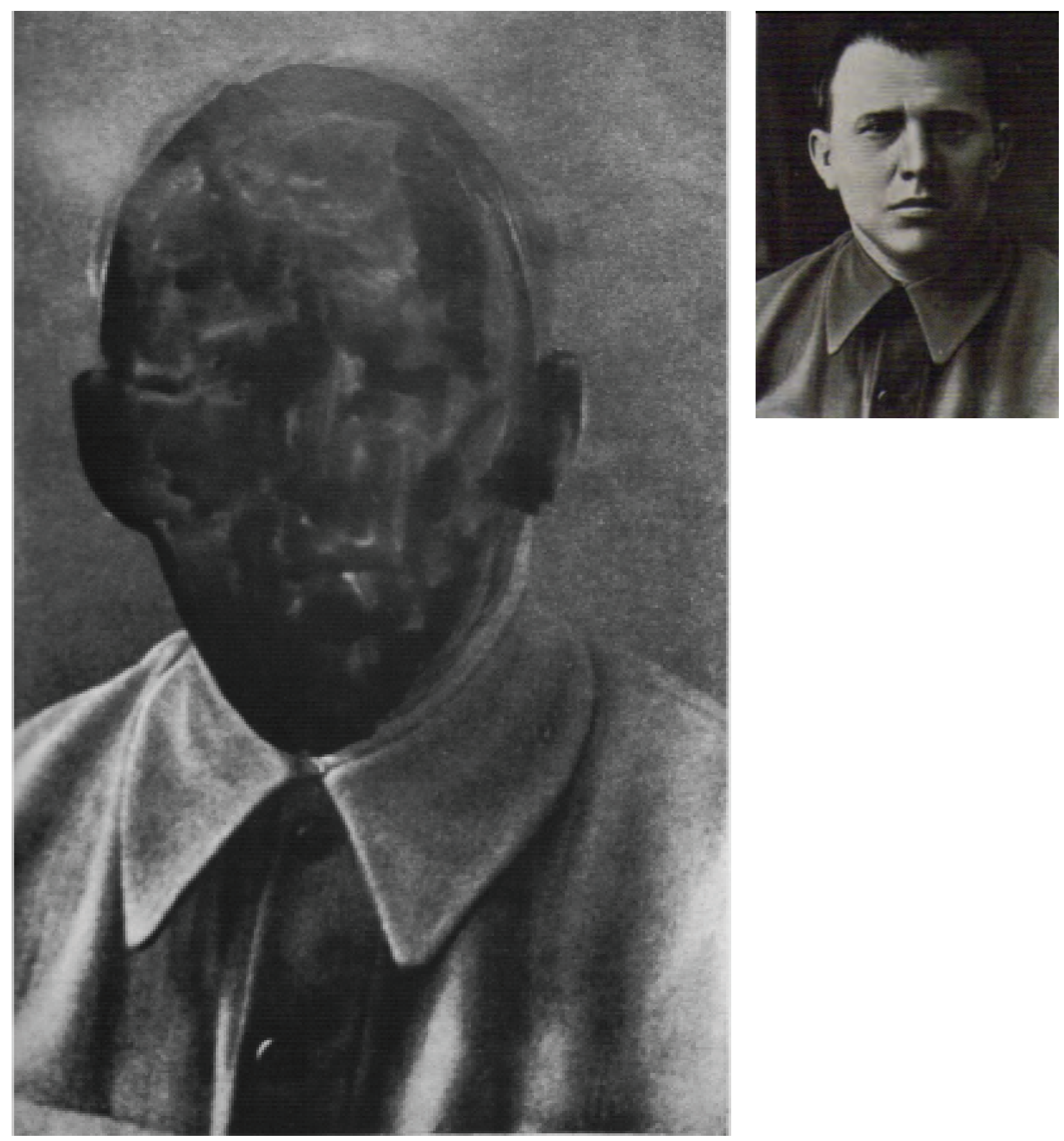

Fig 91 Fac-símile do livro "Dez anos de Uzbequistão" Nesta página, Akmal Ikramov, secretário do Comitê Central do Partido Comunista do Uzbequistão. 
Fig 92 Página da Revista "Sovetskoe Photo",

na qual Rodchenko é acusado de plágio e

formalismo, 1928.

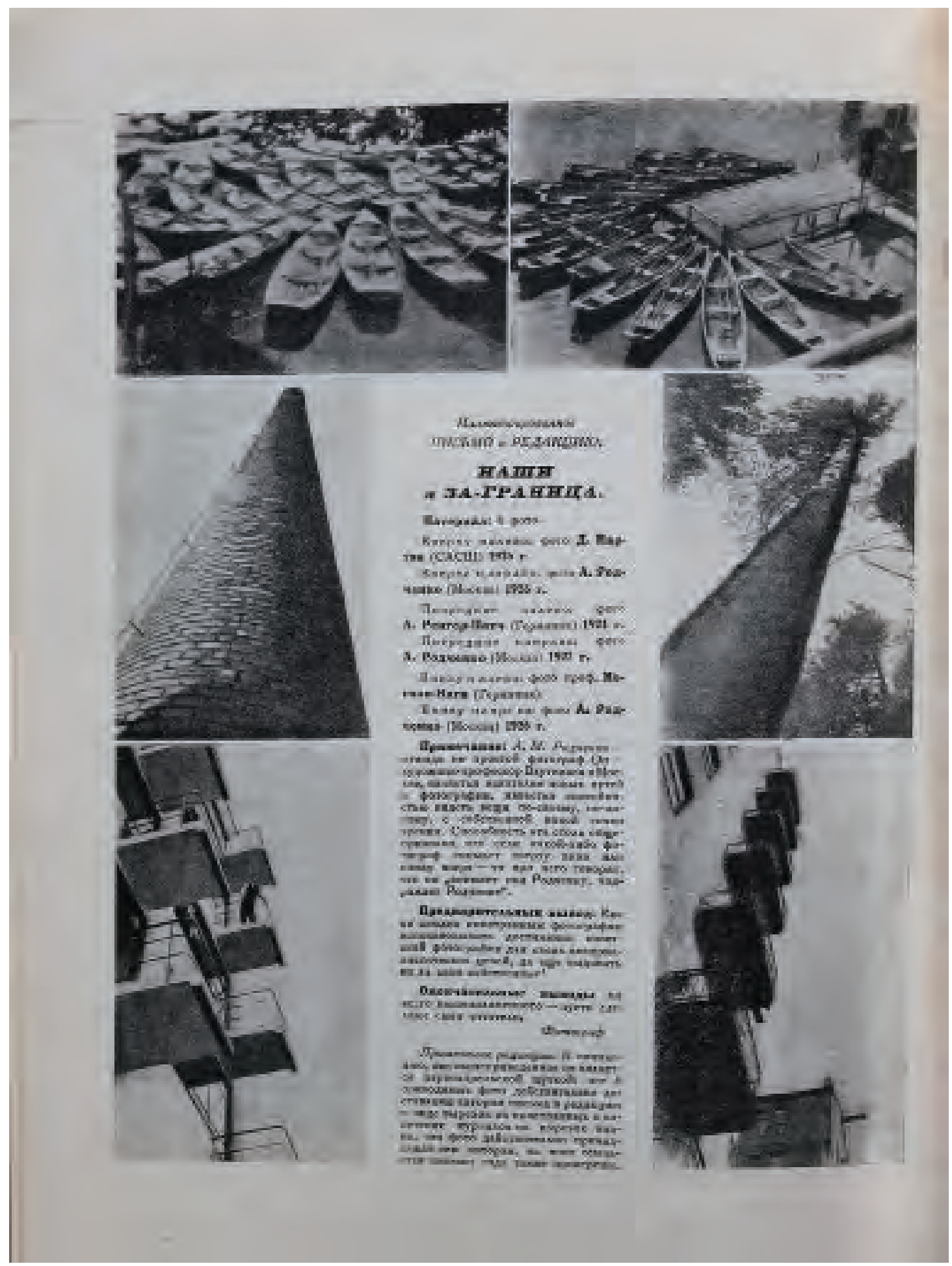




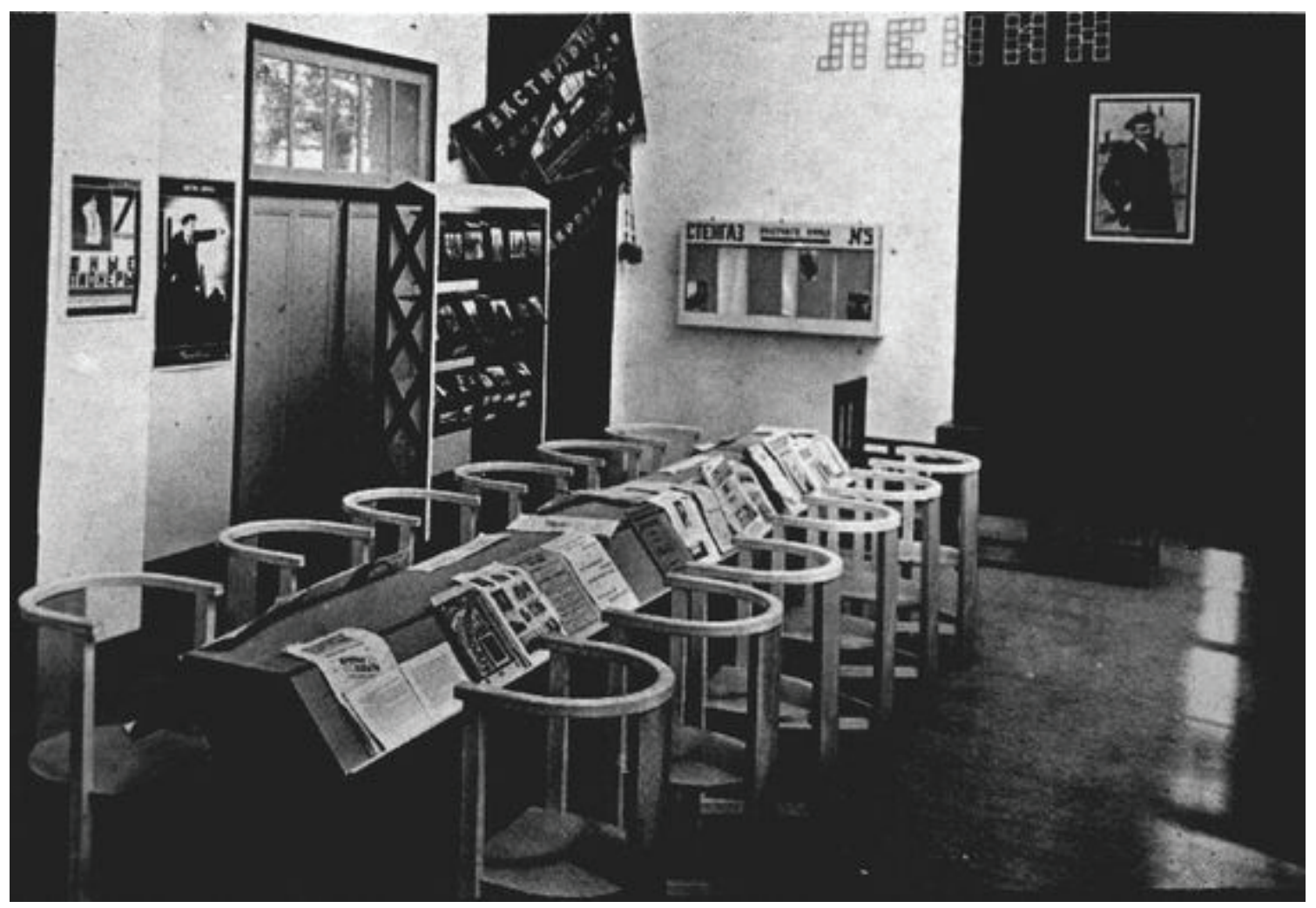

Fig.93 Clube dos trabalhadores (Rodchenko), pavilhão soviético na Exposição Internacional de Artes Decorativas e Modernas Industriais, Paris, 1925

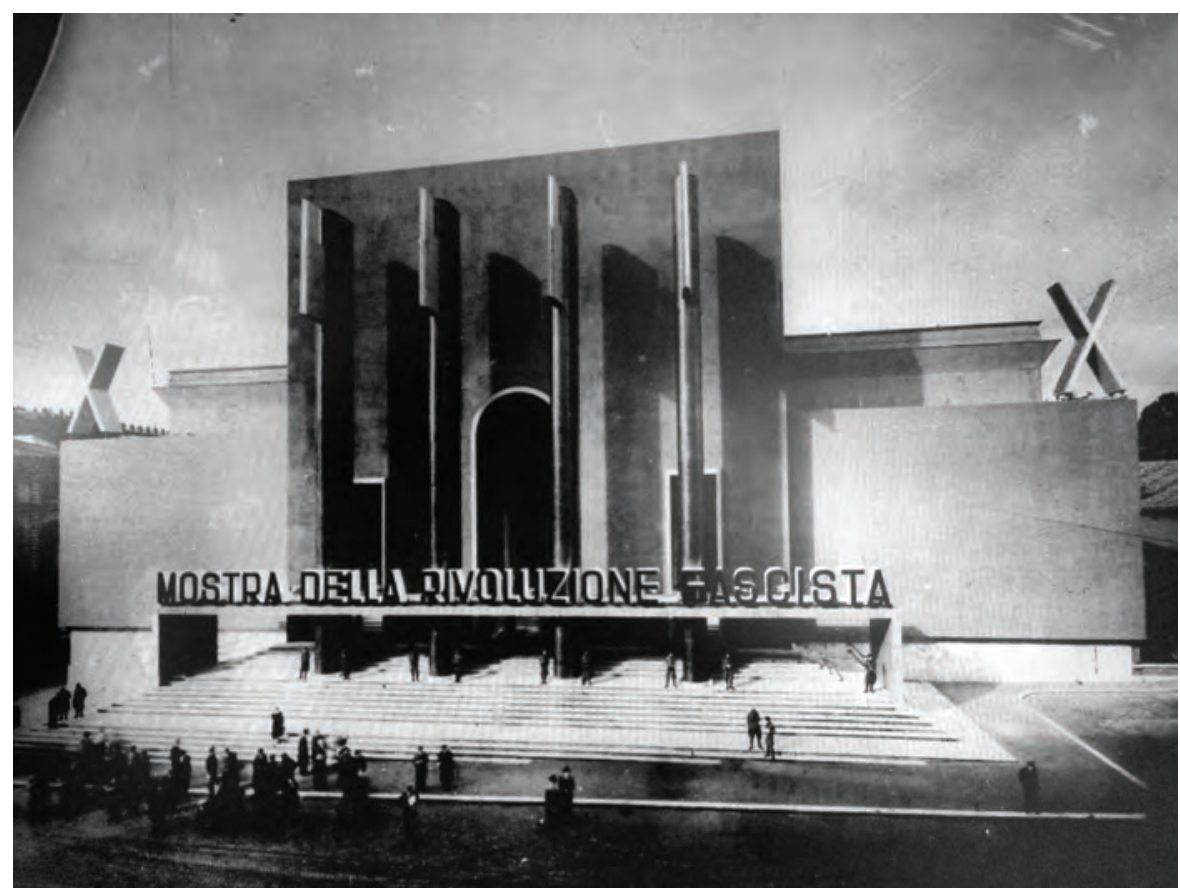

Fig. 94 Fachada da Mostra da Revolução Fascista, Roma, 1932 


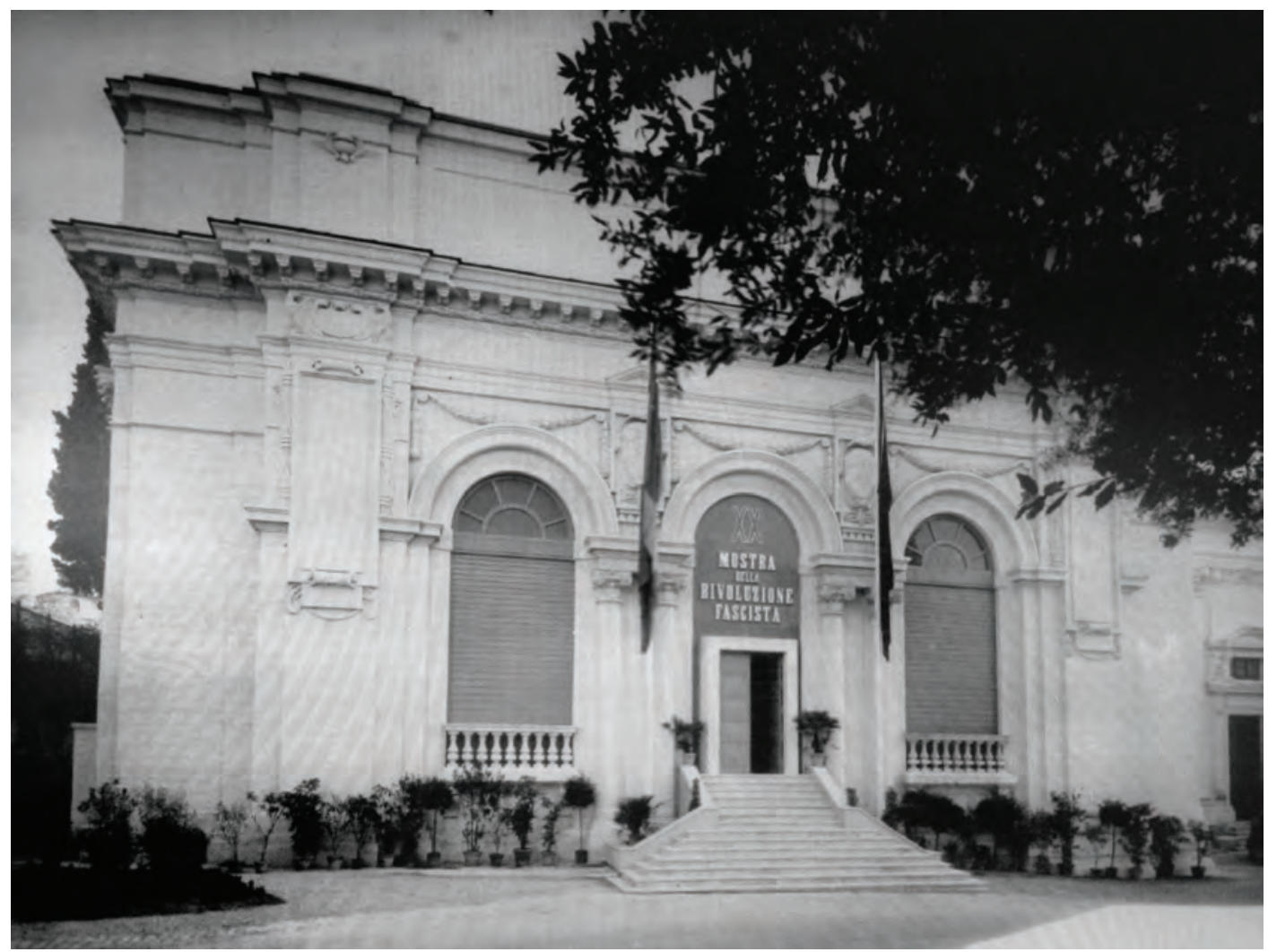

Fig. 96 Fachada da Mostra da

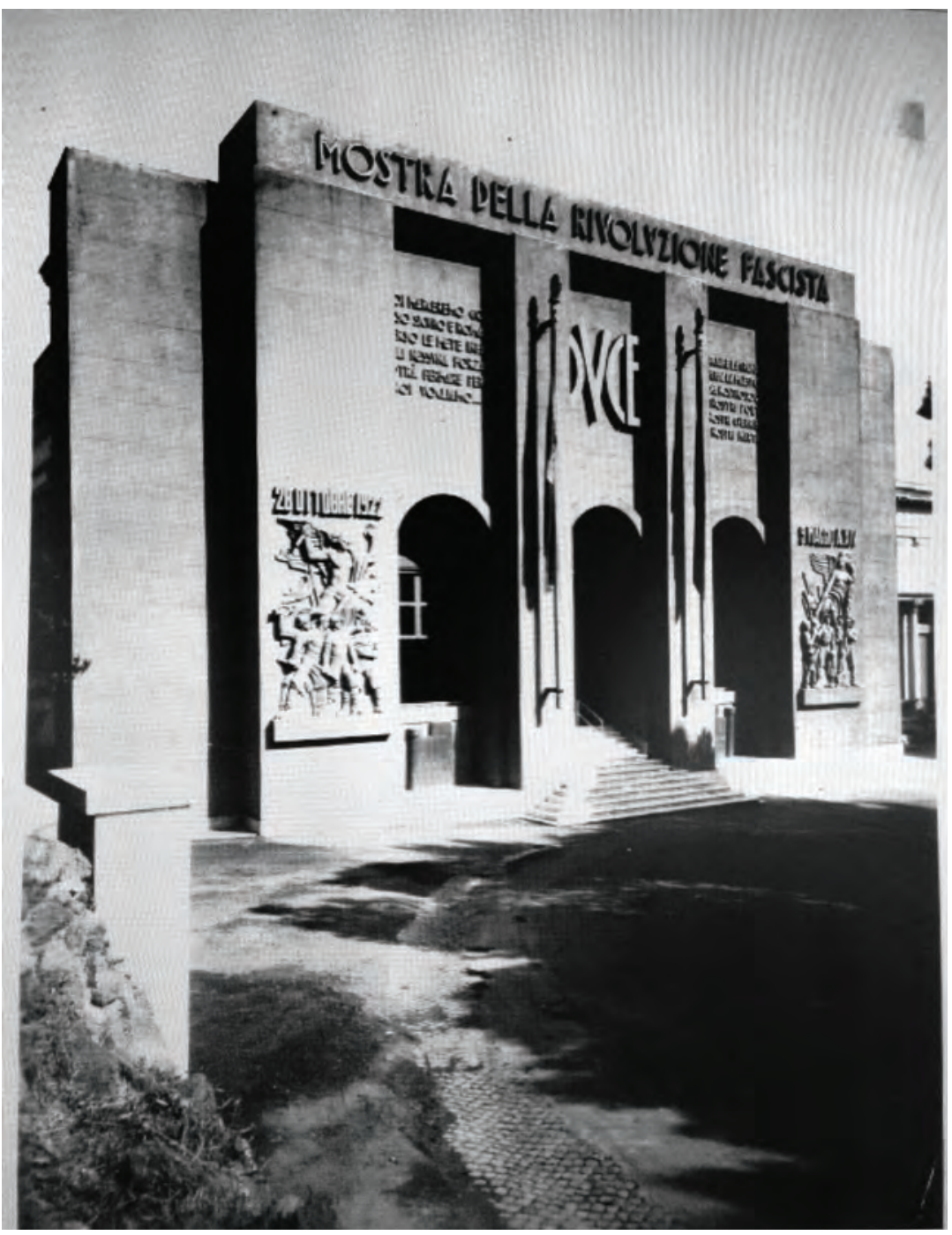




\title{
CAPÍTULO 4 | Entre a política e o mito da modernização
}

\subsection{Preâmbulo | Apropriações e simulacros revolucionários}

Ao analisar a "revolução passiva" fascista, associada às noções de hegemonia e "guerra de posição", ${ }^{349}$ Gramsci estabeleceu contraposições e intersecções entre os processos italiano e russo do período:

\begin{abstract}
Esta ideologia [o corporativismo fascista] serviria como elemento de uma "guerra de posição" no campo econômico (a livre concorrência e a livre troca corresponderiam à guerra de movimento) internacional, assim como a “revolução passiva” é este elemento no campo político. Na Europa de 1789 a 1870, houve uma guerra de movimento (política) na Revolução Francesa e uma longa guerra de posição de 1815 a 1870; na época atual, a guerra de movimento ocorreu politicamente de março de 1917 a março de 1921, sendo seguida por uma guerra de posição cujo representante, além de prático (para a Itália), ideológico (para a Europa), é o fascismo. ${ }^{350}$
\end{abstract}

\footnotetext{
${ }^{349}$ Para Gramsci, "guerra de movimento" ou "guerra de manobra", diria respeito a um enfrentamento direto entre classes (como, por exemplo, a Revolução Russa). Enquanto a "guerra de posição" representaria um embate indireto, no qual mobilizar-se-ia uma ampla gama de recursos, em todos os âmbitos da vida - de acordo com a ideia de Estado integral ou Estado ampliado -, na disputa pela construção da hegemonia, antes da chegada ao poder ou após a tomada do poder. "O conceito de Estado integral indica a relação de unidade-distinção que G.[ramsci] capta entre Estado e sociedade civil, para exprimir o que ele chama de Estado 'em sentido integral' (Q6, \$155, 810-1 [CC, 3, 257]), ou também, numa acepção ligeiramente diferente de Estado (integral, e não [...] um governo tecnicamente entendido). [...] A distinção entre sociedade politica e sociedade civil [para Gramsci] é puramente metódica, não orgânica, na vida histórica concreta, sociedade politica e sociedade civil são uma mesma coisa [...] 'sociedade civil é também 'Estado”'. Daí o recurso ao termo Estado integral ou Estado ampliado, de modo a enfatizar esse caráter mais complexo do entendimento da extensão e capilaridade do aparato Estado, o qual, a partir dessa ampliação do conceito também englobaria as esferas da sociedade civil. LIGUORI, Guido e VOZA, Pasquale (org.), Dicionário gramsciano (1926-1937), pref. Álvaro Bianchi, trad. Ana Maria Chiarini, Diego Silveira Coelho Ferreira, Leandro de Oliveira Galastri e Silvia de Bernardinis, São Paulo: Boitempo, 2017, p. 261. O conceito de hegemonia teria aparecido pela primeira vez no $\$ 44$, Q. 1 (fevereiro de 1930). A noção de hegemonia política ou de direção hegemônica, aliada à de "guerra de posição", teria sido "introduzida para destacar a necessidade de [a hegemonia] ser conquistada antes da ida ao governo". Segundo o estudioso da obra de Gramsci, Giuseppe Vacca o conceito de "guerra de posição", que é complementação de "revolução passiva", teria sido introduzido por Gramsci em novembro de 1930, no parágrafo \$10 do Caderno 7. VACCA, Giuseppe, Vida e pensamento de Antônio Gramsci: 1926-1937, trad. Luiz Sérgio Henriques, Rio de Janeiro: Contraponto, pp. 211-212. Para o conceito de "guerra de posição" e "guerra de manobra", ver: LIGUORI, Guido e VOZA, Pasquale (org.), Dicionário gramsciano..., op. cit., pp. 355-356.

${ }^{350}$ GRAMSCI, A., Cadernos..., op. cit., Q. $10 \$ 1$, 9, p. 300; idem, Quaderni..., op. cit., Q. $10 \$ 1$, 9, p. 1229.
} 
Frosini, no texto "Fascismo, parlamentarismo e luta pelo comunismo em Gramsci", ${ }^{351}$ atribui a datação de 1921 a alguns marcos históricos (como, por exemplo, o fracasso da insurreição armada na Alemanha, da chamada "Ação de março", o término da Guerra Civil Russa e o abandono do "comunismo de guerra" na URSS $)^{352}$ e a uma mudança de atitude do Partido Bolchevique, que indicaria a passagem da "guerra de movimento" para a "guerra de posição" (adoção da NEP na URSS e da estratégia das "frentes únicas" no âmbito internacional). ${ }^{353}$ Segundo Frosini, em 1921, o partido bolchevique abandonou a "dupla estratégia do ataque frontal no front interno (comunismo de guerra) e no front externo (propagação da revolução no Ocidente)" e adotou a "guerra de posições" - isso é, "um método de ataque que se pauta na conquista 'molecular' das massas e das posições de força dentro da sociedade". ${ }^{354}$

Para manter seu projeto hegemônico e impedir o protagonismo das classes subalternas, a "revolução passiva" fascista também assimilaria, de forma "molecular", elementos do campo antagônico. $^{355}$ Frosini cita como exemplo paradigmático de tais incorporações o projeto de restruturação corporativa fascista.

${ }^{351}$ FROSINI, Fabio, "Fascismo, parlamentarismo e lotta per il comunismo in Gramsci”, Laboratorio Culturale, Bologna: Ediesse, Critica Marxista, 2011, pp. 29-35. Texto em português: idem, "Entre a superação do parlamentarismo e lutas sociais: a função do direito e as dinâmicas do poder na análise gramsciana do fascismo e do comunismo soviético", trad. Massimo Sciarretta, in Gramsci Histórico, Seminário Internacional Comemorativo dos 120 anos de Nascimento de Antonio Gramsci, UniRio - Universidade Federal do Estado do Rio de Janeiro, 23-24 de agosto de 2011 (publicação do evento).

${ }^{352}$ FROSINI, F., "Entre superação...”, op. cit., pp. 2-3. Cabe mencionar também que 1921 é o ano no qual se encerra o biênio vermelho italiano. Biênio vermelho é como ficou conhecido o período histórico que compreende os anos 1919 e 1920. Durante esses dois anos, o movimento operário e camponês italiano viveu um momento de grande expansão, foi protagonista de lutas, greves e ocupações de fábricas.

353 "Março de 1921 não é unicamente o mês de Kronstadt e do $10^{\circ}$ Congresso, mas também o do fracasso das greves revolucionárias na Alemanha. [...] Ela [a tentativa revolucionária na Alemanha] vai demonstrar, com seu fracasso, que é preciso abandonar tanto a tática ofensiva quanto as perspectivas revolucionárias de curto prazo. O capitalismo europeu conseguiu se estabilizar e os comunistas devem ajustar sua tática a esta situação. Lenin e Trotski, que a princípio se enfrentam praticamente sozinhos contra uma maioria hostil, conseguem depois de um duro combate convencer os delegados do III Congresso da Internacional. O informe de Trotski se conclui desta maneira: 'A história outorgou à burguesia uma trégua durante a qual poderá respirar (...). O triunfo do proletariado no dia seguinte à guerra foi uma possibilidade histórica, mas, de fato, não se realizou. Devemos aproveitar este período de estabilização relativa para estender nossa influência sobre a classe operária e ganhar sua maioria antes que se produzam acontecimentos decisivos". Os partidos comunistas antes de tomar o poder, devem 'conquistar as massas': esta é a tarefa a que os chama a Internacional Comunista a partir de 1921". BROUÉ, Pierre, O Partido..., op. cit., pp. 152-153. Ver também as discussões dos terceiro e quarto congressos da Internacional Comunista: $\quad<$ https://www.marxists.org/history/international/comintern/3rdcongress/index.htm $>$ e < https://www.marxists.org/history/international/comintern/4th-congress/unitedfront.htm $>$, acessado em 29 de abril de 2015.

${ }^{354}$ FROSINI, F., “Entre superação...”, op. cit., p. 3.

${ }^{355}$ FROSINI, F., "Entre superação...”, op. cit., p. 5. “Tais tendências, todavia, enquanto encaixadas num projeto de revolução passiva, têm de absorver alguns elementos do campo adverso, o que ocorreu a propósito da reivindicação - levada adiante não apenas pelo Spirito, mas também por um autor tão diferente dele como Gino Arias - para uma economia organizada conforme um plano de nível mundial". FROSINI, F., "Entre superação...”, op. cit., p. 9. Ugo Spirito (1896-1979) foi filósofo e professor universitário italiano. Assim como o jurista Gino Arias (1879-1940), Spirito foi um dos principais teóricos do corporativismo italiano. Ver: GRAMSCI, A., Cadernos..., op. cit., pp. 299-300. 
O corporativismo fascista era propagandeado, no período, como “[...] uma vertente ideológica internacional, cuja tarefa consistiria em encarar o desafio representado pelo plano quinquenal soviético, utilizando as mesmas armas desse: organização, planificação, racionalização, centralidade da produção etc" ${ }^{356} \mathrm{Um}$ dos elementos fortes do corporativismo era a retórica de superação da luta de classes e o processo de incorporação das instâncias de representação e expressão das classes trabalhadores (como sindicatos e o Opera Nazionale Dopolavoro).

Analogamente, a mostra fascista de 1932, a cooptação de artistas modernos e a constituição de um discurso fotográfico dinâmico e de representação das massas (discutidos no capítulo 2) não consistiriam em operadores simbólicos da "revolução passiva" fascista? Quais seriam os seus equivalentes no caso do Termidor russo? ${ }^{357}$ Como pensar tais dispositivos e processos no caso stalinista?

O confronto entre as produções artísticas russas e italianas - pavilhão soviético na Exposição Internacional de Imprensa de Colônia [1928], Mostra da Revolução Fascista [1932-1934], cartazes da IZOGIZ [1929-1934], revista URSS em Construção [1930-1934] e exposição Artistas da URSS dos últimos 15 anos [1932-1934] - aponta certas intersecções entre técnicas, materiais e procedimentos adotados (alguns destes já discutidos anteriormente). Tais intersecções apontam para um possível uso inovador de aparatos técnicos e da arte para a manutenção de um projeto hegemônico, bem como para o impedimento do protagonismo político das massas, também no stalinismo. Nesse sentido, o presente capítulo discutirá as intersecções entre "estetização da política” fascista e a política artísticocultural stalinista a partir da articulação das noções de "revolução passiva" em Gramsci e "estetização da política" em W. Benjamin - à luz das discussões de "A obra de arte na era de sua reprodutibilidade técnica" (1935-1936) e "O autor como produtor" (1934).

\subsection{Trincheiras e casamatas de imagens}

Uma das pedras angulares do ensaio "A obra de arte na era de sua reprodutibilidade técnica" é a ligação direta entre o desenvolvimento das técnicas de reprodução e o aparecimento do socialismo revolucionário, conforme escreveu Benjamin em carta destinada a Horkheimer (29 de fevereiro de 1936):

${ }^{356}$ FROSINI, F., “Entre a superação...”, op. cit., pp. 7-8.

${ }^{357}$ Sobre o uso por Lênin, já em 1921, da noção de Termidor, ver nota de rodapé 14 e 369. Posteriormente, como se sabe, Trotsky recorreu muitas vezes ao termo Termidor para se referir à contrarrevolução stalinista. 


\begin{abstract}
"Quando, ao aparecer o primeiro método de reprodução verdadeiramente revolucionário, a fotografia (ao mesmo tempo que o socialismo), a arte pressente a aproximação de uma crise [...] ela reagirá com a teoria da arte pela arte, que constitui uma teologia da arte". Nessa frase, Brill ${ }^{358}$ queria de todo jeito cortar o conteúdo que se encontrava entre parênteses. A perspectiva do meu texto, que encara a história da técnica de reprodução em estreita ligação com a história das massas, me impede de abrir mão dessa frase. ${ }^{359}$
\end{abstract}

\title{
4.2.1 Contrapartidas ao uso revolucionário da foto
}

Em “Cartas de Paris (2): Pintura e fotografia” - texto supostamente encomendado pela revista Das Wort (A palavra ${ }^{360}$ e contemporâneo ao processo de elaboração de “A obra de arte...” -, Benjamin assinalou uma segunda conexão entre desenvolvimento das técnicas reprodutivas e desenvolvimento social e político. Desta vez, analisava o desenvolvimento no outro lado da trincheira da luta de classes: ao discutir “A fotografia na França no século XIX” (1936), de Gisèle Freund (19082000), Benjamin destacou, como contribuição central desta, o mapeamento da "ascensão da fotografia em relação com a ascensão da burguesia". ${ }^{361}$

A reflexão de Benjamin acerca da arte na era da reprodutibilidade técnica, como percebemos nos dois trechos supramencionados, passava precisamente pela análise do papel da arte dentro dos processos produtivos de seu tempo e das relações de forças determinadas pela luta de classes. Ou seja, Benjamin refletia sobre como a reprodutibilidade técnica transformaria a arte a partir do campo econômico, social e politico - bem como sobre o impacto dessas transformações em seu substrato histórico. ${ }^{362}$

${ }^{358}$ Brill foi o responsável pela preparação e publicação do ensaio "A obra de arte na era de sua reprodutibilidade técnica”, em sua versão traduzida para o francês, em meados de fevereiro de 1936. Em carta a Horkheimer, Benjamin lamenta-se das intervenções de Brill em seu texto. Ver: BENJAMIN, W., Benjamin e a obra de arte: técnica, imagem, percepção, org. Tadeu Capistrano, trad. Marijane Lisboa e Vera Ribeiro, Rio de Janeiro: Contraponto, 2012, p. 190.

${ }^{359}$ Fragmento de uma carta escrita por Benjamin a Horkheimer (29 de fevereiro de 1936), na qual critica os cortes editoriais da preparação para a publicação na França do ensaio "A obra de arte...”. BENJAMIN, W., Benjamin e a obra de arte..., op. cit., pp. 125-127. Ver também: idem, Estética e sociologia da arte, trad. João Barrento, São Paulo: Autêntica, 2017, pp. 139-143, e também pp. 193-194 (notas do editor).

${ }^{360}$ Ver: BENJAMIN, W., Estética e sociologia..., op. cit., pp. 224 e 267 (notas do editor).

${ }^{361}$ BENJAMIN, W., “Cartas de Paris (2): Pintura e fotografia”, in idem, Estética e sociologia... op. cit., p. 124.

${ }^{362}$ Segundo W. Benjamin, com advento dos meios técnicos de reprodução e registro, a própria arte transformarse-ia. Nesse sentido, cabe sublinhar que um dos pontos que teriam levado à constituição do próprio produtivismo (a saber, a plataforma do grupo LEF [1922-1928]) seria precisamente as transformações técnicas e produtivas. Conforme os lefistas, o construtivismo e sua radicalização materialista, o produtivismo, resultavam da correlação de três forcas principais: 1) a revolução artística, que sancionou a passagem da "representação" à "construção"; 2) a revolução social, que impôs uma reorganização total da vida; 3) e a revolução técnica, que introduziu novas formas materiais na vida cotidiana. Ver: ARVATOV, Boris, Arte produzione e rivoluzione proletária, Rímini: Guaraldi Editore, 1973; TARABUKIN, Nikolai, El último cuadro: Del caballete a la 
Escrito e reescrito entre 1935 e 1936, o ensaio "A Obra de Arte...” seria um prognóstico amplo sobre as "tendências de desenvolvimento da arte sob as condições atuais [isso é, de sua época] de produção". ${ }^{63}$ Para Benjamin, após o surgimento e a popularização dos novos aparatos técnicos de registro e recepção coletiva e simultânea (rádio, fotografia e cinema), a obra de arte teve sua estrutura aurática rompida e sua função social transformada. ${ }^{364} \mathrm{Com}$ isso, "em vez de fundar-se no ritual, ela [a 'obra de arte'] passaria a fundar-se em outra práxis: a política" $-{ }^{365} \mathrm{ou}$ seja, em sua funcionalidade e conjugação com a práxis política.

$\mathrm{Na}$ medida em que Benjamin, em sua análise, apontou dimensões revolucionárias da fotografia ${ }^{366}$ e uma tendência à politização da arte, apontou também seus usos e apropriações contrarrevolucionários (como na "estetização da política" fascista, isto é, no uso de novos aparatos técnicos pelo fascismo para a perpetuação de um regime de dominação e o impedimento do protagonismo das massas).

\subsection{2 "Estetização da política" e "revolução passiva"}

O [ato] político é um ato criador, um provocador [suscitatore], mas nem cria do nada, nem se move no vazio obscuro [torbido] dos seus desejos e sonhos. Ele se baseia na realidade efetiva, mas o que é essa realidade efetiva? Seria algo de estático e imóvel, e não, na verdade, uma relação de forças em contínuo movimento e mutação? (Gramsci, Q. 13, \$16). ${ }^{367}$

O conceito de "estetização da política" não tratava da experiência russa, no entanto, resguardadas as especificidades de cada caso, poder-se-ia supor que a política governamental de

máquina/Por una teoría de la pintura, Barcelona: Gustavo Gili, 1977 [1. ed., 1923]. Ver também: ZALAMBANI, Maria, L'arte nella produzione..., op. cit., e FIGUEIREDO, C. F., Foto-Grafia..., op. cit.

${ }^{363}$ BENJAMIN, W., A obra de arte na época de sua reprodutibilidade técnica (1936), Porto Alegre: Zouk, 2012, p. 11. Além dessa versão do texto de Benjamin, trabalhamos também com outras versões em português: BENJAMIN, W., "A obra de arte na era de sua reprodutibilidade técnica", in idem, Magia e Técnica, Arte e Politica - Ensaios sobre literatura e história da cultura, Obras Escolhidas, vol. 1, trad. S. P. Rouanet, pref. J. M. Gagnebin, S. Paulo: Brasiliense, pp. 165-196, 1987; BENJAMIN, W., "A obra de arte na era de sua reprodutibilidade técnica", in idem, Benjamin e a obra de arte: técnica, imagem, percepção, org. Tadeu Capistrano, trad. Marijane Lisboa e Vera Ribeiro, Rio de Janeiro, Contraponto, pp. 9-41, 2012; e, BENJAMIN, W., "A obra de arte na época de sua reprodutibilidade técnica", in idem, Estética e sociologia da arte, trad. João Barrento, São Paulo, Autêntica, pp.139-143, 2017.

364 "O que é propriamente aura? Um estranho tecido fino de espaço e tempo: a aparição única de uma distância, por mais próxima que esteja". BENJAMIN, W., A obra de arte..., op. cit., p. 27. "Em outras palavras: o valor único da obra de arte 'autêntica"'. Idem, ibidem, p. 33.

${ }^{365}$ BENJAMIN, W., “A Obra de arte na era...”, op. cit., pp. 171-172; e idem, A obra de arte..., op. cit., p. 35.

${ }^{366}$ Idem, ibidem, p. 35.

${ }^{367}$ GRAMSCI, Antonio, Quaderni..., op. cit., Q. 13, \$16, p. 1577. 
difusão de um simulacro discursivo da revolução, ${ }^{368}$ na URSS, também corresponderia a um processo de "estetização da política". Nesse sentido, o que diferiria e o que aproximaria os processos de formação das "industrias culturais” fascista e stalinista?

A articulação gramsciana entre os conceitos de "revolução passiva", "guerra de posição" e hegemonia poderia responder de modo esclarecedor às tangências e aos contrastes dos dispositivos culturais russos e italianos, construídos em escala industrial e de modo planificado. Tangências corresponderiam, assim, a elementos da apropriação molecular (das técnicas, materiais, dispositivos etc.) do campo antagônico. No entanto, abordada superficialmente, tal leitura poderia incorrer em esquematismos e reducionismos das reflexões e inscrições políticas de Gramsci e Benjamin, bem como da própria matéria histórica em questão. Nesse sentido, cabe rearticular e ajustar tais conceitos segundo as relações de força específicas, bem como tendo em vista o exame dos fatos históricos concretos. $^{369}$

Apesar de a "revolução passiva" representar uma forma de preservação de um determinado sistema de forças contrarrevolucionárias, Gramsci ressaltou o caráter não puramente conservador da "revolução passiva" ${ }^{370}$ Enquanto um dispositivo de análise histórica, o conceito de "revolução passiva" foi inicialmente utilizado para a compreensão da especificidade do processo de constituição do estado moderno italiano (Risorgimento) em oposição à Revolução (seguida de uma contrarrevolução) Francesa. Nesse sentido, cabe apontar as discussões sobre Termidor na Rússia, já em $1921,{ }^{371}$ assim como os paralelismos traçados por Gramsci entre os períodos de "1789 a 1870" e

${ }^{368}$ Benjamin, durante sua estadia em Moscou (1926-1927) observou uma tendência, no governo, de supressão dos conflitos de classe e neutralização do "comunismo militante", por meio da estetização da revolução. BENJAMIN, W., Diário de Moscou (1926-1927), op. cit., p. 67.

${ }^{369}$ Em relação com o conceito de "hegemonia", a discussão sobre "relações de força" aponta não apenas para o método de análise histórica (necessariamente calcado no material histórico concreto e em constante movimento), mas também para a finalidade política de tais análises e uma rearticulação entre as disputas e relações de força. Tais relações de força oscilariam, para a análise concreta, entre coerção e consenso no âmbito político-militar. Ver: GRAMSCI, A., Quaderni..., op. cit., Q. 13, \$17, p. 1578. Ver também: LIGUORI, Guido e VOZA, Pasquale (org.), Dicionário..., op. cit., pp. 682-685.

${ }^{370}$ THOMAS, P., “Modernity as 'passive revolution'...”, op. cit., p. 37.

${ }^{371}$ Como já mencionado no capítulo 1 , Serge registra em suas memórias discussões sobre o Termidor já em 1921. Nas palavras dele: "O Décimo Congresso do Partido, ocorrido em Moscou [março de 1921], adotou, conforme a proposta de Lênin, o fim do sistema de requisições, em outras palavras, do 'comunismo de guerra', e proclamou a 'Nova Política Econômica'. [...] Ao mesmo tempo, o congresso inaugurou um período difícil para todas as oposições. A Oposição Operária foi classificada como 'um desvio anarco-sindicalista incompatível com o partido', apesar de não ter nada em comum com anarquismo e eles meramente pedirem pelo controle da produção pelos sindicatos (o que teria sido um grande passo em direção à democracia para a classe trabalhadora). O congresso mobilizou todos os presentes [...] para a batalha contra os marinheiros de Kronstadt. [...] Nesses dias obscuros, Lênin disse, palavra por palavra, para um de meus amigos: 'Isso é o Termidor. Mas não podemos nos deixar ser guilhotinados. Devemos, nós mesmos, fazer um Termidor"'. SERGE, Victor, Memoirs..., op. cit., pp. 152-153. 
"1917 a 1921". ${ }^{372}$ Também cabe apontar o processo de esvaziamento e atrelamento estatal das formas de organização e luta das classes trabalhadoras russas (sovietes, sindicatos, organização de correspondentes operários e camponeses, liberdade de facções e tendências no partido bolchevique etc.), bem como, posteriormente, o esvaziamento e atrelamento estatal das formas e espaços de expressão e auto-organização dos artistas (reestruturação da Vkhutemas, decreto de 1932 e adoção do "realismo socialista" em 1934 etc.).

Em outras palavras, apontaria tudo isso para uma variante russa da "estetização da política"?

Um dos elementos-chave do conceito de "revolução passiva", especialmente após sua associação aos de hegemonia e "guerra de posição", seria a elaboração de métodos de contenção de massas e suas demandas revolucionárias, mediante o reformismo e a criação de aparatos capilares de construção de hegemonia. Conforme apontou o gramsciano Giuseppe Vacca, Gramsci (Q. 15, §35, 1932-1933) lança mão de uma citação literária para sublinhar não a instabilidade do fascismo, mas a sua força: "Esta [a força do fascismo] decorre do fato de ter conseguido destruir as velhas formas de organização das massas, substituindo-as por outras, voltadas para neutralizar sua iniciativa e controlá-las". ${ }^{373}$

Tendo em vista a profusão que os meios de comunicação e reprodutibilidade técnica adquiriram no início do século XX - com a popularização da fotografia e do cinema, amplamente exploradas no pavilhão soviético de Colônia (1928), nos cartazes de Klutsis para IZOGIZ (1929-1934) e na mostra fascista (1932-1934) -, bem como tendo em vista o esforço de criação de um aparato artístico-cultural fascista, cabe constatar que residiria, justamente, na apropriação contrarrevolucionária destes meios de comunicação e reprodução massivos um dos dispositivos da "revolução passiva" italiana.

Nesse sentido, não residiria também na adoção stalinista desses mesmos dispositivos um eixo de intersecção fulcral entre os casos russo e o italiano?

${ }^{372}$ GRAMSCI, A., Cadernos..., op. cit., Q. $10 \$ 1$, 9, 1932-1935, p. 299; idem, Quaderni..., op. cit., Q. $10 \$ 1,9$, p. 1229.

${ }^{373}$ VACCA, G., Vida e pensamento..., op. cit., p. 209. 


\subsection{3 "Nós devemos revolucionar nosso pensamento visual" 374}

Conforme a argumentação benjaminiana, a reprodutibilidade técnica da obra de arte, ao romper com seu valor de culto (aura), possibilitaria à arte não mais fundar-se em relações sociais estratificadas (calcadas na tradição, na hierarquia e nos rituais), mas fundar-se em seu valor de exposição e sua práxis política.

Para Benjamin, por sua capacidade de exposição (simultânea e coletiva), os meios de registro e reprodução mecânicos (e a própria arte, transformada com o advento destes) estariam aptos a: 1) romper com relações mercantis calcadas na propriedade privada dos meios e métodos de produção e reprodução; 2) romper com estruturas simbólicas de distinção/poder e o próprio modo de circulação artístico hierarquizado; 3) ampliar a capacidade crítica e a percepção das massas; 4) desvelar processos de alienação e apassivamento; e 5) dar a ver movimentações e protagonismos coletivos, trazendo para o horizonte a própria ideia de revolução.

A discussão benjaminiana sobre a atualidade e o potencial revolucionários dos aparatos de reprodutibilidade técnica, especificamente a fotografia e o cinema (visto que o cinema falado, para Benjamin, já estaria em germe na fotografia), deu-se em termos muito próximos aos do grupo LEF. ${ }^{375}$ Benjamin, assim como os lefistas, apontava, por exemplo, para a ampliação da capacidade perceptiva do homem graças ao desenvolvimento técnico (aviões, construções verticais, fotografias etc.). Segundo ele, "desde que o avião entrou em cena [...] aconteceu um corte inegavelmente decisivo. [...] A câmera está mais preparada do que o olho humano para se adaptar a essas novas condições de ver". 376

Em 1926, dez anos antes da publicação do ensaio de Benjamin, o lefista O. Brik escreveu: “A tarefa do cinema e da câmera não é a de imitar o olho humano, mas de ver e registrar aquilo que o

${ }^{374}$ RODCHENKO, A., "Los caminos de la fotografia moderna” (1928), in A.VV., Rodchenko: La construcción del futuro (catálogo da exposição), Catalunya: Fundacion Caixa Catalunya, 2008, pp. 199-200.

${ }^{375}$ Especificamente sobre as concepções e debates sobre fotografia do grupo LEF, ver: FIGUEIREDO, C., FotoGrafia..., op.cit. e DICKERMAN, Leah Anne, Aleksandr Rodchenko's camera-eye: lef vision and the production of revolutionary consciousness, tese de doutorado, Coimbra: Departamento de Filosofia, Universidade de Columbia, 1997.

${ }^{376}$ BENJAMIN, W., "Pintura e arquitetura, fotografia e cinema" (paralipômeno, 1936-1940), in idem, Estética e sociologia..., op., cit., pp. 249-258; p. 249. A questão das transformações perspectivas dos sujeitos frente ao desenvolvimento técnico remete às discussões de Benjamin em "Pequena história da fotografia" (1931), à noção de "inconsciente ótico". "Só a fotografia revela esse inconsciente ótico, como só a psicanalise revela o inconsciente pulsional". Idem, "Pequena história da fotografia" (1931), in idem, Magia e técnica, arte e política/ Ensaios sobre literatura e história da cultura, Obras Escolhidas, vol. 1, trad. S. P. Rouanet, pref. J. M. Gagnebin, S. Paulo: Brasiliense, 1994, pp. 91-108; p. 94. A questão do "inconsciente ótico" foi bastante explorada por pesquisadores de Benjamin, como nos estudos de Rosalind E. Krauss. Ver: KRAUSS, R. E., The optical unconscious, Cambridge, Massachusetts: The MIT Press (October book), 1993. 
olho humano não vê normalmente". ${ }^{377}$ Rodchenko, por sua vez, na mesma direção de Brik, escreveu em 1928:

As cidades contemporâneas, com seus prédios de vários andares, [...] trens, automóveis, a publicidade luminosa e espacial, transatlânticos, aviões [...]. Todas essas coisas, quer você goste ou não, têm deslocado a psicologia tradicional da percepção visual, ainda que só um pouco. Parece até que só a câmera fotográfica está apta a representar a vida moderna. ${ }^{378}$

Por centenas de anos, pintores fazem a mesma velha árvore "a partir do umbigo". Então, os fotógrafos os seguiram. Quando eu apresento uma árvore clicada a partir de baixo, como um objeto industrial - uma chaminé - isso cria uma revolução nos olhos do filisteu e do conhecedor do velho estilo de paisagens. ${ }^{379}$

$\mathrm{Na}$ última citação de Rodchenko, além da crítica à manutenção da perspectiva frontal da pintura (a perspectiva "a partir do umbigo"), tem-se também uma referência implícita à noção de "estranhamento", potencializada, no caso, pelo deslocamento da perspectiva obtida pelo aparelho fotográfico nas mãos de Rodchenko. Muito explorada nas reflexões e produções de Rodchenko (e de outros lefistas, como o próprio Tretiakov), ${ }^{380}$ a noção de "estranhamento" foi desenvolvida pelo também lefista Viktor Chklóvskii.

Conforme as discussões do LEF, por meio do recurso ao "estranhamento", a arte e a experiência artística combateriam os automatismos que o mundo do trabalho e as necessidades práticas cotidianas inserem na vida visual, mental e psíquica dos sujeitos na modernidade. Ao deslocar (recortar, colar, montar etc.) fragmentos da vida e transportá-los para a estrutural formal da arte - mediante processos de decalagens, justaposições etc. -, o artista surpreenderia o espectador e criaria uma nova percepção crítica e ativa dos objetos à sua volta. ${ }^{381} \mathrm{O}$ artista, segundo Rodchenko, criaria "uma revolução nos olhos do filisteu e do velho conhecedor de paisagens".

377 BRIK, O., "What the eye does not see" (Sovetskoe kino, n. 2, 1926), in PHILLIPS, Christopher, Photograph in Modern Era, New York: Metropolitan Museum/Art-Arperture, 1989, pp. 219-220.

${ }^{378}$ RODCHENKO, A., “The paths of contemporary photography” (Novyi Lef, n. 9, 1928), in LAVRENTIEV, A. (org.), Aleksandr Rodchenko experiments for the future: diaries, essays, letters, and other writings, trad. Jamey Gambrell, int. John Bowlt, New York, Museum of Modern Art, 2005, pp. 207-212; p. 210.

${ }^{379}$ RODCHENKO, A., “Downright ignorance or mean trick?”, in PHILLIPS, C. (org.), Photography..., op. cit., p. 245-248; p. 247.

380 TRETIAKOV, S., “La biografia dell' oggetto", in CHUZHAK, N. (org), Literatura fakta, Federacija, Moskva, 1929, in ZALAMBANI, M., La morte del romanzo: dall'avanguardia al "realismo socialista", Roma: Carocci, 2003, Apêndice I, pp. 162-165.

${ }^{381}$ CHKLÓVSKII, V., “A arte como procedimento” (1917), in Teoria da literatura: formalistas russos, trad. Ana M. R. Filipouski; Antônio C. Hohlfeld; Maria A. Pereira; e Regina L. Zilberman, Porto Alegre: Ed. Globo, 1970. 
Conforme Detlev Schottker, especialista em Benjamin, apesar deste não se referir diretamente à obra de Chklóvskii, a noção de "estranhamento" perpassava suas discussões sobre o caráter e as potencialidades revolucionárias da fotografia. Schottker afirma que Benjamin teve contado com tal discussão em sua passagem por Moscou, posto que conhecera pessoalmente Viktor Chklóvskii. Com efeito, Benjamin escreveu, inclusive, uma resenha de "Viagens Sentimentais" (1928) na ocasião da publicação da tradução francesa dessa autobiografia de Chklóvskii. ${ }^{382}$

\subsection{4 "A reprodução imagética da mercadoria"}

Essa mesma reprodutibilidade técnica com potencialidade revolucionária, entretanto, poderia atuar na direção contrária. A fotografia, em sua apropriação contrarrevolucionária, potencializaria a dimensão mercantil e econômica da obra de arte e dos próprios aparatos de reprodutibilidade técnica.

Com a fotografia e, num segundo momento, com o cinema, a demanda das sociedades mercantis por uma produção e circulação artísticas massificadas teriam sido saldadas (quitadas). ${ }^{383} \mathrm{~A}$ diferença da pintura, a fotografia não se restringia ao fato de ela mesma ser mercadoria. Além de mercadoria, a fotografia estaria a serviço da economia mercantil (ao ampliar seu campo de alcance). Conforme Benjamin, já com Disdéri (1819-1889) a fotografia "conquistou para a circulação de mercadorias objetos que antes praticamente não tinham lugar nela". ${ }^{384}$

"O caráter econômico da fotografia", anotou Benjamin em uma das anotações (1936-1940) de “A obra de arte...”, por seu valor de exposição, "não se esgota no fato de ela própria ser mercadoria". ${ }^{385}$ Tal qual a lenda do rei Midas, o registro fotográfico atribui, por seu valor de exposição, valor ao produto registrado. Ao potencializar seu valor de troca, a representação fotográfica, em muitos casos, tornar-se-ia mais importante que a própria realidade, produzindo uma inversão de valores entre

Sobre a própria noção de estranhamento e sobre os procedimentos e usos práticos de tal noção no pavilhão soviético de Colônia, ver discussões do capítulo 1 da presente tese.

${ }^{382}$ SCHOTTKER, Detlev, "Comentário sobre Benjamin e a obra de arte", in BENJAMIN, W., Benjamin e a obra de arte..., op. cit, p. 74.

${ }^{383}$ BENJAMIN, W., Estética e sociologia..., op. cit., p. 254.

${ }^{384}$ BENJAMIN, W., "Pintura e arquitetura, fotografia...”, op. cit., p. 254.

${ }^{385}$ Algumas versões manuscritas de "A obra de arte..." foram acompanhadas de fragmentos e anotações que não integram as versões finais do texto, mas mostram o desenvolvimento das reflexões de Benjamin na construção das várias versões de "A obra de arte...". Destacam-se ali anotações e textos inacabados que datam dos últimos anos de Benjamin (1936 e 1940). Parte de tais anotações e textos constituem, conforme estudiosos da obra de Benjamin, reflexões preparatórias para a redação de uma nova versão ampliada (nunca concluída) de "A obra de arte...”. Os manuscritos e anotações complementares, provavelmente elaborados entre 1936 e 1940, foram deixados por Benjamin aos cuidados de George Bataille (1897-1962) em 1940; foram encontrados em 1982, na Biblioteca Nacional de Paris, por Giorgio Agambem. Entre eles, consta um texto incompleto e fragmentário de 9 páginas, chamado "Pintura e arquitetura, fotografia e cinema". Ver: BENJAMIN, W., Estética e sociologia..., op. cit., pp. 249-258 e pp. 235-254. (notas do tradutor). 
objeto e imagem ${ }^{386}$ - como nos cartazes e revistas dos planos quinquenais russos (conforme discutido no capítulo anterior) ou nas pinturas do "realismo socialista".

Na Rússia stalinista, fotografias retocadas não só reconstruíam a história do passado próximo, como muitas vezes substituíam a própria realidade, ao serem elas - e não a observação da vida - a matéria sintetizada e representada na "pintura de cavalete", nos jornais e nos livros de história stalinistas. $^{387}$

Sobre os usos e apropriações da fotografia e do cinema, adverte Benjamin: "por meio do capital [...], as chances revolucionárias desse controle [o controle dos aparatos de registro e reprodutibilidade técnica] metamorfoseiam-se em contrarrevolucionárias". 388 Metamorfoses contrarrevolucionárias estas, calcadas em inversões, nas quais o fato é substituído pela farsa.

\subsubsection{A utilização política dos aparatos técnicos}

A relação quase direta que o cinema estabelece com as massas pode, assim, em sua apropriação contrarrevolucionária, fomentar as dimensões mercantis, espetaculosas e de culto do estrelato e da personalidade (do chefe). ${ }^{389}$ A perda da aura seria realocada, então, pelos empreendimentos capitalistas e pelo fascismo, respectivamente, no culto ao estrelato e ao líder. ${ }^{390}$

Segundo a Benjamin, a reprodutibilidade técnica, em seu uso contrarrevolucionário, instauraria um novo regime de exposição, seleção e socialização da arte, das massas e da política, "do qual o campeão [esportivo], o astro e o ditador emergem como vencedores".

$\mathrm{Na}$ era da reprodutibilidade técnica, o fascismo responderia, na prática, às crises do pósguerra e à crise de legitimidade do parlamento (agravada pelo assassinato de G. Matteotti, em 1924), também se apropriando das esferas artístico-culturais. Assim, em consonância com a reorganização

\footnotetext{
386 “As marcas de automóveis, de cigarro, de têxteis foram habituando o público a reconhecer na imagem determinadas qualidades dos seus produtos. Colocaram a fotografia no lugar da amostra do produto". BENJAMIN, W., "Pintura e arquitetura, fotografia...”, op. cit., p. 255.

${ }^{387}$ No realismo socialista, muitas fotografias retocadas ou montadas tornaram-se base para pinturas e esculturas, as quais pautavam-se mais pelas imagens falsificadas do que pela observação da realidade. Ver capítulo 3. Ver também DICKERMAN, Leah Anne, “Camera Obscura...”, op. cit., pp. 138-153, e KING, David, The commissar vanishes..., op. cit.

${ }^{388}$ BENJAMIN, W., A obra de arte..., op. cit., p. 77.

389 "Certamente, não se deve esquecer que a utilização política desse controle deve esperar até que o cinema se liberte dos grilhões de sua exploração capitalista”. BENJAMIN, W., A obra de arte..., op. cit., p. 77.

${ }^{390}$ Benjamin aponta a transferência da aura para o valor de culto do estrelato, o qual, em mais de uma passagem, é associado ao culto do líder. Culto e estrelato aparecem em "A obra de arte..." como duas expressões de um mesmo processo, determinadas por seus artífices (capital cinematográfico e fascismo, respectivamente). "O sentido dessa transformação [reprodutibilidade técnica e das condições de exposição], independente de suas tarefas especiais, é o mesmo para o ator de cinema e para o político". BENJAMIN, W., A obra de arte..., op. cit., p. 78. "Resulta disso um novo tipo de seleção, uma seleção diante do aparato, da qual o campeão [esportivo], o astro e o ditador emergem como vencedores", idem, ibidem, p. 78. Sobre a relação entre valor de culto e de estrelato, ver também SCHOTTKER, Detlev, "Comentário sobre Benjamin e a obra de arte", in BENJAMIN, W., Benjamin e a obra de arte..., op. cit., p. 76.
} 
econômico-legislativa estatal, o fascismo - por meio do controle dos aparatos de reprodutibilidade técnica, com a criação de órgãos para produção e gestão dos mesmos, como o Instituto LUCE - se valeu da reestruturação das esferas artístico-culturais para conferir inédita capilaridade ao regime. $\mathrm{Na}$ ordem do dia, estariam a criação e fomento de práticas litúrgicas de culto ao Duce.

De fato, como sugerido por Benjamin, na "estetização da política" fascista tem-se toda uma reestruturação do sistema artístico italiano mediante a transposição de procedimentos e técnicas econômicas (intervencionismo, planejamento, serialização etc.). No mesmo processo dá-se a transformação da obra de arte, a partir da conjugação de práticas da "alta cultura" e da reprodutibilidade da "cultura de massas" (popularização de exposições; ampliação de escalas e suportes da pintura; reprodução técnica de pinturas em cartazes, catálogos, postais e filmes; incorporações de fotografia, jornais e filmes em expografias, exposições, museus e bienais etc.).

A mudança, aqui constatada, no modo de exposição por meio da técnica de reprodução pode ser notada também na política. A crise da democracia pode ser entendida como uma crise nas condições de exposição do homem político. As democracias apresentam o político imediatamente em sua própria pessoa e diante de representantes. O parlamento é seu público. Com as inovações nos aparatos de registro, que permitem ao orador durante o seu discurso ser ouvido e, pouco tempo depois, ser visto por um número ilimitado de pessoas, a exposição do homem político diante desse aparato de registro passa para o primeiro plano. Esvaziam-se os parlamentos ao mesmo tempo que os teatros. Rádio e cinema transformam não só a função do ator profissional, mas igualmente a função daqueles que, tal como o homem político, representam a si mesmo diante destes meios. ${ }^{391}$

\subsubsection{Alienação, da escala artesanal à industrial}

Em “A obra de arte...", Benjamin discute os mecanismos elaborados pelo fascismo para o desafio lançado pelo movimento operário, pelos novos aparatos de reprodutibilidade técnica e pelas crises econômicas do capitalismo. ${ }^{392}$

${ }^{391}$ BENJAMIN, W., A obra de arte..., op. cit., p. 78.

${ }^{392}$ A relação específica entre o desenvolvimento dos aparatos técnicos de registro e a crise econômica pode ser percebida em algumas citações, como na relação que Benjamin estabelece entre o surgimento do cinema falado e a crise econômica. "Os mesmos distúrbios que em geral conduziram à tentativa de manter as relações de propriedade vigentes por meio da violência aberta [nas mobiliza para a guerra fascistas], levaram o capital [...], ameaçado pela crise, a forçar os trabalhos prévios de realização do cinema falado. A introdução do cinema falado gerou, desse modo, um alívio momentâneo". Ver: BENJAMIN, W., A obra de arte..., op. cit., p. 34 (nota II). 
As discussões benjaminianas acerca da "estetização da política" explicitam (ainda que como prognóstico) um processo de construção de hegemonia de novo tipo, apontando a esfera da arte e das novas tecnologias de reprodutibilidade técnica como espaços e instrumentos da luta de classes - ou da "guerra de posição" continental, para usar a terminologia gramsciana. O emprego do termo "guerra de posição" continental dá-se, uma vez mais, de acordo com a hipótese aqui utilizada de que Gramsci e Benjamin discutiam, a partir de suas áreas de ação e estudo, um mesmo processo político e histórico específico (de abrangência continental). Ou seja, ambos discutem a ascensão dos fascismos e seus mecanismos e dispositivos, a reordenação do Estado, do trabalho e da cultura inserindo-os numa conjuntura internacional e no âmbito da noção de luta de classes.

Assim, a apropriação fascista dos novos aparatos de registro e recepção coletiva e simultânea (rádio, fotografia e cinema) adquire, conforme a leitura de Benjamin, um significado estratégico na medida em que eles proporcionam espaços de inclusão das massas, sem com isso alterar as relações tradicionais de classe e propriedade. No fascismo, estética e anestésica foram conjugadas de forma inaugural, à serviço de um projeto hegemônico. Desse modo, "o fascismo procura organizar as massas proletarizadas recém-surgidas sem tocar nas relações de propriedade, por cuja eliminação elas pressionam. Ele vê sua salvação em deixar as massas alcançarem a sua expressão (de modo algum o seu direito)". ${ }^{393}$

$\mathrm{Na}$ representação mecânica do homem e das massas, fomentada pelo fascismo, "a sua [do homem e das massas] auto-alienação experimentou uma utilização altamente produtiva" ${ }^{394}$ Segundo Benjamin, no fascismo as massas foram alocadas num papel duplo "de observadoras e de massa inerte que era formada e moldada", ${ }^{395}$ enquanto simultaneamente contemplavam (com gozo estético) sua própria representação (e destruição).

A coisificação proporcionada ao espectador na recepção estética (contemplação narcísica e passiva) dos registros técnicos de movimentos de massa (grandes desfiles, comícios monstruosos etc.), conduziria, na "revolução passiva" fascista, a um tipo de anestesia da recepção. Anestesia da recepção, por sua vez, proporcionada por “uma visão da 'cena' com prazer estético, ainda que essa cena seja a preparação de toda uma sociedade, por meio de um ritual, para o sacrifício sem questionamento e, em última instância, a destruição, $\mathrm{o}$ assassinato e a morte". ${ }^{396}$

Ao realocar o valor ritualístico e de culto da obra de arte (sua aura) no culto do chefe e das cenas de mobilização de massa, o fascismo esvaziava o potencial revolucionário dos aparatos técnicos de registro e reprodução, além do próprio potencial revolucionário da arte e da auto-organização das

\footnotetext{
${ }^{393}$ BENJAMIN, W., A Obra de arte..., op. cit., p. 117.

${ }^{394}$ BENJAMIN, W., A obra de arte..., p. 75.

${ }^{395}$ BUCK-MORSS, S., "Estética e anestésica: uma reconsideração de A obra de arte de Walter Benjamin", in BENJAMIN, W., Benjamin e a obra de arte..., op. cit., pp. 155-204; p. 190.

${ }^{396}$ BUCK-MORSS, S., “Estética e anestésica...”, op. cit., p. 191.
} 
massas. A "estetização da política" fascista transformava as massas em objeto de prazer estético e auto-alienação, incluindo-as, desse modo, enquanto consumidores de sua própria coisificação.

$\mathrm{Na}$ era da reprodutibilidade técnica, segundo Benjamin, a arte a serviço do fascismo proporcionava ao grande público o consumo estético de sua própria destruição - exatamente como na sala "U” (Sacrário dos Mártires) da Mostra da Revolução Fascista (1932-1934), comentada anteriormente.

\subsubsection{Miracolo!}

Em “A obra de arte...", Benjamin analisou as inflexões no campo da arte e da cultura com o advento da reprodutibilidade técnica. No entanto, precisamente por sua abordagem materialista (segundo a qual a análise do campo artístico dar-se-ia mediante sua inserção dentro dos processos produtivos de seu tempo), tal análise apontava, também, os impactos da reprodutibilidade técnica nas demais esferas da vida. Como uma via de mão dupla, teatro e parlamento esvaziar-se-iam; ator, massa e político transformar-se-iam mediante um novo regime de exposição.

Como os fasci repaginados da Mostra da Revolução Fascista, a "revolução passiva" do século XX teria lançado mão da intervenção do governo nas esferas da arte e da cultura para, analogamente ao período do Risorgimento, "salvar a posição política e econômica das velhas classes feudais, para evitar a reforma agrária e especialmente para evitar que as massas populares entrassem em um período de experiências políticas como aquelas verificadas na França nos anos do jacobinismo". ${ }^{397}$

A "revolução passiva" fascista, conforme a hipótese de Gramsci, levaria a burguesia a soluções reais de enfrentamento da crise capitalista do pós-guerra, ou, pelo menos, daria um novo fôlego à burguesia, ao criar um período de esperanças renovadas. Esperanças essas capazes de "manter o sistema hegemônico e as forças de coerção civil-militar à disposição das classes dirigentes tradicionais". 398

Parte integrante de uma grande "guerra de posições" continental, o stalinista "socialismo num só país" também articularia, de modo inaugural, os dispositivos artístico-culturais russos, para, se não acelerar o desenvolvimento industrial em curso com os Planos Quinquenais, ao menos manter as classes trabalhadoras mobilizadas e exploradas a serviço da dinamização da economia. Um fenômeno mórbido, no qual fotografias, cartazes, revistas e exposições russas, especialmente após 1932, foram operados em chave termidoriana. Assim, na apropriação stalinista dos novos aparatos de reprodutibilidade técnica o potencial revolucionário da obra de arte também metamorfoseou-se em contrarrevolucionário. Não seria precisamente tal metamorfose um dos eixos centrais da definição de "estetização da política"?

${ }^{397}$ GRAMSCI, Antonio, Quaderni..., op. cit., Q. 8, §236; idem, Cadernos..., op. cit., Q. $10 \$ 1,9,1932-1935$, p. 299.

${ }^{398}$ GRAMSCI, Antonio, Quaderni..., op. cit., Q. 8, §236; idem, Cadernos..., op. cit., Q. $10 \$ 1,9,1932-1935$, p. 299. 


\section{3 "0 autor como produtor"}

Em abril de 1934, Walter Benjamin escreveu um ensaio intitulado "O autor como produtor". Este, conforme o narrado pelo próprio Benjamin em carta de 28 de abril de 1934 a Theodor Adorno (1903-1969), fora escrito para uma conferência a ser apresentada no Instituto para o Estudo do Fascismo de Paris. A conferência era destinada a uma pequena audiência de trabalhadores e intelectuais ligados ao Partido Comunista Francês e ao Komintern. ${ }^{399}$

Em seu ensaio, Benjamin, exilado em Paris havia um ano devido à ascensão de Hitler, apoiouse nos termos e perspectivas do grupo LEF para discutir a politização da arte - a partir da noção do artista como trabalhador e do autor como produtor. ${ }^{400}$ Benjamin recusou a autonomia da arte e discutiu o papel da mesma, ao lado do proletariado na luta contra o fascismo e contra o capital.

Assim, frente ao fascismo galopante, à ascensão do nazismo (e aos rumos do stalinismo, consolidados e acentuados em 1934), Benjamin questiona a razão de ser da poesia (da arte como um todo), para então associar a "razão de ser" da poesia ao papel por ela desempenhado na luta de classes. "É o fim de sua [do poeta, do artista] autonomia. Ele orienta a sua atividade por aquilo que é útil ao proletariado na luta de classes. Costuma dizer-se que segue uma tendência”. ${ }^{401}$

Com efeito, o ensaio de Benjamin (abril de 1934) foi escrito dois anos após o decreto "sobre a restruturação das organizações artístico-literárias" (1932) do Partido Bolchevique - que dissolveu e proibiu agrupamentos artísticos - e no ano da adoção da doutrina do "realismo socialista" (agosto de 1934). Foi escrito, também, dois anos antes do início dos "Processos de Moscou" (1936), cinco anos antes da assinatura do pacto "Molotov-Ribbentrop" (1939). Ou seja, em um contexto-limite de supressão das liberdades organizativas no campo artístico/político e um pouco antes da associação estratégica do stalinismo com o nazismo.

Para se contrapor criticamente a esses processos, Benjamin escolheu falar sobre a politização da arte, usando como principal referência o escritor S. Tretiakov (1892-1937). Integrante do grupo

\footnotetext{
${ }^{399}$ Segundo João Barrento, um dos tradutores para o português de "O autor como produtor", a data indicada no subtítulo da conferência (27 de abril de 1934) resultaria talvez de engano e a conferência provavelmente sequer fora proferida. Na referida carta de Benjamin a Adorno (28 de abril de 1934), o primeiro comenta que escreveu o ensaio para tal conferência, mas fala dela enquanto algo futuro, algo ainda por acontecer. Nesse sentido, Barrento, com base em pesquisa nas correspondências de Benjamin e nos arquivos e atas de atividades do INFA (Instituto para o Estudo do Fascismo), do Partido Comunista Francês e do Komintern (as duas entidades que gerenciavam e controlavam o INFA), aventa a possibilidade de que tal conferência não tenha ocorrido. BENJAMIN, W., Estética e sociologia..., op. cit., p. 262.

${ }^{400}$ Sobre a relação entre o ensaio "O autor como produtor" e as discussões do grupo LEF, especialmente a articulação entre as noções de "encomenda social" e "tendência" (em sua acepção benjaminiana), ver FIGUEIREDO, Clara, "Uma noiva...”, op. cit.

${ }^{401}$ BENJAMIN, W., "O autor como produtor", in idem, Estética e sociologia..., pp. 79-105; p. 82.
} 
LEF, Tretiakov foi preso sob acusação de espionagem e deportado pelo regime stalinista em 1937. Morreu, provavelmente, em 1939, num campo de concentração na Sibéria. ${ }^{402}$

Em outras palavras, ao lançar mão da experiência do grupo LEF (enquanto uma contrapartida crítica ao simulacro discursivo stalinista), Benjamin se posicionava diante das relações artísticas, políticas e produtivas de sua época. Isso, inevitavelmente, para os artistas ligados aos círculos de esquerda, implicava uma tomada de posição crítica e próxima à oposição no exílio, frente à URSS stalinista.

\subsubsection{Reverberações e desdobramentos do debate russo}

Em “O autor como produtor”, Benjamin partiu da pergunta acerca da abordagem dialética da relação entre tendência (Tendenzkunst, orientação política da arte) ${ }^{403}$ e qualidade (técnica e artística) algo análogo à própria relação forma e conteúdo - para, por meio da análise de casos concretos, defender a reflexão sobre o papel da arte dentro das relações de produção. ${ }^{404}$

Benjamin, usando como exemplo o texto literário, propôs a reelaboração do binômio formaconteúdo dentro do próprio conceito de tendência (ou seja, a orientação política da obra). Tal conceito, ao ser pensado dentro das esferas de produção, passaria a abarcar também a noção de tendência literária (qualidade artística e técnica) de uma obra em função do papel por ela desempenhado no âmbito da própria produção artística. "A tendência de uma obra só pode ser politicamente correta se também for literariamente correta". ${ }^{405}$

Em outras palavras, se o tratamento dialético da relação entre forma e conteúdo passava pela inserção do artista dentro dos processos políticos e produtivos de seu tempo (no campo da luta de classes) ${ }^{406}$ passava também pela inserção do artista dentro dos processos da produção artística de sua

402 "Esse escritor operativo [definido e personificado por Tretiakov] fornece o exemplo mais palpável da dependência funcional em que se encontram, sempre e em todas as circunstâncias, a tendência [orientação] política correta e a técnica literária progressista”. BENJAMIN, W., “O autor...”, op. cit., p. 86.

${ }^{403}$ Para Benjamin, tendência corresponderia à orientação política (e, num segundo momento, qualidade artística) de uma obra. "Um tipo de escritor mais progressista reconhece essa alternativa. A sua decisão é tomada com base na luta de classes, e ele se coloca ao lado do proletariado. É o fim de sua autonomia. Ele orienta a sua atividade por aquilo que é útil ao proletariado na luta de classes. Costuma dizer-se que ele segue uma tendência". BENJAMIN, W., "O autor...”, op. cit., p. 82. Para o uso do termo "arte de tendência" à época, ver: LÖWY, M., "Lukács and Stalinism”, New Left Review I_91, Londres, May-June 1975, p. 26.

404 "Parti do debate estéril em torno da relação entre a tendência e qualidade da literatura. Poderia ter partido de um outro debate, ainda mais antigo, mas não menos estéril, o das relações entre forma e conteúdo, em particular na literatura política. Essa questão tornou-se suspeita - e com razão. É vista como exemplo típico da tentativa de abordar a problemática literária de forma não dialética, a partir de chavões. Muito bem. Mas, como se apresenta, então, o tratamento dialético da mesma questão?”. BENJAMIN, W., “O autor...”, op. cit., p. 84.

${ }^{405}$ BENJAMIN, W., “O autor...”, op. cit., p. 83.

406 “O escritor burguês que escreve literatura de entretenimento não reconhece essa alternativa [vinculação artística aos interesses da luta de classes]. Provam-lhe que, sem o reconhecer, serve a determinados interesses de classe. Um tipo de escritor mais progressista reconhece essa alternativa. A sua decisão é tomada com base na 
época - visto que esta também constituía uma das esferas determinantes das relações de produção e circulação do objeto artístico.

Ao vincular reciprocamente a relação entre tendência política e tendência artística de uma obra, Benjamin opõe-se aos rumos dominantes no campo artístico da URSS sob o stalinismo. ${ }^{407}$ Isso porque a articulação entre tendência política, tendência artística e inserção da arte dentro da produção (da luta de classes) apontava não apenas para a superação de uma obra meramente propagandista (como no "realismo heroico" e no "realismo socialista"), mas também para o papel ativo da arte na organização (da "cultura material”) de uma sociedade. ${ }^{408}$ Conforme Benjamin:

O autor que tiver refletido profundamente sobre as condições de produção atual está longe de esperar, ou mesmo de desejar, obras dessas. O seu trabalho nunca se ocupará apenas de produtos, mas também, sempre e simultaneamente, dos meios de produção. Em outras palavras: os seus produtos têm de possuir, para além do seu caráter de obra, e antes dele, uma função organizadora. E de modo algum a possibilidade que têm de ser utilizados com uma função organizadora se pode limitar à possibilidade de serem utilizados com uma função propagandística. A tendência, por si só, não chega. ${ }^{409}$

\subsection{2 "Função organizativa da arte" e "cultura material"}

Note-se que Benjamin não utiliza o termo "cultura material". Tal termo foi muito utilizado pelo lefista Boris Arvatov (1896-1940) para designar os objetos e as relações materiais e sociais

luta de classes, e ele se coloca ao lado do proletariado. É o fim de sua autonomia". BENJAMIN, W., "O autor...", op. cit. pp. 81-82.

${ }^{407}$ Com efeito, Benjamin, num texto (provavelmente inacabado) que acompanha a última versão do manuscrito "A obra de arte...", criticou a redução do "realismo socialista", nos círculos de esquerda do período, a uma discussão de temáticas. Segundo Benjamin: "Não dispomos de exemplo melhor do que o cinema para mostrar como as duas coisas estão intimamente relacionadas: a utilidade de uma nova técnica para as necessidades econômicas que se transformam, e a utilidade de um novo modo de ver para as necessidades estéticas que evoluíram. O realismo socialista não tem razões para menosprezar essas ligações. Se elas tiveram uma presença diminuta nas discussões de Paris - ou se, como disse Aragon, foram sabotadas por uma série de participantes -, isso de deve à natureza (pública) de um debate como esse. As consequências negativas de uma tal omissão resultaram na crença, por parte da generalidade [sic] dos oradores, de que a salvação está apenas nos novos assuntos". BENJAMIN, W., "Pintura e arquitetura, fotografia...", op. cit., p. 256.

${ }^{408}$ Neste ponto, o texto de Benjamin parece uma vez mais reverberar o debate do grupo LEF. Como discutido no capítulo 1, o grupo LEF propunha uma produção propagandística de outro tipo. Na contracorrente de práticas litúrgicas e contemplativas, o LEF defendia um tipo de propaganda que fomentasse uma postura crítica e consciente em seu receptor. Conforme escreveu Brik em 1924: "Que tipo de propaganda nós realmente precisamos na Rússia Soviética? Precisamos de propaganda que não estupidifique o público, mas que, ao contrário, esclareça a [sua] consciência". BRIK, O., 1924, apud COX, Randi, "NEP Whitout Nepmen! Soviet Advertising and the Transition to Socialism", in KIAR, C.; NAIMAN, E. (edit.), Every day life in early Soviet Russia: taking the revolution inside, Bloomington: Indiana University Press, 2006, pp. 119-152, p. 134.

${ }^{409}$ BENJAMIN, W., “O autor...”, op. cit., pp. 98-100. 
(proporcionadas por tais objetos), que constituem o modo de vida cotidiano (byt) e o psiquismo dos sujeitos. ${ }^{410} \mathrm{O}$ aspecto material da cultura seria, para o LEF, determinante da constituição dos sujeitos e das sociedades e imprescindível para a transformação destas. Assim, para os lefistas, o artista deveria compreender a "cultura material" de uma sociedade e incidir sobre ela. ${ }^{411}$

Entretanto, a proposta de transformação do byt e psiquismo por meio da transformação da "cultura material" relaciona-se substancialmente com a "função organizadora" reivindicada por Benjamin para a obra de arte - na esteira, aliás, de Tretiakov. ${ }^{412} \mathrm{~A}$ aproximação em questão torna-se ainda mais clara se pensarmos na ênfase dada por Benjamin às relações materiais e produtivas de um objeto artístico. Tal ênfase passava pela compreensão necessária de uma obra a partir das relações materiais (produtivas) às quais ela está submetida e as quais reproduz. ${ }^{413}$

Em suma, nesses termos, Benjamin, alinhado ao debate capitaneado pelo grupo LEF, atribuiu novo significa ao conceito de tendência, definindo-o em termos muito próximos aos da noção lefista de "encomenda social". Conforme as noções de "encomenda social” e de tendência (na acepção benjaminiana), não basta que a obra tenha um conteúdo crítico ou progressista (a "tendência política correta"); é necessário que ela tenha também uma forma que expresse tais características. Do mesmo modo, não basta ao artista refletir apenas externamente os processos de produção da vida, mas é necessário refletir criticamente sobre os modos de inserção da arte (de sua obra) nesse processo de produção.

\subsubsection{Dois pontos sobre o debate em questão}

O debate sobre tendência, especialmente na literatura (e literatura política), era um debate antigo da esquerda alemã. ${ }^{414}$ Acerca desse debate, cabe mencionar dois pontos:

\footnotetext{
${ }^{410}$ Por "cultura material" os lefistas entendiam as formas materiais socialmente úteis, criadas pelo trabalho humano. A noção de "cultura material" abarcava também as esferas da produção e do consumo. Conforme o lefista Boris Arvatov, o byt e o psiquismo de uma pessoa seriam formados pela "cultura material" de uma sociedade e suas relações. Ver: ARVATOV, Boris, "Everyday Life and the Culture of the Thing", trad. Christina Kiar, October 81, Cambridge, MA: MIT Press, summer 1997, pp. 119-128; p. 120.

411 "Entender as tendências em desenvolvimento do byt significa ser capaz de dirigi-las, transformá-las de forma sistemática, ou seja, transformar o byt, de uma força conservadora em uma força progressista. Tal processo, por sua vez, garante a reforma progressiva de duas outras áreas do byt: a social e a ideológica”. ARVATOV, Boris, "Everyday Life...", op. cit., p. 120.

412 TRETIAKOV, S., "Art in the Revolution and the Revolution in Art (Aesthetic Consumption and Production)", in October 118, Cambridge, MA: MIT Press, Fall 2006, pp. 11-18.

${ }^{413}$ Ver a análise que Benjamin faz sobre a atuação e produção de Tretiakov e a de Renger-Patzch em "O autor como produtor". BENJAMIN, W., “O autor...”, op. cit., p. 86, bem como pp. 95-96.

${ }^{414}$ Os debates sobre "tendência” eram, conforme o tradutor e estudioso de Benjamin, João Barreto, "nesta altura, já velhos na literatura alemã. Pelo menos desde meados do século XIX, é possível relatar uma série de polemicas sobre essa problemática". BENJAMIN, W., "O autor...", op. cit., p. 82. (notas do tradutor). Lowy no texto "Lukács and Stalinism" também menciona tal debate mencionado um texto de 1926 de Lukács, no qual tal debate sobre tendência também estava presente.
} 
$\mathrm{O}$ primeiro ponto diz respeito à associação entre tendência e temática de uma obra. $\mathrm{O}$ "realismo socialista" (formulado em 1934, mas em gestação indireta desde 1922, no "realismo heroico"), ${ }^{415}$ foi marcado por uma espécie de farsa celebrativa do "socialismo num só país" e de uma retórica da supremacia do tema, em relação aos demais aspectos de uma obra (a saber: forma, materiais, técnicas e modos de produção e circulação). Não obstante, as definições do "realismo socialista" e das obras demandadas e aprovadas em tal doutrina eram escorregadias e alteravam-se de acordo com a conjuntura e os interesses em jogo - basta ver os vários papeis atribuídos e estilos adotados na produção visual russa discutidos no capítulo $3{ }^{416}$

A noção benjaminiana de tendência parece subverter tal lógica a partir dela mesma. Ao afirmar que "uma obra que apresente a tendência correta terá necessariamente as outras qualidades", Benjamin, em vez de subordinar as demais qualidades à orientação política (tendência) de uma obra as quais estariam necessariamente corretas se a tendência estivesse -, ressaltou, pelo contrário, que é necessário haver uma articulação entre todos os aspectos de uma obra para que a própria tendência esteja correta. "O que quero mostrar é que uma obra só pode ser politicamente correta se também for literariamente correta" - afirmou Benjamin em "O autor como produtor" ${ }^{417}$

Nessa mesmo direção, Benjamin criticou produções meramente propagandísticas, no final de "O autor como Produtor"; ;18 apontou, em sua crítica, a "função organizadora" da arte em oposição à sua função unicamente apologética. Tal questionamento não eliminaria o caráter propagandístico, mas o complexificaria ao associá-lo a outras funções de uma obra de arte de tendência (política e artística).

O segundo ponto diz respeito à influência da experiência russa no desenvolvimento da noção benjaminiana de tendência, tendo em vista a relação entre " $\mathrm{O}$ autor como produtor" e o texto "Réplica a Oscar A. H. Schmitz". Este último texto, publicado em março de 1927, originalmente sob o título "O filme Potemkin e a arte de tendência", consistiu numa réplica à resenha crítica de Schmitz sobre o filme de Eisenstein. Benjamin faz nesse texto (provavelmente redigido durante a sua estadia em Moscou, 1926-1926) uma viva defesa das obras de Eisenstein; introduz elementos sobre a noção de tendência e critica artistas de esquerda contemporâneos a ele (na mesma linha das críticas futuras realizadas no ensaio "O autor como produtor"). Isto é, Benjamin critica artistas com uma orientação

\footnotetext{
${ }^{415}$ Conforme discussão do capítulo 1 e 3, o "realismo heroico" foi o estilo pictórico e escultórico da AKhRR. Este consistia na "documentação" pseudo-realista do "heroísmo" da revolução. AKhRR é a abreviação russa para Associação dos Artistas da Rússia Revolucionária (AKhRR1922-1932). Ver: AKhRR, "Declaration of Association of Artists of Revolutionary Russia" (1922), in BOWLT, John (edit.) E., THE DOCUMENTS..., op. cit., pp. 265-267.

${ }^{416}$ Para que não incorramos em reducionismos, vale mencionar que, entre os gestores, membros da censura e críticos de arte do "socialismo num só país", havia debates que perpassavam também os campos da forma, materiais e estilos artísticos adotados, como no caso dos excluídos ou difamados nas exposições retrospectivas "Artistas da URSS dos últimos 15 anos" (1932-1934). (Ver capítulo 3).

${ }^{417}$ BENJAMIN, W., “O autor...”, op. cit., p. 83.

${ }^{418}$ Idem, ibidem, pp. 98-100.
} 
política supostamente "correta", porém deficitários na questão da forma e das reflexões sobre a inserção de suas obras dentro dos meios de produção e da luta de classes. Nas palavras de Benjamin: "Há muita má arte de tendência também no campo socialista". ${ }^{419}$

Eisenstein, como Tretiakov (elogiado por Benjamin em "O autor como produtor", conforme veremos), era ligado ao grupo LEF. No mesmo período em que Benjamin estava em Moscou redigindo sua réplica à resenha de Schmitz, outra resenha crítica sobre o filme de Eisenstein fora publicada na Kino Gazeta. Tal resenha de Potemkin discutia a obra de Eisenstein por meio da noção de "encomenda social" 420 - reforçando, então, o vinculo entre o debate do LEF, a noção de "encomenda social" e a reelaboração da noção de tendência realizada por Benjamin.

\subsubsection{Benjamin e o LEF}

Nesses termos, Benjamin ecoou, no ensaio de 1934, os debates do LEF. Desse modo, num ensaio destinado a um instituto ligado ao Komintern (portanto, à URSS), Benjamin posicionou-se ao lado daqueles que, em breve, entrariam na mira do stalinismo. De modo análogo, num momento de acirramento da luta de classes e proliferação do fascismo, Benjamin, em "A obra de arte...", acionou o sinal de alarme opondo à "estetização da política" a "politização da arte”.

Assim, estes dois textos praticamente contemporâneos (basta ver as datas de redação dos mesmos: 1934-1936), "O autor como produtor" e "A obra de arte na era de sua reprodutibilidade técnica", postos em relação, desdobram e aprofundam o programa lefista. Isto é, Benjamin dava continuidade ao debate russo, ampliando sua escala e alcance, justamente no momento em que, no campo artístico-cultural russo, o "barco do amor" (da revolução) se espatifava. De fato, não havia mais, na Rússia após 1932-1934, muitos espaços para embates, posicionamentos e críticas públicas. Multiplicavam-se no período as incriminações, prisões e desaparecimentos forçados entre artistas de vanguarda, como nos casos de Malevich, Tretiakov, Eisenstein e Rodchenko. ${ }^{421}$ Tais artistas, se não

${ }^{419}$ BENJAMIN, W., “Réplica a Oscar A. H. Schmitz”, in idem, Estética e sociologia..., op. cit., pp. 139-143; p. 143.

${ }^{420}$ Em 1926 foi publicada na Kino Gazeta uma resenha crítica de O Encouraçado Potemkin (1925), de Sergei Eisenstein, na qual a noção de "encomenda social" foi discutida para ressaltar o caráter revolucionário e autônomo do filme de Eisenstein em questão. Conforme a resenha, a "encomenda" do filme não surgiu "no gabinete de um diretor de estúdio, nem em uma comissão de Estado"; ${ }^{420}$ o artista recebeu sua encomenda junto à revolução proletária, no curso da qual ele se tornou um artista. Essa demanda social não chegou até ele na forma de uma resolução ou proposta de [...obra], mas como processo orgânico de evolução da revolução e da [sua própria] evolução. Kino Gazeta (1926) apud ALBERA, François, Eisenstein..., op. cit., p. 260.

${ }^{421}$ Malevich foi preso e torturado, pela primeira vez, em 1930, sob acusação de espionagem. Foi solto sob a condição da publicação de uma autocrítica sobre sua produção artística. Após sua soltura, Malevich foi difamado e ridicularizado na exposição “Artistas da URSS dos últimos 15 anos” (1932-1934) - conforme uma lógica policialesca que prenunciava a própria exposição da "Arte degenerada" nazista de 1937. DRUTT, Matthew (org.), Kazimir Malévitch: suprematism, Nova York: Guggenheim Museum Publication, 2003, p. 21. Rodchenko e Eisenstein tiveram de justificar-se publicamente mais de uma vez, com autocríticas nas quais negavam suas obras “formalistas". Ver: DICKERMAN, Leah Anne, Aleksandr Rodchenko's camera-eye: lef vision and the production of revolutionary consciousness, Tese de doutorado, Nova Iorque: Departamento de Filosofia, Universidade de Columbia, 1997. 
tiveram de confessar e arrepender-se publicamente de suas obras "formalistas não objetivas", foram isolados, difamados, presos e assassinados, conforme a lógica curatorial da exposição "Artistas da URSS dos últimos 15 anos" (1932-1934).

“A obra de arte...”, conforme já afirmado, não tratava da experiência russa ou mesmo da politização da arte, a ser praticada pelo comunismo, ${ }^{422}$ porém, nessas circunstâncias, dialogava com as práticas e debates artísticos do grupo LEF (1922-1928), com os "Diários de moscou” (1926-1927) e com as reflexões de "O autor como produtor" (1934). ${ }^{423}$

Com efeito, a análise da correspondência de Benjamin mostra que era grande o seu interesse em que o lefista S. Tretiakov recebesse uma cópia do manuscrito de "A obra de arte na era de sua reprodutibilidade técnica". ${ }^{424}$

\subsubsection{As tentativas de publicação de "A obra de arte..." na Rússia}

Trechos da correspondência benjaminiana registram que, entre outubro de 1935 (data da finalização da primeira versão do ensaio) e março de 1937 (quando o ensaio foi recusado pela revista Das Wort), ${ }^{425}$ Benjamin tentou publicar “A obra de arte...” em Moscou. Se a publicação, na Rússia, apresentava-se, para Benjamin, como uma prioridade crucial, ao mesmo tempo seus esforços para tanto pareciam marcados por grande incredulidade e pessimismo. ${ }^{426}$

${ }^{422}$ Quando mencionada a experiência russa em “A obra de arte...”, restringia-se à experiência de vanguarda dos anos 1920, como no caso da produção cinematográfica russa. Ver: BENJAMIN, W., "A obra de arte...”, op. cit., p. 25.

${ }^{423}$ Em relação à conexão entre os textos "O autor como produtor" e "A obre de arte na época de sua reprodutibilidade técnica", vale destacar uma espécie de resgate integral de trechos do primeiro na redação da primeira versão de “A obra de arte...”. Na última versão de “A obra de arte...”, Benjamin ainda mantém partes de "O autor como produtor". Em “A obra...", Benjamin resgata um trecho de "O autor como produtor" no qual ele discute exatamente a produção literária revolucionária soviética (que será representada pela figura de Tretiakov) e a ruptura entre a distinção entre autor e público a partir dos jornais. Ver: BENJAMIN, W., "O autor como produtor", in idem, Estética e sociologia..., op. cit., p. 88; idem, A obra de arte..., op. cit., p. 79; idem, “A obra de arte...", op. cit., p. 23.

${ }^{424}$ BENJAMIN, apud: SCHOTTKER, Detlev, “Comentário sobre...”, op. cit., pp. 128-129.

${ }^{425}$ Das Wort foi um periódico literário alemão veiculado em Moscou entre 1936-1939. Brecht era um dos membros da comissão da redação. Benjamin tentou muitas vezes publicar seus textos nessa revista (visando à circulação destes na Rússia), no entanto as tentativas não tiveram grande êxito. Ele conseguiu publicar apenas um de seus vários artigos destinados à revista. Segundo Barrento, Benjamin teria tentado, sem sucesso, publicar “A obra de arte..." nessa revista. Ver: BENJAMIN, W., Estética e sociologia..., op. cit., pp. 224 e p. 267 (notas do editor).

${ }^{426}$ Numa carta destinada a Alfred Cohn (janeiro de 1936), Benjamin, ao mencionar o envio de uma cópia de "A obra de arte...” para Moscou, afirmou: “de momento, o ensaio programático de que lhe falei [“A obra de arte...”] encontra-se em Moscou [nas mãos de Bernard Reich, de quem Benjamin esperava algum apoio para a publicação], e estou ansioso por saber se irão publicar na Rússia. É possível, mas eu ficaria mais espantado com uma decisão positiva do que negativa”. BENJAMIN, W., Estética e sociologia..., p. 188. Em abril do mesmo ano, numa carta destinada a Kitty Marx-Steinschneider, Benjamin registrou seu pessimismo frente à publicação e repercussão do texto na Rússia. Segundo Benjamin, “A avaliar por essas reações, quase teria razões para concluir que o trabalho terá a menor repercussão no lugar que deveria ser naturalmente o seu, na Rússia”. BENJAMIN, W., (1936), apud BENJAMIN, W., Estética e sociologia, op. cit., p. 219 (comentário do tradutor). 
Em carta a Margarete Steffin, datada de 4 de março de 1936, Benjamin afirmou: "Não considero desprezível o fato de que a problemática de que trato deveria despertar grande interesse na Rússia. [...] Eu gostaria que Tretiakov pudesse receber o trabalho [“A obra de arte...”] e lê-lo. [...] Suponho que a senhora conheça bem Tretiakov e possa lhe entregar o manuscrito". ${ }^{227}$

Em 11 de agosto de 1936, Benjamin relatou a Werner Kraft suas tentativas frustradas de publicação de “A obra de arte...” na revista Das Wort (A palavra): "Não sei quanto tempo se manterá a atual redação da revista [Das Wort]. Por mim, teria interesse que ela se mantivesse como está até que Brecht [membro do comitê editorial da revista alemã publicada na Rússia], o único que o pode fazer, tentasse assegurar a publicação do meu ensaio “A Obra de arte....”. ${ }^{428}$

Concomitantemente às tentativas de publicação do ensaio na Rússia, Benjamin tentou discutir e publicar seu texto nos círculos de esquerda no Ocidente (muitos deles ligados ao Komintern e às Frentes Populares). Em 20 de junho de 1936, Benjamin narrou, em carta a Alfred Cohen, sua frustação frente à tentativa de apresentação de seu trabalho nos círculos de esquerda fora da Rússia, como na União dos Escritores Alemães (em Paris). "O mais interessante foram os esforços dos membros do Partido, entre os escritores, para impedir a apresentação do meu trabalho e o debate a respeito dele". ${ }^{429}$

\subsubsection{Perfilados ao lado da URSS?}

Um ano antes do pacto Molotov-Ribbentrop, e quatro anos após ter escrito "O autor como produtor", Benjamin escreveu, em 3 de agosto de 1938, uma carta a Horkheimer na qual falava sobre o posicionamento dele próprio e de Bertold Brecht (1898-1956) frente à URSS. Ele afirmou que Brecht e ele próprio seguiam "considerando, por enquanto, embora com reservas importantíssimas, a União Soviética como agente de nossos [Brecht e Benjamin] interesses" e, na ocasião de uma guerra, estariam "perfilados ao lado da URSS", embora tal posicionamento fosse "bastante custoso", uma vez que sacrificavam seus próprios “interesses como produtores". Ele concluiu afirmando que "apesar de reconhecer os horrores que se verificam no atual regime [stalinismo] do governo russo, pessoal e autocrático", Brecht não cogitara rechaçar a URSS. ${ }^{430}$

${ }^{427}$ BENJAMIN, W., apud SCHOTTKER, Detlev, "Comentário sobre Benjamin e a obra de arte", in BENJAMIN, W., Benjamin e a obra de arte..., op. cit., pp. 128-129. Ver também BENJAMIN, W., Estética e sociologia..., op. cit., pp. 226-227.

${ }^{428}$ BENJAMIN, W., Estética e sociologia..., op. cit., p. 225 (cartas).

${ }^{429}$ BENJAMIN, W., apud SCHOTTKER, Detlev, “Comentário...", op. cit., p. 55; ver também BENJAMIN, W., Estética e sociologia..., op. cit., p. 224.

${ }^{430}$ WIZISLA, E., Benjamin e Brecht: historia de uma amizade, São Paulo: EDUSP, 2013, p. 109. Ver também: LÖWY, Michael, Walter Benjamin: aviso de incêndio. Uma leitura das teses "Sobre o conceito de história", São Paulo: Boitempo, 2005, p. 32. 
A grande dificuldade (já prevista e reforçada pela recepção negativa de seu trabalho, inclusive nos círculos de esquerda fora da Rússia, conforme carta para Alfred Cohen) e o grande interesse em publicar "A obra..." em território russo ("lugar que deveria ser naturalmente o seu"), podem ser alguns dos motivos pelos quais Benjamin não falou expressamente em "estetização da política" stalinista - silêncio que corresponderia ao seu alinhamento "tático" e "bastante custoso" ao lado da URSS na ocasião de uma guerra.

Poucas são as passagens (textos, cartas, diários) nas quais Benjamin refere-se nominalmente ao "realismo socialista". Quando o faz, é de modo bastante elíptico, como no texto "Pintura e arquitetura, fotografia e cinema", que acompanha um dos manuscritos de "A obra de arte...". "Pintura e arquitetura, fotografia e cinema" é um texto provavelmente inacabado, não destinado à publicação, mas que estabelece algumas das reflexões de Benjamin para a redação de uma nova versão expandida de “A obra de arte...". 431

Em “Pintura e arquitetura...", Benjamin justapõe a discussão sobre o "realismo socialista" a casos de cooptação e repressão artística fascistas, apontando, assim, os riscos (mortais) e as potencialidades políticas da atualidade da pintura na luta contra regimes autoritários. ${ }^{432}$

Mais de uma vez, em seus escritos pessoais e cartas, Benjamin registrou contraposições entre os casos italiano, alemão, americano e russo. Nesses casos, a antítese da estetização da política era representada, quase sempre, pelos trabalhos de artistas ligados às vanguardas russas (em sua maioria, ligados ao grupo LEF). Em uma das anotações que acompanham os manuscritos da primeira versão de "A obra de arte...", Benjamin faz a seguinte anotação: "a posição da grande burguesia em Marinetti, a da pequena burguesia em Duhamel, a revolucionária em Maiakovski” (1935-1936). ${ }^{433}$

Postos em relação, a discussão do caso italiano e alemão parece iluminar o posicionamento de Benjamin frente ao caso russo. Em "Pintura e arquitetura...", Benjamin relaciona, sem maiores mediações, o caráter coercitivo do fascismo e do nazismo e a atualidade da pintura no "realismo

${ }^{431}$ BENJAMIN, W., "Pintura e arquitetura...", op. cit.

432 "De fato, o realismo socialista não é apenas uma questão de assuntos escolhidos, ele significa também para a pintura uma tomada de consciência realista das suas potencialidades sociais. Muita coisa depende do conhecimento correto das suas áreas de intervenção. Talvez estas [as áreas de intervenção da pintura] não sejam tão facilmente identificáveis num país que ainda dispõe de liberdades democráticas como naqueles em que o fascismo tomou o poder. Aí, a pintura continua viva na medida em que contesta a visão da vida do fascismo" BENJAMIN, W., "Pintura e arquitetura...”, op. cit., p. 257. Notemos ainda outra passagem de Benjamin: "O que não acontece na obra dos antigos futuristas, que entraram solenemente para a Real Academia Italiana; muitos deles devem estar ao lado de Dufy, que declarou que, se fosse alemão e tivesse de celebrar o triunfo do Hitler, o faria como certos pintores da Idade Média ao tratarem temas religiosos sem que para isso tivessem de ser crentes. Na Alemanha há pintores que agem de outro modo, e estão proibidos de expor publicamente as suas obras. A polícia proíbe-os até de pintar, fazendo buscas nas suas casas para apreender quadros novos. Esses artistas, que, sem meios de subsistência, pintam as suas paisagens desertas e secas cravadas de bandeiras, os seus retratos dos poderosos transfigurados em figuras de animais, esses sabem o que é o realismo socialista". BENJAMIN, W., "Pintura e arquitetura...”, op. cit., p. 257.

${ }^{433}$ BENJAMIN, W., “Arquivo Benjamin, manuscrito n. 383”, in idem, Estética e sociologia..., op. cit., p. 241 (paralipômenos). 
socialista”. Assim, podemos aventar que, por meio da continuidade textual, Benjamin evocava também as similaridades das condições artísticas no regime "autocrático" stalinista.

Ainda que Benjamin não desenvolva expressamente a relação entre a situação russa e os casos de cooptação e repressão artísticas na Itália e na Alemanha fascistas, pode-se supor, a partir da linha argumentativa do texto e da lógica do parágrafo, que ele também discutia os processos repressivos e reacionários do campo artístico stalinista. Nesse sentido, Benjamin relatou, em carta de 20 de julho de 1938 a Gretel Adorno, que o lefista Tretiakov, tradutor e amigo de Brecht, “provavelmente, já não está vivo". ${ }^{434}$

Correndo-se o risco de imprecisões e distorções - comuns a leituras e análises de diários, manuscritos e textos fragmentários publicados postumamente -, aventamos a possibilidade de haver, mesmo que implicitamente, nos textos de Benjamin, uma crítica ao caráter coercitivo do "realismo socialista” e uma denúncia à "estetização da política” stalinista. Tal hipótese se torna mais persuasiva com a referência a uma nota escrita por Benjamin entre 1938 e 1939, na qual ele aproxima as práticas da polícia política stalinista às da polícia política nazista. Nela, Benjamin, ao comentar as práticas da GPU, escreve que esse órgão respondia a um "modo de comportamento que os piores elementos do PC compartilham com os elementos mais sem escrúpulos do nacional socialismo". ${ }^{435}$

Conforme Michael Löwy, a análise acurada das notas, diários, correspondências e círculos de amizades de Benjamin, aponta a admiração de Benjamin por Trotsky, seu distanciamento exponencial do stalinismo e sua aproximação a oposicionistas e anti-stalinistas como Heinrich Brandler (exdirigente do KPD, exilado na França entre 1939 e 1940). ${ }^{436}$

Na mesma direção, vale retomar passagens dos Diários de Moscou (1926-1927) em que Benjamin já criticava ferrenhamente a "estetização" da revolução na Rússia, o culto à imagem de Lênin e a reintrodução de elementos capitalistas na economia e vida russas com o advento da NEP:437

Em conversas com Reich expus detalhadamente o quanto é contraditória a situação da Rússia neste momento. Em sua política externa, o governo visa à paz, a fim de estabelecer acordos comerciais com Estados imperialistas; internamente, porém, e sobretudo, procura deter o comunismo militante, introduzir um período

\footnotetext{
${ }^{434}$ WIZISLA, E., Benjamin e Brecht..., op. cit., p. 108.

${ }^{435}$ BENJAMIN, w., apud LÖWY, Michael, Walter Benjamin: aviso de incêndio..., op. cit., p. 32 (carta).

${ }^{436}$ Idem, ibidem, p. 31.

${ }^{437}$ Benjamin, em seu diário de Moscou, faz uma série de observações críticas sobre o culto de Lênin. "O culto da imagem de Lênin em particular vai incrivelmente longe aqui [em Moscou]. Existe uma loja na Kusnetzky most especializada em Lênin, onde se pode encontrá-lo em todos os tamanhos, poses e materiais”. BENJAMIN, W., Diário..., op. cit., p. 63. Por fim, um último apontamento a ser feito neste âmbito diz respeito ao contato que Benjamin teve com todo o debate e integrantes da Oposição Unificada durante sua estadia em Moscou. Ver: BENJAMIN, W., Diário..., op. cit., pp. 20, p. 23 e p. 97. Sobre a crítica de Benjamin e do grupo LEF à Nova Política Econômica (NEP: 1921-1928) e ao culto da imagem de Lênin, ver: VILELLA, T. M., O ocaso de outubro..., op. cit., e FIGUEIREDO, C., "Não comercializem Lênin!...”, op. cit.
} 
livre de conflitos de classe, despolitizar tanto quanto possível a vida de seus cidadãos. Por outro lado, a juventude passa por uma educação "revolucionaria", em organizações pioneiras, no Komsomol. Isto significa que o revolucionário não lhes chega como experiência mas apenas como discurso Existe a tentativa de deter a dinâmica do processo revolucionário na vida do Estado - entrou-se, querendo ou não, num período de restauração. ${ }^{438}$

${ }^{438}$ BENJAMIN, W., Diário..., op. cit. p. 67. 


\section{CONSIDERAÇÕES FINAIS}

No início do século XX ocorreu na Europa um acirramento das lutas de classes, assinalado na Rússia pelo episódio revolucionário de $1905,{ }^{439}$ seguido pelas Revoluções de Fevereiro e Outubro de 1917. ${ }^{440} \mathrm{Na}$ Itália, o acirramento das lutas de classes apresentou-se sobretudo na Semana Vermelha $(1914)^{441}$ e no Biênio Vermelho (1919-1920). Consecutivamente, despontou, segundo Gramsci, a necessidade, por parte da burguesia, de desenvolver novas formas de contenção das classes subalternas, e de, paralelamente, efetuar uma modernização-conservadora do aparelho produtivo. ${ }^{442}$ $\mathrm{Na}$ Itália, a "revolução passiva" fascista responderia a tanto.

\subsection{Itália}

Além de ser uma forma de reação antioperária, conforme discutido no capítulo 2, o fascismo italiano se valeu da estratégia da "revolução-restauração" para a manutenção dos sistemas hegemônicos e das forças de coerção militar a serviço das classes dominantes. Para tanto, o regime fascista não só assimilaria em doses moleculares elementos do seu oponente, como também criaria mecanismos de incorporação e contenção das massas.

Com efeito, verificou-se, de modo inaugural, na Itália fascista, os seguintes procedimentos: uso de grandes dispositivos culturais (megaexposições, bienais, museus etc.); apropriação de novos aparatos técnicos de registro e recepção coletiva e simultânea (rádio, fotografia e cinema); apropriação da linguagem de vanguarda, para a satisfação narcísica e a mobilização litúrgica das massas (conforme discutido nos capítulos 2 e 4 ).

Como observado por Benjamin, em empreitadas como a Mostra da Revolução Fascista (19321934) o fascismo lançou mão da "estetização da política", para conter e incluir molecularmente as massas - permitindo a estas alcançar "sua expressão ([mas] de modo algum o seu direito)". 443

${ }^{439}$ FROSINI, F., “'Pueblo’ y 'guerra de posición’...”, op. cit.

${ }^{440}$ A tentativa de revolução em 1905 marcou uma inflexão qualitativa na história das movimentações e insurgências populares russas, sendo uma espécie de prelúdio da Revolução de Outubro de 1917. Ver: BROUÉ, Pierre, O partido bolchevique, op. cit., pp. 36-37.

${ }^{441}$ Ver: FROSINI, F., “'Pueblo' y 'guerra...””, op. cit.

${ }^{442}$ Idem, ibidem.

${ }^{443}$ BENJAMIN, W., A obra de arte..., op. cit., p. 117. 


\subsection{Rússia}

Na Rússia, o acirramento das lutas de classes levou, como se sabe, à ascensão do movimento operário e à Revolução de Outubro de 1917. Seguiu-se anos depois uma reversão dessa onda. Tal reversão foi marcada, num primeiro momento, no front interno, pelo Congresso de Moscou (1921) e a adoção da Nova Política Econômica (NEP, 1921-1922); no front externo, por sua vez, a reversão foi marcada pela proposição da fórmula política das "frentes únicas" por parte do Komintern.

Já em 1921, conforme relatou Victor Serge, o espectro do Termidor rondava os debates do partido bolchevique e dos proletários russos. ${ }^{444}$ Entre 1928 e 1929, a expulsão da Oposição Unificada e a implementação do $1^{\circ}$ Plano Quinquenal consolidou a "reação termidoriana" em curso, abrindo um novo ciclo de modernização acelerada, como discutido no capítulo 1 desta tese.

Analogamente, no âmbito artístico da URSS, sob Stalin, verificou-se um processo de reestruturação do campo artístico, embates e aparentes contradições entre a política cultural nacional e a adotada em revistas, feiras e exposições internacionais - como mostrou o capítulo 1.

Revistas, cartazes e exposições, entre 1928 e 1934, foram, conforme discutido no capítulo 3, apropriados e operados pelos artífices do stalinismo para a dinamização da economia e consolidação de um regime tirânico - calcado, além disso, em simulacros revolucionários e em pinturas baseadas em fotografias forjadas e multiplicadas em escala de massa.

\subsection{Metamorfoses visuais}

Agenciados de modo inaugural, os aparatos de reprodutibilidade técnica e reprodução coletiva e simultânea foram apropriados e utilizados, no fascismo e no stalinismo (resguardadas as devidas diferenças), para a contenção das massas e modernização dos aparatos produtivos italiano e russo.

Com efeito, o desenvolvimento da pesquisa apontou para a utilização, tanto na Rússia quanto na Itália, de aparatos de reprodutibilidade técnica - via intervenções imagéticas e outros recursos de propaganda - no modo de vida e no psiquismo das massas, a fim de obter a "inclusão molecular" e passiva das mesmas. Nos dois casos, pode-se perceber a articulação das estruturas materiais da cultura para a consolidação ideológica ${ }^{445}$ de regimes de dominação. Nesses processos, como observou Benjamin, parlamentos e teatros esvaziados deram lugar a cartazes agigantados e cine-jornais que replicavam e multiplicavam a imagem e a voz de líderes "onipresentes".

${ }^{444}$ Ver: SERGE, Victor, Memoirs..., op. cit. Para o uso do termo Termidor por Lênin, ver nota de rodapé 14 e 369.

${ }^{445}$ Ver: LIGUORI, Guido e VOZA, Pasquale (org.), Dicionário gramsciano..., op. cit., pp. 398-402. 
Tratava-se de cenas decisivas da constituição de um novo dispositivo de dominação mediante a nascente indústria cultural. $\mathrm{O}$ alcance e a potencialidade do dispositivo não passaram desapercebidos ao Ocidente. Nessas cenas observadas, a "função organizadora" e a práxis política da arte metamorfosearam-se numa nova forma de Estado ampliado - segundo a acepção de Estado Integral em Gramsci ou dos termos representados na novela 1984 (1949), de George Orwell (19031950).

Em suma, não mais se tratava de "politização da arte", mas sim de "estetização da política".

\section{4 "Estetização da política" e "revolução passiva"}

O confronto entre "politização da arte" e "estetização da política" foi um tema transversal de todos os capítulos da presente tese. Ainda que Benjamin não falasse expressamente de uma “estetização da política" stalinista, a articulação de seus escritos, o diálogo de suas reflexões com as do grupo LEF e suas anotações no Diário de Moscou permitem entrever uma análise aplicável também à situação da URSS. Trata-se do processo de substituição da experiência revolucionária, usurpada por simulacros da revolução convertida em farsa mediante o aparato cultural-policial do stalinismo.

Gramsci também não discorre abertamente sobre o regime stalinista. Muitas são as suposições e análises de especialistas, nas alusões a Gramsci, que apontam nos Cadernos do Cárcere passagens e críticas camufladas à experiência russa. O presente trabalho não visou à elaboração de uma teoria acerca dos posicionamentos de Gramsci frente ao stalinismo. Buscou-se, de fato, analisar a experiência russa, transpondo para os entrecruzamentos, paralelismo e convergências verificados entre as práticas culturais stalinistas e mussolinianas, a hipótese gramsciana de que o fascismo seria o "representante, além de prático (para a Itália), ideológico (para a Europa)" de uma "guerra de posição" continental, em oposição ao movimento operário e à Revolução de Outubro - ainda que, nos anos 1930, o perigo representado pela Revolução de Outubro operasse mais no plano simbólico.

Benjamin e Gramsci, assim como o grupo LEF, ocuparam, desse modo, na presente tese, uma dupla condição: a de teóricos e personagens históricos, com seus relatos, posicionamentos, atuações políticas e reflexões críticas, renovando o marxismo sob forte cerco. Portanto, vale salientar, a título de conclusão, o potencial de reciprocidade das obras de Gramsci e Benjamin - ainda que o aprofundamento de tal conclusão, quanto ao meu trabalho, fique para pesquisas futuras. 
Articular o passado historicamente não significa conhecê-lo "tal como ele propriamente foi". Significa apoderar-se de uma lembrança tal como ela lampeja num instante de perigo. [...] O perigo ameaça tanto o conteúdo dado da tradição quanto os seus destinatários. Para ambos o perigo é único e o mesmo; deixar-se transformar em instrumento da classe dominante. (W. Benjamin, Tese VI, 1940) 


\section{REFERÊNCIAS BIBLIOGRÁFICAS}

AA.VV. Mostra della rivoluzione fascista: Partito nazionale fascista/ Archivio centrale dello Stato, (a cura di) Gigliola Fioravanti, Roma: Ministero per i beni culturali e ambientali, Ufficio centrale per i beni archivistici, 1990 .

AAVV, Montage and modern life: 1919-1942, Cambridge: Massachusetts Institute of Technology Press, pp. 83-127, 1992 (Catálogo da Exposição).

AA.VV. Aleksandr Rodchenko experiments for the future: diaries, essays, letters, and other writings, org. Alexander Lavrentiev, trad. Jamey Gambrell, int. John Bowlt, New York: Museum of Modern Art, 2005.

AA.VV., Une Arme Visuelle: le photomontage sovietique 1917-1953, MAMM: Moscou 2005.

AA.VV. Rodchenko: La construcción del futuro, org. Art in Project e Imma Duñach, int. Narcis Serra Serra, Barcelona: Fundació Caixa Catalunya, 2008.

AA.VV. Espacios fotográficos públicos: exposiciones de propaganda, de pressa a the family of man, 1928-1955, Barcelona: MACBA, pp. 83-107, 2009 (catálogo de exposição).

ADES, Dawn, Fotomontaje, trad. Elena Llorens Pujol, Barcelona: Gusgato Gili S.A., 2002.

AGGIO, Alberto (org.), Gramsci: a vitalidade de um pensamento, São Paulo: UNESP, 1998.

AGGIO, A.; HENRIQUE, L. S.; VACCA, G. (orgs.), Gramsci no seu tempo, Rio de Janeiro: Contraponto, 2010.

AKINSHA, Konstantin, The second life of soviet photomntage: 1935-1980s, orientador Martin Hammer, Tese de Doutorado em Filosofia, Universidade de Edinburgh, 2012.

ALBERA, F., Eisenstein e o construtivismo russo, trad. Heloisa Araújo Ribeiro, São Paulo: Cosac \& Naify, 2002.

ALBERA, François, La vanguardia en el cine, trad. Heber Cardoso, Buenos Aires: Armand Colin, 2005.

ALBERA, François, “Taurus (Teliéts), de Aleksandr Sokúrov - Mortalhas de Lênin: uma iconografia”, trad. Marcelo Diniz, in Terceira Margem, Rio de Janeiro: UFRJ, Ano XV, no 24, pp. 17-39, jan.-jun., 2011.

ALBERA, François, Modernidade e vanguarda do cinema, trad. Fabio Raddi Uchoa e Adilson Mendes, Rio de Janeiro: Azougue Editorial, 2012.

ALBERA, F.; REIS, R. R.; grupo LEF, "LEF: Cinema e revolução na Rússia soviética (dossiê)”, trad. Maria Lenor Loureiro, in Crítica Marxista, n. 40, São Paulo, pp. 83-91, 2015.

ALFIERI, Dino; FREDDI, Luigi (org), Mostra dela rivoluzione fascista: guida storica, 1o Decennale della Marcia su Roma, Roma: Partito Nazionale Fascista, Instituto Italiano d'Arti Grafiche di Bergamo, 1933. 
ALFIERI, Dino; FREDDI, Luigi (org.), Mostra della rivoluzione fascista: guida storica, Roma: Partito Nazionale Fascista, Istituto Italiano d'Arti Grafiche di Bergamo, 1933 - XI.

AMENDOLA, E. O., Gli anni del regime 1925-1939, Roma: Editori Riuniti, 1999.

ARGENTIERE, Mino, L'occhio del regime, Roma: Bulzooni Editore, 2003.

ANÔNIMO, "Program of the October Photo Section" (1930), Izofront, Moscou, 1931, in PHILLIPS,

C. (Org.), Photography in the modern era: European documents and critical writings, 19131940, New York: The Metropolitan Museum of Art/Aperture, pp. 283-285, 1989.

ANÔNIMO, "O manifesto de Outubro (1928)", in ALBERA, François, Eisenstein e o construtivismo russo: a dramaturgia de forma em Stuttgart, trad. Eloísa Araújo Ribeiro, pref. Luiz Renato Martins, São Paulo: Cosac \& Naify, pp.190-194, 2002.

ANÔNIMO, "Fotomontagem", Lef, n. 4, 1924, trad. Erika Zerwes, in ArtCultura, Uberlândia, v. 10, n. 16, pp. 79-83, jan.- jun. 2008.

A PHOTOGRAPHER, “An illustrated letter to the editor: at home and abroad”, (Soveteskoe foto, ${ }^{\circ}$ 4, 1928), in PHILLIPS, C. (Org.), Photography in the modern era: European documents and critical writings, 1913-1940, New York: The Metropolitan Museum of Art/Aperture, pp. 243244, 1989.

AQUARONE, Alberto, "Italy: the crisis and corporative economy", in Journal of Contemporary History, Vol. 4, n. 4, (The Great Depression), pp. 37-58, Oct. 1969.

ARVATOV, Boris, "Everyday Life and the Culture of the Thing", (1925), trad. Christina Kiar, in October, n. 81, Cambridge: MIT Press, pp. 119-128, Summer 1997.

ARVATOV, Boris, "Respuesta al camarada Katsman”, (1926), pp. 217-221, in ARVATOV, Boris, Arte y produccion: el programa del productivismo, trad. José Fernandez Sanchez, Madrid: Alberto Corazon, 1973.

ARVATOV, B., "L'attuale mercato dell'arte e la pittura di cavalletto", LEF n. 2 (1928); trad. Italiana, in MAGAROTTO, L.; SCALIA, G. (a cura di), L' avanguardia dopo la rivoluzione. Le riviste degli anni Venti nell'URSS: «Il giornale dei futuristi», «L'arte della Comune», «Il Lef», «Il nuovo Lef», Roma: Edizioni Immanenza, pp. 253-258, 1976.

ARVATOV, Boris, Arte produzione e rivoluzione proletária, Rímini, Guaraldi Editore, 1973.

AKhRR, "Declaration of association of artists of revolucionary russia", (1922), in BOWLT, John (edit.) E., The documents of 20th-century art/russian art of the avant-gard: theory and criticism 1902-1934, Nova York: The Viking Press, pp.265-267, 1976.

BANAJI, Jairus, "Retotalizing fascism: reading arthur rosenberg through sartre's critique", text of a paper read to the London Seminar on Contemporary Marxist Theory, King's College London, 14 December 2012.

BARDI, Pietro Maria, "Come è la mostra della rivoluzione", L'Ambrosiano, 31 ottobre 1932, in SCHNAPP, Jeffrey T., Anno X: La Mostra della Rivoluzione fascista del 1932, pref. Claudio Fogu, Pisa, Roma: Istituto Editoriali e Poligrafici Internazionali, MMIII, pp. 73-75, 2003. 
BAROCCHI, Paola (org), Storia moderna dell'arte in Italia manifesti polemiche documenti, Torino: Giulio Einaudi, 1990.

BEILES, La., "The futurist exhibitions at the venice biennale under fascism, 1928-42", palestra proferida em 13 de março de 2008, Nova York: MoMA, disponível em $<$ http://www.moma.org/explore/multimedia/audios/11/246>, acessado em 8 de agosto de 2017.

BEN-GHIAT, Ruth, Fascist modernities: Italy, 1922-1945, Berkeley: University of California Press, 2004.

BENJAMIN, W., "Paris, capital do século XIX", in idem, Textos de Walter Benjamin, org. e trad. Flávio R. Kothe, São Paulo: Ática, 1985.

BENJAMIN, W., Diário de Moscou (1926-1927), trad. Hildegard Herbold, São Paulo: Cia das Letras, 1989.

BENJAMIN, W., "Réplica a Oscar A. H. Schmitz", (1927) in BENJAMIN, W., Estética e sociologia da arte, trad. João Barrento, São Paulo: Autêntica, pp.139-143, 2017.

BENJAMIN, W., "Pequena história da fotografia", (1931), in BENJAMIN, W., Magia e Técnica, Arte e Política/ Ensaios sobre literatura e história da cultura/ Obras Escolhidas, vol. 1, trad. S. P. Rouanet, pref. J. M. Gagnebin, São Paulo: Brasiliense, pp.91-108, 1994.

BENJAMIN, W., El autor como produtor, trad. Bolívar Echeverria, Editorial Itaca, México, 2004.

BENJAMIN, W., "O autor como produtor" (1934) in BENJAMIN, W., Estética e sociologia da arte, trad. João Barrento, São Paulo: Autêntica, pp. 79-105, 2017.

BENJAMIN, W., “A obra de arte na época de sua reprodutibilidade técnica" (1935-1936), in BENJAMIN, W., Magia e técnica, arte e política/ ensaios sobre literatura e história da cultura/ obras Escolhidas, vol. 1, trad. S. P. Rouanet, pref. J. M. Gagnebin, São Paulo: Brasiliense, 1987.

BENJAMIN, W., A obra de arte na época de sua reprodutibilidade técnica (1935-1936) trad. Francisco De Ambrosis Pinheiro Machado, Porto Alegre: Zouk, 2012.

BENJAMIN, W., "A obra de arte na era de sua reprodutibilidade técnica”, in idem, Benjamin e a obra de arte: técnica, imagem, percepção, org. Tadeu Capistrano, trad. Marijane Lisboa e Vera Ribeiro, Rio de Janeiro: Contraponto, pp. 9-41, 2012.

BENJAMIN, W., "A obra de arte na época de sua reprodutibilidade técnica", in idem, Estética e sociologia da arte, trad. João Barrento, São Paulo: Autêntica, pp. 139-143, 2017.

BENJAMIN, W., "Pintura e arquitetura, fotografia e cinema" (paralipômenos, 1936-1940), in idem, Estética e sociologia da arte, trad. João Barrento, São Paulo: Autêntica, pp. 249-258, 2017.

BIANCHI, A., "Revolução passiva: pretérito do futuro", in Crítica Marxista, nº. 23. São Paulo: Revan, pp. 34-58, 2006.

BENJAMIN, W., Estética e sociologia da arte, trad. João Barrento, São Paulo: Autêntica, 2017.

BENJAMIN, W., Benjamin e a obra de arte: técnica, imagem, percepção, org. Tadeu Capistrano, trad. Marijane Lisboa e Vera Ribeiro, Rio de Janeiro: Contraponto, 2012. 
BIRNHOLZ, Alan, C., "Notes on the chronology of El Lissitzky's Proun Composition", in The Arte Bulletin, V. 55, N. 3, pp. 437-439, sep. 1973.

BOBBIO, Norberto, Ensaios sobre Gramsci e o conceito de sociedade civil, trad. Nelson C. Coutinho e Marco Aurélio, 2o ed., São Paulo: Paz e Terra, 2002;

BOIS, Yves-Alain, “El Lissitzky: reading lessons”, in October, n. 11, inverno de 1979, pp. 79-96.

BOTTAI, Giuseppe, "Il nuovo ordine artistico", Critica Fascista, $1^{\circ}$ agosto 1927, in BOTTAI, Giuseppe, La politica delle arti: scritti 1918-1943, Roma: Libreria dello stato, Istituto poligrafico e zecca dello stato, pp. 74-77, 2009.

BRECHET, Bertold, "Sobre o Realismo", in LUKÁCS, Georg; BLOCH, Ernest; EISLER, Hanns; BRECHET, Bertold, Realismo, materialismo, utopia: uma polémica, 1935-1940, int. e org. João Barrento, trad. Fernanda C. M. A. Gomes, João Barreto, Maria A. P. Correia, Maria F. G. P. Da Costa e Vera M. S. P. De Lemos, Lisboa: Moraes Editores, pp. 106-114, 1978.

BRIK, O., "What the eye does not see", (Sovetskoe kino, n. 2, 1926), in PHILLIPS, Christopher, Photograph in modern era, New York: Metropolitan Museum/ Art-Arperture, pp. 219-220, 1989

BRIK, O., "Non una teoria, ma solo un slogan", Péchat'i Revolutsia, Moscou, 1929; trad. Italiana, in MAGAROTTO, L.; SCALIA, G. (a cura di), L' avanguardia dopo la rivoluzione. Le riviste degli anni venti nell'URSS: «Il giornale dei futuristi», «L'arte della Comune», «Il Lef», «Il nuovo Lef», Roma: Edizioni Immanenza, pp. 293-299, 1976.

BROUÉ, Pierre, História da internacional comunista, trad. Fernando Ferrone, São Paulo: Instituto José Luís e Rosa Sundermann, 2007.

BROUÉ, Pierre, O partido bolchevique, trad. Henrique Canary e João Simões, São Paulo: Sundermann, 2014.

BRAUN, Emily, Mario Sironi: arte e politica in Italia sotto il fascismo, Torino: Bollati Boringhieri, 2003.

BUCHLOH, B., "De la faktura a la factografia" (1984), in AA.VV., Espacios Fotográficos Públicos: Exposiciones de Propaganda, de Pressa a the Family of Man, 1928-1955, Barcelona: MACBA, pp. 29-61, 2009 (catálogo de exposição).

BUCHLOH, Benjamin H. D., "From faktura to factography”, in October, v. 30, fall de 1984.

BUCK-MORSS, S., "Estética e anestésica: uma reconsideração de A obra de arte de Walter Benjamin", in BENJAMIN, W., Benjamin e a obra de arte: técnica, imagem e percepção, org. Tadeu Capistrano, Trad. Tereza da Roche, Rio de Janeiro: Contraponto, 2012, pp. 155-204

CANALI, M., "Repressione e consenso nell'esperimento fascista", in GENTILE, E. (a cura di), Modernità totalitária: Il fascismo italiano, Bari: Laterza, 2008.

CAPANNA, Alessandra, Roma 1932: Mostra della rivoluzione fascista, Universale di Architettura, Torino: Testo\&imagine, 2004.

CARR, E. H. A Revolução Russa de Lênin a Stalin, trad. Waltensir Dutra, Rio de Janeiro: Zahar, 1979. 
CHKLÓVSKII, V., “A arte como procedimento" (1917), in Teoria da literatura: formalistas russos, trad. Ana M. R. Filipouski; Antônio C. Hohlfeld; Maria A. Pereira; e Regina L. Zilberman, Porto Alegre: Ed. Globo, 1970.

CHLENOVA, Masha, On display: transformations of the avant-garde in soviet public culture, 19281933, Ph.D. dissertation, New York: Columbia University, 2010.

CHLENOVA, M., "Staging Soviet Art: 15 Years of Artists of the Russian Soviet Republic, 1932-33", in October, n. 147, Cambridge: MIT Press, pp. 38-55, 2014

COGGIOLA, Osvaldo; DIAS, Edmundo Fernandes; SECCO, Lincoln, MASSARI, Roberto; BRAGA, Ruy, O outro Gramsci, 2o ed., São Paulo: Xamã, 1996.

COHEN, Yves, "Política e arte na verdade e na ficção do trabalho: elementos para uma comparação histórica entre o oriente socialista e o ocidente capitalista", in OLIVEIRA, Francisco; BRAGA, Ruy; RIZEK, Cibele, Hegemonia às avessas, São Paulo: Boitempo, pp. 93-108, 2010.

COLARIZZI, S., Storia del novecento italiano: cent'anni di entusiasmo, di paure, di speranza, Milão: Bur Rizzoli, 2000.

COX, Randi, "NEP Whitout Nepmen!: soviet advertising and the transition to socialism”, in KIAR, C.; NAIMAN, E. (edit.), Every day life in early Soviet Russia: taking the revolution inside, Bloomington: Indiana University Press, pp. 119-152, 2006.

DE FELICE, Franco, "Revolução passiva, fascismo, americanismo em Gramsci", in Inst. Gramsci, Política e História em Gramsci, Rio de Janeiro: Civilização Brasileira, 1978.

DE FELICE, Renzo, Mussolini: Il fascista: 1. La conquista del potere, 1921-1925. L'organizzazione dello Stato fascista, 1925-1929, Torino: Enaudi, 1964.

DE FELICE, Renzo, Mussolini il Duce: Gli anni del consenso 1929-1936, Torino: Giulio Einaudi editore, 1974.

DE FELICE, Renzo, Explicar o fascismo, trad. Carlos Veiga Ferreira, Lisboa: Edições 70, pp. 213-250, 1978.

DE FELICE, Renzo; GENTILE, E., A Itália de Mussolini e a origem do fascismo, São Paulo: Ícone Editora, 1988.

DEUTSCHER, Isaac, Trotsky: o profeta desarmado, trad. Waltensir Dutra, Rio de Janeiro: Civilização brasileira, 1966-1968.

DEUTSCHER, Isaac, Trotski: o profeta desarmado, 1921-1929, trad. Waltensir Dutra, Rio de Janeiro: Civilização Brasileira, 2005.

DI MEO A., "La 'rivoluzione passiva' da Cuoco a Gramsci”, <www.filosofia-italiana.it>, acessado em 13 de setembro de 2016.

DICKERMAN, Leah, Aleksandr Rodchenko's camera-eye: lef vision and the production of revolutionary consciousness (tese de doutorado), New York: Departamento de Filosofia/Universidade de Columbia, 1997. 
DICKERMAN, Leah Anne, "Camera obscura: socialist realism in the shadow of photography", in October, n. 93, Cambridge: MIT Press, pp. 138-153. 2000.

DICKERMAN, Leah Anne, "The fact and the photography", in October, n. 118, Cambridge-MA: MIT Presse, pp. 132-152, Fall 2006.

DILLENBURG, Fernando Frota, Gramsci e o novo programa, orientador Alcides Hector Benoit, Tese de doutorado, Programa de Pós Graduação em Filosofia, Instituto de Filosofia e Ciências Humanas, Universidade de Campinas/ UNICAMP, 2011.

DINALE, Ottavio, "Pelegrinaggio di fedeli", La rivoluzione che vince (1914-1934), Roma: F. Campitelli, 1934, pp. 213-19, in SCHNAPP, Jeffrey T., Anno X: la mostra della rivoluzione fascista del 1932, pref. Claudio Fogu, Pisa, Roma: Istituto Editoriali e Poligrafici Internazionali, MMIII, pp. 103-104, 2003.

DRUTT, Matthew (org.), Kazimir Malévitch: suprematism, Nova York: Guggenheim Museum Publication, 2003

EL LISSITZKY, "Espacios de exposición" (1926), in AA.VV., Espacios fotográficos públicos: exposiciones de propaganda, de pressa a the family of Man, 1928-1955, Barcelona: MACBA, pp. 75-79, 2009 (catálogo de exposição).

EL LISSITZKY, apud ANYSLEY, Jeremy, "Pressa, Colonia, 1928 Diseño de exposiciones y publicaciones en la época de Weimer"(1994), in AA.VV., Espacios fotográficos públicos: exposiciones de propaganda, de pressa a the family of man, 1928-1955, Barcelona: MACBA, pp. 83-107, 2009 (catálogo de exposição).

FABRI, T., Fascismo e Bolscevismo: Le relazioni nei documenti diplomatici italo-russi, Padova: libreriauniversitaria.it, pp. 66-67, 2013.

FABRIS, Annateresa, "Entre arte e propaganda: fotografia e fotomontagem na vanguarda soviética", in Anais do Museu Paulista, no 1, vol. 13, São Paulo, jan-jul. 2005.

FABRIS, Annateresa, "Um olhar sob suspeita", in Anais do Museu Paulista, v. 14, n. 2, São Paulo, pp. 107-140, jul./dez., 2006.

FALASCA-ZAMPONI, Simonetta, Fascist spectacle the aesthetics of power in Mussolini's Italy, 1st. pbk, Berkeley: University of California Press, 2000.

FAYET, Jean-François, VOKS. Le laboratoire helvétique. Histoire de la politique culturelle soviétique durant l'entre-deux-guerres, Genéve: Georg, 2014.

FERRARI, Francesco Luigi, Il regime fascista italiano, a cura di Giuseppe Ignesti, Collana Opere di Francesco Luigi Ferrari, Roma: Edizioni di storia e letteratura, 1983.

FERRETTI, Maria, Le Mouvement des correspondants ouvriers, 1917-1931: révolution culturelle et organisation du consensus dans l'Union soviétique des années vingt, tese de doutorado, Paris: EHESS, 1998.

FIGES, Orlando, A people's tragedy: the Russian revolution (1891-1924), New York: Penguin, 1996. 
FIGUEIREDO, Clara de Freitas, Foto-Grafia/o debate na Frente de Esquerda das Artes, Universidade de São Paulo, 2012, Dissertação de Mestrado, Programa de Pós Graduação em Artes Visuais, ECA/USP, disponível em <http://www.teses.usp.br/teses/disponiveis/27/27160/tde-05032013110221/en.php>.

FIGUEIREDO, Clara de Freitas, "Não comercializem Lênin! A crítica da LEF ao culto de Lênin”, in Dazibao - crítica de arte, n. 4, 2016, disponível em: <http://dazibao.cc/textos/naocomercializem-lenin-a-critica-da-lef-ao-culto-de-lenin/>, acessado em 25 de outubro de 2017.

FIGUEIREDO, Clara de Freitas, "Construtivismo russo: história, estética e política", in JINKINGS, I.; DORIA, K. (org.), 1917: o ano que abalou o mundo, São Paulo: Boitempo, Ed. SESC/SP, pp. 91-102, 2017.

FIGUEIREDO, Clara de Freitas, "Uma noiva vermelha!", in SILVA, M., (org.), Revolução russa: passado e presente, São Paulo: Todas as musas, pp. 51-82, 2017.

FIORANI, Mario, Breve historia do fascismo, Rio de Janeiro: Editora Civilização brasileira, 1963.

FITZPATRICK, Sheila, The commissariat of education under Lunacharsky (1917-1921), Ph.D. dissertation, Oxford: University of Oxford, 1969.

FITZPATRICK, Sheila, "The emergence of glaviskusstvo: class war on the cultural front, 1928-29", in Soviet Studies, vol. 23, no. 2 (outubro), Glasgow: University of Glasgow, Taylor \& Francis, Ltd., 1971.

FOGU, Claudio (posf.), L'immaginario storico fascista e la Mostra della Rivoluzione, in SCHNAPP, Jeffrey T., Anno X: la mostra della rivoluzione fascista del 1932, pref. Claudio Fogu, Pisa, Roma: Istituto Editoriali e Poligrafici Internazionali, MMIII, p.133, 2003.

FOSTER, Hal; KRAUSS, Rosalind; BOIS, Yve-alain; BUCHLOH, Benkamin; JOSELIT, David, Art since 1900: modernism, antimodernism, postmodernism, New York: Thames \& Hudson, 2011.

FRATELI, Arnaldo, "Proposta per il Palazzo delle Esposizione (lettera aperta)", La Tribuna, 21 ottobre 1932, in SCHNAPP, Jeffrey T., Anno X: la mostra della rivoluzione fascista del 1932, pref. Claudio Fogu, Pisa, Roma: Istituto Editoriali e Poligrafici Internazionali, MMIII, 2003.

FROSINI, Fabio, "Gramsci 'non contemporaneo", Sul recente libro di Peter Thomas", in Laboratorio Culturale, pp. 43-47, 2009.

FROSINI, Fabio, "Fascismo, parlamentarismo e lotta per il comunismo in gramsci", in Laboratorio Culturale, pp. 29-35, 2011.

FROSINI, Fabio, "Entre a superação do parlamentarismo e lutas sociais: a função do direito e as dinâmicas do poder na análise gramsciana do fascismo e do comunismo soviético", trad. Massimo Sciarretta, in Gramsci histórico, seminário internacional comemorativo dos 120 anos de nascimento de Antonio Gramsci, Rio de Janeiro: UniRio - Universidade Federal do Estado do Rio de Janeiro, 23-24 agosto 2011.

FROSINI, Fabio, "Croce, fascismo, comunismo", in Il Cannocchiale. Rivista di studi filosofici, vol. 48, Napoli: ESI, pp. 141-162, 2012. 
FROSINI, Fabio, "I «quaderni» tra mussolini e croce", in Laboratorio Culturale, pp. 60-68, 2012.

FROSINI, Fabio, "Gramsci e il fascismo: la letteratura e il <<nazionale-popolare $>>$, in PALA, MAURO (a cura di), Narrazione Egemoniche: Gramsci, letteratura e società civile, Bologna: Società Editrice il Mulino, pp. 57-89, 2014.

FROSINI, Fabio, “'Pueblo' y 'guerra de posición' como clave del populismo. Una lectura de los 'Cuadernos de la cárcel' de Antonio Gramsci”, in Cuadernos de Ética y Filosofía Política, ASPEFIP, pp. 63-82, 2014.

GAGLIARDI, Alessio, "O Problema do corporativismo no debate europeu e nos Cadernos", in AGGIO, Alberto; HENRIQUEZ, Luiz Sergio; VACCA, Giuseppe (Orgs.), Gramsci no seu tempo, Rio de Janeiro/Brasilia: Fundação Astrojildo Pereira/Contraponto, pp. 233-62, 2010.

GAGLIARDI, Alessio, "Per rifondare lo Stato: progetti corporativi tra fascismo e antifascismo", in SERNERI, S. N. (a cura di), 1914-1945: L'Italia nella guerra europea dei trent'anni, Toscana, Viella, pp. 237-257, 2016.

GARCÍA, Víctor del Rio, Conceptos factográficos entre el origen soviético y su recepción por la neovanguardia, Tese de Doutorado, Departamento de Filosofía y Filosofía Moral y Política, São Paulo: Faculdade de Filosofia, Universidad Nacional de Educación a Distancia, 2007.

GENTILE, Emilio, Il culto del littorio: La sacralizzazione della politica nell'Italia fascista, Bari: Editori Laterza, 1993.

GENTILE, Emilio, "Introduzione", in BRAUN E., Modernità totalitaria, a cura di Emilio Gentile, Bari: Laterza, 2008.

GILLET, Louis, "La nuova roma”, Revue des Deux Mondes, Parigi, 15 dicembre 1932, in SCHNAPP, Jeffrey T., Anno X: La Mostra della Rivoluzione fascista del 1932, pref. Claudio Fogu, Pisa, Roma: Istituto Editoriali e Poligrafici Internazionali, MMIII, pp. 125-127, 2003.

GOUGH, Maria, "Back in the USSR: John Heartfield, Gustavs Klucis, and the medium of soviet propaganda”, in New German Critique, 36, No. 2, Ithaca: Duke University Press, pp. 133-183, 2009

GRAMSCI, Antonio; TOGLIATTI, Palmiro, “A situação italiana e as tarefas do PCI”, teses aprovadas pelo iii congresso do partido comunista italiano, Lyon, janeiro de 1921, in GRAMSCI, A., Escritos políticos, Volume IV, trad. Manuel Simões, Lisboa: Instituto Gramsci e Seara Nova, pp. 201-241, 1978.

GRAMSCI, Antonio "O apoio do Estado", L'Ordine Nuovo, 13.11.1921, in GRAMSCI, A., Escritos políticos, trad. Manuel Simões, v. III, Lisboa: Seara Nova, Instituto Gramsci, pp. 29-33, 1977.

GRAMSCI, Antonio, “A crise italiana”, L'Ordine Nuovo, 01.09.1924, in GRAMSCI, A., Escritos políticos, trad. Manuel Simões, v. III, Lisboa: Seara Nova, Instituto Gramsci, pp. 123-136, 1977.

GRAMSCI, Antonio, "La crisi italiana", L'Ordine Nuovo, 01.09.1924, in GRAMSCI, Antonio, Scritti politici III, org. Paolo Spriano, Roma: Editori Riuniti, 1973. 
GRAMSCI, Antonio, Lettere dal carcere, pref. Paolo Spriano, $7^{\circ}$ ed. Torino: Einaudi, 1977.

GRAMSCI, Antonio, Sul fascismo, org. Enzo Santarelli, Roma: Riuniti, 1978.

GRAMSCI, Antonio, Cadernos do cárcere, ed. Carlos Nelson Coutinho, trad. Luiz Sérgio Henriques, Rio de Janeiro: Civilização brasileira, 2002.

GRAMSCI, Antonio, Quaderni del carcere, edizione critica dell'Istituto Gramsci, org. Valentino Gerratana, Torino: Einaudi, 2007.

GUSEV, Aleksei, “The 'Bolchevik Leninist' opposition and the Working Class, 1928-1929”, in FILTZER, GOLDMAN, KESSLER AND PIRANI (editors), A Dream Deferred New Studies in Russian and Soviet Labour History. In International and Comparative Social History, vol.11., New York: Peter Lang AG, Internationaler Verlag der Wissenschaften, 2008.

KATSMAN, C., "Que respondan” (1926), pp. 214-216, in ARVATOV, Boris, Arte y produccion: el programa del productivismo, trad. José Fernandez Sanchez, Madrid: Alberto Corazon, 1973.

KAWAMURA, Aya, "La création collective dans le documentaire soviétique: photographie, cinéma et «correspondants-ouvrier»", in 1895: Revue d'histoire du cinéma, n. 63, 2011, pp. 48-144. Disponível online em: <www.cairn.info/revue-1895-2011-1-page-48.htm>, acessado em 4 de maio de 2015.

KIAER, Christina, "Was socialist realism forced labour? the case of aleksandr deineka in the 1930s", in Oxford art journal, n. 28, Oxford: University Press, 2005

KING, David, The commissar vanishes: the falsification of photographs and art in Stalin's Russia, New York: H. Holt, c1997.

KING, David, "Photographic images should not be relied upon, but even falsified photographs can be illuminating for students of history", in New perspective - for modern history students, V. 6, n. 2, 2000, pp. 24-25;

KOLLONTAI, Alexandra, Oposição operária 1920-1921, trad. Grupo Aurora, São Paulo: Global Editora, 1980

KOPP, Anatole, Arquitectura y urbanismo soviético en los años veinte, Barcelona: Lumen, 1974.

KRAUSS, R. E., The optical unconscious, Cambridge, Massachusetts, London: The MIT Press (Na October book), 1993

LEF, “Aos companheiros que dão forma à vida!", Lef, 2, 1923; trad. Italiana in MAGAROTTO, L.; SCALIA, G. (a cura di), L' avanguardia dopo la rivoluzione. Le riviste degli anni Venti nell'URSS: «Il giornale dei futuristi», «L'arte della Comune», «Il Lef», «Il nuovo Lef», Roma: Edizioni Immanenza, pp. 168-169, 1976.

LEF, “Declaration: comrades organizers of life!” (1923), in BOWLT, John (edit.) E., The documents of 20th-century art/russian art of the avant-gard: theory and criticism 1902-1934, Nova York: The Viking Press, pp. 199-201, 1976.

LENOE, Matthew, Closer to the masses: stalinist culture, social revolution and soviet newspapers, Massachusetts: Harvard Press, pp. 121-122, 2004. 
LIGUORI, Guido e VOZA, Pasquale (org.), Dicionário gramsciano: (1926-1937), pref. Alvaro Bianchi, trad. Ana Maria Chiarini, Diego Silveira Coelho Ferreira, Leandro de Oliveira Galastri e Silvia de Bernardinis, São Paulo: Boitempo, pp.41-43, 2017.

LODDER, Christina, Russian constructivism, New Haven: Yale University Press, 1983.

LÖWY, Michael, “Lukács and Stalinism”, in New Left Review I_91, Londres, May-June 1975

LÖWY, Michael, Walter Benjamin: aviso de incêndio. Uma leitura das teses "Sobre o conceito de História", São Paulo: Boitempo, 2005.

LÖWY, Michel, The politics of combined and uneven development: the theory of permanent revolution, Chicago: Haymarket books, 2010.

LUCAS, Marcílio Rodrigues, De Taylor a Stakhanov: utopias e dilemas marxistas em torno da racionalização do trabalho, IFCH, Ciências Sociais, Tese de doutorado, Orient: Liliana Segnini, Campinas: Unicamp, 2015.

LUDWIG, Emilio, Colóquios com Mussolini (1932), trad. Marina Guaspari, Porto Alegre: Livraria do Globo, 1932.

MACCARI, Mino, "Il carattere popolare della mostra della rivoluzione", Illustrazione Italiana, 2 aprile 1933, pp. 498-99, in SCHNAPP, Jeffrey T., Anno X: La Mostra della Rivoluzione fascista del 1932, pref. Claudio Fogu, Pisa, Roma: Istituto Editoriali e Poligrafici Internazionali, MMIII, pp.93-94, 2003.

MACCIOCCHI, Maria Antonietta, A favor de Gramsci, Rio De Janeiro: Paz E Terra, 1980.

MAGAROTTO, L.; SCALIA, G. (a cura di), L' avanguardia dopo la rivoluzione. Le riviste degli anni Venti nell'URSS: «Il giornale dei futuristi», "L'arte della Comune», "Il Lef», "Il nuovo Lef», Roma: Edizioni Immanenza, 1976.

MAIAKOVSKI, Vladmir, “A plenos pulmões” (1929-1930), in SCHNAIDERMAN, Boris (trad.); CAMPOS, Haroldo (trad.); CAMPOS, Augusto (trad.), Maiakovski, poemas, São Paulo: Perspectiva, pp. 131-136, 2006.

MAIAKOVSKI, Vladmir, (1930), apud MIKHAILOV, Aleksandr, Maiakovski - O Poeta da Revolução, trad. Zoia Prestes, Record: São Paulo, 2008.

MALVANO, Laura, Fascismo e politica dell'immagine, Torino: Bollati Boringhieri editore, 1988.

MANNUCCI, Stefano, Luce sulla guerra. La fotografia di guerra tra propaganda e realtà. Italia 194045, Roma: Nuova Arnica Editrice, 2007.

MARINETTI, F. T., "l'arte fascista futurista”, Critica Fascista, 1927, in DEL BUONO, Oreste (a cura di), Eia, eia, eia, alala': la stampa italiana sotto il fascismo 1919-1943, pref. Nicola Tranfaglia, Milano: Feltrinelli, 1971.

MARINETTI, F. T., "Stile rivoluzionario", Gazzetta del Popolo, 30 ottobre 1932, in SCHNAPP, Jeffrey T., Anno X: La Mostra della Rivoluzione fascista del 1932, pref. Claudio Fogu, Pisa, Roma: Istituto Editoriali e Poligrafici Internazionali, MMIII, pp. 85-87, 2003. 
MARINETTI, F. T., "Fundação e manifesto do futurismo", in BERNARDINI, Aurora Fornoni (org), O Futurismo Italiano: Manifestos, São Paulo: Editora Perspectiva, 1980.

MARTINS, Luiz Renato, "O debate entre o construtivismo e o produtivismo, segundo Nikolay Tarabukin”, in Ars, São Paulo: departamento de artes plásticas, ECA-USP, ano 1, n. 2, 2003.

MARX, Karl, O 18 brumário e cartas a Kugelmann, trad. Leandro Konder e Renato Guimarães, 6. ed. São Paulo: Paz e Terra, 1997.

MIGUEL, Jair Diniz, Arte, ensino, utopia e revolução: os ateliês artísticos Vkhutemas/Vkhutein (Rússia/URSS, 1920-1930), Tese de Doutorado em História, São Paulo: FFLCH-USP, 2006.

MORGANA, Pino, A la mostra della rivoluzione. Sonetti popolari, Roma, Lucci, s. p., s.d., 1934, in SCHNAPP, Jeffrey T., Anno X: la mostra della rivoluzione fascista del 1932, pref. Claudio Fogu, Pisa, Roma: Istituto Editoriali e Poligrafici Internazionali, MMIII, pp. 119-120, 2003.

NEGRI, Ada, "Madri di Martiri”, Corriere della Sera, 11 marzo 1933, in SCHNAPP, Jeffrey T., Anno X: la mostra della rivoluzione fascista del 1932, pref. Claudio Fogu, Pisa, Roma: Istituto Editoriali e Poligrafici Internazionali, MMIII, pp. 99-100, 2003.

ORWELL, G., "Resenha de Nós, de Ievguêni Ivánovitch Zamiátin" (4 de janeiro de 1946), in ZAMIÁTIN, I.I., Nós (1924), trad. Gabriela Soares, São Paulo: Editora Aleph, 2017, pp. 317323.

ORWELL, George, 1984, trad. Alexandre Hubner e Heloisa Jahn, São Paulo: Companhia das Letras, 2015.

PELLIZZI, Camillo, "Molti artisti e una rivoluzione", "Corriere della Sera", 25 aprile 1933, in SCHNAPP, Jeffrey T., Anno X: La mostra della rivoluzione fascista del 1932, pref. Claudio Fogu, Pisa, Roma: Istituto Editoriali e Poligrafici Internazionali, MMIII, pp. 79-81, 2003.

PESSOA, P. S., Stachka: Um ensaio sobre os antagonismos, orientador Luiz Renato Martins, Dissertação de mestrado, Programa de Pós-Graduação em Artes Visuais, Escola de Comunicação e Artes, Universidade de São Paulo, São Paulo, 2009.

PHILLIPS, Christopher (org), La nueva vision: fotografia de entraguerras, Ford Motor Company collection, Metropolitan Museum of Art, Nueva York (Spanish Edition), 1994.

PHILLIPS, Christopher, Photograph in modern era, New York, Metropolitan Museum/ ArtArperture, 1989.

PISU, Stefano, L'Unione Sovietica alla mostra internazionale d'arte cinematografica di venezia (19321953), orientatore Giannarita Mele, Tese de dottorato, Cagliari: Dipartimento di Studi Storici, Geografici ed Artistici (dottorato di Ricerca in Storia Moderna e Contemporanea), Università degli Studi di Cagliari, XX ciclo, pp. 38-43, 2010.

PLAMPER, Jan, The Stalin cult in the visual arts, 1929-1953 (Russia), Ph.D, Berkeley: University of California, 2001 
POHLMANN, Ulrich, "Los diseños de exposiciones de El Lissitzky" (1999), in AA.VV., Espacios fotográficos públicos: exposiciones de propaganda, de pressa a the family of man, 1928-1955, Barcelona: MACBA, pp. 167-191, 2009 (catálogo de exposição).

RAFFAELLO, Giolli, "Cronache milanesi: la mostra del sindacato", Bergamo: Emporium, 1929, vol. LXX, n. 420, pp. 369-373, Disponível online em: $<$ http://www.artivisive.sns.it/galleria/libro.php?volume=LXX\&pagina=LXX_420_368.jpg>, acessado em 21 de abril de 2015.

REIS FILHO, Daniel Aarão, URSS: o socialismo real (1921-1964), São Paulo: Brasiliense, 1983.

REIS FILHO, Daniel Aarão e COSTA, Emília Viotti da, As revoluções russas e o socialismo soviético, São Paulo: EDUNESP, 2008

RODCHENKO, A., "Los caminos de la fotografia moderna", (1928) in Rodchenko: La construcción del futuro, Catalunya: Fundacion Caixa Catalunya, pp. 199-200, 2008.

RODCHENKO, Aleksander, "The paths of contemporary photography", Novyi Lef, n. 9, 1928, in Aleksandr Rodchenko experiments for the future: diaries, essays, letters, and other writings, org. Alexander Lavrentiev, trad. Jamey Gambrell, int. John Bowlt, New York: Museum of Modern Art, pp. 207-212, 2005.

RODCHENKO, Aleksander, "Downright ignorance or mean trick?", in PHILLIPS, C. (Org.), Photography in the modern era: european documents and critical writings, 1913-1940, New York: The Metropolitan Museum of Art/Aperture, pp. 245-248, 1989.

RODCHENKO: La construcción del futuro, Catalunya: Fundacion Caixa Catalunya, 2008 (catálogo da exposição).

RODRIGUES, Rogério P., O colapso da URSS: um estudo das causas, orientador: Osvaldo Coggiola, Tese de Doutorado, São Paulo: Departamento de História Econômica, Universidade de São Paulo - USP, 2006.

ROMANENKO, Katerina, The visual language of the soviet illustrated magazines in the 1930s: Rabotnitsa, Krestianka, and URSS in Construction, Ph.D. Dissertation, Doctor of Philosophy, Faculty in Art History, The City University of New York, 2012.

ROSENBERG, A., "Fascism as a mass-movement (1934)", in Historical materialism: research in critical marxista theory, V. 20.1, Boston: Brill, pp. 144-190, 2012.

RUSSO, Antonella, Il fascismo in mostra, Roma: Editori Riuniti, 1999.

SALVAGNINI, Sileno, Il sistema delle arti in italia: 1919-1943, Bologna: Minerva Edizione, 2000.

SCHNAPP, Jeffrey T., Anno X: la mostra della rivoluzione fascista del 1932, pref. Claudio Fogu, Pisa, Roma: Istituto Editoriali e Poligrafici Internazionali, MMIII, 2003.

SECCO, Lincoln, Gramsci e a revolução, São Paulo: Alameda, 2006.

SERGE, Victor, Memoirs of a revolutionary, trad. Peter Sedgwick, New York: Random House, 2012. 
SIRONI, M., "L'architettura della rivoluzione", Il popolo d'italia, 18 nov. 1932, in SCHNAPP, J. T., Anno X: la mostra della rivoluzione fascista del 1932, pref. Claudio Fogu, Pisa, Roma: Istituto Editoriali e Poligrafici Internazionali, MMIII, pp. 77-78, 2003.

STONE, Marla, The politics of cultural production: the exhibition in fascist Italy, 1928-1942, Ph.D. Theses, New Jersey: Department of History, Princeton University (USA), 1990.

STONE, Maria, "Staging fascism: the exhibition of the fascist revolution", in Journal of contemporary history, vol. 28, No. 2. (Apr., 1993), Londres: SAGE Publications, pp. 215-243.

TARABUKIN, N., El último cuadro: del caballete a la máquina/ por una teoría de la pintura (1923), trad. Rosa Feliu e Patrícia Vélez, Barcelona: Gustavo Gili, 1977.

THOMAS, Peter, “Modernity as 'passive revolution': Gramsci and the fundamental concepts of historical materialism", in Journal of the canadian historical association / revue de la société historique du Canada, $\mathrm{n}^{\circ}$ 2, Quebec, Montereal: Érudit, 2006, pp. 61-78, disponível em $<$ http://id.erudit.org/iderudit/016590ar; DOI: 10.7202/016590ar>, acessado em 29 de abril de 2016.

THOMAS, Peter D., "Gramsci and the political: From the state as 'metaphysical event' to hegemony as 'philosophical fact"', in Radical philosophy, Jan.-Feb., pp. 27-36, 2009.

THOMAS, Peter D., the gramscian moment: philosophy, hegemony and marxism, Historical materialism book series, haymarket books, 2011.

THOMAS, Peter D., "Hegemony, passive revolution and the modern prince", in Thesis eleven, Londres: SagePub, Brunel University, 2013, pp. 20-39, disponível em $<$ http://journals.sagepub.com/doi/10.1177/0725513613493991>, acessado em 30 de janeiro de 2017.

TOGLIATTI, Palmiro, Lições sobre o fascismo, trad. Maria Tereza Teixeira, São Paulo: Ciências Humanas, 1978.

TRETIAKOV, Sergei, "Art in the revolution and the revolution in art (aesthetic consumption and production)", in October, n. 118, Cambridge: MIT Press, pp. 11-18, Fall 2006.

TRETIAKOV, S., "La biografia dell' oggetto", in CHUZHAK, N. (org), Literatura fakta, Federacija, Moskva, 1929, in ZALAMBANI, M., La morte del romanzo: dall'avanguardia al "realismo socialista”, Roma: Carocci, Apêndice I, pp. 162-165, 2003.

TRETIAKOV, Sergei, “The new Leo Tolstoy”, in October, n. 118, Cambridge: MIT Press, pp. 47-50, Fall 2006.

TROTSKY, Leon, El nuevo curso (1923), in <http://ceipleontrotsky.org/El-nuevo-curso-1923>, acessado em 17 de abril de 2016.

TROTSKY, Leon, Questões do modo de vida. A moral deles e a nossa (1923), trad. Diego Siqueira, Daniel Oliveira, São Paulo: Instituto José Luís e Rosa Sundermann, 2009.

TROTSKY, Leon, Literatura y revolución (1924), trad. Alejandro Ariel González, Buenos Aires: Edicones RyR, Colección: Serie Clásicos, 2014. 
TROTSKY, Leon, Revolução e contra-revolução na Alemanha (1926), trad. Mário Pedrosa, Rio de Janeiro: Laemmert, 1968.

TROTSKY, Leon, Teses sobre revolução e contra-revolução (1926), in $<$ https://revistaiskra.wordpress.com/especiais-iskra-trotsky-e-engels/teses-sobre-revolucao-econtra-revolucao/>, acessado em 05 de maio de 2016.

TROTSKY, Leon, Revolução e contra-revolução, Rio de Janeiro: Laemmert, 1968.

TROTSKY, Leon, A Revolução desfigurada, trad. João Leske, São Paulo: Livraria Editora Ciências Humanas, 1979.

TROTSKY, Leon, Scritti sull'Italia, (a cura di) Antonella Marazzi, Roma: Erre Emme, 1990.

TROTSKY, Leon, A revolução traída, trad. M. Carvalho e J. Fernandes, São Paulo: Centauro, 2008.

TROTSKY, Leon, O imperialismo e crise da economia mundial: textos sobre a crise de 1929, trad. Roberto Barros, São Paulo: Sundermann, 2008.

TROTSKY, Leon, O imperialismo e a crise da economia mundial, trad. Roberto Barros, São Paulo: Sundermann, 2008.

TROTSKY, Leon, A revolução traída, trad. M. Carvalho e J. Fernandes, São Paulo: Centauro, 2008.

TUMARKIN, Nina, Lenin lives! The Lenin cult in Soviet Russia, Cambridge: Harvard University Press, 1997.

TUPITSYN, Margarita, "The histories of the soviet photograph at home and abroad", in history of photography, vol. 24, n 4, winter 2000.

TUPITSYN, Marguerite, The soviet photography, 1924-1937, New Haven and London: Yale University Press, 1996

TWISS, Thomas Marshall, Trotsky and the problem of soviet bureaucracy, tese de doutorado, Pittsburgh: University of Pittsburgh, 2009, (disponível em: <http://dscholarship.pitt.edu/7502/1/twisstm_etd2009.pdf >).

VACCA, G., Vida e pensamento de Antonio Gramsci: 1926-1937, trad. Luiz Sérgio Henriques, Rio de Janeiros: Contraponto, 2012

VILELLA, Thyago Marão, O ocaso de outubro: o construtivismo russo, a oposição de esquerda e a reestruturação do modo de vida, dissertação de mestrado, São Paulo: PPGAV-USP, 2014 (disponível em: <http://www.teses.usp.br/teses/disponiveis/27/27160/tde-02032015104723/pt-br.php>).

WIZISLA, E., Benjamin e Brecht: historia de uma amizade, São Paulo: EDUSP, 2013

WOLF, Erika, USSR in construction: from avant-garde to socialist realist practice, Ph.D. dissertation, Ann Arbor: The University of Michigan, 1999.

WOLF, Erika. "When photographs speak, to whom do they talk? The origins and audience of SSSR na stroike (USSR in construction)", in Left History, vol. 6, n. 2, pp. 53-82, 2000.

ZALAMBANI, Maria, L' arte nella produzione: avanguardia e rivoluzione nella russia sovietica degli anni'20, Ravenna: Longo Editore, 1998. 
ZALAMBANI, Maria, La morte del romanzo: dall'avanguardia al "realismo socialista", Roma: Carocci, 2003.

ZAMIÁTIN, I.I., Nós (1924), trad. Gabriela Soares, São Paulo: Editora Aleph, 2017. 